\title{
EL PROCEDIMIENTO SANCIONADOR EN MATERIA DE TRÁFICO Y SEGURIDAD VIAL
}




\section{INDICE}

\section{CAPÍTULO I: LA REGULACIÓN DEL PROCEDIMIENTO SANCIONADOR EN MATERIA DE TRÁFICO Y}

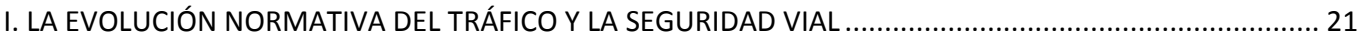

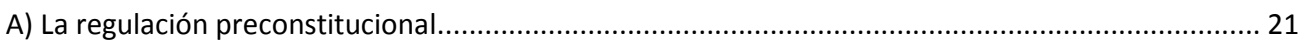

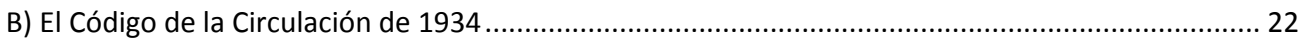

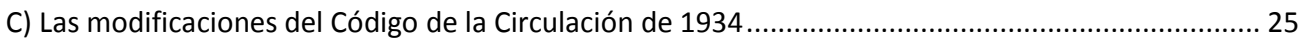

D) La apertura de una vía paralela y la creación de la Jefatura Central de Tráfico ............................... 26

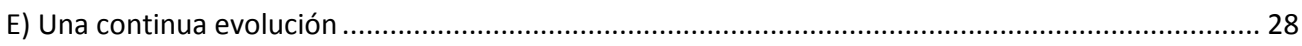

II. CONSTITUCIÓN Y PROCEDIMIENTO SANCIONADOR EN MATERIA DE TRÁFICO ...................................... 31

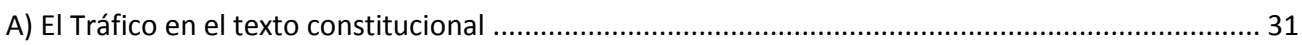

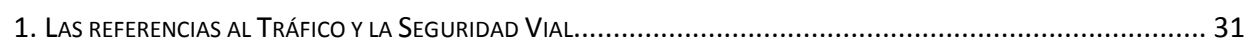

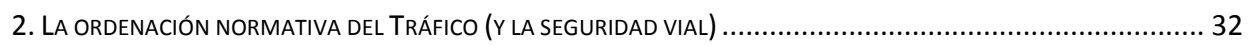

3. EL PRINCIPIO DE LEGALIDAD EN LA REGULACIÓN DEL PROCEDIMIENTO SANCIONADOR EN MATERIA

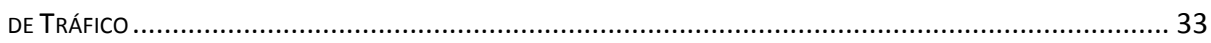

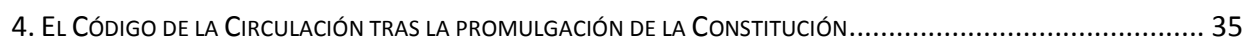

B) La Ley de Bases (Ley 18/1989, de 25 de julio, de Bases de Tráfico, Circulación de

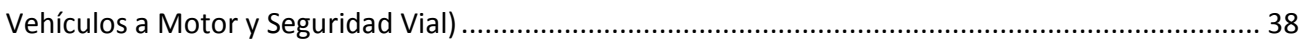

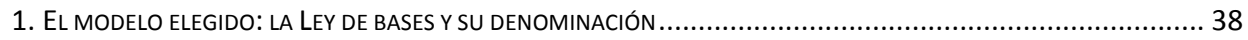

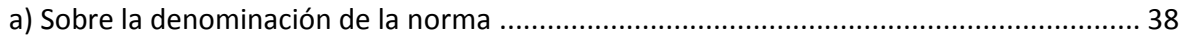

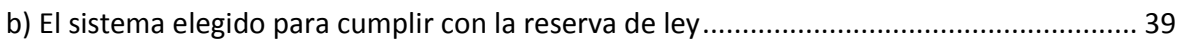

c) Sobre la elección de este sistema (justificación y valoración) ............................................. 40

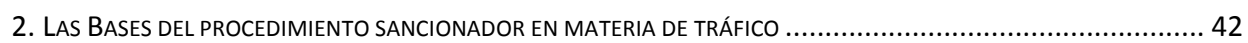

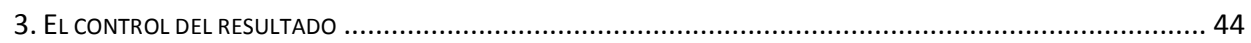

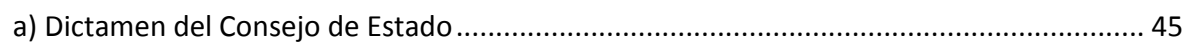

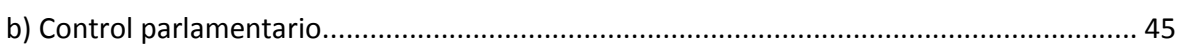

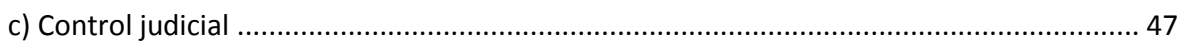

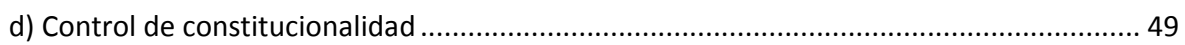

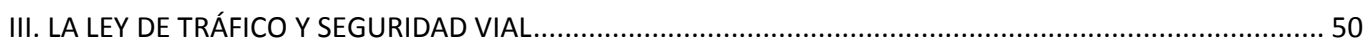

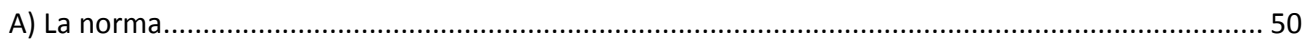

B) El Régimen sancionador en la Ley de Tráfico y Seguridad Vial .................................................... 51

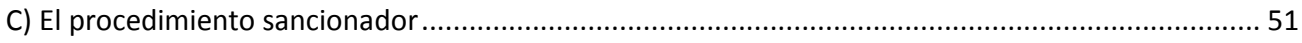

D) Una primera aproximación al punto de partida del procedimiento sancionador establecido en la Ley de Tráfico y Seguridad Vial ............................................................................... 53

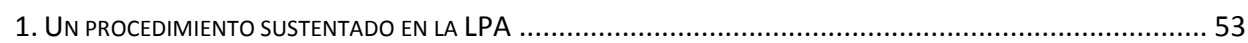

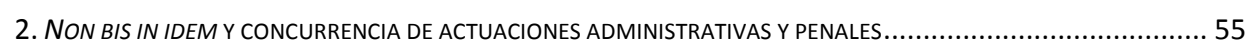

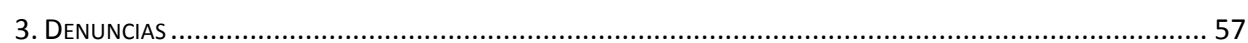

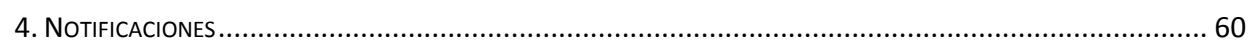

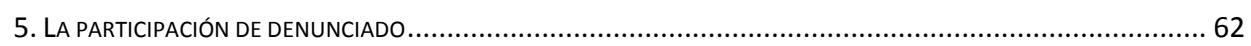

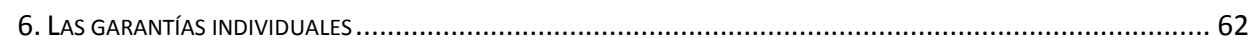

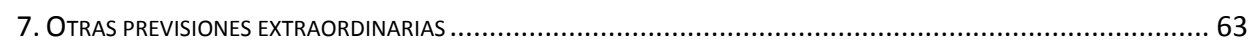

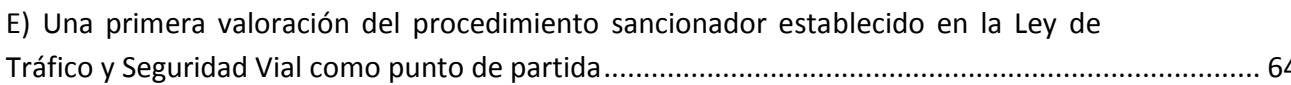

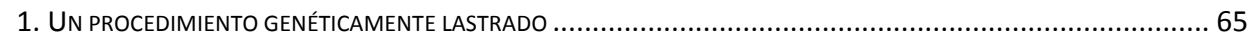

2. UNA INEFICIENTE PREVISIÓN PARA LA INTEGRACIÓN DE ACTUACIONES ADMINISTRATIVAS Y PENALES........................ 67

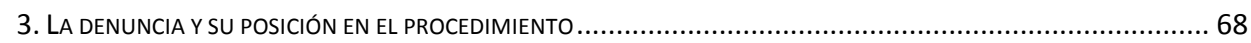




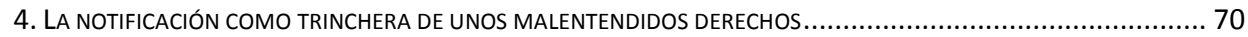

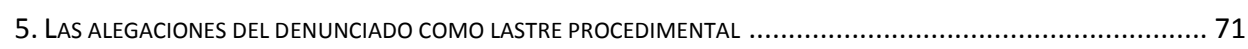

6. UNA FORMA UNIDIRECCIONAL (Y EQUIVOCADA) DE ENTENDER LAS GARANTÍAS PROCEDIMENTALES ....................... 72

IV. MODIFICACIONES Y DESARROLLO DE LA LEY DE TRÁFICO Y SEGURIDAD VIAL........................................ 75

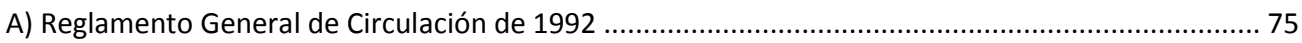

B) Un cambio profundo y silencioso: la promulgación de la LRJ - PAC ................................................ 79

C) El Reglamento de Procedimiento sancionador en materia de tráfico, circulación de

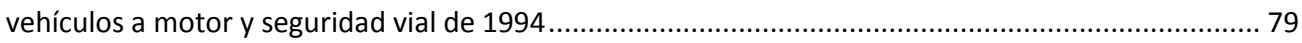

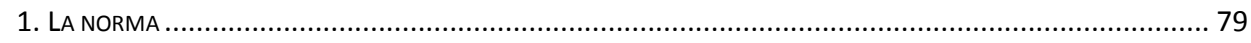

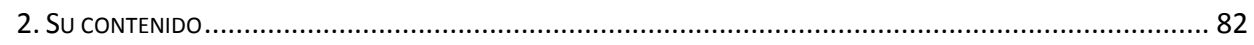

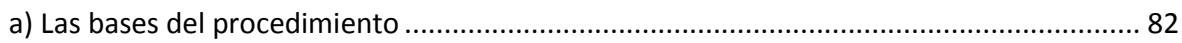

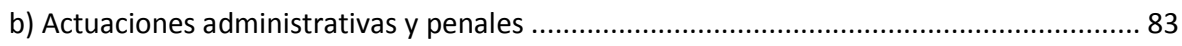

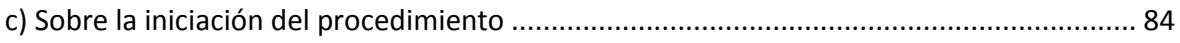

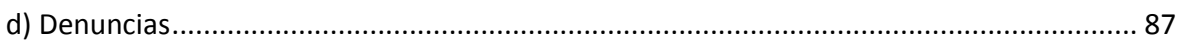

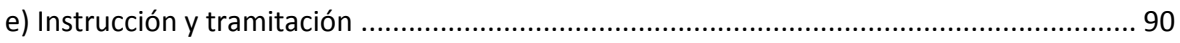

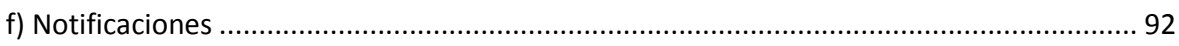

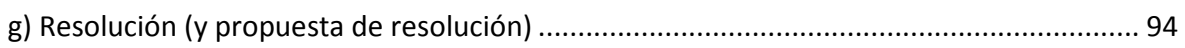

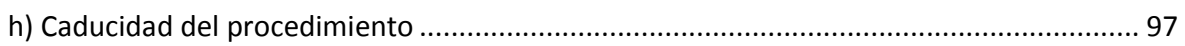

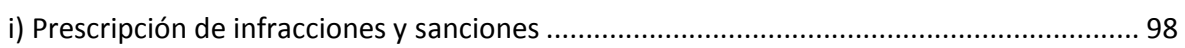

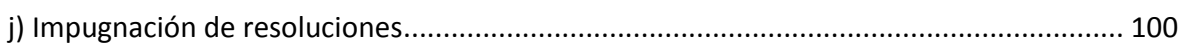

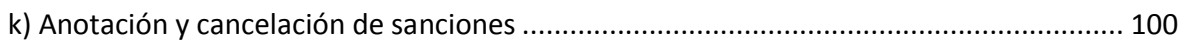

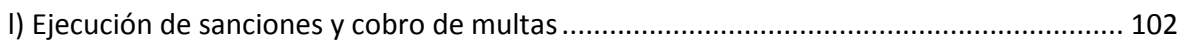

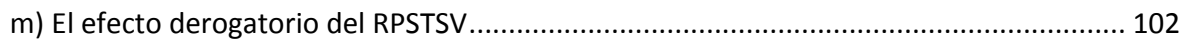

D) Ley 5/1997, de 24 de marzo, de reforma de la Ley de Tráfico y Seguridad Vial ............................ 104

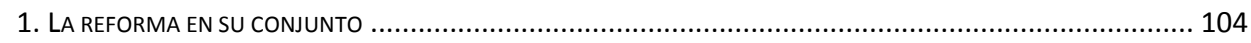

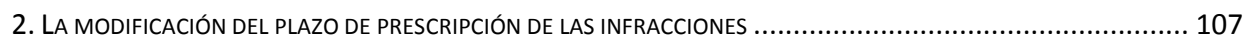

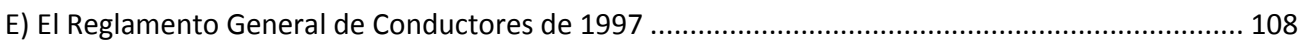

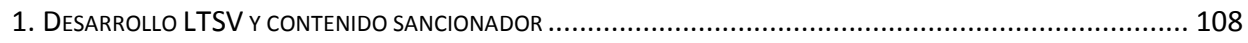

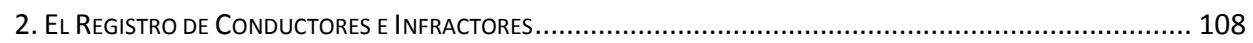

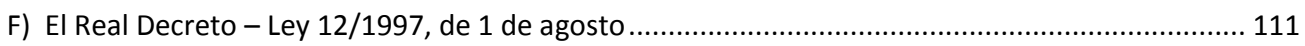

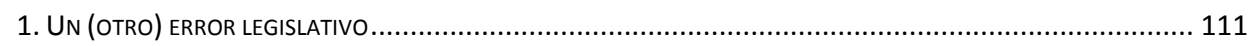

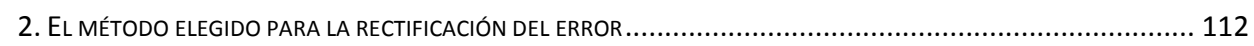

G) El Real Decreto 116/1998, de 30 de enero (que modifica el RPSTSV) ........................................ 115

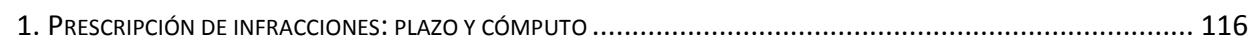

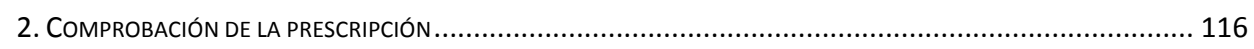

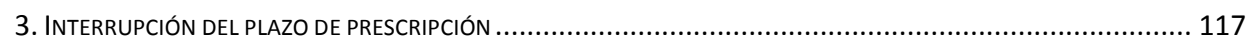

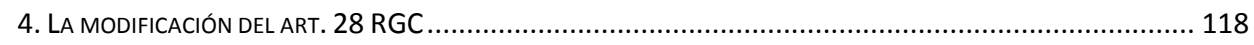

H) El Real Decreto 2822/1998, de 23 de diciembre, por el que se aprueba el

Reglamento General de Vehículos................................................................................................... 118

I) Un cambio profundo y nada silencioso: la Ley 4/1999, de 13 de enero, de

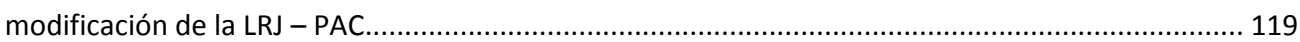

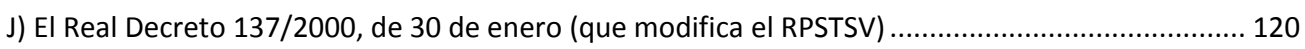

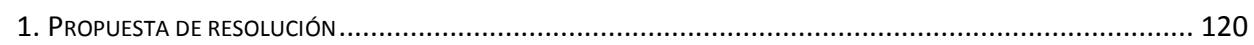

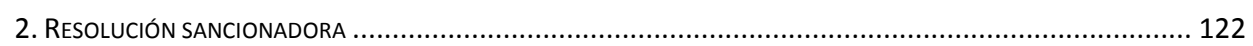

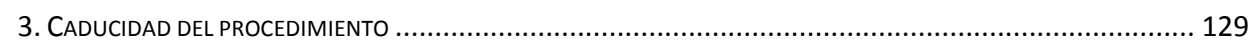

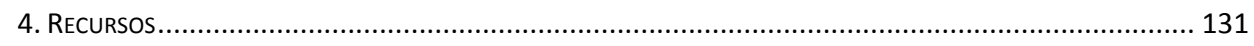

K) La Ley 19/2001, de 19 de diciembre, de reforma de la LTSV ................................................... 131

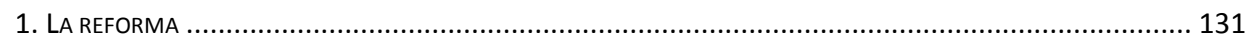

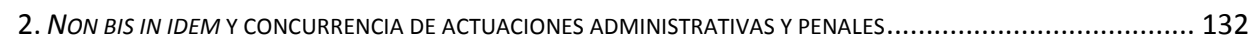

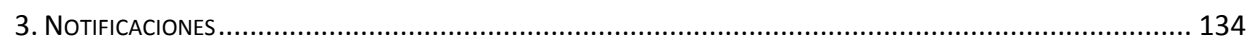

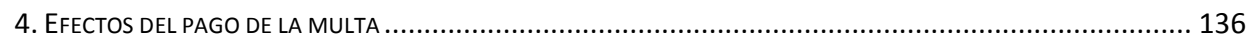

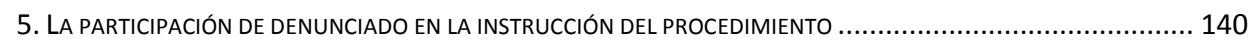

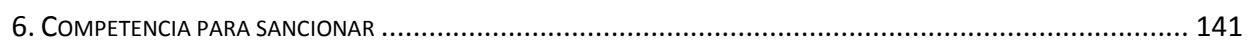

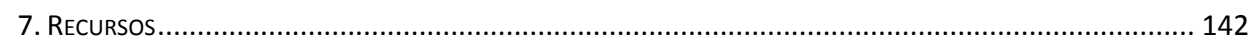


8. SOBRE LA PRESCRIPCIÓN DE INFRACCIONES, PRESCRIPCIÓN DE SANCIONES, CADUCIDAD DEL PROCEDIMIENTO Y CANCELACIÓN DE ANTECEDENTES

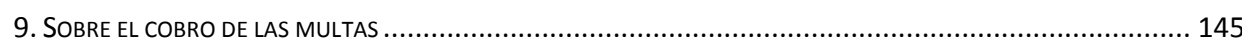

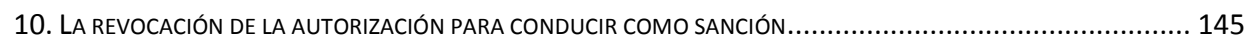

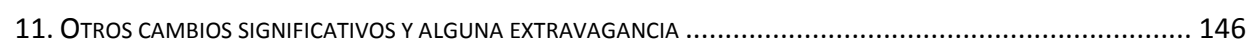

L) El Real Decreto 318/2003, de 14 de marzo, de modificación del RPSTSV para adaptarlo a los cambios realizados en la LTSV por la Ley 19/2001, de 19 de diciembre .................. 148

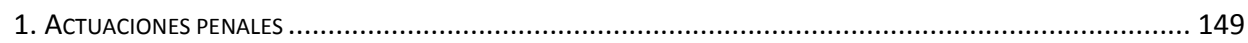

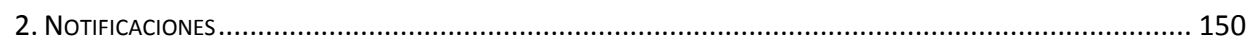

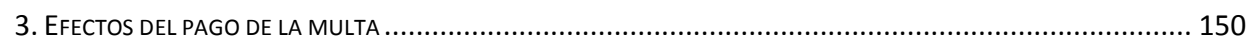

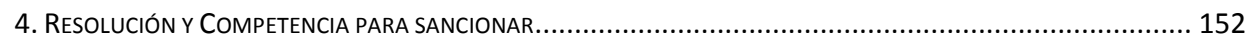

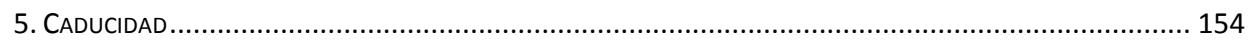

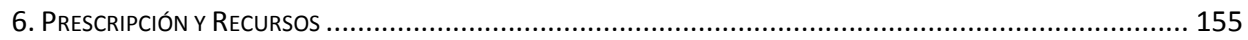

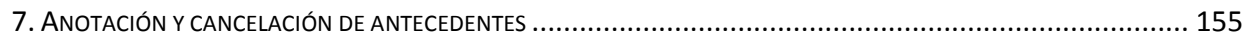

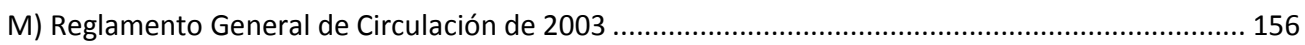

N) La Ley 62/2003, de 30 de diciembre, de medidas fiscales, administrativas y del

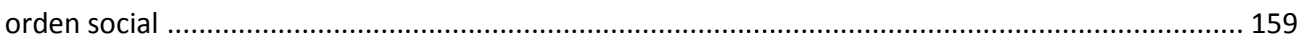

N) La Ley 17/2005, de 19 de julio, del permiso y licencia de conducción por puntos ........................163

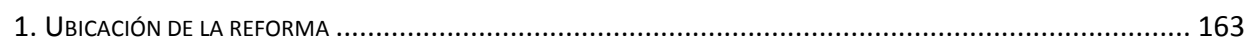

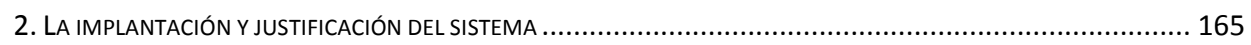

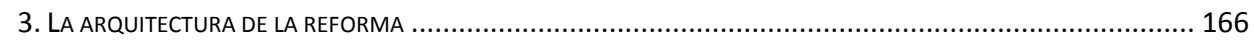

a) La vigencia del permiso o licencia ....................................................................... 166

b) La declaración de pérdida de vigencia por la pérdida de la totalidad de los

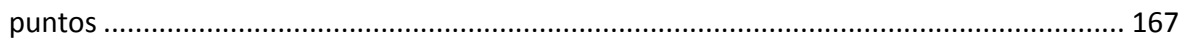

c) Modificación del cuadro general de infracciones .............................................. 167

d) Modificación del régimen de sanciones ................................................................ 169

e) Graduación de las sanciones ......................................................................... 171

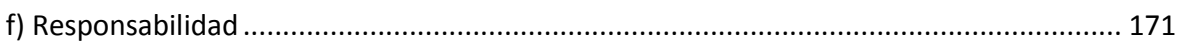

g) Responsabilidad de persona distinta a la que comete la infracción.............................. 172

h) Responsabilidad solidaria en el caso de infracciones cometidas por los

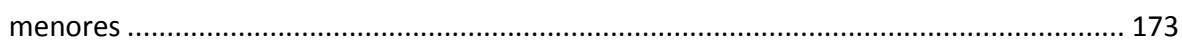

i) Equiparación de arrendatarios a titulares ................................................................. 174

j) Deber de identificar al conductor - infractor ....................................................... 175

k) Abono voluntario de la sanción acogiéndose al beneficio de reducción......................... 176

l) Anotación y cancelación de antecedentes ............................................................ 177

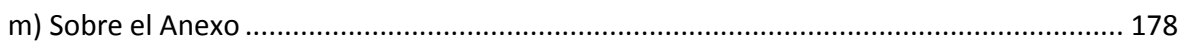

n) Las disposiciones adicionales y finales .............................................................. 180

4) UNA ESCUETA VALORACIÓN DE LA REFORMA POR COMPARACIÓN CON LA EFECTUADA POR LA LEY

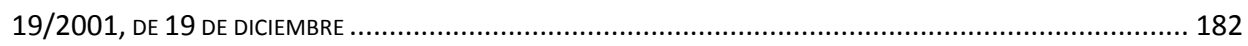

O) La revisión del RGCon realizada por medio del Real Decreto 62/2006, de 27 de

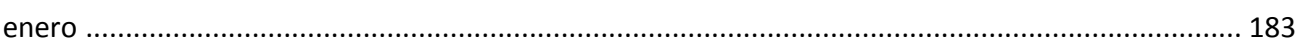

P) La Ley Orgánica 15/2007, de 30 de noviembre, por la que se modifica la Ley

Orgánica 10/1995, de 23 de noviembre, del Código Penal en materia de seguridad vial ................. 187

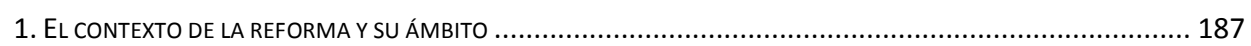

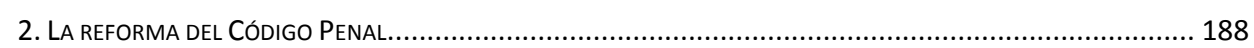

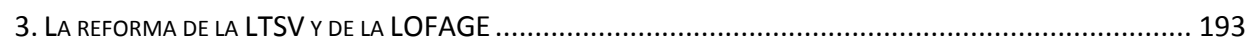

a) Competencia para sancionar las infracciones previstas en la LTSV ............................. 193

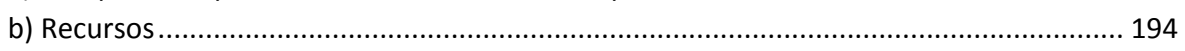

c) Anotación y cancelación de antecedentes ............................................................... 194

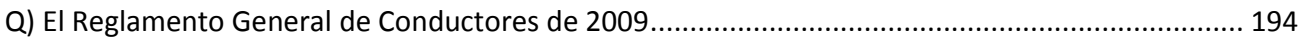

1. PERDIDA DE VIGENCIA POR CARENCIA DE PUNTOS Y PROCEDIMIENTO PARA SU DECLARACIÓN............................ 195

2. SOBRE EL PROCEDIMIENTO PARA LA DECLARACIÓN DE PÉRDIDA DE VIGENCIA POR LA PÉRDIDA

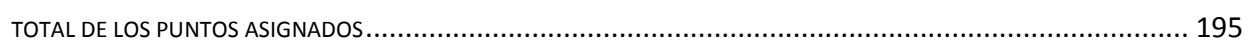

R) La Ley 18/2009, de 23 de noviembre, de modificación del régimen sancionador de

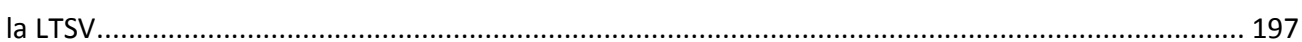




\section{Capítulo II: LA COMPETENCIA PARA SANCIONAR LAS INFRACCIONES DE TRÁFICO Y}

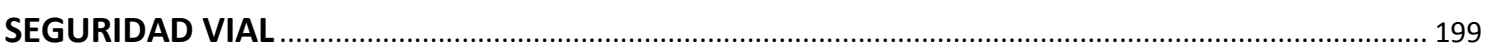

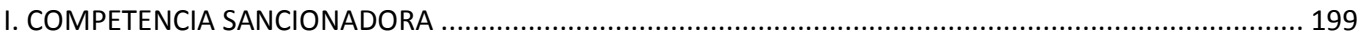

A) La evolución de la norma general de atribución de la competencia para sancionar

las infracciones en materia de tráfico y seguridad vial .................................................................... 199

B) Ubicación de la regulación de la competencia sancionadora (art. 71 LTSV)................................... 201

II. ATRIBUCIÓN Y DISTRIBUCIÓN DE LA POTESTAD SANCIONADORA EN MATERIA DE

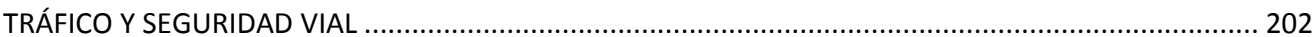

A) Sobre la diversidad de titulares a los que se atribuye la potestad sancionadora .......................... 202

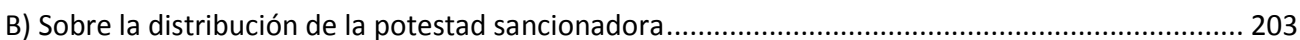

1. LA NORMA General POR LA QUE SE ATRIBUYe a LOS JeFES PROVINCIALES DE tRÁFICO LA

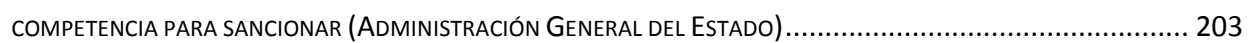

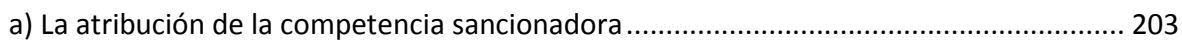

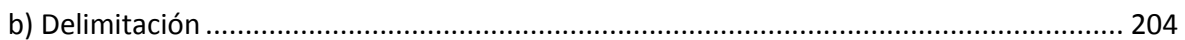

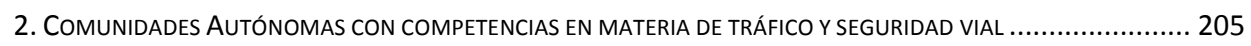

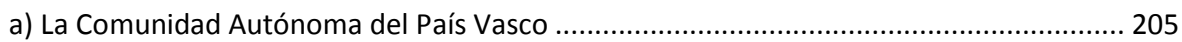

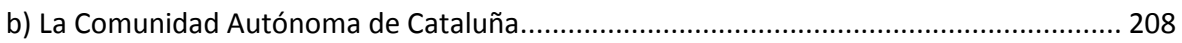

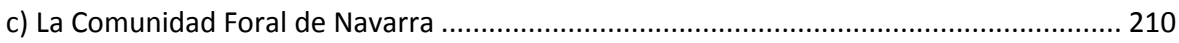

3. LAS COMPETENCIAS MUNICIPALES EN LA ORDENACIÓN DEL TRÁFICO DE VEHÍCULOS Y PERSONAS EN

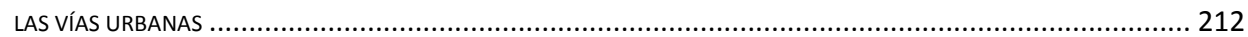

4. COMPETENCIA SANCIONADORA POR RAZÓN DE LA MATERIA (PUBLICIDAD DE LOS VEHÍ́CULOS) .......................... 213

5. EL ESTRAMBÓTICO SUPUESTO DE LA COMPETENCIA PARA IMPONER LA SANCIÓN DE SUSPENSIÓN

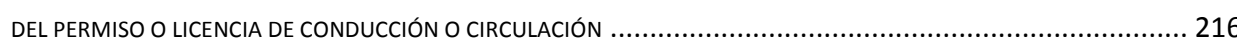

III. SOBRE LA DELEGACIÓN DE LA COMPETENCIA PARA SANCIONAR LAS INFRACCIONES DE TRÁFICO Y SEGURIDAD VIAL Y OTROS SUPUESTOS DE SU DESPLAZAMIENTO..................................... 217

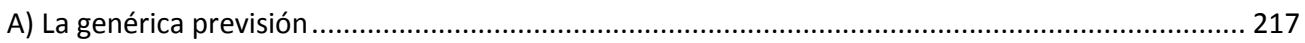

B) La delegación de la competencia sancionadora atribuida a los Jefes Provinciales de

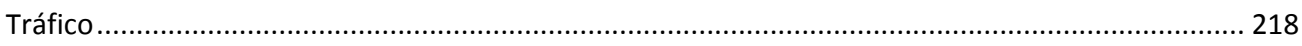

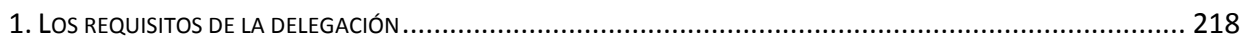

2. LA DELEGACIÓN EN EL DIRECTOR DEL CENTRO DE TRATAMIENTO DE DENUNCIAS AUTOMATIZADAS........................ 220

C) La delegación de la competencia sancionadora de las Comunidades Autónomas.......................... 222

D) La delegación de la competencia sancionadora Municipal ............................................................ 223

E) La delegación de competencias del Director General de Tráfico................................................... 224

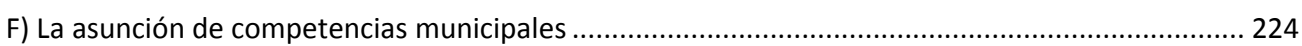

G) La delegación de competencias entre diferentes Administraciones ................................................ 226

H) El ejercicio de la competencia por el órgano delegado.......................................................... 227

Capítulo III: RESPONSABILIDAD POR LA COMISIÓN DE INFRACCIONES DE TRÁFICO

I. DE LA RESPONSABILIDAD POR AUTORÍA A LA RESPONSABILIDAD SIN AUTORÍA (LA CULPABILIDAD COMO PROBLEMA).

A) Autoría y responsabilidad: De la aparente simplicidad de las cosas ............................................... 230

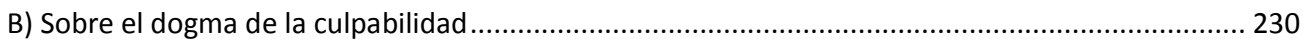

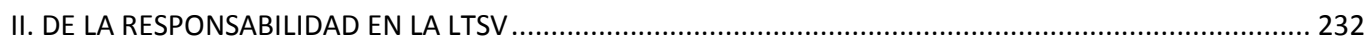

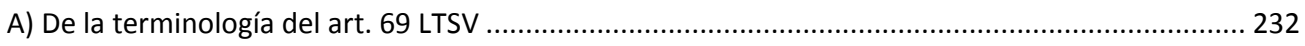

B) El principio general de la responsabilidad por autoría de la infracción ......................................... 233

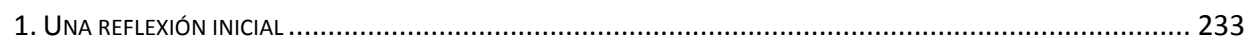

2. EL AUTOR Y EL RESPONSABLE DE LAS INFRACCIONES DE TRÁFICO Y SEGURIDAD VIAL .................................... 234

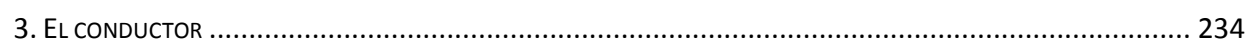

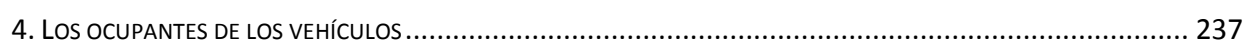


5. El TitUlar del Vehículo Y LA EQUIPARACIÓN QUE AL ÉL SE REALIZA DEL ARRENDATARIO A LARGO PLAZO

a) La necesidad de ubicar esta norma en su contexto histórico..................................... 238

b) La vigente configuración del titular y del arrendatario del vehículo.............................. 239

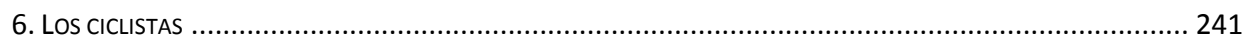

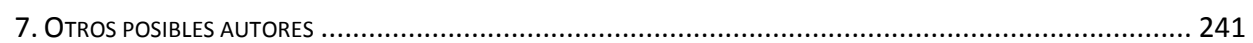

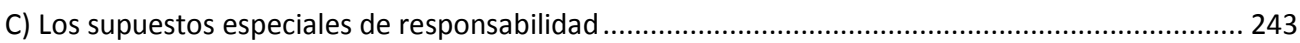

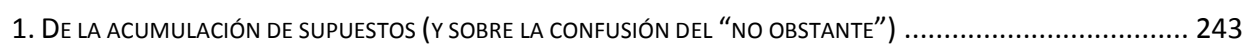

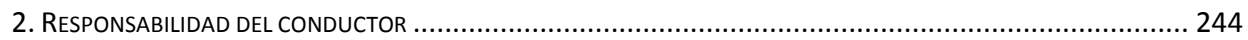

a) Responsabilidad del conductor por la no utilización por el ocupante del casco de seguridad. 244

b) Responsabilidad del conductor por transportar menores con edad inferior de la establecida para ello............................................................................... 246

c) Responsabilidad del conductor por la no de los preceptivos sistemas de

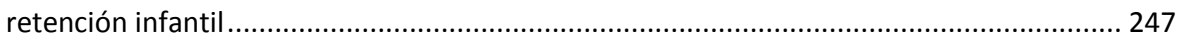

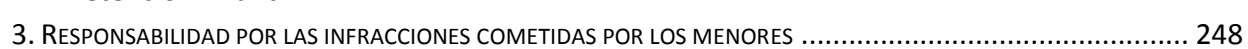

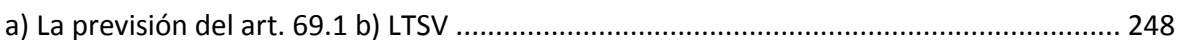

b) Integración en el propio sistema establecido en el art. 69.1 LTSV ............................... 249

4. LA RESPONSABILIDAD POR LA INFRACCIÓN COMETIDA POR CONDUCTOR NO IDENTIFICADO AL MOMENTO DE LA COMISIÓN DE LA INFRACCIÓN

a) Vehículos que no tuvieran designado conductor habitual (titular y

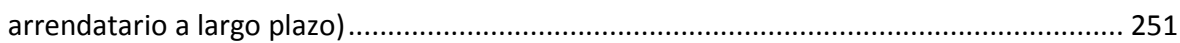

b) Vehículos que tuvieran designado conductor habitual ................................................. 251

c) Arrendamientos a corto plazo y depositarios de vehículos ....................................... 253

d) Infracciones de estacionamiento e impago de peajes ............................................. 253

e) Efectos de la declaración de responsabilidad ............................................................ 253

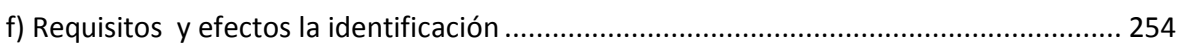

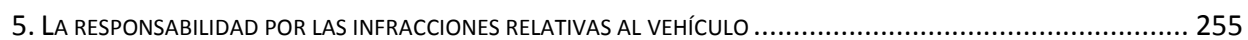

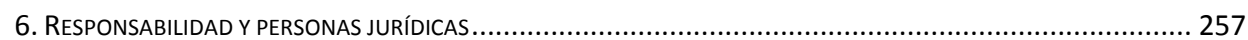

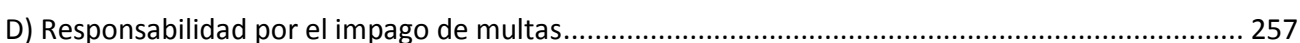

\section{Capítulo IV: LAS FASES DEL PROCEDIMIENTO ADMINISTRATIVO SANCIONADOR EN MATERIA

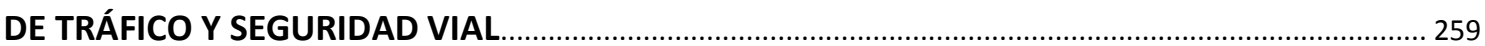

I. DE LA INICIACIÓN DEL PROCEDIMIENTO ADMINISTRATIVO SANCIONADOR EN MATERIA

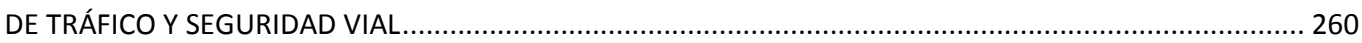

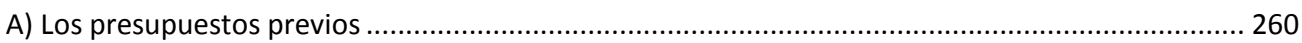

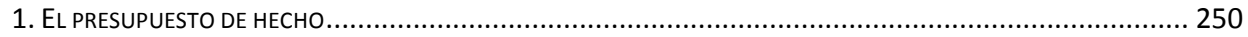

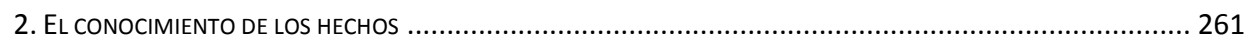

3. LA NECESIDAD DE DAR UN PASO ATRÁS: EL PELIGRO DE LA SENSACIÓN DE IMPUNIDAD Y SUS

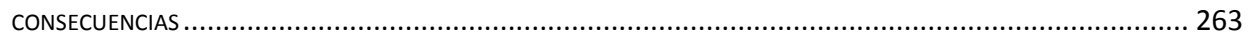

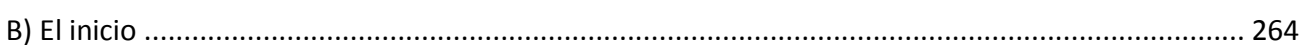

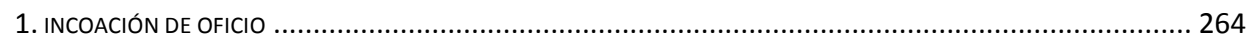

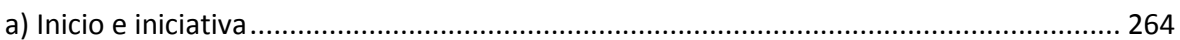

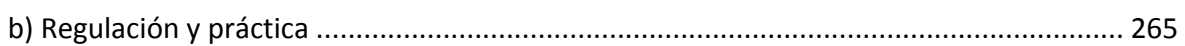

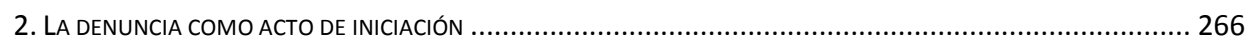

a) Denuncia formulada por los agentes de la autoridad encargados de la

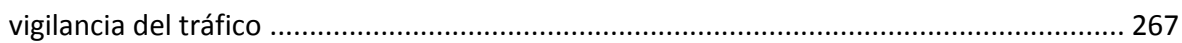

b) Que la denuncia sea notificada en el acto................................................................ 269

c) Sobre lo extraordinario de este modo de iniciación del procedimiento

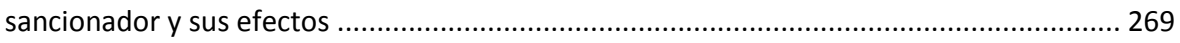

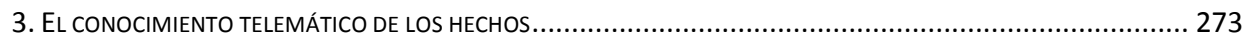

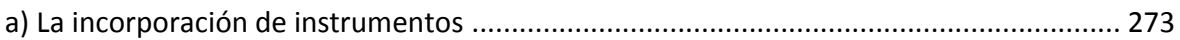

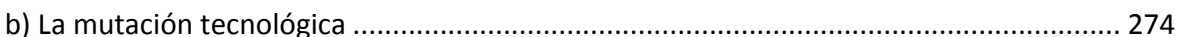


c) El procedimiento administrativo sancionador con uso de elementos

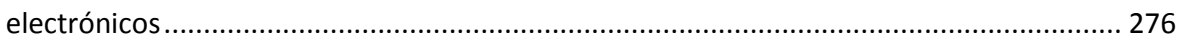

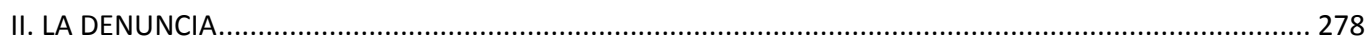

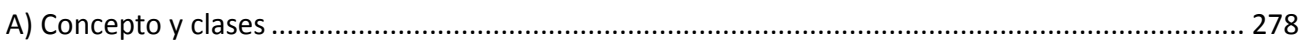

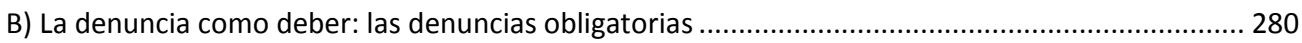

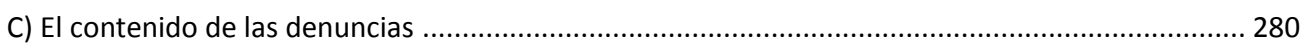

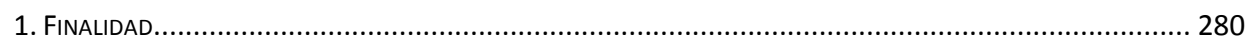

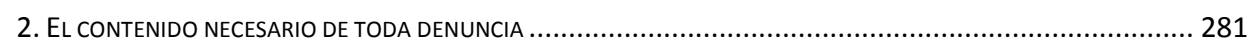

a) El carácter imprescindible de los requisitos previstos en el art. 74.2 LTSV ...................... 281

b) La identificación del vehículo con el que se hubiese cometido la supuesta

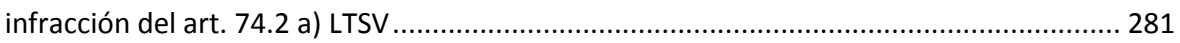

c) La identidad del denunciado, si fuere conocida del art. 74.2 b) LTSV ............................. 283

d) Una descripción sucinta del hecho, con expresión del lugar o tramo, fecha

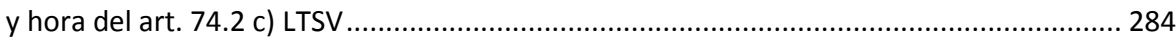

e) El nombre y domicilio del denunciante o, si fuera un Agente de la Autoridad, su número de identificación profesional del art. 74.2 d) LTSV ........................... 286

f) El incumplimiento del contenido necesario de las denuncias y sus efectos .......................287

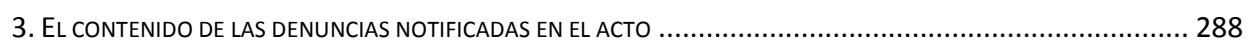

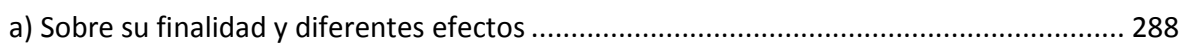

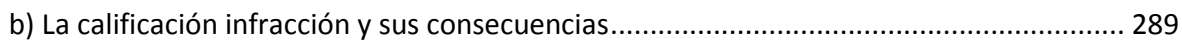

c) El órgano competente para imponer la sanción y la norma que le atribuye

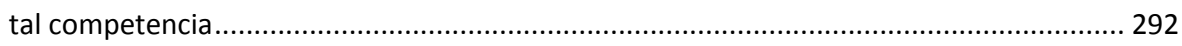

d) En función de si el denunciado procede, o no, al abono de la sanción

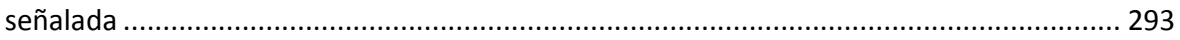

e) El domicilio que, en su caso, indique el interesado a efectos de

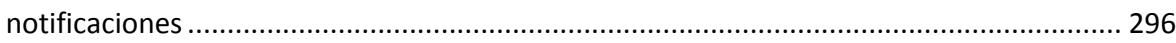

f) El incumplimiento del contenido de las denuncias notificadas en el acto y

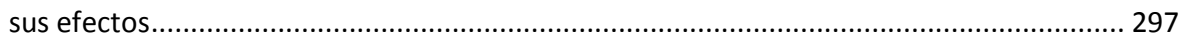

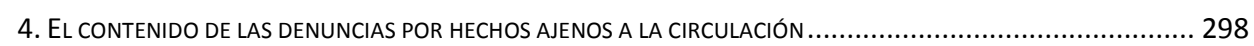

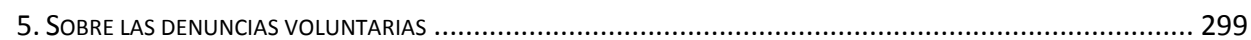

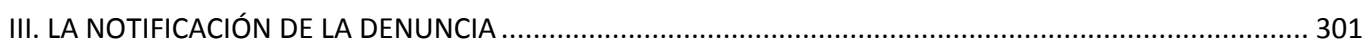

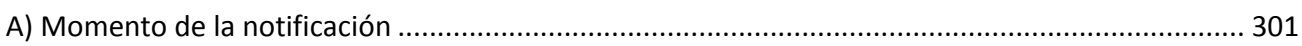

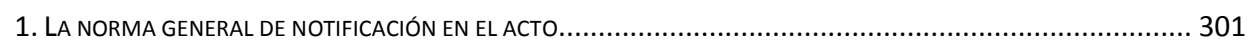

2. EXCEPCIONES A LA NORMA GENERAL: CIRCUNSTANCIAS QUE PERMITEN LA NOTIFICACIÓN EN UN

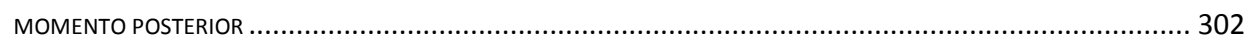

a) Que la denuncia se formule en circunstancias en que la detención del

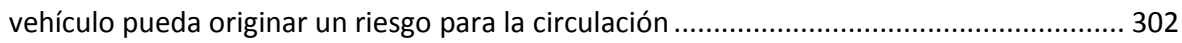

b) Que la denuncia se formule estando el vehículo estacionado, cuando el conductor no esté presente. 304

c) Que la autoridad sancionadora haya tenido conocimiento de los hechos a través de medios de captación y reproducción de imágenes que permitan la identificación del vehículo

3. EFECTOS DEL INCUMPLIMIENTO DE LA NORMA GENERAL QUE OBLIGA A LA NOTIFICACIÓN EN EL

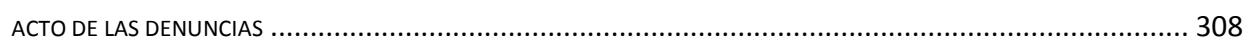

B) Práctica de la notificación de las denuncias (en momento posterior) ............................................ 308

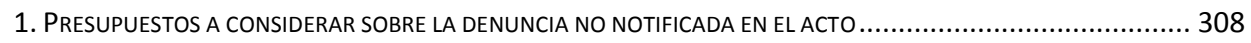

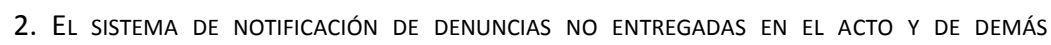

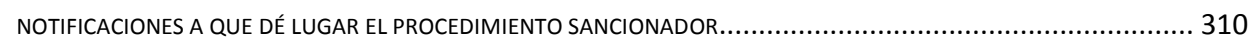

a) Una aproximación al sistema de notificaciones de los arts. 77 y 78 LTSV ....................... 310

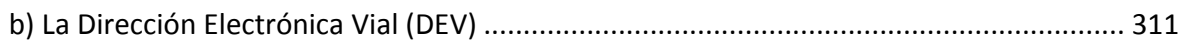

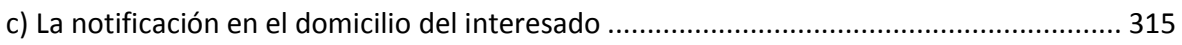

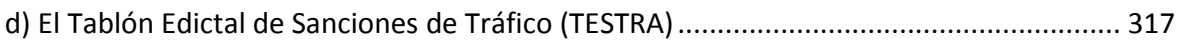

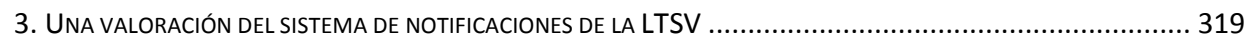

IV. LA PRUEBA.

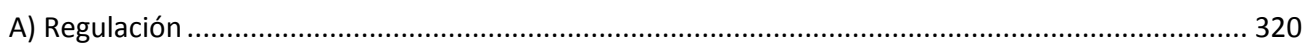


B) El Valor probatorio de las denuncias de los Agentes de la Autoridad ............................................ 323

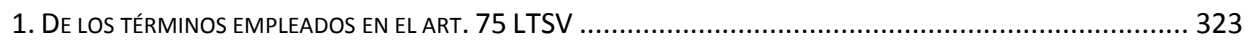

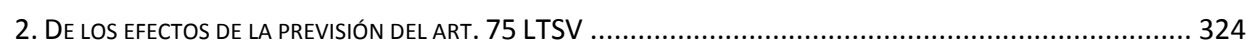

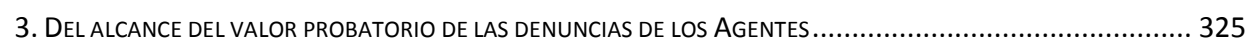

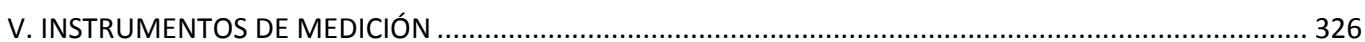

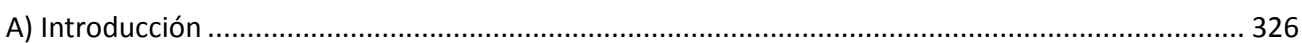

B) Cuestiones comunes a los instrumentos, aparatos o medios y sistema de medida que sean utilizados para la formulación de denuncias por infracciones a la normativa

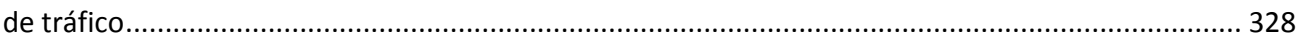

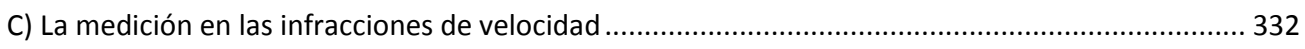

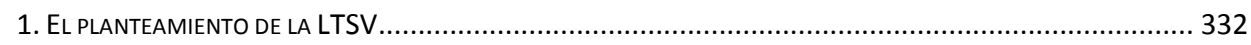

2. LOS ERRORES MÁXIMOS PERMITIDOS EN LOS INSTRUMENTOS UtILIZADOS PARA MEDIR LA

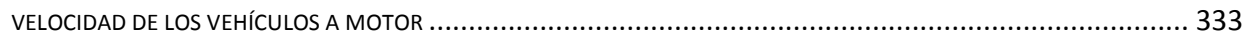

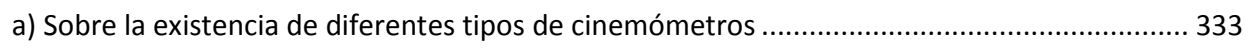

b) De los diferentes errores máximos permitidos para cada tipo de cinemómetro .................... 334

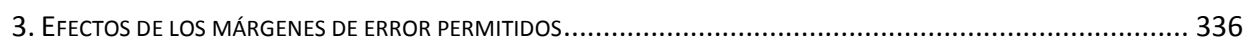

D) La medición en las infracciones por haber ingerido bebidas alcohólicas y conducir con tasas superiores a las que reglamentariamente se establezcan ................................................ 336

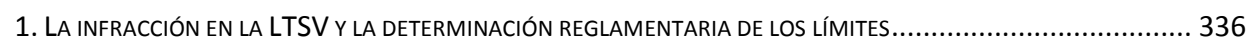

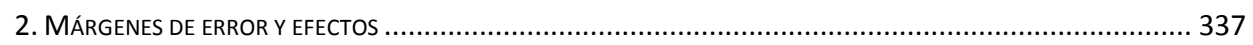

E) La determinación de las infracciones por conducción bajo los efectos de estupefacientes, psicotrópicos, estimulantes y otras sustancias análogas....................................... 338

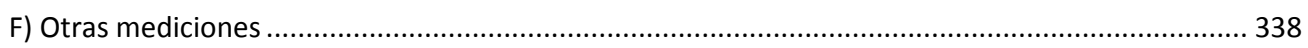

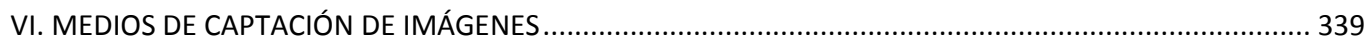

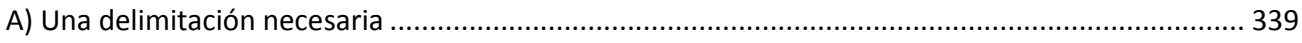

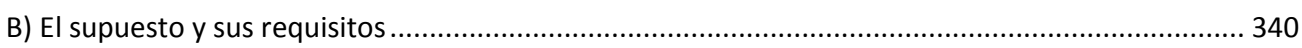

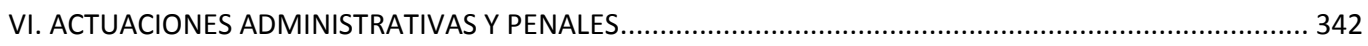

A) La concurrencia de ilícitos administrativos y tipos penales (como presupuesto).......................... 342

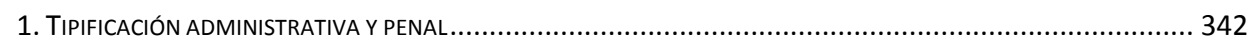

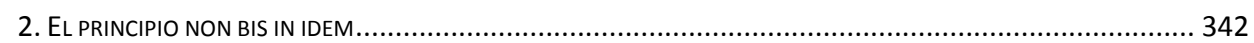

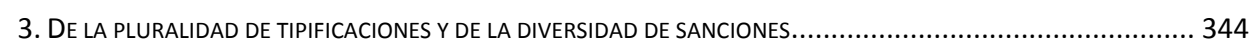

a) De las genéricas previsiones sobre tipos administrativos y penales .................................. 344

b) La distribución del ius puniendi en materia de tráfico y seguridad vial........................... 344

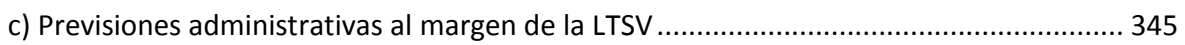

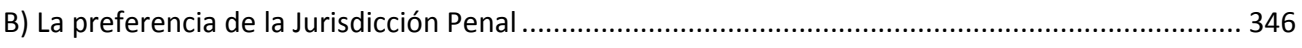

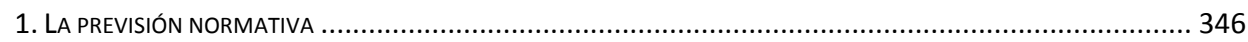

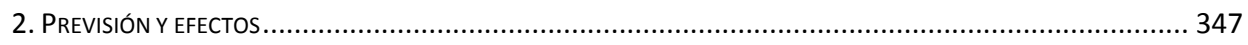

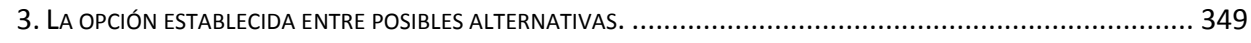

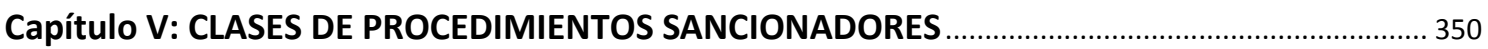

I. DE LA DETERMINACIÓN DE PROCEDIMIENTOS: CUESTIONES GENERALES Y DELIMITACIÓN ................... 351

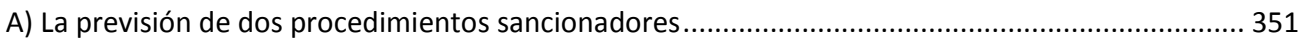

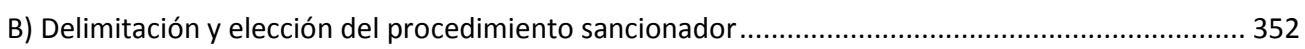

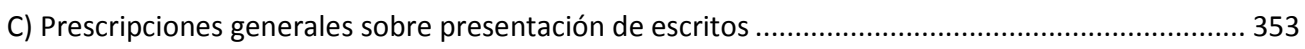

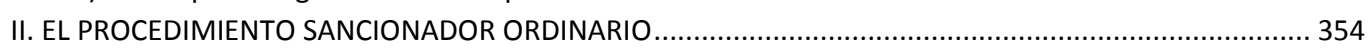

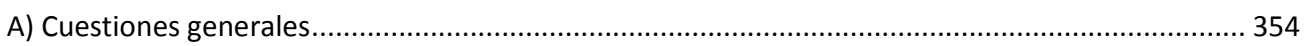

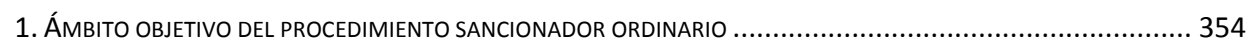

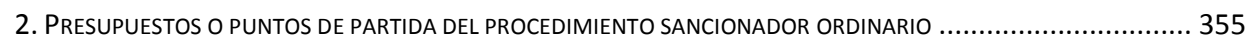

3. OtROS ASPECtOS formales SOBRE LA REGULACIÓN DEL PROCEDIMIENTO SANCIONADOR

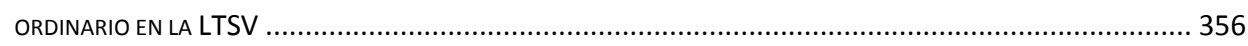

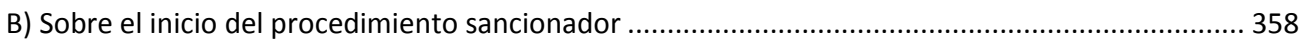

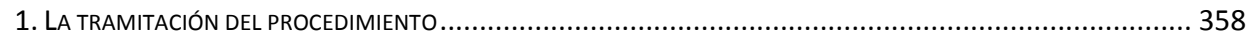

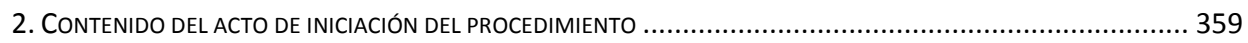




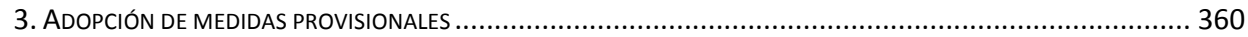

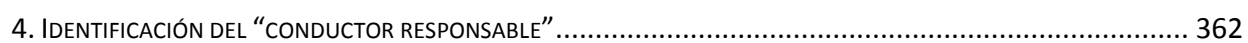

a) El cumplimiento del deber de identificación ..................................................................... 363

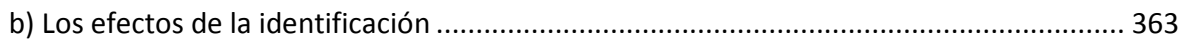

c) Tramitación por el procedimiento sancionador ordinario................................................. 364

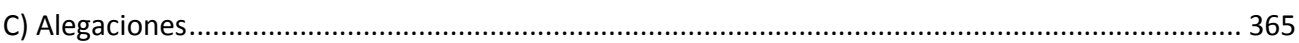

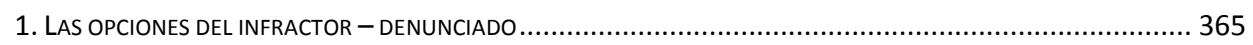

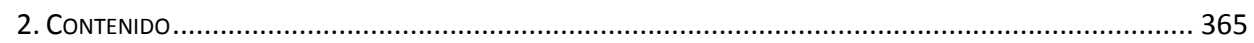

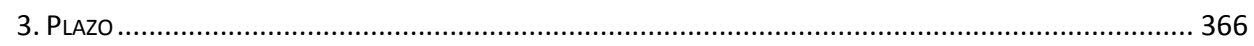

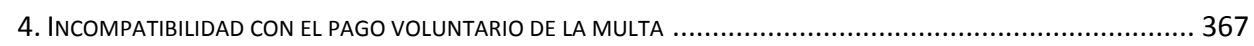

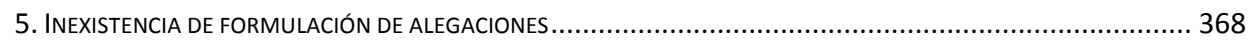

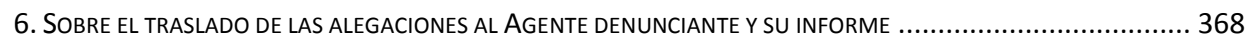

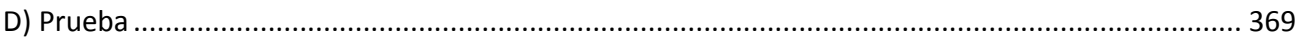

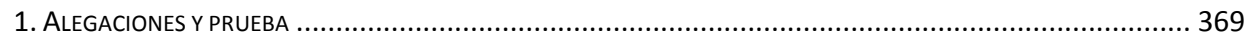

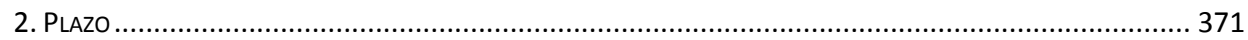

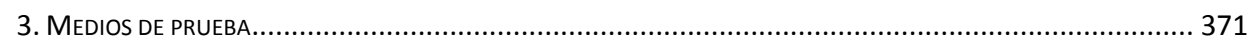

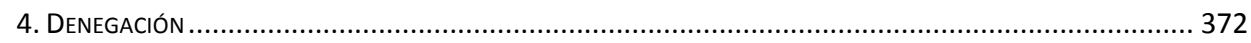

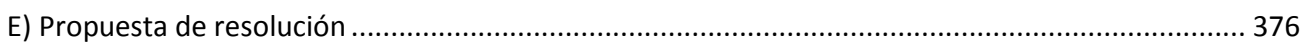

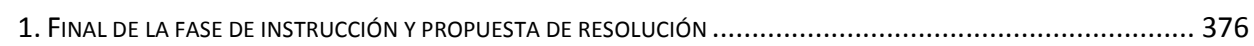

2. SUPUESTOS EN LOS QUE PROCEDE EL TRASLADO DE LA PROPUESTA DE RESOLUCIÓN AL INTERESADO .................... 377

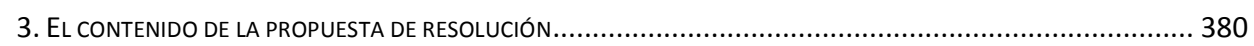

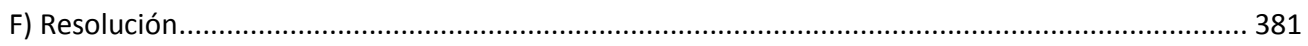

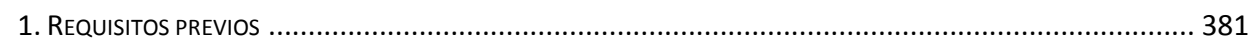

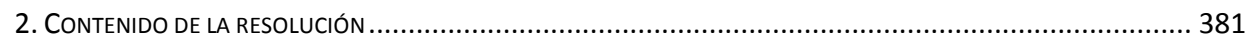

a) Resolución sancionadora o que declare la inexistencia de responsabilidad

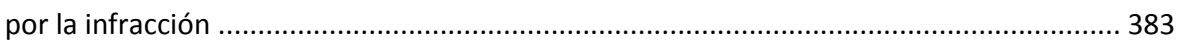

b) La resolución deberá de ser motivada ........................................................................... 385

c) La resolución decidirá todas las cuestiones planteadas por los interesados y aquellas otras derivadas del procedimiento.

d) La resolución no podrá tener en cuenta hechos distintos de los determinados en la fase de instrucción del procedimiento, sin perjuicio de

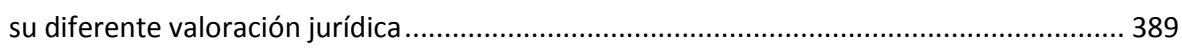

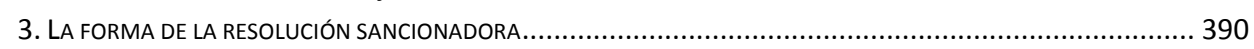

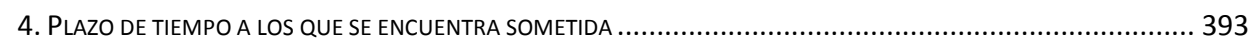

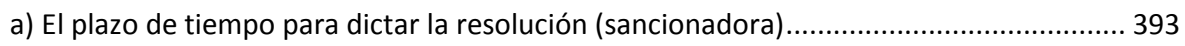

b) El plazo de tiempo para dictar la resolución desde que recibe la propuesta

de resolución del órgano instructor.....

G) Supuesto en el que el denunciado ni realiza alegaciones ni procede al pago de la

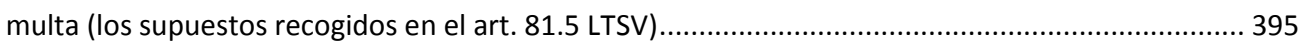

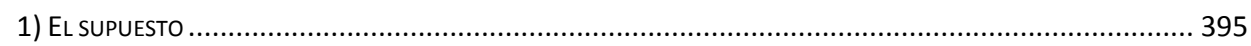

a) La inactividad del denunciado (notificado o dado por tal) .............................................. 395

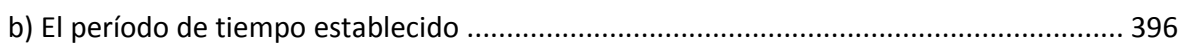

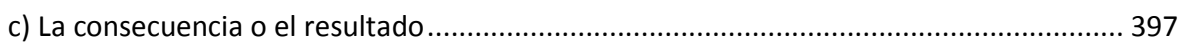

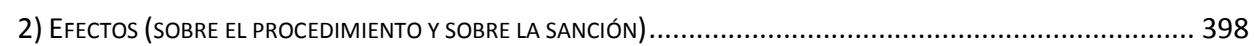

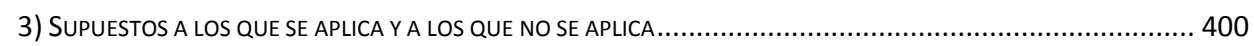

H) Otras causas de terminación (inexistencia o extinción de la responsabilidad) .............................. 401

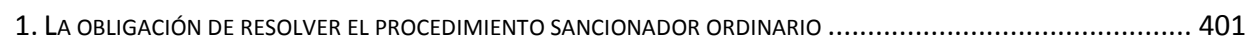

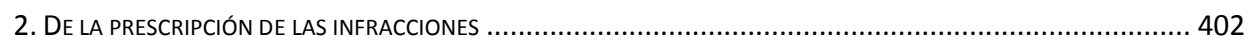

a) Sobre la evolución de la regulación de prescripción de las infracciones y

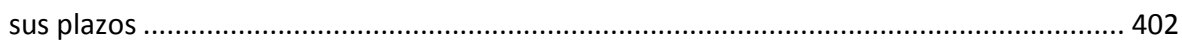

b) Sobre la actual regulación tras la reforma de la LTSV por la Ley 18/2009,

de 23 de noviembre

c) Sobre el cómputo de la prescripción de las infracciones de tráfico y seguridad vial. 
d) Sobre la interrupción de la prescripción de las infracciones de tráfico y seguridad vial

e) Sobre las actuaciones administrativas de las que tiene conocimiento el denunciado

f) Sobre las actuaciones administrativas para averiguar la identidad o el domicilio del denunciado.

g) Sobre la práctica de la notificación de la propia denuncia

h) Sobre la reanudación del plazo de prescripción de las infracciones de tráfico y seguridad vial

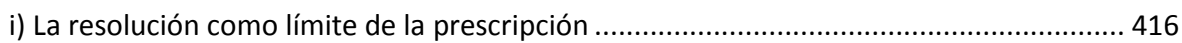

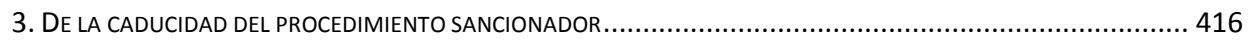

a) De las previsiones específicamente establecidas en la LTSV .......................................... 416

b) Sobre algunas cuestiones previstas en el régimen general.......................................... 418

c) Del supuesto de paralización del procedimiento sancionador por

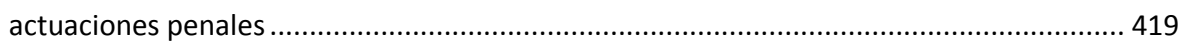

d) La resolución como límite de la caducidad del procedimiento .......................................420

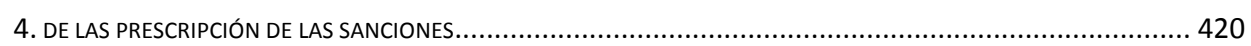

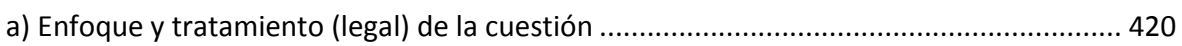

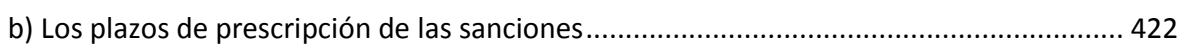

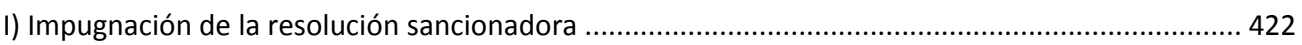

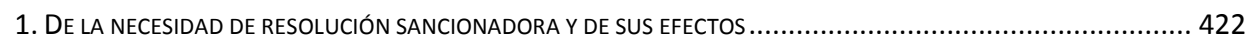

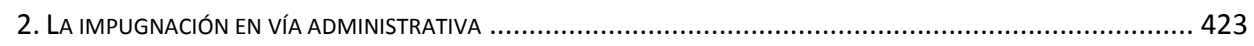

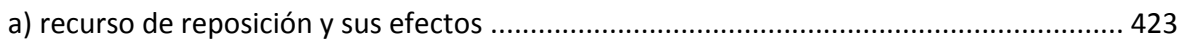

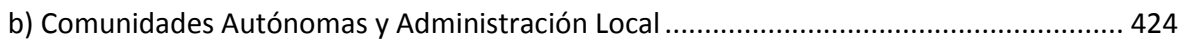

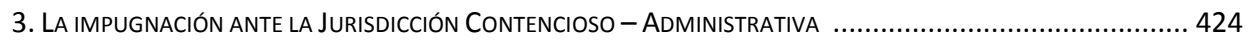

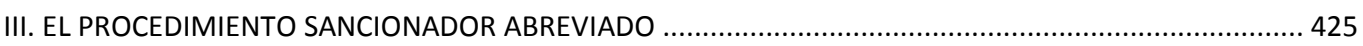

A) Ubicación de este procedimiento en el marco del procedimiento sancionador en materia de tráfico

B) El pago de la multa en el plazo de quince días naturales como presupuesto del procedimiento sancionador abreviado.

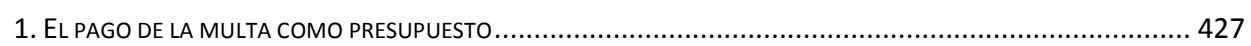

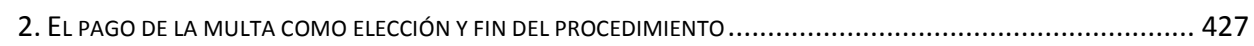

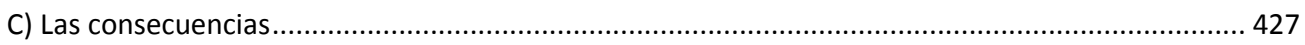

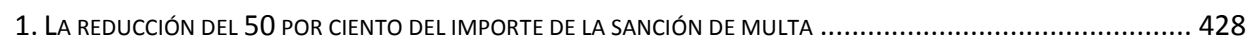

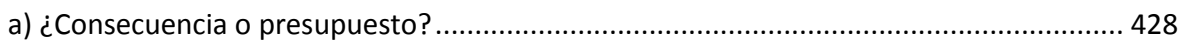

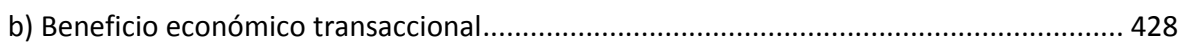

c) Alcance del beneficio de reducción del 50 por ciento ................................................... 429

2. La RenunCia a formular alegaciones que, en CASO de QUe fUeSen formuladas, SE

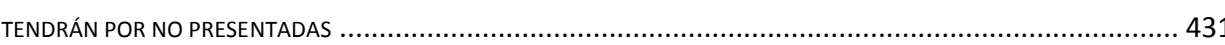

3. LA TERMINACIÓN DEL PROCEDIMIENTO, SIN NECESIDAD DE DICTAR RESOLUCIÓN EXPRESA, EL DÍA EN QUE SE REALICE EL PAGO

a) Forma: "La terminación del procedimiento, sin necesidad de dictar resolución expresa,..."

b) Dies a quo: “La terminación del procedimiento... el día en que se realice el pago"...

4. EL AGOTAMIENTO DE LA VÍA ADMINISTRATIVA SIENDO RECURRIBLE ÚNICAMENTE ANTE EL ORDEN JURISDICCIONAL CONTENCIOSO-ADMINISTRATIVO

5. RECURRIBILIDAD EN EL ORDEN JURISDICCIONAL CONTENCIOSO - ADMINISTRATIVO Y PLAZO PARA INTERPONER EL RECURSO CONTENCIOSO - ADMINISTRATIVO SE INICIARÁ EL DÍA SIGUIENTE A AQUEL EN QUE TENGA LUGAR EL PAGO

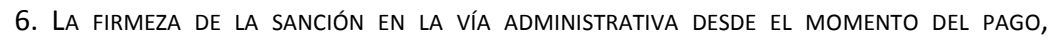
PRODUCIENDO PLENOS EFECTOS DESDE EL DÍA SIGUIENTE

7. La sanción No COMPUTARÁ COMO ANTECEDENTE en EL ReGISTRO de CONDUCTORES E INFRACTORES, SIEMPRE QUE SE TRATE DE INFRACCIONES GRAVES QUE NO LLEVEN APAREJADA PÉRDIDA DE PUNTOS. 
D) A modo de conclusiones: Una valoración en conjunto de las consecuencias establecidas para las denuncias (expedientes sancionadores) tramitadas por el procedimiento sancionador abreviado

Capítulo VI: EL PERMISO DE CONDUCIR POR PUNTOS

I. LA INTRODUCCIÓN DEL PERMISO Y LICENCIA DE CONDUCCIÓN POR PUNTOS EN LA LEY DE TRÁFICO Y SEGURIDAD VIAL.

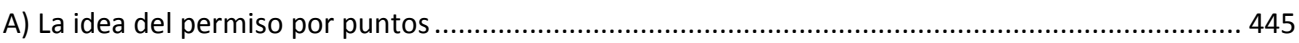

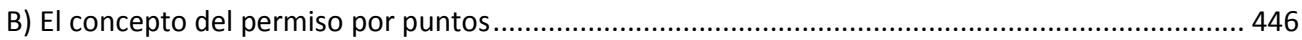

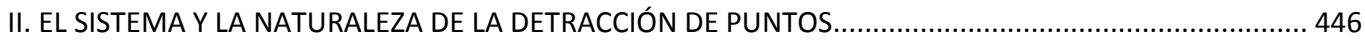

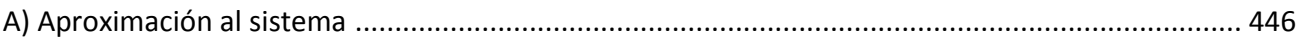

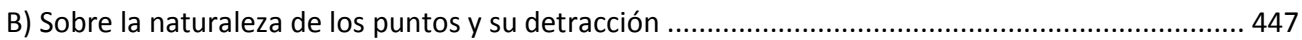

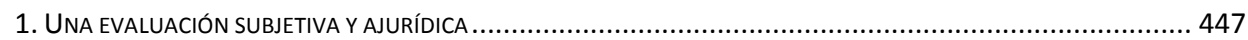

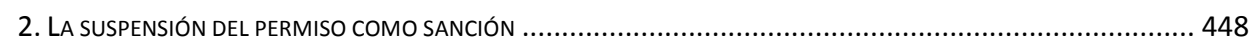

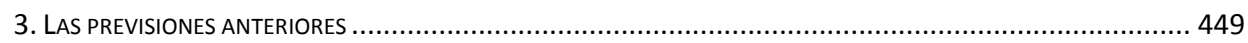

a) La regulación previa introducida en la LTSV por la Ley 19/2001, de 19 de

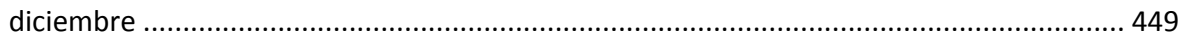

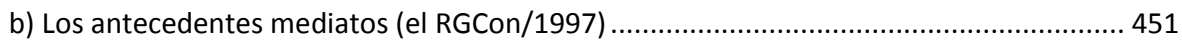

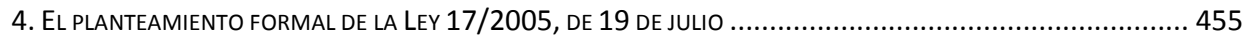

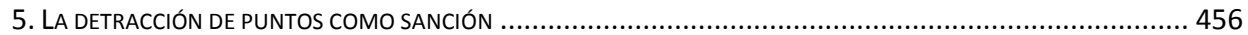

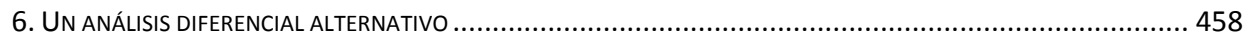

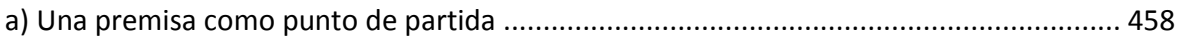

b) El sistema y sus elementos (el sistema por puntos y los puntos) .................................... 458

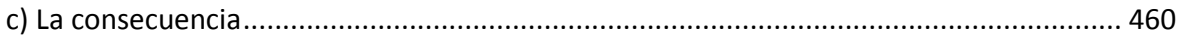

d) Algunas reflexiones y una conclusión provisional ............................................................. 461

III. EL PROCEDIMIENTO PARA LA DECLARACIÓN DE PÉRDIDA DE VIGENCIA ............................................. 462

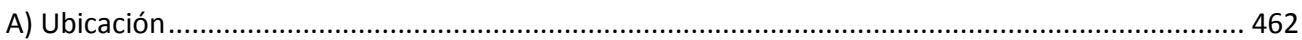

B) El Procedimiento de declaración de pérdida de vigencia ............................................................ 463

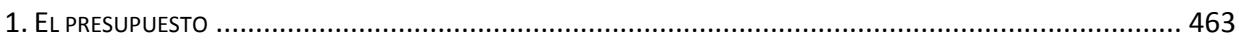

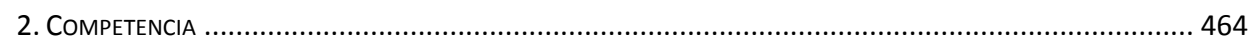

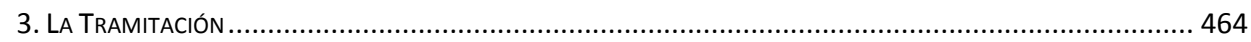

IV. ALGUNAS CONSIDERACIONES ADICIONALES Y UNA CONCLUSIÓN. ..................................................... 466 


\section{ABREVIATURAS}

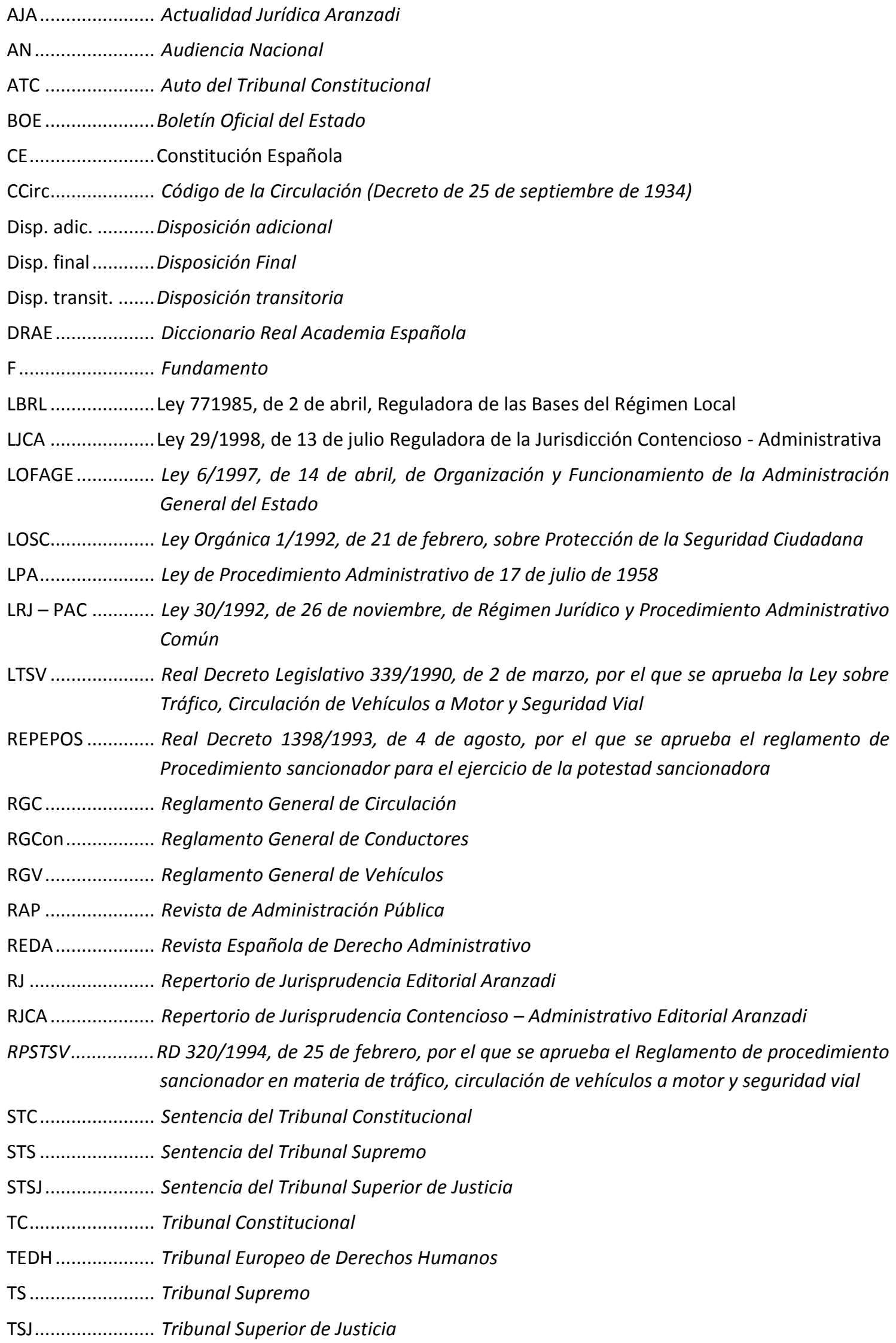

ATC Auto del Tribunal Constitucional

BOE Boletín Oficial del Estado

CE. Constitución Española

CCirc Código de la Circulación (Decreto de 25 de septiembre de 1934)

Disp. adic. Disposición adicional

Disp. final Disposición Final

Disp. transit. Disposición transitoria

DRAE . Diccionario Real Academia Española

F. Fundamento

LBRL Ley 771985, de 2 de abril, Reguladora de las Bases del Régimen Local

LJCA Ley 29/1998, de 13 de julio Reguladora de la Jurisdicción Contencioso - Administrativa

LOFAGE Ley 6/1997, de 14 de abril, de Organización y Funcionamiento de la Administración General del Estado

LOSC Ley Orgánica 1/1992, de 21 de febrero, sobre Protección de la Seguridad Ciudadana

LPA Ley de Procedimiento Administrativo de 17 de julio de 1958

LRJ - PAC Ley 30/1992, de 26 de noviembre, de Régimen Jurídico y Procedimiento Administrativo Común

LTSV Real Decreto Legislativo 339/1990, de 2 de marzo, por el que se aprueba la Ley sobre Tráfico, Circulación de Vehículos a Motor y Seguridad Vial

REPEPOS ............ Real Decreto 1398/1993, de 4 de agosto, por el que se aprueba el reglamento de Procedimiento sancionador para el ejercicio de la potestad sancionadora

RGC Reglamento General de Circulación

RGCon Reglamento General de Conductores

RGV Reglamento General de Vehículos

RAP Revista de Administración Pública

REDA. Revista Española de Derecho Administrativo

RJ Repertorio de Jurisprudencia Editorial Aranzadi

RJCA Repertorio de Jurisprudencia Contencioso - Administrativo Editorial Aranzadi

RPSTSV. RD 320/1994, de 25 de febrero, por el que se aprueba el Reglamento de procedimiento sancionador en materia de tráfico, circulación de vehículos a motor y seguridad vial

STC Sentencia del Tribunal Constitucional

STS Sentencia del Tribunal Supremo

STSJ Sentencia del Tribunal Superior de Justicia

TC. Tribunal Constitucional

TEDH Tribunal Europeo de Derechos Humanos

TS Tribunal Supremo

TSJ Tribunal Superior de Justicia 


\section{INTRODUCCIÓN}

El tráfico de vehículos, y las consecuencias que de él se derivan, hacen precisa la intervención de la Administración con el fin de garantizar la seguridad vial. Sobre esta sencilla premisa se asienta todo un universo de ideas, sobre la forma en la que ha realizarse ese control con el fin último (y esto es algo que no debe olvidarse) de que el ejercicio de la actividad suponga el menor coste para la sociedad.

Trasladar este concepto genérico al ámbito del tráfico de vehículos tiene (o debe tener) como resultado la conversión del propio término (tráfico, circulación o tránsito) en algo que vaya más allá de la propia actividad y que, por definición, incorpore la prevención sobre el resultado. Es el paso natural de circulación a tráfico y seguridad vial.

La nomenclatura utilizada hace uso del camino recorrido en el pasado siglo por las normas que regularon (o al menos eso pretendieron) la circulación de vehículos desde el Decreto de 25 de septiembre de $1934^{1}$ por el que se aprobaba el Código de la Circulación y sus Anexos hasta la promulgación del Real Decreto Legislativo 339/1990, de 2 de marzo, por el que se aprueba la Ley sobre Tráfico, Circulación de Vehículos a Motor y Seguridad Vial, de acuerdo con los principios y criterios contenidos en la Ley de Bases 18/1989, de 25 de julio (a la que nos referiremos como LTSV). Y de ahí, sobre esa base normativa, hasta la actualidad.

Es indudable que a lo largo de todo este tiempo se han producido notables avances, pero también lo es que en cuanto al resultado, la Administración, los poderes públicos, han sido incapaces de establecer un sistema que, de manera real y efectiva, haya garantizado la seguridad vial.

El tráfico se ha convertido en un fenómeno de masas, tal vez en "el fenómeno de masas" y ello ha supuesto la existencia de determinados problemas a los que no se ha sabido hacer frente.

Es en este lugar ( $y$ no en otro) donde resulta preciso ubicar el procedimiento sancionador en materia de tráfico y (sobre todo) de seguridad vial. El régimen

\footnotetext{
${ }^{1}$ En el primer párrafo del texto introductorio que antecede al Código de la Circulación de 1934 se puede leer "El incesante progreso de la industria del automóvil, la importancia adquirida por el transporte de viajeros y mercancías y el mejoramiento de nuestras vías públicas han aumentado la circulación de un modo insospechado, y por hallarse atribuido el conocimiento de las expresadas materias a diversos ramos de la Administración pública, ésta ha dictado, por medio de distintos organismos, multitud de disposiciones que aparecen dispersas y faltas de la necesaria unidad de criterio, originando, con frecuencia, confusión y perturbaciones en los servicios, que es forzoso evitar", ideas que bien podrían ser usadas en cualquier norma actual en materia de tráfico y seguridad vial.
} 
sancionador ha de cumplir con la finalidad que le corresponde. El régimen sancionador, y su procedimiento, son un instrumento al servicio de un fin que, en este caso, es el de garantizar que los ciudadanos desarrollan esa actividad de manera segura.

El régimen sancionador, y el procedimiento para hacerlo efectivo, son instrumentos (mucho más valiosos, por cierto, de lo que normalmente se estima) al servicio de la Administración y, por lo tanto, de la sociedad a la que aquellas sirve. Son medios, y no fines en sí mismos. Son mecanismos en manos de las Administraciones públicas, de todas las implicadas, que tienen la obligación de servir con objetividad a los intereses generales, y que para ello, tienen que actuar de acuerdo con los principios de eficacia, jerarquía, descentralización, desconcentración y coordinación con sometimiento pleno a la Ley y al Derecho, instrumentos al servicio de la seguridad de los ciudadanos.

Hay un objetivo, garantizar la seguridad de los usuarios de las vías públicas de comunicación, de los que por ellas transitan, de todas las personas que hacen uso de ellas. El fenómeno, por su propia naturaleza y efectos, requiere de una regulación, de unas normas de funcionamiento, de una Administración (o Administraciones) que velen por ese funcionamiento regular. Que esas normas impuestas en base a la seguridad de los usuarios (eso es la seguridad vial y no otra cosa) se cumplan, porque su cumplimiento garantiza (cierto es que en abstracto) esa seguridad. $Y$ en caso de incumplimiento la Administración está ahí para con sus poderes, con sus potestades, imponer sanciones a los transgresores.

Y esa actuación represiva, que ataca los derechos del ciudadano transgresor, tiene que ser realizada, necesariamente, con todas las garantías. La imposición de las consecuencias al responsable de una acción proscrita necesita ser realizada conforme al procedimiento establecido y con todas las garantías que un estado social y democrático de derecho impone.

En este escenario de fenómeno masificado, de actividad cotidiana, de derechos de los infractores, de normas sustantivas en ocasiones confusas, de interpretaciones simplistas e interesadas, tiene que desenvolverse un procedimiento, el sancionador en materia de tráfico y seguridad vial, que no pretende más que trasladar al responsable la consecuencia de sus actos.

La Administración se encuentra limitada en su actuar. No puede hacer lo que quiera, como quiera y cuando quiera. Al igual que los ciudadanos está sometida a la Ley y al Derecho. Tiene que atenerse a las normas, tiene que garantizar derechos, tiene que actuar respetando el procedimiento legalmente establecido, que en el caso de la imposición de sanciones requiere de la correspondiente previsión legal... y sólo así puede llegar a imponer la consecuencia legalmente prevista al responsable de esa infracción administrativa (o, en su caso, del tipo penal). La Administración tiene que 
actuar en el marco de las competencias atribuidas por el ordenamiento jurídico y en el ámbito del tráfico y seguridad vial confluyen diferentes Administraciones junto con diversos ámbitos competenciales. Competencias para normar y, a su vez, en diferentes espacios, para incoar, para tramitar, para sancionar, para hacer efectivas y exigir las sanciones impuestas, para controlar las consecuencias accesorias.

Todo ello con el objeto de determinar y depurar responsabilidades, algo que, en este ámbito del tráfico y la seguridad vial, también se complica por diversas razones. Objetivamente por la confluencia, al lado de las infracciones administrativas, de tipos penales que, en no pocas ocasiones, presentan problemas de delimitación. Subjetivamente por el hecho de la presencia de personas jurídicas que, en bastantes casos, se alzan frente al procedimiento, diluyendo, cuando no impidiendo, la normal imposición de la sanción que el correspondiente procedimiento pretende imponer.

El tráfico, sí, ese fenómeno que "se ha generalizado y extendido de tal manera que puede afirmarse que forma parte de la vida cotidiana y que se ha transformado en una de las expresiones más genuinas del ejercicio de la libertad de circulación" ${ }^{2}$, esa actividad en la que todos intervenimos, práctica habitual que, en el caso de la conducción de vehículos a motor y ciclomotores, está sometida a autorización, con millones de conductores y vehículos continuamente circulando por vías y terrenos aptos para la circulación ${ }^{3}$, y en esa actividad es preciso respetar unas normas cuya transgresión, en el caso de las infracciones administrativas, serán sancionadas en los casos, forma y medida que en la propia Ley de Tráfico se determine (como establece el art. 65.1 LTSV), lo que requiere del correspondiente procedimiento sancionador ya que no se podrá imponer sanción alguna por las infracciones tipificadas en la Ley de Tráfico sino en virtud de procedimiento instruido con arreglo a lo dispuesto en la propia Ley de Tráfico y en las disposiciones reglamentarias que lo desarrollen y, supletoriamente, por lo dispuesto en la Ley 30/1992, de 26 de noviembre, de Régimen Jurídico de las Administraciones Públicas y del Procedimiento Administrativo Común (LRJ - PAC), tal y como establece el art. 70.1 LTSV y que no hace más que trasladar al específico ámbito del tráfico y la seguridad vial los principios que inspiran, fundamentan y regulan las garantías procedimentales que nuestro ordenamiento jurídico otorga a quien (presuntamente) ha cometido una infracción administrativa (que incluso puede derivar en un tipo penal contra la seguridad vial).

\footnotetext{
${ }^{2}$ Términos, éstos, empleados por la introducción que precede al texto de la Ley de Tráfico y Seguridad Vial (Cfr. el párrafo segundo de esa explicación previa).

${ }^{3}$ Los términos de los que hace uso el art. 2 LT para definir el ámbito de aplicación de la propia Ley de Tráfico y seguridad vial no son ya, de por sí, sencillos. Esa delimitación prescribe que "los preceptos de esta Ley serán aplicables en todo el territorio nacional y obligarán a los titulares y usuarios de las vías y terrenos públicos aptos para la circulación, tanto urbanos como interurbanos, a los de las vías y terrenos que, sin tener tal aptitud sean de uso común y, en defecto de otras normas, a los titulares de las vías y terrenos privados que sean utilizados por una colectividad indeterminada de usuarios."
} 
El procedimiento sancionador en materia de tráfico y seguridad vial actúa, se desarrolla y ubica, como procedimiento sancionador que es, en la tensión entre legalidad y garantía, entre derechos individuales y derechos colectivos, entre la eficacia y eficiencia y la seguridad jurídica.

Procedimiento como garantía para el presunto infractor pero que, al mismo tiempo y de igual manera, exige de la Administración depurar las correspondientes responsabilidades. Eso es (y si no lo es, debería serlo) la seguridad vial.

La circulación de vehículos ha tenido y tiene innegables secuelas negativas de las que su máximo exponente son los accidentes de circulación, que representan un alto coste para la sociedad y vienen a acentuar la obligada intervención de los poderes públicos en el mantenimiento de la seguridad de la circulación vial ${ }^{4}$, datos que, por sí mismos, suponen que en esta materia, la de la seguridad vual, "la complacencia está fuera de lugar" ${ }^{5}$. La tensión entre infracciones, riesgos, responsables, garantías procedimentales en la imposición de sanciones y seguridad de los usuarios es importante y la consistencia del sistema, como garantía de todos los intereses generales en presencia, mínima. No existe (ni ha existido jamás) un ámbito de actividad en el que la tolerancia de la Administración, como garante de los intereses generales, y de la propia sociedad, con los resultados a soportar haya sido tan alta. Se han asumido con normalidad unas cifras que no encuentran parangón en ningún ámbito de actividad civil y que únicamente podrían ser comparables con el resultado de un gran conflicto bélico.

Pero, además de todos esos problemas comunes, el procedimiento sancionador en materia de tráfico y seguridad vial se inserta, y enfrenta, en un ámbito masificado. Millones de infracciones que dan lugar a millones de procedimientos por cuantías, que aunque individualmente consideradas, son ínfimas, suponen y necesitan de ser sustanciadas en un procedimiento con todas las garantías y en la que los dobleces de ese control de ingentes cantidades de conductas da lugar a un intrincado laberinto en el que, de haber sido el construido en Creta, seguiría deambulando Teseo por muchos esfuerzos que Ariadna hubiera realizado.

Este es el escenario que aquí se pretende abordar y para ello resulta preciso un guión argumental y una trama. Es preciso, en primer término, y antes de pretender siquiera el análisis de la regulación actual, entender la forma en la que se ha llegado a la actual

\footnotetext{
${ }^{4} \mathrm{Cfr}$. el párrafo segundo de la exposición que antecede a la propia Ley de Tráfico.

${ }^{5}$ La Comunicación de la Comisión al Consejo, al Parlamento Europeo, al Comité Económico y Social y al Comité de las Regiones - Prioridades de la seguridad vial de la UE - Informe de situación y clasificación de las acciones (COM/2000/0125 final) se inicia con el siguiente párrafo:

"La complacencia está fuera de lugar en cuestiones de seguridad vial. Aunque el número de víctimas mortales tiende a disminuir, este declive se estabiliza actualmente y más de 40.000 ciudadanos de la UE siguen encontrando una muerte prematura en nuestras carreteras".

Nótese, en cuanto a las cifras que se manejan, que en aquél momento, año 2000, los datos se corresponden con una Unión Europea integrada por 15 Estados (y no con los 27 que actualmente la componen).
} 
regulación. Se hace preciso analizar la evolución, a lo largo del siglo XX, de la forma en la que se han ordenado los mecanismos que permitían depurar responsabilidades por la realización de conductas contrarias a las normas reguladoras de la circulación primero y, más tarde, del tráfico y la seguridad vial. Ello nos ha de permitir entender el sistema tal y como se encuentra configurado en la actualidad.

Porque el procedimiento administrativo sancionador en materia de tráfico y seguridad es un sistema, es decir, un "conjunto de reglas o principios sobre una materia racionalmente enlazados entre sí" o, al menos, pretende serlo. Pero los sistemas jurídicos, los grupos normativos (o partes funcionales de esos grupos o sistemas) no funcionan de forma aislada e independiente del resto de previsiones jurídicas.

Por ello, y al lado de las previsiones que de manera específica regulan el procedimiento administrativo sancionador en materia de tráfico y seguridad vial se hace preciso tomar en consideración otros elementos. $\mathrm{Y}$, así, en este ámbito se ha considerado unir otras piezas a las que de manera esencial y de forma estricta constituyen ese procedimiento sancionador. Al lado de las fases procedimentales y de las clases de procedimientos se analiza otras cuestiones como son competencia sancionadora y responsabilidad. Y ese análisis de los elementos subjetivos se realiza de manera previa y condicionada por la orientación de su incidencia en el procedimiento sancionador en materia de tráfico y seguridad vial. Lo mismo sucede con el sistema del permiso de conducir por puntos en cuanto su relación con el procedimiento sancionador. No se trata, en estos casos, de análisis finales. Se trata de exploraciones mediales en cuanto a la relación, e interacción, que presentan con el objeto directo de esta obra que es el cauce que permite depurar responsabilidades por la infracción de las previsiones establecidas en la Ley de Tráfico y Seguridad Vial.

$Y$, al mismo tiempo, tomando en consideración las interpretaciones que de esa normativa, de la letra de la norma y de su aplicación al caso concreto, han ido realizando los diferentes Juzgados y Tribunales.

Procedimiento sancionador que es el cierre del sistema, de ese conjunto de normas que, de manera organizada, pretenden la ordenación del tráfico de vehículos, como instrumento que garantice el cumplimiento de esa regulación que, a su vez, tiene como finalidad preservar la seguridad vial.

Las normas que regulan el tráfico de vehículos como sistema, no son (ni pueden constituirse) en un fin en sí mismo. Ni siquiera el procedimiento sancionador, como cierre o garantía del sistema, lo es. Son medios, instrumentos al servicio del fin primordial que ese conjunto de disposiciones ordenadas tiene como misión, que no es otra que la de salvaguardar la seguridad de los ciudadanos y permitir aproximarse, en la mayor medida posible, que el tráfico de vehículos se realice de forma segura. 
El objetivo de estudio y análisis es el procedimiento sancionador en materia de tráfico y seguridad vial, pero eso sí, sin olvidar en momento alguno que se trata de un medio, de un instrumento al servicio de la seguridad vial. 


\section{Capítulo I}

\section{LA REGULACIÓN DEL PROCEDIMIENTO SANCIONADOR EN MATERIA DE TRÁFICO Y SEGURIDAD VIAL}

SUMARIO: I. LA EVOLUCIÓN NORMATIVA DEL TRÁFICO Y LA SEGURIDAD VIAL: A) La regulación preconstitucional; B) El Código de la Circulación de 1934; C) Las modificaciones del Código de la Circulación de 1934; D) La apertura de una vía paralela y la creación de la Jefatura Central de Tráfico; E) Una continua evolución. II. CONSTITUCIÓN Y PROCEDIMIENTO SANCIONADOR EN MATERIA DE TRÁFICO: A) El Tráfico en el texto constitucional: 1. LAS REFERENCIAS AL TRÁFICO Y LA

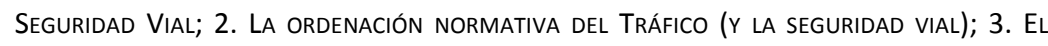
PRINCIPIO DE LEGALIDAD EN LA REGULACIÓN DEL PROCEDIMIENTO SANCIONADOR EN MATERIA DE TRÁfico; 4. El Código de la Circulación tras la promulgación de la Constitución. B) La Ley de Bases (Ley 18/1989, de 25 de julio, de Bases de Tráfico, Circulación de Vehículos a Motor y Seguridad Vial): 1. EL MODELO ELEGIDO: LA LEY DE BASES Y SU DENOMINACIÓN: a) Sobre la denominación de la norma; b) El sistema elegido para cumplir con la reserva de ley; c) Sobre la elección de este sistema (justificación y valoración). 2. LAS BASES DEL PROCEDIMIENTO SANCIONADOR EN MATERIA DE TRÁFICO; 3. EL CONTROL DEL RESUltado: a) Dictamen del Consejo de Estado; b) Control parlamentario; c) Control judicial; d) Control de constitucionalidad. III. LA LEY DE TRÁFICO (RDLEG 339/1990, DE 2 DE MARZO, QUE APRUEBA EL TEXTO ARTICULADO DE LA LEY SOBRE TRÁFICO, CIRCULACIÓN DE VEHÍCULOS A MOTOR Y SEGURIDAD VIAL): A) La norma; B) El Régimen sancionador en la Ley de Tráfico y Seguridad Vial; C) El procedimiento sancionador; D) Una primera aproximación al punto de partida del procedimiento sancionador establecido en la Ley de Tráfico y Seguridad Vial: 1. UN PROCEDIMIENTO SUSTENTADO EN LA LPA; 2. NON BIS IN IDEM Y CONCURRENCIA DE ACTUACIONES ADMINISTRATIVAS Y PENALES; 3. DeNUNCIAS; 4. NOTIFICACIONES; 5. LA PARTICIPACIÓN DE DENUNCIADO; 6. LAS GARANTías INDIVIDUALES; 7. OTRAS PREVISIONES EXTRAORDINARIAS. E) Una primera valoración del procedimiento sancionador establecido en la Ley de Tráfico y Seguridad Vial como punto de partida: 1. UN PROCEDIMIENTO GENÉTICAMENTE LASTRADO; 2. UNA INEFICIENTE PREVISIÓN PARA LA INTEGRACIÓN DE ACTUACIONES ADMINISTRATIVAS Y PENALES; 3. LA DENUNCIA Y SU POSICIÓN EN EL PROCEDIMIENTO, 4. LA NOTIFICACIÓN COMO TRINCHERA DE UNOS MALENTENDIDOS DERECHOS; 5. LAS alegaCiones del denunCIADO COMO LASTRE PROCEDIMENTAL; 6. UNA FORMA UNIDIRECCIONAL (Y EQUIVOCADA) DE ENTENDER LAS GARANTías PROCEDIMENTALES. IV. MODIFICACIONES Y DESARROLLO DE LA LEY DE TRÁFICO Y SEGURIDAD VIAL: A) Reglamento General de Circulación de 1992; B) Un cambio profundo y silencioso: la promulgación de la LRJ - PAC; C) El Reglamento de Procedimiento sancionador en materia de tráfico, circulación de vehículos a motor y seguridad vial de 1994: 1. LA NORMA; 2. SU CONTENIDO: a) Las bases del procedimiento, b) Actuaciones administrativas y penales; c) Sobre la iniciación del procedimiento; d) Denuncias; e) Instrucción y tramitación; f) Notificaciones; g) Resolución (y propuesta de resolución); h) Caducidad del procedimiento; i) Prescripción de infracciones y 
sanciones; j) Impugnación de resoluciones; k) Anotación y cancelación de sanciones; I) Ejecución de sanciones y cobro de multas; $m$ ) El efecto derogatorio del RPSTSV. D) Ley 5/1997, de 24 de marzo, de reforma de la Ley de Tráfico y Seguridad Vial: 1. La Reforma EN SU CONJUNTO; 2. LA MODIFICACIÓN DEL PLAZO DE PRESCRIPCIÓN DE LAS INFRACCIONES. E) El Reglamento General de Conductores de 1997: 1. Desarrollo ltsv y contenido sancionador; 2. El Registro de Conductores e INFRACTORES. F) El Real Decreto - ley 12/1997, de 1 de agosto: 1. UN (OTRO) ERROR LEGISLATIVO; 2. El mÉtodo elegido para LA ReCtificación del eRror. G) El Real Decreto 116/1998, de 30 de enero (que modifica el RPSTSV): 1. PresCRIPCIÓN DE INFRACCIONES: PLAZO Y CÓMPUTO; 2. COMPROBACIÓN DE LA PRESCRIPCIÓN; 3. INTERRUPCIÓN DEL PLAZO DE PRESCRIPCIÓN; 4. LA MODIFICACIÓN DEL ART. 28 RGC. H) El Real Decreto 2822/1998, de 23 de diciembre, por el que se aprueba el Reglamento General de Vehículos. I) Un cambio profundo y nada silencioso: la Ley 4/1999, de 13 de enero, de modificación de la LRJ - PAC. J) El Real Decreto 137/2000, de 30 de enero (que modifica el RPSTSV): 1. PROPUESTA de RESOLUCIÓn; 2. Resolución SANCIONADORA; 3. CAdUCIDAD Del PROCEDIMIENTO; 4. ReCURSOS. K) La Ley 19/2001, de 19 de diciembre, de reforma de la LTSV: 1. LA REFORMA; 2. NON BIS IN IDEM Y PREVISIÓN DE

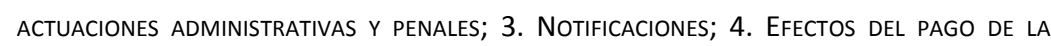
MULTA; 5. LA PARTICIPACIÓN DE DENUNCIADO EN LA INSTRUCCIÓN DEL PROCEDIMIENTO; 6. CompetenCIA PARA SANCIONAR; 7. ReCURSOS; 8. SObRE LA PRESCRIPCIÓN DE INFRACCIONES, PRESCRIPCIÓN DE SANCIONES, CADUCIDAD DEL PROCEDIMIENTO Y CANCELACIÓN DE ANTECEDENTES; 9. SOBRE El COBRO DE LAS MULTAS; 10. LA REVOCACIÓN DE LA AUTORIZACIÓN PARA CONDUCIR

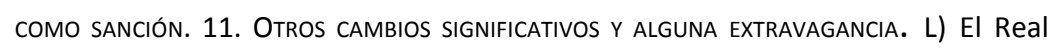
Decreto 318/2003, de 14 de marzo, de modificación del RPSTSV para adaptarlo a los cambios realizados en la LTSV por la Ley 19/2001, de 19 de diciembre: 1 .

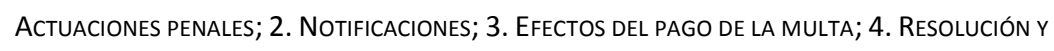
Competencia para sancionar, 5. Caducidad; 6. Prescripción y ReCursos; 7. Anotación y CANCELACIÓN DE ANTECEDENTES. M) Reglamento General de Circulación de 2003. N) La Ley $62 / 2003$, de 30 de diciembre, de medidas fiscales, administrativas y del orden social. Ñ) La Ley 17/2005, de 19 de julio, del permiso y licencia de conducción por puntos: 1. UBICACIÓN DE LA REFORMA; 2. LA IMPLANTACIÓN Y JUSTIFICACIÓN DEL SISTEMA; 3. LA ARQUITECTURA DE LA REFORMA: a) La vigencia del permiso o licencia; b) La declaración de pérdida de vigencia por la pérdida de la totalidad de los puntos; c) Modificación del cuadro general de infracciones; d) Modificación del régimen de sanciones; e) Graduación de las sanciones; f) Responsabilidad; g) Responsabilidad de persona distinta a la que comete la infracción; h) Responsabilidad solidaria en el caso de infracciones cometidas por los menores; i) Equiparación de arrendatarios a titulares; j) Deber de identificar al conductor infractor; k) Abono voluntario de la sanción acogiéndose al beneficio de reducción; I) Anotación y cancelación de antecedentes; m) Sobre el Anexo; n) Las disposiciones adicionales y finales. 4) UNA ESCUETA VALORACIÓN DE LA REFORMA POR COMPARACIÓN CON LA EFECTUADA POR LA LEY 19/2001, DE 19 DE DICIEMBRE. O) La revisión del RGCon realizada por medio del Real Decreto 62/2006, de 27 de enero. P) La Ley Orgánica 15/2007, de 30 de noviembre, por la que se modifica la Ley Orgánica 10/1995, de 23 de noviembre, del Código Penal en materia de seguridad vial: 1. El CONTEXTO de LA REFoRMA y su ÁmBito; 2. LA REFORMA DEL Código Penal; 3. La Reforma de LA LTSV y de LA LOFAGE: a) Competencia para sancionar las infracciones previstas en la LTSV; b) Recursos; c) Anotación y cancelación de antecedentes. Q) El Reglamento General de Conductores de 2009: 1. PERDIDA DE VIGENCIA POR CARENCIA DE PUNTOS Y PROCEDIMIENTO PARA SU DECLARACIÓN; 2. SOBRE EL PROCEDIMIENTO PARA LA DECLARACIÓN DE PÉRDIDA DE VIGENCIA POR LA PÉRDIDA TOTAL DE LOS PUNTOS ASIGNADOS. R) La Ley 18/2009, de 23 de noviembre, de modificación del régimen sancionador de la LTSV. 


\section{LA EVOLUCIÓN NORMATIVA DEL TRÁFICO Y LA SEGURIDAD VIAL}

\section{A) La regulación preconstitucional}

El procedimiento sancionador que, para imposición de sanciones por la comisión de infracciones en materia de tráfico y seguridad vial, nos interesa conocer es el que se perfila y asienta sobre los principios constitucionales.

Cierto es que la circulación de vehículos se inicia con la propia aparición de los primeros automóviles y de las primeras fábricas dedicadas a su construcción a finales del siglo XIX, pero no es hasta el siglo XX que se empieza a regular, de manera ordenada, sobre el fenómeno del tráfico ${ }^{6}$.

En el caso de nuestro país es en la II República cuando se intenta una regulación sistemática con la promulgación del Código de la Circulación por medio del Decreto de 25 de septiembre de 1934 (CCirc), publicado en el BOE (entonces todavía Gaceta de Madrid) núm. 269 de 26 de septiembre de 1934, si bien se trata de una norma que, en buena medida, no hace sino recoger las previsiones que ya se habían plasmado en el Real Decreto de 17 de septiembre de 19007, disposición que, por ello, debe ser considerada la primera norma que, de manera general, pretende la regulación del tráfico como fenómeno ${ }^{8}$.

\footnotetext{
${ }^{6}$ Sobre los antecedentes históricos resulta imprescindible el análisis efectuado por T. CANO CAMPOS en la obra El régimen jurídico - administrativo del tráfico, Civitas, tanto la 1a edición, de 1999, como en la 2a de 2010, el autor destina la primera parte de la obra al análisis del devenir del tráfico como fenómeno "histórico, social, económico y jurídico" (tal y como señala en el segundo párrafo de la Introducción).

${ }^{7}$ Por el que se aprobada el Reglamento para el servicio de coches automóviles por las carreteras del Estado y que fue publicado en la Gaceta de Madrid de 20 de septiembre de 1900.

En este Real Decreto se contienen prescripciones tales como:

- Art. 16: Con independencia de las prescripciones del presente Reglamento, los automóviles, mientras circulen por las carreteras, estarán sujetos á las contenidas en el Reglamento de policía y conservación de aquellas vías.

Regirán también las multas allí señaladas para los casos en que se infrinjan los artículos de la referida Ordenanza de policía, si bien las podrá aumentar el Gobernador civil cuando, á su juicio, lo requiera la importancia de las faltas cometidas La misma Autoridad señalará las que deban imponerse cuando circulen los automóviles sin la competente autorización, tanto para el conductor como para el vehículo, así como en los casos no previstos en este Reglamento.

- Art. 19: El automóvil que por cualquiera circunstancia pierda alguna de sus condiciones reglamentarias será retirado de la circulación en tanto no justifique, mediante nuevo reconocimiento, que ha vuelto á poseerlas.

- $\quad$ Art. 20: El conductor que en el transcurso de un año infringiere dos veces las prescripciones reglamentarias en lo que hace referencia á sus deberes, podrá ser privado de su permiso para conducir automóviles.

- $\quad$ Art. 21: Las contravenciones á lo dispuesto en este Reglamento que no tengan señalada pena especial, quedarán sometidas á la acción de los Tribunales de justicia.

${ }^{8}$ Véanse, en ese sentido, las apreciaciones realizadas por T. CANO CAMPOS, El régimen jurídico administrativo del tráfico, Madrid, Civitas, 2010, 2a ed., pág. 89 y por J. BerMejo VerA, "Calificación normativa del Código de la Circulación", en RAP, núm. 84, 1977, pág. 65.
} 
Pero es el Código de la Circulación de 1934 el que está vigente en 1978 y es ese Código de la Circulación de 1934 sobre el que van a impactar todas las previsiones que, en materia de régimen administrativo sancionador, realiza la Constitución.

Una parte del Código de la Circulación de 1934 (en la redacción vigente al tiempo de promulgarse la Constitución) estaba destinada a regular el correspondiente procedimiento sancionador. Así, y precisamente con esa denominación, la de "Procedimiento sancionador", el Capítulo XVII del Código de la Circulación de 1934 estaba integrado por catorce artículos (desde el art. 276 al art. 289) ${ }^{9}$.

\section{B) El Código de la Circulación de 1934}

El Real Decreto de 25 de septiembre de 1934 por el que, en tiempos de la II República, se aprueba el Código de la Circulación constituye el sistema normativo que, en materia de tráfico y circulación de vehículos, va a regir hasta su paulatina y pausada sustitución por la ordenación actual ${ }^{10}$.

Se trata de una norma que ya estaba vigente al tiempo de instaurarse la dictadura y que va a sobrevivir a ella, llegando hasta el Estado constitucional, no sin sufrir diversas modificaciones, algo absolutamente normal si tomamos en consideración tanto el tiempo transcurrido como la propia materia objeto de regulación y su desarrollo a lo largo del siglo XX.

De todas las modificaciones que van a sucederse sobre la inicial redacción del Código de la Circulación de 1934 interesa señalar aquí, especialmente, aquellas que recayeron sobre el procedimiento para sancionar las infracciones en materia de tráfico y que

\footnotetext{
${ }^{9}$ Redacción que, al tiempo de promulgarse la Constitución de 1978, no se correspondía con la efectuada de manera inicial. En el concreto ámbito del Capítulo XVII y del procedimiento sancionador la regulación no se corresponde con la realizada originalmente. En esa redacción original el Capítulo XVII recibió la denominación "De las infracciones, denuncias y multas sobre circulación" y comprendía los arts. 283 a 297.

${ }^{10}$ La promulgación de la Ley de Tráfico no supuso la desaparición del Código de la Circulación de 1934. Su vigencia fue recortándose mediante la promulgación de sucesivas normas (básicamente los reglamentos de desarrollo de la propia Ley de Tráfico) que iban derogando expresamente determinados artículos del Código de la Circulación, así como derogaciones tácitas que expulsaban del ordenamiento cuantas disposiciones de igual o inferior rango se opusieran a las nuevas normas. Esta es, por ejemplo, la cláusula utilizada por la disposición derogatoria de la propia Ley de Tráfico en la que se establece que “quedan derogadas la Ley 47/1959, de 30 de julio, la Ley 85/1967, de 8 de noviembre, y cuantas disposiciones de igual o inferior rango se opongan a la presente Ley".

Por ello, y conforme se establecía en la disposición transitoria de la Ley 18/1989, de 25 de julio, de Bases de Tráfico, Circulación de Vehículos a Motor y Seguridad Vial, "hasta la entrada en vigor del Texto Articulado continuarán aplicándose las normas que actualmente regulan el tráfico, la circulación de vehículos a motor y la seguridad vial", lo que suponía la pervivencia del Código de la Circulación de 1934, en lo que no fuera contrario a la Constitución, en virtud de la propia estructura de nuestro ordenamiento jurídico y que expresamente se contemplaba en el apartado 3 de la disposición derogatoria de la Constitución, precepto que establece que "asimismo quedan derogadas cuantas disposiciones se opongan a lo establecido en esta Constitución".
} 
llevaron los originales términos en los que fue redactado el Capítulo XVII a su composición final, y ello como forma de dar cuenta de la evolución sufrida en este ámbito y como punto de partida sobre el que se desarrolló y construyó el actual sistema normativo.

En la redacción originaria del Código de la Circulación de 1934 el Capítulo XVII comprendía los arts. 283 a 297, parte del Decreto que contiene el conjunto de normas de lo que, haciendo uso de la actual nomenclatura de la Ley de Tráfico, se vendría a corresponder con el "Régimen sancionador", agrupando disposiciones sobre infracciones, sanciones, responsabilidad, ejecución, medidas provisionales y, también, sobre la tramitación del procedimiento sancionador.

En estos artículos se pueden encontrar prescripciones, tanto generales como específicas, tanto directas como incidentales, sobre diferentes cuestiones relativas al cauce para la imposición de las sanciones correspondientes a las infracciones previstas en el propio Código de la Circulación, tales como:

- Competencias: bajo la denominación "Jurisdicciones" se establece que la facultad de exigir responsabilidades gubernativas por infracciones de este Código, se confiere a los Ingenieros - Jefes de Obras públicas y a los Ingenieros - Jefes de Industria, en la parte que este Código determina y que la competencia corresponderá a los Ayuntamiento únicamente cuando la conservación y vigilancia del camino correspondan a su jurisdicción, se regirán por las disposiciones municipales en vigor, pero deberán hacer cumplir las disposiciones de este Código y aplicar las sanciones que en el mismo se concretan, tal y como establecen las letras a) y b) del art. 286 CCirc.

- Denuncias: Que podrán ser obligatorias o voluntarias, con los efectos que ello supone para la tramitación del expediente (art. 288 CCirc) y que supone la forma de iniciar el expediente (art. 287 CCirc).

- Notificación: La notificación de la infracción cometida y de la multa por ella impuesta, se hará, al mismo tiempo que al conductor, cuando éste fuera el directamente responsable, al titular del vehículo, en concepto de responsable civil subsidiario (art. 285, párrafo segundo CCirc) y la forma en la que se ha de realizar las notificaciones que se hubieran de realizar a interesados cuyo domicilio no radique en la provincia en que se tramite el expediente (art. 290 CCirc)

- Tramitación: Diferenciando en función de los expedientes que tengan su origen en denuncias voluntarias y obligatorias (art. 290 CCirc)

- Alegaciones del interesado: Escritos de descargo formulados frente a denuncias hechas por la Guardia Civil, Vigilantes de caminos, Agentes de la Autoridad, por los Capataces, Camineros o Peones que hagan sus veces, o por los funcionarios facultativos afectos al servicio de las carreteras o los de automóviles de las 
Jefaturas de Industria, que tendrían que serán informados por éstos, y que la ratificación de los mismos haría fe, salvo prueba en contrario, cuando las faltas sean de carácter administrativo (art. 291 CCirc)

- Recursos: Posibilidad de recurrir en alzada contra las providencias que dicten los Ingenieros - Jefes de las respectivas dependencias por infracciones de este Código ante la Dirección General (de Caminos o de Industria) y el que recurso que correspondiera frente a las multas impuestas por las Autoridades municipales (art. 292 y 293 CCirc), siendo requisito indispensable, para la tramitación de cualquier recurso, acreditar que se ha depositado el importe total de las sanciones impuestas en la Caja General de Depósitos o en la Pagaduría de la dependencia en que se haya tramitado el expediente (art. 293 CCirc).

El Código de la Circulación de 1934, y el procedimiento sancionador que en él se contiene, siguen siendo tributarios de la idea que confiere sustantividad, propia y primordial, al hecho del "tránsito de peatones, vehículos y semovientes por las vías públicas de España"11, de ahí que se residencia la competencia para la tramitación, resolución y revisión de los expedientes sancionadores en los Ingenieros - Jefes de Obras públicas y, en su caso, en los de Industria ${ }^{12}$.

El tráfico es, a todos los efectos, la circulación, el movimiento, el tránsito, que se efectúa sobre las estructuras e infraestructuras de comunicación, de ahí que la competencia para conocer de los expedientes sancionadores se lleve a Obras Públicas y a Caminos. El tráfico es, en un segundo plano, la incorporación de los vehículos en general, de los automóviles, de los artefactos o aparatos capaces de circular por las vías públicas ${ }^{13}$ y que, en ese sentido, requieren de la intervención de la Dirección General de industria.

\footnotetext{
11 Términos que son los utilizados en la disposición preliminar del propio Código de la Circulación de 1934.

${ }^{12}$ Conforme determinan los arts. 286 a), 289 b), 292, 293, 294 CCirc.

${ }^{13}$ En este sentido, y sobre la terminología empleada, téngase presente que en el art. 4 CCirc se recogían las definiciones de lo que había de entenderse, a efectos del propio Código, por determinados conceptos, y se establecía que:

Vehículos en general: Todo artefacto o aparato capaz de circular por las vías públicas a que se refiere este Código, exceptuando los comprendidos en la definición de peatón.

Coche: Con el nombre genérico de coche, se designarán, exclusivamente, los carruajes de tracción animal, de dos o más ruedas, destinados al transporte de personas, con capacidad no superior a nueve, incluido el conductor.

Automóviles: Todo vehículo dotado de un dispositivo mecánico de propulsión, que sirva para el transporte de personas o de cosas y que circule por las vías públicas sin intervención de carriles.
} 


\section{C) Las modificaciones del Código de la Circulación de 1934}

De todas las modificaciones que van a sucederse sobre la inicial redacción del Código de la Circulación de 1934 interesa señalar aquí, especialmente, aquellas que recayeron sobre el procedimiento para sancionar las infracciones en materia de tráfico y que llevaron los originales términos en los que fue redactado el Capítulo XVII a su composición final, y ello como forma de dar cuenta de la evolución sufrida en este ámbito y como punto de partida sobre el que se desarrolló y construyó el actual sistema normativo.

No resulta nada sencillo determinar los cambios que se fueron produciendo en la redacción original del Código de la Circulación. La costumbre de aprovechar el dictado de normas que poco, o nada, tienen que ver para la introducción de modificaciones en otros ámbitos o sectores normativos ha sido una práctica especialmente común en la ordenación normativa del tráfico y la seguridad vial y ha existido siempre, sin que se pueda considerar que se trata de una característica o patrimonio exclusivo de los Gobiernos y Legisladores actuales.

La competencia, "la facultad de exigir responsabilidades gubernativas por infracciones de este Código", que se confiere a los Ingenieros - Jefes de Obras públicas y a los Ingenieros - Jefes de Industria, en la parte que el propio Código de la Circulación de 1934 determina, en los términos establecidos en el art. 286 a) CCirc, es objeto de modificación por el Decreto no 439 del Gobierno del Estado ${ }^{14}$, facultades que son transferidas a las Delegaciones Provinciales de Orden Público y, posteriormente a los Gobernadores Civiles, por medio del Decreto de 4 de diciembre de $1941^{15}$, al

${ }^{14}$ El Decreto no 439 establece, como causa, que "mientras duren las circunstancias extraordinarias creadas por la guerra y a fin de ordenar debidamente la circulación por las carreteras" por lo que se dispone que:

“Art. 1ㄴ Las facultades que el art. 286 del Código de la Circulación, aprobado por Decreto de 25 de septiembre de 1934, reconoce a los Ingenieros Jefes de Obras Públicas y a los Ingenieros Jefes de Industria para imponer sanciones sobre infracciones de las reglas de circulación en las carreteras, son transferidas a las Delegaciones Provinciales de Orden Público, que las ejercerán con arreglo a las disposiciones del citado Código y a las instrucciones que dicte la Jefatura de Seguridad Interior, Orden Público e Inspección de Fronteras".

De hecho el Decreto no 439 dictado en plena Guerra Civil, por el Gobierno rebelde, se publica en dos ocasiones. Primero en el Boletín Oficial del Estado de 17 de enero de 1938, en cuyo texto se hace referencia, de manera errónea, al art. 266 CCirc, motivo por el cual en el Boletín Oficial del Estado de 18 de enero de 1938 se señala que "habiéndose padecido error en la inserción del Decreto no 439, se reproduce a continuación debidamente rectificado".

15 Decreto publicado en el Boletín Oficial del Estado de 10 de enero de 1942 y que, además del art. 286 CCir, modifica los arts. 287, 289 y 295 del propio Código de la Circulación.

La redacción del art. 286 del Código de Circulación, en cuanto a la atribución y reparto de competencias para la imposición de sanciones en materia de tráfico, queda establecida en los siguientes términos:

“Art. 286 La facultad de exigir responsabilidades gubernativas por infracciones de este Código se confiere a los Gobernadores Civiles en lo relativo a la circulación de peatones, bicicletas, vehículos análogos, vehículos de tracción animal, automóviles de turismo, de servicio público o urbano, camiones y automóviles". Corresponde a los Ingenieros Jefes de Obras Públicas el conocimiento y sanción de las infracciones a este Código, producidas por ganados, vehículos o 
establecer que "la facultad de exigir responsabilidades gubernativas por infracciones de este Código se confiere a los Gobernadores Civiles en lo relativo a la circulación de peatones, bicicletas, vehículos análogos, vehículos de tracción animal, automóviles de turismo, de servicio público o urbano, camiones y automóviles".

\section{D) La apertura de una vía paralela y la creación de la Jefatura Central de Tráfico}

El tiempo transcurre y el fenómeno del tráfico se desarrolla vertiginosamente. Al lado del Código de la Circulación, cuya vigencia continúa y en el que los cambios no paran de producirse, surgen normas que, sin siquiera mencionar al Código de Circulación, impactan directamente en su contenido y trascienden las bases mismas sobre las que se asienta la norma codificadora.

Así, la promulgación de la Ley $47 / 1959$, de 30 de julio, sobre regulación de la competencia en materia de tráfico en el territorio nacional ${ }^{16}$, se constituye en otro de los hitos claves de la evolución de la ordenación, y ya no solo del procedimiento sancionador, por cuanto que supone un cambio de planteamiento (o, cuando menos, de un intento cualificado) en cuanto a la forma en la que se quiere entender y ordenar el tráfico, la circulación y el transporte por carretera.

Se trata de una norma breve que, aunque ni siquiera llena dos páginas del Boletín Oficial del Estado, distribuye competencias entre los Ministerios de Gobernación, Industria y Obras Públicas, para lo cual diseña un nuevo escenario en el que se reinterpreta, de forma total, el fenómeno del tráfico tal y como hasta ese momento se venía entendiendo.

Los cambios que se realizan son esenciales. Lo son en la superficie y en las formas. Se distribuyen (se redistribuyen o equidistribuyen) las competencias que estaban repartidas entre diversos organismos ${ }^{17}$ y se ubica el centro de gravedad del sistema en el Ministerio de la Gobernación, en el que se residencia la vigilancia y disciplina del tráfico, circulación y trasporte por carreteras y demás vías públicas, así como la sanción gubernativa de las infracciones que se cometan, que se atribuye a los

cargas que produzcan daños en las vías públicas, puentes, túneles, trozos en reparación, daños a terceros; los concernientes a obstáculos, cargas especiales y todas aquellas relacionadas con las autorizaciones que para conducir y circular expide el Ministerio de Obras Públicas. Y a los Ingenieros Jefes de las Delegaciones de Industria, las que les incumben en relación con los reconocimientos de vehículos automóviles, reparaciones y reformas en los mismos".

${ }^{16}$ Publicada en el Boletín Oficial del Estado de 31 de julio de 1959.

17 La Ley hace referencia a los Ministerios y Departamentos de Gobernación, de Industria, de Obras Públicas y de Hacienda, se menciona a la Guardia Civil y a diversos Cuerpos Policiales, las Direcciones Generales de seguridad, Gobiernos Civiles, Comisión Delegada de Servicios Técnicos... y la constitución, como órgano de dirección inmediata, ordenación y coordinación, de la Jefatura Central de Tráfico. 
Gobernadores Civiles $^{18}$ (art. 1 de la Ley 47/1959, de 30 de julio), de manera que el Ministro de la Gobernación ejercerá las facultades que se le asignan en la presente Ley, mediante los servicios y mandos de las Direcciones Generales de Seguridad y Guardia Civil y de los Gobiernos Civiles, constituyéndose (y está es una de las novedades más trascendentes, aunque se recoja en línea y media escondida en el medio de la nada) la Jefatura Central de Tráfico como órgano de dirección inmediata, ordenación y coordinación (art. 3.1 Ley 47/1959, de 30 de julio). Y todo ello sin citar en momento alguno (de manera expresa) el Código de la Circulación, como norma básica ordenadora de esta materia.

De la búsqueda del orden en el reparto de competencias y, sobre todo, de la más adecuada resolución de los expedientes que se generen, se deja especial constancia al establecerse que "se reducirá a un solo expediente, con exclusión de diligencias que puedan resultar innecesarias, la tramitación actualmente exigida en las sustanciación de los citados asuntos (art. 4.2 Ley 47/1959, de 30 de julio).

Los cambios que se efectúan por medio de las previsiones efectuadas en la Ley $47 / 1959$, de 30 de julio, sobre regulación de la competencia en materia de tráfico en el territorio nacional, son manifiestos, pero se quedan en nada cuando la lectura de los mismos se realiza, utilizando como gafas, el texto de la introducción que antecede al articulado de la propia norma. Se trata de modificaciones en la esencia y estructura, en el fundamento y en el fondo de lo que se quiere empezar a entender, a partir de ese momento, por el tráfico.

La norma propone un cambio de sistema. Un cambio estructural de entender y ordenar el tráfico. Se pretende el cambio de las cosas porque la visión, la percepción sobre el fenómeno, sobre la actividad del tráfico, está mutando. Ese planteamiento es el que explica, como conclusión, que "la presente Ley, sin desconocer los elementos materiales a considerar en el problema del tráfico - la carretera y el vehículo reafirma así que el problema es sustancialmente humano, puesto que en el volumen de las infracciones y en la magnitud de los daños que producen los accidentes la conducta de los hombres intervienen en forma decisiva destacando la responsabilidad de quienes, sirviéndose de aquellos medios en forma antirreglamentaria o menospreciando su riesgo constituyen un peligro para la seguridad de las personas o las cosas" ${ }^{19}$.

La conclusión viene precedida de un razonamiento que, en esencia, mantiene su validez hoy en día y que se asienta en la necesidad de regular de forma adecuada un

\footnotetext{
${ }^{18}$ Se trata, como expresamente se indica en la introducción que antecede al articulado de la propia norma, de que la potestad gubernativa sancionadora se ejerza por la autoridad que, en la provincia, representa al Gobierno.

${ }^{19}$ Texto con el que se cierra la nota introductoria que antecede al articulado de la Ley 47/1959, de 30 de julio, sobre regulación de la competencia en materia de tráfico en el territorio nacional, y que, a pesar de haber sido redactado hace más de medio siglo mantiene su valor y actualidad.
} 
fenómeno, el del tráfico, que se ha convertido en un problema, al seguir una "línea progresiva de agravación" que necesita de "prever su segura evolución" y que se trata de un fenómeno, el individual de las circunstancias personales del titular o conductor del vehículo, conectado con la seguridad general.

Nos encontramos, eso sí, con una norma que, abandonando la visión mecanicista e instrumental del tráfico de vehículos, humaniza la actividad (el problema es sustancialmente humano). El cambio conceptual no supone ignorar los elementos materiales (sin obviar la carretera y el vehículo), pero sí determinar que la piedra angular es la persona, lo que sitúa a la seguridad en el centro del sistema y apunta a los infractores, de ahí esa frase con la que se cierra la exposición introductoria que reiteramos: "la responsabilidad de quienes, sirviéndose de aquellos medios en forma antirreglamentaria o menospreciando su riesgo constituyen un peligro para la seguridad de las personas o las cosas". Hacer efectiva esta idea, trasladarla a la práctica, es misión que corresponde, precisamente, al procedimiento sancionador por infracción de las normas de tráfico.

El Real Decreto 1666/1960, de 21 de julio, por el que se desarrollan las competencias en materia de tráfico, circulación y transportes por carretera, determinadas en la Ley 47/1959, de 30 de julio ${ }^{20}$, estableció, en el art. 4.1, que los Gobernadores Civiles sancionarían, con carácter exclusivo, todas las infracciones cometidas contra la legislación de tráfico, circulación y transportes, resolviendo al efecto reglamentariamente los expedientes que se instruyan.

De hecho, esta norma, la Ley 47/1959, de 30 de julio, sobre regulación de la competencia en materia de tráfico en el territorio nacional, es una de las dos únicas disposiciones que aparecen expresamente mencionadas en la disposición derogatoria de la Ley de Tráfico.

\section{E) Una continua evolución}

Las modificaciones del Código de la Circulación continúan. Se pretende su continua adaptación a las cambiantes circunstancias del tráfico. Los cambios en las estructuras materiales y "la paulatina entrada en servicio de autopistas impone la necesidad de completar las normas del Código de la Circulación", como indica el Decreto 1277/1969, de 26 de junio ${ }^{21}$, norma que además de establecer una regulación diferente a la que corresponde a la circulación por otro tipo de vías tiene como objetivo el establecimiento de las sanciones gubernativas que han de garantizar el necesario

\footnotetext{
${ }^{20}$ Publicado en el Boletín Oficial del Estado de 14 de septiembre de 1960.

${ }^{21}$ Decreto publicado en el Boletín Oficial del Estado de 28 de junio de 1969 por el que se modifican diversos artículos del Código de la Circulación y se incluye en el mismo un nuevo Capítulo regulando la circulación por autopista.
} 
respeto a las normas que se introducen, pues la seguridad de la circulación, especialmente en este tipo de vías, exige acatamiento estricto y riguroso de las normas de conducta, que hacen posible la utilización ordenada de las mismas ${ }^{22}$. La idea de la seguridad vial (seguridad de la circulación) subyace a la idea misma del sistema sancionador que se establece, como mecanismo de protección del cumplimiento de las normas que se establecen con el fin de garantizar esa seguridad. El planteamiento realizado se antoja sencillo. Hay una actividad, un fenómeno, un problema, que es el tráfico. Y en ese entorno, el del tráfico, hay un objetivo, directo, prioritario, básico, que es el de la seguridad, y hay un mecanismo para garantizarlo, que no es otro que el establecimiento de un sistema sancionador que, para cumplir con su finalidad, debiera ser efectivo.

En esa espiral de continuos cambios conviene hacer una parada en el Real Decreto 2625/1976, de 1 de octubre, por el que se modifican determinados artículos del Código de la Circulación ${ }^{23}$, norma, que como su propia fecha pone de manifiesto, nos ubica en un momento distinto, en la transición democrática (o hacia la democracia). Esta norma, que se centra en establecer mecanismos de reconocimiento de los permisos de conducción obtenidos en el extranjero, lo que supone el reconocimiento del tráfico como fenómeno global y transnacional, establece, en el concreto ámbito del procedimiento sancionador, "la conveniencia de una regulación más concreta de la figura de la prescripción, de forma tal que, recogiendo los criterios sustentados en vía interpretativa, se eviten dudas y confusiones que disminuyen la seguridad jurídica de los administrados"24.

Por medio de esta norma se introduce una nueva redacción en el art. 284 CCirc que determina el plazo y cómputo para la prescripción tanto de las infracciones en materia de tráfico como de las sanciones que, a aquellas, pudiera corresponder. Prescripciones que estarán vigentes hasta su expresa expulsión del ordenamiento jurídico por la disposición derogatoria única del Real Decreto 320/1994, de 25 de febrero ${ }^{25}$.

El contenido y redacción que el Real Decreto 2625/1976, de 1 de octubre, introduce en el art. 284 CCirc se viene a corresponder, y en ese sentido enlaza, con la previsiones que, en la redacción original, se establecen en el art. 81 LTSV y en el art. 18 del Real Decreto 320/1994, de 25 de febrero. En ambos regímenes el plazo que, de manera

\footnotetext{
${ }^{22}$ En los propios términos empleados por el párrafo tercero de la exposición que antecede al articulado del Decreto 1277/1969, de 26 de junio.

${ }^{23}$ Este Real Decreto fue publicado en el Boletín Oficial del Estado de 23 de noviembre de 1976.

${ }^{24}$ Se trata de la motivación literal utilizada en el texto introductorio que precede a la propio Decreto 2625/1976, de 1 de octubre.

25 Publicado en el Boletín Oficial del Estado de 21 de abril de 1994 y que supone el desarrollo reglamentario de la Ley de Tráfico en base a la autorización establecida en el apartado 1 de la disposición final de la referida Ley de Tráfico por la que "se faculta al Gobierno para dictar las disposiciones necesarias para desarrollar esta Ley, así como para modificar los conceptos básicos contenidos en su Anexo I de acuerdo con la variación de sus definiciones que se produzca en el ámbito de acuerdos y convenios internacionales con trascendencia en España".
} 
general, se establece para la prescripción de las infracciones, es de dos meses y también coincide en cuanto al plazo marcado para la prescripción de las sanciones, que es el de un año. De igual manera las previsiones realizadas en ambas normas, tanto sobre la interrupción como sobre el cómputo de los plazos de prescripción, son coincidentes en sus elementos esenciales ${ }^{26}$.

Todo este devenir configura la redacción que el Código de la Circulación dictado en 1934, y en particular el capítulo XVII del mismo, tiene al momento de la promulgación de la Constitución de 1978, norma suprema de nuestro ordenamiento (art. 5.1 LOPJ). Como se ha puesto de manifiesto, "la Constitución se afirma, pues, a sí misma como una efectiva norma jurídica y en tal sentido la disposición derogatoria tercera declara derogada por ella «cuantas disposiciones se opongan a lo establecido en esta Constitución»" puesto que "tanto las normas pasadas como las futuras deben acomodarse, pues, a la Constitución para mantener o adquirir su validez" ${ }^{27}$.

26 Resulta cuando menos curioso (más bien sorprendente) que la evolución normativa de las previsiones pre y postconstitucionales sean tan coherentes en este ámbito de la prescripción de infracciones y sanciones en materia de tráfico (lugar concreto que sirve de reflejo para todo el sistema del procedimiento sancionador). La lógica del sistema, en cuanto a fijación de plazos, se realiza, y plasma en el ordenamiento jurídico por traslación de la establecida para las faltas en el Código Penal. No parecía lógico (entonces, ni debiera parecerlo ahora) fijar un plazo de prescripción para las infracciones administrativas mayor que el establecido en el Código Penal para las faltas... lógica que se pierde en las sucesivas modificaciones del RD 320/1994, de 25 de febrero, llevándose, sucesivamente a tres meses por el RD 116/1998, de 30 de enero (BOE de 18 de febrero de 1998), que aplica la previsión introducida, en ese sentido, por la Ley 5/1997, de 24 de marzo (BOE de 25 de marzo de 1997) en el art. 81.1 de la Ley de Tráfico y, posteriormente, por medio del RD 318/2003, de 14 de marzo (BOE de 5 de abril de 2003), estableciéndose diferentes plazos de prescripción en función del nivel de gravedad de la propia infracción (tres meses para las infracciones leves, seis meses para las infracciones graves, y un año para las infracciones muy graves y para las infracciones previstas en el art. 67.2 de la Ley de Tráfico), conforme a la modificación realizada en el art. 81.1 de la Ley de Tráfico por la Ley 19/2001, de 19 de diciembre (BOE 20 de diciembre de 2001).

$\mathrm{Ni}$ siquiera el nuevo planteamiento efectuado para el régimen sancionador en materia de tráfico y seguridad vial por medio de la Ley 18/2009, de 23 de noviembre (BOE de 24 de noviembre de 2009), y que ha supuesto la total reestructuración del procedimiento sancionador ha vuelto las aguas a su cauce, de manera que, en el ahora art. 92.1 LTSV, se establece que "el plazo de prescripción de las infracciones previstas en esta Ley será de tres meses para las infracciones leves y de seis meses para las infracciones graves y muy graves".

Lo mismo sucede con la prescripción de sanciones. El plazo de un año fijado entonces se ha convertido ahora, por medio de la reforma realizada por la Ley 18/2009, de 23 de noviembre (BOE de 24 de noviembre de 2009), en un plazo de cuatro años para las sanciones consistentes en multa pecuniaria y de un año para las demás sanciones, computados desde el día siguiente a aquel en que adquiera firmeza en vía administrativa la sanción (art. 92.4 LTSV).

${ }^{27}$ García de Enterría, E. y Fernández Rodríguez T.-R., Curso de Derecho Administrativo, Tomo I, 14a ed., Madrid, Civitas, 2008, pág. 103. 


\section{CONSTITUCIÓN Y PROCEDIMIENTO SANCIONADOR EN MATERIA DE TRÁFICO}

\section{A) El Tráfico en el texto constitucional \\ 1. Las ReFerencias al Tráfico y la Seguridad Vial}

Los efectos de la Constitución de 1978 sobre el ordenamiento jurídico vigente en ese momento son comparables a los de un tsunami. $Y$ nada nos tiene que hacer pensar que las previsiones existentes en materia de procedimiento sancionador en materia de tráfico constituyen excepción alguna. Más bien todo lo contario, dado el cambio que preceptos constitucionales, como son los arts. 24 y $25 \mathrm{CE}$, suponen sobre el ius puniendi.

Hay, por tanto, sobre la existente regulación del procedimiento sancionador en materia de tráfico, unos efectos genéricos, por el hecho de tratarse de los mecanismos y cauces para depurar la responsabilidad por la comisión de infracciones administrativas y la imposición de las sanciones asociadas a esas conductas. $Y$ hay, también, un tratamiento del tráfico que, como actividad, es susceptible de verse reflejada en el texto constitucional.

En cuanto a la presencia del tráfico en la Constitución, este ámbito de derecho aparece reflejado en el marco de la organización territorial del Estado y dentro del reparto de competencias que se efectúa, de manera que el art. 149.1.21a CE establece que el Estado tiene competencia exclusiva sobre la materia de tráfico y circulación de vehículos a motor ${ }^{28}$.

Una segunda reflexión (pues la primera debe limitarse a la constatación de que el tráfico, como fenómeno de masas y con el impacto que en la sociedad tiene, tiene su hueco en el texto constitucional) debe recaer en la forma en la que esa alusión aparece realizada. En los términos que, formalmente, son empleados por la Constitución: tráfico y circulación de vehículos. Sin el menor rastro de referencia alguna a la seguridad vial ${ }^{29}$.

Es cierto que la referencia constitucional al tráfico lo es de manera incidental al realizarse en el marco del reparto de competencias, pero aún así, la forma en la que se

\footnotetext{
${ }^{28}$ Por entender la ubicación y el contexto en el que se realiza esta atribución de competencia al Estado téngase en cuenta que el art. 149.1.21a CE se refiere a "Ferrocarriles y transportes terrestres que transcurran por el territorio de más de una Comunidad Autónoma; régimen general de comunicaciones; tráfico y circulación de vehículos a motor; correos y telecomunicaciones; cables aéreos, submarinos y radiocomunicación".

${ }^{29}$ El Tribunal Constitucional resolviendo conflicto positivo de competencias estableció que la "la seguridad vial comprende tanto la seguridad activa como la pasiva y, dentro de ésta, la protección de conductores y pasajeros" y que "ambas dimensiones son elementos indisolubles de la seguridad del tráfico y circulación, pues es innegable la repercusión que un accidente o fallo de seguridad en el interior de un vehículo, que afecte a las personas que en él viajan (tanto conductor como pasajeros) puede tener en la conducción del mismo, así como en otros vehículos de su entorno" (SSTC 181/1992, de 16 de noviembre, F. 3).
} 
realiza es regresiva en cuanto al concepto que parecía haberse alcanzado o, en todo caso, meramente continuista de la visión que 44 años atrás se había realizado, en tiempos de la II República al redactarse y promulgarse el Código de la Circulación de 1934. En todo caso la Constitución ni incorpora expresamente la idea central de la seguridad vial a la referencia que realiza del tráfico y circulación de vehículos, ni hace un tratamiento diferenciado (al igual que sucede con la inmensa mayoría de sectores o actividades), ni asocia, de manera expresa, efectiva y concreta el fenómeno del tráfico y la seguridad vial a derechos subjetivos de forma concreta.

\section{LA ORDENACIÓN NORMATIVA DEL TRÁFICO (Y LA SEGURIDAD VIAL)}

Tanto la referencia constitucional al tráfico y circulación de vehículos como el posterior concepto legal, el que dará lugar a la denominación empleada por el legislador para la norma básica reguladora de este ámbito, la Ley de Tráfico, el de Tráfico, Circulación de Vehículos a Motor y Seguridad Vial, se encuentran relacionados con diversos derechos y libertades fundamentales.

El tráfico, como actividad, es soporte del derecho a circular por el territorio nacional reconocido en el art. 19 CE. El tráfico, como manifestación de la seguridad vial y de la obligada intervención de los poderes públicos en el mantenimiento de la seguridad de la circulación vial, como corolario inexcusable de la competencia exclusiva que otorga al Estado, en materia de tráfico y de circulación de vehículos a motor, el artículo 149.1.21a $\mathrm{CE}$, se ha transformado en una de las expresiones más genuinas del ejercicio de la libertad de circulación ${ }^{30}$, lo que enlaza con el derecho a la seguridad establecido en el art. 17.1 CE. El régimen sancionador en este ámbito de actividad y el procedimiento instaurado al efecto para la imposición de las consecuencias asociadas a las transgresiones a las normas establecidas, tiene que cumplir con los parámetros impuestos por los arts. 24 y 25 CE.

El procedimiento sancionador es, precisamente, cauce para la imposición de sanciones, que lo son en relación a conductas que han de estar previamente tipificadas $y$, en ese sentido, el art. 25 CE exige, como requisito esencial que, para que alguien pueda ser condenado o sancionado, la correspondiente acción u omisión tiene que estar establecida como delito, falta o infracción por la legislación vigente, lo que requiere de predeterminación normativa por norma con rango de ley.

El procedimiento sancionador es el cierre del sistema, del conjunto de normas que pretenden la ordenación de tráfico, y medio de garantizar el cumplimiento de las normas que se establecen. Así, el procedimiento sancionador se constituye en el

\footnotetext{
${ }^{30}$ Ambos incisos, alterando su orden, forman parte de la introducción que antecede, explica y justifica a la Ley de Tráfico.
} 
instrumento defensor de la seguridad vial a la que se orienta la regulación del tráfico en su conjunto.

\section{EL PRINCIPIO DE LEGALIDAD EN LA REGULACIÓN DEL PROCEDIMIENTO SANCIONADOR EN MATERIA DE TRÁFICO}

El control de la Administración (Administraciones públicas) de la actividad del tráfico (y la seguridad vial) y el ejercicio de la potestad sancionadora en este ámbito de actividad requiere, por imposición constitucional, que la regulación se efectúe mediante norma con rango de ley.

Así, el ejercicio de la potestad sancionadora en éste ámbito, el del Tráfico (y la seguridad vial), como en cualquier otro, precisa de predeterminación por norma legal (art. 25.1 CE), si bien resulta necesario determinar si basta con norma con rango de ley o, por el contrario, es preciso que se trate, por la propia naturaleza del objeto de regulación, de una Ley con la categoría de orgánica, en los términos establecidos en el art. $81 \mathrm{CE}$.

Este precepto, el art. $81 \mathrm{CE}$, exige la regulación mediante Ley Orgánica, además de para los Estatutos de Autonomía, el régimen electoral general y los casos en los que así este previsto en la propia Constitución, para las normas (leyes) relativas al "desarrollo" de los derechos fundamentales. Este término, el de "desarrollo" es sobre el que se han centrado las diferentes interpretaciones que, de manera general, se han realizado, y que enfrentan la idea de la necesidad de Ley Orgánica en todos aquellos casos en los que se regule de cualquier manera, por leve o mínima que sea, y resulte afectado un derecho fundamental, en oposición a la necesidad de este tipo de normas únicamente en aquellos casos en los que se regula de forma directa un derecho fundamental.

Son temas, tanto el de lo que ha de entenderse por una Ley Orgánica como el alcance que a este específico tipo de Leyes corresponde, que han sido objeto de profundos estudios e interpretaciones ${ }^{31}$ y que, en su inmensa mayoría ${ }^{32}$, se posicionan en entender, tal y como ha declarado el Tribunal Constitucional, que la previsión efectuada en el "art. 81 CE se refiere al desarrollo "directo" de los derechos fundamentales, pues este artículo y las otras muchas alusiones de la Constitución al instrumento de la Ley orgánica en materias concretas, que, como se ha dicho, convierte a las Cortes en «constituyente permanente», no puede extremarse, con los

\footnotetext{
${ }^{31}$ García de Enterría, E. y Fernández Rodríguez T.-R., Curso de Derecho Administrativo, Tomo I, 14ạ ed., Madrid, Civitas, 2008, pág. 139.

32 De las que son muestra representativa las posiciones de MORENO CATENA ("Libertad de circulación y normas sobre circulación de vehículos a motor", VIII Jornadas Nacionales Derecho y Tráfico, DGT, 1993) y JIMENEZ CAMPO ("El legislador de los derechos fundamentales", Estudios de derecho público en homenaje a Ignacio de Otto (coord. por Ubaldo Gómez Alvarez), Universidad de Oviedo, 1993, págs. 473 -510 ).
} 
importantes problemas de consenso interno que conlleva, al punto de convertir el ordenamiento jurídico entero en una mayoría de Leyes orgánicas, ya que es difícil concebir una norma que no tenga una conexión, al menos remota, con un derecho fundamental" ${ }^{33}$, que el desarrollo legislativo de un derecho proclamado en abstracto en la Constitución consiste, precisamente, en la determinación de su alcance y límites en relación con otros derechos y con su ejercicio por las demás personas, cuyo respeto, según el art. $10.1 \mathrm{CE}^{34}$ y que "el desarrollo de la Constitución Española, mediante Ley Orgánica, ha de quedar circunscrito al contenido esencial del derecho fundamental de que se trate" 35 .

En el ámbito específico de la regulación de tráfico y la seguridad vial se trata de decidir si ello supone el desarrollo directo de algún derecho fundamental, algo que no ocurre en caso alguno, al no haber ni conexión ni desarrollo directo ${ }^{36}$, por lo que no parece que concurran, para la regulación del tráfico y la seguridad, los requisitos exigidos en nuestro ordenamiento para que tenga que regularse mediante Ley Orgánica ${ }^{37}$.

Otro caso es que se hubiera pretendido, bajo única norma, una regulación integral de todas las conductas proscritas que hubiera incluido, como norma especial extra muros del Código Penal, la tipificación de las conductas (delitos y faltas) y penas, y que éstas últimas hubieran supuesto la privación de libertad, ya que la formulación del principio de legalidad respecto de las normas sancionadoras penales contenido en el art. 25.1 $\mathrm{CE}$, supone la exigencia del rango de Ley formal para este tipo de normas, pero ello no implica, por sí solo, la necesidad de que asuman los caracteres de las Leyes Orgánicas previstas en el art. $81.1 \mathrm{CE}$, y no cabe duda de que las normas penales (como ha admitido la gran mayoría de nuestra doctrina penalista) suponen un desarrollo del derecho a la libertad (aparte de otros derechos fundamentales que no son ahora relevantes), y no existe en un ordenamiento jurídico un límite más severo a la libertad, que la privación de la libertad en sí, y el derecho a la libertad del art. 17.1 CE es el derecho de todos a no ser privados de la misma, salvo "en los casos y en la forma previstos en la Ley". En una Ley que, por el hecho de fijar las condiciones de tal privación, es desarrollo del derecho que así se limita. En este sentido el Código penal y en general las normas penales, estén en él enmarcadas formalmente, o fuera de él en leyes sectoriales, son garantía y desarrollo del derecho de libertad en el sentido del artículo $81.1 \mathrm{CE}$, por cuanto fijan y precisan los supuestos en que legítimamente se puede privar a una persona de libertad. La palabra "legislación", utilizada en el artículo

\footnotetext{
33 Que es lo que textualmente señala la STC 6/1982, de 22 de febrero (F. 6.A) y reproduce la STC 127/1994, de 5 de mayo (F. 3.A).

${ }^{34}$ Cfr. STC 140/1986, de 11 de noviembre, FJ 50.

${ }^{35}$ STS de 1 de octubre de 1997 (RJ 1997, 7789), F. 4.

${ }^{36}$ Vide supra el análisis que enlaza normativa sobre tráfico y seguridad vial con los arts. 17, 19, 14 y 25 $\mathrm{CE}$, sin que en ninguno de estos supuestos esta relación, que existe, pueda ser calificada de desarrollo directo.

${ }^{37}$ CANO CAMPOS, T., El régimen jurídico - administrativo del tráfico, 2ª ed., Madrid, Civitas, 2010, 2ae ed., págs. $136-140$.
} 
25.1 CE, configura una auténtica reserva de Ley en esta materia, intensificada en algún aspecto hasta alzarse al rango orgánico para establecer penas privativas de libertad ${ }^{38}$. De ahí que deban tener carácter de $\operatorname{Orgánicas}^{39}$ y de ahí que la regulación del tráfico y la seguridad vial no requiera de ser realizada mediante Ley Orgánica.

\section{El Código de la Circulación tras la promulgación de la Constitución}

Lo cierto es que entre la promulgación de la Constitución y la integración en el ordenamiento jurídico de una norma que, con rango de ley, regulara el tráfico y la seguridad vial, transcurrió un considerable espacio de tiempo, lo que vino a suponer, en la práctica, que durante la década de los 80 la norma básica continuó siendo el Código de la Circulación. Una norma reglamentaria que establecía (continuaba estableciendo) infracciones y sanciones y que determinaba (continuaba determinando) el procedimiento a través del cual se producía la efectiva imposición de las sanciones a los infractores... y ello en el marco constitucional que imponía el principio de legalidad.

El ambiente que generaba la promulgación de la Constitución, y la genérica derogatoria en ella contenida, era de tensión entre la normativa anterior (la regulación preconstitucional) y el nuevo régimen jurídico establecido. Una interpretación literal de las circunstancias y el resultado no parecía dejar margen alguno para la duda. La Constitución era la nueva regla maestra, la criba jurídica, por la que había que pasar las normas. Las que se realizaran en el futuro y las que provenían del pasado. Las que pasaran ese examen, el de la disposición derogatoria de la Constitución, en la medida que se establecían que "asimismo quedan derogadas cuantas disposiciones se opongan a lo establecido en esta Constitución", continuarían formando parte del ordenamiento jurídico, mientras que las que no fueran capaces de superarlo, serían expulsadas.

Se trata de un planteamiento puro, tan claro (y evidente) como poco realista (e ineficiente). Su aplicación directa, y mecánica, supondría la expulsión de las normas que no cumplieran con el patrón constitucional. De las normas que no respetaran los principios básicos allí establecidos, las que, por ejemplo, no cumplieran con la reserva de ley impuesta a la determinación de infracciones y sanciones, como era el caso del Código de la Circulación, aprobado por Decreto de 25 de septiembre de 1934.

Una interpretación literal, en el sentido indicado, se volvería, en la práctica, en contra del propio ordenamiento jurídico, dejando huérfanos de regulación un gran número de sectores y actividades al ser causa de la eliminación de normas por el hecho de no cumplir con parámetros inexistentes al tiempo de su promulgación. Así, en una de las

\footnotetext{
${ }^{38}$ Cfr. STC 184/1995, de 12 de diciembre, FJ 3ㅇ.

${ }^{39}$ Cfr. SSTC 25/1984, de 23 de febrero, FJ 3 o y 140/1986, de 11 de noviembre, FJ 5ㅇ.
} 
primeras sentencias del Tribunal Constitucional, ya se plantea el problema de las normas preconstitucionales y se establece que "no es posible exigir la reserva de ley de manera retroactiva para anular disposiciones reguladoras de materias y de situaciones respecto de las cuales tal reserva no existía de acuerdo con el Derecho anterior, especialmente cuando la fuente de Derecho que se cuestiona se produjo respetando el sistema de creación jurídica vigente en el momento de su promulgación" ${ }^{40}$.

Pero las complicaciones particulares que se van presentando, y que ponen en conflicto el principio de reserva de ley con materias reguladas por normas preconstitucionales, se resuelven, siempre, sobre la base de interpretaciones finalísticas que justifican (o pretenden justificar) esa decisión favorable a la vigencia de una norma que no cumple, de manera inflexible y literal, con ese patrón constitucional.

Así, las normas legales preconstitucionales, porque al tiempo de su promulgación cumplían con ese requisito de rango legal. Las disposiciones anteriores a 1978 que se limitan "sin innovar el sistema de infracciones y sanciones en vigor, a aplicar ese sistema preestablecido al objeto particularizado de su propia regulación material", ya que en realidad, se trata más bien de una reiteración de las reglas sancionadoras establecidas en otras normas más generales, por aplicación a una materia singularizada incluida en el ámbito genérico de aquéllas", y ello porque "bien porque se adecúa a la reserva constitucional de Ley, bien porque esta reserva no le alcanza retroactivamente" (STC 42/1987, de 7 de abril, F. 4). Los reglamentos que se apoyan y, por tanto, conforman un grupo normativo con disposiciones con rango de ley de la que traen causa, incluso cuando es evidente tanto el carácter reglamentario de tal disposición como su fecha, posterior a la entrada en vigor de la Constitución, si se sustentan en normas con rango de ley preconstitucionales.

Ninguna de estas argumentaciones resulta suficiente, por sí misma, para el Código de la Circulación de 1934. Estamos ante un caso palmario (prototípico a título de ejemplo) de reglamento independiente. El conjunto de circunstancias que lo rodean es, cuando menos, curioso.

Es una norma preconstitucional, pero procede de un Gobierno democrático y ha sobrevivido al régimen dictatorial que la hecho suya, reformándola constantemente, pero sin llegar a derogarla. Carece de rango de Ley y deambula por el ordenamiento sin directa conexión a disposición con ese rango. Nadie duda de su operatividad tras la Constitución. Pasan los años, continúan sus reformas... En definitiva, se la trata como una norma propia del sistema, atribuyéndosele, con absoluta normalidad, ese rango

\footnotetext{
${ }^{40}$ Cfr. STC 11/1981, de 8 de abril, FJ 5o, en el que con todas las limitaciones se permite la regulación efectuada por un Real Decreto Ley en materia que la Constitución reserva a norma investida del carácter de Ley Orgánica.
} 
del que carece. Siguen pasando los años, más de diez ${ }^{41}$, y a pesar de los enormes problemas que presenta el cambiante ámbito del tráfico y la seguridad vial, el Código de la Circulación permanece vigente.

Los hechos parecen empecinarse en demostrar que ni el tráfico ni la seguridad vial formaban parte de las prioridades del momento. Ni de las políticas ni de las sociales. El tráfico, como fenómeno de masas, continuaba su imparable desarrollo en términos cuantitativos $^{42}$ y, si miramos de reojo a las estadísticas de siniestralidad ${ }^{43}$, encontramos una actividad que, al mismo tiempo, perseveraba en una testaruda e incesante degeneración de la seguridad vial que, por única respuesta, encontraba la pasividad. Ociosidad y despreocupación en la Administración responsable, en los usuarios y afectados y en los representantes políticos de estos.

Siniestra historia en rojo sobre negro. Tal vez (y solo tal vez) los datos que esta historia ha dejado tras de sí pudieran permitir algún análisis y alguna conclusión. Lo cierto es que esos datos muestran que desde la promulgación de la Constitución, y durante la década de los 80, accidentes, heridos y víctimas mortales ascienden sin cesar y alcanzan su punto máximo en $1989^{44}$. Tal vez no sea una simple casualidad que sea justo ese año en que la voluntad política recupera el asunto del tráfico (y la seguridad vial) para la agenda de tareas pendientes y que en ese momento comience el descenso de las cifras de siniestralidad. Y es que, a lo mejor (solo tal vez) las normas, y el uso ponderado de las mismas, sirvan para algo más que llenar páginas (ya sean de papel o electrónicas) de los Diarios Oficiales.

\footnotetext{
${ }^{41}$ Es cierto que en ese período hubo intentos normativos anteriores a la Ley 18/1989, de 25 de julio, de Bases de Tráfico, Circulación de Vehículos a Motor y Seguridad Vial y el Real Decreto Legislativo 339/1990, de 2 de marzo, que aprueba el Texto Articulado de la Ley sobre Tráfico, Circulación de Vehículos a Motor y Seguridad Vial). Así, en 1985, el Anteproyecto de Ley de Seguridad Vial que llegó a ser informado por el Consejo de Estado sin que llegara a ver cumplida su tramitación.

${ }^{42}$ El parque de vehículos en el año 1990 ascendía a más de 15 millones (de los cuales turismos y motocicletas sumaban más de 13 millones). El censo de conductores superaba los 14 millones en 1990. En ese año, 1990, se suspendieron 3.135 permisos por la autoridad gubernativa y se retiraron 1.038 por la autoridad judicial. Tras la entrada en vigor de la LTSV el número de permiso suspendidos por la Administración fue de 18.173 en 1991 , 35.717 en 1992, 50.774 en 1993... 82.676 en 1996. A partir de 1996 las privaciones del derecho a conducir acordadas por la autoridad judicial pasan a ser de 30.000 al año para el período 1996 - 2002 (fuente DGT).

${ }^{43}$ Los registros estadísticos recogen 5.017 fallecidos en 1980 (con un tasa de mortalidad de 132,4 por millón de habitantes), 4.903, en 1985 (tasa de mortalidad de 127,4) y 6.948 en 1990 (tasa de mortalidad $173,7)$ y 5.751 (tasa de mortalidad 141,7), conforme a las estadísticas de la propia DGT.

${ }^{44}$ Cfr. Anuario Estadístico de Accidentes de 2010, DGT, Madrid, pág. 10. Existe un gran número de publicaciones de la propia Dirección general del Tráfico y es posible consultar una importante recopilación de información y datos sobre estadísticas e indicadores de Seguridad Vial a los que se puede acceder en http://www.dgt.es/portal/es/seguridad_vial/estadistica.
} 


\section{B) La Ley de Bases (Ley 18/1989, de 25 de julio, de Bases de Tráfico, Circulación de Vehículos a Motor y Seguridad Vial)}

\section{EL MODELO ELEGIDO: LA LEY DE BASES Y SU DENOMINACIÓN}

a) Sobre la denominación de la norma

Fracasado el intento de convertir en Ley el anteproyecto de Seguridad Vial de 1985 se antoja inaplazable dotar al sistema de una norma que regule el tráfico y la seguridad vial.

Lo cierto es que la denominación elegida para el anteproyecto de 1985, referida de manera exclusiva a la seguridad Vial, no había sido bien acogida. El Consejo de Estado considero en su correspondiente Dictamen que sería mucho más adecuada que la Ley se denominara de "Ordenación pública de la circulación urbana e interurbana", planteamiento compartido por CANO CAMPOS que señala, como primera característica a destacar de este anteproyecto, "la impropiedad del título o denominación" ${ }^{45}$.

Siendo un tema menor (si es que la denominación que se atribuya a las normas lo es ${ }^{46}$ ) la denominación que haya de darse y deba recibir la norma básica en esta materia, no comparto la crítica a la denominación. Es cierto que la Constitución, al atribuir las competencias, se refiere a esta materia, en el art. 149.1.21a como "tráfico y circulación de vehículos a motor". En todo caso se antoja que la crítica a realizar no es tanto el uso por la norma reguladora del término seguridad vial como la ausencia en la Constitución de este término.

La Ley de Bases 18/1989, de 25 de julio, utiliza como denominación los términos empleados en la Constitución, expresión a la que adosa la referencia a la Seguridad Vial. El resultado es que la Ley de Bases lo es de tráfico, circulación de vehículos a motor y seguridad vial.

Sea como fuere, la expresión seguridad vial es la que se ha ido imponiendo, llegando al ordenamiento, de manera que es la que finalmente da nombre, en la actualidad, a la rúbrica del correspondiente apartado del Código Penal en el que se recogen los delitos contra la seguridad vial ${ }^{47}$ y a la Comisión del Congreso de los Diputados ${ }^{48}$.

\footnotetext{
${ }^{45}$ CANo CAMPos, T., El régimen jurídico - administrativo del tráfico, 2a ed., Madrid, Civitas, 2a ed., 2010, pág. 140.

46 Véase, sobre esta cuestión, CAzorla Prieto, El lenguaje jurídico actual, Aranzadi, 2007, MerCEDES FUERTES “Once tesis y una premática para restablecer la dignidad de la Ley", RAP, no 177, septiembre diciembre 2008 y PRIETO DE PEDRO, Jesús: Lenguas, lenguaje y Derecho, Civitas, 1991, 192 págs.

${ }^{47}$ Aunque en la redacción inicial del Código Penal de 1995 la rúbrica del Capítulo IV del Título XVII era la de "delitos contra la seguridad del tráfico", la Ley Orgánica 15/2007, de 30 de noviembre, que modifica el Código penal en materia de Seguridad Vial (Boletín Oficial del Estado de 1 de diciembre de 2007) alteró su redacción dejándola en los términos actuales "De los delitos contra la seguridad vial".
} 


\section{b) El sistema elegido para cumplir con la reserva de ley}

De todas las opciones que en nuestro sistema jurídico permiten cumplir con la reserva de Ley que, como hemos tenido oportunidad de analizar, es necesaria para llevar a efecto la regulación del tráfico y la seguridad vial, el legislador opta por el empleo de la delegación legislativa prevista en el art. 82 CE para la formación del oportuno texto articulado, lo que requiere de que se otorgue la correspondiente Ley de Bases.

Y eso fue lo que se hizo. Las Cortes Generales autorizaron al Gobierno para que, a propuesta del Ministro del Interior y previo dictamen del Consejo de Estado, aprobara, en el plazo de un año, el Texto Articulado de la Ley sobre Tráfico, Circulación de Vehículos a Motor y Seguridad Vial, con sujeción a los principios y criterios que resultaban de las Bases que se aprobaban y que integraban la Ley 18/1989, de 25 de julio, de Bases sobre Tráfico, Circulación de Vehículos a Motor y Seguridad Vial ${ }^{49}$.

Se cumplían todos los requisitos establecidos en el art. 82 CE para que se llevara a cabo la habilitación legislativa de las Cortes Generales en el Gobierno ${ }^{50}$ :

- Las Cortes Generales aprobaron (otorgaron) una Ley de Bases (la Ley 18/1989, de 25 de julio $^{51}$ )

- No se trataba de desarrollar derechos fundamentales (al no haber conexión ni desarrollo directo de derechos fundamentales ${ }^{52}$ )

48 Esta es la denominación que también recibe la correspondiente Comisión del Congreso de los Diputados que, en la VII Legislatura (2004 - 2008) recibió la denominación de Comisión no Permanente sobre seguridad vial y prevención de accidentes de tráfico, denominación que mantuvo en la IX Legislatura (2008 - 2011) y que en la presente legislatura, la X, iniciada en 2011 ha mutado a Comisión Permanente no Legislativa sobre seguridad vial y movilidad sostenible.

${ }^{49}$ Publicada en el Boletín Oficial del Estado de 27 de julio de 1989. En el Boletín Oficial del Estado de 28 de marzo de 1990 se publicó una corrección de errores en la que se señala que advertido error en el texto publicado se procede a subsanarlo, error que consiste en que en la base octava, número 1, párrafo segundo, séptima línea, donde dice “... paradas y estacionamientos en lugares peligrosos que obstaculicen gravemente el tráfico..." debe decir “... paradas y estacionamientos en lugares peligrosos o que obstaculicen gravemente el tráfico...", redacción, esta última, que efectivamente se corresponde con la aprobada por el pleno del Congreso de los Diputados.

50 El artículo único de la Ley 18/1989, de 25 de julio, de Bases sobre Tráfico, Circulación de Vehículos a Motor y Seguridad Vial establecía que:

"Se autoriza al Gobierno para que, a propuesta del Ministro del Interior y previo dictamen del Consejo de Estado, apruebe, en el plazo de un año, el Texto Articulado de la Ley sobre Tráfico, Circulación de Vehículos a Motor y Seguridad Vial, con sujeción a los principios y criterios que resultan de las siguientes Bases..."

${ }^{51}$ El Pleno del Congreso de los Diputados aprobó, en su sesión de 12 de julio de 1989, de manera definitiva y de conformidad con lo establecido en el art. 90 CE el proyecto de Ley de bases sobre tráfico, circulación de vehículos a motor y seguridad vial. El texto puede consultarse en el Boletín Oficial de las Cortes Generales, Congreso de los Diputados, III Legislatura, Serie A, Proyectos de Ley, de 14 de julio de 1989, núm. 104 - 10, págs. 53 - 56 (http://www.congreso.es/public_oficiales/L3/CONG/BOCG/A/A_10410.PDF). 
- La delegación legislativa constaba de manera expresa ("se autoriza al Gobierno para que ... apruebe ... el Texto Articulado...")

- Se establecía la materia concreta ("el Texto Articulado de la Ley sobre tráfico, circulación de vehículos a motor y seguridad vial")

- Se determinaba un plazo preciso para el ejercicio de la delegación ("para que... apruebe, en el plazo de un año...")

- Se delimitaban con suficiente precisión el objeto y alcance de la delegación legislativa y los principios y criterios que habrían de seguirse en su ejercicio (las nueve bases, una disp. transitoria y dos disps. adicionales, determinando la primera de esas bases que el objeto es "establecer una regulación legal en materia de tráfico, circulación de vehículos a motor y seguridad vial)

\section{c) Sobre la elección de este sistema (justificación y valoración)}

Parece oportuno detenerse, aunque sea levemente, en considerar los motivos, e intentar entender las razones, que llevaron al legislador de aquel momento a hacer uso de un sistema excepcional extendiendo el ámbito de construcción reglamentaria mediante la específica habilitación para que fuera el Gobierno, y en definitiva la Administración, la que diera forma a la norma con la que se había de regular el tráfico, la circulación de vehículos a motor y la seguridad vial.

El texto introductorio que antecede a la delegación legislativa que se confiere y a las bases sobre las que esa habilitación habría de realizarse contiene una explicación al respecto al señalar que:

El empleo de la Ley de Bases como instrumento normativo previsto en el artículo 82 de la Constitución para determinar los principios y criterios que han de seguirse en su posterior regulación obedece a una doble motivación: Por un lado, la de revestirla del rango legal requerido por su importancia y por amparar el ejercicio de la potestad sancionadora de la Administración en la ordenación del Tráfico. Y por otro, para permitir que el Gobierno, en el desarrollo de la misma, disponga de un instrumento normativo idóneo, como es el Decreto Legislativo, para adaptar la regulación objeto de esta Ley de Bases y con el alcance en ella previsto, a la multiplicidad de supuestos que la ordenación del tráfico comporta; la complejidad técnica de toda regulación sobre el tráfico y seguridad vial, aconseja no someter la normativa en todos sus extremos a la consideración de las Cortes Generales, y sí establecer las bases para la regulación legal en materia de tráfico, circulación de vehículos y peatones y seguridad vial.

De esos dos motivos que se exponen para "el empleo de la Ley de Bases", el primero de ellos, el "de revestirla del rango legal requerido por su importancia y por amparar el

\footnotetext{
52 Véase, sobre esta cuestión, el apartado II.A.3 sobre el principio de legalidad en la regulación del procedimiento sancionador en materia de Tráfico de este mismo capítulo.
} 
ejercicio de la potestad sancionadora de la Administración en la ordenación del Tráfico" no es, en puridad, razón alguna. Pretender justificar el uso de esta técnica de mediante lo cual la propia Constitución autoriza al Gobierno para que dicte normas con rango de ley es, exactamente lo mismo, que no decir nada, dado que cualquier norma con rango de ley cumpliría con ese mismo objetivo, constitucionalmente impuesto, de necesidad de reserva de ley para regular la potestad sancionadora de la Administración.

De esta manera parece quedar, únicamente, una causa que determine el empleo de la delegación legislativa para este caso. Una selección de los términos expresamente utilizados en ese "y por otro lado" permite extraer las expresiones "(disponer) de un instrumento normativo idóneo", la "complejidad técnica de toda regulación sobre el tráfico y seguridad vial ${ }^{53 "}$ para, y finalmente, indicar que, todo ello, "aconseja no someter la normativa en todos sus extremos a la consideración de las Cortes Generales".

Se trata, en definitiva, de una decisión que se fundamenta en criterios de oportunidad que recomiendan, que hacen "aconsejable", que no sean los representantes políticos los que adopten, discutan y aprueben una norma con rango de ley en este ámbito del tráfico y la seguridad vial.

Puede resultar sorprendente esta justificación que, en definitiva, hurtaba a los representantes populares, la posibilidad de discutir y fijar los términos de una norma que a todos afectaba y que regularía el fenómeno social por excelencia ${ }^{54}$. Se limitaba el ejercicio de la potestad legislativa a determinar los principios y criterios en un ámbito de semejante trascendencia social y que, como se señalaba en el propio texto introductorio de la Ley 18/1989, de 25 de julio, de Bases sobre Tráfico, Circulación de Vehículos a Motor y Seguridad Vial, se trataba de una exigencia, la de una nueva regulación que reemplazara al todavía vigente Código de la Circulación de 1934, que "viene impuesta tanto por adaptar la norma a los principios de la vigente Constitución, como por la necesidad de disponer de un instrumento legal idóneo para afrontar la solución de la actual problemática, no contemplada, en toda su amplitud, por la anterior normativa". Planteamiento que, tal y como se señalaba, pretendía desplazar el centro de la regulación desde una posición "puramente policial" a un diseño normativo activo "orientado a promover la seguridad de la circulación y la prevención de accidentes" ${ }^{55}$.

\footnotetext{
${ }^{53}$ Nótese que en este punto, tan sensible a nuestro juicio, la expresión de la que se hace uso para definir la materia sobre la que se está tratando no coincide, literalmente ni con los términos

${ }^{54}$ Véanse, sobre las magnitudes de los diferentes elementos que integran el tráfico, las notas 37 y 38 de este mismo capítulo.

${ }^{55}$ Los términos de los que hacía uso el párrafo tercero de la introducción de la propia Ley 18/1989, de 25 de julio, de Bases sobre Tráfico, Circulación de Vehículos a Motor y Seguridad Vial, eran los siguientes:
} 
Por si ello no fuera suficiente encontramos un dato, incidental, adicional. La tramitación de la Ley 18/1989, de 25 de julio, de Bases sobre Tráfico, Circulación de Vehículos a Motor y Seguridad Vial, se produce en la III Legislatura ${ }^{56}$, y el ejercicio de la delegación legislativa se va a producir en el marco de una legislatura diferente, al mediar entre ambas la celebración de una elecciones generales, las celebradas el 29 de octubre de 1989.

La opción de la delegación legislativa como técnica para regular el tráfico y la seguridad vial no parecía una decisión razonable. Se trataba de una solución que, cuando menos, se presentaba como discutible.

El tiempo transcurrido nos sitúa en disposición de valorar, y hacerlo objetivamente, lo adecuado, o inadecuado, de esta decisión, y lo cierto es que la tramitación de las sucesivas reformas de la Ley de Tráfico y Seguridad Vial mediante leyes ordinarias deja poco espacio para la duda: fue una decisión completamente acertada ya que esas sucesivas modificaciones ha dejado al descubierto las grandes dificultades que, en la práctica, existen para de convertir en normas las discusiones parlamentarias en esta materia $^{57}$.

\section{LAS BASES DEL PROCEDIMIENTO SANCIONADOR EN MATERIA DE TRÁFICO}

La Ley 18/1989, de 25 de julio, de Bases sobre Tráfico, Circulación de Vehículos a Motor y Seguridad Vial, contenía, como no podía ser de otra manera, la correspondiente Base en materia de procedimiento sancionador en materia de tráfico y seguridad vial.

La Base Novena ${ }^{58}$ establecía, bajo la rúbrica "Procedimiento sancionador" los principios y los criterios que en el texto articulado debían contenerse en este concreto

“La magnitud del fenómeno de la circulación, con su trágico índice de siniestralidad, ha movido a la Administración a abandonar la primitiva concepción, puramente policial de su actuación, para pasar a un planteamiento activo de la misma, orientada a promover la seguridad de la circulación y la prevención de accidentes, tanto en carretera como en zonas urbanas".

56 El Proyecto de Ley de Bases sobre Tráfico, Circulación de Vehículos a Motor y Seguridad Vial (121/000105) realizado por el Gobierno fue presentado el 30 de diciembre de 1988 y calificado el 9 de enero de 1989

57 Véase, en este mismo capítulo, el apartado IV, destinado a analizar las diferentes modificaciones realizadas a la Ley de Tráfico y Seguridad Vial desde su promulgación.

${ }^{58}$ Los términos en los que se encontraba redactada la Base Novena de la Ley 18/1989, de 25 de julio, eran los siguientes:

BASE NOVENA

Procedimiento sancionador

1. Se regularán las especialidades tendentes a garantizar la celeridad y sumariedad del mismo, sin detrimento de las garantías individuales.

El procedimiento se iniciará mediante denuncia y no se podrá dictar resolución sin conceder previamente audiencia al interesado. 
ámbito regulatorio. Los principios y criterios que se establecían giraban en torno a los siguientes conceptos:

- Sobre el procedimiento general (por aquel entonces regulado en la Ley de Procedimiento Administrativo de 17 de julio de 1958 que, conforme señala la disp. adic. Primera tendrá carácter supletorio en esta materia) y sin detrimento de las garantías individuales (contempladas en la Constitución) se establecerían las particularidades (especialidades que fueran necesarias) que asegurase la celeridad y sumariedad de ese procedimiento sancionador (Apartado 1, párrafo primero).

- El procedimiento sancionador se iniciaría por denuncia (apartado 1, párrafo segundo).

- El procedimiento sancionador, y la consiguiente resolución sancionadora, requerirían, en todo caso y con carácter esencial de la audiencia al interesado (apartado 1, párrafo segundo).

- Las denuncias formuladas por Autoridades y Agentes en el ámbito de sus "harían fe, salvo prueba en contrario" (Apartado 2).

- Las infracciones prescribirían a los dos meses de su comisión (Apartado 3).

- Las sanciones prescribirían al año de su firmeza (Apartado 3).

- El procedimiento (o los procedimientos) para hacer efectivo el cobro de las sanciones económicas serían los establecidos en la legislación aplicable a las propias Administraciones sancionadoras (Apartado 4).

Al lado de esa Base Novena es preciso ubicar la previsión efectuada en la disposición adicional primera en la medida en la que en ella se establecía que La Ley de Procedimiento Administrativo tendría carácter supletorio para determinadas materias entre las que se incluía la regulada por la propia Base Novena, así como para el Texto Articulado que las desarrolle ${ }^{59}$.

Estos eran los principios y criterios a los que el Gobierno tenía que atenerse, y que se constituían en límites de la encomienda efectuada por el legislativo. Así, se ha

2. Las denuncias por infracciones de las normas sobre tráfico y seguridad vial formuladas por las Autoridades y sus Agentes, en el ámbito de sus atribuciones respectivas, harán fe salvo prueba en contrario, respecto de los hechos denunciados, sin perjuicio del deber de aquéllos de aportar todas las que sean posibles sobre tales hechos.

3. Las infracciones prescribirán a los dos meses de su comisión. Las sanciones prescribirán al año de su firmeza.

4. Los procedimientos de cobro de las multas serán los establecidos en la legislación aplicable para las Administraciones que los hayan impuesto.

59 La disposición adicional primera de la Ley 18/1989, de 25 de julio, se encontraba redactada en los siguientes términos:

DISPOSICIONES ADICIONALES

Primera.

La Ley de Procedimiento Administrativo tendrá carácter supletorio en las materias reguladas por las Bases séptima, octava y novena y por el Texto Articulado que las desarrolle. 
señalado que las bases no son de aplicación directa como normas y son, al propio tiempo, las directivas y los límites de la delegación confiada al Gobierno ${ }^{60}$.

Por ello, esta técnica legislativa prevista en el art. 82 CE se configura como una delegación recepticia, al adquirir la norma delegada la naturaleza de ley, pero sólo en aquello en que no se sobrepase el límite de la delegación; si se superase tal límite, o se regulase "ex novo" alguna materia, la norma quedaría reducida a un simple reglamento $y$, por tanto, sometida al control de la potestad reglamentaria, a través de las técnicas que para tal control se establecen en nuestro ordenamiento jurídico y que son ejercitables ante la jurisdicción contencioso-administrativa; lo que no sería posible si no se produce "ultra vires", porque entonces estaríamos en presencia de una disposición con rango de ley, revisable únicamente por el Tribunal Constitucional ${ }^{61}$.

\section{EL CONTROL DEL RESULTADO}

La propia configuración de la delegación legislativa requiere de la existencia de mecanismos de control de la ejecución, por el Gobierno, del mandato otorgado por las Cortes Generales.

De manera general el art. 82.6 CE establece que "sin perjuicio de la competencia propia de los Tribunales, las leyes de delegación podrán establecer en cada caso fórmulas adicionales e control". Previsión constitucional que, para el caso que nos ocupa, se concreta con las prescripciones genéricas, establecidas en el ordenamiento jurídico para cualquier delegación legislativa, y las que, de manera específica se establecieron para la efectuada por medio de la Ley 18/1989, de 25 de julio, de Bases sobre Tráfico, Circulación de Vehículos a Motor y Seguridad Vial.

De esta forma, los sistemas de control de la habilitación otorgada al Gobierno por las Cortes Generales, pueden ser:

- Generales: Dictamen del Consejo de Estado

- Adicionales: Verificación parlamentaria

- Hipotética: control judicial por el orden jurisdiccional Contencioso Administrativo y control de constitucionalidad por el Tribunal Constitucional

\footnotetext{
${ }^{60}$ García de Enterría, E. y Fernández Rodríguez T.-R., Curso de Derecho Administrativo, Tomo I, 14ạ ed., Madrid, Civitas, 2008, pág. 263.

${ }^{61}$ Tal y como han señalado las SSTS de 9 de febrero de 2000 (RJ 2000, 323), de 10 de febrero de 2000 (RJ 2000, 325) y de 1 de marzo de 2001 (RJ 2001, 3071).
} 


\section{a) Dictamen del Consejo de Estado}

La Ley Orgánica 3/1980, de 22 de abril, de Consejo de Estado, establece en el art. $21.3^{62}$ que el Consejo de Estado en pleno deberá ser consultado en los proyectos de decretos legislativos. Se trata de un dictamen preceptivo, sí, pero no vinculante. La propia Ley de Bases se hacía eco de esta previsión al señalarlo en el apartado 1 de la disposición adicional Segunda ${ }^{63}$.

En el caso del Real Decreto Legislativo elaborado por el Gobierno en base a la habilitación efectuada por la Ley 18/1989, de 25 de julio, de Bases sobre Tráfico, Circulación de Vehículos a Motor y Seguridad Vial, El Consejo de Estado emitió el correspondiente dictamen en el que se realizan observaciones sobre la regulación del procedimiento administrativo sancionador sin que ninguna de ellas reciba la calificación de esencial por el propio Consejo de Estado ${ }^{64}$.

\section{b) Control parlamentario}

Las previsiones constitucionales que establecen y regulan la delegación legislativa no requieren, necesariamente, de la existencia de un control, por parte del poder legislativo, de la norma resultante de esa habilitación otorgada al Gobierno. No se trata de un trámite preceptivo del que dependa el que la norma elaborada por el Gobierno alcance el rango de ley.

El art. 86.2 CE establece que las respectivas Leyes de delegación pueden (podrán) establecer fórmulas adicionales de control. Se trata, por tanto, y conforme determina

\footnotetext{
${ }^{62}$ La ubicación actual de este art. 21.3 procede de la renumeración efectuada para este artículo por la Ley Orgánica 3/2004, de 28 de diciembre, de modificación de la propia ley Orgánica del Consejo de Estado, que en la redacción originaria, y con la misma redacción, ocupaba el art. 21.1.

${ }^{63}$ La disposición adicional segunda, apartado 1, de la Ley 18/1989, de 25 de julio, de Bases sobre Tráfico, Circulación de Vehículos a Motor y Seguridad Vial, prescribía que:

“1. El Consejo de Estado dictaminará el proyecto de Decreto Legislativo que haya de aprobarse por el Gobierno en ejercicio de la delegación que esta Ley le confiere, de conformidad con los términos establecidos en su propia Ley Orgánica".

64 Dictamen del Pleno del Consejo de Estado no 54.317, de 22 de febrero de 1990, Recopilación de doctrina legal de 1990, pág. 22 y siguientes). El Dictamen destina el apartado III.A) 6 al análisis del procedimiento sancionador, realiza observaciones sobre esta parte del Anteproyecto de la LTSV en el apartado III.B) sobre técnica y sistemática jurídicas en relación a remisiones y colocación sistemática legislativa y en el apartado III.C) sobre orientación y cuestiones gramaticales, sin que ninguna de ellas sea calificada, por el propio Consejo de Estado, como esenciales en cuanto al procedimiento sancionador.

En cuanto al procedimiento sancionador el Dictamen hace referencia a las notificaciones y su práctica, considera que la estructura procedimental que se contiene en el artículo 76 del Proyecto resulta adecuada como fórmula general y que aunque la presunción de veracidad de las denuncias de los Agentes reproduce lo previsto en la Base Novena de la Ley 18/1989, de 25 de julio, "resultaría conveniente que el Proyecto matizase esa presunción, dándole un diferente alcance en función de las circunstancias concurrentes en cada caso".
} 
el propio texto constitucional, de una posibilidad en manos del poder legislativo al habilitar al Gobierno ${ }^{65}$.

En el caso de la Ley 18/1989, de 25 de julio, de Bases sobre Tráfico, Circulación de Vehículos a Motor y Seguridad Vial, su propia disposición adicional Segunda contenía no una, sino dos fórmulas adicionales de control (además del Dictamen del Consejo de Estado) en manos del propio Congreso de los Diputados ${ }^{66}$, al establecerse que:

- La Comisión de Justicia e Interior del Congreso de los Diputados conocerá tras su publicación, a los efectos del art. 82.6 CE, del Decreto Legislativo que apruebe el Gobierno.

- El Pleno del Congreso de los Diputados, de acuerdo con el art. 82.6 CE, conocerá del Decreto Legislativo que apruebe el Gobierno verificando la adecuación del mismo a lo dispuesto en esta Ley.

Independientemente de cómo fue llevado a la práctica ese control inicialmente establecido en la propia Ley de Bases de la norma resultante, del Real Decreto Legislativo, los términos empleados para establecer el control parlamentario resultan enigmáticos.

Se trata, sí, de dos controles en manos del Congreso de los Diputados. Distintos en cuanto al órgano (Comisión de Justicia e Interior uno y del Pleno del Congreso el otro), diversos en cuanto al momento (a la aprobación del Decreto Legislativo por el Gobierno el control del Congreso, mientras que el de la Comisión lo es una vez publicado el Decreto Legislativo) y parece que diferentes, también, en cuanto al alcance (se emplea el término "conocerá" para la Comisión de Justicia e Interior mientras que para el Pleno del Congreso se hace uso de la expresión "conocerá... verificando").

\footnotetext{
${ }^{65}$ Esta previsión constitucional se encuentra recogida en el art. 153 del Reglamento del Congreso de los Diputados que establece el procedimiento cuando, de conformidad con lo establecido en el artículo 82.6 $\mathrm{CE}$, las leyes de delegación establecieren que el control adicional de la legislación delegada se realice por el Congreso de los Diputados. La redacción vigente del Reglamento del Congreso puede consultarse en www.congreso.es/portal/page/portal/Congreso/Congreso/Hist_Normas/Norm/reglam_congreso.pdf.

${ }^{66}$ El contenido de la disposición adicional Segunda de la Ley 18/1989, de 25 de julio, de Bases sobre Tráfico, Circulación de Vehículos a Motor y Seguridad Vial, era del siguiente tenor literal:

Disposiciones Adicionales

Segunda

1. El Consejo de Estado dictaminará el proyecto de Decreto Legislativo que haya de aprobarse por el Gobierno en ejercicio de la delegación que esta Ley le confiere, de conformidad con los términos establecidos en su propia Ley Orgánica.

La Comisión de Justicia e Interior del Congreso de los Diputados conocerá tras su publicación, a los efectos del artículo 82.6 de la Constitución (RCL 1978, 2836), del Decreto Legislativo que apruebe el Gobierno.

2. El Pleno del Congreso de los Diputados, de acuerdo con el artículo 82.6 de la Constitución, conocerá del Decreto Legislativo que apruebe el Gobierno verificando la adecuación del mismo a lo dispuesto en esta Ley.
} 
Esto ocasionó un estado de confusión, y de discusión, en sede parlamentaria que dio lugar a diferentes interpretaciones y no solo de lo que había de suceder en este concreto caso, sino de lo que de manera general suponía el control de la delegaciones legislativas ${ }^{67}$.

Como ya se ha señalado estas fórmulas adicionales de control son las que confiere el rango de ley a la disposición elaborada por el Gobierno, su objetivo se ciñe a comprobar la adecuación del Decreto Legislativo, y de su contenido, a las bases establecidas y al cumplimiento de los principios y criterios establecidos (conforme señala el art. 82.4 CE), de manera que como previene el art. 153.5 del reglamento del Congreso "los efectos jurídicos del control serán los previstos en la ley de delegación", pues, en definitiva, "la adquisición del rango de Ley depende de que el texto articulado se mantenga dentro de los límites de la delegación" ${ }^{68}$.

De todas maneras la, a mi juicio, ininteligible previsión efectuada en la disposición adicional Segunda de la Ley 18/1989, de 25 de julio, de Bases sobre Tráfico, Circulación de Vehículos a Motor y Seguridad Vial, se tramitó conforme a las previsiones del art. 153 del Reglamento del Congreso de los Diputados.

No se tratá, ni es la previsión constitucional ni fue lo previsto en el caso de la delegación legislativa para establecer una regulación legal en materia de tráfico, circulación de vehículos a motor y seguridad vial, de un procedimiento de ratificación por el poder legislativo de la disposición elaborada por el Gobierno, trámite que de existir (y con la tramitación adecuada) supondría la conversión en Ley del Decreto Legislativo, con todas las consecuencias que ello supondría, entre ellas la subsanación de los posibles excesos sobre la habilitación concedida en los que hubiera podido incurrir el, hasta el momento en el que se produce y practica esa ratificación, Decreto Legislativo.

\section{c) Control judicial}

El control judicial de los Decretos Legislativos forma parte del ámbito del orden contencioso - administrativo precisamente "en cuanto excedan de los límites de la delegación" tal y como establece el art. 1.1 LCA, precepto que materializa el inciso inicial del art. 82.6 CE que señala la posibilidad de establecer formulas adicionales de control "sin perjuicio de la competencia propia de los tribunales". Si hay exceso sobre

\footnotetext{
${ }^{67}$ De la Quadra Salcedo, T., La delegación legislativa en la Constitución en "Estudios sobre la Constitución Española: Homenaje al profesor Eduardo García de Enterría”, vol. I El ordenamiento jurídico, págs. 327 406, 1991; Vírgala ForURIA, E., La delegación legislativa en la Constitución y los decretos legislativos como normas con rango incondicionado de ley, Madrid, Publicaciones del Congreso de los Diputados, D.L. 1991, pág. 223 y siguientes.

68 García de Enterría, E. y Fernández Rodríguez T.-R., Curso de Derecho Administrativo, Tomo I, 14a ed., Madrid, Civitas, 2008, págs. 262, 263, 266 y 267.
} 
la habilitación recibida el resultado normativa, en esa parte, no alcanza la categoría de ley ${ }^{69}$.

El resumen es que "el rango de Ley es predicable del Decreto delegado sólo intra vires de la delegación; ultra vires no hay rango de Ley posible, porque no estando cubierto en este caso el contenido de la norma delegada por la Ley de delegación, el Decreto no puede darse a sí mismo un rango superior" ${ }^{\prime 70}$.

Pero este tipo de control, el que pueden efectuar los Tribunales, es hipotético. Puede llegar a ocurrir en la medida de que alguien lo demande y pida que ese control se efectúe. El órgano jurisdiccional se tiene que encontrar con la situación que le permita apreciar la existencia de un exceso en los términos en los que fue constituida la delegación o un defecto de forma en su elaboración. Los órganos jurisdiccionales necesitan de un apoyo que les permita hacer pie y apoyarse en el art. 9.3 CE y en el art. 6 LOPJ para no aplicar los reglamentos o cualquier otra disposición contrarios a la Constitución, a la Ley o al principio de jerarquía normativa, o para actuar, conforme a lo establecido en los arts. 26 y 27 LJCA para el orden contencioso - administrativo, en los recursos, ya sean directos o indirectos, contra disposiciones generales, puesto que pertenecen al ámbito normal de poderes del Juez el inaplicar los Decretos legislativos en lo que exceden de la delegación o más propiamente el no conferir al exceso el valor de Ley $^{71}$.

En el caso de la Ley 18/1989, de 25 de julio, de Bases sobre Tráfico, Circulación de Vehículos a Motor y Seguridad Vial, si existió la posibilidad de control judicial sobre la existencia de posibles excesos en la delegación al interponerse recurso contencioso administrativo directo "frente al Texto articulado de la Ley sobre Tráfico, Circulación de Vehículos a Motor y Seguridad Vial, aprobado por Real Decreto Legislativo 339/1990 de 2 marzo, instando en el suplico de la demanda rectora del recurso, su nulidad de pleno derecho, o subsidiariamente que no son conformes a Derecho el art. 71.2 y los arts. 9 a 52 del precitado Texto articulado" (como señala el Fundamento de

\footnotetext{
69 Téngase en cuenta que, al momento de la promulgación de la LTSV, estaba vigente la LJCA/1956, norma que, en su art. 1.1, disponía que "la Jurisdicción contencioso - administrativa conocerá de las pretensiones que se deduzcan en relación con los actos de la Administración pública sujetos al Derecho administrativo y con las disposiciones de categoría inferior a la Ley", sin expresa mención a los decretos legislativos que excedieran los límites de la delegación. Pero, de igual manera, resulta preciso tener presente que el Tribunal Supremo había interpretado el art. 1 LJCA/1956 estableciendo que, desde el punto de vista de su fiscalización, las leyes delegadas sólo eran fiscalizables por el Orden jurisdiccional Contencioso - Administrativo para comprobar su adecuación o no a la delegación concedida o si se dictaron dentro del plazo señalado al efecto (como señalan, entre otras, las SSTS 30 de diciembre de 1986, RJ 1986, 7708, de 6 de marzo de 1991, RJ 1991, 2883 y de 2 de julio de 1992, RJ 1992, 6107).

70 García de Enterría, E. y Fernández Rodríguez T.-R., Curso de Derecho Administrativo, Tomo I, 14ạ ed., Madrid, Civitas, 2008, pág. 268. A lo que añaden que “... del mismo modo que nadie puede levantarse del suelo tirándose a sí mismo de los pelos".

${ }^{71}$ ATC 69/1983, de 17 de febrero, F. 3. Véase el apartado siguiente sobre el control por el Tribunal Constitucional de los Decretos Legislativos.
} 
Derecho Primero de la propia STS de 21 de octubre de 1993 (RJ 1993, 7201) 72 que resolvió sobre el recurso formulado.

El Tribunal Supremo avala el Decreto Legislativo resultante y lo considera adecuado a las bases, principios y criterios establecidos en la Ley de Bases ${ }^{73}$.

\section{d) Control de constitucionalidad}

La delegación legislativa también es susceptible de control de constitucionalidad por parte del Tribunal Constitucional.

La Ley Orgánica 2/1979, de 3 de octubre, del Tribunal Constitucional (LOTC), contempla, en el art. 27.2 b), que son susceptibles de declaración de inconstitucionalidad "las demás leyes, disposiciones normativas y actos del Estado con fuerza de ley" y que "en el caso de los decretos legislativos, la competencia del Tribunal se entiende sin perjuicio de lo previsto en el número 6 del art. 82 CE".

Se trata de dos controles, el jurisdiccional y el constitucional, que pueden recaer sobre el mismo objeto, en virtud de lo establecido en el art. 6 LOPJ, en el art. 1.1 LCA y en este art. 27.2 b) LOTC.

En el caso del control que se efectúa por parte del Tribunal Constitucional es competente, en virtud de los arts. 163 CE y 27.2 b) LOTC, para ejercer su control de constitucionalidad sobre los Decretos Legislativos, tanto por razones materiales (si el precepto cuestionado es, por razón de su contenido, contrario a la Constitución), como por razones formales (si se ha incurrido en exceso en el ejercicio de la delegación legislativa o "ultra vires"), y ello sin perjuicio de que este control sea compartido con el

${ }^{72}$ Los términos en los que se encuentra redactado el Fundamento de Derecho segundo de la STS de 21 de octubre de 1993 (RJ 1993, 7201) son los siguientes:

"SEGUNDO.- La pretensión de nulidad de pleno derecho que se postula de la totalidad del Texto articulado de la Ley 18/1989, carece de toda justificación, alegándose como fundamento de la misma lo dispuesto en determinados preceptos de nuestro Ordenamiento Jurídico -art. 47 de la Ley de Procedimiento Administrativo, art. 28 de la Ley de Régimen Jurídico de la Administración del Estado, 1.2 del Código Civil y art. 6.o de la Ley Orgánica del Poder Judicial-, cuya vulneración por el Texto articulado de la Ley sobre Tráfico, Circulación de Vehículos a Motor y Seguridad Vial en nada se explicita y menos se acredita, y otro tanto cabe decir de la impugnación genérica de la validez jurídica de los arts. 9 a 52 del precitado Texto articulado, por tipificar conductas no establecidas ni previstas en la Ley 18/1989, remitiéndose a normas reglamentarias para completar los tipos de conducta sancionables, alegación carente de consistencia al no concretar las supuestas conductas que el Texto articulado combatido tipifica como infracciones, sin que estuviesen contempladas como tales por la Ley de Bases sobre Tráfico, Circulación de Vehículos a Motor y Seguridad Vial, inconcreción que no permite, como se aduce por el señor Abogado del Estado al contestar la demanda, un debate procesal sobre la materia".

73 Cuestiones, todas ellas, objeto de análisis por T. CANO CAMPOS en "El control jurisdiccional de los Decretos Legislativos: la adecuación a las bases de la Ley sobre Tráfico y Seguridad Vial”, Diario La Ley, La Ley, 1995, Tomo I, pág. 1086 y ss. 
que corresponde la jurisdicción Contencioso-Administrativa (art. 82.6 CE y art. 1.1 de la LJCA $^{74}$.

\section{LA LEY DE TRÁFICO Y SEGURIDAD VIAL}

\section{A) La norma}

El día 14 de marzo de 1990 se publica en el Boletín Oficial del Estado el Real Decreto Legislativo 339/1990, de 2 de marzo, por el que se aprobaba el texto articulado de la Ley sobre Tráfico, Circulación de Vehículos a Motor y Seguridad Vial ${ }^{75}$ y en el Boletín Oficial del Estado de 3 de agosto de 1990 se publicaba la correcciones de los errores advertidos en su publicación.

Una escueta introducción de cuatro párrafos antecedía al texto articulado compuesto por 84 artículos, una disposición transitoria, otra derogatoria y otra final, terminado la norma con un Anexo en el que se recogían 69 definiciones a los efectos de la Ley y de sus disposiciones complementarias.

Una norma que sustentaba la intervención de los poderes públicos en este ámbito "como corolario inexcusable de la competencia exclusiva que otorga al Estado, en materia de tráfico y de circulación de vehículos a motor, el artículo 149.1.21. a CE" (párrafo tercero del texto introductorio), que se apoyaba en la entonces vigente Ley de Procedimiento Administrativo de 17 de julio de 1958, cuyo carácter supletorio se establecía para el procedimiento sancionador previsto en la Ley (art. 73 de la propia Ley de Tráfico y seguridad Vial), que derogaba, de manera expresa, la Ley 47/1959, de 30 de julio y la Ley $85 / 1967$, de 8 de noviembre, y, de forma tácita, cuantas disposiciones de igual o inferior rango se opusieran a la presente Ley (disposición derogatoria), que mantenía vivo, como Reglamentos de la propia Ley, el Código de la Circulación aprobado por Decreto de 25 de septiembre de 1934, y disposiciones complementarias, en la medida en que no se opusieran a lo que en ella se establecía

\footnotetext{
74 Tal y como se ha establecido en las SSTC 51/1982, de 19 de julio, F. 1, 47/1984, de 4 de abril, F. 3, 61/1997, de 20 de marzo, F. 2.a, 159/2001, de 5 de julio, F. 5, 205/1993, de 17 de junio, FF. 3 a 6, y 51/2004, de 5 de julio, FF. 5 a 8 y 166/2007, de 4 de julio, F.2.

Así, se ha señalado, que la revisión, en cuanto a los posibles excesos, por el orden contencioso administrativo de los Decretos Legislativos no impide el control de los mismos por el Tribunal Constitucional (SSTC 51/1982, de 18 de julio, F. 1 y 47/1984, de 4 de abril, F. 3), lo que no ha impedido que, en determinados casos, el Tribunal Constitucional haya inadmitido el examen de cuestiones de inconstitucionalidad planteadas frente a un Decreto Legislativo al entender que de lo que se discutía, precisamente, era del exceso sobre la delegación y que, por lo tanto, se trataba de materia controlable por la jurisdicción ordinaria y no por el Tribunal Constitucional (ATC 69/1983, de 17 de febrero, F. 3).

${ }^{75}$ La Ley de Tráfico y Seguridad Vial no contiene indicación expresa sobre la fecha de su entrada en vigor por lo que, en virtud de lo prescrito en el art. 2.1 del Código Civil, precepto en el que se establece que "las leyes entrarán en vigor a los veinte días de su completa publicación en el «Boletín Oficial del Estado", si en ellas no se dispone otra cosa", la Ley de Tráfico y Seguridad Vial entró en vigor el día 3 de abril de 1990.
} 
(disposición transitoria) y que facultaba al Gobierno tanto para dictar las disposiciones necesarias para desarrollar la presente Ley, como para modificar los conceptos básicos contenidos en su anexo de acuerdo con la variación de las definiciones de los mismos que se produzca en el ámbito de Acuerdos y Convenios internacionales con trascendencia en España (disposición final primera).

\section{B) El Régimen sancionador en la Ley de Tráfico y Seguridad Vial}

El texto articulado de la Ley sobre Tráfico, Circulación de Vehículos a Motor y Seguridad Vial (LTSV) ordenaba el régimen sancionador en sus veinte artículos finales (arts. 65 a 84) que distribuía en dos grupos, con forma de Títulos (el IV y el V) ${ }^{76}$.

El Título IV (art. 65 a 72) recibía la denominación "de las infracciones y sanciones, de las medidas cautelares y de la responsabilidad" y el Título $V$ (art. 73 a 84) la de "Procedimiento sancionador y recursos".

Se trataba de una concepción que, en cierta medida, resultaba bastante continuista con los planteamientos hasta entonces efectuados por el Código de la Circulación de $1934^{77}$.

\section{C) El procedimiento sancionador}

La Ley de Tráfico y Seguridad Vial regulaba, de forma aparentemente separada, aislada y estanca, el procedimiento sancionador. El Título VI de la Ley, bajo la denominación "procedimiento sancionador y recursos", daba cobertura a cuatro capítulos que, respectivamente, ordenaban el "procedimiento sancionador" (en sentido estricto), "los recursos", "la prescripción y cancelación de antecedentes" y "la ejecución de las sanciones".

El procedimiento sancionador establecido partía del principio de legalidad y del carácter supletorio de la Ley de Procedimiento Administrativo de 1958 (art. 73 LTSV).

\footnotetext{
76 Esta es la estructura que, de manera original, presentaba el régimen sancionador (denominación actual bajo la que se agrupan los arts. 65 a 93) ya que en la actualidad, la Ley de Tráfico y Seguridad Vial y que, como tendremos ocasión de analizar, ha ido variando con el paso del tiempo hasta presentar, a día de hoy, una conformación totalmente distinta.

77 De hecho, en el "Estudio generalizado sobre el Anteproyecto de Texto Articulado sobre Tráfico, Circulación de Vehículos a Motor y Seguridad Vial", de 25 de enero de 1990, realizado por la Federación Española de Municipios y Provincias se señalaba que la LTSV "sólo contempla un incremento de sanciones, pero no una mejora del procedimiento sancionador", tal y como recoge el Dictamen del Pleno del Consejo de Estado no 54.317, de 22 de febrero de 1990, en el Antecedente tercero.
} 
La regulación establecida, como desarrollo de los criterios y principios establecidos en la Ley de bases, se asentaba sobre unos fundamentos tan sencillos como ingenuos, tal y como el tiempo pondría en evidencia. Estos principios eran:

- La imposición de las sanciones previstas en la Ley de tráfico y seguridad vial requiere del procedimiento legalmente establecido (art. 73 párrafo primero LTSV)

- Carácter supletorio de la LPA (art. 73 párrafo segundo LTSV)

- Actuaciones administrativas y jurisdiccionales penales (art. 74 LTSV)

- Incoación: de oficio por la autoridad competente o por denuncia (art. 75.1 LTSV)

- Denuncias obligatorias: deber de los Agentes de la Autoridad encargados del servicio de vigilancia de tráfico de denunciar las infracciones que observen cuando ejerzan funciones de vigilancia y control de la circulación vial (art. 75.2 LTSV)

- Contenido de las denuncias: La identificación del vehículo con el que se hubiese cometido la supuesta infracción, la identidad del denunciado, si fuere conocida, una relación circunstanciada del hecho, con expresión del lugar, fecha y hora y el nombre, profesión y domicilio del denunciante (art. 75.3 inciso inicial LTSV)

- Cuando éste sea un Agente de la Autoridad podrán sustituirse estos datos por su número de identificación. En las denuncias por hechos ajenos a la circulación se especificarán todos los datos necesarios para la exacta descripción de los mismos (art. 75.3 inciso final LTSV).

- Denuncias de las autoridades y sus Agentes: lo que se dio en denominar "presunción de veracidad" (Las denuncias efectuadas por los Agentes de la Autoridad encargados de la vigilancia del tráfico harán fe, salvo prueba en contrario, respecto de los hechos denunciados, sin perjuicio del deber de aquéllos de aportar todos los elementos probatorios que sean posibles sobre el hecho denunciado, art. 76 LTSV)

- Notificación de denuncias: La norma general es la notificación en el acto con el contenido del art. 75 y el derecho a presentar alegaciones en el plazo de quince del art. 79.1, estableciéndose que "por razones justificadas que deberán constar en la propia denuncia, podrá notificársele la misma con posterioridad" (art. 77 LTSV).

- Domicilio de notificaciones: se establece, como norma general que se considerará domicilio del conductor y del titular del vehículo aquel que los interesados hayan expresamente indicado y, en su defecto, el que figure en los Registros de Conductores e Infractores, y en el de Vehículos, respectivamente (art. 78.1 párrafo primero LTSV) 
- Obligación de comunicar los cambios de domicilio tanto de los titulares de los vehículos como de los titulares de los permisos para conducir (art. 78.1 párrafo segundo LTSV)

- Denuncia no notificadas en el acto y demás notificaciones del procedimiento sancionador: se cursarán al domicilio indicado en el 78.1 y se ajustarán al régimen y requisitos previstos en la Ley de Procedimiento Administrativo (art. 78.2 LTSV)

- Tramitación: Instrucción por Jefatura Central de Tráfico y Ayuntamientos, que deberán notificar las denuncias, si no se hubiere hecho por el denunciante, al presunto infractor, concediéndole un plazo de quince días para que alegue cuanto considere conveniente a su defensa y proponga las pruebas que estime oportunas (art. 79.1 LTSV)

- Tramitación: De las alegaciones del denunciado se dará traslado al denunciante para que informe en el plazo de quince días (art. 79.2 LTSV)

- Resolución: Transcurridos los plazos señalados en los números anteriores a la vista de lo alegado y probado por el denunciante y el denunciado, y tras la eventual práctica de la prueba y ulterior audiencia a los interesados, en los casos en que ello fuera estrictamente necesario para la averiguación y calificación de los hechos, se dictará la resolución que proceda (art. 79.3 LTSV)

- Otras cuestiones: en el mismo título se regulan las cuestiones relativas a los recursos, prescripción y ejecución de sanciones.

\section{D) Una primera aproximación al punto de partida del procedimiento sancionador establecido en la Ley de Tráfico y Seguridad Vial}

Con la ventaja que otorga el paso del tiempo, y el conocimiento de lo que en su transcurso ha ido sucediendo, nos aproximamos a la configuración que, del procedimiento sancionador, se efectuaba en la Ley de Tráfico y Seguridad Vial y así, con las cartas marcadas, realizamos las siguientes consideraciones sobre esas previsiones.

\section{UN PROCEDIMIENTO SUSTENTADO EN LA LPA}

El procedimiento sancionador diseñado por la Ley de Tráfico y Seguridad Vial se muestra respetuoso con los principios a los que se encuentra sometido y, así, su primera declaración de principios, recogida en el art. 73 LTSV como "normas generales", consiste en recepcionar en este ámbito el principio de legalidad para la determinación de las infracciones y sanciones, cuya imposición habrá de realizarse por medio del procedimiento que habrá de ser instruido conforme a las normas 
legalmente establecidas ( $\mathrm{y}$, aunque nada se diga, sin perjuicio de su posterior desarrollo reglamentario).

Ese procedimiento sancionador que se establece contiene una serie de características propias, de peculiaridades ${ }^{78}$ (básicamente son cuestiones relacionadas con la denuncia como medio de inicio del procedimiento), pero su esencia se sustenta, se sigue sustentando, en la regulación establecida en la Ley de Procedimiento Administrativo de 17 de julio de 1958, que da soporte supletorio (tal como prescribía la disposición adicional primera de la propia Ley de Bases) ${ }^{79}$ a las previsiones establecidas en la Ley de Tráfico y Seguridad Vial ${ }^{80}$ y a la que, en varios puntos de la propia regulación del procedimiento sancionador, se refiere de manera expresa ${ }^{81}$. De todo ello se desprende que más que de un procedimiento en sí mismo se trata de una adaptación del genéricamente establecido a este concreto ámbito.

Esta parece ser la realidad con la que se corresponde el procedimiento sancionador establecido en la Ley de Tráfico y Seguridad Vial, la de un procedimiento sancionador que, establecido sobre la regulación que la Ley de procedimiento Administrativo de 17 de julio de 1958 realiza del "procedimiento especial sancionador", recibe una serie de pecularidades, y no la de un "singular régimen sancionador" 82 .

${ }^{78}$ El propio art. 2 f) de la Ley de Tráfico y Seguridad Vial señala que la Ley regula "Las infracciones derivadas del incumplimiento de las normas establecidas y las sanciones aplicables a las mismas, así como las peculiaridades del procedimiento sancionador en este ámbito".

79 La disp. adic. Primera de la Ley 18/1989, de 25 de julio, disponía que "la Ley de Procedimiento Administrativo, tendrá carácter supletorio en las materias reguladas por las Bases séptima, octava y novena y por el Texto Articulado que las desarrolle".

${ }^{80}$ A lo largo del articulado de la Ley de Tráfico y Seguridad Vial se pueden encontrar diversas referencias a la aplicación de la ley de Procedimiento Administrativo. Así sucede en:

- Art. 63, sobre anulación y revocación de autorizaciones, lugar en el que se establece que "las autorizaciones administrativas reguladas en el presente título podrán ser objeto de declaración de nulidad o anulación, de acuerdo con lo previsto en los artículos 109 y siguientes de la Ley de Procedimiento Administrativo" (art. 63.1) y que "el procedimiento para la declaración de nulidad o anulación se ajustará a lo dispuesto en el título V, capítulo primero, del mencionado texto legal"

- Art. 69, en el que bajo la rúbrica de "graduación de sanciones" se prescribe que "no tendrán el carácter de sanciones las medidas cautelares o preventivas que se pueden acordar con arreglo a la presente Ley y conforme se establece en la Ley de Procedimiento Administrativo" (art. 69.2)

${ }^{81}$ Así sucede, además de en la declaración del carácter supletorio que de la Ley de Procedimiento administrativo se realiza en el art. 73 , en el marco del propio procedimiento sancionador que la Ley de Tráfico y seguridad establece, en relación a la adopción de medidas cautelares (art. 74.2), la notificación de denuncias no notificadas en el acto y del resto de notificaciones a que dé lugar el procedimiento sancionador (art. 78.2) y a la tramitación de recursos (art. 80).

82 Por mucho que la introducción que antecede al Reglamento General de Circulación, aprobado por el RD 13/1992, de 17 de enero (y publicado en el Boletín Oficial del Estado de 31 de enero de 1992), así lo califique, en su primer párrafo, al señalar que "la complejidad y diversidad de cuestiones abordadas en el Real Decreto Legislativo 339/1990, de 2 de marzo, por el que se aprueba el texto articulado de la Ley sobre Tráfico, Circulación de Vehículos a Motor y Seguridad Vial, que incluye desde normas específicamente técnicas sobre la circulación y, en general, sobre el comportamiento de los usuarios y 


\section{NON BIS IN IDEM Y CONCURRENCIA DE ACTUACIONES ADMINISTRATIVAS Y PENALES}

El procedimiento sancionador, como instrumento y cauce establecido para depurar la responsabilidad por la comisión de infracciones administrativas y la imposición de las sanciones asociadas a esas conductas, no ignora (no puede hacerlo) la existencia de los delitos y faltas contenidos en el Código Penal en este ámbito ${ }^{83}$.

titulares de las vías de comunicación, hasta un singular régimen sancionador, pasando por una detallada distribución de competencias entre las diversas instancias públicas, exige que dicho texto contenga a lo largo de su articulado numerosas remisiones reglamentarias, a través de las cuales se detallará el régimen y los requisitos aplicables a las cuestiones técnicas y jurídicas que plantean tan complejas materias".

83 En el momento en el que entra en vigor la Ley de Tráfico y Seguridad Vial estaba vigente el Código Penal de 1973, aprobado por el Decreto 3096/1973, de 14 de septiembre, en el que estaban tipificados los "Delitos contra la seguridad del tráfico", arts. 340 bis a) a 340 bis d), que integraban la Sección 1a del Capítulo II del Título V. Los términos de esos preceptos a la entrada en vigor de la Ley de Tráfico y Seguridad Vial, en la redacción recibida de la Ley Orgánica 3/1989, de 21 de junio (y modificaciones previas realizadas por la Ley 20/1978, de 8 de mayo y Ley Orgánica 8/1983, de 25 de junio), eran los siguientes:

\section{Art. 340 bis a.}

Será castigado con las penas de arresto mayor o multa de 100.000 a 1.000 .000 de pesetas y privación, en todo caso, del permiso de conducción por tiempo de tres meses y un día a cinco años:

1ㅇ El que condujera un vehículo de motor bajo la influencia de bebidas alcohólicas, drogas tóxicas, estupefacientes o sustancias psicotrópicas.

2 El que condujere un vehículo de motor con temeridad manifiesta y pusiera en concreto peligro la vida o la integridad de las personas.

\section{Art. 340 bis b.}

Será castigado con las penas de arresto mayor o multa de 100.000 a 1.000 .000 de pesetas el que origine un grave riesgo para la circulación de alguna de las siguientes formas:

Primera.- Alterando la seguridad del tráfico mediante la colocación en la vía de obstáculos imprevisibles, derramamiento de sustancias deslizantes o inflamables, mutación o daño de la señalización o por cualquier otro medio.

Segunda.- No restableciendo la seguridad de la vía, cuando haya obligación de hacerlo.

\section{Art. 340 bis c.}

Cuando de los actos sancionados en los dos artículos anteriores se ocasionare, además del riesgo prevenido, un resultado lesivo, cualquiera que sea su gravedad, los Tribunales apreciarán tan sólo la infracción más gravemente penada.

En la aplicación de las penas establecidas en los citados artículos procederán los Tribunales según su prudente arbitrio, sin sujetarse a las reglas prescritas en el artículo 61.

\section{Art. 340 bis d.}

Será castigado con las penas de prisión menor, multa de 150.000 a 3.000 .000 de pesetas y privación del permiso de conducción por tiempo de dos a diez años el que, con consciente desprecio por la vida de los demás, realizare la conducta descrita en el número 2 del artículo 340 bis a).

Cuando no se hubiere puesto en concreto peligro la vida o la integridad de las personas, la pena privativa de libertad será la de arresto mayor en su grado medio a prisión menor en su grado mínimo.

El vehículo de motor utilizado se considerará instrumento del delito a los efectos del artículo 48 de este Código. 
La Ley de Tráfico y seguridad Vial recoge como el principio general non bis in idem procedimental la preferencia y prioridad de las actuaciones penales sobre las administrativas sancionadoras.

El principio general del derecho conocido por non bis in idem supone, en una de sus más conocidas manifestaciones, que no recaiga duplicidad de sanciones (ya sean administrativas o penales) en los casos en que se aprecie la identidad del sujeto, hecho y fundamento sin existencia de una relación de supremacía especial de la Administración que justificase el ejercicio del ius puniendi por los Tribunales y a su vez de la potestad sancionadora de la Administración ${ }^{84}$, principio non bis in idem que impide que por autoridades del mismo orden y a través de procedimientos distintos se sancione repetidamente la misma conducta, pues semejante posibilidad entrañaría una inadmisible reiteración en el ejercicio del ius puniendi del Estado e, inseparablemente, una abierta contradicción con el mismo derecho a la presunción de inocencia, porque la existencia de dos procedimientos sancionadores para un determinado ilícito deja abierta la posibilidad contraria a aquel derecho de que unos mismo hechos, sucesiva o simultáneamente, existan y dejen de existir para órganos del Estado $^{85}$.

En definitiva, el principio non bis in idem se configura, de un lado y desde una perspectiva sustancial, como un derecho fundamental del ciudadano frente a la decisión de un poder público de castigarlo por unos hechos que ya fueron objeto de sanción, como consecuencia del anterior ejercicio del ius puniendi del Estado y, por otra, su vertiente procedimental se orienta, esencialmente, no tan sólo a impedir el proscrito resultado de la doble incriminación y castigo por unos mismos hechos, sino

A su lado podían encontrarse otros tipos relacionados con las infracciones previstas en la LTSV, como la omisión de socorro, así como la imprudencia simple con infracción de reglamentos.

Art. 489 ter (Omisión de socorro)

El que no socorriere a una persona que se hallare desamparada y en peligro manifiesto y grave, cuando pudiere hacerlo sin riesgo propio ni de tercero, será castigado con la pena de arresto mayor o multa de 30.000 a 60.000 pesetas.

En la misma pena incurrirá el que, impedido de prestar socorro, no demandare con urgencia auxilio ajeno.

Si la víctima lo fuere por accidente ocasionado por el que omitió el auxilio debido, la pena será de prisión menor.

Art. 600

Serán castigados con multa de 25.000 a 100.000 pesetas los que por simple imprudencia, con infracción de los reglamentos, causen daños en las cosas cuyo importe exceda de la cuantía del Seguro Obligatorio.

Si el hecho se hubiere cometido con vehículo de motor podrá imponerse además, la privación del permiso de conducir por tiempo de hasta tres meses.

Las infracciones previstas en este artículo sólo serán perseguibles mediante denuncia del perjudicado.

${ }^{84}$ Reiterada doctrina constitucional desde la STC 2/1981, de 30 de enero... como se recuerda en la STC 177/1999, de 11 de octubre y STS de 18 de marzo de 2004, RJ 2005, 2129.

${ }^{85}$ SSTC 159/1985, de 27 de noviembre, F. 3; 94/1986, de 8 de julio, F. 4; 107/1989, de 8 de junio, F. 4; 150/1991, de 4 de julio, F. 9; 221/1997, de 4 de diciembre, F. 3; 222/1997, de 4 de diciembre, F. 3 y STS de 18 de marzo de 2004, RJ 2005, 2129. 
también a evitar que recaigan eventuales pronunciamientos de signo contradictorio, en caso de permitir la prosecución paralela o simultánea de dos procedimientos -penal y administrativo sancionador- atribuidos a autoridades de diverso orden, a ello, a impedir tales resultados, se encamina la atribución prioritaria a los órganos jurisdiccionales penales del enjuiciamiento de hechos que aparezcan, prima facie, como delitos o faltas, atribución prioritaria que descansa en la exclusiva competencia de este orden jurisdiccional para depurar y castigar las conductas constitutivas de delito, y no en un abstracto criterio de prevalencia absoluta del ejercicio de su potestad punitiva sobre la potestad sancionadora de las Administraciones públicas, que encuentra también respaldo en el Texto Constitucional ${ }^{86}$.

Las previsiones efectuadas en la redacción originaria del art. 74 LTSV en cuanto a la conexión y acoplamiento entre las posibles actuaciones administrativas y jurisdiccionales penales recoge la doctrina emanada previamente del Tribunal Constitucional que establece la subordinación de los actos de la Administración de imposición de sanciones a la autoridad judicial en la medida que esa sumisión exige que la colisión entre una actuación jurisdiccional y una actuación administrativa haya de resolverse en favor de la primera y ello debido a la imposibilidad de que los órganos de la Administración lleven a cabo actuaciones o procedimientos sancionadores en aquellos casos en que los hechos puedan ser constitutivos de delito o falta según el Código Penal o las leyes penales especiales, mientras la autoridad judicial no se haya pronunciado sobre ellos, con la necesidad de respetar la cosa juzgada, que despliega un efecto positivo, de forma que lo declarado por sentencia firme constituye la verdad jurídica y un efecto negativo, que determina la imposibilidad de que se produzca un nuevo pronunciamiento sobre el tema ${ }^{87}$.

\section{DENUNCIAS}

Las previsiones establecidas en la Ley de Tráfico y Seguridad Vial sobre la denuncia, como medio de incoación del procedimiento sancionador en materia de tráfico, difieren de las previsiones efectuadas en la entonces vigente Ley de Procedimiento Administrativo de 17 de julio de 1958 (LPA) y, al mismo tiempo, presentan un alto grado de continuidad con el régimen formalmente establecido por el Código de la Circulación de $1934^{88}$.

\footnotetext{
${ }^{86}$ STC 177/1999, de 11 de octubre, FF. 3 y 4, ATC 26/2002,, de 26 de febrero, F.5 (sobre distribución competencias en materia de tráfico y seguridad vial entre la Administración del Estado y la Comunidad Autónoma de Cataluña), STC 180/2004, de 2 de noviembre, F. 4 y STS de 18 de marzo de 2004 (RJ 2005, 2129).

${ }^{87}$ STC $77 / 1983$, de 3 de octubre, F. 3.

${ }^{88}$ El sistema previsto en la redacción originaria de los arts. 288 y 289 del Código de la Circulación ya consideraba que en la tramitación de las denuncias de carácter obligatorio la propia entrega de la denuncia suponía el inicio del expediente sancionador.
} 
El art. 134.1 LPA disponía que "el procedimiento deberá incoarse por providencia del órgano competente en cada caso" si bien es cierto que la regulación establecida en la LPA para el procedimiento sancionador, como procedimiento especial, tenía carácter supletorio de la dispuesta para la imposición de sanciones en cada ámbito concreto ${ }^{89}$. $\mathrm{Y}$, en ese marco, el art. 75.1 LTSV establece que "el procedimiento sancionador se incoará de oficio por la Autoridad competente que tenga noticias de los hechos que puedan constituir infracciones a los preceptos de esta Ley o mediante denuncia que podrá formular cualquier persona que tenga conocimiento directo de los mismos", y esta redacción originaria, que va a permanecer vigente hasta la total revisión e implantación de un nuevo modelo de procedimiento sancionador por la Ley 18/2009, de 23 de noviembre, hace uso de unos términos que, en puridad, dan a entender que cualquier tipo de denuncia (ya sea obligatoria o voluntaria) pone en marcha el procedimiento sancionador.

Esta redacción que, en definitiva, no hace sino desarrollar la previsión efectuada en la Ley de Bases en la que se establecía que "el procedimiento se iniciará mediante denuncia" (Base Novena, apartado 1, párrafo segundo, inciso primero) ${ }^{90}$, resulta un tanto extraña y confusa y, sobre ella, incidirá, posteriormente el RD 320/1994, de 25 de febrero, por el que se aprueba el Reglamento de procedimiento sancionador en materia de tráfico, circulación de vehículos a motor y seguridad vial (RPSTSV) ${ }^{91}$.

De igual manera se establecía la obligación de los Agentes de la Autoridad encargados del servicio de vigilancia de tráfico de denunciar las infracciones que observasen en el ejercicio de sus funciones de vigilancia y control de la circulación vial (art. 75.2 LTSV) lo que remitía a la idea ya formulada en el Código de la Circulación de 1934 de las denuncias obligatorias ${ }^{92}$ así como los datos que habrían de constar en esa denuncia, es decir, su contenido, cuestión en la que se percibe una evolución respecto al sistema normativo anterior que refleja tanto los cambios operados en el tráfico como actividad como en las garantías para quien resulte denunciado. Así, mientras en el Código de la Circulación de 1934, se hacía referencia a que "el denunciador entregará, en el acto, al

\footnotetext{
${ }^{89}$ Así lo indicaba, de manera expresa, la propia Exposición de Motivos de la Ley de Procedimiento Administrativo de 17 de julio de 1958 al señalar, en el apartado VII.3 que:

“El procedimiento sancionador tiene carácter supletorio. Sin embargo, las normas esenciales de garantía del interesado, contenidas en la Ley, se aplicarán cuando no estén consignadas en las de un procedimiento especial".

${ }^{90}$ Es más, los términos empleados por la Ley de Bases vienen a establecer que la forma de iniciación del procedimiento sancionador es (siempre) mediante denuncia. Véase supra la nota 53 en la que se reproduce la Base Novena de la Ley de Bases.

91 Publicado en el Boletín Oficial del Estado de 21 de abril de 1994 y que analizaremos, como desarrollo de la Ley de Tráfico y Seguridad Vial.

92 El art. 288 del Código de la Circulación de 1934 clasificaba las denuncias, según su origen en voluntarias y obligatorias. Tenían la consideración de denuncias voluntarias "las que pueda hacer cualquier persona que observe la infracción" y eran obligatorias las denuncias "para la Guardia Civil, Vigilantes de caminos, capataces, Peones camineros, peones que hagan sus veces, personal facultativo encargado del Servicio de los caminos y del Reconocimiento de los vehículos", con tramitaciones diferentes (art. 289) para cada caso.
} 
denunciado un boletín, según el modelo 27 , en el que hará constar la infracción cometida, el lugar, fecha y hora, domicilio del denunciado, o, en su defecto, la reseña de la placa de matrícula si se tratara de vehículo obligado a llevarla, y la sanción que proceda según este Código" el art. 75.3 de la Ley de Tráfico y Seguridad Vial establece que "en las denuncias por hechos de circulación deberá constar: La identificación del vehículo con el que se hubiese cometido la supuesta infracción, la identidad del denunciado, si fuere conocida, una relación circunstanciada del hecho, con expresión del lugar, fecha y hora y el nombre, profesión y domicilio del denunciante. Cuando éste sea un Agente de la Autoridad podrán sustituirse estos datos por su número de identificación. En las denuncias por hechos ajenos a la circulación se especificarán todos los datos necesarios para la exacta descripción de los mismos".

La comparación entre ambas redacción permite constatar lo que permanece y lo que cambia:

- Se mantienen los datos para la determinación espacio - temporal (lugar, fecha y hora), pero no ya como meros datos de concreción, sino dentro de un contexto de acontecimientos, al añadirse que será preciso que en la denuncia conste "una relación circunstanciada del hecho"

- Se requiere, siempre que así resulte posible, la identidad del denunciado

- La identificación del vehículo adquiere la consideración de elemento esencial, en lugar de ser una mera cuestión accidental y subsidiaria

- El hecho que origina la denuncia pasa de ser "la infracción cometida" a "la supuesta infracción" (pues de eso trata precisamente el procedimiento sancionador)

- Es preciso que en la denuncia quede constancia de la persona del denunciante

- No resulta necesario que el denunciante indique la sanción que procede ${ }^{93}$

Sobre las denuncias obligatorias, el art. 76 LTSV establece que "harán fe, salvo prueba en contrario, respecto de los hechos denunciados, sin perjuicio del deber de aquéllos

\footnotetext{
${ }^{93}$ Se trata de una cuestión formal y que enraiza en el temor a que se considere que el sistema no respeta los principios establecidos (separación entre fase instructora y sancionadora) tal y como, posteriormente, será señalado en la nota introductoria al RD 1398/1993, de 3 de agosto, que regula el procedimiento para el ejercicio de la potestad sancionadora (REPEPOS) con cita de la STC 18/1981, de 8 de junio. Por ello se entiende que no corresponde al denunciante fijar la sanción, y se omite toda referencia a ello, ya que se trata de un sistema en el que, conforme a lo que se establece de manera general (pero no única) en el art. 67.1 de la propia Ley de Tráfico y Seguridad Vial, "las infracciones leves serán sancionadas con multa de hasta 15.000 pesetas, las graves con multa de hasta 50.000 pesetas y las muy graves con multa de hasta 100.000 pesetas" y que "en el caso de infracciones graves o muy graves podrá imponerse, además, la sanción de suspensión del permiso o licencia de conducir hasta tres meses", lo que supone la necesidad de determinar la sanción que, de manera concreta, corresponde a cada caso. Planteamiento que, con el tiempo, virará ciento ochenta grados para considerar que la indicación en la denuncia de la cuantía de la multa, lejos de suponer vulneración de derechos del interesado se convierten en garantía ya que "ciertamente no puede negarse que se facilita la defensa, cuando desde el pliego de cargos se hace ya una determinada calificación jurídica" (SSTS de 17 de noviembre de 1993, RJ 1993, 8367 y de 12 de febrero de 2003, RJ 2003, 1084).
} 
de aportar todos los elementos probatorios que sean posibles sobre el hecho denunciado", lo que supone el establecimiento reconocimiento de lo que, genéricamente, será denominado presunción de veracidad de las denuncias efectuadas por los Agentes de la Autoridad y que alcanza a los hechos denunciados ("respecto de los hechos denunciados") que aparezcan recogidos en este tipo de denuncias, previsión que coincide la previsión establecida en la Ley de Bases (Base Novena, apartado 2$)^{94}$.

\section{NOTIFICACIONES}

El art. 77 LTSV establece, como norma general, que las denuncias obligatorias tendrán que ser notificadas en el acto al denunciado y que únicamente "por razones justificadas que deberán constar en la propia denuncia, podrá notificársele la misma con posterioridad".

Esas notificaciones, las de las denuncias realizadas con posterioridad al momento en el que se hubiese cometido la supuesta infracción, así como el resto de notificaciones a que dé lugar el procedimiento sancionador se cursarán al domicilio del interesado (ya sea del supuesto infractor identificado, o de la persona que figura como titular del vehículo con el que se hubiera cometido).

Resulta preciso destacar aquí que el régimen de notificaciones establecido en el art. 78 LTSV, en cuanto a la determinación del domicilio en el que ha de realizarse esa notificación, es distinto en el caso de las notificaciones realizadas en el acto de las que no se efectúan en ese momento (al menos en cuanto a la notificación de la denuncia).

En el caso de las notificaciones de denuncias obligatorias que no han sido efectuadas en el acto esa comunicación habrá de realizarse en el domicilio que, del titular del vehículo con el que se ha cometido la infracción, figure en el Registro de Vehículos.

Para el caso de las notificaciones al identificado como denunciado, estas se habrán de realizar en el que se hubiera "expresamente indicado", a tal efecto, por el interesa, y solo en caso de que no se haya realizado esa manifestación (en su defecto, en términos de la propia Ley) en el que figure en los Registros de Conductores e Infractores, y en el de Vehículos, respectivamente. Norma que se extiende a las sucesivas notificaciones a las que diera lugar el procedimiento sancionador, puesto que se trata de una opción que se confiere al interesado y que puede ejercer en cualquier momento a lo largo de ese procedimiento.

\footnotetext{
${ }^{94}$ Véase supra la nota 53 en la que se reproduce la Base Novena de la Ley de Bases.
} 
La Ley de Tráfico y Seguridad Vial impone a los titulares de vehículos y a los titulares de permisos de conducción el deber de comunicar los cambios de domicilio, lo que supone que pesa sobre ellos la obligación de mantener actualizado ese dato como forma de garantizar la eficacia de las notificaciones que, en el marco de un procedimiento sancionador, se les tuviera que realizar.

Sobre estas premisas se establece que las notificaciones (con exclusión de las realizadas en el acto, en el mismo momento de la denuncia) se ajustarán al régimen y requisitos previstos en la Ley de Procedimiento Administrativo de 17 de julio de $1958^{95}$.

\footnotetext{
${ }^{95}$ Remisión que ha de entenderse efectuada a los arts. 78 a 80 de la entonces vigente LPA en cuanto que en ellos se regulaban las comunicaciones y notificaciones en la ordenación del procedimiento administrativo:
}

Artículo 78.

1. La comunicación entre los órganos administrativos se efectuará siempre directamente, sin que puedan admitirse traslados y reproducciones a través de órganos intermedios.

2. Las comunicaciones y notificaciones serán cursadas directamente a los interesados por el órgano que dictó el acto o acuerdo.

3. Cuando alguna autoridad u órgano intermedio deba tener conocimiento de la comunicación, se le enviará copia de la misma.

Artículo 79.

1. Se notificarán a los interesados las resoluciones que afecten a sus derechos o intereses.

2. Toda notificación se practicará en el plazo máximo de diez días, a partir de la resolución o acto que se notifique, y deberá contener el texto íntegro del acto, con la indicación de si es o no definitivo en la vía administrativa y, en su caso, la expresión de los recursos que contra la misma procedan, órgano ante el que hubieran de presentarse y plazo para interponerlos, sin perjuicio de que los interesados puedan ejercitar cualquier otro que estimen pertinente.

3. Las notificaciones defectuosas surtirán, sin embargo, efecto a partir de la fecha en que se haga manifestación expresa en tal sentido por el interesado o se interponga el recurso pertinente.

4. Asimismo surtirán efecto por el transcurso de seis meses las notificaciones practicadas personalmente al interesado que, conteniendo el texto íntegro del acto hubieran omitido otros requisitos, salvo que se hubiera hecho protesta formal, dentro de este plazo, en solicitud de que la Administración rectifique la deficiencia.

Artículo 80.

1. Las notificaciones se realizarán mediante oficio, carta, telegrama o cualquier otro medio que permita tener constancia de la recepción, de la fecha y de la identidad del acto notificado, y se dirigirá en todo caso al domicilio del interesado o al lugar señalado por éste para las notificaciones. Si se tratase de oficio o carta, se procederá en la forma prevenida en el número tres del artículo 66, uniéndose al expediente el resguardo del certificado.

2. De no hallarse presente el interesado en el momento de entregarse la notificación, podrá hacerse cargo de la misma cualquier persona que se encuentre en el domicilio y haga constar su parentesco o la razón de permanencia en el mismo.

3. Cuando los interesados en un procedimiento sean desconocidos, o se ignore su domicilio, la notificación se hará por medio de anuncios en el tablón de edictos del Ayuntamiento de su último domicilio y en el «Boletín Oficial del Estado» o de la provincia. 


\section{LA PARTICIPACIÓN DE DENUNCIADO}

El art. 79 LTSV establece las bases que ha de seguir la tramitación del procedimiento sancionador y lo hace desde una perspectiva de garantizar el derecho del interesado (del presunto infractor) la participación en el expediente sancionador.

De esta manera el art. 79 LTSV se centra en el deber del órgano instructor de notificar la denuncia (si no se hubiere hecho por el denunciante) al presunto infractor para que tenga la oportunidad de alegar lo que a su derecho convenga y proponer las pruebas que estime oportunas (art. 79.1 LTSV), a establecer la garantía de que de realizar alegaciones el denunciado tendrán que ser trasladadas al denunciante que informar sobre ellas (art. 79.2 LTSV) y que se dictará la resolución que en derecho proceda siempre, eso sí, "a la vista de lo alegado y probado por el denunciante y el denunciado, y tras la eventual práctica de la prueba y ulterior audiencia a los interesados, en los casos en que ello fuera estrictamente necesario para la averiguación y calificación de los hechos" (art. 79.3 LTSV), que es la traslación y desarrollo de la previsión establecida en la ley de bases conforme a la que "no se podrá dictar resolución sin conceder previamente audiencia al interesado" (Base Novena, apartado primero, párrafo segundo, inciso final) ${ }^{96}$.

\section{LAS GARANTÍAS INDIVIDUALES}

El procedimiento sancionador en materia de tráfico se constituye en garantía del presunto responsable. Así lo establecía la Ley de Bases al determinar que "se regularán las especialidades tendentes a garantizar la celeridad y sumariedad del mismo, sin detrimento de las garantías individuales" (Base Novena, apartado primero, párrafo primero). Garantías que no se agotan en el propio procedimiento sancionador y que deben permitir el control, formal y material, de la tramitación efectuada, de manera que, en el mismo título y al lado del procedimiento sancionador, la Ley de Tráfico y Seguridad Vial regula las cuestiones relativas a los recursos, prescripción y ejecución de sanciones

Sobre los recursos el art. 80 LTSV se limita a establecer la posibilidad de recurrir en alzada (de acuerdo con la Ley de Procedimiento Administrativo) las resoluciones sancionadoras y la de acudir a la Jurisdicción Contencioso - Administrativa para combatir las resoluciones que pongan fin al procedimiento en vía administrativa.

Se establece, conforme al principio establecido en la Ley de Bases (Base Novena, apartado tercero $)^{97}$. Un plazo para la prescripción de las infracciones de dos meses, contados a partir del día siguiente a aquél en que se hubiesen cometido (art. 81.1

\footnotetext{
${ }^{96}$ Véase supra la nota 53 en la que se reproduce la Base Novena de la Ley de Bases.

${ }^{97}$ Ibidem
} 
LTSV), y de un año para las sanciones, a computar desde el momento en que adquieran firmeza (art. 81.2 LTSV), plazo que vienen a coincidir con los establecidos en el entonces vigente Código Penal para la prescripción de las faltas y de las penas leves ${ }^{98}$.

La prescripción de las infracciones se interrumpe por cualquier actuación de la Administración de la que tenga conocimiento el denunciado o esté encaminada a averiguar su identidad o domicilio y la de las sanciones únicamente por las actuaciones encaminadas a su ejecución.

La ejecución de las sanciones requiere que hayan adquirido firmeza en vía administrativa (art. 83.1 LTSV), estableciéndose que en caso de impago de las multas su exacción se llevará a efecto por el procedimiento de apremio (art. 84.2 LTSV) que, en el caso de las sanciones impuestas por la Administración del Estado se realizará conforme a lo establecidos en el Reglamento General de Recaudación y demás normas de aplicación y, para el resto de Administraciones, siguiendo los procedimientos establecidos en sus respectivas legislaciones (art. 84.3 LTSV), tal como establecía la previsión efectuada en la Ley de Bases (Base Novena, apartado cuarto) ${ }^{99}$, lo que se ubica su impugnación en el ámbito de la vía económico-administrativa (art. 84.4 LTSV).

\section{OTRAS PREVISIONES EXTRAORDINARIAS}

La regulación del procedimiento sancionador en materia de tráfico no se agota con las previsiones que la Ley efectúa en el ámbito por ella destinado al "procedimiento sancionador y recursos". Esperar que la situación fuera tan sencilla sería desconocer el propio carácter asistemático de la norma.

Especial relevancia tienen, a efectos del procedimiento sancionador, alguna de las prescripciones realizadas en el marco destinado a las sanciones. El art. 67 LTSV, bajo esa rúbrica, la de "sanciones" es un vaso absolutamente desbordado. Un coctel en el que se han mezclado, con esa regulación de los castigos que merecen las conductas que vulneran lo establecido en la LTSV en materia de tráfico y seguridad vial,

\footnotetext{
${ }^{98}$ El art. 112 del CP/1973 establecía, al momento de promulgación de la LTSV, que la responsabilidad penal se extinguía por la prescripción del delito (apartado 6ㅇ) y por la prescripción de la pena (apartado 7ㅇ) .

El art. 113 CP/1973 prescribía la prescripción de las faltas a los dos meses y el art. 115 CP/1973 que las penas leves impuestas por sentencia firme prescribían al año.

Por otra parte, el contenido y redacción que el Real Decreto 2625/1976, de 1 de octubre, introduce en el art. 284 CCirc se viene a corresponder, y en ese sentido enlaza, con la previsiones que, en la redacción original, se establecían en el art. 81 LTSV y, posteriormente, en el art. 18 del Real Decreto 320/1994, de 25 de febrero. En ambos casos el plazo que, de manera general, se establece para la prescripción de las infracciones, es de dos meses y también coincide en cuanto al plazo marcado para la prescripción de las sanciones, que es el de un año. De igual manera las previsiones realizadas en ambas normas, tanto sobre la interrupción como sobre el cómputo de los plazos de prescripción, son coincidentes en sus elementos esenciales.

${ }^{99}$ Véase supra la nota 53 en la que se reproduce la Base Novena de la Ley de Bases.
} 
infracciones que deberían haberse ubicado en el recipiente correspondiente (art. 65 LTSV) y cuestiones que conforman auténticas previsiones procedimentales en supuestos específicos.

Es el caso de lo establecido en el art. 67.1 párrafo tercero LTSV ${ }^{100}$ para el supuesto de las denuncias obligatorias notificadas en el acto cuando el infractor no acredite su residencia habitual en territorio español, por el hecho de que esas circunstancias conllevan la adopción de unas medidas cautelares sobre las que ninguna referencia se realiza en los arts. 73 a 84 LTSV y que van suponer la necesidad de que el infractor afiance el importe de la multa, provisionalmente fijado por el agente, ya que en caso contrario, si el infractor no lo hace (no puede o no quiere depositar esa cantidad) se procederá a la inmovilización del vehículo con el que se ha cometido la supuesta infracción ${ }^{101}$.

Se trata de una previsión extraordinaria por los efectos que supone, realizada de forma extravagante y que no explica ni toma en consideración los efectos sobre un tipo de infractores que, aun no pudiendo acreditar su residencia en territorio nacional, merecen para nuestro ordenamiento un tratamiento especial, como es el caso de los nacionales de otros Estados miembros de la Unión Europea, ni si lo aquí prescrito resulta aplicable a los infractores que aun siendo nacionales no pudieran acreditar su residencia.

\section{E) Una primera valoración del procedimiento sancionador establecido en la Ley de Tráfico y seguridad Vial como punto de partida}

La crítica del sistema de procedimiento sancionador establecido en la redacción originaria de la Ley de Tráfico y Seguridad Vial desde una perspectiva tan distante en el tiempo puede resultar tan fácil como injusta, por ello resulta preciso valorar la norma de acuerdo al momento y circunstancias en las que fue promulgada ${ }^{102}$.

\footnotetext{
${ }^{100}$ Téngase en cuenta los efectos que, sobre este apartado tercero del art. 67.1 LTSV, tuvo la tramitación y promulgación de la Ley 5/1997, de 24 de marzo, que supuso su fortuita desaparición del texto de la Ley, así como el posterior Real Decreto - Ley 12/1997, de 1 de agosto, por el que se recuperó para el texto legal.

${ }^{101}$ El art. 67.1 párrafo tercero LTSV establecía, en su redacción originaria, que:

"Cuando el infractor no acredite su residencia habitual en territorio español, el Agente denunciante fijará provisionalmente la cuantía de la multa, y de no depositarse su importe o garantizarse su pago por cualquier medio admitido en derecho, inmovilizará el vehículo en los términos y condiciones que se fijen reglamentariamente. En todo caso, se tendrá en cuenta lo previsto en el párrafo anterior respecto a la reducción del 20 por $100 "$.

102 A estos efectos sirva como ejemplo, como ya se ha señalado, la crítica vertida en el "Estudio generalizado sobre el Anteproyecto de Texto Articulado sobre Tráfico, Circulación de Vehículos a Motor y Seguridad Vial", de 25 de enero de 1990, realizado por la Federación Española de Municipios y Provincias se señalaba que la LTSV “sólo contempla un incremento de sanciones, pero no una mejora del procedimiento sancionador" (cfr. Dictamen del Pleno del Consejo de Estado no 54.317, de 22 de febrero
} 


\section{UN PROCEDIMIENTO GENÉTICAMENTE LASTRADO}

El procedimiento sancionador, tal y como se estructura y diseña por la Ley de Tráfico y Seguridad Vial, llega al mundo jurídico lastrado y con unas taras que, en cuanto la errónea percepción del escenario en el que tiene que desenvolverse y que afectan a la esencialidad del sistema, van a impedir que el procedimiento establecido pueda cumplir, de una forma eficaz y de una manera eficiente, con la función que se le asigna.

El problema, el gran problema, no se encuentra siquiera en la propia Ley de Tráfico y Seguridad Vial. El gran inconveniente es la propia definición del sistema, al pretender asentar el procedimiento sancionador en el sistema definido, de manera general, por la Ley de Procedimiento Administrativo de 17 de julio de 1958.

Si el procedimiento administrativo general se encontraba en dificultades para la gestión de la tramitación ordinaria, mucho de los cuales no han hecho más que consolidarse con la Ley 30/1992, de 26 de noviembre, de Régimen Jurídico de las Administraciones Públicas y Procedimiento Administrativo Común (LRJ - PAC), la traslación de ese sistema como base a un fenómeno que, "al efectuarse de forma masiva y simultánea lleva consigo una serie de problemas que es necesario regular para que aquél ejercicio no lesione intereses individuales o colectivos que deben ser objeto de protección pública” ${ }^{103}$.

La configuración del procedimiento sancionador en materia de tráfico y seguridad vial, como elección de un conjunto de medidas instrumentales para articular la depuración de responsabilidades por infracción de las normas establecidas no resulta adecuada. De la misma manera que se percibe la necesidad de establecer determinadas peculiaridades para el ámbito sancionar en materia de tráfico y seguridad vial, no se distingue cuales han de ser esas singularidades diferenciadoras ${ }^{104}$.

La crítica, que lo es, no se dirige ni tiene como objeto la decisión de adoptar como base, la regulación establecida en la Ley de Procedimiento Administrativo de 17 de julio de 1958 (tanto del procedimiento general como del establecido de manera especial para el ámbito sancionador). La crítica, que como decimos lo es, apunta a que no se establecen las peculiaridades adecuadas a las necesidades que, en ese momento,

de 1990, en el Antecedente tercero). O la que acertadamente realiza NIETO al sistema de infracciones en la primera edición de su Derecho Administrativo Sancionador, Tecnos, 1993, 424 págs.

103 Términos de los que hace uso la propia nota introductoria que antecede al articulado de la Ley de Tráfico y seguridad Vial.

${ }^{104}$ Cuestión a la que ya hemos hecho referencia en el Apartado anterior al señalar que el propio art. 2 f) de la Ley de Tráfico y Seguridad Vial señala que la Ley regula "Las infracciones derivadas del incumplimiento de las normas establecidas y las sanciones aplicables a las mismas, así como las peculiaridades del procedimiento sancionador en este ámbito". 
ya presenta de un forma ostensible y evidente, el instrumento que resulta preciso como cauce formal de la serie de actos en que se ha de concretar la actuación administrativa para la realización de un fin que, en este caso, es el de depurar las responsabilidades e imposición de sanciones por la infracción de las normas establecidas en materia de tráfico y seguridad vial ${ }^{105}$.

La crítica, que lo es, no es tanto en términos de disquisición sobre sí debía haberse establecido o no un procedimiento especial o sí hubiera sido suficiente con profundizar en esas peculiaridades, determinando aquellas que realmente eran necesidades propias del fenómeno del tráfico y de su procedimiento sancionador. Ambas soluciones hubieran sido válidas en cuanto se antoja que, por ambos medios, se hubiera podido dotar al ordenamiento de un procedimiento acorde con las necesidades.

Porque la crítica, que los es, se dirige a la ausencia de regulación de un procedimiento sancionador coherente, congruente $y$, en definitiva, consistente, con las necesidades que, en la práctica y en ese momento, requería la Administración para poder con todas las garantías, tanto las del presunto infractor como de las que justifican "la obligada intervención de los poderes públicos en el mantenimiento de la seguridad de la circulación vial”106, una regulación que fuera respetuosa con la finalidad perseguida, y así establecida por la propia Ley de Bases al prescribir, sobre el procedimiento sancionador, que "se regularán las especialidades tendentes a garantizar la celeridad y sumariedad del mismo, sin detrimento de las garantías individuales" (Base Novena, apartado primero, párrafo primero).

Independientemente del momento, y de la diversidad de aspectos que separan al actual de aquél (especialmente en el desarrollo tecnológico y su posible aplicación al derecho administrativo sancionador, en general, y al procedimiento sancionador, en particular), el legislador no tomó las medidas adecuadas y el traje que se obtuvo como resultado no resultó ni el esperado ni, menos aún, el adecuado.

\footnotetext{
105 Expresión que pretende combinar, haciendo uso de los términos de la época, el concepto de procedimiento administrativo (recogido en el apartado VI.1 de la Exposición de Motivos de la Ley de Procedimiento Administrativo de 17 de julio de 1958) con la previsión que, como norma general, se establece para el procedimiento sancionador en materia de tráfico y seguridad vial conforme a la que "no se impondrá sanción alguna por las infracciones a los preceptos de esta Ley, sino en virtud de procedimiento instruido con arreglo a las normas del presente capítulo" (art. 73 párrafo primero de la propia Ley de Tráfico y Seguridad Vial).

106 Haciendo uso, una vez más de los propios términos empleados por el legislador en la nota introductoria de la propia Ley de Tráfico y Seguridad Vial.
} 


\section{UNA INEFICIENTE PREVISIÓN PARA LA INTEGRACIÓN DE ACTUACIONES ADMINISTRATIVAS Y PENALES}

La Ley de Tráfico y Seguridad Vial regula la integración de actuaciones administrativas y penales sobre unos mismos hechos y lo hace en base a los principios non bis in idem y de preferencia y prioridad de las actuaciones penales sobre las administrativas sancionadoras. Es lógico, no se puede sancionar dos veces por los mismo hechos por lo que, en su caso, de ser esos hechos constitutivos de un delito (o falta) la consecuencia penal (en un sistema dotado de coherencia) cubriría completamente a la sanción administrativa que dejaría de tener sentido ${ }^{107}$.

Nada hay que objetar a ese planteamiento, a su origen y lo que se pretende ${ }^{108}$. Pero ello no significa que la forma en la que se lleva a la práctica, la regulación que se realiza y como se plasma en la letra de la Ley, permita cumplir con el efecto deseado y garantice el fin perseguido. $Y$ este es el caso del art. 74 LTSV.

La previsión, en los términos en los que se efectúa, suponía que cometidos unos hechos que podían ser constitutivos de ilícito administrativo o tipo (o falta) penal, la Administración esperaba (tenía que esperar) a la resolución judicial que, declarando la existencia de los hechos, no impusiera responsabilidad penal por los mismos, para proceder a iniciar, continuar o reanudar el correspondiente procedimiento sancionador y determinar, en su caso, la existencia de infracción administrativa y su consecuencia.

Esta regulación ignoraba la realidad de los hechos y su efectividad garantizaba la hipótesis de no transgredir el principio de non bis in idem porque existieran dos resoluciones, una administrativa y otra penal, sobre unos mismos hechos a los que podían pretender imponer una pena y una sanción y que, además, podían llegar a ser, incluso, contradictorias. Pero a cambio también garantizaban que en aquellos casos en los que los hechos fueran constitutivos de infracción administrativa pero no constituyeran transgresión penal, la correspondiente sanción no podría llegar a imponerse por haber prescrito, conforme a los plazos establecidos en la propia Ley de Tráfico y Seguridad Vial, esa infracción, pues la suma de tiempos de la tramitación jurisdiccional y la administrativa iba a suponer, en la práctica, que para cuando la Administración tuviera conocimiento de esa resolución judicial que le daba vía libre y procedía a la tramitación del expediente sancionador era muy probable (cuando no casi seguro) que la culminación de ese procedimiento sancionador y la

\footnotetext{
107 Siempre y cuando el sistema resulte congruente. Cuestión sobre la que resulta especialmente interesante el planteamiento efectuado por GARCíA AMADO ("Sobre el ius puniendi: su fundamento, sus manifestaciones y sus límites”, Documentación Administrativa, no 280 - 281, 2008, págs. 11 - 41).

${ }^{108} \mathrm{O}$ todo, si se toma en consideración el planteamiento realizado por A. Nieto y que, como conclusión, señala que "la regulación concreta de esta regla (non bis in idem), tal y como ha sido elaborada por la jurisprudencia, deja, en fin, mucho que desear puesto que la precedencia del orden penal sobre el administrativo carece de justificación cuando han intervenido jueces contencioso - administrativos" (Derecho Administrativo Sancionador, Madrid, Tecnos, 2012, 5a ed., pág. 496).
} 
correspondiente resolución sancionadora se produciría una vez consumido ese perentorio plazo de dos meses que, como ya ha quedado señalado, establecía el art. 78.1 de la propia Ley de Tráfico y Seguridad Vial al prescribir que "la acción para sancionar las infracciones prescribe a los dos meses, contados a partir del día siguiente a aquél en que se hubiesen cometido", plazo que únicamente quedaba interrumpido "por cualquier actuación de la Administración de la que tenga conocimiento el denunciado o esté encaminada a averiguar su identidad o domicilio, o por la notificación efectuada de acuerdo con lo establecido en el art. 78" (es decir, en el lugar expresamente indicado por el interesado o, en su defecto, en la que figurase en los Registros de Conductores e Infractores y en el Registro de Vehículos).

De esta manera la previsión efectuada como medio de integrar actuaciones administrativas y jurisdiccionales penales eran garantistas para con el presunto infractor, hasta el punto de llegar a impedirla sanción de conductas que, por haber cometido la infracción prevista, eran merecedoras de ese reproche. Esta cuestión era especialmente grave y sensible si se tiene en cuenta que los supuestos en los que se podía producir se correspondían, precisamente, con las infracciones administrativas más graves que, por ello, eran las que se encontraban más próximas a los tipos penales.

A ello se unía la tipificación de infracciones realizada, bajo la denominación de "cuadro general de infracciones" en el art. 65 LTSV y su interacción con la tipificación realizada en Código Penal de 1973. Se trata de una cuestión, la de la relación entre actuaciones administrativas y jurisdiccionales penales, ha atravesado diferentes etapas $y$ planteamientos con reformas de la Ley de Tráfico y Seguridad Vial y del Reglamento de Procedimiento sancionador en materia de Tráfico sin que esté muy claro el planteamiento que se persigue.

\section{LA DENUNCIA Y SU POSICIÓN EN EL PROCEDIMIENTO}

La configuración que se realiza de la denuncia en el procedimiento administrativo sancionador en materia de tráfico y seguridad vial es ciertamente especial.

La propia Ley de Bases establece como principio que "el procedimiento se iniciará mediante denuncia" (Base Novena, apartado 1, párrafo segundo, inciso primero) ${ }^{109}$ herida sobre la que la Ley de Tráfico y Seguridad Vial no hace sino hurgar al establecer, en el art. 75.1 que "el procedimiento sancionador se incoará de oficio por la Autoridad competente que tenga noticias de los hechos que puedan constituir infracciones a los preceptos de esta Ley o mediante denuncia que podrá formular cualquier persona que tenga conocimiento directo de los mismos".

\footnotetext{
${ }^{109}$ Véase supra la nota 53 en la que se reproduce la Base Novena de la Ley de Bases
} 
Los términos empleados no son correctos. Ciertamente, la denuncia puede ser un modo de inicio del procedimiento sancionador, pero ni todo procedimiento sancionador en materia de tráfico y seguridad vial ha de comenzar por denuncia, ni toda denuncia tiene que dar lugar al inicio de un procedimiento sancionador.

Cuando la Ley de Bases establece, como principio y criterio, que el procedimiento sancionador en materia de tráfico se iniciará mediante denuncia emplea unos términos que, de manera estricta, y como única posibilidad de incoación, no resultan ajustados a la realidad, puesto que la denuncia no es la única forma posible de que se inicie el procedimiento sancionador en materia de tráfico. Es una de las posibilidades, pero no la única.

Pero la Ley de Tráfico y Seguridad Vial toma esa previsión, la contenida en el párrafo segundo del apartado primero de la Base Novena e, intentando respetar el principio establecido, profundiza en el error al establecer, como se acaba de señalar, que el procedimiento sancionador podrá ser incoado mediante denuncia que podrá formular cualquier persona que tenga conocimiento directo de los mismos (art. 75.1 LTSV).

Es perfectamente posible que la norma en la que se establece y regula el procedimiento sancionador prescriba que la denuncia del agente de la autoridad inicie el procedimiento sancionador. No es lo normal en nuestro sistema, en el que la incoación suele estar en manos de la autoridad competente que tenga noticia de los hechos, pero es posible y encuentra cobertura en la propia regulación del procedimiento. Pero de ahí a que la denuncia efectuada por cualquier persona que tenga conocimiento directo de unos hechos que pueden ser constitutivos de infracción suponga la incoación del expediente... eso es algo sencillamente imposible en la práctica.

Aunque se trata de una forma que no se corresponde con la que, de manera ordinaria y en otros ámbitos, inicia el procedimiento sancionador, la denuncia realizada por los Agentes de la Autoridad encargados del servicio de vigilancia de tráfico se constituye en la manera normal (y habitual) en la que se van a iniciar los procedimientos sancionadores en materia de tráfico, ya que la Ley de Tráfico y Seguridad Vial traslada a los agentes de la autoridad encargados de la vigilancia de tráfico una competencia que, en el resto de los sectores, corresponde al órgano competente para iniciar el procedimiento $^{110}$.

Esta cuestión, defectuosamente formulada por la Ley de Bases y por la Ley de Tráfico y Seguridad Vial, será objeto de ulteriores desarrollo y reformas hasta llegar a la actual configuración normativa mucho más adecuada a la finalidad que se persigue y a la práctica procedimental.

${ }^{110}$ T. CANO CAMPOS, El régimen jurídico - administrativo del tráfico, Madrid, Civitas, 2010, 2ạ ed., pág. 522 


\section{LA NOTIFICACIÓN COMO TRINCHERA DE UNOS MALENTENDIDOS DERECHOS}

Con todo, uno de los mayores errores de cálculo del redactor de la Ley de Tráfico y Seguridad Vial fue la pretensión de hacer uso, en sus propios términos, de las previsiones efectuadas en la Ley de Procedimiento Administrativo de 17 de julio de 1958, tal y como de manera expresa se indicaba en art. 78.2, al señalar que "las notificaciones de las denuncias que no se entreguen en el acto y las demás notificaciones a que dé lugar el procedimiento sancionador se cursarán al domicilio indicado en el anterior apartado de este artículo y se ajustarán al régimen y requisitos previstos en la Ley de Procedimiento Administrativo".

La mezcla de ambos ingredientes, sistema ordinario de notificación previsto en la Ley de Procedimiento Administrativo con el procedimiento sancionador en materia de tráfico, como fenómeno masificado, aderezado con el establecimiento, por la propia Ley de Tráfico y Seguridad Vial, de determinadas peculiaridades que afectaban directamente a la práctica de las notificaciones a los interesados en el marco de este procedimiento, iba a dar lugar a que, en la práctica, muchos expedientes sancionadores fueran incapaces de llevar a término su misión.

En ese conjunto de circunstancias concurrían la enorme cantidad de expedientes sancionadores que se tramitaban por la infracción de las normas de tráfico junto con el exiguo plazo de tiempo del que se dispone (como la propia Ley determina, al establecer un plazo que, aunque es prescripción, lo es de tan solo dos meses, en el art. 81.1 LTSV) para la tramitación de ese expediente, masa (como conjunto de previsiones) sobre la que la posibilidad que se ofrece al interesado (denunciado) de determinar el lugar en el que debía de practicarse la notificación para que esta pudiera ser considerada válida y eficaz ${ }^{111}$, actuaba como el más eficiente de los reactivos para impedir el funcionamiento del procedimiento establecido. Si a ello se añade el ingrediente adicional de que las infracciones muy graves (en todo caso) y las muy graves (potestativamente) podían dar lugar a la sanción de suspensión de la autorización administrativa para conducir se había creado el escenario perfecto de autodestrucción del procedimiento administrador sancionador por las propias normas que lo regulaban.

Y claro, al pastel resultante de esta masa solo resta añadirle la guinda del factor humano (o factor sanción), como es la escasa (por no decir nula) curiosidad del interesado (del presunto infractor) en escuchar esos cantos de las sirenas administrativas advirtiéndole de que queremos sancionarte... ¿Quién podía resistirse a

\footnotetext{
${ }^{111}$ Pues este es, a fin de cuentas, el resultado de la previsión establecida en el 78.1 LTSV al determinar que "a efectos de notificaciones, se considerará domicilio del conductor y del titular del vehículo aquel que los interesados hayan expresamente indicado y, en su defecto, el que figure en los Registros de Conductores e Infractores, y en el de Vehículos, respectivamente".
} 
esa sensación? Si el propio sistema, las propias normas del juego sancionador, venían a establecer que podía quedar en manos del presunto infractor el cumplimiento de la notificación, el perfeccionamiento de ese intento realizado por la Administración. El procedimiento sancionador en materia de tráfico se convertía, así, en una paciente espera del denunciado. En un simple siéntate a la puerta de tu casa (o del lugar que designes) y verás como prescribe la infracción...

Ciertamente se puede afirmar que el principio o criterio establecido en el inciso final apartado primero de la Base Novena, eso de que se regularía un procedimiento sancionador en materia de tráfico y seguridad vial "sin detrimento de las garantías individuales" se había cumplido hasta sus últimas consecuencias. Casi estaba plenamente garantizado que si el interesado quería, si tenía interés y lo ponía, no iba a ser sancionado. De igual manera, aunque en sentido inverso, el principio y criterio con el que abría ese mismo apartado primero de la Base Novena el de que "se regularán las especialidades tendentes a garantizar la celeridad y sumariedad del mismo" únicamente se podía entender cumplido en cuanto a que se había garantizado la celeridad de poder llevar a la prescripción la mayoría de las infracciones objeto denuncia y expediente sancionador.

El que se entendiera que ese intento de notificación se había perfeccionado y había cumplido con el objetivo establecido y en la forma prescrita por la Ley quedada, sino totalmente, casi en la exclusiva esfera de la voluntad del destinatario al que si se le había notificado la denuncia en el acto siempre le quedaba la opción de las siguientes notificaciones a las que daba lugar la tramitación del expediente para empezar a jugar "al que no me pillas" y poner a prueba la ineficacia del sistema establecido.

Hay que tener en cuenta, además, el efecto que esta regulación, y sus efectos, supusieron sobre el procedimiento que vio incrementado el número de presuntos infractores que combatían las denuncias efectuadas en la esperanza de conseguir alcanzar la legítima aspiración de no ser sancionados. Se produjo un efecto llamada, a formular escritos de alegaciones y recursos, que tuvo como resultado dificultar todavía más, si cabe, las pocas posibilidades de llevar a su fin estos expedientes sancionadores.

La notificación y su regulación, tal y como quedo establecida, se convirtieron en los pies de barro del gigante y en una invitación al infractor - denunciado para escribir, para alegar en todo caso frente a la denuncia, lo que hundió todavía más al titán administrativo en el lodazal que el mismo había creado.

\section{LAS ALEGACIONES DEL DENUNCIADO COMO LASTRE PROCEDIMENTAL}

En los términos en los que quedaba configurada la notificación, tanto la de las denuncias que no habían sido entregadas en el acto como del resto de notificaciones 
del procedimiento sancionador, incitaban al destinatario de las mismas a hacer uso de todos los trámites y alegaciones que la propia regulación del procedimiento sancionador le ofrecía.

En principio, y teniendo en cuenta los términos de los que se había hecho uso, la redacción del art. 79 LTSV eran lo más parecido a una invitación para presentar cualquier tipo de alegaciones ya que a la concesión de "un plazo de quince días para que alegue cuanto considere conveniente a su defensa y proponga las pruebas que estime oportunas" (art. 79.1 LTSV) se unía la previsión de lo que había que hacer esas alegaciones, necesariamente, que era trasladárselas al denunciante "para que informe en el plazo de quince días" (art. 79. 2 LTSV) y, además, todavía quedada "la eventual práctica de la prueba" (art. 79.3 LTSV) e, incluso, la "ulterior audiencia a los interesados, en los casos en que ello fuera estrictamente necesario para la averiguación y calificación de los hechos", antes de estar en disposición de poder dictar la resolución que procediera.

El sistema de garantías, que era el fin que había que conseguir, se había configurado de tal forma que el cauce procedimental se había llenado de vericuetos, recodos y rincones que convertían al procedimiento sancionador en materia de tráfico en un recoveco sin fin en manos del presunto infractor - denunciado que estuviera dispuesto a hacer uso de las normas procedimentales en contra del propio procedimiento.

\section{UNA FORMA UNIDIRECCIONAL (Y EQUIVOCADA) DE ENTENDER LAS GARANTÍAS PROCEDIMENTALES}

El procedimiento sancionador establecido por la Ley de Tráfico y Seguridad Vial quedaba configurado de tal forma que era como mandar a la batalla a un soldado como un arma de juguete.

Tal vez la mejor forma de hacerse a la idea del resultado es analizar la cronología del propio procedimiento sancionador iniciado por medio de una denuncia obligatoria y comprobar que era un campo minado, un recorrido repleto de trampas.

- Hito 1: El Agente de la Autoridad encargados del servicio de vigilancia de tráfico observa un hecho que puede resultar constitutivo de infracción y no lo denuncia en el acto

- Sin que conste en la denuncia razón alguna que justifique el no haberla notificado en el acto

- Constando motivos que no constituyen razón suficiente para no haberla notificado en el acto

- Hito 2: El Agente de la Autoridad notifica en el acto la denuncia

- Sin que en ella conste los datos que configuran su contenido necesario

- Carece de una relación circunstanciada de los hechos 
- No realiza correctamente la notificación

- Hito 3: La Administración competente para tramitar el expediente sancionador

- No notifica la denuncia que no hubiera sido notificada en el acto

- Notifica en lugar distinto al señalado expresamente por el interesado

- Hito 4: La Administración competente para tramitar el expediente sancionador

- No traslada al denunciante las alegaciones realizadas por el denunciado

- No practica las pruebas solicitadas ni justifica su no realización

- No da audiencia al interesado siendo necesario

- Hito 5: El Agente denunciante que recibe las alegaciones del denunciado

- No informa sobre las mismas

- Supera con creces el plazo establecido y facilita la prescripción

- Hito 6: La Administración dicta resolución para tramitar el expediente sancionador

- Transcurrido el plazo de dos meses sin actuaciones que interrumpan el plazo de prescripción

- Sin cumplir con los requisitos establecidos en cuanto a las alegaciones del denunciado, las pruebas propuestas, la audiencia al interesado...

Y podríamos seguir buscando pliegues que podían ser percibidos, y debían haberlo sido, al momento de establecer las normas reguladoras del procedimiento sancionador por la Ley de Tráfico y Seguridad Vial. Podríamos seguir con cuestiones como que el denunciante no es agente de la autoridad encargado del servicio de vigilancia del tráfico, con problemas relativos a la falta de competencia de quien pretende imponer la sanción... Pero no se trata ni de magnificar la situación, ni de buscar todas las hipótesis que podrían darse al margen del procedimiento establecido o por errores en su tramitación.

No. Se trata de ponderar la situación de partida del procedimiento y determinar, de manera objetiva, sus carencias. Para entender la situación. Para poder comprender los cambios y, en definitiva, para poder estar en condiciones de aprehender la regulación actual, como regulación derivada que la inicialmente efectuada por la Ley de Tráfico y Seguridad Vial en 1990, como ordenación que, evolucionado desde ella, ha dado lugar al actual procedimiento sancionador en materia de tráfico y seguridad vial.

Cuesta entenderlo. Resulta difícil comprender que el salto a una regulación democrática fuera incapaz de asimilar, e integrar, principios constitucionales y control del tráfico.

Cuesta entenderlo. Resulta difícil comprender en que se empleó todo ese tiempo. Una regulación tardía. Con una década, la de los ochenta, estéril en esta materia, perdida.

Pero sobre todo, y por encima de todo, cuesta entender como transcurrido todo ese tiempo, con la experiencia acumulada en otros ámbitos, tras varios intentos 
infructuosos de dotar al tráfico y a la seguridad vial de un ordenamiento eficaz, eficiente, acorde con los nuevos tiempos, con las nuevas normas y principios, se optase por un sistema de regulación legal excepcional, como es la regulación mediante delegación legislativa, y que habiéndose alegado la necesidad de un "instrumento normativo idóneo" y la "complejidad técnica de toda regulación sobre el tráfico y seguridad vial"112 como razones que aconsejaban "no someter la normativa en todos sus extremos a la consideración de las Cortes Generales" sea la propia Administración la que diseña y construye el procedimiento sancionador, conforme sí, a los principios y criterios aprobados por el legislativo, pero con la libertad de conformar el resultado final (sin estar sometido a la ruleta que, una tramitación parlamentaria, puede suponer) y, sobre todo, como garantía de congruencia y consistencia. Es la propia Administración que va a hacer uso de ese sistema ${ }^{113}$, de ese procedimiento administrativo sancionador en materia de tráfico y seguridad vial, la que le da forma, la que lo cincela y la que redacta los artículos que lo componen, los que configuran "una norma innovativa de la realidad legal existente" ${ }^{114}$.

En definitiva. Que no fue el legislador, ni una sinuosa e incomprensible tramitación parlamentaria la que originó el procedimiento sancionador que aparece recogido en la Ley de Tráfico y Seguridad Vial. El legislador se limitó a establecer una Base (la Novena de la Ley 18/1989, de 25 de julio) en la que, tal y como se aprobó, como criterio y principio del procedimiento sancionador, se puede afirmar que cabía prácticamente cualquier solución y fue la propia Administración la que regó, rego y rego el camino, la que inundó el cauce (procedimental) hasta convertirlo en un lodazal intransitable...

Esta es la situación a la entrada en vigor de la Ley de Tráfico y Seguridad Vial. A partir de ahí se inicia un largo y tortuoso camino y, ya se sabe, que "dada la debilidad de la naturaleza humana, los remedios son siempre más lentos que los males".

\footnotetext{
${ }^{112}$ Véase, sobre esta cuestión, el análisis realizado en esta misma obra en el apartado "La Ley de Bases (Ley 18/1989, de 25 de julio, de Bases de Tráfico, Circulación de Vehículos a Motor y Seguridad Vial) Sobre la elección de este sistema (justificación y valoración)".

${ }^{113}$ Téngase presente, en este sentido, que el artículo único de la Ley de Bases 18/1989, de 25 de julio, de Bases de Tráfico, Circulación de Vehículos a Motor y Seguridad Vial, establece que "se autoriza al Gobierno para que, a propuesta del Ministro del Interior... apruebe, en el plazo de un año, el Texto Articulado de la Ley sobre Tráfico, Circulación de Vehículos a Motor y Seguridad Vial, con sujeción a los principios y criterios que resultan de las siguientes Bases".

${ }^{114}$ García de Enterría, E. y Fernández Rodríguez T.-R., Curso de Derecho Administrativo, Tomo I, 14ạ ed., Madrid, Civitas, 2008, pág. 262. Por eso resulta tan difícil de entender el desatino porque "los Textos articulados de las Leyes de Bases tienen un punto más de intensidad, porque la norma cuya elaboración se confía al Gobierno y a la que anticipadamente se le asigna rango de Ley es una norma innovativa de la realidad legal existente y no simplemente sistematizadora de la misma, como en el caso de los Textos Refundidos".
} 


\section{MODIFICACIONES Y DESARROLLO DE LA LEY DE TRÁFICO Y SEGURIDAD VIAL}

Desde el mismo momento en el que la Ley de Tráfico y Seguridad Vial se incorpora al ordenamiento jurídico ${ }^{115}$ surge tanto la necesidad, prevista en la propia Ley, de desarrollar las previsiones en ella contenidas ${ }^{116}$, como la de buscar soluciones a los problemas que, día a día, su aplicación van presentando en la práctica.

A continuación recorremos y analizamos, cronológicamente, el camino recorrido por la Ley de Tráfico y Seguridad Vial tanto internamente (modificaciones) como externamente (desarrollo) prestando especial atención a las vicisitudes que han afectado (tanto de forma directa como indirecta) a la configuración del procedimiento sancionador en materia de tráfico.

\section{A) Reglamento General de Circulación de 1992}

La primera norma que va a desarrollar la Ley de Tráfico y Seguridad Vial es el Real Decreto 13/1992, de 17 de enero, por el que se aprueba el Reglamento General de Circulación (RGC/1992) ${ }^{117}$.

Que este reglamento sea el primero en el tiempo es algo que puede considerarse, hasta cierto punto, normal, ya que el desarrollo legal estableciendo las normas generales de circulación en un plazo inferior a dos años (aunque lo deseable es que hubiera sido en menos tiempo) se constituye en el progreso lógico de regulación del tráfico y seguridad vial ${ }^{118}$. Así se señala al indicarse que "parece conveniente que uno de los primeros reglamentos que se publiquen, sea precisamente el presente Reglamento General de Circulación por ser el encargado de desarrollar el artículo 2 del

\footnotetext{
${ }^{115}$ Conforme se señala en la nota 70 la Ley de Tráfico y Seguridad Vial entró en vigor el día 3 de abril de 1990.

${ }^{116}$ En la propia Disposición Final.1 de la Ley de Tráfico y seguridad Vial "se faculta al Gobierno para dictar las disposiciones necesarias para desarrollar la presente Ley, como, asimismo, para modificar los conceptos básicos contenidos en su anexo de acuerdo con la variación de las definiciones de los mismos que se produzca en el ámbito de Acuerdos y Convenios internacionales con trascendencia en España". De igual manera, se establece y reconoce la transitoriedad de la situación en tanto se proceda a realizar el desarrollo reglamentario que la Ley de Tráfico y seguridad Vial requiere, al establecerse en la disposición transitoria que "hasta que entren en vigor las disposiciones necesarias para el desarrollo de esta Ley, se aplicarán como Reglamentos de la misma el Código de la Circulación aprobado por Decreto de 25 de septiembre de 1934, y disposiciones complementarias, en la medida en que no se opongan a lo que en ella se establece".

117 Publicado en el Boletín Oficial del Estado de 31 de enero de 1992 y que, conforme establece la disposición Final Cuarta "entrará en vigor el día 15 de junio de 1992".

${ }^{118}$ Sin ánimo de hacer causa belli sobre esta decisión, también hubiera sido perfectamente entendible que el primer reglamento hubiera sido, precisamente, el destinado al procedimiento sancionador en materia de tráfico. Y ello tanto por motivos cuantitativos, ya que como se verá posteriormente eran un puñado de breves preceptos (el reglamento se presentó, en su momento con 21 artículos), como, y sobre todo, razones cualitativas, por tratarse de la parte más sensible en cuanto a impacto en la esfera de derechos de los intervinientes en el fenómeno del trafico y la seguridad vial.
} 
Título preliminar y los Títulos II y III del Texto Articulado de la Ley sobre Tráfico, Circulación de Vehículos a Motor y Seguridad Vial”119.

Pero en ningún momento se advierte de la existencia de normas que en ese marco, el de desarrollar las normas generales de circulación, se introducen en el ámbito del procedimiento sancionador en materia de tráfico.

Esta situación no debe resultar en exceso extraña. Por mucho que, conceptualmente, se quiera compartimentar un determinado ámbito de actividad, en este caso el del Tráfico y la Seguridad Vial, y se establezcan bloques, como pueden ser, en este caso, circulación, conductores, vehículos, régimen sancionador, ello no significa que esos compartimentos sean, y resulten, del todo estancos. El régimen normativo de cualquier sector está repleto de relaciones entre las normas y preceptos que lo regulan. El Tráfico y la Seguridad Vial no constituye una excepción a este principio. Pero ello no significa que no sea una de las cuestiones básicas que sea preciso destacar, y más cuando, como sucede en el presente caso, el desarrollo reglamentario de la Ley se reparte entre diversas normas reglamentarias.

Hay un ámbito, en concreto, en el que el desarrollo reglamentario que se realiza contiene, de forma básica y esencial, prescripciones de procedimiento sancionador. Cuando el Reglamento General de Circulación desarrolla, en los arts. 20 a 28 RGC, las previsiones efectuadas en el art. 12 LTSV sobre "bebidas alcohólicas, sustancias estupefacientes y similares" lo que en realidad se está haciendo es determinar las normas por las que se regula el procedimiento para probar (o descartar) la comisión de la infracción de conducir con tasas superiores a las establecidas ${ }^{120}$.

El RGC no se limita a cumplir con las previsiones efectuadas en el art. 12.1 LTSV de determinar reglamentariamente, las tasas permitidas y prohibidas $^{121}$ y en los apartados 2, párrafo segundo, y 3 del propio art. 12 LTSV en cuanto a la determinación del tipo de pruebas que se establecen para detectar y verificar las posibles intoxicaciones de alcohol $^{122}$ y de las demás sustancias prohibidas ${ }^{123}$.

\footnotetext{
${ }^{119}$ Términos de los que hace uso el párrafo tercero de la Introducción que acompaña al articulado del Reglamento.

${ }^{120}$ De hecho la disposición derogatoria Segunda del Reglamento General de Circulación establece, entre las disposiciones que quedan derogadas, Orden de 29 de julio de 1981, sobre investigación del grado de impregnación alcohólica de los usuarios de las vías públicas (que había sido publicada en el Boletín Oficial del Estado de 5 de agosto de 1981).

Sobre la estructura de la norma derogada se intentan incorporar las garantías que, para el presunto transgresor de la infracción administrativa (o del tipo penal), se establecen constitucionalmente.

${ }^{121}$ El art. 12.1 de la Ley de Tráfico y seguridad Vial establecía que "No podrá circular por las vías objeto de esta Ley el conductor de vehículos con tasas superiores a las que reglamentariamente se establezcan de bebidas alcohólicas, estupefacientes, psicotrópicos, estimulantes u otras sustancias análogas".

${ }^{122}$ El art. 12.2 párrafo segundo de la Ley de Tráfico y Seguridad Vial determinaba que "dichas pruebas que se establecerán reglamentariamente y consistirán normalmente en la verificación del aire espirado mediante alcoholímetros autorizados, se practicarán por los Agentes encargados de la vigilancia del
} 
Los arts. 20 a 28 RGC contienen todo un conjunto de prescripciones procedimentales, de previsiones en cuanto a la forma en la que hay que actuar $y$, por ello, en la redacción de esos preceptos se encuentran términos como denuncia y denunciado (arts. 21.3 y $24.1 \mathrm{RGC}$ ), procedimiento (art. $23.1 \mathrm{RGC}$ ), prueba (arts. 21, 22, 23, 24, 25, 26 y 28 RGC).

Se trata de una regulación bastante exhaustiva, en cuanto a supuestos, realización de las pruebas, repetición... que culminan con la descripción detallada, en el art. 24 RGC, del proceder al que habrá de ceñirse el Agente de la autoridad que "además de ajustarse, en todo caso, a lo establecido en la Ley de Enjuiciamiento Criminal" deberá cumplir con una serie de requisitos que se especifican de forma detallada y precisa ${ }^{124}$. Es decir, se establece el procedimiento a seguir para que dicha prueba pueda ser utilizada como prueba de cargo, y ello tanto en el correspondiente procedimiento administrativo sancionador como, en su caso, en el eventual proceso penal al que los hechos, caso de ser (o poder ser) constitutivos de una conducta delictiva, pudieran derivarse.

Esta situación, la de que las pruebas de detección alcohólica, puedan terminar tanto en un procedimiento administrativo sancionador como en actuaciones ante la jurisdicción penal, supone que, en todo caso, las pruebas han de realizarse cumpliendo el estándar más alto que, en este caso, es la hipótesis de que tuvieran que ser utilizadas en un proceso penal. Este es, por tanto, el nivel de garantías que es preciso cumplir y que se

tráfico. A petición del interesado o por orden de la Autoridad Judicial se podrán repetir las pruebas a efectos de contraste, pudiendo consistir en análisis de sangre, orina u otros análogos".

${ }^{123} \mathrm{El}$ art. 12.3 de la Ley de Tráfico y Seguridad Vial prescribía que "Reglamentariamente podrán establecerse pruebas para la detección de las demás sustancias a que se refiere el apartado primero del presente artículo, siendo obligatorio el sometimiento a las mismas de las personas a que se refiere el apartado anterior".

${ }^{124}$ El art. 24 RGC estaba redactado en los siguiente términos:

Artículo 24. Diligencias del Agente de la Autoridad

Si el resultado de la segunda prueba practicada por el Agente, o el de los análisis efectuados a instancia del interesado, fuera positivo, o cuando el que condujere un vehículo de motor presentara síntomas evidentes de hacerlo bajo la influencia de bebidas alcohólicas o apareciera presuntamente implicado en una conducta delictiva, el Agente de la Autoridad, además de ajustarse, en todo caso, a lo establecido en la Ley de Enjuiciamiento Criminal, deberá:

1. Describir con precisión, en el boletín de denuncia o en el atestado de las diligencias que practique, el procedimiento seguido para efectuar la prueba o pruebas de detección alcohólica, haciendo constar los datos necesarios para la identificación del instrumento o instrumentos de detección empleados, cuyas características genéricas también detallará.

2. Consignar las advertencias hechas al interesado, especialmente la del derecho que le asiste a contrastar los resultados obtenidos en las pruebas de detección alcohólica por el aire espirado mediante análisis adecuados, acreditándose en las diligencias las pruebas o análisis practicados en el Centro sanitario al que fue trasladado el interesado.

3. Conducir al sometido a examen, o al que se negare a someterse a las pruebas de detección alcohólica, en los supuestos en que los hechos revistan caracteres delictivos, de conformidad con lo dispuesto en la Ley de Enjuiciamiento Criminal, al Juzgado correspondiente a los efectos que proceda. 
determina mediante el procedimiento establecido en el RGC, de manera que la prueba practicada pueda ser incorporada, con todas las garantías, tanto en el expediente sancionador como, en su caso, en las correspondientes diligencias penales.

El art. 26.2 RGC disponía que "las infracciones a las distintas normas de este Capítulo, en cuanto relativas a la ingestión de bebidas alcohólicas, tendrán la consideración de graves", redacción que dio lugar al planteamiento de cuestión de ilegalidad por el Tribunal Superior de Justicia de Castilla - La Mancha por entender que el hecho de considerar como falta grave la negativa al sometimiento a la prueba de alcoholemia de las personas a las que se refiere el art. 21 RGC hace que el art. 26 RGC carezca de cobertura legal, ya que el art. 65.4 LTSV consideraba (en su redacción originaria y hasta su modificación por la Ley 5/1997, de 24 de marzo) falta grave "las conductas relativas a la ingestión de sustancias que perturben o disminuyan las facultades psicofísicas del conductor", por lo que, en opinión de la Sala que promueve la cuestión, negarse a someterse a la prueba de alcoholemia o el incumplimiento de las demás prescripciones reguladas en cuanto a su práctica contenidas en el Capítulo IV, "en cuanto no tengan que ver con la ingestión, no pueden equipararse a la misma ingestión por encima de las tasas reglamentarias establecidas". El Tribunal Supremo entiende que la cuestión de ilegalidad debe ser desestimada por cuanto es evidente que la expresión "conductas relativas a" del art. 65.4 LTSV (vigente en el momento de producirse los hechos) no se limita exclusivamente a la ingesta de alcohol por encima de las tasas establecidas, sino que en tal expresión se comprenden todas las conductas que guarden relación con tal ingestión y entre ellas es manifiestamente claro que debe entenderse comprendida la negativa a someterse a la prueba de alcoholemia en los supuestos establecidos en la norma, ya que en modo alguno el precepto legal cabe interpretarlo como limitado a la ingestión de sustancias que perturben o disminuyan las facultades psicofísicas del conductor, entre las que se encuentran las bebidas alcohólicas, en tasa superior a las establecidas, ya que en tal caso el precepto no se referiría a conductas relativas a la ingestión, es decir, relacionadas con, sino simple y llanamente a la ingestión de las referidas sustancias y que, por otra parte no cabe negar la directa relación de la prueba de alcoholemia con la necesidad de controlar la ingestión de bebidas alcohólicas por los conductores, habida cuenta la necesidad del citado control para hacer efectiva la prohibición de ingestión por encima de la tasa permitida $^{125}$.

\footnotetext{
${ }^{125}$ Cfr. STS de 19 de julio de 2003 (RJ 2003, 4440).
} 


\section{B) Un cambio profundo y silencioso: la promulgación de la LRJ - PAC y del Reglamento para el ejercicio de la potestad sancionadora}

El siguiente cambio que se va a producir en las normas que regulan el procedimiento sancionador en materia de tráfico y seguridad vial no se va a producir por la directa modificación o el desarrollo reglamentario de la Ley de Tráfico y Seguridad Vial.

Es el cambio de la norma general que regula el Procedimiento Administrativo. La promulgación de la Ley 30/1992, de 26 de noviembre, de Régimen Jurídico de las Administraciones Públicas y procedimiento Administrativo Común (LRJ - PAC) y del Real Decreto 1398/1993, de 4 de agosto, por el que se aprueba el reglamento de Procedimiento sancionador para el ejercicio de la potestad sancionadora.

La LRJ - PAC viene a derogar la Ley de Procedimiento Administrativo de 1958 a la que se remitía la LTSV y un desarrollo de la misma para el ejercicio de la potestad sancionadora que configuran un nuevo escenario sobre el que ha de ubicarse el procedimiento sancionador de la LTSV.

Es el momento esperado por la Administración para promulgar el reglamento del procedimiento sancionador en materia de tráfico y seguridad vial.

\section{C) El Reglamento de Procedimiento sancionador en materia de tráfico, circulación de vehículos a motor y seguridad vial de 1994}

\section{LA NORMA}

Han de transcurrir cuatro años, desde la entrada en vigor de la Ley de Tráfico y Seguridad Vial, para que se promulgue el Real Decreto 320/1994, de 25 de febrero, por el que se aprueba el Reglamento de Procedimiento sancionador en materia de tráfico, circulación de vehículos a motor y seguridad vial (RPSTSV) ${ }^{126}$.

Se trata, sin lugar a dudas, de un dilatado espacio de tiempo, si bien es cierto que en ese período se producen importantes cambios en las normas generales (y básicas) sobre las que se sustenta la regulación del procedimiento sancionador que se había regulado en la Ley de Tráfico y Seguridad Vial (y que en cierta medida podrían justificar ese retraso), como es la promulgación de la Ley 30/1992, de 26 de noviembre, de Régimen Jurídico de las Administraciones Públicas y Procedimiento Administrativo Común (LRJ - PAC) ${ }^{127}$ y del Real Decreto 1398/1993, de 4 de agosto, por el que se

\footnotetext{
${ }^{126}$ Reglamento que, aunque de fecha 25 de febrero de 1994, no fue publicado en el Boletín Oficial del Estado hasta el 21 de abril de 1994 y que, conforme establece la disposición Final Única "entrará en vigor a los veinte días de su publicación", es decir, que el día 11 de mayo de 1994.

${ }^{127}$ De hecho, el texto introductorio que antecede al propio RPSTV invoca este motivo, y lo hace de forma imperativa, al señalar que "la disp. adic. Tercera LRJ - PAC ordena llevar a efecto
} 
aprueba el reglamento de Procedimiento sancionador para el ejercicio de la potestad sancionadora.

De esta forma, la propia norma señala, en la introducción que la antecede, que "pendiente el desarrollo reglamentario y abierto el período de adecuación, se ha estimado necesario acometer ambas tareas en un mismo texto reglamentario" y que "según la pauta acostumbrada se transcriben primero los artículos correspondientes del Texto Articulado de la Ley sobre Tráfico, Circulación de Vehículos a Motor y Seguridad Vial, haciendo constar, entre paréntesis, el número del artículo del Texto Articulado de dicha Ley, adaptándolos a la vigente Ley 30/1992, de 26 de noviembre, de Régimen Jurídico de las Administraciones Públicas y del Procedimiento Administrativo Común, cuando es necesario, lo que es posible en virtud de la deslegalización operada por esta última Ley, y desarrollándolos a continuación en aquellos aspectos en que se ha estimado era menester la ulterior explicitación y precisión reglamentaria"128.

Este es el marco en el que se promulga el RPSTSV ${ }^{129}$ que lo primero que dispone es la derogación de "los artículos 276, 277, 278, 279.I y II, 280, 281, 282, 283, 284, 285, 286, 287 y 289, todos ellos incluidos en el Capítulo XVII del Código de la Circulación y cuantos preceptos se opongan a lo dispuesto en el Reglamento aprobado por el presente Real Decreto" ${ }^{130}$.

Al momento de la publicación del RPSTSV la regulación del procedimiento sancionador se encontraba en el Capítulo XVII del Código de la Circulación de 1934 que, con esa misma denominación, estaba integrado por catorce artículos (arts. 276 a 289 CCirc) en

reglamentariamente la adecuación a la misma de las normas reguladoras de los distintos procedimientos administrativos, cualquiera que sea su rango".

Esa disposición adicional Tercera LRJ - PAC establecía, en su redacción originaria, que "reglamentariamente en el plazo de seis meses a partir de la entrada en vigor de esta Ley, se llevará a efecto la adecuación a la misma de las normas reguladoras de los distintos procedimientos administrativos, cualquiera que sea su rango, con específica mención de los efectos estimatorios o desestimatorios que la falta de resolución expresa produzca", previsión temporal que fue incrementada a "dieciocho meses" por el Real Decreto Ley 14/1993, de 4 de agosto, por la concurrencia de una serie de factores que "han hecho imposible la culminación del proceso de adecuación en el plazo previsto por la Ley".

${ }^{128}$ Algo que, como veremos, plantea serías dudas en cuanto lo que se establece en el reglamento en relación a lo prescrito en la Ley de Tráfico y el alcance que deba darse a esa "deslegalización" a la que, por adaptación a la LRJ - PAC se hace referencia.

${ }^{129}$ El texto explicativo que precede al propio reglamento señala que dos son las tareas del texto. De un lado, llevar a efecto reglamentariamente la adecuación a la LRJ - PAC de las normas reguladoras de los distintos procedimientos administrativos, cualquiera que sea su rango (párrafo primero de esa introducción) y, de otro, desarrollar las previsiones que, el procedimiento administrativo de imposición de las correspondientes sanciones en materia de tráfico y circulación de vehículos a motor previsto en la Ley de Tráfico y seguridad Vial que el apartado 1 de la disposición final del propio Texto Articulado, autoriza a desarrollar al Gobierno (párrafo primero de esa introducción).

${ }^{130}$ Tal y como se establece en la disposición derogatoria Única del propio Real Decreto 320/1994, de 25 de febrero, por el que se aprueba el Reglamento de Procedimiento sancionador en materia de tráfico, circulación de vehículos a motor y seguridad vial. 
la redacción que habían recibido del Decreto 3268/1968, de 26 de diciembre, por el que se modificaban determinados artículos del Código de la Circulación ${ }^{131}$, Capítulo que es expresamente derogado excepto en lo relativo a los arts. $279.11 I^{132}$ y $288^{133}$ cCirc.

${ }^{131}$ Norma que fue publicada en el Boletín Oficial del Estado de 16 de enero de 1969. En la introducción
de ese Decreto se señalaba que "por otro lado, las crecientes dificultades con las que las autoridades
municipales de las grandes ciudades vienen luchando para mantener la efectiva práctica de un
procedimiento sancionador que garantice al mismo tiempo el respeto a la disciplina y los derechos de
defensa de los administrados aconsejan la nueva redacción del Capítulo XVII del Código, regulador del
procedimiento sancionador" (párrafo cuarto).
${ }_{132}$ El art, $279 . I I I$ del Código de la Circulación establecía que "las sanciones señaladas en el presente
Código no serán acumuladas cuando una infracción sea medio necesario para cometer otra, o cuando
un mismo hecho constituya dos o más infracciones, imponiéndose en estos casos únicamente la sanción
más grave de las que corresponda". ${ }^{133} \mathrm{El}$ art. 288 del Código de la Circulación disponía que:

Artículo 288. - Las denuncias por infracciones a preceptos de este Código cometidas por personas que no acrediten su residencia habitual en territorio español, se ajustarán a las siguientes normas:

a) La cuantía de la multa se fijará provisionalmente por el Agente denunciante, con sujeción a las normas de este Código y aplicando las reducciones previstas en el artículo anterior.

b) El importe de la multa deberá ser entregado en el acto, en concepto de depósito y en moneda de curso legal en España, al Agente denunciante, el cual entregará al denunciado el boletín de denuncia y el recibo correspondiente. En el primero constarán los extremos previstos en el inciso a) del artículo 282, y en el recibo, con caracteres impresos, deberá constar la cuantía de la multa percibida.

c) La cantidad entregada quedará a resultas del acuerdo que en definitiva adopte la Autoridad gubernativa, a la que se remitirá aquélla en unión del boletín original.

d) La ulterior tramitación de las denuncias a que se refiere el presente artículo se ajustará a lo prevenido en el ya citado artículo 282 , reservándose a los denunciados idénticos derechos que a los residentes en España.

e) En estos expedientes no se podrá imponer sanción pecuniaria que exceda del depósito hecho, pero el Gobernador civil podrá acordar, si procediere, suspender el permiso para conducir automóviles dentro del territorio nacional, conforme a las normas contenidas en el artículo siguiente.

f) Si se dejase sin efecto la denuncia o se redujera el importe de la multa, se pondrá a disposición del interesado o de su representante la cantidad que en cada caso proceda. Si el acuerdo fuera confirmatorio, el depósito se convertirá en papel de pagos al Estado o Municipal, según los casos, remitiéndose al interesado o a su representante la parte correspondiente con la notificación de aquél.

g) Transcurridos diez días desde la notificación sin que el interesado se persone en el expediente con la aportación del escrito de descargos y pruebas pertinentes, se entenderá que está conforme con la multa. En tal caso, el acuerdo que se dicte tendrá el carácter de firme y no procederá contra el mismo recurso de alzada, a menos que al propio tiempo se imponga la suspensión del permiso de conducción.

h) Si el denunciado no hiciere efectivo el depósito del importe de la multa en el acto de la denuncia, se le permitirá que señale persona o Entidad que constituya caución suficiente, y de no lograrse ésta, el Agente denunciante hará conducir el vehículo a la localidad más cercana, donde quedará depositado en el lugar que designe la Alcaldía, comunicándolo, por el medio más rápido y conducto regular, al Gobierno Civil o Alcaldía competente para la resolución que proceda. 


\section{SU CONTENIDO}

EI RPSTSV es una norma breve, compuesta por 21 artículos, lo que no es demasiado, y más si tenemos en cuenta que a esas materias la redacción originaria de la Ley de Tráfico y Seguridad Vial le dedicaba 12 artículos (los que van del 73 al 84) y que, como ya se ha señalado, pretende el doble objetivo de adecuarse al nuevo escenario establecido por la LRJ - PAC al tiempo que desarrollar las normas establecidas por la Ley de Tráfico y Seguridad Vial sobre procedimiento sancionador en este ámbito.

Pero el RPSTSV no se corresponde, exactamente, con el desarrollo de lo que, de manera estricta, la Ley de Tráfico y Seguridad Vial había denominado procedimiento sancionador. En el RPSTSV van a aparecer cuestiones que van más allá de lo regulado, específicamente, en el Capítulo Primero del Título VI de la Ley de Tráfico y Seguridad Vial.

El problema reside en la delimitación que, de los términos "procedimiento sancionador" (en este caso en el ámbito de tráfico y la seguridad vial), se realice. El RPSTSV viene a desarrollar ${ }^{134}$ el Título VI de la Ley de Tráfico y Seguridad que con la denominación "Procedimiento sancionador y recursos" regulaba, además de esas cuestiones, las relativas a la prescripción de infracciones y sanciones, anotación y cancelación de antecedentes en el Registro de Conductores e Infractores y ejecución de las sentencias, planteamiento que viene a coincidir con "procedimiento sancionador" en sentido amplio.

\section{a) Las bases del procedimiento}

El art. 1 del RPSTSV reproduce la necesidad del procedimiento como cauce instrumental imprescindible para la imposición de sanciones por la comisión de las infracciones tipificadas en la Ley de Tráfico.

La previsión reglamentaria (bajo la rúbrica "ámbito de aplicación") se corresponde con lo establecido en el art. 73 LTSV, si bien se actualizan las remisiones que allí se efectúan, redirigiendo la referencia a que "con carácter supletorio se aplicará el Título IV de la Ley de Procedimiento Administrativo"135 a que "en todo aquello que no esté previsto en este Reglamento será de aplicación el procedimiento regulado en el

\footnotetext{
${ }^{134}$ La exposición introductoria que antecede al texto del RPSTSV se refiere de manera expresa al Título VI LTSV como materia objeto de desarrollo (Cfr. párrafo segundo).

135 Esta referencia a la Ley de Procedimiento Administrativo se mantendrá en la Ley de Tráfico y Seguridad Vial hasta la reforma en ella efectuada por medio de la Ley 19/2001, de 19 de diciembre, que establecerá, como redacción para este artículo que "No se impondrá sanción alguna por las infracciones a los preceptos de esta Ley, sino en virtud de procedimiento instruido con arreglo a las normas del presente capítulo y el Título IX de la Ley 30/1992, modificada por la Ley 4/1999", desapareciendo toda referencia (en la Ley) al carácter supletorio del RD 1398/1993, de 4 de agosto, por el que aprobaba el Reglamento de procedimiento para el ejercicio de la potestad sancionadora.
} 
procedimiento para el ejercicio de la potestad sancionadora aprobado por Real Decreto 1398/1993, de 4 de agosto".

EI RPSTSV considera, y así la trata, que la referencia efectuada en el art. 73 LTSV a la Ley de Procedimiento Administrativo de 17 de julio de 1958 lo es, de manera genérica, a la norma básica que regule el procedimiento administrativo y no una referencia específica a una norma concreta ${ }^{136}$. Es más, el RPSTSV además de actualizar la remisión legal a la normativa vigente, la efectúa con un mayor grado de precisión, puesto que la realizada en el art. 73 LTSV lo era al Título IV de la Ley de Procedimiento Administrativo en cuanto que en esa parte de la Ley (arts. 67 a 108 LPA) se regulaba el procedimiento administrativo en general, mientras que el art. 1 RPSTSV la efectúa, de manera específica a la norma que regula el procedimiento para el ejercicio de la potestad sancionadora que, eso sí, tiene rango reglamentario (el Reglamento para el procedimiento para el ejercicio de la potestad sancionadora aprobado por el Real Decreto 1398/1993, de 4 de agosto (REPEPOS).

$\mathrm{Y}$, de la misma forma, la revisión de las resoluciones sancionadoras que ponen fin al procedimiento sancionador en materia de tráfico y seguridad vial se regulan conforme a las normas generales establecidas a tal efecto en la LRJ - PAC.

\section{b) Actuaciones administrativas y penales}

El art. 2 RPSTSV limita su contenido a reproducir las disposiciones que sobre non bis in idem y previsión de concurrencia de actuaciones administrativas y penales se efectúan en el art. 74 LTSV.

El único cambio se produce en cuanto a la actualización de la remisión que se efectúa a la regulación del procedimiento administrativo que en el reglamento pasa a serlo a la "Ley de Régimen Jurídico y Procedimiento Administrativo Común" en lugar de a la "Ley de Procedimiento Administrativo", tal y como sucede en el art. 74.2 LTSV.

La redacción originaria del art. 2 RPSTSV se va a mantener hasta su modificación por el RD 318/2003, de 14 de marzo, que cumple con el mandato legislativo, contenido en la disp. final Segunda de la Ley 19/2001, de 19 de diciembre, de reforma de la Ley de Tráfico y Seguridad Vial, que obligaba a modificar el RPSTV y adaptarlo a los cambios

\footnotetext{
${ }^{136}$ Por otra parte, y aunque la referencia lo sea de manera a expresa a un punto concreto de una norma determinada (Título IV de la Ley de Procedimiento Administrativo) una interpretación que se limitara, de manera estricta, a entender esa remisión como algo estático no se compadecería con la finalidad pretendida que, a todas luces, persigue el disponer como subsidiario, de la regulación específicamente establecida, el régimen previsto de manera general.
} 
realizados por dicha Ley $^{137}$, si bien, en este caso, los términos empleados para el Reglamento no van a reproducir los utilizados por la Ley de Tráfico y Seguridad Vial ${ }^{138}$.

\section{c) Sobre la iniciación del procedimiento}

El art. 3 RPSTSV se refiere, y así lo indica su rúbrica, a la "incoación del procedimiento" y se corresponde con lo establecido en el art. 75.1 LTSV, precepto legal que realizaba una confusa (además de defectuosa) regulación en cuanto a las formas en las que podía iniciarse el procedimiento sancionador en materia de tráfico y seguridad vial ${ }^{139}$.

La Ley de Tráfico y Seguridad Vial señalaba que "el procedimiento sancionador se incoará de oficio por la Autoridad competente que tenga noticias de los hechos que puedan constituir infracciones a los preceptos de esta Ley o mediante denuncia que podrá formular cualquier persona que tenga conocimiento directo de los mismos" (redacción originaria del art. 75.1 LTSV), lo que suponía que el procedimiento podía ser iniciado por la autoridad competente, previsión que se compadecía con la regulación general vigente al momento de publicación de la Ley de Tráfico y Seguridad Vial ${ }^{140}$, pero que también podía comenzar (el procedimiento sancionado en materia de tráfico y seguridad vial) por denuncia, y de los términos que se utilizaban, por cualquier tipo de denuncia, ya fuese la realizada por quienes tenían la obligación de hacerlo, de denunciar las infracciones que observaran en el ejercicio de sus funciones de vigilancia y control de la circulación vial, ya fuera la realizada por cualquier persona que tuviera conocimiento directo de hechos que pudieran constituir infracciones a la Ley de Tráfico y seguridad Vial.

\footnotetext{
${ }^{137}$ La disp. final Segunda de la Ley 19/2001, de 19 de diciembre, otorgaba al Gobierno un plazo de seis meses, desde la entrada en vigor de las modificaciones por ella efectuadas en la Ley de Tráfico y Seguridad Vial, para realizar los cambios que resultaran precisos para adaptar los reglamentos de desarrollo a las nuevas previsiones legales (plazo que vencía en julio de 2002 y que, por supuesto, no se cumplió)

${ }^{138}$ La redacción introducida en el art. 2 RPSTSV/1994 por el RD 318/2003, de 14 de marzo, se viene a corresponder con la establecida por la Ley 19/2001, de 19 de diciembre, para la Ley de Tráfico y Seguridad Vial, si bien se hace uso de términos distintos, ya que mientras el art. 74.2 LTSV señala que "no se ordenará la suspensión de las actuaciones del procedimiento administrativo que continuará tramitándose hasta el momento en que el procedimiento esté pendiente de resolución en que se acordará la suspensión" el inciso final del art. 2.1 RPSTSV/1994 prescribe que "proseguirá el procedimiento absteniéndose de dictar resolución mientras la autoridad judicial no pronuncie sentencia firme o dicte otra resolución que le ponga fin".

139 Tal y como se señala al analizar esta cuestión en el apartado correspondiente en el que se analiza la regulación de las denuncias efectuada por la LTSV en al apartado III.D.3 de este mismo capítulo.

${ }^{140}$ Conforme al régimen establecido, en ese momento, en la Ley de Procedimiento Administrativo de 1958 en la que se establecía que "los procedimientos se iniciarán de oficio por acuerdo del órgano competente, bien por propia iniciativa o como consecuencia de orden superior, a petición razonada de otros órganos o por denuncia" (art. 69.1 LPA) y que "El procedimiento deberá incoarse por providencia del órgano competente en cada caso" (art. 134.1 LPA).
} 
A esa segunda posibilidad de incoación del procedimiento sancionador prevista en el art. 75.1 LTSV conforme a la que era posible que "el procedimiento sancionador se incoará... mediante denuncia que podrá formular cualquier persona que tenga conocimiento directo de los mismos (hechos que puedan constituir infracciones a los preceptos de esta Ley)" era, cuando menos, un uso poco medido $y$, en todo caso, desafortunado, de los términos empleados.

El art. 3 RPSTSV/1994 pretende maquillar este desatino y lo hace mediante la siguiente redacción:

"El procedimiento sancionador se incoará de oficio por la autoridad competente que tenga noticias de los hechos que puedan constituir infracciones a los preceptos del Texto Articulado de la Ley sobre Tráfico, Circulación de Vehículos a Motor y Seguridad Vial o mediante denuncia formulada por los agentes de la autoridad encargados de la vigilancia y seguridad del tráfico. Asimismo se podrá incoar un procedimiento por la autoridad competente como consecuencia de denuncia formulada por cualquier persona que tenga conocimiento de los hechos mencionados".

Sin lugar a dudas se trata de una redacción que no concuerda con lo previsto en el art. 75.1 LTSV ya que se diferencian dos supuestos.

En el primer inciso del art. 3 RPSTSV se establece que el inicio del procedimiento sancionador en materia de tráfico y seguridad vial podrá producirse o bien "de oficio por la autoridad competente" o bien "mediante denuncia obligatoria". En estos términos no resulta posible que se entienda incoado "mediante la denuncia formulada por cualquier persona", ya se trata de un particular o de un agente de la autoridad de los que no tienen encomendada la vigilancia y la seguridad del tráfico.

El segundo inciso permite que se incoe un procedimiento sancionador en materia de tráfico, por aquellos a los que el inciso primero reconoce esa facultad, "como consecuencia de denuncia formulada por cualquier persona que tenga conocimiento de los hechos mencionados", sin que el procedimiento se inicie por el hecho de haberse formulado una denuncia por persona en la que no concurre la condición de "agente de la autoridad encargado de la vigilancia y seguridad del tráfico".

La desviación de lo previsto en el art. 3 del RPSTSV respecto a lo prescrito en art. 75.1 LTSV no termina ahí, ya que, además, al referirse en ese segundo inciso a las denuncias formuladas por quien no es "agente de la autoridad encargado de la vigilancia y seguridad del tráfico" se modula el requisito establecido en la LTSV que exige, respecto al conocimiento de los hechos que puedan ser constitutivos de infracciones, que sea 
directo, mientras que para el reglamento sancionador basta con tener conocimiento de esos hechos ${ }^{141}$.

Sin duda se trata de una interpretación muy razonable de la forma en la que había de entenderse la incoación del procedimiento sancionador en materia de tráfico y seguridad vial $y$, de igual manera, tampoco cabe duda que lo establecido en el reglamento sancionador difería, y establecía una regulación distinta, a la establecida por la Ley de Tráfico y Seguridad Vial. Por ello, hubiera sido preciso modificar la redacción del art. 75.1 LTSV algo que no se consideró preciso ${ }^{142}$.

La cobertura para tal forma de actuación se fundamente, y así se recoge expresamente en el mismo inicio del propio texto introductorio que antecede al RPSTSV, es que "la disp. adic. Tercera de la LRJ - PAC ordena llevar a efecto reglamentariamente la adecuación a la misma de las normas reguladoras de los distintos procedimientos administrativos, cualquiera que sea su rango", disposición a la que ya nos hemos referido y que, al momento de promulgarse el RPSTSV establecía que "reglamentariamente, en el plazo de dieciocho meses a partir de la entrada en vigor de esta Ley, se llevará a efecto la adecuación a la misma de las normas reguladoras de los distintos procedimientos administrativos, cualquiera que sea su rango, con específica mención de los efectos estimatorios o desestimatorios que la falta de resolución expresa produzca".

No parece que el alcance que deba darse a esta disp. adic Tercera LRJ - PAC pueda extenderse a cambios que, a todas luces, van mucho más allá de la "adecuación" autorizada y que, por lo tanto, se producen sobre aspectos de la Ley de Tráfico y seguridad Vial en los que no es posible entender que se haya producido una deslegalización en virtud del referido mandato. Este argumento, el de que esto "es posible en virtud de la deslegalización operada" por la LRJ - PAC, no se corresponde con la realidad por mucho que sea la explicación expresamente empleada en esa introducción explicativa que antecede al propio Reglamento de procedimiento sancionador en materia de tráfico y seguridad vial ${ }^{143}$.

141 El Dictamen del Consejo de Estado 1239/1993, de 9 de diciembre de 1993, sobre Proyecto Real Decreto por el que se aprueba el Reglamento de Procedimiento Sancionador en materia de Tráfico, Circulación de Vehículos a Motor y Seguridad Vial, advertía "que el proyectado Reglamento no puede válidamente ampliar los funcionarios a los que se impone la citada obligación de formular denuncias" observación que se considera de carácter esencial, pero sin que se haga apreciación alguna sobre la cuestión que aquí se ha señalado.

142 Hasta el punto que el art. 3 RPSTSV ha mantenido en sus originarios términos y la regulación de la incoación del procedimiento sancionador en la Ley de Tráfico y Seguridad Vial no fue modificada hasta la promulgación de la Ley 18/2009, de 23 de noviembre, que reconfiguró, totalmente, el procedimiento sancionador en materia de tráfico, mediante la nueva redacción de los Títulos V y VI (infracciones y sanciones, y procedimiento sancionador de tráfico) de la Ley de Tráfico y Seguridad Vial y que reguló la incoación en el art. 73 LTSV hace uso de unos términos mucho más correctos y precisos.

${ }^{143}$ La introducción que acompaña al RPSTSV hace uso de estos términos "que es posible en virtud de la deslegalización operada por esta última Ley (en referencia a la LRJ - PAC)" sin indicar en momento 


\section{d) Denuncias}

La regulación que, de las denuncias, efectúa el Reglamento de procedimiento sancionador en materia de tráfico y seguridad vial, se corresponde con el patrón expuesto en la introducción explicativa que precede el Reglamento sancionador en materia de tráfico y seguridad vial conforme al que se recoge la norma legal (LTSV), se adapta a la LRJ - PAC y se desarrollan aquellos aspectos en que se ha estimado era menester la ulterior explicitación y precisión reglamentaria ${ }^{144}$.

EI RPSTSV destina los artículos 4 a 9 y 14 a la regulación de las denuncias (además de los arts. 10 y 11 en los que se abordan las cuestiones relativas a su notificación y que son tratados separadamente).

Se trata del desarrollo reglamentario de las previsiones efectuadas en los arts. 75.2 y 3 y 76 LTSV. La simple comparación, en términos cuantitativos (dos artículos de la LTSV frente a 7 del RPSTSV), permite determinar la existencia de "explicitación y precisión reglamentaria".

Así, el contenido de los arts. 4.1, 5, 8.1 y 14 RPSTSV se vienen a corresponder, y se limita a reproducir (de manera literal o en esencia), las previsiones efectuadas en los arts. $75.2,75.3$ y 76 LTSV $^{145}$, y es en el resto de preceptos del RPSTSV donde se

alguno que partes del procedimiento sancionador previsto en la Ley de Tráfico y Seguridad Vial han sido deslegalizados por su necesidad de adaptación, algo que sería normal (cuando no necesario) cuando la redacción del RPSTSV se aparta de lo previsto en la Ley y regula, de manera diferente a las previsiones en ella contenidas.

${ }^{144}$ Cfr. la parte final del segundo párrafo de la introducción que se antepone al articulado del propio RPSTSV.

${ }^{145}$ El art. 4.1 RPSTSV reproduce literalmente (con el matiz del uso de la partícula "del" en lugar de la preposición "de") y hace expresa referencia al art. 75.2 LTSV en cuanto a la obligación de denunciar las infracciones que observen los agentes encargados del servicio de vigilancia de tráfico cuando ejerzan las funciones de vigilancia y control de la circulación vial.

El art. 5 RPSTSV trascribe los dos primeros incisos del art. 75.3 LTSV (aunque la referencia incluía en el Reglamento haga referencia, de manera errónea a los "párrafos primero y segundo" en lugar de a "incisos") sobre el contenido establecido para las denuncias por hechos de circulación.

El art. 8.1 RPSTSV reitera el inciso final del art. 75.3 LTSV (aunque, al igual que en el caso anterior, se señale el "párrafo tercero" cuando la referencia debería serlo al inciso tercero o final) sobre el contenido de las denuncias por hechos ajenos a la circulación.

El art. 14 RPSTSV se corresponde con lo preceptuado por el art. 76 LTSV (aunque el reglamento no hace constar el precepto legal con el que se corresponde) sobre el valor que se debe atribuir a las denuncias realizadas por los agentes de la autoridad encargados de la vigilancia del tráfico, si bien es cierto que, en este caso se modifica la rúbrica, ya que el art. 14 RPSTSV aparece bajo la indicación "presunción de veracidad de las denuncias efectuadas por los agentes de la autoridad" que es mucho más precisa que la genérica expresión "denuncias de las autoridades y sus agentes" empleada por el art. 76 LTSV, lo que supone el expreso uso y consideración de que se trata de una "presunción de veracidad", algo que no se hace en la Ley, además de sustituir los términos legales "harán fe" por los reglamentarios "tendrán valor probatorio" en relación a este tipo de denuncias. 
encuentra la colaboración reglamentaria con las prescripciones efectuadas en la Ley de Tráfico y Seguridad Vial.

El art. 6 RPSTSV viene a desarrollar la regulación de las denuncias realizadas por los agentes de la autoridad encargados de la vigilancia del tráfico (de ahí su denominación como "denuncias de carácter obligatorio" o "denuncias obligatorias) y no tanto en cuanto a su contenido material y la información que en ellas debe constar (fijado en el art. 75.3 LTSV y reproducido por el art. 5 RPSTSV) como en lo relativo a los requisitos formales y la manera en que estos han de articularse.

El art. 6 RPSTSV introduce los boletines de denuncia (por triplicado) como sistema documental para dar soporte a las denuncias de carácter obligatorio y el contenido que en ellas debe constar, así como el sistema de notificación del denunciante al denunciado. El procedimiento establecido supone la entrega del contenido de la denuncia en un documento del que se extienden tres copias (una para el denunciante, otra para el denunciado y la última de ellas para la autoridad competente para tramitar $y$, en su caso, sancionar) en la que constará la firma de denunciante y denunciado y, caso que éste último se niegue a firmar, quedará constancia de ello.

El art. 7 RPSTSV contiene el desarrollo reglamentario para el caso de las denuncias de carácter voluntario, es decir, las formuladas por quien no está obligado, legalmente, a hacerlo.

La LTSV se limita a establecer la posibilidad de que cualquier persona que tenga conocimiento directo de hechos que puedan ser constitutivos de infracciones podrá formular la correspondiente denuncia (art. 75.1 LTSV), previsión que reproduce el art. 4.2 RPSTSV.

Las precisiones con las que el reglamento completa la previsión legal realizada para este supuesto se concretan en:

- La posibilidad de que el denunciante pueda formular la denuncia por escrito dirigido a la Administración competente o de manera verbal ante los agentes de la autoridad encargados de la vigilancia del tráfico

- En la denuncia deberán constar los mismos datos y circunstancias exigidos para la denuncias de carácter obligatorio (art. 75.3 LTSV y art. 5 RPSTSV)

- Si el denunciante opta por formular la denuncia ante los agentes de vigilancia del tráfico serán estos quien formalicen el correspondiente boletín de denuncia, en el que, además deberá constar "si personalmente comprobaron o no la infracción denunciada" y el nombre y domicilio del particular denunciante. En estos casos se remitirá el boletín a la Administración competentes para tramitar y, en su caso, imponer la correspondiente sanción y, si fuera posible, se le entregará copia del mismo al denunciante. 
El art. 9.2 RPSTSV contiene una previsión más sobre las denuncias, ya que en él se establece el tratamiento que debe de darse a las denuncias anónimas. Se disponen, reglamentariamente, dos pautas. De un lado, que este tipo de denuncias "serán archivadas sin que deban efectuarse ulteriores trámites al respecto", y de otro, que ese archivo no es una imposición automática no impide ("sin perjuicio de" en términos de la norma) "que los órganos competentes puedan comprobar los hechos a que se refieran, en los casos en que puedan suponer un riesgo para la seguridad vial".

Se trata de una previsión normativa un tanto compleja, algo que trasciende a la propia forma en la que se encuentra redactado el art. 9.2 RPSTSV, y que intenta integrar en la práctica algo que, en teoría, no puede llegar a suceder, ya que el art. 75.3 LTSV (y el art. 5 RPSTSV que reproduce ese contenido) al regular el contenido de las denuncias exigen como requisito de las mismas que conste la identificación del denunciante. Por ello, si entendemos que la expresión utilizada para determinar los elementos que deben de estar presentes y integrar una denuncia (ya sea obligatoria o voluntaria), ese "deberá constar", se configura como determinante de cuáles son los elementos esenciales para que una denuncia pueda ser considerada como tal, y que se trata de una requisito, esas denominadas "denuncias de carácter anónimo" a las que se refiere el art. 9.2 RPSTSV no son "denuncias" en los términos del art. 75.3 LTSV. O son "denuncias", y entonces consta la identificación del denunciante, o son "anónimas", y las podremos denominar de cualquier forma (informaciones, avisos, notas...), pero no como denuncias. Podrán ser medios para que la Administración competente inicie el procedimiento sancionador, para que se incoe de oficio por la autoridad competente que tenga noticias de los hechos que puedan constituir infracciones a la Ley de Tráfico y Seguridad Vial (conforme señalan el art. 75.1 LTSV y el art. 3 RPSTSV) o, incluso, para proceder, con anterioridad a la iniciación del procedimiento, a realizar actuaciones previas con objeto de determinar, con carácter preliminar si concurren circunstancias que justifiquen tal iniciación, algo que no se encuentra expresamente previsto en la normativa reguladora ( $\mathrm{ni}$ en la LTSV, ni en el RPSTSV), pero que resultaría posible en virtud del carácter subsidiario del Reglamento de procedimiento para el ejercicio de la potestad sancionadora establecido en el art. 1 RPSTSV y que permitiría hacer uso de la previsión establecida en el art. 12 REPEPOS.

Se trata, en todo caso, de una previsión innecesaria, ya que recoge, de manera explícita, el normal comportamiento de la Administración en estos casos, que no se encuentra obligada a tramitar un expediente salvo que se llegue a la conclusión de que hay motivo para ello. Previsión ubicada en el art. 9 RPSTSV, precepto que con la denominación "tramitación de las denuncias" se ubica en el punto en que se ha formulado una denuncia y ha de comenzar (en su caso) la tramitación del procedimiento sancionador. 


\section{e) Instrucción y tramitación}

Como se acaba de señalar, el art. 9 RPSTSV, se refiere al encauzamiento de la denuncia una vez ha sido formulada, completando las escuetas previsiones establecidas en la Ley de Tráfico y Seguridad Vial que únicamente destina a la tramitación del expediente sancionador el art. 79 LTSV.

Y allí, donde la Ley de Tráfico y Seguridad Vial se limita a establecer unas mínimas pautas procedimentales bajo esa denominación, la de tramitación (rúbrica empleada por el referido art. 79 LTSV), que necesitan del soporte de la regulación general (de la LPA al tiempo de promulgación de la LTSV, y de la LRJ - PAC al momento de publicación del RPSTSV), el Reglamento de Procedimiento sancionador en materia de tráfico hace uso, por un lado (art. 9 RPSTSV), de los términos "tramitación de denuncias" $y$, por otro (art. 12 RPSTSV), de la expresión "instrucción del procedimiento". Además, el Reglamento realiza un tratamiento separado de las cuestiones relativas a la prueba (art. 13 RPSTSV) y a la resolución sancionadora (art. 15 RPSTSV), cuestiones que en la LTSV se encuentra integradas, y sucintamente atendidas, en el propio art. 79 LTSV. Asimismo, el tratamiento correspondiente a la notificación, en ambos casos, Ley y Reglamento, es tratado de manera específica, siendo las prescripciones contenidas en los arts. 10 y 11 RPSTSV una mera transcripción de lo establecido en los arts. 77 y 78 LTSV.

El hecho de que la Ley de Tráfico y Seguridad Vial se redactara estando vigente la Ley de Procedimiento Administrativo de 1958 y que cuando se promulga el Reglamento sancionador en materia de tráfico y seguridad vial esa norma había sido derogada por la LRJ - PAC, situación que como se ha tenido oportunidad de señalar (HACER NOTA) es uno de los ejes sobre los que gira la regulación reglamentaria, en cuanto a la adecuación reglamentaria del procedimiento sancionador a la nueva norma, no supone alteración del sistema establecido en la LTSV, hasta el punto que las previsiones establecidas en el art. 79.1 y 2 LTSV, en cuanto principios básicos de la tramitación del procedimiento sancionador, son fielmente reproducidos por el art. 12 RPSTSV que, eso sí, introduce una matización a las previsiones establecidas por la Ley de Tráfico y Seguridad Vial.

Así, el desarrollado efectuado reglamentariamente sobre cuestiones relativas a la instrucción del procedimiento no va a significar, salvo en aspectos muy concretos, precisiones sobre lo previsto en la Ley o de aquello que, de una manera directa y evidente, pudiera desprenderse de esas previsiones legales tan genéricas como concisas, desarrollo, el del referido art. 79 LTSV que en el Reglamento de procedimiento sancionador en materia de tráfico y seguridad vial se reparte entre los arts. 9 y 12 RPSTSV. El primero de ellos bajo la rúbrica "tramitación de las denuncias" que, como se ha puesto de manifiesto, regula el paso de la denuncia a la tramitación 
del expediente. El segundo, con la denominación "instrucción del procedimiento", a recoger derechos del denunciado.

El art. 9 RPSTSV dibuja un iter evidente cuando la autoridad competente recibe una denuncia. Calificar los hechos y, en caso de ser constitutivos de infracción, proceder a determinar la sanción, estableciendo el grado que les corresponda, o proceder a la verificación de la calificación y graduación efectuadas cuando esas acciones hayan sido realizadas por el agente denunciante. $\mathrm{Y}$, en su caso, determinar la inexistencia de infracción o la imposibilidad de sanción (improcedencia de imponer sanción en términos del art. 9.1 RPSTSV) por no resultar posible identificar al responsable de la infracción denunciada.

El art. 12 RPSTSV determina que la instrucción corresponde "a los órganos competentes de las Jefaturas Provinciales de Tráfico y de los Ayuntamientos", con olvido de las entonces atribuidas a las Comunidades Autónomas ${ }^{146}$. Y, como órganos responsables de la instrucción, tienen el deber de notificar de notificar las denuncias, al presunto infractor, en el caso de que ello no hubiera sido efectuado por el denunciante, concediéndole un plazo de quince días para que alegue cuanto considere conveniente a su defensa y proponga las pruebas que estime oportunas, haciendo uso el 12.1 RPSTSV de los mismos términos empleados por el art. 79.1 LTSV, lo que deriva en la regulación efectuada, a tal efecto, para las notificaciones y el domicilio en el que éstas ha de ser efectuadas, cuestiones que, son tratadas, de manera específica, en el correspondiente apartado.

El art. 12.2 RPSTSV contiene una precisión a la regulación efectuada en el art. 79.2 LTSV, ya que sobre la base de que "de las alegaciones del denunciado se dará traslado al denunciante para que informe en el plazo máximo de quince días" el reglamento establece que no es una norma general absoluta, y que ese traslado al denunciante y esa exigencia de que informe sobre ellas requiere que en esas alegaciones formuladas

\footnotetext{
${ }^{146}$ Al momento de dictarse el RD 320/1994, de 25 de febrero, por el que se aprobaba el Reglamento de Procedimiento Sancionador en Materia de Tráfico y seguridad Vial, la Comunidad Autónoma del País Vasco ya contaba, en base a lo dispuesto en el art. 17 de su Estatuto de Autonomía, de competencias en este ámbito. El Real Decreto 3256/1982, de 15 de octubre, de traspaso de servicios del Estado en materia de ejecución de la legislación estatal sobre tráfico y circulación de vehículos, establecía que en cuanto a las competencias "como consecuencia de lo dispuesto en el art. 17 del Estatuto de Autonomía para el País Vasco, Ley Orgánica 3/1979, de 18 de diciembre, cuyo desarrollo se inició a través del Real Decreto 2903/1980, de 22 de diciembre, y del reconocimiento expreso del Estado a unos antecedentes históricos debidamente actualizados, corresponde a la Comunidad Autónoma del País Vasco las funciones que en este acuerdo se citan, de ejecución de la legislación del Estado en materia de tráfico y circulación de vehículos" y, sobre los servicios e instituciones traspasadas, que a partir de la entrada en vigor del Real Decreto aprobatorio del presente acuerdo de la Comisión Mixta de Transferencias, la Comunidad Autónoma del País Vasco asume (entre otras) las funciones y competencias referidas a la ejecución de la legislación del Estado en materia de tráfico y circulación de vehículos en cuanto a "la facultad de sancionar establecida en el Código de la Circulación", y que esa "facultad implica la de instruir el expediente, así como la de dictar la resolución que le ponga término y hacerla ejecutar, percibiendo, en su caso, el importe de las multas" (RD 2903/1980, de 22 de diciembre, Anexo, apartados A y B.1 a).
} 
por el denunciado se "aporten datos nuevos o distintos de los inicialmente constatados por el denunciante". Se trata, con ello, de obstaculizar el procedimiento sancionador y que cualquier alegación, cualquier escrito formulado frente a la denuncia, suponga un esfuerzo procedimental que, a todas luces resulta innecesario, y que, teniendo en cuenta el plazo de prescripción establecido en ese momento (dos meses conforme a lo establecido en el art. 81.1 LTSV y 18 RPSTSV), podría suponer, en muchas ocasiones, la prescripción de la infracción perseguida.

Sí contiene el Reglamento de Procedimiento Sancionador en materia de Tráfico y Seguridad Vial precisiones adicionales en cuanto a la prueba y su práctica. En este sentido el art. 13.1 y 2 RPSTSV regulan la apertura del período de prueba por un plazo que no será ni superior a treinta días ni inferior a diez para que se practiquen todas las pruebas que sean adecuadas. De igual manera se establece que el instructor del procedimiento sólo podrá rechazar mediante resolución motivada las pruebas propuestas por los interesados, cuando sean improcedentes y que cuando se solicite la práctica de pruebas cuya realización implique gastos que no deba soportar la Administración se podrá exigir el abono de los mismos de manera previa y a reserva de la liquidación definitiva, una vez practicada la prueba. La liquidación de los gastos se practicará uniendo los comprobantes que acrediten la realidad y cuantía de los mismos. Regulación que supone la mimética traslación (adaptación) de lo establecido en los arts. 80.2 y 3 y 81.3 LRJ - PAC ${ }^{147}$.

\section{f) Notificaciones}

A las notificaciones se destinan los arts. 10 y 11 RPSTSV, que contienen algunas precisiones relevantes sobre lo establecido en los arts. 77 y 78 LTSV.

En cuanto a la notificación, recuerda el art. 10 RPSTSV, el principio general conforme al que las denuncias obligatorias han de ser notificadas en el acto y que, únicamente, por razones justificadas que deberán constar en la propia denuncia, podrán notificarse con posterioridad. El art. 10.1 RPSTSV determina que en esa notificación, y además de los datos que se exigen en el art. 5 RPSTSV (que reproduce lo establecido en el art. 75.3 LTSV), es preciso hacer constar que con la propia denuncia queda incoado el correspondiente expediente sancionador y que, por tanto y como consecuencia de ello, el denunciado dispone de un plazo de quince días para que alegar y proponer pruebas.

\footnotetext{
${ }^{147}$ La redacción del art. 13.1 RPSTSV se corresponde con las previsiones que, en este ámbito, se realizan en la LRJ - PAC. Así, el art. 13.1 RPSTSV párrafo primero se corresponde con la previsión efectuada en el art. 80.2 LRJ - PAC, el art. 13.1 párrafo segundo RPSTSV con el art. 80.3 LRJ - PAC (si bien el texto legal hace uso de la expresión "manifiestamente improcedentes e innecesarias que, en el Reglamento, se queda en "improcedentes") y el art. 13.1 párrafo tercero RPSTSV reproduce literalmente los términos empleados por el art. 81.3 LRJ - PAC.
} 
Por su parte, y en relación a los motivos que habilitan y permiten que las denuncias obligatorias no sean notificadas en el acto, el reglamento muestra una mayor precisión sobre la previsión legal establecida en el art. 77 párrafo segundo LTSV conforme a la que "por razones justificadas que deberán constar en la propia denuncia, podrá notificársele la misma con posterioridad" que, reproducida en el inciso final del art. 10.1 2 RPSTSV, es completada por el art. 10.2 RPSTSV al establecer que "las denuncias formuladas por los agentes de la autoridad sin parar a los denunciados no serán válidas a menos que consten en las mismas y se les notifique las causas concretas y específicas por las que no fue posible detener el vehículo", términos de los que se desprenden que, además de la necesaria presencia en la propia denuncia de ese motivo, es necesario la determinación de esa causa, la que impidió la notificación en el acto de esa concreta denuncia de manera específica, que no puede ser una causa genérica, lo que requiere de la expresa conexión entre la causa alegada y el supuesto concreto, de manera que pueda ser objeto de debate e impugnación si la notificación realizada con posterioridad cumple (o no) con los requisitos exigidos para que pueda ser considerada válida.

En cuanto al lugar en el que ha de ser practicada la notificación, el art. 11 RPSTSV se limita a transcribir las previsiones efectuadas en la Ley de Tráfico y Seguridad Vial, de manera que el art. 11.1 RPSTSV reproduce los dos párrafos que componen el art. 78.1 LTSV y el art. 11.2 RPSTSV hace lo propio con lo establecido en el art. 78.2 LTSV actualizando, eso sí, la referencia que la LTSV efectuada a la Ley de Procedimiento administrativo de 1958 por la correspondiente a la LRJ - PAC, con la única precisión, efectuada por medio del art. 11.3 RPSTSV, de advertir que cuando el objeto de las denuncias se corresponda con cuestiones relativas a centros de formación o centros de reconocimiento de conductores esas denuncias será notificadas en el en el domicilio que, de esos centros, conste en los Registros Oficiales, es decir, la que figure en el Registro de Centros de Formación de Conductores y en el Registro de Centros de Reconocimiento para Conductores ${ }^{148}$.

\footnotetext{
${ }^{148}$ Nótese que el art. 11.3 RPSTSV, en los términos en los que fue publicado en el BOE y que no han sido objeto de modificación alguna, parece presentar una defectuosa redacción, ya que hace referencia "a las denuncias formuladas en materia de centros de formación de conductores y de conocimientos para conductores", donde parece que ese "conocimientos" pudiera ser, o debiera haber sido, la referencia a los centros de reconocimiento de conductores". Sea como fuere, la redacción continua en los términos en los que fue publicada en el BOE de 21 de abril de 1994 y la lógica invita a pensar que la notificación en el "domicilio que de dichos centros figure en los correspondientes Registros" se refiere (o se quiso referir) a centros de formación y a centros de reconocimiento ya que, en caso contrario, no se entendería el uso del plural en la expresión "que de dichos centros figure en los correspondientes registros".

La normativa reguladora de los Centros de Conductores era, al momento de dictarse el Reglamento de Procedimiento Sancionador en materia de Tráfico y Seguridad Vial el RD 1753/1984, de 30 de agosto, por el que se aprobaba Reglamento de las Escuelas Particulares de Conductores de Vehículos de Motor y que hacía referencia al "Registro de la Dirección General de Tráfico" (arts. 4 y 12 del propio reglamento). Sobre este tipo de registros téngase en cuenta que el art. 5 h) LTSV establecía que se atribuían
} 


\section{g) Resolución (y propuesta de resolución)}

La única mención a la resolución realizada en la Ley de Tráfico y Seguridad Vial se corresponde con la realizada para indicar que el procedimiento sancionador terminará mediante la correspondiente resolución, al indicar el art. 79.3 LTSV que una vez tramitado el expediente "se dictará la resolución que proceda".

El Reglamento de Procedimiento Sancionador en materia de Tráfico y Seguridad Vial desarrolla esa afirmación y precisa diferentes hitos que resulta preciso cumplir para finalizar el procedimiento mediante el dictado de la resolución que proceda.

Estas prescripciones reglamentarias son de distinta naturaleza, recaen sobre diferentes elementos del procedimiento y son realizadas de manera asistemática en diversos lugares del Reglamento.

Así, en el marco del art. 13 RPSTSV y bajo la rúbrica "período de prueba", puede encontrarse la previsión de que la instrucción del procedimiento concluye con la propuesta de resolución de la que se dará traslado a los interesados para que, en un plazo no inferior a diez días ni superior a quince y con vista del expediente, formulen las alegaciones que tengan por convenientes, planteamiento que viene a coincidir por el efectuado en los arts. 18 y 19 REPEPOS.

Pero a diferencia de lo previsto en el art. 12.2 del propio RPSTSV que libera al instructor de enviar al denunciante las alegaciones del denunciado cuando en ellas no se aporten datos nuevos o distintos de los inicialmente constatados por el denunciante y de lo prevenido en el art. 19.2 REPEPOS, que permite prescindir del trámite de audiencia cuando no figuren en el procedimiento ni sean tenidos en cuenta otros hechos ni otras alegaciones y pruebas que las aducidas por el interesado, no existe en el RPSTSV previsión expresa alguna que contemple esta posibilidad, es decir, la de no notificar la propuesta de resolución al interesado.

competencias al Ministerio del Interior, sin perjuicio de las que tuvieran asumidas las Comunidades Autónomas, sobre los registros de vehículos, de conductores e infractores, de profesionales de la enseñanza de la conducción, de centros de formación de conductores, de los centros de reconocimiento para conductores de vehículos a motor y de manipulación de placas de matrícula, en la forma que reglamentariamente se determine. El vigente RD 1295/2003, de 17 de octubre, por el que se aprobó el Reglamento de Escuelas Particulares de Conductores, y por el que se derogó el RD 1753/1984, de 30 de agosto, si hace referencia al Registro de Centros de Formación de Conductores.

Los Centros de reconocimientos de conductores estaban regulados por el Real Decreto 2272/1985, de 4 de diciembre, por el que se determinan las aptitudes psicofísicas que deben poseer los conductores de vehículos y regula los Centros de reconocimiento destinados a verificarlas, que hacía referencia al "Registro que, a tal efecto, llevará la Jefatura Central de Tráfico" (arts. 3 y 10) y lo mismo sucedía con la Orden de 13 de mayo de 1986, que desarrollaba el referido Reglamento (art. 3), normas que fueron derogadas por el RD 170/2010, de 19 de febrero, por el que se aprueba el reglamento de centros de reconocimiento destinados a verificar las aptitudes psicofísicas de los conductores y que hace referencia al Registro de centros de reconocimiento para conductores de vehículos a motor (arts. 2 y 5 ). 
Los términos empleados por el art. 13.2 RPSTSV parecían exigir, en su literalidad, que "en todo caso" la propuesta de resolución debía de ser puesta en conocimiento del interesado. Pero, por otra parte, y teniendo en cuenta el carácter subsidiario que el art. 1 RPSTSV atribuía al REPEPOS, podía interpretarse que el traslado de la propuesta de resolución sólo era exigible cuando se hubieran formulado alegaciones y, además, no figuren en el procedimiento ni hubieran sido tenidos en cuenta otros hechos ni otras alegaciones y pruebas que las que hubieran sido aducidas, en su caso, por el propio interesado, por integración de lo establecido en el art. 19.2 REPEPOS.

Esta forma de entender lo previsto en el art. 13.2 RPSTSV, en cuanto a la no preceptividad del traslado de la propuesta de resolución al interesado, es la que se presentaba como interpretación más adecuada y correcta, y así fue entendido por el Tribunal Supremo que estableció como doctrina legal que la notificación al interesado de la propuesta de resolución no es un trámite preceptivo, siendo innecesario su traslado cuando no se hayan formulado alegaciones o cuando, habiéndolas formulado, en la propuesta de resolución no se tengan en cuenta otros hechos ni otras alegaciones y pruebas que las aducidas, en su caso, por el interesado ${ }^{149}$.

El art. 15 RPSTSV se encuentra redactado bajo la rúbrica "resolución" y contiene previsiones en relación a los requisitos que ha de cumplir la resolución sancionadora con la que se pone fin al procedimiento sancionador.

La regulación del Reglamento de Procedimiento Sancionador en materia de Tráfico y seguridad no hace, en este punto, sino adecuarse a lo establecido en la LRJ - PAC y en el REPEPOS.

La resolución que se dicte por el órgano competente ha de estar motivada. Se trata de una imposición que, conforme a lo establecido en los arts. 54.1 a) y 89.3 LRJ - PAC, se impone a los actos que limiten derechos subjetivos o intereses legítimos y que, de manera específica se establece para las resoluciones que pongan fin al procedimiento

\footnotetext{
149 La Sentencia del Tribunal Supremo (Sala 3o, Sección 6ạ) de 19 de diciembre de 2000 dictada en recurso de casación en interés de la Ley estableció, como doctrina legal, que "el artículo 13.2 del Real decreto reglamentario 320/1994, sobre procedimiento sancionador en materia de tráfico, circulación de vehículos a motor y seguridad vial debe interpretarse en el sentido de que la notificación de la propuesta de resolución que corresponda dictar en el procedimiento no es preceptiva ni tiene, por tanto, que notificarse al interesado, siendo también innecesario el trámite de audiencia, en cualquiera de estos dos casos: 1ㅇ Cuando el interesado no haya formulado alegaciones sobre el contenido del boletín de denuncia que inicia el procedimiento, y 2ㅇ Cuando, habiéndolas formulado, no se tengan en cuenta otros hechos ni otras alegaciones y pruebas que las aducidas, en su caso, por el interesado".

Téngase en cuenta que esta doctrina legal lo es sobre la redacción originaria en la que estaba redactado el art. 13.2 RPSTSV, aunque en la fecha en la que se dicta la sentencia esos términos habían sido modificados por el RD 137/2000, de 30 de enero, que habían incorporado, de manera expresa, la interpretación que el Tribunal Supremo realiza. Véase, en este mismo capítulo, el apartado IV J) correspondiente al estudio del RD 137/2000, de 30 de enero.
} 
sancionador, tal y como determinan el art. 138.1 LRJ - PAC y el art. 20.2 REPEPOS ${ }^{150}$ (el art 87.2 in fine LRJ - PAC señala que la resolución que se dicte será motivada en todo caso pero no sé si se refiere a toda resolución que termine un procedimiento o a aquellas en las que se declare que es imposible continuarlo). El que los términos empleados sean los de "sucintamente motivada" (en relación a la resolución sancionadora o a la resolución por la que se establezca la inexistencia de infracción) no tiene mayor trascendencia desde el momento en que se ha establecido de forma reiterada y continua que la motivación pude ser breve, sin dejar de ser motivación, y que "concisión" y "motivación" no tienen porqué ser términos excluyentes.

Se establece un plazo de seis meses para dictar la resolución que ponga fin al procedimiento sancionador. Plazo de tiempo cuyo cómputo inicial se corresponde con el inicio del propio procedimiento, cuestión sobre la que, desde una perspectiva absolutamente práctica, resulta preciso tener en cuenta que, en el caso de los procedimientos sancionadores en materia de tráfico y seguridad vial, y caso de las denuncias obligatorias notificadas en el acto, se corresponde con el momento en el que se dice cometida la infracción, ya que conforme establecen el art. 75.1 LTSV y el art. 10.1 RPSTSV, con ellas, con las denuncias de carácter obligatorio formuladas por los agentes de la autoridad encargados de la vigilancia del tráfico "quedan incoados los correspondientes expedientes".

El art. 42 LRJ - PAC ${ }^{151}$ establece que la Administración está obligada a dictar resolución en todos los procedimientos (art. 42.1 LRJ - PAC) y que cuando la norma de procedimientos no fije plazos, el plazo máximo de resolución será de tres meses (art. 42.2 LRJ - PAC) y, en ese sentido, el art. 15.1 RPSTSV determina un plazo específico, para dictar la correspondiente resolución, que será el de seis meses.

La resolución sancionadora no puede vulnerar los derechos de defensa del denunciado y por ello se establece que la resolución no podrá tener en cuenta hechos distintos de los determinados en la fase de instrucción del procedimiento (vinculación fáctica), sin perjuicio de su diferente valoración jurídica (art. 15.2 RPSTSV), trasladando lo establecido, y adecuándose a ello, en los arts. 138.2 LRJ - PAC y en el art. 20.3 REPEPOS, ya que si bien es cierto que la propuesta de resolución no vincula en cuanto

\footnotetext{
${ }^{150}$ Previsión que no supone novedad alguna al corresponderse con la establecida en los arts. 43.1 y 93.2 de la Ley de Procedimiento Administrativo de 1958.

${ }^{151}$ Téngase en cuenta que la redacción del art. 42 LRJ - PAC a la que aquí se hace referencia se corresponde con la vigente al momento de publicación del Reglamento de Procedimiento Sancionador en materia de Tráfico y Seguridad Vial, que se corresponde con los términos originales, redacción que se vio afectada de manera importante por la Ley 4/1999, de 13 de enero, que en lo que aquí interesa estableció que "La Administración está obligada a dictar resolución expresa en todos los procedimientos y a notificarla cualquiera que sea su forma de iniciación", que "el plazo máximo en el que debe notificarse la resolución expresa será el fijado por la norma reguladora del correspondiente procedimiento" y que "este plazo no podrá exceder de seis meses salvo que una norma con rango de Ley establezca uno mayor o así venga previsto en la normativa comunitaria europea".
} 
a la valoración jurídica de los hechos, también lo es que el interesado tiene derecho a ejercer una defensa efectiva frente a la concreta posibilidad de imposición de sanción.

\section{h) Caducidad del procedimiento}

El incumplimiento de la obligación de dictar la resolución sancionadora (o la que, en su caso, establezca la inexistencia de infracción) en el plazo de seis meses desde que se inició la tramitación del procedimiento sancionador supone el inicio del cómputo del plazo de caducidad establecido.

La LTSV no contenía prescripción alguna sobre la caducidad del procedimiento por ausencia de la resolución sancionadora ${ }^{152}$. El art. 16 RPSTSV establece que "si no hubiese recaído resolución transcurridos treinta días desde la finalización del plazo de seis meses desde la iniciación del procedimiento, se producirá la caducidad".

Los términos en los que se establece la caducidad del procedimiento sancionador parte de la previsión establecida en el art. 20.6 REPEPOS que exige el transcurso del plazo de seis meses desde la incoación del procedimiento sancionador, plazo que no tiene que coincidir con los seis meses naturales siguientes a la fecha de inicio del procedimiento dado que se establece la posibilidad de interrupción y reanudación de ese espacio de tiempo por lo que, para su cómputo (el de esos seis meses) resulta preciso, en cada caso, tener en cuenta las posibles interrupciones de su cómputo por causas imputables a los interesados o por la suspensión del procedimiento por la concurrencia de actuaciones en la jurisdicción penal conforme a lo establecido en el art. 74 LTSV y en el art. 2 RPSTSV.

Transcurrido ese plazo de seis meses y agotado, por tanto, el tiempo establecido para que la Administración competente proceda a dictar la resolución que ponga fin al procedimiento sancionador en materia de tráfico y seguridad vial sin que hubiera recaído esa resolución, se inicia un plazo de treinta días ${ }^{153}$ y, de no producirse la

\footnotetext{
152 No será hasta la reforma efectuada por medio de la Ley 19/2001, de 19 de diciembre, que se introduzca en el art. 81 LTSV una previsión sobre la caducidad del procedimiento conforme la que "si no hubiere recaído resolución sancionadora transcurrido un año desde la iniciación del procedimiento, se producirá la caducidad de éste y se procederá al archivo de las actuaciones, a solicitud de cualquier interesado o de oficio por el órgano competente para dictar la resolución". Con ello se adapta el procedimiento sancionador en materia de tráfico y seguridad vial a las prescripciones establecidas en la LRJ - PAC tras la reforma realizada por la Ley 4/1999, de 13 de enero, que introdujo un redacción en el 42.2 LRJ - PAC que exige que "el plazo máximo en el que debe notificarse la resolución expresa será el fijado por la norma reguladora del correspondiente procedimiento" y que "este plazo no podrá exceder de seis meses salvo que una norma con rango de Ley establezca uno mayor o así venga previsto en la normativa comunitaria europea".

${ }^{153}$ El art. 43.4 LRJ - PAC (en su redacción originaria), al que se remite el art. 20.6 del RD 1398/1993, de 4 de agosto, por el que se aprueba el Reglamento para el ejercicio de la potestad sancionadora, establecía que la caducidad del procedimiento se producía "en el plazo de treinta días desde el vencimiento del plazo en que debió ser dictada".
} 
resolución dentro de este plazo, es cuando finalizará el procedimiento y se procederá al archivo de las actuaciones.

El art. 16 RPSTSV establece dos supuestos (excepciones) en los que el transcurso del plazo establecido no conlleva la caducidad del procedimiento sancionador. El primero de ellos es que el procedimiento se hubiera paralizado por causa imputable a los interesados y el segundo cuando, como consecuencia de un proceso penal, la Administración se hubiera abstenido de actuar para sancionar posibles infracciones a la Ley Tráfico y Seguridad Vial, supuesto de suspensión del procedimiento sancionador previsto en el art. 74 LTSV y en el art. 2.1 del propio RPSTSV.

\section{i) Prescripción de infracciones y sanciones}

La regulación que, sobre prescripción de infracciones y sanciones, se efectúa en el marco del art. 81 LTSV es objeto de desarrollo por medio del art. 18 RPSTSV.

En cuanto a la prescripción de las infracciones, la previsión reglamentaria no coincide, plenamente, con lo establecido en la Ley de Tráfico y Seguridad Vial, ya que mientras el art. 81.1 LTSV determina que "la acción para sancionar las infracciones prescribe a los dos meses, contados a partir del día siguiente a aquél en que se hubienen cometido" el art. 18.1 párrafo primero RPSTSV estipula que "la acción para sancionar las infracciones prescribe a los dos meses, contados a partir del día en el que los hechos se hubiesen cometido", lo que supone coincidencia en cuanto al plazo de prescripción previsto (dos meses) y divergencia en la forma de realizar su cómputo en cuanto a la determinación del dies a quo para el inicio de su cómputo, lo que supone adaptación del Reglamento de Procedimiento Sancionador en materia de Tráfico y Seguridad Vial a las previsiones establecidas en el art. 133.2 LRJ - PAC en la medida en que en ese precepto se dispone que "el plazo de prescripción de las infracciones comenzará a contarse desde el día en que la infracción se hubiera cometido", lo que supone una diferente forma de determinación del dies a quo y, por lo tanto, del plazo que se establezca ${ }^{154}$.

En el art. 18.1 párrafo tercero RPSTSV se transcribe la previsión efectuada en el inciso final del art. 81.1 LTSV que establece la interrupción de ese plazo de prescripción por las actuaciones de las que tenga conocimiento el denunciado, estén encaminadas a averiguar la identidad del mismo o por la notificación efectuada conforme se establece en el art. 78 LTSV y en el art. 11 RPSTSV.

\footnotetext{
${ }^{154}$ No se recoge, por el contrario, la idea enunciada en el art. 133.1 LRJ - PAC sobre el establecimiento de diferentes plazos de prescripción en función de la gravedad de la infracción que, de manera genérica y para aquellos supuestos en los que las leyes no establezcan plazos específicos de prescripción, determina que "las infracciones muy graves prescribirán a los tres años, las graves a los dos años y las leves a los seis meses".
} 
Sobre la prescripción de infracciones el Reglamento precisa lo establecido por la Ley de Tráfico y Seguridad Vial al establecer en el art. 18.1 párrafo segundo RPSTSV la obligación de la Administración instructora de examinar de manera previa al inicio del procedimiento sancionador si la supuesta infracción ha prescrito, en cuyo caso no se deberá iniciar el procedimiento. Se trata de un precepto que encuentra su fundamento en razones de seguridad jurídica y economía procedimental (eficacia y eficiencia) y que impone el análisis previo de la prescripción y, en su caso, obliga a su declaración de oficio con la consecuencia de que no habrá lugar a su iniciación (o continuación) ya que, del mismo modo, el art. 18.3 RPSTSV establece que "la prescripción se aplicará de oficio por los órganos competentes en las diversas fases de tramitación del expediente".

Contiene el art. 18.1 párrafo cuarto RPSTSV una precisión adicional en una redacción que, por los términos empleados, resulta confusa al señalar que "el plazo de prescripción se reanudará si el procedimiento estuviere paralizado durante más de un mes por causa no imputable al denunciado". Se trata de una expresión desafortunada que se contradice en sus propios términos al establecer la "reanudación" de un plazo de tiempo que, en todo caso, y por el hecho de estar sometido al instituto de la prescripción, podrá ser "reiniciado" pero nunca reanudado. Esa forma en la que se encontraba redactada la previsión reglamentaria dio lugar a todo tipo de interpretaciones en cuanto a la forma en la que había de ser entendido, cuánto tiempo se necesitaba y cuál era la forma para su cómputo, ese plazo de dos meses establecido para la prescripción de infracciones.

De igual manera fue preciso recordar (y hacerlo continuamente) que las previsiones de prescripción de las infracciones lo eran en tanto se sustanciaba el correspondiente procedimiento sancionador y hasta que se producía la resolución sancionadora, pero no más allá. De manera que una vez dictada la resolución sancionadora la prescripción que entraba en juego era la correspondiente a las sanciones, con diferentes plazos y previsiones, pero ya no resultaba posible apreciar la prescripción de la infracción en vía de recurso, en donde, en su caso, lo que debe operar es el instituto del silencio administrativo ${ }^{155}$.

Sobre la prescripción de las sanciones el art. 18.2 RPSTSV reproduce, si bien es cierto que con distinta redacción, la triple previsión efectuada en el art. 81.2 LTSV en cuanto a que el plazo de prescripción establecido es el de un año, que comienza con la firmeza de la sanción y que ese plazo únicamente se interrumpe por la actuaciones encaminadas a la ejecución de la sanción, siendo la única precisión reglamentaria la relativa a que ese plazo de prescripción se iniciará, comenzará a computarse, desde el

\footnotetext{
155 Véase, entre otras, las Sentencias TSJ Comunidad Valenciana de 12 de noviembre de 1998 (RJCA 1998, 4198), del TSJ Castilla y León - Burgos de 17 de mayo de 1999 (RJCA 1999, 2122), del TSJ Aragón de 21 de enero 2000 (RJCA 2000, 678) y del TSJ Andalucía - Málaga de 26 de julio de 2000 (RJCA 2001).
} 
día siguiente a aquel en el que haya adquirido firmeza la resolución por la que se impone la sanción.

Prescripción de sanciones que, de existir, y al igual que sucede con la de las infracciones, ha de ser aplicada de oficio por la Administración en virtud del mandato contenido en el art. 18.3 RPSTSV.

\section{j) Impugnación de resoluciones}

Así, el art. 17.1 RPSTSV actualiza las previsiones que en la redacción originaria del art. 80 LTSV se hacían a la formulación del recurso de alzada en el plazo de quince días y hace referencia a la posibilidad de interponer el recurso ordinario regulado en los arts. 114 a 117 LRJ - PAC, en el plazo de un mes, que es el establecido en el art. 114.2 LRJ PAC, ante el Ministro del Interior, estando prevista la posibilidad de delegación en el Director General de Tráfico. Regulación que se refiere a las resoluciones dictadas en el marco de la competencia de la Administración General del Estado, atribuida por el art. 68 LTSV al Gobernador Civil de la provincia en la que se hubiera cometido la infracción.

En el caso de las competencias municipales y de Comunidades Autónomas habrá que estar a lo establecido en sus correspondientes regímenes de procedimiento.

Resulta preciso tener en cuenta, además, que aunque nada se señale al respecto tal y como se establece en el inciso final del art. 114.2 LRJ - PAC una vez transcurrido ese plazo de un mes sin que se hubiera interpuesto el recurso ordinario frente a la resolución sancionadora, ésta será firme a todos los efectos, sin perjuicio, en su caso, de la procedencia del recurso extraordinario de revisión.

Por su parte, la impugnación en vía contencioso - administrativa, requiere del previo agotamiento de la vía administrativa, tal y como se establece en el inciso final del art. 80 LTSV a lo que el art. 17.2 inciso final RPSTSV añade, en consonancia con lo establecido en el art. 110.3 LRJ - PAC, el requisito de la previa comunicación de la interposición del recurso contencioso - administrativo al órgano autor de la resolución sancionadora que se pretende impugnar.

\section{k) Anotación y cancelación de sanciones}

El art. 82 LTSV establece la anotación de las sanciones en el Registro de Conductores e Infractores. No de todas las sanciones, únicamente de las correspondientes a infracciones graves y muy graves y una vez, eso sí, que se hayan adquirido su firmeza.

El control de las sanciones graves y muy graves tiene como objeto, en el sistema establecido, la determinación de los antecedentes del infractor como elemento de 
graduación de posteriores sanciones o de la adopción de otro tipo de medidas y, por ello, la propia Ley de Tráfico y Seguridad Vial establece que esas inscripciones serán canceladas de oficio una vez hayan transcurrido seis meses desde su total cumplimiento o prescripción.

Para el resto de cuestiones, y en particular, para la forma en la que se tienen que actuar para la inscripción de sanciones impuestas por la comisión de infracciones graves y muy graves la ley recurre a la colaboración reglamentaria.

En este sentido son varias las precisiones que se realizan, por medio del art. 19 RPSTSV a lo establecido en el art. 82 LTSV.

El iter que se establece reglamentariamente parte de la atribución que, por medio del art. 5 h) y 6 LTSV, se efectúa a la Jefatura Central de Tráfico en cuanto a la gestión de todos los registros existentes en el ámbito de tráfico y la seguridad vial, con la precisión de que la anotación será realizada en el Registro de Conductores e Infractores (que es el supuesto normal) o, en su caso, en el que proceda, ya que puede darse la circunstancia de que la inscripción de la sanción derivada de la comisión de una determinada infracción grave o muy grave tenga que inscribirse en un registro distinto, como pueden ser los Registros de Centros de Formación de Conductores y en el Registro de Centros de Reconocimiento para Conductores ${ }^{156}$, inscripción que se realizará por la propia Jefatura Provincial de Tráfico que haya sido la instructora del expediente sancionador.

Para el caso de que el origen de la sanción se encuentre en la tramitación del procedimiento sancionador por otra Administración con competencias para instruir y sancionar (Ayuntamientos y Comunidades Autónomas) o en actuaciones realizadas por la Administración de Justicia las anotaciones se efectuarán por la Jefatura Provincial de Tráfico correspondiente por razón de territorio.

El art. 19 RPSTSV establece precisiones en cuanto a los requisitos que se han de cumplir para que se practique la anotación, que requiere de unos datos mínimos como son el documento nacional de identidad del sancionado, el precepto aplicado, así como la naturaleza y duración de la sanción impuesta.

Dado el carácter y finalidad de los Registros (y en especial del de Conductores e Infractores) se establecen previsiones reglamentarias en cuanto al acceso a la información que en ellos se contienen, de manera que sobre las sanciones sólo se certificarán a petición del propio interesado, de las autoridades judiciales o de las administrativas con potestad sancionadora en materia de tráfico. $Y$, de igual manera, $\mathrm{Y}$ dado el carácter temporal de las anotaciones que allí se realizan y sus efectos como

\footnotetext{
${ }^{156}$ Véase supra la nota 143 en lo relativo a la regulación y denominación de estos Registros al momento de publicación del Reglamento de procedimiento sancionador en materia de tráfico y seguridad vial.
} 
antecedentes del infractor se prescribe que una vez canceladas las anotaciones únicamente se podrán utilizar por la Dirección General de Tráfico para fines estadísticos o de gestión reglamentaria.

\section{I) Ejecución de sanciones y cobro de multas}

Las previsiones efectuadas en los arts. 20 y 21 RPSTSV sobre ejecución de sanciones y cobro de multas se limitan a reproducir las efectuadas en los correspondientes arts. 83 y 84 LTSV, lo que se señala de manera expresa al final de cada uno de los diferentes párrafos que integran los referidos artículos reglamentarios, sin que se añada, por lo tanto, precisión alguna a las prescripciones realizadas, en esta materia, por la Ley de Tráfico y seguridad Vial.

\section{m) El efecto derogatorio del RPSTSV}

El Reglamento de Procedimiento Sancionador en materia de Tráfico y Seguridad Vial supone, y así lo señala la propio texto introductorio que antecede al articulado del reglamento, el desarrollo reglamentario de la parte de la Ley de Tráfico y seguridad Vial destinada a la regulación del procedimiento sancionador y de los recursos al tiempo que la adecuación de este procedimiento a la prescripciones establecidas en la LRJ - PAC.

Pero, además, la promulgación del Reglamento de Procedimiento Sancionador en materia de Tráfico y Seguridad Vial supone la expulsión del ordenamiento jurídico de determinadas normas que configuraban el anterior sistema.

Así, la disposición derogatoria única RPSTSV establece la expresa supresión de determinados preceptos del Código de la Circulación de 1934, la práctica totalidad de los que integraban el Capítulo XVII del Código de la Circulación, pero no de todos ellos, así como la tácita derogación de cuantos se opongan a lo establecido en el RPSTSV ${ }^{157}$.

Interesa aquí hacer referencia a esas dos normas que, estando ubicadas dentro de la regulación que del procedimiento sancionador se efectuaba en el Código de Circulación, mantienen su vigencia.

Por un lado se mantiene la previsión del art. 279.III del Código de la Circulación conforme a la cual no se castigan, ni acumulan las sanciones, correspondientes a infracciones mediales, "cuando una infracción sea medio necesario para cometer otra"

\footnotetext{
${ }^{157}$ La disposición derogatoria única del RPSTS establece que:

“Quedan derogados los artículos 276, 277, 278, 279.I y II, 280, 281, 282, 283, 284, 285, 286, 287 y 289, todos ellos incluidos en el Capítulo XVII del Código de la Circulación y cuantos preceptos se opongan a lo dispuesto en el Reglamento aprobado por el presente Real Decreto".
} 
ni se duplica la sanciones "cuando un mismo hecho constituya dos o más infracciones", supuesto en el que se impondrá únicamente la sanción más graves de las que corresponda $^{158}$.

Por otro, se mantenía la regulación que, en materia del procedimiento sancionador en caso de denuncias notificadas en el acto por infracciones a preceptos de este Código cometidas por personas que no acrediten su residencia habitual en territorio español, se contenía en el art. 288 del Código de la Circulación ${ }^{159}$.

${ }^{158}$ La redacción del art. 279.III del Código de la Circulación de 1934 al tiempo de la promulgación del Reglamento de Procedimiento Sancionador en Materia de Tráfico y Seguridad Vial lo era en los siguientes términos:

“III. Las sanciones señaladas en el presente Código no serán acumuladas cuando una infracción sea medio necesario para cometer otra, o cuando un mismo hecho constituya dos o más infracciones, imponiéndose en estos casos únicamente la sanción más grave de las que corresponda".

159 Los términos del art. 288 del Código de la Circulación, en la redacción recibida del Decreto 3268/1968, de 25 de diciembre (BOE de 16 de enero de 1969 y corrección de errores en BOE 1 de febrero de 1969), eran del siguiente tenor literal:

“Artículo 288.-Las denuncias por infracciones a preceptos de este Código cometidas por personas que no acrediten su residencia habitual en territorio español, se ajustarán a las siguientes normas:

a) La cuantía de la multa se fijará provisionalmente por el Agente denunciante, con sujeción a las normas de este Código y aplicando las reducciones previstas en el artículo anterior.

b) El importe de la multa deberá ser entregado en el acto, en concepto de depósito y en moneda de curso legal en España, al Agente denunciante, el cual entregará al denunciado el boletín de denuncia y el recibo correspondiente. En el primero constarán los extremos previstos en el inciso a) del artículo 282, y en el recibo, con caracteres impresos, deberá constar la cuantía de la multa percibida.

c) La cantidad entregada quedará a resultas del acuerdo que en definitiva adopte la Autoridad gubernativa, a la que se remitirá aquélla en unión del boletín original.

d) La ulterior tramitación de las denuncias a que se refiere el presente artículo se ajustará a lo prevenido en el ya citado artículo 282, reservándose a los denunciados idénticos derechos que a los residentes en España.

e) En estos expedientes no se podrá imponer sanción pecuniaria que exceda del depósito hecho, pero el Gobernador civil podrá acordar, si procediere, suspender el permiso para conducir automóviles dentro del territorio nacional, conforme a las normas contenidas en el artículo siguiente.

f) Si se dejase sin efecto la denuncia o se redujera el importe de la multa, se pondrá a disposición del interesado o de su representante la cantidad que en cada caso proceda. Si el acuerdo fuera confirmatorio, el depósito se convertirá en papel de pagos al Estado o Municipal, según los casos, remitiéndose al interesado o a su representante la parte correspondiente con la notificación de aquél.

g) Transcurridos diez días desde la notificación sin que el interesado se persone en el expediente con la aportación del escrito de descargos y pruebas pertinentes, se entenderá que está conforme con la multa. En tal caso, el acuerdo que se dicte tendrá el carácter de firme y no procederá contra el mismo recurso de alzada, a menos que al propio tiempo se imponga la suspensión del permiso de conducción.

h) Si el denunciado no hiciere efectivo el depósito del importe de la multa en el acto de la denuncia, se le permitirá que señale persona o Entidad que constituya caución suficiente, y de no lograrse ésta, el Agente denunciante hará conducir el vehículo a la localidad más cercana, donde quedará depositado en el lugar que designe la Alcaldía, comunicándolo, por el medio 


\section{D) Ley 5/1997, de 24 de marzo, de reforma de la LTSV}

\section{LA REFORMA EN SU CONJUNTO}

Una vez puesta en circulación la Ley de Tráfico y Seguridad Vial y sus principales reglamentos de desarrollo ${ }^{160}$ se procede a realizar una primera revisión de la norma básica del sistema, lo que se realiza por medio de la Ley 5/1997, de 24 de marzo, de reforma del texto articulado de la Ley sobre Tráfico, Circulación de Vehículos a Motor y Seguridad Vial, aprobado por Real Decreto Legislativo 339/1990, de 2 de marzo ${ }^{161}$.

El principal objeto de la reforma se centra en las actuaciones municipales en materia de tráfico y seguridad vial y sus competencias para sancionar, en especial en el concreto ámbito de la ordenación de la regulación del aparcamiento.

La Exposición de Motivos de la propia Ley 5/1997, de 24 de marzo, señala que "no obstante y pese al convencimiento de ser ésa la correcta interpretación de las competencias municipales en la materia, es lo cierto que existen dudas a la hora de interpretar de manera correcta las competencias y la actuación municipal en la materia, habiéndose producido una jurisprudencia contradictoria" (párrafo tercero) y que "ante la confusión jurídica que se ha venido observando en esta materia, la única solución posible es la realización de una reforma legislativa que diese cobertura legal a la actuación municipal mediante la reforma del Real Decreto Legislativo 339/1990, de 2 de marzo, por el que se aprueba el texto articulado de la Ley sobre Tráfico, Circulación de Vehículos a Motor y Seguridad Vial, y del Real Decreto 13/1992, de 17 de enero, por el que se aprueba el Reglamento General de Circulación, para la aplicación y desarrollo del texto articulado de la Ley sobre Tráfico, Circulación de Vehículos a Motor y Seguridad Vial”'162.

más rápido y conducto regular, al Gobierno Civil o Alcaldía competente para la resolución que proceda.

Precepto que, aunque no ha sido derogado expresamente, hay que entender que no está vigente tras la modificación realizada en la LTSV por medio de la Ley 18/2009, de 23 de noviembre, en la medida que la nueva redacción del art. 67.4 (84 y 85) LTSV contiene previsiones al respecto.

160 De los grandes bloques en los que se podía descomponer la Ley de Tráfico y Seguridad Vial (circulación, conductores, vehículos y régimen sancionador) ya se habían implementado los desarrollos correspondientes a circulación (Reglamento General de Circulación de 1992), Procedimiento Sancionador (Reglamento de 1994) y se estaba elaborando el correspondiente a conductores (el Reglamento General de Conductores vería la luz en mayo de 1997). Únicamente quedaban pendientes las cuestiones relativas a los vehículos, y no sería hasta finales de 1998 que se promulgase el Reglamento General de Vehículos, norma mucho más técnica, sujeta a continuas modificaciones y dependiente de la normativa de la Unión Europea y su incorporación al derecho interno.

${ }^{161}$ Publicada en el BOE de 25 de marzo de 1997 y por la que se da nueva redacción a los arts. 7 b) y c); $38.4,39.1$ y $2,65.3,4$, y $5,67.1$ y $4,70,71.1$ a), e) y f) y 81.1 LTSV.

162 Sobre esta cuestión hemos de tener presente que tal y como se señala en la propia Exposición de Motivos las competencias municipales en esta materia derivan de lo establecido en el art. 25.2 b) LRBL (así como de los arts. 7 y 38.4 LTSV), pero que en ese momento, cuando se modifica por la Ley 5/1997, 
Pero (cómo no) se aprovecha la ocasión para realizar otros retoques en la Ley de Tráfico y Seguridad Vial en el terreno del régimen sancionador. Algunos de ellos se anuncian en la Exposición de Motivos, como son la modificación del art. 65 LTSV "con el objeto de que las infracciones relativas a alcohol y drogas, siempre constituyan infracción muy grave" ${ }^{163}$.

De algunos otros cambios ninguna noticia hay en esa Exposición de Motivos. Esa mejora sistemática si conlleva la individualización de las infracciones graves y muy graves y su ordenación con letras en los apartados 4 y 5 del art. 65 LTSV. Pero nada se dice de la recalificación de determinadas conductas que pasan de graves a muy graves, como son la conducción temeraria, la omisión de socorro en caso de urgente necesidad o accidente grave o las competencias o carreras entre vehículos no autorizadas, que pasan a integrar el art. 65.5 .2 c), d) y e) LTSV, ni tampoco de la innovación que supone el hecho de que, además de que la conducción bajo los efectos de bebidas alcohólicas y otras sustancias prohibidas merezca en todo caso la calificación de infracción muy grave, integrando el art. 65.5.2 a) LTSV, se introduzca el "incumplir la obligación de todos los conductores de vehículos de someterse a las pruebas que se establezcan para la detección de posibles intoxicaciones de alcohol, estupefacientes, psicotrópicos, estimulantes y otras sustancias análogas, y la de los demás usuarios de la vía cuando se hallen implicados en algún accidente de circulación", como infracción muy grave en el art. 65.5.2b) LTSV.

Cuesta entender el objetivo del legislador cuando tipifica infracciones en el marco de la regulación de las sanciones y, además, se aduce para ello que "la modificación del artículo 67.4 de dicho Real Decreto Legislativo pretende mejorar la sistemática y la redacción, añadiendo además las infracciones relativas al régimen de autorización administrativa de los vehículos (que desaparecen como infracciones graves del artículo 65.4), que por error no se tipificó así en la primera redacción”164.

$\mathrm{Y}$, de igual manera, no resulta sencillo comprender la modificación efectuada en el art. 67.1 LTSV a la que ninguna referencia se efectúa en la Exposición de Motivos de la propia Ley 5/1997, de 24 de marzo, dada la entidad de los dos cambios que la nueva redacción supone sobre el contenido previsto en la redacción originaria del art. 67.1 LTSV, ya que, por una parte, se establece que las infracciones muy graves llevarán aparejadas "en todo caso" la sanción de suspensión del permiso del permiso o licencia de conducción ${ }^{165}$, lo que, hasta ese momento, era una posibilidad, puesto que, además

de 24 de marzo, la LTSV, no se había realizado modificación de la LBRL, que posteriormente efectuó la Ley 57/2003, de 16 de diciembre, de Medidas para la Modernización del Gobierno Local, incorporando entre otras cosas, el Título IX (arts. 139 a 141) por el que se regulaba la tipificación de las infracciones y sanciones por las Entidades Locales en determinadas materias.

${ }^{163}$ Cfr. párrafo final de la Exposición de Motivos de Ley 5/1997, de 24 de marzo.

164 Ibidem.

165 Aunque, como se ha indicado, nada señala sobre este cambio la Exposición de Motivos de la Ley 5/1997, de 24 de marzo, posteriormente, en el Real Decreto - Ley 12/1997, de 1 de agosto, se señala al 
de la multa correspondiente a las infracciones graves o muy graves, se podía imponer esa sanción de suspensión de la autorización administrativa. El cambio era trascedente, puesto que ya no resultaba preciso, para el caso de las infracciones muy graves, motivar la imposición de esa sanción de suspensión, siendo suficiente con justificar el plazo de tiempo (entre uno y tres meses) impuesto al infractor ${ }^{166}$.

La otra mutación que sufría el art. 67.1 LTSV era incomprensible y, ante el silencio que sobre ello guardaba la Exposición de Motivos de la Ley 5/1997, de 24 de marzo, resultaba de todo punto inexplicable la desaparición del párrafo tercero de la primitiva redacción original de ese artículo que regulaba la especial forma en la que se había de proceder en las denuncias obligatorias notificadas en el acto cuando el denunciado no acreditase su residencia en territorio nacional, norma que, aunque ciertamente resultaba peculiar dentro del contenido efectuado en el art. 67 LTSV formaba parte del sistema establecido por la Ley de Tráfico y Seguridad Vial para el procedimiento sancionador, ya que, simplemente, la nueva redacción suponía su desaparición, sin que esa previsión fuera ubicada en otro lugar más adecuado ${ }^{167}$.

Tampoco se advierte nada sobre el cambio efectuado en el art. 67.4 LTSV en cuanto a la modificación de las infracciones que pueden dar lugar a las suspensión y cancelación de la correspondiente autorización administrativa, así como al establecimiento de un sistema que pone en relación las cuantías de las sanciones impuestas con el tiempo que puede durar la suspensión o cancelación como medida sancionadora.

respecto que "La reciente Ley 5/1997, de 24 de marzo, de reforma del texto articulado de la Ley sobre Tráfico, Circulación de Vehículos a Motor y Seguridad Vial, aprobado por Real Decreto legislativo 339/1990, de 2 de marzo, ha introducido diversas modificaciones, entre las cuales se incluye una nueva redacción del apartado 1 del artículo 67. Esta última modificación tenía como único objeto incorporar la sanción de suspensión del permiso o licencia de conducción por un período de hasta tres meses en todos los supuestos de comisión de infracciones muy graves, en consonancia con lo previsto en el art. 33.4 del Código Penal vigente", en referencia a lo establecido en el referido precepto del CP/1995 sobre las penas y su clasificación, lugar en el que se determina que la privación del derecho a conducir vehículos a motor y ciclomotores de tres meses a un año es una pena grave -art. 33.4 a) CP/1995-, muestra de la relación (o la menos preocupación en este caso por ello) de la relación que deben de guardar las sanciones administrativas y las penas como correlación, a su vez, entre infracciones administrativas y tipos penales.

${ }^{166}$ La redacción de la parte final del art. 67.1 párrafo LTSV pasaba, por medio de la reforma que la Ley 5/1997, de 24 de marzo, efectuaba de establecer que "en el caso de infracciones graves o muy graves podrá imponerse además la sanción de suspensión del permiso o licencia de conducir hasta tres meses" a que "En el caso de infracciones graves podrá imponerse además la sanción de suspensión del permiso o licencia de conducción hasta tres meses. En el supuesto de infracciones muy graves esta sanción se impondrá en todo caso".

167 Lo que daría lugar a la corrección de esta omisión de carácter "fortuito" y a su recuperación y reintroducción en la Ley de Tráfico y Seguridad Vial por medio del Real Decreto - Ley 12/1997, de 12 de agosto y la Ley 59/1997, de 19 de diciembre, normas en las que se señala que "prueba del carácter fortuito de este olvido es que en el debate parlamentario sobre este precepto no se planteó en ningún momento la supresión de la posibilidad de inmovilización de vehículos ante el impago citado". 


\section{LA MODIFICACIÓN DEL PLAZO DE PRESCRIPCIÓN DE LAS INFRACCIONES}

En el concreto ámbito del procedimiento sancionador en materia de tráfico se ve afectado el art. 81.1 LTSV sin que tampoco exista advertencia ni explicación alguna sobre ello en la Exposición de Motivos.

La Ley 5/1997, de 24 de marzo, establece la modificación de los términos en los que se había sido redactado el art. 81.1 LTSV y, por lo tanto, una modificación de las previsiones originariamente establecidas para la prescripción de las infracciones en materia de tráfico y seguridad vial, mutación que afecta tanto al propio plazo como a su cómputo.

El cambio previsto supone que el inciso inicial del art. 81.1 LTSV pasa de los términos "la acción para sancionar las infracciones prescribe a los dos meses, contados a partir del día siguiente a aquél en que se hubiesen cometido" a "la acción para sancionar las infracciones prescribe a los tres meses contados a partir del día en que los hechos se hubieren cometido".

En definitiva, el plazo de prescripción para todo tipo de infracciones (ya se trate de las calificadas como leves, como graves o como muy graves) se incrementa en un mes y pasa a ser de tres meses aunque, eso sí, el dies a quo se inicia a hora en el mismo día de comisión de la infracción, y no uno más tarde (al día siguiente), como se establecía en la redacción originaria del art. 81.1 LTSV, previsión, la de iniciar el cómputo del plazo de prescripción en el mismo día en el que se comete la infracción, que se corresponde con la ya establecida en el art. 18.1 del Reglamento de Procedimiento Sancionador en materia de Tráfico y Seguridad Vial.

No se justifica la oportunidad de esta reforma ni el motivo de establecer este nuevo plazo de prescripción de las infracciones y, lo que es más llamativo, no se establecen diferentes plazos de prescripción en función de la gravedad de las infracciones, en la línea enunciada por en el art. 133.1 LRJ - PAC que, reconociendo la posibilidad de que sean las leyes sectoriales las que determinen los plazos de prescripción de infracciones y sanciones, establece unas pautas al señalar que en el caso de que no se fijen los plazos de prescripción "las infracciones muy graves prescribirán a los tres años, las graves a los dos años y las leves a los seis meses".

Finalmente cabe señalar que la disp. adic. única de la Ley 5/1997, de 24 de marzo, concedía al Gobierno un plazo (máximo) de seis meses para proceder a modificar el RGC/1992 y el RPSTSV, con el fin de para adecuarlos a las modificaciones contenidas en la presente Ley, algo que, en la mejor (y continua) tradición normativa de nuestro país fue incumplido ya que la referida adaptación no fue realizada hasta la promulgación del RD 116/1998, de 30 de enero, publicado en el BOE de 18 de febrero de 1998, es decir, casi un año después de la publicación de la Ley 5/1997, de 24 de marzo y casi en el doble del tiempo establecido. 


\section{E) El Reglamento General de Conductores de 1997}

\section{DeSARROLLO LTSV Y CONTENIDO SANCIONADOR}

El Real Decreto 772/1997, de 30 de mayo, por el que se aprueba el Reglamento General de Conductores (RCon) ${ }^{168}$, supone el desarrollo de las prescripciones de la Ley de Tráfico y Seguridad Vial sobre las autorizaciones administrativas para conducir, pero además, y en lo que aquí interesa, también contiene la regulación del Registro de Conductores e Infractores ${ }^{169}$, lugar en el que el art. 82 LTSV establecía que serían anotadas las sanciones firmes graves y muy graves.

De este modo las referencias a las cuestiones específicas en materia de régimen sancionador se saldan (en el Título IV del Reglamento, bajo la rúbrica "de las infracciones y sanciones") con un único artículo (el art. 83 RCon) que se limita a establecer que "las infracciones a los preceptos del presente Reglamento serán sancionadas de conformidad con lo dispuesto en el art. 67 del texto articulado de la Ley sobre Tráfico, Circulación de Vehículos a Motor y Seguridad Vial, aprobado por Real Decreto Legislativo 339/1990, de 2 marzo".

Pero sí se realiza en él, como se ha señalado, la regulación del Registro de Conductores e Infractores al que se hace referencia en los arts. 5 h), 78, 82 y 83 LTSV, ordenación que se realiza en el Título $V$ (arts. 84 a 86 RGCon) y de las incidencias que en el mismo se anotan, amparadas en el correspondiente deber de confidencialidad ${ }^{170}$.

\section{El REGISTRO dE CONDUCTORES E INFRACTORES}

El Registro de Conductores e Infractores, llevado y gestionado por la Dirección General de Tráfico (art. 84.1 RGCon), tiene como finalidad, conforme señala el art. 85 RGCon, "recoger y gestionar de forma automatizada los datos de carácter personal de los solicitantes y titulares de autorizaciones administrativas para conducir, así como su comportamiento y sanciones por hechos relacionados con el tráfico y la seguridad vial".

\footnotetext{
${ }^{168}$ Publicado en el BOE de 6 de junio de 1997.

169 Tal y como advierte en el párrafo segundo del texto que sirve de introducción explicativa al propio Reglamento General de Conductores de 1997 "el objeto del presente Reglamento es desarrollar los artículos 5 b) y h), en lo referente, respectivamente, al canje de permisos de conducción y al registro de conductores e infractores, 59, 60, 63, 64, 65 y 66 del texto articulado de la Ley sobre Tráfico, Circulación de Vehículos a Motor y Seguridad Vial, en cuanto se refieren a las autorizaciones administrativas para conducir, al mismo tiempo que transponer a la normativa española la Directiva del Consejo de las Comunidades Europeas 91/439/CEE, de 29 de julio, sobre el permiso de conducción, modificada por las Directivas 94/72/CE, de 19 de diciembre y 96/47/CE, de 23 de julio".

${ }^{170}$ Como advierte el párrafo decimosexto de la introducción que precede al articulado del propio Reglamento General de Conductores.
} 
Se trata de un "registro" o "fichero automatizado", como expresamente señala el art. 84.2 RGCon que, como tal, es un conjunto organizado de datos de carácter personal que sean objeto de un tratamiento automatizado, cualquiera que fuere la forma o modalidad de su creación, almacenamiento, organización y acceso ${ }^{171}$ y que, por lo tanto, tiene que cumplir (hacer efectivas) todas las garantías, obligaciones y derechos reconocidos en las normas reguladoras de protección de datos personales, responsabilidad que recae en la Dirección General de Tráfico como órgano administrativo que decida sobre la finalidad, contenido y uso del tratamiento.

Los datos que han de figurar en el Registro de Conductores e Infractores se determinan en al art. 86 RGCon y se corresponden con:

- Nombre, apellidos y domicilio del titular de la autorización, el número de su Documento Nacional de Identidad si es español o, en su caso, el de identificación de extranjeros o, excepcionalmente, otro número asignado al efecto por la Administración, art. 86 a) RGCon

- Fecha, lugar de nacimiento y sexo del titular de la autorización, art. 86 b) RGCon

- Clases de permiso o licencia de conducción y otras autorizaciones administrativas o documentos necesarios para conducir o relacionados con la conducción, art. 86 c) RGCon

- Nivel de estudios y, en su caso, condición de profesional de la enseñanza de la conducción, art. 86 d) RGCon

- Historial y resultados de las distintas pruebas de aptitud realizadas para obtener autorizaciones administrativas para conducir, art. 86 e) RGCon

- Historial, menciones y períodos de vigencia de las distintas autorizaciones o documentos que autoricen a conducir, art. 86 f) RGCon

- Menciones, incidencias, restricciones y limitaciones relacionadas con la propia autorización, la persona titular de la misma, el vehículo o la circulación, art. 86 g) RGCon

- Identificación del servicio sanitario o centro de reconocimiento que realizó la exploración del conductor y emitió el correspondiente informe de aptitud psicofísica, así como el resultado final de dicho informe, art. 86 h) RGCon

- Condenas judiciales que afecten a la autorización administrativa para conducir y las sanciones administrativas que sean firmes impuestas por infracciones graves y muy graves, art. 86 i) RGCon

- Nulidad, anulabilidad, pérdida de vigencia, medidas cautelares y, en su caso, la intervención de las autorizaciones administrativas para conducir, art. 86 j) RGCon

\footnotetext{
${ }^{171}$ Definición establecida en el art. 3 b) de la Ley Orgánica 5/1992, de 29 de octubre, de regulación del tratamiento automatizado de los datos de carácter personal, norma vigente en ese ámbito al momento de la promulgación del Reglamento General de Conducto res.
} 
- Otras incidencias relacionadas con las autorizaciones administrativas para conducir, art. 86 k) RGCon

En definitiva, todos aquellos datos (personales) que permitan la identificación e individualización del conductor como titular de una autorización administrativa a las que la conducción de vehículos se encuentra sometida de manera preceptiva y previa así como el nivel de estudios y la condición, en su caso, de profesional de la enseñanza de la conducción (apartados a y d), las clases de permisos y autorizaciones que posee ese titular con los datos relativos al historial de su obtención y vigencia (apartados c, e y f), circunstancias personales que supongan la existencia de restricciones o limitaciones sobre las autorizaciones de las que es titular (apartado g), identificación del centro de reconocimiento de conductores y resultado de la reconocimiento (apartado h), sanciones administrativa, graves y muy graves, y condenas judiciales (apartado i), cuestiones relativas a la nulidad, lesividad, medidas cautelares e intervención de las autorizaciones que habilitan la conducción (apartado j) y, finalmente, cualesquiera otra circunstancia que estuviera relacionada con esas autorizaciones administrativas (apartado k).

Al lado de esa regulación del Registro del Conductores e Infractores, el Reglamento de Conductores del 1997 contiene diversas referencias al Registro y alguna de ellas de importancia no menor. Es el caso de la inscripción en el Registro de conductores e infractores de los permisos de conducción expedidos en países miembros de la Unión Europea cuando sus titulares hubieran adquirido su residencia en España ${ }^{172}$ prevista en el art. 23 RGCon, la no superación del reconocimiento médico por titulares de permisos de conducción expedidos en Estados miembros de la Unión Europea (art. 24 RGCon), sustitución de permisos expedidos en Estados miembro de la Unión Europea en caso de sustracción, extravío o deterioro del original por el correspondiente español (art. 25 RGCon), Solicitud de canje de permisos de conducción y requisitos para realizarla (arts. 27 y 30 RGCon), requisitos para la obtención de las autorizaciones especiales para realizar el transporte escolar o de menores (art. 32 RGCon) o las cuestiones relativas a la pérdida de vigencia de las autorizaciónes administrativas que habilitan la conducción de vehículos (art. 39 RGCon).

Pero con todo, la referencia que en el propio Reglamento General de Conductores de 1997 presenta una mayor relevancia es la prevista en el art. 18 RGCon sobre la obligación de los titulares de las autorizaciones para conducir de comunicar a la Jefatura Provincial de Tráfico "cualquier variación de los datos que figuren en el

\footnotetext{
${ }^{172}$ Cuestión sobre la que el párrafo quinto del texto introductorio que precede al propio Reglamento General del Conductores señala que "de cualquier forma, la mayor innovación contenida en dichas Directivas y, por tanto, en el presente Reglamento, es el establecimiento de un auténtico permiso de conducción de ámbito comunitario, no precisado de canje, que siempre es posible con carácter voluntario, aun cuando sí de un registro cuando su titular adquiera la residencia normal en España y, por tanto, asuma de una forma más completa la aplicación de las normas específicas españolas".
} 
permiso o licencia de conducción" y de hacerlo "dentro del plazo de quince días" contados desde la fecha en que se produzca ese cambio para que esa modificación sea incorporada en el registro de Conductores e Infractores ${ }^{173}$. Y ello por los efectos que de esta obligación, establecida como deber ("deberá ser comunicada", en términos del Reglamento), se pudieran derivar para el procedimiento sancionador en materia de tráfico y seguridad vial y, en particular, sobre las notificaciones efectuadas (intentadas o realizadas) al domicilio que en el Registro de conductores e Infractores constara ya que el "domicilio del titular de la autorización" es uno de los datos específicamente señalados por el art. 86 a) RGCon entre los que han de estar recogidos en ese Registro $^{174}$.

En principio pudiera interpretarse que al establecerse la obligación de mantener actualizados los datos que se exigen al momento de expedición de las autorizaciones administrativas, ello se constituye en un deber del titular del permiso o licencia y que las consecuencias que se derivasen del incumplimiento de ese deber tendrían que ser soportadas por su causante que, en este caso, sería el propio titular de la autorización que, ya sea de forma voluntaria y consciente o por dejadez, no ha cumplido con la exigencia de mantener al día esos datos.

\section{F) El Real Decreto - Ley 12/1997, de 1 de agosto}

\section{UN (OTRO) ERROR LEGISLATIVO}

El Real Decreto - Ley 12/1997, de 1 de agosto, es la norma por la "que se añade un párrafo tercero al artículo 67.1 del texto articulado de la Ley sobre Tráfico, Circulación de Vehículos de Motor y Seguridad Vial, aprobado por Real Decreto legislativo 339/1990, de 2 de marzo" ${ }^{175}$.

De esta norma llama la atención tanto su tipo, Real Decreto - Ley, como su contenido, el de añadir un párrafo de tres líneas al art. 67.1 LTSV, como la desmesurada explicación que, en comparación, precede a esa adición normativa.

\footnotetext{
${ }^{173}$ Los términos en los que se encontraba redactado el art. 18 RGCon/1997 eran los siguientes:

Artículo 18. Variación de datos

Cualquier variación de los datos que figuran en el permiso o licencia de conducción deberá ser comunicada por su titular dentro del plazo de quince días, contados desde la fecha en que se produzca, a la Jefatura Provincial de Tráfico la que, previos los trámites oportunos, lo pondrá en conocimiento del Registro de Conductores e Infractores.

${ }^{174}$ A diferencia de lo que ocurre con la regulación de los datos que han de constar en el permiso o licencia de conducción, ya que los arts. 4, 9 y Anexos I, I bis y II RGCon no indican que el domicilio tenga que formar parte de la información que ha de contener el Permiso o licencia de conducción.

${ }^{175}$ Siendo esta la denominación que recibe la norma al momento de su publicación en el BOE de 16 de agosto de 1997 .
} 
Poca explicación necesitaba la corrección del error cometido al reformar la Ley de Tráfico y seguridad Vial por medio de la Ley 5/1997, de 24 de marzo, y eliminar en ese proceso, un párrafo de la Ley modificada, cuya supresión no se quería realizar. Esa es, en definitiva, la misión de la norma. Recuperar un párrafo eliminado por error en la tramitación parlamentaria.

Una muestra de que la negligencia se trata de un concepto aplicable, de manera exclusiva, a la conducción de vehículos, y que se trata de una noción que puede ser extendida a los procedimientos de producción de normas jurídicas.

\section{EL MÉTOdO ELEGIDO PARA LA RECTIFICACIÓN DEL ERROR}

No resulta fácil de comprender el sistema elegido para subsanar la omisión fortuita de la transcripción del párrafo tercero al efectuarse la Ley 5/1997, de 24 de marzo, la reforma (entre otros) del art. 67.1 LTSV, ya que se acude, para ello, al excepcional mecanismo previsto en el art. $86 \mathrm{CE}$ de que el Gobierno proceda a dictar un Real Decreto - Ley, algo reservado, conforme señala el propio precepto constitucional, a casos de extraordinaria y urgente necesidad, concepto jurídico indeterminado cuyo alcance concreto no puede precisarse a priori, pero sí caso por caso en función de las circunstancias coetáneas e, incluso posteriores a su publicación ${ }^{176}$.

$\mathrm{Y}$, en este caso, esa extraordinaria y urgente necesidad no resultan fácilmente perceptibles. Ni por el objeto, ni por las circunstancias.

El objeto no es otro que reintroducir en la Ley de Tráfico y Seguridad Vial un mecanismo en ella previsto que se había expulsado de la misma de forma fortuita o accidental, acción que requiere de una norma con rango de ley. La argumentación empelada por el propio Real Decreto - Ley para justificar esa necesidad (extraordinaria y urgente) que permita el uso de este tipo de disposición es que se trata de recuperar la norma sobre "las infracciones cometidas por no residentes en España y la inmovilización de sus vehículos en el supuesto de no depositarse o garantizarse el pago de las multas provisionales que les sean impuestas" y que "resulta inaplazable la reincorporación inmediata al ordenamiento jurídico del párrafo suprimido por la Ley $5 / 1997$, al ser la temporada estival en la cual nos encontramos el período del año durante el que se produce una mayor afluencia de vehículos conducidos por personas no residentes en territorio español" ya que "es sabido que en dicho lapso de tiempo las carreteras de nuestro país sufren un intensísimo crecimiento del tráfico de automóviles conducidos por estas personas que o bien pasan sus vacaciones en España, o bien utilizan su red viaria para llegar a sus países de origen" por lo que "de

\footnotetext{
${ }^{176}$ García de Enterría, E. y Fernández Rodríguez T.-R., Curso de Derecho Administrativo, Tomo I, 14a ed., Madrid, Civitas, 2008, pág. 147.
} 
no actuarse de manera inmediata para solventar el problema normativo planteado, se estaría ante una situación que en la práctica dejaría a un determinado colectivo -el de los no residentes en territorio nacional- al margen de la disciplina viaria, con las lamentables consecuencias que ello puede producir en la seguridad del tráfico" ${ }^{177}$.

Esta argumentación es la que, a su vez, permite establecer que "una vez puesta de manifiesto la necesidad extraordinaria -muy localizada temporalmente, puesto que una vez finalizado el período estival la intensidad del problema disminuiría considerablemente-, es preciso además, señalar que dicha necesidad no puede ser afrontada por el cauce parlamentario ordinario, ni siquiera en sus formas más abreviadas, ya que cualquier iniciativa en este sentido requeriría un período para su aprobación que excede con mucho el tiempo en el que la laguna normativa debe ser cubierta de una manera más inaplazable" y que, por lo tanto, nos encontramos ante un caso que "reúne los requisitos de extraordinaria y urgente necesidad exigidos en la norma suprema, tal y como han sido interpretados por la jurisprudencia constitucional” ${ }^{178}$.

Discrepo que la jurisprudencia constitucional a la que se hace referencia, de una forma genérica y sin que ello se concrete en referencia específica alguna, permita establecer que este concreto supuesto se estaba ante un "caso de extraordinaria y urgente necesidad". La doctrina constitucional precisa que el Decreto - Ley representa un instrumento constitucionalmente lícito, en tanto que pertinente y adecuado para la consecución del fin que justifica la legislación de urgencia, que no es otro, según tenemos reiterado, que subvenir a "situaciones concretas de los objetivos gubernamentales que por razones difíciles de prever requieran una acción normativa inmediata en un plazo más breve que el requerido por la vía normal o por el procedimiento de urgencia para la tramitación parlamentaria de las Leyes"179 y que es preciso la existencia de una necesaria conexión entre la situación de urgencia definida y la medida concreta adoptada para subvenir a la misma ${ }^{180}$.

Cuestiones que resulta adecuado poner en relación con las circunstancias concurrentes en supuesto concreto y, que en el este caso, permiten determinar que:

- Efectivamente, la tramitación de la Ley 5/1997, de 24 de marzo, por la que se modificaba la Ley de Tráfico y seguridad Vial, supuso la eliminación del último apartado del art. 67.1 LTSV

\footnotetext{
${ }^{177}$ Cfr. Texto introductorio del Real Decreto - Ley 12/1997, de 1 de agosto, párrafos 4 a 7.

${ }^{178}$ Cfr. Texto introductorio del Real Decreto - Ley 12/1997, de 1 de agosto, párrafos 8 y 9.

179 Tal y como señalan las Sentencias del TC 6/1983, de 4 de febrero, FD. 5, 11/2002, de 17 de enero, FD. 4, 137/2003, de 3 de julio, FD. 3, 189/2005, de 7 de julio, FD. 3 y 68/2007, de 28 de marzo, FD. 6.

${ }^{180}$ Conforme se establece en las Sentencias del TC 29/1982, de 31 de mayo, F. 3, 182/1997, de 20 de octubre, F. 3, 137/2003, de 3 de julio, FD. 4 y 189/2005, de 7 de julio, F. 4.
} 
- Esa consecuencia, en cuanto a la eliminación de una norma en la Ley de Tráfico y Seguridad, no parece que fuera objetivo del legislador al modificar dicha Ley

- La Ley 5/1997, de 24 de marzo, fue publicada en el BOE del día siguiente (25 de marzo de 1997) y que esa nueva redacción derivada de la modificación entraba en vigor, a falta de indicación expresa en la propia norma, a los veinte días de su completa publicación en BOE, conforme establece el art. 2.1 del Código Civil

- No es hasta el día 1 de agosto de 1997 y transcurridos, por tanto, más de cuatro meses desde su publicación en el BOE, que el Gobierno parece percibir el desatino, el "carácter fortuito de este olvido", y procede a dictar el Real Decreto - Ley 12/1997, de 1 de agosto, alegando la existencia de "requisitos de urgente y extraordinaria necesidad"

- Esa urgencia se pone en relación "con la temporada estival", entendiendo por tal el verano o los meses de julio y agosto

- Esa "urgencia" no impide que la publicación en el BOE no se produzca de manera inmediata (como había ocurrido con la ley 5/1997, de 24 de marzo, por ejemplo) y se demore 15 días, al no producirse hasta el día 16 de agosto de 1997

Es cierto que la necesidad justificadora de los Decretos - Leyes no se puede entender como una necesidad absoluta que suponga un peligro grave para el sistema constitucional o para el orden público entendido como normal ejercicio de los derechos fundamentales y libertades públicas y normal funcionamiento de los servicios públicos, sino que hay que entenderlo con mayor amplitud como necesidad relativa respecto de situaciones concretas de los objetivos gubernamentales, que, por razones difíciles o imposibles de prever, que requieren una acción normativa inmediata o en que las coyunturas económicas exigen una rápida respuesta ${ }^{181}$. Es evidente que el concepto "extraordinaria y urgente necesidad" que se contiene en la Constitución, no es en modo alguno, una cláusula o expresión vacía de significado dentro de la cual el lógico margen de apreciación política del Gobierno se mueva libremente sin restricción alguna sino, por el contrario, la constatación de un límite jurídico a la actuación mediante Decretos - Leyes ${ }^{182}$, de lo contrario cualquier situación sería susceptible de ser calificada como tal. Y ello por mucho que en el trámite de convalidación del Real Decreto - Ley 12/1997, de 1 de agosto, realizada en la sesión del Congreso de los Diputados celebrada el 18 de septiembre de 1997, todas las intervenciones aceptaran por bueno este sistema para devolver al texto de la Ley de Tráfico y seguridad Vial el párrafo suprimido sin intención ${ }^{183}$.

\footnotetext{
${ }^{181}$ STC 6/1983, de 4 de febrero, F. 5.

182 Sentencias del TC 182/1997, de 28 de octubre, FD. 3, 11/2002, de 17 de enero, FD. 4 y 68/2007, de 28 de marzo, FD. 12.

183 En el Diario de Sesiones del Congreso de los Diputados (Año 1997, Vı Legislatura, núm. 101) correspondiente a la sesión plenaria núm. 97 celebrada el jueves 18 de septiembre de 1997 se recogen las intervenciones de los diferentes grupos parlamentarios para la convalidación del Real Decreto - Ley
} 
Lo cierto que este descuido (error), o esta serie de sucesivos descuidos, pues a la eliminación de lo que no se quería suprimir debemos añadir el paso de varios meses hasta que alguien se percata de lo que ha ocurrido, se pretende subsanar mediante un sistema inadecuado. Y, sea como fuere, alguna extraña sensación debía sentir alguien cuando, finalmente, la vuelta del perdido párrafo tercero del art. 67.1 LTSV termina realizándose mediante la tramitación y aprobación de la Ley 59/1997, de 19 de diciembre ${ }^{184}$.

Y ello porque tal vez (y solo tal vez) alguien tuviera presente que conforme ha señalado el Tribunal Constitucional la convalidación que el Congreso de los Diputados puede realizar de un Decreto - Ley no produce una sanción del mismo, si éste fuera originariamente nulo por haberse producido con extralimitación, pues la "sanción" sólo podría producirse mediante su transformación en ley una vez seguida la correspondiente tramitación parlamentaria ${ }^{185}$.

\section{G) El Real Decreto 116/1998, de 30 de enero (que modifica el RPSTSV)}

Tal y como señalábamos al analizar la Ley 5/1997, de 24 de marzo, de reforma de la Ley de Tráfico y Seguridad Vial, esta norma se cerraba con el mandato dirigido al Gobierno (disp. final única), para que en el plazo máximo de seis meses procediera a modificar el Reglamento General de Circulación (Real Decreto 13/1992, de 17 de enero ${ }^{186}$ ) y el Reglamento de Procedimiento Sancionador en materia de Tráfico y Seguridad Vial (Real Decreto 320/1994, de 25 de febrero ${ }^{187}$ ) y que fueran adecuados a I reforma efectuada.

Esa orden fue incumplida en cuanto al plazo de tiempo establecido para ello ya que no se va a realizar hasta la promulgación del Real Decreto 116/1998, de 30 de enero, publicado en el BOE de 18 de febrero de 1998.

\footnotetext{
12/1997, de 1 de agosto, que, efectivamente, resulto convalidado (pág. 5055 - 5057 del Diario de Sesiones del Congreso de los Diputados, Año 1997, VI Legislatura, núm. 101).

${ }^{184}$ En la referida Sesión de 18 de septiembre de 1997 el Pleno del Congreso de los Diputados procedió a convalidar el Real Decreto - Ley 12/1997, de 1 de agosto, lo que se produce con 318 votos favorables y 3 abstenciones para, acto seguido, tal y como consta en el propio Diario de Sesiones del Congreso de los Diputados, someter a votación su tramitación como Ley por haberlo solicitado el Grupo Catalán, con 317 votos a favor y una abstención (pág. 5072 del Diario de Sesiones del Congreso de los Diputados, Año 1997, VI Legislatura, núm. 101).

La publicación de la Ley 59/1997, de 19 de diciembre, se produce en el BOE de 20 de diciembre de 1997.

${ }^{185}$ Sentencias del Tribunal Constitucional 29/1982, de 31 de mayo, FD. 2 y 6/1983, de 4 de febrero, FD. 5.

${ }^{186}$ Véase el apartado IV A) de este mismo capítulo.

${ }^{187}$ Véase el apartado IV C) de este mismo capítulo.
} 
En cuanto al Reglamento de Procedimiento Sancionador en materia de Tráfico y Seguridad Vial, el art. 2 RD 116/1998, de 30 de enero, supone la modificación del art. 18.1 RPSTSV y la regulación en él contenida sobre prescripción de infracciones.

\section{PRESCRIPCIÓN DE INFRACCIONES: PLAZO Y CÓMPUTO}

La nueva redacción que el párrafo primero del art. 18.1 RPSTSV recibe del RD 116/1998, de 30 de enero, supone la modificación del plazo de prescripción de infracciones determinado hasta ese momento y establece una perfecta congruencia entre la previsión reglamentaria y la establecida en el primer inciso del art. 81.1 LTSV, al fijar que "la acción para sancionar las infracciones prescribe a los tres meses, contados a partir del día en que los hechos se hubieren cometido" ${ }^{188}$, lo que supone que, por vez primera desde que conviven ambas normas, los términos en los que en ellas se contempla la prescripción de las infracciones (plazo y cómputo) coinciden.

Este era, en realidad, el único cambio que se había producido en materia de prescripción de infracciones con la promulgación de la Ley 5/1997, de 24 de marzo, en el art. 81.1 LTSV, con lo que el resto de alteraciones efectuadas en los términos en los que estaba redactado el art. 18.1 RPSTSV se producen por otros motivos, y ello por mucho que en la introducción que acompaña al RD 116/1998, de 30 de enero, se señale como único motivo de la modificación reglamentaria que ésta se efectúa "para adecuarlos a la citada reforma" ${ }^{189}$.

\section{COMPROBACIÓN DE LA PRESCRIPCIÓN}

La redacción originaria del art. 18.1 párrafo segundo RPSTSV también es objeto de modificación por el RD 116/1998, de 30 de enero. Se trata de una previsión en la que el reglamento colabora con la Ley de Tráfico y Seguridad Vial y lo hace precisando la necesidad de comprobar si la infracción objeto del procedimiento está, o no, prescrita.

\footnotetext{
${ }^{188}$ Sobre la redacción que recibe el art. 18.1 párrafo primero RPSTSV debe tenerse en cuenta que el Dictamen del Consejo de Estado de 18 de diciembre de 1997 correspondiente al expediente relativo al Proyecto de Real Decreto por el que se adaptan a la Ley 5/1997, de 24 de marzo, de Reforma del Texto Articulado de la Ley sobre Tráfico, Circulación de Vehículos a Motor y Seguridad Vial, el Reglamento General de Circulación y el Reglamento de procedimiento sancionador en materia de Tráfico señalaba en su Consideración III. 3 párrafo primero que:

“Debe modificarse el texto de la modificación propuesta para el artículo 18.1 del Reglamento de procedimiento sancionador en materia de Tráfico, Circulación de Vehículos a Motor y Seguridad Vial. No es correcto decir que la acción para sancionar prescribe. Lo que prescribe es la infracción. El poder sancionador se ejerce en virtud de la correspondiente potestad que, en cuanto tal, no prescribe sino que caduca".

${ }^{189}$ Cfr. el inciso final del párrafo primero de ese texto introductorio.
} 
En sus primigenios términos, el art. 18.1 párrafo segundo RPSTSV imponía al órgano encargado de la instrucción del procedimiento el deber comprobar si la infracción estaba o no prescrita, y hacerlo de manera previa a la iniciación del expediente, para poder determinar, por lo tanto, si tenía sentido o no proceder a practicar esas actuaciones. Se trataba de una previsión que, como ya se ha puesto de manifiesto ${ }^{190}$, imponía el análisis previo de la existencia de prescripción de la infracción y, en el caso de que así fuera, impedía se diera comienzo al procedimiento.

Las mismas razones de eficiencia y economía procedimental son las que llevan a modificar el art. 18.1 párrafo segundo RPSTSV en el sentido de que el control de la prescripción de la infracción ha de realizarse no solo al momento de dar comienzo al procedimiento sino que es algo que deber verificarse a lo largo de la tramitación del expediente, es decir, "previamente a la iniciación y durante la sustanciación del procedimiento sancionador", de forma que si se detecta que la infracción está prescrita no procederá su inicio, caso de no haber comenzado, o su no continuación, caso de haberse empezado con su tramitación.

Se trata de expresa introducción de un mandato dirigido a quien corresponde la instrucción del procedimiento sancionador que aunque no constaba de manera expresa bien podía deducirse de lo determinado en el art. 18.3 del propio RPSTSV, precepto que mantiene su redacción, y que establece que "la prescripción se aplicará de oficio por los órganos competentes en las diversas fases de tramitación del expediente".

\section{INTERRUPCIÓN DEL PLAZO DE PRESCRIPCIÓN}

El párrafo tercero del art. 18.1 RPSTSV, en el que se establecen disposiciones sobre la interrupción del plazo de prescripción de las infracciones, es objeto de modificación en virtud de las previsiones establecidas en el RD 116/1998, de 30 de enero.

No se trata de una modificación que tenga su origen en la necesidad de adaptación del Reglamento de Procedimiento Sancionador en materia de Tráfico y seguridad Vial a los cambios realizados en la Ley de Tráfico y seguridad Vial por la Ley 5/1997, de 24 de marzo. Ni siquiera se trata de una modificación que estuviera prevista en la originaria redacción y planteamiento que del RD 116/1998, de 30 de enero, se realiza.

La razón de esta modificación por la que a la originaria previsión en la que se encontraba redactado el art. 18.1 párrafo tercero RPSTSV conforme a la que "la prescripción se interrumpe por cualquier actuación de la Administración de la que tenga conocimiento el denunciado o esté encaminada a averiguar su identidad o domicilio o por la notificación efectuada de acuerdo con lo establecido en el artículo

${ }^{190}$ Véase, en el examen del RPSTSV, el apartado a la prescripción ( II.C.2 i). 
11 del presente Reglamento" y que, inicialmente, no hacía si no cambiar los términos en los que se encontraba redactada sin alterar su sentido, ya que se limitaba al cambio de la expresión "actuación de la Administración" por "actuación administrativa", se encuentra en la valoración efectuada en el Dictamen de 18 de diciembre de 1997 emitido por el Consejo de Estado como respuesta a la consulta efectuada sobre el Proyecto de Real Decreto por el que se adaptan a la Ley 5/1997, de 24 de marzo, de Reforma del Texto Articulado de la Ley sobre Tráfico, Circulación de Vehículos a Motor y Seguridad Vial, el Reglamento General de Circulación y el Reglamento de procedimiento sancionador en materia de Tráfico señalaba que "por razones técnicas y de seguridad jurídica, además, se sugiere que en el apartado 1, párrafo tercero, se incluya inmediatamente después de la frase «esté encaminada a averiguar su identidad o domicilio», una referencia a que esas actividades tengan proyección externa a la dependencia en la que originan"191.

\section{LA MODIFICACIÓN DEL ART. 28 RGC}

EI RD 116/1998, de 30 de enero, modifica la redacción de los arts. 28.1.2, 48.1.1.b) y 1.5, 93.1 y 94.1 .2 y 3 RGC. Aquí interesa destacar la realizada en el primero de ellos, ya que la nueva redacción que recibe el art. 28.1.2 RGC incorpora un inciso final conforme al que "en los casos de negativa a efectuar dichas pruebas, el Agente podrá proceder a la inmediata inmovilización del vehículo en la forma prevista en el artículo 25 del Reglamento", lo que supone una la posibilidad de adoptar una medida provisional como consecuencia de la comisión de una infracción.

\section{H) El Real Decreto 2822/1998, de 23 de diciembre, por el que se aprueba el Reglamento General de Vehículos}

El RD 2822/1998, de 23 de diciembre, que aprueba el Reglamento General de Vehículos $(\mathrm{RGV})^{192}$ es un Reglamento ejecutivo, que desarrolla, complementa y pormenoriza el texto articulado de la Ley de Seguridad Vial, aunque no se trata de un desarrollo general o completo de dicho texto, sino de un desarrollo o ejecución parcial, pues se limita a desarrollar y complementar parte del Título I y el Título IV LTSV ${ }^{193}$.

\footnotetext{
${ }^{191}$ Tal y como señala en su Consideración III. 3 párrafo segundo el Dictamen del Consejo de Estado de 18 de diciembre de 1997 correspondiente al expediente relativo al Proyecto de Real Decreto por el que se adaptan a la Ley 5/1997, de 24 de marzo, de Reforma del Texto Articulado de la Ley sobre Tráfico, Circulación de Vehículos a Motor y Seguridad Vial, el Reglamento General de Circulación y el Reglamento de procedimiento sancionador en materia de Tráfico.

192 Publicado en el BOE de 26 de enero de 1999.

193 Tal y como señala el párrafo quinto del propio texto introductorio que acompaña al Reglamento General de Vehículos.
} 
Se trata de una norma técnica que se encuentra sometida al Derecho de la Unión Europea en cuanto a que la regulación de las cuestiones relativas a los vehículos conforman uno de los objetivos prioritarios la armonización de las legislaciones de los Estados en cuanto "a la fabricación y uso de vehículos y de sus componentes y piezas, con el fin de lograr su aceptación recíproca entre todos los Estados miembros"194.

No es el Reglamento General de Vehículos una norma especialmente orientada al régimen sancionador en materia de tráfico y seguridad vial pero ello no significa que, a lo largo de su articulado, se puedan encontrar algunas disposiciones que incidan tangencialmente en ese ámbito.

Así sucede en los arts. 32 y 33 RGV, preceptos en los que se establecen prescripciones en cuanto a la transmisión de los vehículos, ya sea entre particulares (art. 32 RGV) o mediando personas que se dedican a la actividad de compraventa de vehículos (art. 33 RGV), y que contienen previsiones en cuanto a la instrucción del correspondiente procedimiento sancionador a los transmitentes que incumplieran con las obligaciones de comunicación establecidas y que seguirán siendo considerados titulares de esos vehículos transmitidos a efectos de la legislación sobre tráfico y seguridad vial en tanto ese vehículo no sea inscrito a nombre de otra persona (arts. 32.1 y 33.1 RGV) y a que se proceda a ordenar la inmovilización del vehículo (art. 32.4 y 33.4 RGV).

\section{I) Un cambio profundo y nada silencioso: la Ley 4/1999, de 13 de enero, de modificación de la LRJ - PAC}

Tal y como señalábamos al analizar el procedimiento administrativo sancionador establecido en la LTSV, las previsiones establecidas se sustentaban en lo dispuesto en la Ley de Procedimiento Administrativo, sustituida por la LRJ - PAC. El art. 73 LTSV establecía el carácter supletorio de lo allí establecido (aunque no fuera hasta la modificación realizada por medio de la Ley 19/2001, de 19 de diciembre, que la referencia fuera a la LRJ - PAC).

Esa dependencia suponía la posibilidad de cambios sin necesidad de que estos se produjeran en el marco de la propia LTSV y eso es lo que, precisamente, va a suceder con la modificación que, por medio de la Ley 4/1999, de 13 de enero, se produce en la LRJ - PAC.

De todos los cambios que se introducen el realizado en el art. 127 LRJ - PAC tiene un enorme en impacto en el procedimiento sancionador en materia de tráfico y seguridad vial puesto que se elimina el inciso final del apartado segundo que prohibía la delegación de la potestad sancionadora en órgano distinto de aquel que la tenía atribuida.

${ }^{194}$ Cfr. párrafo 3 de la exposición introductoria del propio Reglamento General de Vehículos. 
Sobre ello, el párrafo primero del apartado de la Exposición de Motivos de la propia Ley 4/1999, de 13 de enero, señala que "en el Título IX, y con el objeto de favorecer la descentralización en aras del principio de eficacia, se suprime la prohibición de la delegación del ejercicio de la potestad sancionadora". Sea como fuere, la modificación es trascedente para el procedimiento sancionador previsto en la LTSV.

\section{J) El Real Decreto 137/2000, de 30 de enero (que modifica el RPSTSV)}

El Real Decreto 137/2000, de 30 de enero, que modifica el Reglamento de Procedimiento Sancionador en materia de Tráfico y Seguridad Vial ${ }^{195}$, es consecuencia, de la reforma que, por medio de la Ley 4/1999, de 13 de enero, es efectuada en el LRJ - PAC, eso sí, demorada en el tiempo ${ }^{196}$.

Tal y como se señala en el propio texto explicativo que acompaña al Real Decreto 137/2000, de 30 de enero, la modificación realizada en la LRJ - PAC por medio de la Ley 4/1999, de 13 de enero, "repercute necesariamente en algunos aspectos del procedimiento sancionador en materia de tráfico que es preciso ajustar a la nueva normativa", modificación que alcanza a los arts. 13.2, 15, 16 y 17.1 del RPSTSV y que supone cambios en cuanto al tratamiento jurídico de la propuesta de resolución, de la resolución sancionadora y la posibilidad de su delegación, la caducidad del procedimiento sancionador y del régimen de impugnación de las resoluciones.

\section{PROpuesta de RESOlUCión}

Tal y como se señala en la introducción que acompaña al propio RD 137/2000, de 30 de enero, se procede a la modificación del art. 13.2 RPSTSV en el sentido de precisar más nítidamente la distinción entre el trámite de audiencia al interesado y la propuesta de resolución para ajustar dicho artículo a lo establecido en el art. 84.4 LRJ PAC.

Lo que no se indica es que esa adaptación que se realiza del Reglamento de Procedimiento Sancionador en materia de Tráfico y Seguridad Vial lo es a la originaria redacción de la LRJ - PAC, ya que el art. 84 LRJ - PAC no fue objeto de modificación por la Ley 4/1999, de 13 de enero.

Sobre esta base, tres son las consideraciones a realizar sobre lo que se modifica (y sobre lo que no se toca) del art. 13.2 RPSTSV.

\footnotetext{
195 Publicado en el BOE de 18 de febrero de 2000.

${ }^{196}$ Si tenemos en cuenta que los efectos de la modificación efectuada en la LRJ - PAC por la Ley 4/1999, de 13 de enero (publicada en el BOE de 14 de enero), necesitan de más de trece meses para su traslación a la regulación del procedimiento sancionador en materia de tráfico y seguridad vial.
} 
En primer término, y sobre el núcleo de la reforma efectuada en este precepto, se hace notar que se trata de establecer una norma que, de manera expresa e indubitada, no exija el imperativo traslado de la propuesta de resolución al interesado, que era lo que parecía se derivaba de la redacción originaria del art. 13.2 RPSTSV. De ahí que se introduzca la previsión de que el traslado de la propuesta de resolución a los interesados no será preciso "cuando no figuren en el procedimiento ni sean tenidos en cuenta en la resolución otros hechos y otras alegaciones y pruebas que las aducidas por el interesado", situación esta, la de que no existan en el procedimiento más hechos $\mathrm{y}$ alegaciones que los aportados por el denunciado frente a denuncia formulada, que en la práctica es la situación más común.

De esta forma, los términos introducidos en el art. 13.2 RPSTSV se adaptan a la previsión establecida, de manera originaria, en el art. 84.4 LRJ - PAC que, de forma general y sobre la participación de los interesados en el procedimiento, había establecido que "se podrá prescindir del trámite de audiencia cuando no figuren en el procedimiento ni sean tenidos en cuenta en la resolución otros hechos ni otras alegaciones y pruebas que las aducidas por el interesado".

Esta previsión, la de la necesidad del traslado de la propuesta de resolución en todo caso, se había mostrado como terreno de discusión, ya que la interpretación literal, en ese sentido, no se ajustaba al resto de previsiones que, de manera equivalente, se realizaban en la redacción original del Reglamento de Procedimiento Sancionador en materia de Tráfico y Seguridad Vial, debate que finalizó, eso sí, una vez modificada la redacción del art. 13.2 RPSTSV con la Sentencia del TS de 19 de diciembre de 2000 que, resolviendo recurso de casación en interés de la ley, establecía como doctrina legal, que la notificación de la propuesta de resolución (en los términos de la redacción originaria del art. 13.2 RPSTSV) no era preceptiva, siendo innecesario el trámite de audiencia cuando el interesado no haya formulado alegaciones sobre el contenido del boletín de denuncia que inicia el procedimiento y cuando, habiéndolas formulado, no se tengan en cuenta otros hechos ni otras alegaciones y pruebas que las aducidas, en su caso, por el interesado ${ }^{197}$ y con la Sentencia del Tribunal Supremo que desestimaba el recurso contencioso - administrativo formulado contra el RD 137/2000, de 30 de enero, y la nueva redacción, que por él, se daba al art. 13.2 RPSTSV ${ }^{198}$.

\footnotetext{
197 Sobre esta cuestión véase, en este mismo capítulo, el apartado IV.C.2 g) correspondiente a la resolución y propuesta de resolución en el RPSTSV y la Nota 145 en la que se puede encontrar la redacción literal de la doctrina legal que se fija en la Sentencia del Tribunal Supremo de 19 de diciembre de 2000 (RJ 2001, 2617).

198 Sentencia del TS de 22 de mayo de 2001, que desestimaba el recurso contencioso - administrativo formulado frente al RD 137/2000, de 30 de enero, en el que la parte demandante argumentaba que la nueva redacción operada en el art. 13.2 RPSTSV por el Real Decreto 137/2000, de 30 de enero, plantea el problema, según la recurrente, de la notificación del trámite de audiencia, pues esta nueva regulación "se ha apartado de la norma procedimental sancionadora de inmediata aplicación, como es el art. 79.3 LTSV" y por la que el Tribunal Supremo hallaba ajustado a derecho la nueva redacción del art. 13.2 RPSTSV.
} 
La modificación efectuada conlleva, así mismo, la desaparición del resto de precisiones que, en la redacción originaria, se efectuaban sobre los plazos y la forma de la participación de los interesados.

En segundo lugar, se produce una alteración de los términos empleados en la redacción del art. 13.2 RPSTSV, al sustituirse la expresión "la instrucción del expediente y formulada su propuesta de resolución" por la de "la instrucción del procedimiento y practicada la audiencia al interesado" que, también en el plano formal, supone una mayor acomodo a los términos empleados en la LRJ - PAC.

La tercera cuestión hace referencia a algo que no se hace, ya que se mantiene, como rúbrica del art. 13 RPSTSV, la de original de "período de prueba", denominación que, sin lugar a dudas, no se corresponde con el contenido que se efectúa en el referido precepto reglamentario, de manera que no hubiera estado de más, y hubiera sido muy oportuno, proceder a su rectificación por una más ajustada al auténtico contenido del art. 13 RPSTSV.

\section{RESOLUCIÓN SANCIONADORA}

De entre los diferentes cambios que la Ley 4/1999, de 13 de enero, introdujo en la LRJ - PAC, uno de los más significativos fue, sin duda, el de la modificación del art. 127.2 LRJ - PAC suprimiendo la prohibición de delegación de la potestad sancionadora que, hasta ese momento estaba establecido en la redacción originaria de la LRJ - PAC ${ }^{199}$, mutación que impacta directamente en el entorno del procedimiento sancionador en materia de tráfico y seguridad vial y que hace aconsejable que se prevea expresamente esta posibilidad fijando reglamentariamente las autoridades delegadas en el art. 15 RPSTSV ${ }^{200}$.

La supresión, por la Ley 4/1999, de 13 de enero, de la prohibición de la delegación del ejercicio de la potestad sancionadora, hasta entonces establecida en el art. 127.2 LRJ PAC, va a suponer que se regule en el art. 13 RPSTSV esa posibilidad, mediante la adición de un apartado (el tercero) a los ya existentes. Pero las novedades en cuanto a las alteraciones que va a sufrir ese art. 13 RPSTSV ni se agotan ahí, ni el resto de las

Sobre las resoluciones judiciales de los Tribunales Superiores de Justicia en ausencia de propuesta de resolución en los procedimientos sancionadores en materia de tráfico y seguridad vial antes y después del RD 137/2000, de 30 de enero, véase "La propuesta de resolución en los procedimientos sancionadores en materia de tráfico, antes y después del RD 137/2000", M. SÁNCHEZ AdSUAR, Sentencias de TSJ y AP y otros Tribunales num. 17/2000 parte Comentario, Aranzadi, 2000.

${ }^{199}$ Como se ha señalado en al apartado anterior la Ley 4/1999, de 13 de enero, suprime el inciso final del art. 127.2 LRJ - PAC en el que se establecía, sobre el ejercicio de la potestad sancionadora por el órgano que la tuviera expresamente atribuida que "sin que pueda delegarse en órgano distinto" y lo hace, conforme señala en la Exposición de Motivos, "con el objeto de favorecer la descentralización en aras del principio de eficacia, se suprime la prohibición de la delegación del ejercicio de la potestad sancionadora".

${ }^{200}$ Tal y como se señala en el propio texto introductorio del RD 137/2000, de 30 de enero. 
que se acometen tienen que ver con los cambios realizados por la Ley 4/1999, de 13 de enero, en la previa redacción de la LRJ - PAC. Y, como suele ocurrir en estos casos, aunque algunas de estas reformas son advertidas en el texto introductorio que precede a la norma, sobre otras, sin embargo, se guarda el más absoluto de los silencios.

Hasta ese momento la atribución de competencias para sancionar las infracciones cometidas contra lo establecido en la Ley de Tráfico y Seguridad Vial estaba atribuida, de manera expresa por el art. 68 LTSV, a los Gobernadores Civiles y a los Alcaldes en sus respectivos ámbitos de competencia ${ }^{201}$, a quienes les estaba prohibido delegar el ejercicio de esa potestad sancionadora. Al cambio que sobre ellos se va realizar, en el particular sobre la referencia que se efectuaba a los "Gobernadores Civiles" se refiere la introducción del RD 137/2000, de 30 de enero, cuando señala que "al propio tiempo, es preciso introducir algunas modificaciones en este artículo al haber desaparecido la figura de los Gobernadores Civiles" ${ }^{202}$.

La supresión de los Gobernadores Civiles efectuada por medio de la Ley 6/1997, de 14 de abril, de Organización y Funcionamiento de la Administración General del Estado (LOFAGE) supone una nueva atribución en cuanto a las competencias que la Ley de Tráfico y Seguridad Vial había depositado en esa figura que ahora desaparece.

La LOFAGE establece, como órganos territoriales de la Administración General del Estado, a los Delegados del Gobierno en las Comunidades Autónomas, a los Subdelegados del Gobierno en las Provincias y los Directores Insulares de la Administración General del Estado.

\footnotetext{
${ }^{201}$ La redacción del art. 68 LTSV se mantendrá en sus términos originales hasta la promulgación de la Ley 19/2001, de 19 de enero, momento en el que se recogerán las figuras del Delegado y Subdelegado del Gobierno y se hará expresa referencia a la Comunidades Autónomas que tengan transferidas competencias ejecutivas en materia de tráfico y circulación de vehículos.

${ }^{202}$ El art. 154 CE establece que "un Delegado del Gobierno dirigirá la Administración del Estado en el territorio de la Comunidad Autónoma y la coordinará, cuando proceda, con la Administración propia de la Comunidad", mandato constitucional que dio lugar a la Ley 17/1983, de 16 de noviembre, reguladora de la figura del Delegado del Gobierno en las Comunidades Autónomas, norma que se limitó a "diseñar el marco de actuación del Delegado, atribuyéndole sobre los Gobernadores civiles una posición de supremacía en la que se fundamentan las facultades que sobre los Gobiernos Civiles y la Administración del Estado debe ejercer", de hecho, y conforme se determinaba en el art. 11 de la Ley 17/1983, de 16 de noviembre "el Delegado del Gobierno podrá asumir y ejercer las funciones propias del Gobernador civil de la provincia en que radique su sede cuando así se determine en el Real Decreto de nombramiento" señalando, eso sí que "en todo caso, en las Comunidades Autónomas uniprovinciales el Delegado del Gobierno asumirá y ejercerá las funciones que las Leyes y demás normas vigentes atribuyen al Gobernador civil".

No será hasta la Ley 6/1997, de 14 de abril, de Organización y Funcionamiento de la Administración General del Estado (LOFAGE), que para hacer más efectiva la simplificación de la Administración periférica del Estado, no se considere adecuada la actual existencia de la figura de los Gobernadores Civiles y, en consecuencia, sean suprimidos, creando la figura de los Subdelegados del Gobierno, que dependen orgánicamente de los Delegados del Gobierno en las Comunidades Autónomas, tal y como se señala en el párrafo primero del apartado IV de la propia Exposición de Motivos de la LOFAGE.
} 
El art. 23.7 LOFAGE establece, como competencia de los delegados del Gobierno "Ejercer las potestades sancionadoras, expropiatorias y cualesquiera otras que les confieran las normas o que les sean desconcentradas o delegadas". De igual manera, el art. 29.2 e) LOFAGE determina que corresponde a los Subdelegados del Gobierno en las Provincias "ejercer las competencias sancionadoras que se les atribuyan normativamente" y el art. 30.2 párrafo segundo LOFAGE dispone que "los Directores Insulares dependen jerárquicamente del Delegado del Gobierno en la Comunidad Autónoma o del Subdelegado del Gobierno en la provincia , cuando este cargo exista, y ejercen, en su ámbito territorial, las competencias atribuidas por esta Ley a los Subdelegados del Gobierno en las provincias".

A estas prescripciones se une lo establecido en la disp. adic. Cuarta LOFAGE que, en cuanto a la asunción de competencias que tenían atribuidas los Gobernadores Civiles, y en el concreto ámbito del tráfico y la seguridad vial, determina en el párrafo tercero que "corresponderá a los Delegados del Gobierno la imposición de sanciones por la comisión de infracciones graves y muy graves previstas en el texto articulado de la Ley sobre Tráfico, Circulación de Vehículos a Motor y Seguridad Vial, aprobado por Real Decreto Legislativo 339/1990, de 2 de marzo" y que "la imposición de sanciones por infracciones leves previstas en dicha Ley corresponderá a los Subdelegados del Gobierno"203.

Sobre este esquema de atribución competencial realizado por la LOFAGE entre Delegados del Gobierno y Subdelegados del Gobierno (a los que hay que equiparar, en su caso, a los Directores Insulares, conforme a lo establecido en el art. 30.2 LOFAGE) el art. 15.1 inciso primero establece que los Delegados o Subdelegados del Gobierno, en su caso, y los Alcaldes, dictarán resolución sancionadora o resolución que declare la inexistencia de responsabilidad por la infracción.

Esta redacción, que ha de ser integrada con lo establecido en la LOFAGE, supone que la sanción por infracciones graves y muy graves corresponden a los Delegados del Gobierno en el ámbito de su Comunidad Autónoma y en el caso de las infracciones leves al Subdelegado del Gobierno (o Director Insular en su caso).

\footnotetext{
${ }^{203}$ El texto íntegro de la redacción originaria de la disp. adic. Cuarta LOFAGE lo era en los siguientes términos:

"El Delegado del Gobierno asumirá las competencias sancionadoras atribuidas a los Gobernadores Civiles en la Ley Orgánica 1/1992, de 21 de febrero, sobre Protección de la Seguridad Ciudadana, y por la Ley 23/1992, de 30 de julio, de Seguridad Privada, correspondiendo las demás competencias de carácter sancionador a los Subdelegados del Gobierno.

En los casos en que la resolución corresponda al Delegado del Gobierno, la iniciación e instrucción de los procedimientos corresponderá a la Subdelegación del Gobierno competente por razón del territorio. Igualmente corresponderá a los Delegados del Gobierno la imposición de sanciones por la comisión de infracciones graves y muy graves previstas en el texto articulado de la Ley sobre Tráfico, Circulación de Vehículos a Motor y Seguridad Vial, aprobado por Real Decreto Legislativo 339/1990, de 2 de marzo. La imposición de sanciones por infracciones leves previstas en dicha Ley corresponderá a los Subdelegados del Gobierno.

Asimismo, el Delegado del Gobierno desempeñará las demás competencias que la legislación vigente atribuye a los Gobernadores Civiles".
} 
Al lado de esta modificación, para adaptarse a lo establecido en la LOFAGE, el RD 137/2000, de 30 de enero, realiza otras modificaciones en el art. 15.1 RPSTSV sobre la resolución sancionadora en relación la forma que puede adoptar y sobre el plazo en el que ha de efectuarse esa resolución sancionadora.

Sobre la forma de la resolución sancionadora nada se establecía en la redacción original del art. 15.1 RPSTSV. Al momento de su promulgación, y ya vigente la LRJ $P A C$, se entiende que, lo normal, es que las resoluciones sancionadoras adopten la forma escrita ${ }^{204}$, tal y como se establece en el art. 55.1 LRJ - PAC al determinar que "Ios actos administrativos se producirán por escrito a menos que su naturaleza exija o permita otra forma más adecuada de expresión y constancia".

Sobre esta base, y la configuración que el art. 55.2 LRJ - PAC realiza de la posibilidad de que los órganos administrativos ejerzan su competencia de forma verbal, se establece una redacción para el segundo inciso del art. 15.2 RPSTSV en el que partiendo de que, como norma general, la resolución en los procedimientos sancionadores en materia de tráfico y seguridad vial "se dictará por escrito conforme previene el art. 55.1 LRJ - PAC" se establece la posibilidad, sin someterla a condición alguna (a menos que su naturaleza exija o permita otra forma más adecuada de expresión y constancia) de que esa competencia sancionadora sea ejercida de forma verbal, con la única condición de que, en ese caso "el titular de la competencia deberá autorizar una relación de las que haya dictado de forma verbal, con expresión de su contenido conforme previene el art. 55.2 LRJ - PAC, es decir, que esa forma escrita para su constancia "se efectuará y firmará por el titular del órgano inferior o funcionario que la reciba oralmente, expresando en la comunicación del mismo la autoridad de la que procede" y que, por tratarse de resoluciones, será preciso, además que "el titular de la competencia deberá autorizar una relación de las que haya dictado de forma verbal, con expresión de su contenido" ${ }^{205}$.

La redacción que el art. 15.1 RPSTSV recibe del RD 137/2000, de 30 de enero, no parece, en este sentido, afortunada. Así, mientras que en el art. 55.1 LRJ - PAC se establece que la forma normal de producción de los actos administrativos es la forma escrita, y que esa forma escrita ha de ser la manera en que han de producirse "a menos que su naturaleza exija o permita lo contrario". No cabe duda que ninguna razón exige la forma verbal para el dictado de resoluciones sancionadoras y aunque

\footnotetext{
${ }^{204}$ En referencia a su forma de producción, y no ha su forma de constancia. Cfr., en este sentido, García de Enterría, E. y Fernández Rodríguez T.-R., Curso de Derecho Administrativo, Tomo I, 14a ed., Madrid, Civitas, 2008, págs. 569 a 571.

${ }^{205}$ Requisitos exigidos por el art. 55.2 LRJ - PAC al establecer que "En los casos en que los órganos administrativos ejerzan su competencia de forma verbal, la constancia escrita del acto, cuando sea necesaria, se efectuará y firmará por el titular del órgano inferior o funcionario que la reciba oralmente, expresando en la comunicación del mismo la autoridad de la que procede. Si se tratara de resoluciones, el titular de la competencia deberá autorizar una relación de las que haya dictado de forma verbal, con expresión de su contenido".
} 
nada lo impide, en el sentido de que ni el art. 138 LRJ - PAC ni el art. 20 del RD 1398/1993, de 4 de agosto, por el que se aprueba el Reglamento para el ejercicio de la potestad sancionadora, ni prohíben que las resoluciones sean verbales ni impiden de manera expresa esta forma de producción, no parece que el ejercicio de la potestad sancionadora de forma verbal sea el medio más adecuado para acreditar la certeza, la seguridad jurídica y todas las garantías que se ven implicadas en un procedimiento, como el sancionador, que va a afectar y limitar derechos subjetivos e intereses legítimos. No parece, en definitiva, que la forma verbal sea, como forma de terminar el procedimiento, la que mejor se compadezca y adapte con el conjunto de garantías que el procedimiento, como conjunto de protecciones y salvaguardas, debe de prestar al interesado, y más cuando se trata de un procedimiento de naturaleza sancionadora.

Tal redacción no pretendía sino santificar el uso de la forma verbal para el ejercicio de la potestad sancionadora con lo que se ignoraba que de manera constante se había señalado por los Tribunales sobre que la forma verbal de la resolución sancionadora no eximía a esa resolución de contar con la necesaria motivación y de que, por el hecho de ser una resolución, resultaba preciso la forma escrita de constancia con la expresión de su contenido.

Así, resoluciones judiciales anteriores y posteriores a la modificación que, sobre la redacción originaria del art. 15.1 RPSTSV, realiza el RD 137/2000, de 30 de marzo, venían a advertir de la dificultad práctica de que el ejercicio de la potestad sancionadora se realizara mediante la producción de manera verbal de la resolución sancionadora $^{206}$.

No lo entendió así el Tribunal Supremo que estableció que el art. 15.1 RPSTSV, en la redacción recibida del RD 137/2000, de 30 de enero, al permitir la posibilidad de dictar resoluciones en forma verbal, no conculca el art. 55 LRJ - PAC pues, en cuanto a la forma, expresamente alude a la escrita como la más habitual, y permite la verbal en los supuestos contemplados en el párrafo segundo del citado art. 55 LRJ - PAC, en los que el titular de la competencia la ejerce verbalmente y la hace constar por escrito al inferior "cuando sea necesaria" dicha constancia ${ }^{207}$.

\footnotetext{
${ }^{206}$ Tal es el caso, a título de ejemplo, de lo argumentado en la Sentencia del TSJ de la Región de Murcia de 14 de marzo de 2001 que en su Fundamento de Derecho Cuarto:

“De acuerdo con el párrafo primero del art. 55 de la Ley 30/92, como regla general, los actos administrativos deben dictarse por escrito a menos que su naturaleza exija otra forma más adecuada de expresión y constancia; regla general que en casos como el presente en que los actos tienen por objeto la imposición de sanciones, debe ser la aplicada, máxime teniendo en cuenta que la resolución que pone fin a los procedimientos sancionadores ha de ser en todo caso motivada según lo dispuesto en el art. 138. 1 de la Ley 30/92, en relación con el art. 20.2 del RD 1398/93, de 4 de agosto. Solamente de haberse constatado la resolución verbal por escrito de forma motivada cabría plantearse su validez".

207 Sentencia del TS de 22 de mayo de 2001, que desestimaba el recurso contencioso - administrativo formulado frente al RD 137/2000, de 30 de enero, en el que la parte demandante argumentaba que "la
} 
La nueva redacción del art. 15.1 RPSTSV se cierra con una referencia al plazo de tiempo del que dispone el órgano con competencia sancionadora para tramitar la correspondiente resolución que si bien, establece el mismo plazo de tiempo previsto en la previa redacción del Reglamento de Procedimiento Sancionador en materia de Tráfico y Seguridad Vial al establecer que será "en el plazo de seis meses desde que se inició el procedimiento", pero que difiere en cuanto a la forma en la que ha de computarse ese plazo, ya que a partir de ese momento ese es el espacio de tiempo del que se dispone para notificar la resolución, mientras que en la originaria redacción del art. 15.1 RPSTSV ese plazo lo era para dictar la resolución. La nueva redacción supone una reducción del plazo puesto que ya no es suficiente con dictar la resolución sancionadora en ese espacio de seis meses siendo necesario, además, que se produzca su notificación (en los términos para ello establecido en el art. 78 LTSV y 11.2 RPSTSV), cuestión que nos dirige a la caducidad del procedimiento regulada en el art. 16 RPSTSV y que, a su vez, es objeto de modificación por el propio RD 137/2000, de 30 de enero.

El art. 15.1 RPSTSV se cierra con un inciso en el que se prescribe que esa resolución sancionadora deberá ser "motivada" (precisión, ésta, añadida por el RD 137/2000, de 30 de enero) y que tendrá que decidir "todas las cuestiones planteadas por los interesados y aquellas otras derivadas del procedimiento", cuestiones, ambas, que no era preciso señalar dado que se trata de requisitos con los que tiene que cumplir, por su propia naturaleza, toda resolución que ponga fin a un procedimiento administrativo sancionador.

Atribuida la competencia sancionadora a Delegados y Subdelegados del Gobierno, y una vez que se ha permitido, de manera general, la posibilidad de la delegación de la competencia sancionadora tras el cambio introducido por la Ley 4/1999, de 13 de enero, en la LRJ - PAC, el RD 137/2000, de 30 de enero, introduce una regulación específica, cuestión sobre la que, como se ha señalado, la propia introducción de la norma advierte al señalar que "la supresión de la prohibición de delegación de la potestad sancionadora, que se establecía en el antiguo art. 127.2 LRJ - PAC aconseja que se prevea expresamente esta posibilidad fijando reglamentariamente las autoridades delegadas en el art. 15 RPSTSV".

En el ámbito de la Administración General del Estado el régimen de delegación, que se establece en el art. 15.3 RPSTSV, supone las autoridades con competencia para sancionar en materia de tráfico y seguridad vial "podrán delegar sus competencias en los Jefes Provinciales y Locales de Tráfico o en éstos y en los Subdelegados del Gobierno correspondientes cuando se trate del Delegado del Gobierno", prescripción que ubica a Delegados y Subdelegados del Gobierno que pueden ceder el ejercicio de

nueva redacción del art. 15 RPSTSV es contraria, a su entender, a los arts. 54.1 y 55.1 LRJ - PAC, por cuanto subsiste la posibilidad de adoptar el acto sancionador de forma verbal, en lo que advierte una vulneración del art. 24.1 CE, al ser susceptible de generar indefensión" y por la que el Tribunal Supremo hallaba ajustado a derecho la nueva redacción del art. 15.1 RPSTSV. 
las competencias que tienen atribuidas y a los propios Subdelegados y a los Jefes de Tráfico (Provinciales y Locales) como posibles receptores de esa competencia para sancionar.

Esto es así porque esa redacción da soporte a diferentes supuestos, de manera que los Delegados del Gobierno en la Comunidad Autónoma pueden delegar su competencia sancionadora en materia de tráfico y seguridad tanto en los Subdelegados como en los Jefes de Tráfico 0 , incluso, distribuirlas entre ambos. $Y$, del mismo modo, los Subdelegados puede recibir la competencia inicialmente atribuida por la LOFAGE a los Delegados del Gobierno (sanciones por infracciones graves y muy graves) y atribuir la que a ellos se les ha otorgado (por las infracciones leves) a los Jefes Provinciales. Lo que no podrá ocurrir (aunque no esté expresamente señalado en el art. 15.3 RPSTSV) es que los Subdelegados del Gobierno que hubieran recibido, por delegación del Delegado del Gobierno, la competencia para sancionar las infracciones graves y muy graves procedieran a la transmisión de esa competencia a los Jefes de Tráfico, puesto que esa posibilidad no se encontraba prevista en la Ley y el art. 13.5 LRJ - PAC establece que "salvo autorización expresa de una Ley, no podrán delegarse las competencias que se ejerzan por delegación".

El inciso final del art. 15.3 RPSTSV contiene, asimismo, la posibilidad de que en el ámbito municipal la potestad sancionadora atribuida, en su ámbito de competencia, por la Ley de Tráfico y Seguridad Vial a los Alcaldes también pueda ser objeto de delegación que, en todo caso, habrá de realizarse "con arreglo a las normas por las que se rige la Administración Local" lo que supone una remisión (como no podía ser de otra manera) a lo establecido en la Ley $7 / 1985$, de 2 de abril, de Bases de Régimen Local (LBRL).

El art. 21.3 LBRL establece que el Alcalde puede delegar el ejercicio de sus atribuciones, salvo aquellas en las que, expresamente, esta posibilidad este prohibida. $\mathrm{Ni}$ en la redacción originaria de la LBRL (vigente al momento en el que el RD 137/2000, de 30 de enero, añade al art. 15 RPSTSV el párrafo tercero), ni en la posterior, procedente de la reforma efectuada por la Ley 11/1999, de 21 de abril (y que llega hasta el momento actual), ha existido previsión alguna que impida al Alcalde la delegación de la competencia sancionadora que le atribuye, en su ámbito de competencia, la Ley de Tráfico y Seguridad Vial.

En cuanto a las competencias de las Comunidades Autónomas en este ámbito nada señala el art. 15.3 RPSTSV en la redacción que para este apartado establece el RD $137 / 2000$, de 30 de enero, delegación que, en todo caso, y al igual que sucede en el ámbito local, se encontraría sometida a lo establecido en la normas de organización y funcionamiento de la propia Comunidad Autónoma con competencias sancionadores en materia de tráfico y seguridad vial. 


\section{CADUCIDAD DEL PROCEDIMIENTO}

A la obligación de resolver el procedimiento sancionador, y al establecimiento de un plazo de tiempo para dictar la resolución sancionadora y notificarla al interesado, para lo que se le concede, por el art. 15.1 RPSTSV, un plazo de seis meses al establecer que "la resolución habrá de notificarse en el plazo de seis meses desde que se inició el procedimiento", se asocia, en caso de incumplimiento del plazo establecido, la consecuencia de terminación del procedimiento por caducidad del mismo.

La presencia de un precepto sobre la caducidad del procedimiento sancionador no es, en sí misma, una novedad, puesto que en la originaria redacción del Reglamento de Procedimiento Sancionador en materia de Tráfico y Seguridad Vial ya se encontraba el art. 16 RPSTSV que, bajo esta denominación, la de "caducidad", regulaba esta forma de terminación del procedimiento.

No había previsión alguna en la Ley de tráfico y Seguridad Vial a la caducidad del procedimiento por ausencia de la resolución sancionadora y la redacción originaria del art. 16 RPSTSV partían de la base (sin señalarlo expresamente) de lo establecido en el art. 20.6 REPEPOS precepto que hace referencia a un plazo de tiempo susceptible de ser interrumpido y reanudado, al referirse "a las posibles interrupciones de su cómputo" el del plazo de caducidad.

La novedad se encuentra en la forma en la que, a partir de este momento, se va a regular la caducidad del procedimiento sancionador en el ámbito del tráfico y seguridad vial puesto que mientras que la redacción original del art. 16 RPSTSV se sustentaba en lo establecido en el art. 20.6 REPEPOS y seguía el sistema allí diseñado, la redacción que por medio del RD 137/2000, de 30 de enero, se otorga al art. 16 RPSTSV difiere de la efectuada en el reglamento general, de manera que se construye un régimen específico para el procedimiento sancionador en materia de tráfico y seguridad vial.

El cambio, ya señalado en el art. 15 RPSTSV en cuanto a que el plazo del que dispone el órgano con competencia para sancionar lo es para dictar la resolución y, además, notificarla, se reproduce en la nueva redacción del art. 16 RPSTSV asociando, a ese incumplimiento, el de que no se hubiese notificado la resolución transcurridos seis meses desde que se inició el procedimiento, que ello dará lugar (producirá) la caducidad del procedimiento y que, por lo tanto, se procederá al archivo de las actuaciones.

Esta regla general, la de establecer un plazo de seis meses cuyo cómputo se inicia con el propio procedimiento $y$ en el que es preciso dictar y notificar la resolución sancionadora, se sujeta a una serie de excepciones, al establecer, el propio art. 16 RPSTSV que ello será así (la regla general) excepto si concurren determinadas circunstancias. 
En términos de la nueva redacción que se dispone por el art. 16 RPSTSV se producirá la caducidad de procedimiento "excepto en los casos en que el procedimiento se hubiera paralizado por causa imputable a los interesados o en el supuesto de suspensión del procedimiento previsto en el artículo 2.1 del presente Reglamento, así como también por las causas previstas en el artículo 42.5 de la Ley 30/1992, de 26 de noviembre, modificada por la Ley 4/1999, de 13 de enero".

Los dos primeros supuestos (paralización del procedimiento imputable al interesado y actuaciones penales) coinciden con los establecidos en la redacción originaria del art. 16 RPSTSV.

La innovación se produce en cuanto al tercero de los supuestos que se establecen y que consiste en una remisión a lo previsto en el art. art. 42.5 LRJ - PAC, y las causas en él previstas, con la precisión, incluida en el texto de la propia redacción reglamentaria, que esa remisión se hace a la LRJ - PAC "modificada por la Ley 4/1999, de 13 de enero".

En este sentido, la redacción introducida para el art. 42.5 LRJ - PAC por la Ley 4/1999, de 13 de enero (y que continua vigente en la actualidad), determina los casos en los que se podrá suspender el transcurso del plazo máximo legal para resolver un procedimiento y notificar la resolución adoptada. Esos supuestos que van permitir la suspensión del plazo de seis meses establecido en el propio art. 16 RPSTSV son:

- Cuando deba requerirse a cualquier interesado para la subsanación de deficiencias y la aportación de documentos y otros elementos de juicio necesarios, por el tiempo que medie entre la notificación del requerimiento y su efectivo cumplimiento por el destinatario, o, en su defecto, el transcurso del plazo concedido, todo ello sin perjuicio de lo previsto en el art. 71 LRJ - PAC

- Cuando deba obtenerse un pronunciamiento previo y preceptivo de un órgano de las Comunidades Europeas, por el tiempo que medie entre la petición, que habrá de comunicarse a los interesados, y la notificación del pronunciamiento a la Administración instructora, que también deberá serles comunicada.

- Cuando deban solicitarse informes que sean preceptivos y determinantes del contenido de la resolución a órgano de la misma o distinta Administración, por el tiempo que medie entre la petición, que deberá comunicarse a los interesados, y la recepción del informe, que igualmente deberá ser comunicada a los mismos. Este plazo de suspensión no podrá exceder en ningún caso de tres meses.

- Cuando deban realizarse pruebas técnicas o análisis contradictorios o dirimentes propuestos por los interesados, durante el tiempo necesario para la incorporación de los resultados al expediente.

- Cuando se inicien negociaciones con vistas a la conclusión de un pacto o convenio en los términos previstos en el art. 88 LRJ - PAC, desde la declaración formal al respecto y hasta la conclusión sin efecto, en su caso, de las referidas 
negociaciones que se constatará mediante declaración formulada por la Administración o los interesados.

\section{RECURSOS}

La nueva redacción que, del RD 137/2000, de 30 de enero, recibe el art. 17.1 RPSTSV, se adapta a los diferentes cambios normativos que se han producido, tanto en la regulación de la revisión de actos en vía administrativa en el procedimiento general, como en la estructura de la atribución de la competencia para sancionar las infracciones en materia de tráfico y seguridad vial.

Por una parte por el efecto producido por la Ley 4/1999, de 13 de enero, al modificar la regulación establecida para los recursos y recuperar la tradicional denominación de recurso de alzada en detrimento de la de "recurso ordinario" que había sido empleada por la redacción original de la LRJ - PAC. De otro por el reparto de las competencias que, al momento de la redacción de la LTSV y del RPSTSV, correspondía a los Gobernadores Civiles entre las nuevas figuras de los Delegados del Gobierno en las Comunidades Autónomas y de los Subdelegados del Gobierno ${ }^{208}$.

De ahí que se establezca que el recurso procedente frente a las resoluciones sancionadoras dictadas los Subdelegados y delegados del Gobierno sea el de alzada y que el plazo para formularlo sea el de un mes. En el caso de las resoluciones de los Subdelegados del Gobierno el recurso se interpondrá ante el delegado del Gobierno y en el caso de que se trate resoluciones procedentes de los Delegados del Gobierno ante el Ministro del Interior.

Nada se indica sobre las resoluciones sancionadoras dictadas por los otros órganos que pueden sancionar las infracciones en materia de tráfico y seguridad vial. Ni sobre los Alcaldes, ni sobre las Comunidades Autónomas con competencias en esta materia.

\section{K) La Ley 19/2001, de 19 de diciembre, de reforma de la LTSV ${ }^{209}$}

\section{LA REFORMA}

La Ley 19/2001, de 19 de diciembre ${ }^{210}$, supone la primera gran modificación de la Ley de Tráfico y Seguridad Vial, ya que se ven afectados cerca de la mitad de los artículos que componen la norma.

\footnotetext{
${ }^{208}$ Téngase en cuenta lo comentado en relación a la modificación que, el propio RD 137/2000, de 30 de enero, realiza del art. 15.2 RPSTSV (véase, en este sentido, el apartado IV.J.2 de este mismo capítulo).

${ }^{209}$ A esta reforma, bajo la denominación "La esperada reforma de la Ley de Tráfico", le dediqué, en su momento, un análisis específico en Actualidad Jurídica Aranzadi, no 517, enero 2002.

${ }^{210}$ Publicada en el BOE de 20 de diciembre de 2001 y por la que se procede a modificar los artículos 4 , apartado i); $5 . j$ ) y k); 6 ; 7. b); 8.2 y $4 ; 10.1$ y $6 ; 11.3$, 4 y $5 ; 15.1 ; 18.1 ; 19.5 ; 20.2$ у 3, 23.5.c); 33.4; 34.4;
} 
La reforma, de tremendo calado en términos cuantitativos, es especialmente profunda en cuanto al régimen sancionador, donde se ven afectados la mayoría de los preceptos de esta parte de la LTSV, alcanzado a la regulación de infracciones, de sanciones, de competencias, de las medidas cautelares (tanto la inmovilización como la retirada del vehículo), la responsabilidad y al procedimiento sancionador. En este último apartado La Ley 19/2001, de 19 de diciembre, altera la previa redacción de los arts. 73, 74, 77 y 79.3 LTSV.

En el concreto ámbito del procedimiento sancionador, y tal y como señala la propia Exposición de Motivos de la Ley 19/2001, de 19 de diciembre, la reforma introduce las modificaciones precisas para ajustar la Ley de Tráfico y Seguridad Vial tanto a la LRJ PAC con las modificaciones recibidas de la Ley 4/1999, de 13 de enero, como a la Ley 6/1997, de 14 de abril, de Organización y Funcionamiento de la Administración General del Estado, planteamiento sobre el que es preciso señalar y tener en cuenta que, entre tanto, desde que se promulga la LTSV hasta el momento en el que se produce esta revisión general, se había dictado el RPSTSV , precisamente, sobre la base de acometer, y hacerlo al mismo tiempo, el desarrollo reglamentario en la parte correspondiente al procedimiento sancionador y la adecuación al nuevos sistema instaurado por la LRJ - PAC ${ }^{211}$. Y así, en el precepto con el que se abre la regulación del procedimiento sancionador, el art. 73 LTSV, al prescribir la necesidad de que la imposición de sanciones por infracciones a lo previsto en la Ley de Tráfico y Seguridad Vial se establece que ese marco procedimental será el previsto en las normas del presente capítulo y "el Título IX de la Ley 30/1992, modificada por la Ley 4/1999", sustituyendo así la obsoleta referencia la Ley de Procedimiento Administrativo de 1958 que aparecería en la redacción original de la LTSV.

No deja de ser curioso esa mención, en los términos que se realiza, a la Ley 4/1999 y, de igual manera, que a lo largo del articulado se mantienen referencias a la LPA (como sucede en los arts. 69.2 y 78.2 LTSV en materia de responsabilidad y domicilio de las notificaciones).

\section{NON BIS IN IDEM Y CONCURRENCIA DE ACTUACIONES ADMINISTRATIVAS Y PENALES}

Una de las modificaciones más significativas que la Ley 19/2001, de 19 de diciembre, produce en la regulación del procedimiento sancionador en materia de tráfico es la referente a la concurrencia de actuaciones administrativas y jurisdiccionales penales sobre unos mismos hechos.

37; 39.1.j); $42.3 ; 45 ; 52 ; 53.1 ; 60.2 ; 61.5 ; 63$, apartados $1,2,3$, 4 y $5 ; 64 ; 65$, apartados $1,4,5$ y $6 ; 67 ; 68$; 70; 71.1.g); 72, apartados 1 у 3; 73; 74; 77; 79.3; 80; 81; 82; 84.5; los apartados 68, 70, 71, 72, 73, 74 y 75 del anexo y el enunciado del capítulo IV del Título IV de la LTSV.

${ }^{211}$ Tal y como se establece en la introducción que precede al propio RPSTSV. 
De hecho, la propia Exposición de Motivos de la Ley 19/2001, de 19 de diciembre, advierte de este cambio que califica de "modificación sustancial"212 y que, ciertamente, lo es.

El cambio que se introduce pretende eliminar el equívoco sistema establecido en la redacción original del art. 74 LTSV y que había reproducido el art. 2 del RPSTSV. Esa previsión conforme a la cual la mera existencia de actuaciones penales suponía la paralización del procedimiento administrativo sancionador, pues la intervención de la autoridad penal daba lugar a la abstención del órgano administrativo y al malentendido de proceder a la paralización de las actuaciones administrativas.

El objeto de la reforma del art. 74 LTSV es establecer la adecuada relación entre las actuaciones administrativas y las penales que, por unos mismos hechos se pudieran llegar a producir y regularlas de la forma más eficiente en relación al principio "non bis in idem", y que con la manifiesta e indudable preferencia y prioridad de las actuaciones penales sobre las administrativas sancionadoras, no se produzca menoscabo alguno de las garantías que el procedimiento administrativo sancionador, tiene la obligación de cumplir. Y ello porque la regulación anterior, la originariamente establecida en el art. 74 LTSV y en el art. 2 RPSTSV daban lugar a que esa preferencia de las actuaciones penales conllevara, de una forma automática y sin medir las consecuencias que ello pudiera suponer, la suspensión del procedimiento administrativo sancionador y la paralización de su tramitación, en el mismo instante que la jurisdicción penal comenzaba a conocer de esos hechos sobre los que la Administración competente estaba tramitando el correspondiente expediente sancionador con el objeto de depurar, en su caso, las oportunas responsabilidades.

Tal forma de actuar, la de apartarse sin más y abandonar la tramitación, podía tener perniciosas consecuencias cuando el resultado final de esas actuaciones penales fuese una resolución que pusiera fin al proceso sin declaración de responsabilidad penal y que no declarase la inexistencia del hecho, ya que en esos casos revivía el procedimiento administrativo sancionador y sus posibilidades de éxito iban a depender, como así se constataba en la práctica, de la forma y manera en que se hubiera producido esa previa abstención de la Administración sancionadora.

Sin perjuicio de que las actuaciones administrativas han de reconocer el principio de prioridad penal la paralización y suspensión de la tramitación del procedimiento administrativo sancionador ha de realizarse de manera ordenada y teniendo presente que ese procedimiento puede que tenga que ser reactivado para alcanzar su objetivo que no es otro que dictar la resolución que, conforme a derecho, corresponda, fin al

\footnotetext{
212 Cfr. el párrafo decimosegundo de la Exposición de Motivos de la Ley 19/2001, de 19 de diciembre, que, textualmente, señala que "se recoge una modificación sustancial en el procedimiento administrativo no suspendiendo el mismo sino solamente al llegar a la resolución, cuando existan actuaciones jurisdiccionales penales, que de sobreseerse obligarían a retomar la instrucción administrativa con mengua de los derechos de los interesados".
} 
que tienen que estar orientadas todas las actuaciones del procedimiento, lo que incluye también a aquellas que, por respeto a la preferencia del proceso penal, supongan la propia suspensión de ese procedimiento administrativo sancionador.

Este planteamiento que, como se ha señalado, procede de la experiencia práctica es el que está en el origen de la reforma que se efectúa y conforme a la que por la existencia de actuaciones penales "no se ordenará la suspensión de las actuaciones del procedimiento administrativo que continuará tramitándose hasta el momento en que el procedimiento esté pendiente de resolución en que se acordará la suspensión", redacción que es la que se establece para el art. 74.2 LTSV.

Así, de esta forma, en caso de que se produzcan unas actuaciones penales sobre los mismos hechos que ya son objeto de un procedimiento administrativo sancionador, la tramitación ha de continuar y suspenderse en el momento en el que, precisamente, se vaya a alcanzar la resolución, ya que, en caso de que no haya condena penal el procedimiento sancionador se encontrará en la situación más adecuada para ser reanudado ya que únicamente restará dictar la resolución que corresponda en el procedimiento administrativo sancionador, tal y como se establece en la nueva redacción del art. 74.3 LTSV.

Se pretende minimizar, en la medida de lo posible, y este es el objeto de la reforma, que cuando tenga que reanudarse el procedimiento se reduzca el riesgo tanto de la prescripción de la infracción como, y sobre todo, de la caducidad del procedimiento. Se trata, en definitiva, de una medida cuya finalidad es la de establecer las máximas garantías de que el procedimiento cumpla con la misión que tiene encomendada y pueda depurar las responsabilidades que en su caso correspondan.

\section{NOTIFICACIONES}

La redacción originaria del art. 77 LTSV se limitaba a establecer que, como normal general, las denuncias formuladas por los agentes de la autoridad encargados de la vigilancia del tráfico (las denuncias obligatorias) se notificarían en el acto al denunciado con el contenido establecido en el art. 75 y haciendo constar el derecho a formular alegaciones y formular prueba en el plazo de quince días (del art. 79.1 LTSV). Régimen general, el de la notificación de las denuncias obligatorias en el acto, que, "por razones justificadas que deberán constar en la propia denuncia" podría excepcionarse y permitiría la notificación posterior.

En Reglamento de Procedimiento Sancionador en materia de Tráfico y Seguridad Vial preciso, sobre esta cuestión, que en esa denuncia posterior era necesario que se indicasen "las causas concretas y específicas por las que no fue posible detener el vehículo" (la redacción originaria del RPSTSV establecía, en el art. 10.2 que "las 
denuncias formuladas por los agentes de la autoridad sin parar a los denunciados no serán válidas a menos que consten en las mismas y se les notifique las causas concretas y específicas por las que no fue posible detener el vehículo").

El inciso final (originario) del art. 77.1 LTSV ("por razones justificadas que deberán constar en la propia denuncia, podrá notificársele la misma con posterioridad") es sustituido por tres nuevos párrafos con los que se completa ese art. 77.1 LTSV $^{213}$. La reforma pretende establecer una serie de excepciones al principio general de (deber) de notificación en el acto algunas de las cuales, tal y como se establecen vienen a desvirtuar ese principio de garantía para el supuesto infractor ya que al lado de supuestos en los que la realidad se impone, como son la detección de la infracción a través de medio de captación y reproducción de imágenes que permitan la identificación del vehículo (párrafo tercero) y la denuncia de vehículos estacionados (mal estacionados, habría que decir) sin que el conductor esté presente, se pretende que la concurrencia de determinadas circunstancias "ambientales" justifiquen y no obliguen a cumplir con la norma general.

Así, el nuevo párrafo segundo del art. 77.1 LTSV establece que "será causa legal que justifique la notificación de la denuncia en momento posterior, el hecho de formularse la misma en momentos de gran intensidad de circulación o concurriendo factores meteorológicos adversos, obras u otras circunstancias en que la detención del vehículo también pueda originar un riesgo concreto".

Nada se señala en el precepto sobre la necesidad de que esa causa, y su prueba, consten en la denuncia, ya que el inciso final con el que se cerraba la originaria redacción del art. 77.1 LTSV (eso de "por razones justificadas que deberán constar en la propia denuncia, podrá notificársele la misma con posterioridad") desaparece en esta revisión de la Ley aunque la interpretación del precepto no presente ninguna duda de que ello debe ser así.

${ }^{213} \mathrm{El}$ art. 77.1 LTSV quedada redactado en los siguientes términos:

"Como norma general, las denuncias de carácter obligatorio, formuladas por agentes de la autoridad, se notificarán en el acto al denunciado, haciendo constar en las mismas, los datos a que hace referencia el artículo 75 y el derecho reconocido en el artículo 79.1.

Será causa legal que justifique la notificación de la denuncia en momento posterior, el hecho de formularse la misma en momentos de gran intensidad de circulación o concurriendo factores meteorológicos adversos, obras u otras circunstancias en que la detención del vehículo también pueda originar un riesgo concreto.

Asimismo, la notificación de la denuncia podrá efectuarse en un momento posterior cuando la autoridad haya tenido conocimiento de los hechos a través de medios de captación y reproducción de imágenes que permitan la identificación del vehículo.

Procederá también la notificación de la denuncia en momento posterior a su formulación en los casos de vehículos estacionados cuando el conductor no esté presente". 


\section{EFECTOS deL PAGO de LA MULTA}

En el más puro estilo de asistemática imprecisión normativa y manteniendo lo que, durante mucho tiempo, se ha constituido en una tradición especialmente respetada en la regulación del tráfico y la seguridad vial, la alteración de los términos de un precepto suponen la regulación de cuestiones que poco o nada tienen que ver con lo que anuncia la rúbrica o título de ese artículo objeto de modificación, sin que se proceda a modificar esa rúbrica y sin que se lleve a su correspondiente lugar esa materia introducida a golpe de maza en cualquier lugar.

Esto es, exactamente, lo que sucede con el apartado dos que, por medio de la Ley 19/2001, de 19 de diciembre, se viene a añadir al art. 77 LTSV manteniendo la originaria rúbrica "notificación de denuncias", nuevo apartado en el que se regulan los efectos que, sobre el procedimiento sancionador, va a suponer el abono del importe de la multa que puede haber sido fijado en la denuncia notificada en el acto o, posteriormente, por el instructor del procedimiento ${ }^{214}$. El legislador aprovecha la incidental posibilidad de que esa cantidad sea fijada por el agente denunciante para introducirla en el marco de la "notificación de la denuncia" lo que, sin lugar a dudas, supone un exabrupto en cuanto al orden que cabe esperar de la regulación efectuada por la Ley.

Fuera de lugar, y fuera como fuere, lo que se pretende es regular los efectos que, sobre el procedimiento sancionador y su tramitación, ha de producir el pago de la multa establecida, ya se haya fijado su cantidad en la notificación, realizada en el acto, de la denuncia (art. 77 LTSV) o ese cantidad sea la fijada al inicio de la instrucción por el órgano instructor (art. 79.1 LTSV).

De lo que se trata, en definitiva, es de precisar que el pago de la multa que se señala al inicio del procedimiento puede dar lugar a la finalización del procedimiento, pero sin que ello, el hecho de que se proceda al pago de esa cantidad fijada como sanción económica suponga, siempre y en todo, la terminación del procedimiento sancionador. $Y$ ello por diversas circunstancias que pueden concurrir en el propio procedimiento.

Puede ocurrir, y esa es la primera previsión que se realiza en el art. 77.2 LTSV, que no sea la voluntad del denunciado poner fin al procedimiento aun habiendo procedido a realizar el pago de la cuantía que se ha establecido al inicio del procedimiento. Ese propósito se mostraría de forma indubitada si, a pesar de haber realizado ese pago, se

\footnotetext{
${ }^{214}$ El art. 77.2 LTSV quedada redactado, por la Ley 19/2001, de 19 de diciembre, en los siguientes términos:

"El abono del importe de la multa indicado en la notificación de la denuncia, tanto si es señalado por el agente en el acto de la misma, como en la notificación enviada posteriormente por el Instructor, implicará la terminación del procedimiento una vez concluido el trámite de alegaciones sin que el denunciado las haya formulado, finalizando el expediente, salvo que se acuerde la suspensión del permiso o licencia para conducir y sin perjuicio de la posibilidad de interponer el recurso correspondiente".
} 
formularan en plazo las correspondientes alegaciones. En ese caso la instrucción del procedimiento habría de continuar. Ello se debe a que por medio de la propia Ley 19/2001, de 19 de diciembre, se procedía a modificar la redacción del art. 67. LTSV en el que, en otras innovaciones, se introducía (como nuevo párrafo segundo del apartado 1) una previsión conforme a la cual las sanciones de multa podían hacerse efectivas "con una reducción del 30 por 100 sobre la cuantía correspondiente que se haya consignado "correctamente» en el boletín de denuncia por el agente o, en su defecto, en la notificación posterior de dicha denuncia por el instructor del expediente" antes de que se dictara la resolución del expediente sancionador ${ }^{215}$, beneficio para el denunciado que no requería (ni le imponía) su renuncia a formular alegaciones, por lo que este derecho a reducir el importe de la sanción económica, fijado en la denuncia o en la notificación realizada por el instructor del procedimiento, lo era a cambio de garantizar, en su caso, el pago de la multa. Como consecuencia de esta previsión era preciso esperar a que hubiera transcurrido el plazo establecido para formular alegaciones y proponer prueba sin que el interesado, que había procedido al pago con ese descuento que le ofrecía el art. 67.1 LTSV, las hubiera formulado para poder entender que se daba por terminado el procedimiento sancionador. El denunciado saldaba la multa que se le hubiera podido imponer acogiéndose a un beneficio de reducción que, legalmente establecido, suponía un descuento sobre los importes establecidos en el art. 67.1 LTSV, y al no formulara alegaciones se entendía que se aquietaba y conformaba con la denuncia formulada sin que fuera preciso continuar el procedimiento y dictar resolución sancionadora. Era la concurrencia de ambas manifestaciones del denunciado una positiva, la de pagar con el beneficio de reducción previsto en el art. 67.1 LTSV, y otra negativa, la de no formular alegaciones en el plazo que para ello se establecía, lo que implicaba la terminación del procedimiento conforme se establecía en el art. 77.2 LTSV.

Pero no siempre ello era así. La mera conformidad del denunciado mostrada mediante el pago de la multa y la no presentación de alegaciones en plazo no podían suponer, en todo caso, la terminación del procedimiento administrativo sancionador. Podía ser así cuando la posible sanción a imponer se limitase a una multa de manera que el denunciado liquidaba su responsabilidad con el abono de esa sanción económica. Porque también podía suceder, con la regulación sobre sanciones existente en ese momento, que la sanción a imponer no se limitase, no se correspondiese ni fuera exclusivamente, la multa. Y ello, porque conforme a lo establecido en el art. 67.1 LTSV a las infracciones graves podía corresponderles, además de la multa, la sanción de

${ }^{215}$ El art. 67.1 párrafo segundo LTSV establecía, conforme a la redacción recibida de la Ley 19/2001, de 19 de diciembre, que:

"Las sanciones de multa previstas en el párrafo anterior y en el apartado 2 de este artículo podrán hacerse efectivas antes de que se dicte resolución del expediente sancionador, con una reducción del 30 por 100 sobre la cuantía correspondiente que se haya consignado correctamente en el boletín de denuncia por el agente o, en su defecto, en la notificación posterior de dicha denuncia por el instructor del expediente". 
suspensión del permiso o licencia de conducción, sanción de suspensión que, en el caso de las infracciones muy graves, sería impuesta en todo caso junto con la correspondiente sanción económica.

En estos casos el pago de la multa no liquidada la sanción a imponer y el procedimiento tenía que continuar para que la resolución sancionadora determinase cual era la sanción que correspondía a la infracción cometida.

Esta regulación, el conjunto conformado por la integración de las previsiones efectuadas en los arts. 67.1 y 77.2 LTSV, no eran, desde un punto de vista técnico jurídico, afortunadas y provocaban disfunciones en el procedimiento sancionador en cuanto al menoscabo de las garantías que todo interesado debía recibir.

El problema se concentró en aquellos supuestos en los que el denunciado realizaba el pago de la multa, acogiéndose el beneficio de reducción establecido en el art. 67.1 LTSV, sin presentar, posteriormente, alegaciones a la denuncia, en la confianza que con ello se daba por finalizado el procedimiento. Confianza que se veía defraudada al encontrarse, posteriormente, con una resolución sancionadora que establecía como sanción, junto a esa multa que ya había sido abonada, la suspensión de permiso o licencia del conducción de la que era titular el infractor.

La cuestión no era tan sencilla como en muchas ocasiones se pretendía, por parte de la administración instructora, en base a la previsión establecida en el art. 67.1 LTSV sobre determinación de sanciones a imponer por la comisión de infracciones a la Ley de Tráfico y Seguridad Vial.

$Y$ es que la predeterminación normativa no era tan clara como hubiera cabido desear. Estaba claro que a una infracción leve nunca le podía corresponder como sanción la suspensión de la autorización para conducir ${ }^{216}$. De igual manera se podía mantener que el responsable de una infracción grave podía (y tenía que) esperar que además de la multa se le iba a imponer una suspensión del permiso o licencia por un plazo de uno a tres meses. Pero a partir de ahí la seguridad jurídica se diluía. Ni se podía anticipar, a ciencia cierta, si por las infracciones graves la consecuencia se iba a limitar (o no) a una sanción económica, ni se podía establecer a veces la calificación (definitiva) para una determinada conducta, que podía establecerse en grave o en muy grave.

\footnotetext{
${ }^{216}$ Tal y como se establece en la STSJ Comunidad Valenciana de 10 de diciembre de 1997, que deja sin efecto la imposición de la sanción de suspensión de la autorización administrativa durante un mes por la comisión de una infracción leves y en la que se indica que "en el caso de infracciones graves o muy graves podrá imponerse además la sanción de suspensión del permiso o licencia de conducir hasta tres meses, pero no contempla la posibilidad de imposición de esta última sanción en el caso de infracciones leves siendo su imposición no conforme a Derecho".
} 
Además, estaba la precisión efectuada en el art. 67.1 LTSV de que el beneficio de reducción lo era, en todo caso, sobre la cuantía "correcta" que a la multa le correspondiera... $^{217}$

Y todo ello sin perjuicio, además, de que en la tramitación del procedimiento no se hiciera participe al denunciado de las consecuencias de su acción, por lo que, en ocasiones, podía resultar muy tentador dar por cierto que con el pago (reducido, además) de la sanción de multa señalada, el denunciado terminaba con ese asunto. Cuando no era, y así se convertía, en la disculpa perfecta, en el doblez normativo preciso, en el que ampararse, aun a sabiendas de que el resultado esperable era la suspensión del permiso por haberse cometido, por ejemplo, una infracción de las calificadas como muy graves.

No era fácil, no. La integración de ambas previsiones, las contenidas de un lado en el art. 67.1 LTSV con las establecidas en el art. 77.1 LTSV que, inocuas sobre el papel, daban como resultado, en la práctica, un monstruo de imprevisible comportamiento y de difícil doma y control.

De los términos en los que se encuentra redactado en inciso segundo del art. 67.1 LTSV puede establecerse que el infractor puede (y debe) saber que la sanción de suspensión de la autorización administrativa es una consecuencia que en el supuesto de la comisión de infracciones muy graves se produce "en todo caso", por lo que, en esos supuestos no se puede alegar nada en contrata la continuación del procedimiento y la imposición de esa sanción, respetando, eso sí, en todo caso el principio de proporcionalidad.

Pero esa conclusión no se puede extender al supuesto de las infracciones muy graves ya que, en estos casos, es una posibilidad y, por lo tanto, al denunciado no se le puede exigir que suponga esa consecuencia si ello, aunque sea como eventualidad, no consta en la denuncia de la que se le ha hecho participe, pues ese tipo de actuación, de proseguir con la tramitación del procedimiento para la imposición de la sanción de suspensión al interesado que ha pagado y no ha realizado alegaciones en el convencimiento de que con ello pone fin al procedimiento sancionador, le situaría en

\footnotetext{
${ }^{217}$ Sobre esta cuestión la STS de 27 de octubre de 2004 (RJ 2005, 14) señalaría "contiene el primero de los indicados preceptos una precisión, que la representación procesal de la asociación demandante omite o elude, cual es que la reducción del treinta por ciento de la cuantía de la multa debe serlo de la que se haya consignado correctamente en el boletín de denuncia por el agente o en la notificación posterior del instructor del expediente, de manera que, si la cantidad consignada en aquel boletín o en esta notificación no fuese la correcta, es decir, la que corresponde a la infracción cometida, la reducción del treinta por ciento, a que tiene derecho el denunciado por abonarla antes de que se dicte resolución en el expediente sancionador, no debe ser calculada sobre la incorrectamente señalada por el agente o el instructor sino sobre la cuantía de la multa que proceda imponer a la infracción cometida, razón por la que dicho pago anticipado no permite prescindir de una resolución que ponga fin al expediente sancionador, en la que se habrá, lógicamente, de fijar, si procede, la sanción pecuniaria ajustada a derecho y su cuantía total es la que deberá quedar reducida, a efectos de pago, en un treinta por ciento"
} 
una posición de indefensión proscrita por el ordenamiento jurídico y que determina la nulidad de la sanción en lo que hace referencia a la suspensión de la autorización administrativa para conducir ${ }^{218}$.

Y todo ello, tal y como señala el inciso final de ese nuevo art. 77.2 LTSV, sin perjuicio de la posibilidad de interponer el recurso correspondiente.

\section{LA PARTICIPACIÓN DE DENUNCIADO EN LA INSTRUCCIÓN DEL PROCEDIMIENTO}

La nueva redacción que recibe el art. 79.3 LTSV perfila con algo más de nitidez la tramitación del procedimiento $y$, en especial, a su parte final. Así, de una redacción que se remite a los plazos establecidos y a la audiencia al interesado "en los casos en que ello fuera estrictamente necesario para la averiguación y calificación de los hechos" para llegar a la resolución sancionadora, se pasa a otra en la que se establece, como novedad respecto a la previa regulación, que "ultimada la instrucción del procedimiento y practicada la audiencia al interesado por el órgano correspondiente, salvo cuando ésta no sea necesaria de acuerdo con lo dispuesto en el art. 84.4 LRJ PAC, éste elevará propuesta de resolución", precepto este que no había sido objeto de modificación por la Ley 4/1999, de 13 de enero.

Los términos en los que queda redactado el art. 79.3 LTSV recogen la diferenciación entre la fase instructora, que concluye con la propuesta de resolución, y la fase de resolución que concluye con la adopción de la correspondiente resolución sancionadora (o la que declare la inexistencia de responsabilidad por la infracción)

A su vez, la regulación da un nuevo perfil a la intervención de los interesados en el procedimiento sancionador, que tienen que tener la posibilidad de participar. Los términos empleados suponen una adaptación a lo establecido en la LRJ - PAC, a la que, la nueva regulación, expresamente se remite. La audiencia del interesado al final de la instrucción, y como momento de participación previo a la redacción de la propuesta de la resolución sancionadora, se configura como un trámite esencial, pero no imprescindible, ya que se podrá prescindir de él, conforme señal el art. 84.4 LRJ - PAC, cuando no figuren en el procedimiento ni sean tenidos en cuenta en la resolución otros hechos ni otras alegaciones y pruebas que las aducidas por el interesado.

Esta previsión supone un cambio respecto a la literal redacción del art. 13.2 RPSTSV y que viene a recoger en la letra de Ley la interpretación realizada un año antes por el Tribunal Supremo que resolviendo un recurso de casación en interés de la ley había establecido como doctrina legal el carácter no preceptivo, e innecesario, de la notificación al interesado de la propuesta de resolución cuando ese interesado no

\footnotetext{
${ }^{218}$ Tal y como se establece en multitud de Sentencias. A título de ejemplo la STSJ Andalucía, Sevilla (Sala de lo Contencioso-Administrativo, Sección 4ạa), sentencia de 19 enero 2001 (JUR 2001, 121656).
} 
hubiera formulado alegaciones al contenido del boletín de denuncia o cuando habiéndolas formulado, no se hubieran tenido en cuenta otros hechos ni otras alegaciones y pruebas que las aducidas, en su caso, por el interesado ${ }^{219}$.

\section{COMPETENCIA PARA SANCIONAR}

Tal y como se señala en la propia Exposición de Motivos de la Ley 19/2001, de 19 de diciembre, "el nuevo régimen de Organización y Funcionamiento de la Administración General del Estado establecido por la Ley 6/1997, de 14 de abril, motiva la modificación del art. 68 LTSV para ajustar a dicha Ley las competencias sancionadoras en materia de tráfico" ${ }^{220}$.

La nueva redacción supone eso. La traslación al art. 68 LTSV de la regulación establecida en la LOFAGE para los órganos territoriales de la Administración General del Estado y la sustitución, como ya se había hecho antes en el RPSTSV, por medio del RD $137 / 2000$, de 30 de enero ${ }^{221}$, del Gobernador Civil por las nuevas figuras del Delegado y del Subdelegado del Gobierno.

Pero además de esa adaptación a las nuevas previsiones realizadas en el marco de la LOFAGE y de la revisada LRJ - PAC (tras la Ley 4/1999, de 13 de enero), recogiendo el sistema de delegación de la competencia para sancionar que ya se había llevado al RPSTSV, la Ley 19/2001, de 19 de diciembre, va a introducir dos nuevas previsiones en el marco de la competencia sancionadora, y que lo son tanto desde la perspectiva de la redacción original de la LTSV, que ahora se reforma, como de lo establecido en el propio RPSTSV.

De un parte, en la redacción del art. 68 LTSV aparece, por vez primera, la referencia a la competencia de las Comunidades Autónomas, en las que serán competentes para sancionar los órganos designados por sus respectivos Consejos de Gobierno.

De otra que al lado de la competencia territorial se establece que la imposición de la sanción de suspensión del permiso o licencia de conducción (que el art. 67.1 LTSV asociada a la comisión de infracciones graves y muy graves) corresponde, en todo caso, a los Delegados del Gobierno, facultad que puede ser objeto de delegación en el Subdelegado del Gobierno o en el Jefe Provincial de Tráfico.

\footnotetext{
219 STS de 19 de diciembre de 2000 (RJ 2001, 2617). Vide supra Nota 145 que recoge el fallo de la sentencia y el apartado IV.C) 2 g) correspondiente a la resolución y propuesta de resolución en el RPSTSV.

${ }^{220}$ Cfr. párrafo octavo Exposición de Motivos Ley 19/2001, de 19 de diciembre.

${ }^{221}$ Véase apartado IV.C) 2 de este mismo capítulo en el que se analiza el RD 137/2000, de 30 de enero.
} 


\section{RECURSOS}

La redacción del art. 17.1 RPSTSV se limitaba, tras la reforma en él efectuada por el RD $137 / 2000$, de 30 de enero, a reflejar la estructura y atribución de competencias establecida por la LOFAGE para los órganos territoriales del Administración del Estado (Delegados y Subdelegados del Gobierno), establecer la posibilidad de delegación y recoger el régimen de recursos establecido en la LRJ - PAC tras la modificación realizada por la Ley $4 / 1999$, de 13 de enero, que es en definitiva lo que se advierte en la exposición de Motivos de la propia Ley 19/2001, de 19 de diciembre ${ }^{222}$.

Es el art. 80 LTSV el que en la redacción que recibe de la Ley 19/2001, de 19 de diciembre, va a contener una mayor grado de precisión que el determinado en el Reglamento de Procedimiento Sancionador en materia de Tráfico y Seguridad Vial.

Por un lado al establecer el régimen de silencio negativo, ya que se entenderá desestimado el recurso de alzada una vez transcurridos tres meses sin que hubiera recaído la correspondiente resolución, quedando expedita la vía contenciosoadministrativa (art. 80.1 párrafo cuarto).

$\mathrm{Y}$, por otro, al remitir a su propia normativa de organización y funcionamiento, la impugnación de las resoluciones de los procedimiento sancionadores en materia de tráfico y seguridad vial dictadas, en el ámbito de sus respectivas competencias, por las Comunidades Autónomas y los Ayuntamientos (art. 80.1 párrafo cuarto).

8. SOBRE LA PRESCRIPCIÓN DE INFRACCIONES, LA PRESCRIPCIÓN DE SANCIONES, LA CADUCIDAD DEL PROCEDIMIENTO Y LA CANCELACIÓN DE ANTECEDENTES

La Ley 19/2001, de 19 de diciembre, modifica la regulación de la prescripción de sanciones que, por medio de la Ley 5/1997, de 24 de marzo, había pasado de los dos meses establecidos en la redacción original a tres meses.

La Exposición de Motivos de la Ley 19/2001, de 19 de diciembre, advierte de modificaciones en cuanto a la prescripción de las infracciones y del plazo de cancelación de la sanciones en el Registro de Conductores e Infractores ${ }^{223}$.

El art. 81.1 LTSV, en cuanto a la prescripción de infracciones, recoge la idea del art. 132 LRJ - PAC en cuanto a determinar diferentes plazos de prescripción en función de la calificación que esas conductas merezcan, pero establece unos plazos de

\footnotetext{
${ }^{222}$ Cfr. párrafo undécimo Exposición de Motivos Ley 19/2001, de 19 de diciembre.

${ }^{223}$ El último párrafo de la Exposición de Motivos de la Ley 19/2001, de diciembre, señala que "por último, en el capítulo III, de la prescripción y cancelación de antecedentes, el plazo de prescripción de las infracciones, se pone en relación con la gravedad de las mismas y se amplía el plazo de cancelación de las sanciones graves y muy graves a dos años, con objeto de poder tener en cuenta durante todo ese tiempo los antecedentes de los conductores, pues los mismos se consideran esenciales en materia de seguridad vial".
} 
prescripción específicos para la infracciones en materia de tráfico y seguridad vial al fijar un plazo de prescripción de tres meses para las infracciones leves, de seis meses para las infracciones graves y de un año tanto para las infracciones calificadas como muy graves como para las infracciones previstas, al margen de su calificación, en el art. 67.2 LTSV, plazos de tiempo que no coinciden con los establecidos, de manera general, en el art. 132.1 LRJ - PAC ${ }^{224}$.

Y en cuanto al cómputo de ese plazo de prescripción y las causas de interrupción, la reforma supone recoger en la Ley (art. 81.1 párrafo segundo LTSV) los términos en los que habían quedado redactados los párrafos tercero y cuarto del art. 18.1 RPSTSV tras la modificación en él efectuada por medio del RD 116/1998, de 30 de enero ${ }^{225}$.

De igual manera, y tal como se advierte en la Exposición de Motivos de la propia Ley 19/2001, de 19 de diciembre, se modifica el plazo de tiempo necesario para que se produzca la cancelación de las sanciones que, como consecuencia de la comisión de infracciones graves y muy graves son inscritas en el Registro de Conductores e Infractores, que pasa de los seis meses, previstos en la originaria redacción, a los dos años, ampliación que se justifica en "tener en cuenta durante todo ese tiempo los antecedentes de los conductores, pues los mismos se consideran esenciales en materia de seguridad vial" ${ }^{226}$.

Ningún aviso se realiza, por el contrario, sobre el resto de cambios que se introducen en la redacción del art. 81 LTSV.

Se realizan cambios sobre la prescripción de las sanciones ${ }^{227}$. Y aunque se mantiene el plazo de un año, plazo de prescripción que sólo se interrumpirá por las actuaciones encaminadas a su ejecución, la nueva redacción precisa, por una parte, que el cómputo de ese plazo se inicia desde el día siguiente a aquel en que adquiera firmeza la resolución por la que se imponga la correspondiente sanción y que interrupción de ese plazo requiere que del procedimiento de ejecución tenga conocimiento el interesado, volviendo a transcurrir el plazo si aquél está paralizado durante más de un

\footnotetext{
${ }^{224}$ Que, recordemos, establece que "las infracciones y sanciones prescribirán según lo dispuesto en las leyes que las establezcan" y que "si éstas (leyes) no fijan plazos de prescripción, las infracciones muy graves prescribirán a los tres años, las graves a los dos años y las leves a los seis meses".

${ }^{225}$ Véase, en este mismo capítulo, el apartado IV.G).

${ }^{226}$ Tal y como señala el párrafo con el que se cierra la Exposición de Motivos Ley 19/2001, de 19 de diciembre.

${ }^{227}$ La redacción prevista en el art. 81.2 de la originara redacción de la LTSV lo era en los siguientes términos:

"Las sanciones, una vez que adquieran firmeza, prescriben al año, prescripción que sólo se interrumpirá por las actuaciones encaminadas a su ejecución"

Y la Ley 19/2001, de 19 de diciembre, fija la prescripción de sanciones, en el art. 81.3 LTSV con la siguiente redacción:

“El plazo de prescripción de las sanciones será de un año, computado desde el día siguiente a aquel en que adquiera firmeza la resolución por la que se imponga la correspondiente sanción. Interrumpirá la prescripción la iniciación, con conocimiento del interesado, del procedimiento de ejecución, volviendo a transcurrir el plazo si aquél está paralizado durante más de un mes por causa no imputable al infractor".
} 
mes por causa no imputable al infractor, lo que sin duda clarifica los requisitos que han de cumplirse para que pueda establecerse la prescripción de una determinada sanción de las impuestas por la comisión de infracciones contra lo establecido en la Ley de Tráfico y Seguridad Vial.

Se incorporan, además, al texto del art. 81 LTSV, previsiones sobre la finalización del procedimiento por caducidad del mismo. Nada había previsto, expresamente, la redacción originaria de la Ley de Tráfico y Seguridad Vial que, por medio de la Ley 19/2001, de 19 de diciembre, introduce en el precepto destinado (o al menos eso señala su rúbrica) a regular la "prescripción", las previsiones sobre la caducidad del procedimiento sancionador.

Se trata del art. 81.2 LTSV (que desplaza al 81.3 las previsiones sobre prescripción de las sanciones) que traslada al texto de la Ley la regulación sobre la caducidad del procedimiento sobre la base de la regulación ya efectuada en el art. 16 RPSTSV en los términos establecidos para ese precepto por el RD 137/2000, de 4 de febrero. Si bien es cierto que la previsión legal va a revisar esa previa regulación reglamentaria.

El plazo, de seis meses, establecido en el art. 16 RPSTSV se duplica en la redacción del art. 81.2 LTSV, y esa extensión, a un año, del plazo previsto para que se produzca la caducidad del procedimiento no se justifica en modo alguno $y$, una vez más, la Exposición de Motivos guarda riguroso silencio sobre esta modificación y las causas que impulsan a efectuarla. Pero, además, la redacción que se establece para el art. 81.2 LTSV, determina que el cómputo del plazo lo sea desde la iniciación del procedimiento hasta que recaiga la resolución, y no hasta su notificación al interesado, como se establecía en el art. 16 RPSTSV.

El art. 81.2 LTSV contiene referencia a la paralización del procedimiento producida por actuaciones penales, pero ninguna se realiza al art. 42.5 LRJ - PAC y a las causas allí recogidas. $Y$ se introduce, como nuevo supuesto de interrupción del plazo de caducidad del procedimiento aquellos supuestos en los que, en virtud de la competencia exclusiva atribuida a los Delegados del Gobierno para imponer la sanción de suspensión de las autorizaciones administrativas para conducir, hubiera intervenido otra autoridad con competencia para imponer la sanción de multa y haya que trasladar el expediente para sustanciar esa suspensión del permiso o licencia de conducción a la Administración General del Estado.

Sobre el plazo de caducidad y su cómputo se establece que en los casos señalados (actuaciones penales y sanción de suspensión por órgano distinto al que impone la sanción de multa) ese plazo de caducidad se suspenderá y reanudará, por el tiempo que reste hasta un año, una vez haya adquirido firmeza la resolución judicial o administrativa correspondiente.

También se modifica (art. 82 LTSV) el espacio de tiempo durante el cual las sanciones por infracciones graves y muy graves permanecen anotadas en el registro de 
Conductores e Infractores que pasa de seis meses a dos años, lo que se hace "con objeto de poder tener en cuenta durante todo ese tiempo los antecedentes de los conductores, pues los mismos se consideran esenciales en materia de seguridad vial" 228 .

Demasiados cambios y, también, demasiada distancia con el régimen establecido en la LRJ - PAC, sin que se expliciten los motivos de esta regulación, que no parecen ir más allá de la imposibilidad de hacer frente a los procedimientos sancionadores que se incoan y, sobre todo, al cúmulo de alegaciones y recursos, que frente a denuncias y resoluciones sancionadoras, se formulan por los interesados...

\section{SOBRE EL COBRO DE LAS MULTAS}

La Ley 19/2001, de 19 de diciembre, añade un apartado 5 al art. 84 LTSV que, en relación al cobro de las sanciones económicas, permite a los órganos con competencia para imponer estas sanciones distintos de la Administración del Estado hacer uso de sus propias normas de recaudación ejecutiva incluso cuando los sancionados tengan su domicilio fuera del ámbito de competencia territorial de esas autoridades, podrá ser realizado por las mismas, conforme a su legislación específica.

Previsión, sin duda, de orden de práctico, que se fundamente en el lugar de comisión de la infracción relegando a un segundo plano el domicilio del infractor - sancionado.

\section{LA REVOCACIÓN DE LA AUTORIZACIÓN PARA CONDUCIR COMO SANCIÓN}

La Ley 19/2001, de 19 de diciembre, modifica, como ya se ha señalado, el art. 67 LTSV y lo hace dando una nueva redacción a la totalidad del precepto e introduciendo en él un nuevo apartado 3 que supone una de las innovaciones más relevantes de todas las realizadas en esta reforma ${ }^{229}$.

\footnotetext{
${ }^{228}$ Cfr. el último párrafo de la Exposición de Motivos de la propia Ley 19/2001, de 19 de diciembre.

${ }^{229}$ La redacción del art. 67.3 LTSV queda fijada en los siguientes términos:

3. Al autor de una infracción muy grave se le impondrá en caso de reincidencia, además de la sanción pecuniaria correspondiente, la revocación del permiso o licencia de conducción. En este caso, la graduación de la sanción pecuniaria se realizará exclusivamente atendiendo a la gravedad y trascendencia del hecho, así como al peligro potencial creado.

A los efectos de este artículo se reputarán reincidentes a quienes hubieren sido sancionados en firme en vía administrativa durante los dos años inmediatamente anteriores por dos infracciones muy graves de las previstas en el artículo 65.5 de esta Ley.

No se procederá a la revocación del permiso o licencia de conducción prevista en este apartado cuando el titular de la autorización solicite la realización de un curso de reciclaje y sensibilización en centro autorizado para ello y acredite haberlo superado con aprovechamiento dentro del plazo y en las condiciones que reglamentariamente se determinen. En tal caso, la revocación del permiso o licencia de conducción se sustituirá por la sanción de suspensión de los mismos en los términos establecidos en el apartado 1 del artículo 67.
} 
Se establece la posibilidad de la sanción de revocación del permiso o licencia de conducción, medida que se asocia a la reincidencia. Para ello se establece una definición, a estos efectos, de lo que ha de entenderse por reincidencia como el haber sido "sancionados en firme en vía administrativa durante los dos años inmediatamente anteriores por dos infracciones muy graves de las previstas en el artículo 65.5 de esta Ley".

Pero la previsión no se agota ahí, ya que de forma inmediata se ofrece una transacción al que resulte afectado por esa medida que minora la previsión establecida y la muta por la sanción de suspensión de la autorización prevista en el apartado 1 del propio art. 67 LTSV a condición de que el afectado realice un curso de reciclaje y sensibilización en un centro autorizado para impartir este tipo de formación y, además, acredite haberlo superado con aprovechamiento.

Por si a alguien le quedaran dudas sobre la bondad de esta oferta sustitutoria de la sanción de revocación en el párrafo con el que se cierra esa nueva redacción del art, 67.3 LTSV se dispone que "en los supuestos de revocación del permiso o licencia de conducción no podrá obtenerse una nueva autorización administrativa para conducir mientras no se haya cancelado la sanción que dio origen a la revocación", lo que nos sitúa en el art. 82 LTSV (que, como se ha analizado, también es objeto de reforma por las Ley 19/2001, de 19 de diciembre) y en el que se establece que las sanciones graves y muy graves permanecerán en el Registro de Conductores e Infractores durante "dos años desde su total cumplimiento o prescripción", plazo mucho más largo que el de tres meses previsto para la sanción de suspensión en el art. 67.1 LTSV.

Se trata de una medida de privación del permiso de conducir, mediante la figura de la revocación de la autorización utilizada como sanción, que se fundamenta en la reincidencia de su titular en la comisión de infracciones muy graves (dos de ellas) en un plazo de tiempo determinado (dos años) y siempre que esas sanciones adquirieran firmeza. Construcción que puede ser tenida como un antecedente de lo que, cuatro años después, daría lugar al permiso por puntos.

\section{OTROS CAMBIOS SIGNIFICATIVOS Y ALGUNA EXTRAVAGANCIA}

No se agotan ahí los cambios que, en virtud de la Ley 19/2001, de 19 de diciembre, se producen en la Ley de Tráfico y Seguridad Vial.

Por su incidencia, aunque en algunos casos sea tangencial, sobre el procedimiento sancionador en materia de tráfico y seguridad vial resulta preciso hacer referencia a algunos otros.

En los supuestos de revocación del permiso o licencia de conducción no podrá obtenerse una nueva autorización administrativa para conducir mientras no se haya cancelado la sanción que dio origen a la revocación. 
Es el caso de las modificaciones introducidas en el texto de la Ley de Tráfico y Seguridad Vial en materia de responsabilidad, infracciones, sanciones y medidas cautelares.

En materia de responsabilidad la Ley 19/2001, de 19 de noviembre, modifica el art. 72 LTSV y, tal como señala la propia Exposición de Motivos ${ }^{230}$, se establece que "Cuando sea declarada la responsabilidad de los hechos cometidos por un menor de 18 años, responderán solidariamente con él sus padres, tutores, acogedores y guardadores legales o de hecho por este orden, en razón al incumplimiento de la obligación impuesta a los mismos que conlleva un deber de prevenir la infracción administrativa que se impute a los menores", responsabilidad solidaria limitada a la sanción de multa que, además, podrá ser moderada por la autoridad sancionadora, lo que supone que no resulta transmisible, del autor a las personas a las que corresponde su custodia, de la sanción del suspensión del permiso o licencia de conducción que, en su caso, se impusiera. Y que, además, para el caso de infracciones calificadas como leve y, previo el consentimiento de esos custodios, podrá sustituirse la sanción económica de la multa por otras medidas también reeducadoras".

Así mismo, y en el ámbito de la responsabilidad del titular del vehículo y su deber de identificar al conductor responsable de la infracción, se establecen dos novedades. De un lado que la sanción por esta infracción calificada como grave será impuesta en su máxima cuantía, es decir, con los $301 €$ establecidos por el art. 67.1 LTSV como máxima cuantía que puede ser impuesta por la comisión de una infracción grave y, por otro, que esa responsabilidad se extiende tanto a la no identificación del infractor como, y esta es la innovación, a los supuestos en los que "no sea posible notificar la denuncia al conductor que aquél identifique, por causa imputable a dicho titular".

En el ámbito de las infracciones se configuran las infracciones muy graves de forma autónoma (con sustantividad propia, en términos de la Exposición de Motivos ${ }^{231}$ ) no siendo ya una mera recalificación de las infracciones graves en función de determinadas circunstancias de peligro.

En cuanto a las sanciones, son diversas e importantes. El derecho de reducción se incrementa hasta el treinta por cien del importe de la multa, la posibilidad de

\footnotetext{
${ }^{230}$ Como indica el párrafo décimo de la Exposición de Motivos de la propia Ley 19/2001, de 19 de diciembre "en el capítulo III, y en conexión con lo dispuesto en el apartado 3 del art. 130 LRJ - PC, modificada por la Ley 4/1999, de 13 de enero, como también en la Ley 5/2000, de 12 de enero, reguladora de la responsabilidad penal de los menores, se establece la responsabilidad solidaria, en lo referente a la multa pecuniaria por las infracciones cometidas por los menores, de aquellas personas, que, por tener la custodia legal de los mismos, tienen también el deber de prevenir la infracción".

${ }^{231}$ Cfr. el párrafo sexto de la Exposición de Motivos, que explica que las modificaciones "van dirigidas a configurar las infracciones muy graves como infracciones con sustantividad propia, dejando de ser elementos constitutivos de las mismas las circunstancias concurrentes de peligro, las cuales pasan a ser circunstancias de graduación de las sanciones" y que "se suprime del catálogo de infracciones muy graves la omisión del deber de socorro, al tratarse de una conducta tipificada y sancionada en el Código Penal vigente".
} 
sustitución de la sanción por otras medidas de carácter reeducador y la posibilidad de fraccionamiento de la sanción de suspensión de la suspensión de la autorización administrativa para conducir

Y sobre las medidas cautelares, la modificación introducida responde a la necesidad de ampliar las facultades de los agentes de tráfico en cuanto a la inmovilización del vehículo para comprobar determinadas infracciones o ante la gravedad de las mismas (como señala la Exposición de Motivos en el párrafo noveno) como es el caso de de la inmovilización del vehículo en los casos de superar los niveles de gases, humos y ruido permitidos reglamentariamente según el tipo de vehículo, en el caso de la reformas de importancia no autorizada, exceso en los tiempos de conducción o una minoración en los tiempos de descanso superiores al 50 por 100 de los tiempos establecidos, indicios que pongan de manifiesto cualquier posible manipulación en los instrumentos de control...

La Ley 19/2001, de 19 de diciembre, no se agota ahí y sus previsiones se siguen desbordando a través de sus disposiciones... la tercera es, cuando menos, peculiar ${ }^{232}$ y la sexta queda en el limbo de la propia Ley 19/2001, de 19 de diciembre, puesto que ninguna previsión se establece sobre su incorporación al texto de la LTSV ${ }^{233}$.

\section{L) El Real Decreto 318/2003, de 14 de marzo, de modificación del RPSTSV para adaptarlo a los cambios realizados en la LTSV por la Ley 19/2001, de 19 de diciembre}

La Ley 19/2001, de 19 de diciembre, se cerraba con varias disposiciones finales entre las que se encontraba (disp. final segunda) el mandato al Gobierno para que, en el plazo de seis meses desde su entrada en vigor $^{234}$, procediera a la reforma del

\footnotetext{
${ }^{232}$ La dips. adic. tercera establece que "se declara de urgencia la ocupación de los bienes afectados por las expropiaciones a que dé lugar la ejecución de las obras necesarias para la realización de las actuaciones en las carreteras que se detallan en el anexo l" y en la quinta se modifica

${ }^{233}$ La disp. adic. sexta se determina que "En accidentes de tráfico por atropellos de especies cinegéticas, será causa legal que permita atribuir la responsabilidad al conductor del vehículo por los daños producidos en un accidente de circulación el hecho de que se le pueda imputar un incumplimiento de las normas de circulación que pueda ser causa suficiente de los daños ocasionados, ello sin perjuicio de la responsabilidad que sea exigible a quien corresponda conforme a la normativa específica y de que sean probadas debidamente las circunstancias del accidente" sin que, como se ha señalado, se traslade esa previsión al texto de la LTSV. Y no será hasta la Ley 17/2005, de 19 de julio, que esta previsión se incorpore a la LTSV como disp. adic. novena.

${ }^{234}$ La disp. final Cuarta de la Ley 19/2001, de 19 de diciembre establecía que:

“La presente Ley de reforma del texto articulado del Real Decreto Legislativo 339/1990, de 2 de marzo, por el que se aprueba el texto articulado de la Ley sobre Tráfico, Circulación de Vehículos a Motor y Seguridad Vial, entrará en vigor al mes de su publicación en el «Boletín Oficial del Estado» y se aplicará a todos los hechos sancionables que se cometan a partir de su vigencia.

Las previsiones contenidas en los apartados 1 y 3 del artículo 67 y en el apartado 1 del artículo 72 , en cuanto se refiere a la sustitución o renovación de las autorizaciones administrativas para
} 
Reglamento General de Circulación, del Reglamento Regulador de las Escuelas Particulares de Conductores de Vehículos de Motor y, en lo que aquí más nos interesa, del Reglamento de Procedimiento Sancionador en materia de Tráfico y Seguridad $\mathrm{Vial}^{235}$.

Esa obligación fue incumplida, en cuanto al plazo establecido para efectuarla, y no será hasta la aprobación del RD 318/2003, de 14 de marzo ${ }^{236}$, que se vea efectivamente realizada en relación al Reglamento de Procedimiento Sancionador en materia de Tráfico y Seguridad Vial, lo que va a suponer, como se indica en el artículo único del referido RD 318/2003, de 14 de marzo, la modificación de los arts. 2, 10.3, 12.2 y 3, $13.3,15.1,16,17,18.1$ y 2 , y 19.1 y 2 del RPSTSV, lo que significa, en términos cuantitativos, que resultan afectados casi la mitad de los preceptos reglamentarios.

\section{ActuACIONES PENALES}

La modificación del art. 2 RPSTSV supone su adaptación a los términos en los que había sido fijada la redacción del art. 74 LTSV por la Ley 19/2001, de 19 de diciembre.

El Reglamento recoge el principio de prioridad penal y precisa la forma en la que tiene que actuar el órgano instructor. A la puesta en conocimiento del Ministerio Fiscal, de esos hechos (que ofrecen la apariencia de delito o falta y que son perseguibles de oficio) y el mandato legal de que "no se ordenará la suspensión de actuaciones del procedimiento administrativo que continuará tramitándose hasta el momento en el que el procedimiento esté pendiente de resolución en que se acordará la suspensión" es matizado por la redacción reglamentaria que, en la redacción que recibe del RD 318/2003, de 14 de marzo, establece que "proseguirá el procedimiento absteniéndose de dictar resolución mientras la autoridad judicial no pronuncie sentencia firme o dicte otra resolución que le ponga fin", lo que supone que el procedimiento ha de llegar hasta el momento en el que, conforme establece el art. 13.2 del propio RPSTSV ${ }^{237}$ "el instructor elevará propuesta de resolución al órgano que tenga atribuida la

conducir por determinados cursos u otras medidas también reeducadoras, entrarán en vigor en el momento de completarse por el Gobierno el desarrollo reglamentario de los cursos de reciclaje y sensibilización en materia de seguridad vial previstos en dichos preceptos".

${ }^{235}$ La disp. final Segunda de la Ley 19/2001, de 19 de diciembre establecía que:

"El Gobierno, en el plazo máximo de seis meses desde la entrada en vigor de la presente Ley, procederá a modificar el Reglamento General de Circulación, aprobado por Real Decreto 13/1992, de 17 de enero, para la aplicación y desarrollo del texto articulado de la Ley sobre Tráfico , Circulación de Vehículos a Motor y Seguridad Vial y el Reglamento de Procedimiento Sancionador en Materia de Tráfico, Circulación de Vehículos a Motor y Seguridad Vial aprobado por Real Decreto 320/1994, de 25 de febrero, para adecuarlos a las modificaciones contenidas en la presente Ley".

${ }^{236}$ Publicado en el Boletín Oficial del Estado de 5 de abril de 2003.

${ }^{237}$ En la redacción que el RD 137/2000, de 4 de febrero, había establecido para este art. 13.2 RPSTSV. 
competencia sancionadora para que dicte la resolución que proceda", sin que ésta, la resolución (sancionadora), se dicte ${ }^{238}$.

\section{NOTIFICACIONES}

La adición de un apartado, el tercero, al art. 10 RPSTSV supone la transcripción en el Reglamento de la reforma realizada en materia de notificaciones realizadas en momento posterior al de la denuncia. El art. 10.3 RPSTSV reproduce el contenido de los párrafos segundo, tercero y cuarto del art. 77.1 LTSV en la redacción que a este precepto atribuye la Ley 19/2001, de 19 de diciembre, y que pretende establecer supuestos por el hecho de que concurran determinadas circunstancias.

La introducción señala que "Por otra parte, se concretan de manera precisa los casos en que se admite la notificación de la denuncia con posterioridad a la comisión de la infracción, reforzando de este modo la vigilancia en zonas urbanas"... no hay más concreción que la realizada en la Ley que el reglamento se limita a reproducir.

\section{Efectos del pago de LA MULTA}

La extravagante previsión que, sobre los efectos del pago de la multa, se había introducido, en el marco de la notificación de las denuncias, por medio de la Ley 19/2001, de 19 de diciembre, es trasladada al RPSTSV.

La ubicación de esta disposición en el art. 12.2 párrafo primero RPSTSV no mantiene la asistemática ubicación empleada para la Ley de Tráfico y Seguridad Vial, situándola en la parte que el Reglamento destina a la regulación de la instrucción, lugar en el que se trascribe literalmente ${ }^{239}$ la previsión efectuada en el art. 77.2 LTSV. Pero la regulación reglamentaria en este asunto no concluye ahí y pretende colaborar con la regulación establecida en la Ley mediante dos precisiones adicionales sobre ese beneficio de reducción de la cuantía de las multas.

En el art. 12.2 párrafos segundo y tercero RPSTSV, en la redacción recibida del RD $318 / 2003$, de 14 de marzo, se establecía que:

"La resolución que se dicte lo será por el importe total de la multa que proceda imponer y tendrá en cuenta el pago anticipado que se hubiera efectuado con anterioridad a los efectos previstos en el artículo 77.2 del Texto Articulado de la Ley sobre Tráfico, Circulación de Vehículos a Motor y Seguridad Vial, en cuanto se refiere a la terminación del procedimiento. En todo caso, el importe total de la multa impuesta podrá ser objeto de impugnación en el

\footnotetext{
238 “Pendiente de resolución” en términos del art. 74.2 LTSV y “absteniéndose de dictar resolución” en los empleados por el art. 2.1 RPSTSV.

${ }^{239}$ Así se puede afirmar aunque se modifique una palabra, ya que el RPSTSV utiliza la expresión "en el acto de la denuncia" en lugar de la originaria de la LTSV "en el acto de la misma".
} 
correspondiente recurso que se formule, cuya resolución no quedará vinculada por el pago anticipadamente realizado.

Cuando se haya minorado la cuantía de la sanción pecuniaria por pago anticipado efectuado con anterioridad a la resolución que se dicte, no será posible aplicar a la cantidad resultante ninguna otra reducción basada en la realización de medidas reeducadoras. No obstante, la minoración de la sanción pecuniaria por pago anticipado será compatible con la reducción por el desarrollo de medidas reeducadoras de la sanción de suspensión de la autorización para conducir o con el fraccionamiento de esta última sanción".

Curiosa decisión normativa la de colaborar y precisar una previsión legal en la que, precisamente, se reconocía un beneficio, un derecho, al denunciado, cuestión sobre la que la introducción que precede al texto del propio RD 318/2003, de 14 de marzo señala que "se tiene en cuenta la incidencia del pago anticipado a la resolución durante la instrucción del procedimiento, regulando la reducción legal del 30 por 100 del importe de la multa y su incompatibilidad con otros beneficios legales de reducción de sanciones por sometimiento a medidas reeducadoras". Y difícil, puesto que las precisiones reglamentarias allí donde la Ley ha reconocido un derecho pueden suponer vulneraciones la principio de jerarquía normativa.

Y eso es lo que sucedía con la previsión efectuada en el art. 12.2 párrafo segundo RPSTSV que en su medida ambigüedad parecía pretender limitar el derecho de reducción tal y como había quedado configurado en el art. 77.2 LTSV.

Si el denunciado tenía reconocido por la Ley derecho a una reducción del 30 por cierto del importe de la multa fijado por el agente o por el instructor (art. 77.2 LTSV) con el único límite de que ese cantidad hubiese sigo fijada correctamente (art. 67.1 párrafo segundo LTSV) ninguna limitación podía imponerse a ello desde el desarrollo reglamentario.

La confusa, por no decir turbia, redacción del art. 12.2 párrafo segundo RPSTSV no explica de una forma clara e inequívoca que sucede con el beneficio de reducción del importe de la multa previsto en el art. 77.2 LTSV que se convierte en un pago anticipado, ya que "la resolución que se dicte lo será por el importe total de la multa que proceda imponer" y "el importe total de la multa impuesta podrá ser objeto de impugnación en el correspondiente recurso que se formule, cuya resolución no quedará vinculada por el pago anticipadamente realizado".

La única interpretación posible de este art. 12.2 párrafo segundo RPSTSV consistía en entender que el denunciante que recurría en defensa de su derecho frente a la resolución sancionadora perdía ese beneficio de reducción de la multa (correctamente) fijada por mucho que ya hubiera procedido al pago anticipado, solución que, sin lugar a dudas, suponía la supresión del derecho legalmente establecido, innovación imposible de realizar desde una norma reglamentaria. 
La discusión terminó con la Sentencia del Tribunal Supremo de 27 de octubre de $2004^{240}$ que declaró nulo de pleno derecho del art. 12.2 párrafo segundo RPSTSV por vulnerar lo dispuesto en los arts. 67.1, párrafo segundo, y 77.2 LTSV en la redacción que ambos preceptos habían recibido de Ley 19/2001, de 19 de diciembre.

Ningún obstáculo encontraron, sin embargo, el resto de previsiones establecidas en el art. 12.2 párrafo tercero, tanto sobre la incompatibilidad del beneficio de reducción del 30 por ciento por otras posibles minoraciones de carácter económico que encontraran su sustento en la realización de medidas reeducadoras, así como la posibilidad de compatibilizar ese beneficio de reducción del 30 por ciento con la reducción o fraccionamiento de la sanción de suspensión de la autorización para conducir por el desarrollo de medidas reeducadoras.

\section{RESOLUCIÓN Y COMPETENCIA PARA SANCIONAR}

La previsión establecida en el art. 68.3 LTSV (en la redacción recibida de la Ley 19/2001, de 19 de diciembre) que atribuía el monopolio de la sanción de suspensión del permiso o licencia de conducción a los delegados del Gobierno en las Comunidades Autónomas sin perjuicio, eso sí, de su posible delegación en los Subdelegados del Gobierno o en los Jefes Provinciales de Tráfico no suponía una innovación sobre el régimen previo, ya que la originaria redacción del art. 68.4 LTSV otorgaba esta competencia a los Gobernadores Civiles.

\footnotetext{
${ }^{240}$ En el Fundamento de Derecho Quinto de esta sentencia se señalaba que "Ios términos en que ha sido redactado el párrafo segundo del apartado 2 del artículo 12 del Reglamento de procedimiento sancionador en materia de tráfico, circulación de vehículos a motor y seguridad vial, por el Real Decreto 318/2003, de 14 de marzo, no permite dicha interpretación sino que conduce a la sostenida por la demandante, pues, en los supuestos de reacción del denunciado, autoriza a imponer y exigir a éste el importe íntegro de la multa que proceda, ya que sólo tiene en cuenta el pago anticipado cuando el procedimiento termine por no haberse formulado alegaciones, $y$, en el caso de impugnarse la resolución sancionatoria, se desvincula la decisión del recurso del hecho de haberse pagado anticipadamente, con lo que el precepto reglamentario impugnado modifica e innova los preceptos legales, al suprimir el derecho a la reducción de la multa procedente cuando el denunciado no se conforma con ella" y que "Sin embargo, como hemos expresado antes, la posible reacción inconformista del denunciado con la sanción pecuniaria impuesta no le priva del beneficio de la reducción con arreglo a lo dispuesto en los dos preceptos legales transcritos, mientras que la ambigua redacción del precepto reglamentario cuestionado, al realizar las precisiones "en cuanto se refiere a la terminación del procedimiento" y "cuya resolución no quedará vinculada por el pago anticipadamente realizado», no tendría sentido sino para advertir al alegante o recurrente que en tal caso puede verse privado de la reducción del treinta por ciento de la multa procedente, aunque tampoco participemos del criterio de la demandante, para quien la resolución que se dicte debe limitarse a imponer la cuantía de la multa con la reducción del treinta por ciento cuando hubiese sido abonada por el denunciado antes de dictarse resolución en el expediente sancionador, pues, como hemos indicado también, la reducción debe calcularse sobre la multa que proceda, con arreglo a derecho, imponer a la infracción cometida, exégesis esta que no evita declarar la nulidad radical del precepto reglamentario combatido por vulnerar lo dispuesto en los artículos 67.1, párrafo segundo, y 77.2 de la Ley de Seguridad Vial, según establecen concordadamente los artículos 62.2 de la Ley 30/1992, de Régimen Jurídico de las Administraciones Públicas y del Procedimiento Administrativo Común, y70.2 de la Ley de esta Jurisdicción 29/1998, de 13 de julio".
} 
Pero al lado del cambio estructural derivado de la sustitución de la figura de los Gobernadores Civiles, el reparto de las competencias que tenían, en materia de tráfico, entre delegados y Subdelegados del Gobierno (LOFAGE) y la posibilidad de delegación de la competencia sancionadora (LRJ - PAC tras la reforma realizada por medio de la Ley 4/1999, de 13 de enero), esa atribución en exclusiva a la Administración General del Estado de la competencia para imponer la suspensión del permiso o licencia de conducción requería de un desarrollo reglamentario que se ubicó (por principios anárquicos o de azar) en el art. 13 RPSTSV, precepto en el que, conforme indica su rúbrica, cabría esperar las cuestiones relativas la "período de prueba".

Así, en el art. 13.3 RPSTSV, quedo ubicada la disposición que establecía la forma de actuar de la Administración autonómica o local que, en el ejercicio de sus competencias, tuviera que conocer de un expediente sancionador en el que a la infracción cometida le pudiera corresponder, además de la multa, la sanción de suspensión de la autorización administrativa para conducir.

Ni la forma de resolver las disfunciones, que la previsión de atribuir en exclusiva la competencia sobre una de las posibles sanciones establecidas para la comisión de infracciones graves y muy graves, había sido, en la práctica, pacífica, ni la regulación que por medio del RD 318/2003, de 14 de marzo, solucionaba los problemas que esa atribución establecía.

La disposición que se añadía al Reglamento y conformaba el nuevo apartado 3 del art. 13 RPSTSV partía, como no podía ser de otra manera, del hecho cierto e incuestionable de que podía ocurrir que una Administración distinta de la estatal no pudiera imponer la totalidad de la sanción establecida para esa conducta al carecer, en virtud de lo establecido en el art. 68 LTSV, de la competencia para imponer la sanción de suspensión de la autorización administrativa para conducir que en todo caso debía de acompañar a la multa en la infracción muy graves y que podía establecerse para las infracciones graves.

El art. 13.3 RPSTSV ${ }^{241}$ establecía que la autoridad autonómica o local remitirían a la autoridad estatal competente el expediente tramitado, y en el que únicamente se habría impuesto la sanción económica, una vez hubiera adquirido firmeza esa resolución sancionadora, momento en el que la Administración General del Estado

\footnotetext{
${ }^{241}$ La redacción del art. 13.3 RPSTSV quedaba fijada por el RD 318/2003, de 14 de marzo, en los siguientes términos:

“Cuando, por razón de la posible sanción de suspensión de la autorización administrativa para conducir, la Administración General del Estado deba conocer del expediente resuelto por las autoridades competentes de la Administración local o autonómica que hayan impuesto la sanción de multa correspondiente, estas autoridades, una vez que haya adquirido firmeza su resolución, remitirán el expediente a la autoridad competente de la Administración General del Estado. Esta última autoridad notificará la propuesta de resolución que contemple la suspensión del permiso o licencia de conducción que se pueda acordar y dará traslado ésta en trámite de audiencia, por 15 días, al interesado".
} 
procedería a notificar la propuesta de resolución que contemple la suspensión del permiso o licencia de conducción que se pueda acordar y a dar traslado de esta, en trámite de audiencia y por plazo de 15 días, al interesado.

Una solución, sobre el papel, sencilla y clara, pero que ignoraba los problemas que, tanto en la teoría como en la práctica, se presentaban por el hecho de repartir entre dos instrucciones sucesivas, cuando no diferentes, la sanción que había de atribuirse a unos hechos constitutivos de infracción.

El problema no era, como quiso verse, de infracción del principio non bis in idem. Nada que objetar a que la sanción establecida fuera la suma de diferentes medidas, sanción económica y suspensión de la autorización en este caso. Las complicaciones comenzaban desde el momento en que la sanción de suspensión era una medida potestativa para el supuesto de las infracciones graves, ya que podía ser (o no ser) impuesta, continuaban con la determinación de la sanción en su conjunto, como suma de dos resoluciones, que podían ponderar adecuadamente, o no, la proporcionalidad de la sanción resultante, seguían con la posibilidad de que dictada la resolución por la Administración competente para conocer de la infracción no se remitiera el expediente (incluso aunque se tratara de una infracción muy grave a la que, en todo caso, el habría de corresponder la suspensión de la autorización para conducir), proseguían con el hecho de que el interesado podía llegar a creer (incluso de manera legítima) que resolución sancionadora dictada por la Administración autonómica o local finiquitaba el procedimiento, lo que podía inducirle a adoptar decisiones, como el pago anticipado acogiéndose al beneficio de reducción y la no presentación de alegaciones, dando por bueno un resultado, la imposición de una multa que, a la postre no se correspondía con la consecuencia sancionadora total. Demasiada complejidad tras una solución tan sencilla.

La única previsión que, a estos efectos, se realiza es la de establecer como supuesto de interrupción del plazo establecido para que se produzca la caducidad del procedimiento la necesidad de trasladar el expediente a la Administración General del Estado para sustanciar esa suspensión del permiso o licencia de conducción.

\section{CADUCIDAD}

EI RD 318/2003, de 14 de marzo, modifica una previsión e introduce otra en cuanto a lo establecido sobre caducidad del procedimiento sancionador en materia de tráfico y seguridad vial.

Se modifica, en los arts. 15.1 y 16 párrafo primero RPSTSV, el plazo de tiempo en el que ha de dictarse y notificarse la resolución sancionadora desde que se inició el procedimiento que, siguiendo lo establecido en el art. 81.2 LTSV por la Ley 19/2001, de 
19 de diciembre, pasa de seis meses a un año. Ambas previsiones reglamentarias establecen el plazo de un año, pero divergen en cuanto a lo que ha de pasar en ese espacio de tiempo, ya que mientras que el art. 15.1 RPSTSV prescribe que habrá de notificarse la resolución, el art. 16 párrafo primero RPSTSV, que sigue literalmente lo establecido en el art. 81.2 LTSV, establece que es el período en el que tiene que recaer la resolución sancionadora.

El art. 16 RPSTSV es modificado para reproducir, en su párrafo primero, las previsiones efectuadas en el art. 81.2 LTSV sobre la caducidad del procedimiento y para especificar la forma en la que ha de computarse la interrupción y reanudación de la caducidad, al establecer, en el art. 16 párrafo segundo RPSTSV que "la interrupción de la caducidad se computará desde que se notifique la resolución al interesado y se reanudará cuando la resolución sea firme, bien porque la consienta el interesado, bien porque se resuelva el recurso interpuesto por éste".

Resulta difícil imaginar una redacción más confusa y desafortunada. En primer lugar por el cambio en cuanto a la forma en la que se determina el cumplimiento del plazo de caducidad que deja de ser el de la notificación de la resolución para pasar a ser el de la emisión de la resolución sancionadora, algo que, sin lugar a dudas, no ofrece las mismas garantías al interesado. A ello se añade el hecho de que una vez firme la resolución no parece que lo adecuado sea referirse al instituto de la caducidad pues, en su caso, se estará ante la prescripción, en su caso, de esa sanción firme.

\section{PRESCRIPCIÓN Y RECURSOS}

El RD 318/2003, de 14 de marzo, procede a dar nueva redacción a lo art. 17 RPSTSV, modificación que consiste en trascribir, literalmente, los términos en los que la Ley 19/2001, de 19 de diciembre, había fijado el contenido del art. 80 LTSV.

Lo mismo sucede en cuanto a las previsiones reglamentarias en materia de prescripción de infracciones y sanaciones. En este caso los apartados que integran el art. 18 RPSTSV reproducen los términos en los que habían quedado redactados los apartados primero y tercero del art. 81 LTSV.

\section{ANOTACIÓN Y CANCELACIÓN DE ANTECEDENTES}

La Ley 19/2001, de 19 de diciembre, había procedido a ampliar el espacio de tiempo durante el cual las sanciones impuestas por la comisión de infracciones graves y muy graves habrían de permanecer anotadas en el registro de Conductores e Infractores, espacio de tiempo que pasaba de seis meses a dos años, aumento que se hacía con el 
objeto de incrementar el plazo de tiempo en el que esas sanciones debían tomarse en consideración como antecedentes de los conductores.

Además de la adaptación a ese plazo de dos años establecido en el art. 82 LTSV para la cancelación de los antecedentes, las prescripciones reglamentarias originales son modificadas en dos aspectos. Así, por una parte, en el art. 19.1 RPSTSV se establece un plazo para que las sanciones impuestas por la Administración Local y autonómica y susceptibles de ser anotadas sean comunicadas en un plazo de quince días desde que adquieren firmeza. Por otra, se establece que esa anotación, la de las sanciones que hayan sido adoptadas por otras administraciones o por la autoridad judicial, ha de ser practicada por la Jefatura de Tráfico de su demarcación, previsión a la que se añade, al final del art. 19.2 RPSTSV "salvo que se establezca un sistema informático por el que se pueda realizar directamente en los registros de la Dirección General de Tráfico".

\section{M) Reglamento General de Circulación de 2003}

El transcurso del tiempo y las sucesivas reformas efectuadas sobre la redacción original de la Ley de Tráfico y Seguridad Vial aconsejan la revisión del Reglamento General del Circulación aprobado en 1992, trabajo que se acomete mediante la promulgación del Real Decreto 1428/2003, de 21 de noviembre ${ }^{242}$.

De hecho, esta reforma del Reglamento General de Circulación, que termina con la redacción de una nueva norma, suponía cumplir con lo ordenado en la disp. Final Segunda de la Ley 19/2001, de 19 de diciembre, conforme a la que se concedía un plazo de seis meses al Gobierno para que procediera a la modificación, entre otros, del Reglamento General de Circulación, con el objeto de adecuarlo a las modificaciones contenidas en esa Ley ${ }^{243}$, mandato que se lleva a efecto cuando han transcurrido casi dos años desde la publicación de la Ley 19/2001, de 19 de diciembre, y año y medio después del momento en el que, como muy tarde, debería de haberse realizado esa reforma.

Pero, como se ha señalado, se termina dictando un nuevo Reglamento General de Circulación, porque con la aprobación del Real Decreto 1428/2003, de 21 de noviembre, se "trasciende dicho mandato legislativo, pues aparte de su cumplimiento, la magnitud de las reformas que precisa el Reglamento General de Circulación, aprobado por el Real Decreto 13/1992, de 17 de enero, aconseja la promulgación de uno nuevo, en el que además se refundan las modificaciones anteriores efectuadas por el Real Decreto 116/1998, de 30 de enero, que adaptó el Reglamento General de Circulación a la Ley 5/1997, de 24 de marzo, también de reforma del Texto Articulado

\footnotetext{
${ }^{242}$ Publicado en el Boletín Oficial del Estado de 23 de diciembre de de 2003 y que, conforme establece la disposición Final Quinta "entrará en vigor al mes siguiente de su publicación en el Boletín Oficial del Estado".

${ }^{243}$ Vide supra nota 230 en la parte dedicada al RD 318/2003, de 14 de marzo, sobre reforma del RPSTSV.
} 
de la Ley sobre Tráfico, Circulación de Vehículos a Motor y Seguridad Vial, como, asimismo, el Real Decreto 1333/1994, de 20 de junio, y el Real Decreto 2282/1998, de 23 de octubre, que modificó el Reglamento General de Circulación en materia de alcoholemia" $^{244}$.

La redacción del Reglamento General de Circulación en la parte que aquí interesa, como quedo expuesto al analizar la originaria redacción del $\mathrm{RGC} / 1992^{245}$, es la regulación del procedimiento que ha de seguirse para la denuncia y prueba por infracción de lo previsto conducción bajo la influencia de bebidas alcohólicas u otras sustancias.

Las precisiones que desde la publicación del RGC/1992 hasta la promulgación de este nuevo RGC/2003 son, en lo sustancial, cambios en las tasas toleradas en la conducción, que se van reduciendo progresivamente ${ }^{246}$, así como ajustes de tipo técnico - jurídico para la práctica de la prueba de detección y la configuración del sistema procedimental.

\footnotetext{
${ }^{244}$ Tal y como se señala el párrafo con el que se inicia el texto explicativo que precede al propio RD 1428/2003, de 21 de noviembre, por el que se aprueba el nuevo Reglamento General de Circulación (RGC/2003).

${ }^{245}$ Véase, en este mismo capítulo, el apartado IV.A) sobre el RGC/1992.

${ }^{246}$ Las tasas de alcohol en sangre inicialmente establecidas en el art. 20.1 RGC/1992 eran, de manera general, la de 0,8 gramos por $1.000 \mathrm{~cm}^{3}$, con unas determinaciones específicas que eran una tasa de 0,5 gramos por $1.000 \mathrm{~cm}^{3}$ para los conductores de vehículos destinados al transporte de mercancías con un peso máximo autorizado superior a 3.500 kilogramos y de 0,8 gramos por $1.000 \mathrm{~cm}^{3}$ para los conductores de vehículos destinados al transporte de viajeros de más de nueve plazas, o de servicio público, al escolar y de menores, al de mercancías peligrosas o de vehículos de servicio de urgencia o transportes especiales.

Por medio del RD 1333/1994, de 20 de junio, se modificó el art. 20.1 RGG/1992 pero no tanto en cuanto al nivel de la tasa permitida como en cuanto a que esa referencia podía serlo a una tasa de alcohol en sangre y, además, a una tasa de alcohol en aire espirado, por lo que se modificada la rúbrica del artículo que pasaba a ser la de "tasas de alcohol en sangre y aire espirado". Estas últimas se correspondían, exactamente, con la mitad del valor establecido para aquellas, de manera que las tasas quedaban fijadas, para los mismos casos que en la redacción originaria en "una tasa de alcohol en sangre superior a 0,8 gramos por litro, o de alcohol en aire espirado superior a 0,4 miligramos por litro", "una tasa de alcohol en sangre superior a 0,5 gramos por litro, o de alcohol en aire espirado superior a 0,25 miligramos por litro" y "una tasa de alcohol en sangre superior a 0,3 gramos por litro, o de alcohol en aire espirado superior a 0,15 miligramos por litro".

El RD 2282/1998, de 23 de octubre, dio nueva redacción al art. 20.1 RGC/1992 modificando, por su reducción, tanto los valores de esas tasas como los supuestos. La regla general era la prohibición de conducir con una tasa de alcohol en sangre superior a 0,5 gramos por litro, o de alcohol en aire espirado superior a 0,25 miligramos por litro". Al lado de esta norma se establecían dos supuestos especiales. En el primero de ellos se refundían los relativos a los conductores de vehículos de transporte, ya fueran vehículos destinados al transporte de mercancías con un peso máximo autorizado superior a 3.500 kilogramos, vehículos destinados al transporte de viajeros de más de nueve plazas, o de servicio público, al escolar o de menores, al de mercancías peligrosas o de servicio de urgencia o transportes especiales, para los que se fijaba "una tasa de alcohol en sangre superior a 0,3 gramos por litro, o de alcohol en aire espirado superior a 0,15 miligramos por litro". A su lado, se creaba un nuevo supuesto para los conductores noveles durante los dos años siguientes a la obtención del permiso o licencia que les habilita para conducir que no podrían superar "la tasa de alcohol en sangre de 0,3 gramos por litro, ni de alcohol en aire respirado de 0,15 miligramos por litro".
} 
Estos aspectos, los que inciden en la práctica de la prueba de detección alcohólica, en cuanto que inciden y conforman el procedimiento sancionador en este tipo de infracciones administrativas, o delitos, son los que interesan, aunque sea de forma sumaria, a nuestro análisis.

Por una parte, y por medio del RD 1333/1994, de 20 de junio, se produce la modificación efectuada en el art. art. 22.1 párrafo primero, lugar en el que, y como medio normal para proceder a la detección de la intoxicación alcohólica, se introducen los etilómetros ${ }^{247}$ (verificación de la tasa de alcohol en aire espirado) que sustituyen a los alcoholímetros ${ }^{248}$ (verificación de la tasa de alcohol en sangre), como sistema para la determinación, de forma cuantitativa, del grado de impregnación alcohólica, aunque la letra del art. 12 LTSV sigue prescribiendo que esas las pruebas de detección alcohólica "se establecerán reglamentariamente y consistirán normalmente en la verificación del aire espirado mediante alcoholímetros autorizados".

Por otra parte, el art. 23.1 RGC/1992 es objeto de modificación tanto por el RD 1333/1994, de 20 de junio, como por el RD 2282/1998, de 23 de octubre. Si en el primer caso se trata, únicamente, de adaptar la redacción del precepto a la modificación realizada en el art. 20 del propio RGC/1992, en el caso del RD 2282/1998, de 23 de octubre, la modificación es sustantiva, ya que se exige que la prueba de contraste, la práctica de una segunda prueba de detección alcohólica por el aire espirado, en aquellos casos en los que la primera prueba hubiera dado un resultado positivo o cuando la persona que la ha realizado presenta signos evidentes de encontrarse bajo la influencia de bebidas alcohólicas, el mediante un procedimiento similar al que sirvió para efectuar la primera prueba, es preciso informar de ello al interesado y hacerlo de manera previa, es decir, que se le va a realizar una segunda prueba y el por qué de esa realización ${ }^{249}$.

\footnotetext{
${ }^{247}$ Regulados, en ese momento, por la Orden de 27 de julio de 1994, por la que se establece el control metrológico del Estado para los instrumentos destinados a medir la concentración de alcohol en el aire espirado (BOE de 30 de julio de 1994) y que tiene por objeto, tal y como prescribe su art. 1, "regular el control metrológico del Estado establecido en la Ley 3/1985, de 18 de marzo, de Metrología, y en el Real Decreto 1616/1985, de 11 de septiembre, sobre los instrumentos, denominados en adelante "etilómetros», destinados a medir la concentración de alcohol en el aire espirado y que se utilicen como medio para la imposición de sanciones, para la realización de pruebas judiciales o para la aplicación de normas o reglamentaciones que exijan su uso para medir la concentración alcohólica", norma que sería derogada por la Orden ITC/3707/2006, de 22 de noviembre, que regula el control metrológico del Estado de los instrumentos destinados a medir la concentración de alcohol en el aire espirado (BOE 7 de diciembre de 2006).

${ }^{248}$ La Orden de 28 de diciembre de 1988 (BOE 24 de enero de 1989) regulaba los alcoholímetros, aerómetros para alcohol y tablas alcoholimétricas. La Orden ITC/2451/2011, de 12 de septiembre establece (BOE de 16 de diciembre de 2011), en el art. 2.1 la derogación de determinadas órdenes ministeriales que regulan instrumentos de medida con efecto a partir de 1 de enero de 2015, entre las que se encuentran, en el apartado f), la referida Orden de 28 de diciembre de 1988.

${ }^{249} \mathrm{El}$ art. $23.1 \mathrm{RGC} / 1992$ quedaba, tras la modificación efectuada por el RD 2282/1998, de 23 de octubre, redactado en los siguientes términos (donde le subrayado se corresponde con el añadido efectuado):
} 
Finalmente, el art. 28.1.2 RGC/1992 fue objeto de modificación por el RD 116/1998, de 30 de enero, que estableció que en los casos en los que quien estando obligado, por encontrarse en alguno de los supuestos establecidos en el art. 21 del propio $\mathrm{RGC} / 1992$, a someterse a las pruebas de detección alcohólica, se negara a ello, y siempre que no pudiera hacerse cargo del vehículo otra persona debidamente habilitada, el agente podía proceder, como medida provisional, "a la inmediata inmovilización del vehículo en la forma prevista en el art. 25 RGC/1992".

Sobre esta redacción consolidada del RGC/1992, la nueva redacción que el RGC/2003 realiza de estos preceptos, los destinados a bebidas alcohólicas y otras sustancias prohibidas, mantienen, en lo que aquí interesa, el mismo contenido y numeración ${ }^{250}$.

Los problemas en este ámbito eran lo recogidos en la Circular 2/1986, de 14 de febrero, de la Fiscalía General del Estado sobre la prueba de alcoholemia como integradora del tipo definido en el art. 340 bis A del Código Penal (Boletín del Ministerio de Justicia de 31 de diciembre de 1986)

En definitiva, el RGC/2003 como hiciera su predecesor, mantenía y continuaba con la regulación de determinados aspectos procedimental en cuanto a las infracciones en materia de bebidas alcohólicas y sustancias prohibidas.

\section{N) La Ley 62/2003, de 30 de diciembre, de medidas fiscales, administrativas y del orden social}

El año 2003 se cierra con la Ley 62/2003, de 30 de diciembre, de medidas fiscales, administrativas y del orden social ${ }^{251}$, disposición con la que, y mediante la aprobación de diversas medidas normativas, se pretende una mejor y más eficaz ejecución del programa del Gobierno y de los objetivos establecidos en la Ley de Presupuestos

\footnotetext{
“RD 2282/1998, de 23 de octubre Si el resultado de la prueba practicada diera un grado de impregnación alcohólica superior a 0,5 gramos de alcohol por litro de sangre, o a 0,25 miligramos de alcohol por litro de aire espirado, o al previsto para determinados conductores en el artículo 20 del presente Reglamento, o aun sin alcanzar estos límites, presentara la persona examinada síntomas evidentes de encontrarse bajo la influencia de bebidas alcohólicas, el agente someterá al interesado, para una mayor garantía y a efecto de contraste, a la práctica de una segunda prueba de detección alcohólica por el aire espirado, mediante un procedimiento similar al que sirvió para efectuar la primera prueba, de lo que habrá de informarle previamente".
}

${ }^{250}$ Los cambios que la nueva redacción efectuada por el RGC/2003 se limitan a aspectos formales, como es el que los apartados de los arts. 21 y 24 RGC/2003 se ordenan de manera alfabética, y no numérica. Relevancia tiene, sí, el hecho del cambio de consideración de estas infracciones que pasan a merecer, siguiendo lo establecido en el art. 65.5 a) y b) LTSV (tras la Ley 5/1997, de 24 de marzo), la calificación de muy graves, en lugar de la de grave que aparecía en el RGC/1992, modificación que, a pesar del tiempo transcurrido, no se había al texto del referido RGC/1992.

${ }^{251}$ Publicada en el Boletín Oficial del Estado del 31 de diciembre de 2003. 
Generales del Estado para el año 2004, que en lo concerniente a gestión en materia de tráfico y seguridad vial supone la modificación de la Ley de Tráfico y seguridad Vial ${ }^{252}$.

No es este el momento de entrar a valorar en profundidad esta inapropiada forma de legislar que, en este caso, va a significar la modificación de cinco artículos de la Ley de Tráfico y seguridad Vial, cuatro de los cuales se encuentra ubicados en el espacio destinado a la regulación del régimen sancionador (arts. 67, 71 bis, 72 y 81 LTSV), pero si resulta curioso, y por ello precisamente digno de mención, que una reforma que recae sobre el régimen de sanciones y su anotación, la medidas cautelares que pueden ser adoptadas y personas responsables, sea calificada como una reforma en materia de gestión en materia de tráfico y seguridad vial.

Sea como fuere, y se enuncie como se quiera, la Ley de medidas que acompaña y corteja a la Ley de Presupuestos Generales para el año 2004, por medio del art. 71 y bajo la rúbrica, como se ha señalado, "gestión en materia de tráfico y seguridad vial", introduce una modificación en las normas que regulan el adelantamiento (art. 34.4 LTSV) y nueve innovaciones en aspectos del régimen sancionador, de las cuales seis recaen en el art. 67 LTSV, una adición en las previsiones efectuadas en materia de medidas cautelares que supone la incorporación de la medida cautelar de intervención del permiso o licencia de conducción (con la incorporación a la norma de un nuevo art. 71 bis LTSV), otra modificación en cuanto a las personas responsables (en el art. 72 LTSV) y, finalmente, un alteración en cuanto a las previsiones que regulan la anotación de sanciones por infracciones graves y muy graves en el Registro de Conductores e Infractores (art. 82 LTSV).

Las modificaciones realizadas suponen, en lo que aquí interesa:

- Imposibilidad de obtener la autorización administrativa para conducir y depósito obligatorio del vehículo: La conducción sin la autorización administrativa llevará aparejada la imposibilidad de obtener el permiso o licencia de conducción durante un año, así como el depósito obligatorio del vehículo cuando éste sea de titularidad del conductor o de quienes ostenten su custodia o guarda legal o de persona que hubiere autorizado su utilización por un tiempo de un mes, que será de tres meses en caso de reincidencia (nuevo párrafo tercero del art. 67.2 TSV)

- Reincidencia: Se establece que, los efectos del art. 67 LTSV, se reputarán reincidentes a quienes hubieran sido sancionados en firme en vía administrativa por dos infracciones muy graves de las previstas en el artículo 65.5 LTSV, siempre que sus antecedentes no se hubieren cancelado o hubieren debido serlo en el plazo de dos años en los términos establecidos en el artículo 82 de esta Ley (art. 67.3 párrafo segundo LTSV)

\footnotetext{
${ }^{252}$ Cfr. Tal y como se señala en el párrafo primero del apartado I y en el párrafo séptimo del apartado $\mathrm{V}$ de la Exposición de Motivos de la propia Ley 62/2003, de 30 de diciembre.
} 
- Sobre la revocación de autorizaciones administrativas y la realización de cursos de sensibilización: No se procederá a la revocación del permiso o licencia de conducción prevista en este apartado cuando el titular de la autorización solicite la realización de un curso de reciclaje y sensibilización en centro autorizado para ello y acredite haberlo superado con aprovechamiento dentro del plazo y en las condiciones que reglamentariamente se determinen. En tal caso, la revocación del permiso o licencia de conducción se sustituirá por la sanción de suspensión de los mismos durante un año con carácter continuado (art. 67.3 párrafo tercero LTSV)

- Revocación de licencia de conducción de ciclomotores y posibilidad de obtener un permiso de conducción: A los titulares de licencias de conducción de ciclomotores que hubieran sido sancionados en firme en vía administrativa por dos infracciones graves en el plazo de dos años, o por una muy grave, les será revocada la mencionada licencia, sin perjuicio de que puedan obtener un permiso de conducción (nuevo art. 67.5 LTSV)

- Revocación del permiso de conducción por la comisión de infracciones: Durante los dos años siguientes a la obtención del permiso de conducción, el haber sido sancionado en firme en vía administrativa por la comisión de tres infracciones graves o dos muy graves, supondrá la revocación del permiso de conducción, sin que pueda obtener un nuevo permiso hasta transcurrido el plazo de un año desde la firmeza de la resolución (nuevo art. 67.6 LTSV)

- Comisión de infracciones y suspensión de la autorización sin posibilidad de fraccionamiento: El que en el período de dos años, hubiere sido sancionado en firme en vía administrativa como autor de tres infracciones, siendo una de ellas grave y habiendo supuesto las otras dos la suspensión del permiso de conducción, deberá cumplir la sanción de suspensión de la autorización administrativa para conducir que le correspondiere por la última infracción, sin posibilidad de fraccionamiento (nuevo art. 67.7 LTSV)

- Posibilidad de intervención del permiso o licencia de conducción: se establece que cuando el agente de la autoridad compruebe que el conductor infractor o implicado en un accidente presente, además, síntomas evidentes de que ha perdido las condiciones físicas necesarias para conducir, intervendrá de manera inmediata el permiso o la licencia de conducción, sin perjuicio de la iniciación del procedimiento para declarar la pérdida de vigencia de autorizaciones, según lo dispuesto en el artículo $63 \mathrm{y}$, en su caso, de la iniciación del oportuno expediente sancionador (nuevo art. 71 bis LTSV)

- Acreditación del infractor por la empresas de alquiler de vehículos: Las empresas de alquiler sin conductor acreditarán el cumplimiento de la obligación legal de identificar al conductor responsable de la infracción mediante la remisión, al órgano instructor correspondiente, de un duplicado o 
copia del contrato de arrendamiento donde quede acreditado el concepto de conductor de la persona que figure en el contrato (art. 72.3 LTSV)

- Inscripción y cancelación de antecedentes en el registro de Conductores e infractores: Las sanciones graves y muy graves firmes en vía administrativa serán anotadas en el Registro de Conductores e Infractores el día de su firmeza, y las anotaciones se cancelarán de oficio, a efectos de antecedentes, una vez transcurridos dos años desde su total cumplimiento o prescripción (art. 82 LTSV)

Los párrafos que se acaban de detallar son significativos, desbordan esa pretendida "gestión" a la que se hace referencia en la Exposición de Motivos de la norma reformadora y suponen importantes cambios en la estructura del régimen sancionador preexistente.

Se trata, en definitiva, de una remodelación del sistema de suspensión y cancelación de las autorizaciones administrativas del que, habiendo existido desde la redacción originaria de la LTSV, no se había hecho uso en la práctica.

Las modificaciones del paradigmático (y casi esotérico) art. 67 LTSV parece que quieran apuntar en la dirección de dar cierto orden y sentido a la medida sancionadora de suspensión de las autorizaciones administrativas para conducir. Una lectura bienintencionada de las modificaciones efectuadas y una comparación compasiva con la redacción previa permite percatarse tanto del intento de ajustar técnicamente el régimen de la suspensión de autorizaciones (como sanción) mediante la objetivación de sus causas (determinación de infracciones en términos cuantitativos y cualitativos y de la reincidencia) y de sus efectos (suspensión, revocación y, en su caso, imposibilidad de nueva obtención de las autorizaciones), como de lo inadecuado e imperfecto del trabajo realizado.

Pero, con todo y aunque no aflore a la práctica, el avance es mucho más importante de lo que pudiera parecer. En el fondo de la reforma, pero sin querer abordarla de una manera diáfana y directa se están poniendo las bases para que se pueda establecer una relación objetiva entre la comisión de infracciones y la pérdida de la autorización que habilita para conducir. $Y$ ya no por como consecuencia de la comisión de una infracción grave o muy grave. Se están estableciendo de una forma excesivamente rudimentaria (no tanto por la forma como por su percepción) como la comisión de infracciones graves o muy graves y tomando en consideración las características del titular de la autorización y cual sea esa autorización (antigüedad del permiso, licencias o permisos de conducción, historial infractor) deba suponer la suspensión de la autorización o su revocación.

Es cierto que la confusión lo impregna absolutamente todo en un precepto en el que, bajo la rúbrica sanciones, ha tenido cabida absolutamente todo. Y por ello resulta muy difícil determinar la naturaleza de la medida de revocación de la autorización 
administrativa. Sancionadora conforme a la propia ubicación en la LTSV, pero que bien pudiera admitir su consideración como medida de pérdida de vigencia si se parte de la hipótesis de que la reincidencia no hace sino intentar objetivar que se ha acreditado la desaparición de los requisitos sobre conocimientos, habilidades o aptitudes psicofísicas exigidas para el otorgamiento de la autorización, como establecía en ese momento (y establece ahora) el art. 63.4 LTSV, precepto al que, por supuesto, ninguna mención se hacía desde el art. 67 LTSV cuando se lanzaban todos esos perdigonazos que, por muy buena intención que tuvieran, era bastante difícil que pudieran alcanzar objetivo alguno.

Muestra del fuego indiscriminado que esta reforma supone es la incorporación al texto legal de un nuevo artículo, el art. 71 bis LTSV, que permitía al agente de la autoridad la intervención automática del permiso o licencia de conducción. Los términos en los que se encontraba redactado ese art. 71 bis LTSV bien merecen su completa y literal reproducción:

Cuando el agente de la autoridad compruebe que el conductor infractor o implicado en un accidente presente, además, síntomas evidentes de que ha perdido las condiciones físicas necesarias para conducir, intervendrá de manera inmediata el permiso o la licencia de conducción, sin perjuicio de la iniciación del procedimiento para declarar la pérdida de vigencia de autorizaciones, según lo dispuesto en el artículo 63 y, en su caso, de la iniciación del oportuno expediente sancionador.

Son, sin duda, términos mucho más propios de épocas pasadas que del año 2004 en el que comienza la vigencia de una norma que no deja en pie principio alguno, ni del tráfico, ni del procedimiento administrativo general ${ }^{253}$.

\section{Ñ) La Ley 17/2005, de 19 de julio, del permiso y licencia de conducción por puntos}

\section{UBICACIÓN DE LA REFORMA}

Desconocemos hacia donde iba dirigida, y hasta donde hubiera llegado, la reforma incidentalmente efectuada en la Ley de Tráfico y Seguridad Vial por medio de la Ley

\footnotetext{
253 Este precepto merecería un estudio mucho más sereno y detallado. Sea suficiente señalar que deposita esa competencia exorbitante en cualquier agente de la autoridad, y no ya en aquellos que, de manera específica, están encargados de la vigilancia del tráfico; que el presunto responsable pasa a ser, directamente, infractor; Que se atribuyen al agente de la autoridad competencias para determinar que una persona ha perdido las condiciones físicas para conducir; que se le permite imponer una medida que, por mucho que se califique de cautelar, se parece más a una sanción de plano; y el final del precepto, advirtiendo, en una terminología que parece más propia de de la posibilidad que de la obligatoriedad, que esa actuación lo es sin perjuicio de la iniciación del procedimiento para declarar la pérdida de vigencia de autorizaciones y, en su caso, de la iniciación del oportuno expediente sancionador.
} 
$62 / 2003$, de 30 de diciembre, y que tras año y medio de inusual estabilidad ${ }^{254}$ en la regulación de este ámbito va a dar paso a la Ley 17/2005, de 19 de julio, del carnet de conducir por puntos y se modifica el texto articulado de la ley sobre tráfico, circulación de vehículos a motor y seguridad vial ${ }^{255}$.

Es cierto que en diciembre de 2003, y de manera coetánea a la tramitación de la Ley $62 / 2003$, de 30 de diciembre, de medidas fiscales, administrativas y del orden social, que introduce los cambios que se acaban de señalar, se produce la aprobación por la Comisión de Justicia e Interior del Congreso de los Diputados del Informe de la Subcomisión de Seguridad Vial y Prevención de Accidentes de Tráfico ${ }^{256}$ de 16 de diciembre de 2003 en el que se había formulado, de manera expresa, como una de las propuestas en el marco de la planificación e investigación, a estudiar la conveniencia de la implantación de un permiso de conducción por puntos, así como las posibles medidas reeducadoras asociadas a este sistema ${ }^{257}$.

Esta cuestión, la del debate sobre la oportunidad de implantación en nuestro sistema un permiso de conducir por puntos no constituía novedad alguna. Desde el año 2001 se habían formulado proposiciones sobre la necesidad de articular ese sistema, incluso, se habían llegado a aprobar resoluciones en las que, de manera expresa, se instaba al Gobierno a estudiar el permiso por conducir por puntos, dinámica que va a continuar tras las elecciones generales celebradas en 2004 con nuevas propuestas sobre la introducción del permiso por puntos ${ }^{258}$.

\footnotetext{
${ }^{254}$ Estabilidad normativa que no es casual dado que su origen se encuentra en el cambio de Gobierno producido tras las elecciones generales celebradas en marzo de 2004 y que conllevan un cambio en la DGT.

255 Publicada en el BOE de 20 de julio de 2005.

${ }^{256}$ Esta Subcomisión de la Comisión de Justicia de Interior (VII Legislatura) había sido constituía el 22 de mayo de 2002 y funcionó hasta concluir este informe, siendo disuelta el 18 de diciembre de 2003.

El Grupo Parlamentario CiU había presentado, el 28 de marzo de 2001, una propuesta de creación de una Subcomisión, dentro de la Comisión de Justicia e Interior, sobre Seguridad Vial y Prevención de Accidentes de Tráfico (núm. expediente 158/000026). La Mesa del Congreso de los Diputados, en su reunión de 3 de abril de 2001, la admitió a trámite y acordó remitirla a la Comisión de Justicia e Interior que, en su sesión del 11 de diciembre de 2001, aprobó la propuesta de creación de una Subcomisión sobre seguridad vial y prevención de accidentes de tráfico.

${ }^{257}$ El informe de la subcomisión sobre seguridad vial y prevención de accidentes de tráfico (con número de expediente 154/000010), al que se habían formulado varios votos particulares por diversos grupos parlamentarios, fue objeto de discusión y aprobación en la sesión de la Comisión de Justicia e Interior del Congreso de los Diputados celebrada el día 16 de diciembre de 2003, informe que resultó aprobado por 24 votos a favor, 13 en contra y una abstención (Diario de Sesiones del Congreso de los Diputados, Comisiones, VII Legislatura, 2003, núm. 892, pág. 28292).

${ }^{258}$ Véase, a título de ejemplo de lo que aquí se señala, el Diario de Sesiones del Congreso de los Diputados, Comisiones, Comisión no permanente sobre seguridad vial y prevención de accidentes de tráfico, VIII Legislatura, Sesión de 24 de noviembre de 2004, en la que se dos proposiciones no de Ley sobre esta cuestión. Una por la que se instaba al Gobierno a reducir la siniestralidad mediante el establecimiento del permiso de conducción por puntos (presentada por el Grupo Parlamentario Convergència i Unió, con número de expediente 161/000085) y otra sobre el establecimiento del carné por puntos (presentada por el Grupo Parlamentario Socialista del Congreso, con número de expediente 161/000216) que fueron debatidas de forma conjunta y aprobadas por unanimidad.
} 


\section{LA IMPLANTACIÓN Y JUSTIFICACIÓN DEL SISTEMA}

La Ley 17/2005, de 19 de julio, del carnet de conducir por puntos, supone muchos cambios en cuanto a la forma en la que, hasta la fecha, se habían efectuado la incorporación y reforma de las regulaciones en materia de tráfico y seguridad vial.

Desde un punto de vista formal resulta fácil constatar que las normas que habían incidido en el ámbito de tráfico, incluidas las Ley de Bases y la propia LTSV, no se habían caracterizado por dar excesivas explicaciones sobre los cambios que se abordaban y las regulaciones que se efectuaban. Las exposiciones de motivos (que ni siquiera recibían formalmente esa denominación) no eran ni extensas ni pródigas en explicar lo que se hacía, ni en justificar las razones que a ello llevaban, guardando silencio, en muchas ocasiones, sobre la motivación de los cambios que se introducían.

La Ley 17/2005, de 19 de julio, supone un cambio importante en este aspecto, pues el legislador anticipa en la Exposición de Motivos todos y cada uno de los preceptos que se ven alterados, da noticia de las disposiciones adicionales que se incorporan (si bien es cierto que sin analizarlas individualmente) y se refiere a los dos Anexos que se incorporaran al texto legal. Actuación digna de elogio y mención aunque tal actitud no entrañe de por sí que todas estas explicaciones resulten afortunadas e, incluso, que en algunos casos esas justificaciones sean incoherentes, cuando sucede al definir el concepto del sistema del permiso por puntos se señala, como característica esencial, "su carácter eminentemente reeducar" para, pocas líneas después señalar "su efecto punitivo", lo que ocasiona que la explicación que se da resulte ambigua ${ }^{259}$, cuestión que tendremos ocasión de examinar en el marco del análisis de la naturaleza del permiso por puntos.

El inicio de la Exposición de Motivos de la Ley 17/2005, de 19 de julio, del carnet de conducir por puntos, es ciertamente cauteloso, ya que, en lugar de afirmar de forma rotunda el objetivo que se persigue, se hace un uso retórico del lenguaje para señalar que:

\footnotetext{
"Se pretende con esta Ley establecer un sistema que ha dado en denominarse «permiso y licencia de conducción por puntos» y que, incidiendo sobre las autorizaciones administrativas para conducir, sea la combinación de dos elementos esenciales".
}

Esos dos elementos esenciales son, tal y como se señala al inicio de la propia Exposición de Motivos de la Ley, en primer lugar, "su carácter eminentemente reeducador al configurar el cauce adecuado para modificar aquellos comportamientos, mediante la realización de cursos de sensibilización y reeducación vial de los

\footnotetext{
${ }^{259}$ Cfr. T. CANO CAMPOS, El régimen jurídico - administrativo del tráfico, Madrid, Civitas, 2010, 2a ed.,
} pág. 499. 
conductores multirreincidentes" $y$, en segundo lugar, "su efecto punitivo para aquellos comportamientos, consistente en la disminución o pérdida del crédito en puntos con que cuenta un conductor, titular de permiso o licencia de conducción".

A ello se une (a falta de una auténtica definición de lo que es el permiso por puntos) lo que son esos puntos que dan nombre y sobre los que se asienta el sistema, que se conceptualizan como "reflejo del nivel de confianza que como tal conductor le otorga la sociedad en un momento dado y cuya pérdida, a su vez, señala el reproche que tales conductas merecen, derivado y con un claro sustento en la reiterada comisión de infracciones".

A la consecución de ese objetivo se dirigen los cambios efectuados en el articulado de la Ley de Tráfico y Seguridad Vial.

\section{LA ARQUITECTURA DE LA REFORMA}

Desde la perspectiva del sistema normativo planteado por la Ley de Tráfico y Seguridad Vial la Ley $17 / 2005$, de 19 de julio, del carnet de conducir por puntos, se constituye, desde un punto de vista cronológico, en la segunda gran reforma, tras la realizada por la Ley $19 / 2001$, de 19 de diciembre ${ }^{260}$, la más importante de las realizadas hasta la fecha y una de las piezas claves sobre las que se asienta la vigente regulación del tráfico como fenómeno y de la seguridad vial como garantía.

\section{a) La vigencia del permiso o licencia}

A la previsión establecida en el art. 60.4 LTSV conforme a la que "el permiso y la licencia para conducir podrán tener vigencia limitada en el tiempo, pudiendo ser revisado en los plazos y condiciones que reglamentariamente se determinen" se añade que esa vigencia "estará condicionada a que su titular no haya perdido su asignación total de puntos".

Se asignan, al titular del permio o licencia, unos puntos y para que esa licencia mantenga su vigencia resulta preciso que se mantenga alguno de esos puntos, es decir, que no se lleguen a perder todos.

La reforma del art. 60 LTSV supone la adición de nuevos párrafos al apartado 4 así como la adición de los apartados 5 y 6 en los que se establece la mecánica del sistema en cuanto a la adquisición y pérdida de puntos y que ese saldo de puntos se corresponde y, por lo tanto, afecta al permiso o licencia de conducción cualquiera que sea su clase.

${ }^{260}$ Véase, en este mismo capítulo, el apartado IV.K) sobre la ley 19/2001, de 19 de diciembre. 
b) La declaración de pérdida de vigencia por la pérdida de la totalidad de los puntos

En el art. 63 LTSV se añaden tres nuevos apartados (del 6 al 8) en los que se regula la forma en la que se ha de llevar a efecto la declaración de pérdida de vigencia de la autorización administrativa cuando el titular se queda sin puntos así como los plazos a los que queda sometida la obtención de una nueva autorización.

En la regulación de este procedimiento de declaración de pérdida de vigencia del permiso o licencia se hace referencia al Anexo II LTSV en el que se recogen las infracciones que dan lugar a la pérdida de puntos, la necesidad de superar un curso de sensibilización y reeducación vial y posterior superación de las pruebas que reglamentariamente se determinen y la consideración de la condición de conductor profesional como razón que va suponer la reducción a la mitad de los plazos establecidos para la recuperación de la autorización administrativa que habilita la conducción, concepto que a efectos de la LTSV, y aunque no se indica, se encuentra definido en la disp. adic. Tercera LTSV como "toda persona provista de la correspondiente autorización administrativa para conducir, cuya actividad laboral principal sea la conducción de vehículos a motor dedicados al transporte de mercancías o de personas, extremo que se acreditará mediante certificación expedida por la empresa para la que ejerza aquella actividad, acompañada de la correspondiente documentación acreditativa de la cotización a la Seguridad Social como trabajador de dicha empresa" a lo que se añade que "si se trata de un empresario autónomo, la certificación a que se hace referencia en el párrafo anterior será sustituida por una declaración del propio empresario".

\section{c) Modificación del cuadro general de infracciones}

La definición de un sistema de permiso por puntos se fundamenta en la atribución de de una serie de punto al titular de la autorización administrativa que pierde por la comisión de determinadas infracciones. La creación de un catálogo de infracción cuya comisión lleva aparejada la pérdida de puntos, y dado que no todas las infracciones graves y muy graves van a llevara aparejada la pérdida de puntos, requiere de una adecuada sistematización del cuadro de infracciones establecido en el art. 65 LTSV.

Por ello, de la instauración del permiso por puntos y la determinación de las infracciones cuya comisión supone la pérdida de puntos, va a suponer varios efectos sobre ese cuadro de infracciones. 
- Va a suponer una sistematización y reordenación de las infracciones previstas que, en algunos casos, se va a traslucir en su recalificación ${ }^{261}$

- Va a significar la tipificación de nuevas infracciones, tanto por la redefinición y ampliación de las ya existentes, como por la creación de nuevas infracciones ${ }^{262}$

${ }^{261}$ El centro de gravedad del cuadro de infracciones se encuentra ubicado en las infracciones que merecen la califican de graves. Hasta la reforma efectuada por la Ley 17/2005, de 19 de julio, el apartado destinado a las infracciones graves (art. 65.4 LTSV) contenía seis letras - de la a) a la f)- que, tras la reforma, pasa a contar con dieciocho -hasta la letra q)- y lo mismo su cede con las infracciones calificadas como muy graves (art. 64.5 LTSV) que pasa de tener ocho letras - de la a) a la h)- a disponer de diecisiete -llegando hasta la letra p)-.

Además, la modificación del art. 67 LTSV va a suponer que las infracciones no calificadas que allí se ubicaban se incorporen al cuadro general de infracciones, con la calificación de muy graves (Cfr. párrafo 22 de la Exposición de Motivos de la Ley 17/2005, de 19 de julio) tal y como se detalla en la siguiente nota.

${ }^{262}$ En el caso de las infracciones de las infracciones graves supone la calificación como tales de las siguientes letras:

c) Circular sin el alumbrado reglamentario en situaciones de falta o disminución de visibilidad o produciendo deslumbramiento a otros usuarios de la vía y en aquellos supuestos en los que su uso sea obligatorio (en cuanto a este último inciso)

d) Realización y señalización de obras en la vía sin permiso, y retirada o deterioro de la señalización permanente u ocasional.

e) Conducir utilizando dispositivos incompatibles con la obligatoria atención permanente a la conducción en los términos que se determinen reglamentariamente.

f) Conducir utilizando cascos o auriculares conectados a aparatos receptores o reproductores de sonido, el uso durante la conducción de dispositivos de telefonía móvil, así como cualquier otro medio o sistema de comunicación que implique su uso manual, en los términos que se determine reglamentariamente, con las excepciones por motivos específicos relacionados con la seguridad, higiene o prevención laboral.

g) Conducir vehículos que tengan instalados mecanismos o sistemas encaminados a eludir la vigilancia de los agentes de tráfico, o que lleven instrumentos con la misma intención, así como la utilización de mecanismos de detección de radar.

h) Conducir un vehículo o circular sus ocupantes sin hacer uso del cinturón de seguridad, el casco y demás elementos de protección o dispositivos de seguridad de uso obligatorio en las condiciones y con las excepciones que se establezcan reglamentariamente.

i) Circular con menores de 12 años como pasajeros de ciclomotores o motocicletas con las excepciones que se determinen reglamentariamente.

j) No respetar las señales de los agentes que regulan la circulación (infracción específica en materia de prioridad y señalización).

k) No respetar la luz roja de un semáforo (infracción específica en materia de prioridad y señalización).

I) No respetar una señal de stop (infracción específica en materia de prioridad y señalización).

m) Que el adquiriente de un vehículo no solicite la renovación del permiso o licencia de circulación, cuando varíe su titularidad registral, en el plazo que se establezca reglamentariamente (extraía del art. 67 LTSV).

n) Conducir un vehículo siendo titular de una autorización de conducción que carece de validez por no haber cumplido los requisitos administrativos exigidos reglamentariamente (extraía del art. 67 LTSV).

q) Circular con un vehículo que incumpla las condiciones técnicas reglamentariamente establecidas, salvo que pudieran estimarse incluidas en el apartado 5.I) siguiente, así como las infracciones relativas a las normas que regulan la inspección técnica de vehículos (extraía del art. 67 LTSV). 


\section{d) Modificación del régimen de sanciones}

Se produce la modificación del art. 67 LTSV que (como ya se ha señalado) bajo la rúbrica de sanciones se había convertido, desde su redacción originaria, en un auténtico cajón de sastre.

El establecimiento del permiso por puntos supone la desaparición de varios de los contenidos que encontraban cobijo en el art. 67 LTSV dado que la redacción anterior, en especial la procedente de la Ley 62/2003, de 30 de diciembre, "lo hacía incompatible con el sistema del permiso y la licencia por puntos, que se establece con esta Ley" ${ }^{263}$, lo que va a suponer la eliminación de las previsiones que, por medio de aquella norma, se habían introducido sobre revocación de autorizaciones y reincidencia.

Y, esta oportunidad, no es desaprovechada por el legislador para realizar otras revisiones de este precepto como son:

En el caso de las infracciones muy graves supone la atribución de esta calificación a las conductas que se incorporan al art. 65.5 LTSV con las letras i) a p):

i) El incumplimiento por el titular o el arrendatario del vehículo con el que se haya cometido la infracción de la obligación de identificar verazmente al conductor responsable de dicha infracción, cuando sean debidamente requeridos para ello y no exista causa justificada que lo impida (infracción que pasa de la calificación de grave a la de muy grave y a laque, además, se le asocia una sanción de entre 301 y hasta $1.500 €$ por el art. 67.2 LTSV)

j) La conducción de un vehículo sin ser titular de la autorización administrativa correspondiente (extraía del art. 67 LTSV y que puede ser sancionada con multa de entre 301 y hasta $1.500 €)$.

k) Circular con un vehículo no matriculado o careciendo de las autorizaciones administrativas correspondientes, o que éstas carezcan de validez por no cumplir los requisitos exigidos reglamentariamente (extraía del art. 67 LTSV y que puede ser sancionada con multa de entre 301 y hasta $1.500 €)$.

I) Circular con un vehículo que incumpla las condiciones técnicas que afecten gravemente a la seguridad vial, establecidas reglamentariamente (extraía del art. 67 LTSV y que puede ser sancionada con multa de entre 301 y hasta $1.500 €)$.

m) Incumplir las normas, reglamentariamente establecidas, sobre el régimen de autorización y funcionamiento de los centros de enseñanza y formación, sobre conocimientos y técnicas necesarios para la conducción (extraía del art. 67 LTSV y que puede ser sancionada con multa de entre 301 y hasta $1.500 €)$.

n) Incumplir las normas, reglamentariamente establecidas, sobre el régimen de autorización y funcionamiento de los centros de reconocimiento de conductores (extraía del art. 67 LTSV y que puede ser sancionada con multa de entre 301 y hasta $1.500 €$ ).

ñ) Incumplir las normas, reglamentariamente establecidas, que regulan las actividades industriales que afectan de manera directa a la seguridad vial (extraía del art. 67 LTSV y que puede ser sancionada con multa de entre 301 y hasta $1.500 €)$.

o) Circular por autopistas o autovías con vehículos expresamente prohibidos para ello.

p) Circular en posición paralela con vehículos prohibidos expresamente para ello por esta Ley.

263 Tal y como se advierte, de manera expresa, en la propia Exposición de Motivos (apartado 19)de la Ley $17 / 2005$, de 19 de julio. 
- La actualización de las cuantías eliminado las fracciones de euros y su referencia a pesetas a cantidades de euros sin que ello suponga, como se señala en la Exposición de Motivos, "un aumento de dichas cuantías, antes al contrario, un descenso poco significativo de éstas, salvo las que se señalan en el apartado 2, cuya cuantía en su grado mínimo se hace congruente con su nueva calificación" ${ }^{264}$.

- Determinación del plazo de un mes como límite mínimo para las suspensiones de las autorizaciones para conducir, cuyo cumplimiento podrá realizarse de manera fraccionada, a petición del interesado, en períodos que en ningún caso serán inferiores a 15 días naturales, fraccionamiento que podrá ser por plazos inferiores (a esos quince días) en el caso de los conductores profesionales, siempre que éstos lo soliciten y el cumplimiento íntegro de la sanción se realice en el plazo de doce meses desde la fecha de la resolución de la suspensión y la exclusión de su cumplimiento fraccionado en los casos de reincidencia (entendiendo por tal cuando en un período de dos años hubiera sido sancionado en firme en vía administrativa como autor de dos infracciones que lleven aparejada la suspensión de las autorizaciones).

- Resolver el conflicto sobre los efectos y condiciones del pago voluntario acogiéndose al beneficio de reducción del 30 por 100 en la multa, determinado que "implicará únicamente la renuncia a formular alegaciones y la terminación del procedimiento sin necesidad de dictar resolución expresa, sin perjuicio de la posibilidad de interponer los recursos correspondientes" y "siempre que dicho pago se efectúe durante los 30 días naturales siguientes a aquel en que tenga lugar la citada notificación ${ }^{265}$.

- La eliminación de las infracciones que, desde la redacción originaria, se habían introducido en este artículo y que ahora se trasladan, como infracciones muy graves, al cuadro general de infracciones del art. 65 LTSV.

- La determinación de una sanción singular para la infracción muy grave consistente en la conducción de un vehículo sin ser titular de la autorización administrativa correspondiente del art. 65.5 j) LTSV, por "la especial peligrosidad que tal comportamiento conlleva y que se estima merecedor de la adecuada respuesta punitiva" ${ }^{266}$.

\footnotetext{
${ }^{264}$ Cfr. el párrafo veinte de la Exposición de Motivos de la Ley 17/2005, de 19 de julio.

Como puede comprobarse en la nota anterior las sanciones a las que se hace referencia (las correspondientes al art. 67.2 LTSV) son, precisamente, las que se habían llevado de la antigua redacción del art. 67.2 LTSV a las letras j), k), I), m), n) y ñ) del nuevo art. 65.5 LTSV, supuestos a los que se añade el previsto en el art. 65.5 i) LTSV, que es la infracción del incumplimiento de identificación veraz del conductor de la infracción objeto de denuncia.

${ }^{265}$ Previsión que viene determinada por la STS de

${ }^{266}$ Cfr. el párrafo veintidós de la Exposición de Motivos de la Ley 17/2005, de 19 de julio.
} 


\section{e) Graduación de las sanciones}

La Ley 17/2005, de 19 de julio, del carnet de conducir por puntos, modifica los términos en los que, originariamente se había establecido, en el art. 69 LSV, la regulación de la graduación de las sanciones.

Los cambios introducidos en el párrafo primero introducen cuatro matices importantes sobre la forma en la que han de graduarse las sanciones:

- Que esa graduación tendrá que mantener la "debida adecuación" entre la gravedad y trascendencia del hecho

- Que esa graduación tendrá presentes los antecedentes del infractor (lo que ya se indicaba) "y su condición de reincidente"

- Que esa graduación tomará en consideración todos los elementos del peligro potencial creado y, por tanto, habrá de incluir los que se generen tanto "para los demás usuarios de la vía" como "para él mismo" infractor

- Que esa graduación se realizará conforme "al criterio de proporcionalidad"

- Y todo ello dentro de los "límites establecidos en el art. 67 LTSV".

"Debida adecuación" (entre gravedad y trascendencia del hecho), "condición de reincidencia", entendimiento del peligro potencial creado con inclusión de todos los que se hubieran generado, incluyendo el "creado para el mismo (infractor)", "criterio de proporcionalidad" y "limites" legalmente establecidos para las sanciones. Todos ellos conceptos deducibles pero sobre los que, sin lugar a dudas, resulta mucho más adecuada su expresa incorporación al texto legal.

El otro cambio, meramente formal, es la sustitución de la referencia que se efectuaba a la Ley de Procedimiento Administrativo de 1958 por la correspondiente a la LRJ PAC, sustitución que no había sido efectuado, por las razones que fuera, como el resto de remisiones que la redacción originaria de la LTSV realizaba a la LPA por la Ley 19/2001, de 19 de diciembre.

\section{f) Responsabilidad}

Las modificaciones que se efectúan en el art. 72 LTSV suponen cambios significativos en cuanto a la determinación del sujeto responsable de la infracción. Con la modificación introducida por medio de la Ley 17/2005, de 19 de julio, del carnet de conducir por puntos, se mantiene la norma general de la responsabilidad por autoría, pero matizada para determinados supuestos en función de las circunstancias concurrentes. Al mismo tiempo, se precisan los contornos de la responsabilidad solidaria de las personas bajo cuya responsabilidad se encuentran los menores de edad 
respecto a las infracciones cometidas por estos que se había ido definiendo por las Leyes 19/2001, de 19 de diciembre, y por la Ley 62/2003, de 30 de diciembre. Y, de igual manera, se concreta, dando una nueva definición, el deber de los titulares de los vehículos, a los que se equipara a los arrendatarios, de identificar al conductor responsable de la infracción.

\section{g) Responsabilidad de persona distinta a la que comete la infracción}

La norma general, como no puede ser de otra manera, de responsabilidad por la autoría de la infracción sigue siendo la base del sistema, pero se incorpora un supuesto específico por razón de las circunstancias que concurren en el propio tipo infractor.

Así, y conforme a lo establecido en el art. 47.1 LTSV, precepto que determina que "Ios conductores y ocupantes de vehículos a motor y ciclomotores están obligados a utilizar el cinturón de seguridad, el casco y demás elementos de protección en los casos y en las condiciones que reglamentariamente se determinen" y el art. 118.1 párrafo primero RGC, que prescribe que "los conductores y pasajeros de motocicletas o motocicletas con sidecar, de vehículos de tres ruedas y cuadriciclos y de ciclomotores deberán utilizar adecuadamente cascos de protección homologados o certificados según la legislación vigente, cuando circulen tanto en vías urbanas como en interurbanas" 267 , es claro que la infracción se comete por la persona obligada a hacer uso del casco, de manera que siendo el ocupante de la motocicleta el destinatario de la norma y siendo él quien la incumple por no hacer uso de ese elemento de seguridad, la responsabilidad por la comisión de esa infracción se traslada al conductor del vehículo, decisión perfectamente justificable desde la utilización práctica de este tipo de vehículos, ya que resulta absolutamente razonable exigir a quien conduce una motocicleta que el ocupante (u ocupantes en el caso de motocicletas con sidecar) utilicen el casco, tan razonable como no transportar en la motocicleta a quien no haga uso de ese elemento de seguridad.

Y, del mismo modo, esa traslación de la responsabilidad del ocupante - infractor al conductor de la motocicleta encuentra cobertura en las propias normas generales a las que se encuentran sometidos los conductores, ya que el art. 11 LTSV (y el concordante art. 18.1 RGC) establece que el conductor de un vehículo tiene el deber de que su conducción garantice "su propia seguridad, la del resto de ocupantes del vehículo y la de los demás usuarios de la vía", norma general que, para el caso de los conductores

\footnotetext{
${ }^{267}$ Téngase en cuenta que la redacción del art. 118.1 párrafo primero RGC de la que aquí se hace uso es la vigente al momento de la entrada en vigor de la reforma efectuada por la Ley 17/2005, de 19 de julio, y que ese art. 118.1 párrafo RGC fue modificado por el RD 965/2006, de 1 de septiembre, que fijo su redacción, vigente en este momento, en los siguientes términos "Los conductores y pasajeros de motocicletas o motocicletas con sidecar, de vehículos de tres ruedas y cuadriciclos, de ciclomotores y de vehículos especiales tipo "quad", deberán utilizar adecuadamente cascos de protección homologados o certificados según la legislación vigente, cuando circulen tanto en vías urbanas como en interurbanas".
} 
de motocicletas y ciclomotores, no se compadece con permitir que el ocupante no haga uso del casco.

Dos son las críticas que, a mi juicio, merece la redacción de este precepto en el contexto temporal que se realiza. La primera es el tratamiento aislado de un caso (incumplimiento de la obligación del uso del casco por ocupante de ciclomotor) con ignorancia del resto de supuestos que deberían haberse englobado en esa previsión, ya que de ese caso específico se puede extraer (y es lo que se debería haber hecho) un regla general, como es la responsabilidad del conductor en el uso de elementos de seguridad cuando las circunstancias, como en este caso, impongan a ese conductor una especial obligación (responsabilidad) en su uso. Tal vez no haya base suficiente para trasladar al conductor de un turismo la responsabilidad del ocupante mayor de edad que no hace uso del cinturón de seguridad, pero, de igual forma, pocas dudas puede haber de la existencia de esa responsabilidad cuando un menor no hace uso del elemento de seguridad establecido, ya sea el propio cinturón o los sistemas de retención homologados ${ }^{268}$.

Por otra parte, y tratándose de tipos diferentes como son, de un lado "no hacer uso del elemento de seguridad establecido" y, de otro, que el conductor "permita que el ocupante no haga uso del elemento de seguridad establecido", tal vez resultaría más correcto establecer dos tipos distintos, uno para el infractor y otro para el conductor, como plus de coactividad dado que se trata de infracciones por la no utilización de los elementos de seguridad establecidos, de manera que ocupante (mayor de edad) y conductor fueran responsables, cada uno de ellos, de su conducta: el ocupante por no hacer uso y el conductor por permitirlo ${ }^{269}$.

\section{h) Responsabilidad solidaria en el caso de infracciones cometidas por los menores}

Desde la introducción en la Ley de tráfico y Seguridad Vial, por medio de la Ley 19/2001, de 19 de diciembre, de responsabilidad solidaria, respecto de las infracciones cometidas por menores de edad, de las personas a cuyo cargo se encuentran esos menores (padres, tutores, acogedores y guardadores legales o de hecho, por ese orden) ha sido preciso ir puliendo esa previsión.

En esa línea la Ley $17 / 2005$, de 19 de julio, del carnet de conducir por puntos, introduce dos cambios muy sutiles sobre esa responsabilidad solidaria limitada,

\footnotetext{
268 Línea esta, de traslación de la responsabilidad del infractor menor al conductor, en la que efectivamente se ha avanzado, tras la modificación efectuada en la LTSV (ahora en el art. 69), tras reforma efectuada por la Ley 23/2009, de 23 de noviembre, sin que ello signifique la vigente redacción sea, todavía, la adecuada.

${ }^{269}$ Sobre estas cuestiones véase el análisis que se realiza en el capítulo destinado al estudio de la responsabilidad por la comisión de infracciones de tráfico y, en particular, el apartado II.C) 2 sobre la responsabilidad del conductor del vehículo.
} 
estrictamente, a la pecuniaria derivada de la multa impuesta y que, en ningún caso iba a alcanzar a la suspensión del permiso o licencia o a la detracción de puntos.

El primero de esos cambio consiste en sustituir, en el art. 72.1 párrafo segundo LTSV, la expresión "cuando sea declarada la responsabilidad de los hechos cometidos por un menor de 18 años" por los términos "cuando la autoría de los hechos cometidos corresponda a un menor de 18 años", modificación que, como hemos indicado es muy fina y que, conlleva un cambio en la propia definición de la responsabilidad establecida, dado que autoría y responsabilidad, por infracciones de tráfico, suelen coincidir (esa es la norma general), pero no siempre.

Colocada esta previsión junto con la efectuada en el art. 72.1 párrafo primero LTSV, en los términos que para este precepto establece la propia Ley 17/2005, de 19 de julio, parece desprenderse que a quienes tienen el deber de custodia del menor se les impone, a partir de ahora la responsabilidad solidaria cuando su protegido sea el autor, pero ya no el responsable. Piénsese, en el caso del art. 72.1 párrafo primero LTSV en una motocicleta en la que conductor y ocupante son menores de edad. Conforme al art. 72.1 párrafo primero LTSV la responsabilidad por la comisión de la infracción del ocupante, por no hacer uso del casco, se traslada al conductor y de acuerdo a lo establecido en el inciso inicial del art. 72.1 párrafo segundo la responsabilidad solidaria con el menor lo es en caso de autoría. Esta duda se eleva a categoría de confusión cuando el propio inciso final del art. 72.1 párrafo segundo LTSV (que mantiene la redacción que ya tenía) determina que la razón de que se establezca esa responsabilidad solidaria lo es "en razón al incumplimiento de la obligación impuesta a éstos que conlleva un deber de prevenir la infracción administrativa que se impute a los menores", que introduce la "imputación" frente a "la autoría" como razón de esa responsabilidad solidaria que se establece.

Este planteamiento normativo plantea dudas en cuanto a cual sea la correcta interpretación en el supuesto planteado y quién sea el responsable de la infracción cometida por el menor ocupante de la motocicleta, si lo son los padres, tutores, acogedores y guardadores legales o de hecho del autor de la infracción (ocupante) o los del responsable de esa infracción (conductor de la motocicleta).

La segunda modificación, también de matiz, es que la imposición de sanciones por infracciones leves cometidas por menores y su sustitución, previo consentimiento de esas personas a las que corresponde la custodia del menor, por medidas sociales, requiere que esas medidas lo sean en el específico ámbito de la seguridad vial y que se trate no de cualquier tipo de medida reeducadora sino de "medidas sociales relacionadas con la seguridad vial".

\section{i) Equiparación de arrendatarios a titulares}

La reforma equipara al arrendatario del vehículo con el titular del mismo a efectos del deber de identificación del conductor que ha cometido, con ese vehículo, una 
infracción. Deber de identificación que, de igual manera, se traslada, caso de incumplimiento, a la infracción muy grave del art. 65.5 i) LTSV que tipifica, en el cuadro general de infracciones, ese incumplimiento del deber de identificación.

La norma que se introduce no permite distinguir más allá de la existencia de un arrendatario, sin diferenciar en razón del tipo de duración del contrato, por lo que todo arrendatario, desde el que contrata un vehículo para un día hasta el que lo hace para meses o años, son equiparados al titular del vehículo y soportan ese deber de identificación en la forma que se establece en el siguiente apartado.

\section{j) Deber de identificar al conductor - infractor}

El deber del titular del vehículo y ahora, también, del arrendatario, de identificar al conductor responsable de la infracción había sido introducido en la redacción originaria del art. 72 LTSV si bien sus perfiles se habían ido modificando con el paso del tiempo.

Esta obligación, la de identificar al conductor - infractor en aquellos supuestos en los que no se producía la detención del vehículo, se había encontrado (y se encuentra) con una correosa resistencia de manera que, en muchas ocasiones, el procedimiento sancionador terminaba en este punto. A ello ha contribuido, de manera muy importante, el desequilibrio que podría producirse entre la sanción que podía corresponder a ese infractor desconocido y la que el titular del vehículo podía recibir por incumplir con el deber que se le imponía de identificar al conductor que, con su vehículo, había cometido una infracción, infractor que podría ser incluso el propio titular del vehículo.

La raíz del problema siempre ha estado perfectamente identificada y sin que para ello sea necesario escarbar mucho para encontrarla. La regulación del supuesto no tenía en cuenta el principio de proporcionalidad que perfectamente expone el art. 131.2 LRJ $P A C$, ese conforme al que "el establecimiento de sanciones pecuniarias deberá prever que la comisión de las infracciones tipificadas no resulte más beneficioso para el infractor que el cumplimiento de las normas infringidas".

De ahí que resultara insuficiente la reforma efectuada por la Ley 19/2001, de 19 de diciembre, de imponer la sanción correspondiente a esa infracción grave en su cuantía máxima y que fuera preciso revisar, nuevamente, esa previsión.

La reforma que se efectúa por medio de la Ley 17/2005, de 19 de julio, implementa una serie de medidas con el fin de lograr un mayor grado de efectividad en ese deber de identificación del infractor.

Por una parte se modifica la calificación de la infracción que pasa a merecer la consideración de muy grave y ubicarse en el art. 65.5 i) LTSV y, que además, recibe un tratamiento especial en cuanto se establece que esta infracción puede ser sancionada con multa de 301 hasta 1.500 euros (art. 67.2 LTSV) y por otra ese deber de identificar 
al conductor responsable de la infracción pasa a ser "deber de identificar verazmente al conductor responsable de la infracción". A ello se une una tercera innovación por la que se establece el titular y el arrendatario responderán, pese a haber relacionado una identificación, "cuando no sea posible notificar la denuncia al conductor que aquéllos identifiquen, por causa imputable a ellos". Este conjunto de medidas modifican el deber de identificación, tal y como hasta ese momento estaba configurado, al establecer un plus con el objeto de disuadir al titular del vehículo, o al arrendatario, de la tentación de no cumplir con el deber de identificación siempre y cuando no exista una causa justificada que impida realizar esa identificación ${ }^{270}$.

Hubiera sido deseable una mayor concreción en cuanto a la sanción a imponer pues la horquilla establecida no parece ajustarse a todos los supuestos que, en la práctica, pueden producirse, quedando sometida, la determinación la concreta sanción, a lo establecido en el art. 69 LTSV sobre la graduación de las sanciones.

\section{k) Abono voluntario de la sanción acogiéndose al beneficio de reducción}

Se modifica el art. 77.2 LTSV, algo que conforme se señala en la Exposición de Motivos de la propia Ley 17/2005, de 19 de julio, tiene como fin hacerlo congruente con la nueva redacción del art. 67.1 LTSV por motivos de eficacia (párrafo 27).

Sí, es cierto, pero sobre todo para resolver el problema que se había planteado con la redacción introducida por la Ley 19/2001, de 19 de diciembre y las modificaciones efectuadas por el RD 318/2003, de 14 de marzo, en el art. 12.2 RPSTSV y que habían terminado con la nulidad de una parte del citado precepto reglamentario y con una interpretación del beneficio de reducción de la sanción y de sus consecuencias que no se correspondían con los fines perseguidos, y que eran tan claros como lo que se señala en el párrafo 21 de la Exposición de Motivos, lugar en el que se precisa que "se prevé el pago anticipado y voluntario de la multa, con reducción del 30 por 100, que implicará únicamente la renuncia a formular alegaciones y la terminación del procedimiento sin necesidad de dictar resolución expresa, sin perjuicio de la

\footnotetext{
${ }^{270}$ El párrafo 26 de la Exposición de Motivos de la Ley 17/2005, de 19 de julio, señala a este respecto que "por otra parte, especial relevancia tiene la modificación del apartado 3, ya que, sustentado en los principios de equidad y proporcionalidad y para que produzca el deseado efecto disuasorio, se ha considerado oportuno elevar a infracción muy grave el incumplimiento del deber de identificar al conductor responsable de la infracción, identificación que a los efectos del cumplimiento de esta obligación debe ser veraz, y que deben cumplir, salvo que exista causa justificada que lo impida, tanto el titular del vehículo como el arrendatario del mismo"
} 
posibilidad de interponer los recursos correspondientes, en aras del principio constitucional de eficacia que ha de regir la actuación de la Administración"271.

\section{I) Anotación y cancelación de antecedentes}

La anotación y la cancelación de las sanciones graves y muy graves en el Registro de Conductores e Infractores era, y es, algo esencial para el sistema en su conjunto. De las sanciones administrativas y de todas las medidas punitivas que pudieran imponerse por razón del tráfico y la seguridad vial. No hay más que pensar en la forma en la que el art. 69 LTSV se asienta, para la graduación de las sanciones, en los antecedentes del infractor y su condición de reincidente.

Lo cierto es que el art. 82 LTSV había conservado la denominación originaria de cancelación, ignorando el hecho de que únicamente se puede cancelar lo que previamente está inscrito y limitando su tránsito jurídico al incremento del plazo de prescripción de las sanciones que en la redacción originaria se había fijado en dos años desde su total cumplimiento o prescripción y que la Ley 19/2001, de 19 de diciembre, había llevado hasta los dos años.

La Ley 17/2005, de 19 de julio, modifica la rúbrica del artículo 82 LTSV, que recibe la denominación de "anotación y cancelación" y traslada las previsiones que, por medio del RD 318/2003, de 14 de marzo, se habían introducido en el art. 19 RPSTSV, en cuanto a la obligación del resto de Administraciones con competencia para sancionar (Comunidades Autónomas y Administración Local) y de las autoridades judiciales, cuando impongan la privación del permiso de conducir, a notificar a la Dirección General de Tráfico esas decisiones y a hacerlo en un plazo de quince días desde que esas resoluciones hubieran adquirido firmeza.

La reforma supone además, y para no romper la tradición establecida, un nuevo aumento en cuanto al plazo de permanencia de esas anotaciones en el Registro de Conductores e Infractores que, a partir de ese momento, pasa a ser de tres años desde su total cumplimiento o prescripción.

El concepto de perseguir la inscripción de todas las sanciones y penas impuestas en materia de seguridad vial es, además de necesario, loable, sin que sea necesario realizar grandes disquisiciones sobre la dificultad de articular mecanismos que permiten el cumplimiento en la forma y plazos establecidos.

\footnotetext{
${ }^{271}$ Cuestión objeto de análisis en los lugares correspondientes. Véase Efectos del pago de la multa tanto en el análisis de la Ley 19/2001, de 19 de diciembre, en el apartado IV.K) 4 de este mismo capítulo, como en el estudio del Real Decreto 318/2003, de 14 de marzo, de modificación del RPSTSV, en el apartado IV.L) 3 de este mismo capítulo.
} 
La cancelación de los antecedentes, en los términos planteados, se hace acreedora de dos críticas. La primera dirigida al plazo. La segunda a la falta de distinción entre las diferentes sanciones, y penas, objeto de anotación.

Se antoja más adecuado diferenciar, en cuanto al plazo de permanencia en el Registro, y por lo tanto como antecedentes, a las sanciones en función del grado de la infracción, y a todas ellas de las sentencias penales.

Tres años es el plazo establecido en el art. 136.2.2 $\mathrm{CP}^{272}$ para la cancelación de los antecedentes penales para las penas menos graves (siempre que excedan de 12 meses) y resulta que esa calificación, la de pena menos grave, es la que se atribuye, por el art. 33.3 d) CP a "la privación del derecho a conducir vehículos a motor y ciclomotores de un año y un día a ocho años", mereciendo la de pena leve "la privación del derecho a conducir vehículos a motor y ciclomotores de tres meses a un año", conforme establece el art. 33.4 a) CP, a la que, penalmente, se le asigna un plazo de cancelación de antecedentes de seis meses. Resulta extraño que a una infracción grave de permanezca en el Registro de Conductores el mismo tiempo, que una infracción muy grave y que un delito.

\section{m) Sobre el Anexo}

La reforma incorporaba, como parte fundamental del sistema, un Anexo ${ }^{273}$ que se agregaba a la Ley. En él se detallaban las infracciones cuya comisión suponía la pérdida

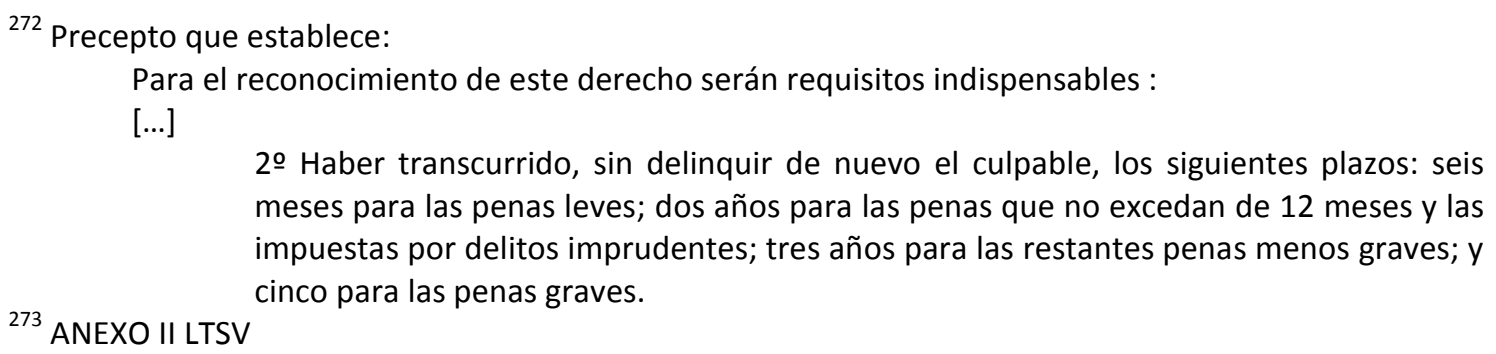
meses para las penas leves; dos años para las penas que no excedan de 12 meses y las impuestas por delitos imprudentes; tres años para las restantes penas menos graves; $y$ ${ }^{273}$ ANEXO II LTSV cinco para las penas graves.

Infracciones que llevan aparejada la pérdida de puntos El titular de un permiso o licencia de conducción que sea sancionado en firme en vía administrativa por la comisión de alguna de las infracciones que a continuación se relacionan perderá el número de puntos que, para cada una de ellas, se señalan a continuación:

\begin{tabular}{|l|c|}
\hline & Puntos \\
\hline $\begin{array}{l}\text { 1. Conducir con una tasa de alcohol superior a la reglamentariamente establecida: } \\
\text { Valores } \mathrm{mg} / \mathrm{l} \text { aire espirado, más de } 0,50 \text { (profesionales y titulares de permisos de conducción con } \\
\text { menos de dos años de antigüedad más de } 0,30 \mathrm{mg} / \mathrm{l} \text { ) }\end{array}$ & 6 \\
\hline $\begin{array}{l}\text { Valores } \mathrm{mg} / \mathrm{l} \text { aire espirado, superior a } 0,25 \text { hasta } 0,50 \text { (profesionales y titulares de permisos de } \\
\text { conducción con menos de dos años de antigüedad más de 0,15 hasta 0,30 mg/l) }\end{array}$ & 4 \\
\hline $\begin{array}{l}\text { 2. Conducir bajo los efectos de estupefacientes, psicotrópicos, estimulantes y otras sustancias de efectos } \\
\text { análogos }\end{array}$ & 6 \\
\hline $\begin{array}{l}\text { 3. Incumplir la obligación de someterse a las pruebas de detección del grado de alcoholemia, de } \\
\text { estupefacientes, psicotrópicos, estimulantes y otras sustancias de efectos análogos }\end{array}$ & 6 \\
\hline
\end{tabular}


de puntos y el número de puntos que se asociaba a esas infracciones. Sobre ese Anexo II de la LTSV resulta preciso efectuar algunas consideraciones.

Aunque la Exposición de Motivos de la Ley 17/2005, de 19 de julio, que "sólo las infracciones graves y muy graves, recogidas en los apartados 4 y 5 del art. 65 LTSV, han de constituir la referencia legal obligada sobre la que actuará todo el sistema por

\begin{tabular}{|c|c|}
\hline $\begin{array}{l}\text { 4. Conducir de forma manifiestamente temeraria, circular en sentido contrario al establecido o conducir } \\
\text { vehículos en competiciones y carreras no autorizadas }\end{array}$ & 6 \\
\hline 5. Circular por autopistas o autovías con vehículos con los que esté expresamente prohibido & 4 \\
\hline $\begin{array}{l}\text { 6. Sobrepasar en más de un } 50 \text { por } 100 \text { la velocidad máxima autorizada, siempre que ello suponga superar, } \\
\text { al menos, en } 30 \text { kilómetros por hora dicho límite máximo }\end{array}$ & 6 \\
\hline $\begin{array}{l}\text { 7. El exceso en más del } 50 \text { por } 100 \text { en los tiempos de conducción o la minoración en más del } 50 \text { por } 100 \text { en } \\
\text { los tiempos de descanso establecidos en la legislación sobre transporte terrestre }\end{array}$ & 6 \\
\hline $\begin{array}{l}\text { 8. Conducir un vehículo con una ocupación que suponga aumentar en un } 50 \text { por } 100 \text { o más el número de } \\
\text { plazas autorizadas, excluido el conductor salvo que se trate de autobuses urbanos o interurbanos }\end{array}$ & 4 \\
\hline 9. Conducir un vehículo con un permiso o licencia que no le habilite para ello & 4 \\
\hline $\begin{array}{l}\text { 10. Arrojar a la vía o en sus inmediaciones objetos que puedan producir incendios o accidentes de } \\
\text { circulación }\end{array}$ & 4 \\
\hline 11. Conducir de forma negligente creando un riesgo cierto y relevante para los otros usuarios de la vía & 4 \\
\hline 12. Exceder los límites de velocidad establecidos: & \\
\hline En más de $40 \mathrm{~km} / \mathrm{h}$ salvo que esté incurso en lo indicado en el apartado 6 & 4 \\
\hline En más de $30 \mathrm{~km} / \mathrm{h}$ hasta $40 \mathrm{~km} / \mathrm{h}$ & 3 \\
\hline En más de $20 \mathrm{~km} / \mathrm{h}$ hasta $30 \mathrm{~km} / \mathrm{h}$ & 2 \\
\hline $\begin{array}{l}\text { 13. Incumplir las disposiciones legales sobre prioridad de paso, y la obligación de detenerse en la señal de } \\
\text { stop, y en los semáforos con la luz roja encendida }\end{array}$ & 4 \\
\hline $\begin{array}{l}\text { 14. Incumplir las disposiciones legales sobre adelantamiento poniendo en peligro o entorpeciendo a quienes } \\
\text { circulen en sentido contrario y adelantar en lugares o en circunstancias de visibilidad reducida }\end{array}$ & 4 \\
\hline 15. Adelantar poniendo en peligro o entorpeciendo a ciclistas & 4 \\
\hline $\begin{array}{l}\text { 16. Efectuar el cambio de sentido incumpliendo las disposiciones recogidas en esta Ley y en los términos } \\
\text { establecidos reglamentariamente }\end{array}$ & 3 \\
\hline 17. Realizar la maniobra de marcha atrás en autopistas y autovías & 4 \\
\hline $\begin{array}{l}\text { 18. Aumentar la velocidad o efectuar maniobras que impidan o dificulten el adelantamiento por el conductor } \\
\text { del vehículo que va a ser adelantado }\end{array}$ & 4 \\
\hline 19. No respetar las señales de los agentes que regulan la circulación & 4 \\
\hline 20. No mantener la distancia de seguridad con el vehículo que le precede & 3 \\
\hline $\begin{array}{l}\text { 21. Conducir utilizando manualmente el teléfono móvil, auriculares o cualquier otro dispositivo incompatible } \\
\text { con la obligatoria atención permanente a la conducción en los términos que se determinen } \\
\text { reglamentariamente }\end{array}$ & 3 \\
\hline $\begin{array}{l}\text { 22. Parar o estacionar en las curvas, cambios de rasante, túneles, pasos inferiores, intersecciones o } \\
\text { cualquier otro lugar peligroso que constituya un riesgo a la circulación o los peatones en los términos que se } \\
\text { determinen reglamentariamente }\end{array}$ & 2 \\
\hline 23. Parar o estacionar en los carriles destinados para el transporte público urbano & 2 \\
\hline $\begin{array}{l}\text { 24. Conducir vehículos que tengan instalados mecanismos o sistemas encaminados a eludir la vigilancia de } \\
\text { los agentes de tráfico, o que lleven instrumentos con la misma intención, así como la utilización de } \\
\text { mecanismos de detección de radares }\end{array}$ & 2 \\
\hline $\begin{array}{l}\text { 25. Circular sin alumbrado cuando sea obligatorio } 0 \text { utilizarlo sin ajustarse a lo establecido } \\
\text { reglamentariamente }\end{array}$ & 2 \\
\hline $\begin{array}{l}\text { 26. Conducir sin utilizar el cinturón de seguridad, el casco y demás elementos de protección o dispositivos } \\
\text { de seguridad, en los casos y condiciones que se determinen reglamentariamente }\end{array}$ & 3 \\
\hline $\begin{array}{l}\text { 27. Circular con menores de } 12 \text { años como pasajeros de motocicletas o ciclomotores con las excepciones } \\
\text { que se determinen reglamentariamente }\end{array}$ & 2 \\
\hline
\end{tabular}


puntos tanto de los permisos como de las licencias de conducción, pues será en ambos tipos de autorizaciones sobre las que actuará el sistema que con esta Ley se configura" (párrafo 6), luego se añade que las infracciones que integran el Anexo y, por tanto, suponen la pérdida de puntos "son, fundamentalmente, aquellas que implican un riesgo evidente para la seguridad vial, habiéndose descartado aquellas otras infracciones que aun siendo calificadas como graves o muy graves son consideradas infracciones de carácter administrativo".

También resulta preciso hacer referencia a la previsión efectuada en el último párrafo del art. 60.4 LTSV que establece que "Ios conductores no perderán más de ocho puntos por acumulación de infracciones en un solo día, salvo que concurra alguna de las infracciones muy graves a que se refieren los apartados a), b), c), d), e), f), g) y h) del art. 65.5, en cuyo caso perderán el número total de puntos que correspondan" ${ }^{274}$.

Por otra parte hay que tener presente que el propio art. 60.4 LTSV establece que para se produzca de manera efectiva la pérdida de puntos se precisa, además de la previsión en ese sentido del Anexo II, que la sanción adquiera firmeza en vía administrativa.

\section{n) Las disposiciones adicionales y finales}

La Ley 1772005 , de 19 de julio, incorpora trece disposiciones adicionales a la Ley de Tráfico y Seguridad Vial con el objeto de completar las modificaciones realizadas en el articulado (párrafo 30 de la Exposición de Motivos), afirmación que, básicamente, se viene a corresponder con la realidad, y así sucede con la mayoría de esas disposiciones. Es el caso de las cuestiones relativas a:

- Los puntos del sistema: Pérdida de puntos en los permisos y licencias de conducción (disp. adic. Primera), Acceso al Registro de conductores e infractores para conocer el saldo de puntos (disp. adic. Sexta)

- El permiso: Garantía de la antigüedad de permisos y licencias de conducción obtenidos tras la pérdida total de puntos (disp. adic. Segunda), Formato del permiso o licencia de conducir (disp. adic. Duodécima)

- Los cursos: Definición del concepto de conductores profesionales (disp. adic. Tercera), Comunidades Autónomas con competencias ejecutivas transferidas en materia de tráfico y circulación de vehículos a motor (disp. adic. Quinta), Cursos para conductores profesionales (disp. adic. Octava)

- La reforma de la Ley: Seguimiento de la aplicación de la Ley (disp. adic. Décima), Dotación de medios humanos necesarios para la aplicación de la Ley (disp. adic. Undécima)

\footnotetext{
274 Téngase en cuenta que la Ley 18/2009, de 223 de noviembre, modificó la relación de tipos contenidos en el art. 65.5 LTSV y que en el art. 60.4 LTSV se estableció que las infracciones muy graves que estaban exceptuadas de esta previsión eran las contendidas en el art. 65.5 letras a) a i) LTSV.
} 
- La privación penal del permiso de conducir: Obtención del permiso o licencia de conducción cuando su titular haya sido condenado por sentencia penal con la privación del derecho a conducir (disp. adic. Decimotercera)

Al margen quedan las previsiones que se realizan

- Sobre aspectos formales de los permisos: Permisos y licencias de conducción en las Comunidades Autónomas con lengua cooficial (disp. adic. Cuarta),

- Igualdad de oportunidades y no discriminación: Condiciones básicas y de accesibilidad para las personas con discapacidad (disp. adic. Séptima)

- Responsabilidad accidentes tráfico: atropellos de especies cinegéticas (disp. adic. Novena), en tanto que supone la recuperación de la disposición prevista en la Ley 19/2001, de 19 de diciembre, y que no había sido trasladada al texto de la LTSV ${ }^{275}$.

De todas estas disposiciones únicamente la relativa a la Obtención del permiso o licencia de conducción cuando su titular haya sido condenado por sentencia penal con la privación del derecho a conducir (disp. adic. Decimotercera) planteaba un problema de interpretación, ya que los términos en los que estaba redactada establecían que, en la práctica, para la recuperación de la autorización administrativa que habilita la conducción en cualquier supuesto de pérdida penal del derecho a conducir era suficiente con superar con aprovechamiento el curso de reeducación y sensibilización vial del art. 63.7 LTSV, al que, curiosamente, suponía un requisito menos riguroso que el establecido para los supuestos de pérdida de vigencia declarada como consecuencia de la pérdida total de los puntos asignados por infracciones administrativas) en los que, además, se exigía la posterior superación de las pruebas que reglamentariamente se determinen. Disp. adic. Decimo tercera que ha sido la única que ha visto modificada su redacción original por la Ley 18/2009, de 23 de diciembre.

La Ley 17/2005, de 19 de julio, se cerraba con dos disposiciones finales.

La última de ellas, la disp. final Segunda, prescribía la entrada en vigor de lo previsto en la Ley a 20 días de su publicación en el BOE (publicación que, como ya se ha señalado, se produjo el día 20 de julio de 2005), si bien se demoraba la incorporación al ordenamiento jurídico de los preceptos en los que se regulan el sistema del permiso y la licencia de conducción por puntos, así como el Anexo II, entrarán en vigor cuando lo

${ }^{275}$ La disp. adic. Sexta de la Ley 19/2001, de 19 de diciembre, establecía que:

En accidentes de tráfico por atropellos de especies cinegéticas, será causa legal que permita atribuir la responsabilidad al conductor del vehículo por los daños producidos en un accidente de circulación el hecho de que se le pueda imputar un incumplimiento de las normas de circulación que pueda ser causa suficiente de los daños ocasionados, ello sin perjuicio de la responsabilidad que sea exigible a quien corresponda conforme a la normativa específica y de que sean probadas debidamente las circunstancias del accidente. 
haga su normativa de desarrollo y, en todo caso, al año de la publicación de la presente Ley en el BOE.

Por su parte, la disp. final Primera de la Ley 17/2005, de 19 de julio, contenía el mandato, dirigido al Gobierno de modificar el desarrollo reglamentario de la Ley de Tráfico y Seguridad Vial para adecuarlo a las modificaciones que se habían realizado., señalando expresamente:

- El Reglamento General de Conductores, aprobado por el Real Decreto 772/1997, de 30 de mayo

- El Reglamento General de Circulación, aprobado por el Real Decreto 1428 / 2003 , de 21 de noviembre ${ }^{276}$

- El Reglamento de Procedimiento Sancionador en Materia de Tráfico, Circulación de Vehículos a Motor y Seguridad Vial, aprobado por el Real Decreto 320/1994, de 25 de febrero ${ }^{277}$

- El Reglamento Regulador de las Escuelas Particulares de Conductores, aprobado por el Real Decreto 129/2003, de 17 de octubre 278

La primera de esas previsiones, la de modificar el RGCon/1997, fue efectuada a los seis meses, por medio del RD 62/2006, de 27 de enero, y es objeto de análisis en el siguiente apartado.

4. UNA ESCUETA VALORACIÓN DE LA REFORMA POR COMPARACIÓN CON LA EFECTUADA POR LA LEY 19/2001, DE 19 DE DICIEMBRE

Siendo, como lo son, dos reformas de inmenso calado, la contraposición entre ambas permite determinar importantes diferencias. La Ley 19/2001, de 19 de diciembre, acude al auxilio de una norma que, desbordada por la realidad, a duras penas es capaz de imponer su fuerza de Ley. $Y$, en aquél momento, se opta por una cirugía mayor en la que el origen de la reforma da paso a multitud de cambios entre los que las prioridades se diluyen. La Ley 17/2005, de 19 de diciembre, opta por dar un paso atrás, y atacar, en primer lugar y únicamente, el principal problema. Y nada más. Es una cirugía de intervención mínima (que no hay que confundir con nimia). Es una reforma

\footnotetext{
${ }^{276}$ Revisión que se efectuaría por medio del Real Decreto 965/2006, de 1 de septiembre (BOE de 5 de septiembre de 2006).

${ }^{277}$ El mandato de modificación de RPSTSV no se vería cumplido y la adaptación, o cambio de sistema, se produciría mediante la modificación de la LTSV por la Ley 18/2009, de 23 de noviembre, que daría nueva redacción a la totalidad de artículos que integran el Régimen sancionador.

${ }^{278}$ Mandato de revisión con el que no se ha cumplido, ya que la única modificación a la que se ha visto sometido este Reglamento es la realizada por medio del Real Decreto 369/2010, de 26 de marzo (BOE de 27 de maro de 2010) que tenía por objeto la adecuación tanto a la Ley 17/2009, de 23 de noviembre, como a la Ley 25/2009, de 22 de diciembre, sobre el libre acceso a las actividades de servicios y su ejercicio.
} 
de ingentes dimensiones, pero que no se difumina en el habitual planteamiento de "ya puestos" vamos a aprovechar esta oportunidad de reforma para cambiar más cosas.

La modificación efectuada en el 2001 es una reforma de cantidad y que se convierte en global (por extensión y cantidad de preceptos afectados). La del 2005 intenta serlo de calidad y se contiene en su objetivo prioritario: nada más que el permiso por puntos (y poco más ${ }^{279}$ ).

\section{0) La revisión del RGCon realizada por medio del Real Decreto 62/2006, de 27 de enero}

Como se ha señalado al final del apartado anterior, la Ley 17/2005, de 19 de julio, que regulaba el permiso y licencia de conducción por puntos, establecía, de manera expresa, en la disp. final, que el Gobierno tendría que proceder a modificar, entre otros desarrollos reglamentarios, el RGCon/1997 para adaptarlo a ese nuevo sistema, revisión que se lleva a efecto por medio del RD 62/2006, de 27 de enero ${ }^{280}$.

No era esta la primera modificación que sufría el RGCon $/ 1997^{281}$, pero si adquiría un especial significado por lo que suponía al ser, precisamente, el necesario y prioritario

\footnotetext{
279 Fuera de ese ámbito se encuentran la adición de la letra q) al art. 5 LTSV, sobre igualdad de oportunidades y no discriminación, y el retoque en las normas generales de conductores del art. 11 LTSV.

${ }^{280}$ Publicado en el Boletín Oficial del Estado de 2 de febrero de 2006 y, cuya entrada en vigor, queda sometida a lo establecido en su disposición final única:

“La modificación de los artículos 22, 23, 24 y 25 y la supresión de la disposición transitoria séptima, entrarán en vigor el día siguiente al de la publicación del presente Real Decreto en el Boletín Oficial del Estado.

La modificación del artículo 39, el nuevo artículo 41 bis y el nuevo anexo VIII, entrarán en vigor el día 1 de julio de 2006.

La modificación de los artículos 44, 51, 56 y 57, y la de los anexos III y VI , entrará en vigor al mes de la publicación de este Real Decreto en el Boletín Oficial del Estado"

281 El RD 772/1997, de 30 de mayo, por el que se aprobaba el RGCon/1997, ha sido objeto del correspondiente análisis en el apartado IV.E) de este mismo capítulo. Regulación que había sido objeto de diversas modificaciones a las que no hemos prestado atención de manera específica e individualizada. Así, durante su permanencia en el ordenamiento jurídico el RGCon/1997 se vio sometido, además de la a realizada por el RD 62/2006, de 27 de enero, a diversas modificaciones:

- Real Decreto núm. 2824/1998 de 23 de diciembre

- Real Decreto núm. 1110/1999 de 25 de junio (que modifica el art. 41)

- Real Decreto núm. 1907/1999 de 17 de diciembre

- Real Decreto núm. 1598/2004 de 2 de julio, que afecta a 25 artículos, a diversas disposiciones adicionales y transitorias y modifica los Anexos II, IV, VI y VII (entre ellos modifica los art. 38, 40, 41 y 42)

- Real Decreto núm. 64/2008 de 25 de enero (que, curiosamente, presente una fecha anterior y un número de orden posterior al RD 62/2008, de 27 de enero, y que fue publicado en el BOE 26 de enero de 2008)
}

Para, finalmente, ser objeto de derogación por el RD 818/2009, de 8 de mayo, por el que se aprueba un nuevo Reglamento General de Conductores, el RGCon/2009, objeto de análisis en el apartado XX. 
desarrollo para adaptar dicho Reglamento a las novedades del sistema del permiso y de la licencia de conducción por puntos para hacer posible su implantación ${ }^{282}$.

Así, en el propio texto que justifica la modificación normativa, se establece en alcance de los cambios que es preciso efectuar ${ }^{283}$ :

- Incorporar la pérdida total de los puntos asignados como causa para la declaración de la pérdida de vigencia de la autorización para conducir

- Determinar las pruebas que habrán de realizar los titulares de los permisos y licencias de conducción para obtener nuevamente una autorización para conducir tras la pérdida del total del crédito de puntos, una vez hayan realizado y superado con aprovechamiento, como requisito previo, el curso de sensibilización y reeducación vial regulado en la Orden INT/2596/2005, de 28 de julio, por la que se regulan los cursos de sensibilización y reeducación vial para los titulares de un permiso o licencia de conducción

De esta forma, y en el marco de las diferentes modificaciones que, por medio de este RD 62/2006, de 27 de enero, se efectúa en el RGCon/1997, presentan una especial relevancia las relativas a la declaración de nulidad o lesividad y pérdida de vigencia de la autorizaciones administrativas para conducir $y$, en especial, en lo referente al procedimiento para realizar esa declaración.

En cuanto a la pérdida de vigencia, el art. 39 RGC/1997, recibe una nueva redacción que, en cuanto al primero de sus apartados supone la adición a la redacción originaria, en la que se señalaba que "con independencia de lo dispuesto en el artículo anterior, la vigencia de las autorizaciones para conducir estará condicionada a que su titular mantenga los requisitos exigidos para su otorgamiento", del inciso "y a que no haya perdido su asignación total de puntos".

En el apartado segundo del art. 39 RGCon/1997 se realizan varias modificaciones. La primera de ellas consiste en que la declaración de pérdida de vigencia ya no es (al menos nominalmente) una posibilidad para la Jefaturas Provinciales de Tráfico en aquellos casos en los que se acredite que han desaparecido los requisitos que se exigían para obtener una autorización de las que habilitan para conducirlas, ya que la previsión reglamentaria pasa del potestativo "podrán" al asertivo (y forzoso) "procederán", supuesto al que se adiciona, como segunda modificación, "cuando tengan constancia de que el titular de la autorización ha perdido la totalidad de su crédito de puntos", especificando la nueva redacción, tercera de las modificaciones, que el momento en el que se ha de proceder a esa declaración de pérdida de vigencia es "una vez se haya anotado en el Registro de conductores e infractores la última sanción firme en vía administrativa que suponga la pérdida de ese crédito".

\footnotetext{
${ }^{282}$ Tal y como señala el párrafo la introducción explicativa que antecede al propio RD 62/2008, de 27 de enero.

${ }^{283}$ Ibídem.
} 
Pero la determinación de la pérdida de vigencia de una autorización que carece de puntos necesita del establecimiento de un cauce para su realización (afinar esta frase), para lo que se incorpora un nuevo art. 41 bis al RGC/1997 en el que se establece el procedimiento para la declaración de pérdida de vigencia por la pérdida total de los puntos asignados.

El procedimiento que, se configura sobre la base, que actúa como presupuesto, de la constatación de la "pérdida por el titular del permiso o de la licencia de conducción de la totalidad de los puntos asignados" (art. 41 bis.1 RGCon/1997) se conforma en torno a las siguientes determinaciones:

\section{Competencia}

Jefe Provincial de Tráfico de de la provincia correspondiente al domicilio del titular de la autorización (apartados 1 y 5 del art. 41 bis RGCon/1997)

\section{Contenido del Acuerdo de Iniciación}

Se establece como contenido de ese Acuerdo (art. 41 bis.1 RGCon/1997):

- Relación detallada de las resoluciones firmes en vía administrativa que hubieran dado lugar a la pérdida de los puntos

- Indicación del número de puntos que a cada una de ellas hubiera correspondido

En ese acuerdo se concederá al interesado un plazo máximo de diez días para formular las alegaciones que estime convenientes (art. 41 bis.1 RGCon/1997.

\section{$\underline{\text { Resolución }}$}

Se establece que transcurrido el plazo de diez días concedido al interesado para presentar alegaciones, "el jefe provincial de tráfico dictará resolución declarando la pérdida de vigencia del permiso o de la licencia de conducción, que se notificará al interesado en el plazo de quince días, en los términos previstos en la LRJ - PAC (art. 41 bis.1 RGCon/1997).

De esta redacción parece deducirse que no importan demasiado las alegaciones que se efectúen, ni el contenido de las mismas, a las que ni siquiera se hace referencia en cuanto a su toma en consideración para dictar la resolución.

La norma parte de la base de que se trata de un procedimiento de mera ejecución y que esos procedimientos a sancionadores previos que han ido originado la pérdida de puntos hasta que, el último de ellos, supone que el titular se queda sin puntos. Y que, conforme a lo establecido en la nueva redacción que recibe el inciso final del art. 39.2 
RGCon/1997, requiere, como presupuesto para la puesta en marcha del procedimiento de pérdida de vigencia que éste se inicie "una vez se haya anotado en el Registro de conductores e infractores la última sanción firme en vía administrativa que suponga la pérdida de ese crédito", por lo que, parece, se le da un tratamiento más de "mera ejecución" que de procedimiento administrativo, planteamiento que no parece se compadezca con los principios básicos del procedimiento administrativo en cuanto a las garantías que se deben de prestar al interesado. No parece que se admita, siquiera, la posibilidad de un error, por ejemplo, en la atribución de puntos a persona distinta.

Esa previsión contenida en el art. 41 bis.2 RGC/1997 no parece ni afortunada, ni compatible, en los términos en los que está redactada, con los principios básicos a los que todo procedimiento administrativo, y más si se trata de restrictivo de derechos, debe atenerse.

En ese mismo art. 41 bis RGCon/1997, y junto con el procedimiento para la declaración de pérdida de vigencia, se entremezclan los requisitos para la obtención, para que esos titulares de autorizaciones para conducir cuya pérdida de vigencia haya sido declarada por carecer de puntos, de una nueva licencia:

\section{Superación de cursos y pruebas}

Se establece (ver LTSV) la necesidad de realizar y superar con aprovechamiento un curso de sensibilización y reeducación vial de recuperación del permiso o la licencia de conducción, así como la posterior superación de la prueba de control de conocimientos a que se refiere el Anexo VIII (del propio RGC/1997), lugar en el que se regula la prueba de control de conocimientos para la recuperación del permiso o licencia de conducción, sobre la base de que, de manera previa, se deberá haber realizado y superado con aprovechamiento el curso de sensibilización y reeducación vial para la recuperación del permiso o la licencia de conducción regulado en la Orden INT/2596/2005.

Plazos generales, especiales en razón de las circunstancias del titular de la autorización y supuestos de reincidencia

La norma general es la necesidad del transcurso de un plazo de seis meses, desde la fecha en que fue notificado el acuerdo de declaración de la pérdida de vigencia, para que el titular pueda obtener una nueva autorización.

Ese plazo de seis meses se reduce a la mitad (tres meses) para los que tengan la condición de conductores profesionales (sin que se haga referencia a la ubicación de su definición en la disp. adic. Tercera LTSV). 
Como criterio de reincidencia se establece la nueva pérdida de vigencia por haber perdido otra vez la totalidad del crédito de puntos asignados. En ese caso se duplica el tiempo que ha de transcurrir para poder obtener un nuevo permiso o licencia de conducción (doce meses), que se reduce a la mitad (seis meses) para los conductores.

\section{P) La Ley Orgánica 15/2007, de 30 de noviembre, por la que se modifica la Ley Orgánica 10/1995, de 23 de noviembre, del Código Penal en materia de seguridad vial}

\section{EL CONTEXTO DE LA REFORMA Y SU ÁMBITO}

La Subcomisión de Seguridad Vial y Prevención de Accidentes de Tráfico a la que hemos tenido ocasión de referirnos al analizar, y ubicar en su contexto, la Ley 17/2005, de 19 de julio, por la que se aprueba el permiso y la licencia de conducir por puntos ${ }^{284}$, había sido disuelta, el 18 de diciembre de 2003, una vez concluido el su Informe (de la Subcomisión de Seguridad Vial y Prevención de Accidentes de Tráfico). Pero en la siguiente legislatura se constituye la Comisión no permanente sobre seguridad vial y prevención accidentes tráfico ${ }^{285}$.

Es en este contexto en el que hay que entender el Preámbulo de la Ley Orgánica 15/2007, de 30 de noviembre, de reforma del Código Penal en materia de seguridad vial cuando en él se señala que "el Congreso de los Diputados considera oportuno impulsar la modificación del Código Penal, teniendo en cuenta las distintas propuestas que se están estudiando en la Comisión de Seguridad Vial del Congreso de los Diputados, con el objetivo de definir con mayor rigor todos los delitos contra la seguridad del tráfico y los relacionados con la seguridad vial, evitando que determinadas conductas calificadas como de violencia vial puedan quedar impunes" y que "la reforma sobre los delitos contra la seguridad vial cuenta con un amplio consenso de los grupos parlamentarios en torno a las propuestas formuladas ante la Comisión sobre Seguridad Vial”286.

Ahora bien que la norma tenga como objetivo la reforma de los tipos penales en materia de tráfico y seguridad vial no es obstáculo para incluir en esa tramitación otras cuestiones de otras cuestiones que nada tienen que ver con el Código Penal, aunque en este caso sí, con el tráfico y la seguridad vial. Y bien conocido es el gusto del

\footnotetext{
${ }^{284}$ Véase el apartado IV.O.1 en este capítulo sobre la ubicación de la al reforma efectuada en la LTSV por medio de la Ley $17 / 2005$, de 19 de julio, del permiso y licencia de conducción por puntos.

${ }^{285}$ Comisión que se constituye el 20 de mayo de 2004, bajo la presidencia del Diputado del Grupo CiU Jordi Jané i Guasch, y que va a continuar sus trabajos a lo largo de toda la legislatura hasta su disolución que se produce el 15 de enero de 2008.

${ }^{286}$ Cfr. Párrafos primero y segundo de la Exposición de Motivos de la referida Ley Orgánica 15/2007, de 30 de noviembre.
} 
legislador patrio por no dejar escapar la oportunidad de legislar, una vez se ha puesto a ello, en otros ámbitos.

Así pues, e incluido en el precio de reforma por Ley Orgánica, se modifican, además de los correspondientes artículos de Código Penal, normas de tráfico y seguridad vial contenidas en la LTSV y en la LOFAGE.

\section{LA REFORMA del Código Penal ${ }^{287}$}

No siendo, como no lo es, objeto directo de nuestro análisis los tipos penales en materia de tráfico y seguridad vial, resulta adecuado hacer un somero análisis de lo que esta reforma del Código Penal supone y hacerlo desde la óptica, y con los elementos de juicio, del momento en que se efectúa esa revisión de los tipos penales.

La razón que justifica este interés no se encuentra tanto en los tipos penales, en sí mismos considerados, como en la relación que, entre estos, y las infracciones administrativas previstas en la LTSV, se pueda y deba establecer, puesto que en la tramitación del procedimiento nos podemos enfrentar a determinar si la naturaleza de los hechos es administrativa o penal, cuestión cuya resolución requiere de la previa delimitación entre tipos administrativos e infracciones penales. Por ello, y teniendo en cuenta que el art. 72.1 LTSV $^{288}$ establece que cuando en un procedimiento administrativo de carácter sancionador se ponga de manifiesto un hecho que ofrezca apariencia de delito o falta perseguible de oficio, la autoridad administrativa lo pondrá en conocimiento del Ministerio Fiscal, por si hubiere lugar al ejercicio de la acción

\footnotetext{
${ }^{287}$ Tras esta reforma se realizaría la de la Ley Orgánica 5/2010, de 22 de junio que fijaría los actuales términos de este Capítulo.

Apartado XXV del Preámbulo de la Ley Orgánica 5/2010, de 22 de junio, de modificación del Código penal:

“En la búsqueda de una mayor proporcionalidad en la respuesta jurídico penal a determinadas conductas de peligro abstracto, concretamente en el ámbito de los delitos contra la seguridad vial, se ha considerado conveniente reformar los arts. 379 y 384 en un triple sentido. En primer lugar se equipara la pena de prisión prevista para ambos delitos, al entender que no existe razón de fondo que justifique la diferencia en la respuesta punitiva. Por otra parte, se elimina la actual disyuntiva entre la pena de prisión y la de multa y trabajos en beneficio de la comunidad, estableciéndose los tres tipos de penas como alternativas. De este modo se concede un mayor grado de arbitrio al Juez a la hora de decidir sobre la imposición de cualquiera de las tres penas previstas, permitiendo reservar la pena de prisión, como la de mayor gravedad, para supuestos excepcionales. De otro lado, superando el sistema actual en el que únicamente se prevé para el caso del delito del arts. 381, se introduce un nuevo artículo 385 bis en el que se establece que el vehículo a motor o ciclomotor utilizado en los hechos previstos en el Capítulo se considerará instrumento del delito a los efectos de los arts. 127 y 128.

Por último, en los supuestos de imposición de la pena de prisión, tratándose de los delitos contenidos en los arts. 379, 383, 384 y 385, se concede a los jueces la facultad excepcional de rebajarla en grado atendiendo a la menor entidad del riesgo y a las demás circunstancias del hecho enjuiciado".

${ }^{288}$ Art. 74 LTSV tras la reforma efectuada por medio de la Ley 18/2009, de 23 de noviembre.
} 
penal, se hace preciso realizar un somero análisis de cuáles son los puntos de conexión y los principales problemas que se producían con la reforma del Código Penal.

Hay un cambio radical. Un conjunto de alteraciones que, trasladados a los tipos penales que integran los delitos contra la seguridad del tráfico, pasan a serlo contra la seguridad vial. Así, la modificación que se introduce en la rúbrica del Capítulo IV del Título XVII no es un mero formalismo, es una declaración de intenciones, y su traslación a la configuración y delimitación de los tipos, independientemente de la opinión, favorable o desfavorable, que ello merezca, supone un cambio tangible.

Los tipos penales se objetivan y se enlazan con las previsiones realizadas en el cuadro de infracciones del art. 65 LTSV.

Se pasa de una prohibición de conducir un vehículo a motor o un ciclomotor "bajo la influencia de drogas tóxicas, estupefacientes, sustancias psicotrópicas o de bebidas alcohólicas" a que la conducta proscrita sea la de que no se puede conducir "con una tasa de alcohol en aire espirado superior a 0,60 miligramos por litro o con una tasa de alcohol en sangre superior a 1,2 gramos por litro". Sustanciosa diferencia, sin duda, pues mientras en la redacción anterior a la reforma se requería, para cumplir con el tipo penal "no sólo la presencia de una determinada concentración alcohólica en el conductor, sino además que esta circunstancia influya o se proyecte sobre la conducción" ya que "para apreciar la existencia del delito resulta necesario acreditar que la ingesta de alcohol ha producido una merma significativa en las facultades de aquél, de suerte que, como consecuencia de ello, se haya generado un peligro para la seguridad de la circulación, aunque tal peligro no se haya puesto de manifiesto de modo concreto, bastando la abstracta "puesta en peligro»" ${ }^{289}$, ahora se cumple con el tipo por el hecho de conducir con una determinada tasa de alcohol.

Esta forma de tipificar penalmente supone dar continuidad a la infracción administrativa con el tipo penal, o al revés, si se prefiere. Se establece una conducta permitida que termina cuando empieza la infracción administrativa muy grave del art. 65.5 a) LTSV que, a su vez, finaliza con el inicio del delito. Objetivación que está sometida, en virtud del principio de presunción de inocencia a que se tengan en cuenta los márgenes de error establecidos para los diferentes instrumentos de medición ${ }^{290}$.

Planteamiento que se reproduce con el nuevo tipo introducido en el art. 379.1 LTSV que criminaliza la velocidad al proscribir la conducción de "un vehículo de motor o un

\footnotetext{
${ }^{289}$ Cfr. las SSTC de 256/2007, de 17 de diciembre, F. 4 y 1/2009, de 12 de enero, F. 3, especialmente significativas por ser coetáneas con la entrada en vigor de las nuevas previsiones.

${ }^{290}$ La prueba de la infracción y del delito se fundamenta en los mismos sistemas de medición (metrología) pero su regulación difiere para cada uno de esos dos ámbitos, administrativo sancionador y procesal penal, tal y como se analiza en la parte destinada en esta obra a la prueba de las infracciones en el marco del procedimiento administrativo sancionador.
} 
ciclomotor $^{291}$ a velocidad superior en sesenta kilómetros por hora en vía urbana o en ochenta kilómetros por hora en vía interurbana a la permitida reglamentariamente", previsión penal que, de nuevo, enlaza con las infracciones administrativas que, en ese momento, se realizaban en los apartados 4 a) y 5 c) del art. 65 LTSV. En este caso, el de la velocidad excesiva, se produce la misma continuidad lineal desde la conducta permitida, pasando por la infracción grave y por la muy grave, hasta llegar al tipo penal.

Más complejas, sin duda, resultan las previsiones penales sobre conducción temeraria y su relación con la infracción muy grave del art. 65.5 d) LTSV. La arquitectura penal muestra una estructura escalonada sobre el concepto de conducción con "temeridad manifiesta" que puede ser:

- Conducir con temeridad manifiesta y poner en concreto peligro la vida o la integridad de las personas (art. 380.1)

- Conducir con temeridad manifiesta y no se hubiere puesto en concreto peligro la vida o la integridad de las personas (art. 381.2)

- Conducir con temeridad manifiesta con manifiesto desprecio por la vida de los demás (art. $381.1 \mathrm{CP}$ )

Además, el art. 380.2 CP tendrá por manifiestamente temeraria la conducción en la que concurrieren las circunstancias previstas en el apartado primero y en el inciso segundo del apartado segundo del art. $379 \mathrm{CP}$, es decir, los tipos de alcohol y velocidad.

La puesta en conexión de esta tipificación con las infracciones administrativas generaba problemas de delimitación e interpretación desde el momento que el art. 65.5 d) LTSV que es infracción muy grave, cuando no sea constitutiva de delito, la conducción manifiestamente temeraria ${ }^{292}$, es decir, con coincidencia del tipo penal establecido en el art. 381.2 CP. Cabía plantearse si había espacio para la infracción administrativa de "conducción manifiestamente temeraria" o si, como parecía desprenderse de la identidad de términos la conducción que fuera calificada como "manifiestamente temeraria" habría de ser, en todo caso, constitutiva del tipo penal. Y al lado de este problema que habría de suceder con las conductas que fueran calificadas de "conducción temeraria" (sin esa adjetivación del "manifiestamente") que

\footnotetext{
${ }^{291}$ Aunque sea a título de mera curiosidad cabe destacar que resulta, cuando menos, llamativo que en la descripción del tipo se haga uso del término "ciclomotor" dado que, para serlo, tiene que tratarse de un vehículo "con una velocidad máxima por construcción no superior a $45 \mathrm{~km} / \mathrm{h}$ ”, de manera que, y por definición, si un ciclomotor supera esa velocidad es que no es ciclomotor, por lo que supere en sesenta $\mathrm{u}$ ochenta $\mathrm{km} / \mathrm{h}$ la establecida en una determinada vía es difícil.

292 En los términos establecidos por la Ley 17/2005, de 19 de julio, vigentes al momento de la promulgación y entrada en vigor de las previsiones que efectuaba la Ley Orgánica 15/2007, de 30 de noviembre. Tipo administrativo que sería modificado por la Ley 18/2009, de 23 de noviembre, pasando a integrar el art. 65.5 e) LTSV como infracción muy grave consistente en la "conducción temeraria".
} 
no serían constitutivas de ni del tipo penal de la infracción administrativa del art. 65.5 d) LTSV. Es más, ni siquiera de infracción grave, al no existir tipificación sobre ella. Cierto que frente a la calificación como leve de la "conducción temeraria" en virtud del principio establecido en el art. 65.3 LTSV de que "son infracciones leves las cometidas contra las normas contenidas en esta Ley y en los Reglamentos que la desarrollen que no se califiquen expresamente como graves o muy graves en los apartados siguientes" existirían dos opciones para su calificación como grave. De un lado, la posibilidad de que esa temeridad fuera incardinable en otro tipo administrativo concreto o, de otro, que sin cumplir la conducta con la calificación de "manifiestamente temeraria" pudiera ser calificada como constitutiva de la infracción grave de "conducción negligente" del art. 65.4 ñ) LTSV.

En todo caso, y en lo que aquí interesa, el conjunto de previsiones, penales y administrativas, no parecían defender al sistema, al menos adecuadamente, frente a quienes condujeran de forma temeraria.

En el estricto ámbito de la regulación penal llamaba la atención la previsión efectuada en el art. 381.3 CP por la que "el vehículo a motor o ciclomotor utilizado en los hechos previstos en el presente precepto se considerará instrumento del delito a los efectos del art. 127 de este Código". Es claro el objetivo que se persigue pero no es fácil de entender la razón de limitar esta previsión, de manera exclusiva, a los supuestos de conducción temeraria tipificados en el art. $381 \mathrm{CP}$, y no hacerlo extensivo ni al tipo de imprudencia temeraria del art. $380 \mathrm{CO}$ ni al resto de delitos contra la seguridad vial ${ }^{293}$.

También presenta problemas de delimitación la comparación entre el art. 383 CP y el art. 655 b) LTSV ${ }^{294}$ ya que en ambos casos se trata de no someterse a las pruebas establecidas para la detección de tasas de alcohol o presencia de sustancias prohibidas. La cuestión es evidente, cuál ha de ser el criterio que permita determinar que esa negativa (término empleado en el precepto penal) o ese incumplimiento (expresión utilizada en el ámbito administrativo) es constitutiva de delito y cuando de infracción administrativa, delimitación que se ha venido realizando en función del supuesto de hecho que dé lugar a esas pruebas (de entre los previstos en el art. 21 RGC) y la apreciación de los agentes, como prueba, sobre el estado del conductor que se niega a realizar las pruebas. Así, cuando el origen del sometimiento a las pruebas tuviera su origen en que ese conductor estuviera implicado en un accidente de tráfico o presentara evidentes síntomas de embriaguez, la negativa supondría la comisión del tipo penal. En cambio, en los casos de que la prueba viniese determinada por haber

\footnotetext{
${ }^{293}$ Que es lo que sucedería con la reforma efectuada por la Ley Orgánica 5/2010, de 22 de junio, que eliminó el apartado 3 del art. 381 CP para introducir en un nuevo precepto, el art. 385 bis CP la previsión conforme a la cual "el vehículo a motor o ciclomotor utilizado en los hechos previstos en este Capítulo se considerará instrumento del delito a los efectos de los artículos 127 y 128".

${ }^{294}$ Que con la reforma efectuada por medio de la Ley 18/2009, de 23 de noviembre, pasará a ser el art. 65.5 d) LTSV.
} 
sido denunciado el conductor por la comisión de alguna infracción o por tratarse de un control preventivo el tipo penal era aplicable en la medida en que los agentes adviertan en el conductor requerido que está conduciendo bajo los efectos de bebidas alcohólicas y así se lo hagan saber. Y, por el mismo motivo, cuando las agentes no adviertan síntomas la negativa del conductor sería constitutiva de infracción administrativa $^{295}$. Tal vez todo fuera mucho más sencillo con la pura y simple eliminación del tipo administrativo.

Las previsiones que se realizan en el art. $384 \mathrm{CP}$ no presentan problemas para su delimitación con las infracciones administrativas sobre conducción sin contar con la correspondiente autorización. Son conductas delictivas conducir habiendo cuando se carece de la autorización correspondiente al haber sido declarada su pérdida de vigencia por la pérdida total del saldo de puntos (art. $384.1 \mathrm{CP}$ ), conducir haber sido privado del permiso o licencia por decisión judicial o conducir sin haber obtenido nunca permiso o licencia de conducción (art. 384.2 $\mathrm{CP}^{296}$ ).

Las infracciones previstas en la Ley de Tráfico y Seguridad Vial tipifican en el ámbito administrativo supuestos que, recayendo sobre las autorizaciones administrativas para conducir son perfectamente deslindables de las previstas penalmente, ya que, de un lado, se establece como infracción grave, en el art. 64.4 n) LTSV $^{297}$ el conducir un vehículo siendo titular de una autorización de conducción que carece de validez por no haber cumplido los requisitos administrativos exigidos reglamentariamente y se califica como infracción muy grave, en el art. 65.5 j) LTSV $^{298}$ la conducción de un vehículo sin ser titular de la autorización administrativa correspondiente.

El art. 385 CP tipifica, siempre y cuando se origine riesgo para la circulación, el colocar en la vía obstáculos imprevisibles, derramando sustancias deslizantes o inflamables o mutando, sustrayendo o anulando la señalización o por cualquier otro medio y el no restablecer la seguridad de la vía, cuando haya obligación de hacerlo. Ese requisito, el de que se origine un riesgo para la circulación, permite diferenciar estos tipos de las infracciones administrativas previstas como infracciones graves en el art. 65.6 a) LTSV de realizar en la vía obras sin la autorización correspondiente, así como la retirada, ocultación, alteración o deterioro de la señalización permanente u ocasional y en el art. 65.6 b) consistente en no instalar la señalización de obras o hacerlo incorrectamente, poniendo en grave riesgo la seguridad vial.

\footnotetext{
${ }^{295}$ Véanse, en este sentido las SSTS de la sala de lo Penal de 9 de diciembre de 1999 y de 22 de marzo de 2002.

${ }^{296}$ Precepto, este, sobre el que la disp. final tercera establecía la especial previsión de que su entrada en vigor se produciría el 1 de mayo de 2008.

${ }^{297}$ Tipo administrativo que, con la reforma de la Ley 18/2009, de 23 de noviembre, pasa al art. 64.4 II) LTSV modificando ligeramente sus términos y pasar el tipo a "conducir un vehículo siendo titular de una autorización que carece de validez por no haber cumplido los requisitos administrativos exigidos reglamentariamente en España".

${ }^{298}$ Que en la redacción recibida de la Ley 18/2009, de 23 de noviembre, se ubica en el art. 65.5k) LTSV.
} 


\section{LA REFORMA DE LA LTSV Y DE LA LOFAGE}

La Ley Orgánica 15/2007, de 30 de noviembre, incluía la modificación de la LTSV y de la LOFAGE sin que ello supusiera que esas disposiciones tuvieran carácter de Ley Orgánica $^{299}$, previsiones que modificaban la regulación establecida en la Ley de Tráfico y Seguridad Vial en cuanto a recursos, anotación y cancelación de antecedentes y, sobre todo, en relación a la competencia para sancionar las infracciones.

\section{a) Competencia para sancionar las infracciones previstas en la LTSV}

La competencia para sancionar las infracciones en materia de tráfico y seguridad vial estaba residenciada en los Delegados y Subdelegados del Gobierno que la habían heredado de la originariamente atribuida a los Gobernadores Civiles, al desaparecer estos.

La eliminación de la LRJ - PAC, por medio de la Ley 4/1999, de 13 de enero, de la prohibición de delegar las potestades sancionadoras, supuso un cambio importante en el régimen establecido en la LTSV que, con el cambio de circunstancias que supone la creación del Centro de Tratamiento de Denuncias Automatizadas ${ }^{300}$ aconseja la modificación del órgano con competencia para sancionar.

Los cambios que se realizan en el art. 68 LTSV son para atribuir la competencia sancionadora a los Jefes Provinciales de Tráfico y permitir que éste pueda delegar en el Director del Centro de Tratamiento de Denuncias Automatizadas la de las infracciones que hayan sido detectadas a través de medios de captación y reproducción de imágenes que permitan la identificación del vehículo.

Al lado de este cambio, central en el sistema, se introducen una serie de reformas de ajuste, como son que Jefes Provinciales de Tráfico, en su caso, órganos competentes de las Comunidades Autónomas que tengan transferidas las competencias ejecutivas puedan asumir las competencias que la LTSV otorga a los Alcaldes cuando, por razones justificadas o por insuficiencia de los servicios municipales, no pueda ser ejercida por éstos, el reconocimiento de competencia a las Comunidades Autónomas con competencias ejecutivas para sancionar, en su ámbito territorial, las infracciones en materia de publicidad de los vehículos, que en el Estado corresponde al Director General de Tráfico y que en las Ciudades Autónomas de Ceuta y Melilla, las

\footnotetext{
${ }^{299}$ Y así lo establecía, expresamente, la disp. adic. Segunda de la propia Ley Orgánica 15/2007, de 30 de noviembre, al disponer que "Tienen el carácter de Ley Orgánica todos los preceptos de esta Ley, excepto la disposición adicional, la disposición derogatoria única y la disposición final primera".

${ }^{300}$ Centro creado por la Orden INT/2035/2007, de 2 de julio, publicada en el Boletín Oficial del Estado de 10 de julio de 2007.
} 
competencias que se atribuyen a los Directores Provinciales de Tráfico corresponderán a los Jefes Locales de Tráfico.

Para llevar a efecto este cambio resulta preciso derogar un apartado de la LOFAGE, ya que es en esa norma (en el párrafo tercero de la disp. adicional cuarta) el lugar en el que se realizaba la atribución de la competencia sancionadora en materia de tráfico y seguridad vial a Delegados y Subdelegados del Gobierno.

\section{b) Recursos}

La atribución de la competencia para sancionar las infracciones de tráfico conlleva la modificación del art. 80 LTSV para determinar que contra la resolución, por parte de los Jefes Provinciales (y Locales) de Tráfico cabe el correspondiente recurso de alzada ante el Director General de Tráfico.

\section{c) Anotación y cancelación de antecedentes}

De igual manera resulta preciso modificar el art. 82 LTSV para establecer que la anotación de sanciones (graves y muy grave) será practicada "por el órgano competente de la Jefatura Central de Tráfico que instruye el procedimiento" que en unos casos será la Jefatura de Tráfico instructora del procedimiento y, en otros, por el Centro de Tratamiento de Denuncias Automatizadas, tal y como advierte el último de párrafo del Preámbulo de la Ley Orgánica 15/2007, de 30 de noviembre

\section{Q) El Reglamento General de Conductores de 2009}

En el año 2009 se procede a la revisión del Reglamento General de Conductores que, hasta ese momento se encontraba regulado por el Real Decreto 772/1997, de 30 de mayo (RGCon/1997), y que había sido objeto de modificación para adaptarlo a los cambios introducidos a la instauración del permiso de conducción por puntos ${ }^{301}$.

Se trata de una profunda revisión que da lugar, por medio de la aprobación del Real Decreto 818/2009, de 8 de mayo, a un nuevo Reglamento General del Conductores (RGCon/2009) ${ }^{302}$.

El cambio viene originado por la necesidad de adaptar el RGCon/1997 a las Directivas Comunitarias dictadas en materia de armonización de normas sobre el permiso de

\footnotetext{
${ }^{301}$ Véase el apartado correspondiente (16. Modificación del RGC/1997 por el RD 62/2006, de 26 de enero)

302 Publicado en el Boletín Oficial del Estado de 8 de junio de 2009 y que, conforme establece la disp. adic. Sexta entrará en vigor a los seis meses de su publicación en el BOE.

El RD 818/2009, de 8 de mayo, aprueba un nuevo Reglamento General de Conductores (RGCon/2009) y procede a la derogación (disp. derogatoria Única) del RGCon/1997 y del Código de la Circulación, aprobado por Decreto de 25 de septiembre de 1934 (lo que a esa fecha todavía quedaba vigente).
} 
conducir pero, tal y como se pone de manifiesto en el primero de los párrafos del texto explicativo que precede al articulado del nuevo RGCon/2009 "las múltiples modificaciones parciales que ha sufrido el citado Reglamento, como por ejemplo la última realizada mediante el Real Decreto 62/2006, de 27 de enero, que la adaptó al sistema del permiso y licencia de conducción por puntos, hace necesario dictar un nuevo Reglamento General de Conductores que sustituya al vigente y que facilite su conocimiento y aplicación".

Desde este punto de interesa aquí ver como quedan las cuestiones relativas a la declaración de pérdida de vigencia por la pérdida de puntos y el procedimiento para efectuarla, así como las cuestiones relativas al Registro de Conductores e Infractores.

\section{PERDIDA DE VIGENCIA POR CARENCIA DE PUNTOS Y PROCEDIMIENTO PARA SU DECLARACIÓN}

Las cuestiones relativas a la nulidad o lesividad y pérdida de vigencia de las autorizaciones administrativas para conducir se regulan en los arts. 34 a 40 RGCon/2009 (Capítulo IV del Título I).

En el art. 35 RGCon/2009 contiene la regulación de la declaración de pérdida de vigencia sobre la base de lo que, hasta ese momento (competencia del Jefe Provincial de Tráfico del domicilio del titular de la autorización), establecía el art. 39 RGCon/1997, supone las siguientes innovaciones:

- Se sustituye la expresión "que su titular mantenga los requisitos exigidos para su otorgamiento y a que no haya perdido su asignación total de puntos" por la de "cuyo titular no posea los requisitos para su otorgamiento o haya perdido totalmente su asignación de puntos" (art. 34.1 RGCon/2009)

- Se establece un plazo de seis meses para notificar la pérdida de vigencia (art. 34.1 RGCon/2009)

- Se elimina, la mención expresa (que se realizaba en el art. 39.2 RGC/1997), como presupuesto para proceder a declarar la pérdida de vigencia por perdida de la totalidad del crédito de puntos el que el inicio de procedimiento se produjera "una vez se haya anotado en el Registro de conductores e infractores la última sanción firme en vía administrativa que suponga la pérdida de ese crédito".

2. SOBRE EL PROCEDIMIENTO PARA LA DECLARACIÓN DE PÉRDIDA DE VIGENCIA POR LA PÉRDIDA TOTAL DE LOS PUNTOS ASIGNADOS

El art. 37 RGCon/2009 contiene las disposiciones sobre el Procedimiento para la declaración de pérdida de vigencia por la pérdida total de los puntos asignados. 
El régimen que se establece conserva la esencia de los perfiles que se le habían atribuido. Previamente, en el art. 41 bis RGCon/1997, norma sobre el que se introducen las siguientes modificaciones:

- Al titular de la autorización administrativa objeto de declaración de pérdida de vigencia se le dará vista del expediente (art. 37.1 RGCon/2009)

- Que una vez declarada la pérdida de vigencia, el interesado deberá entregar el permiso o licencia de conducción en la Jefatura Provincial de Tráfico la cual, de no hacerlo, ordenará su retirada por los Agentes de la autoridad (art. 37.2 párrafo Segundo RGC/2009).

- Se extraen de la regulación del procedimiento todas las cuestiones relativas a las condiciones para la obtención de una nueva autorización para conducir, que se ubican, bajo la rúbrica "requisitos para recuperar el permiso o la licencia de conducción" en el art. 38 RGC/2009, y que hasta ese momento se encontraban en los apartados 3 y 4 del art. 41 bis RGC/1997, disposiciones a las que se añade la correspondiente a los requisitos que tienen que cumplir quienes hubieran perdido la vigencia de su autorización por haber sido condenados a la pena de privación del derecho a conducir vehículos de motor y ciclomotores por tiempo superior a dos años (art. 38.4 RGC/2009)

Sobre la prueba de control de conocimientos para la obtención de un nuevo permiso el art. 38.1 RGC/2009 se remite al art. 47.2 del Propio RGC/2009 (referencia que el art. 41 bis.3 RGC/1997 efectuaba al Anexo VIII del RGC/1997) en el que se determina que la nueva obtención de la autorización administrativa requerida de la realización con aprovechamiento del correspondiente curso de sensibilización y reeducación vial y, posteriormente, de la realización de una prueba de control de conocimientos sobre las materias descritas en la Orden INT/2596/2005, de 28 de julio, por la que se regulan los cursos de sensibilización y reeducación vial para los titulares de un permiso o licencia de conducción (art. 38.1 RGC/2009), prueba que puede ser solicitada y efectuada en cualquier Jefatura Provincial de Tráfico, sin que sea preciso, por tanto, que se realice en la correspondiente al domicilio del titular de la autorización (art. 38.2 RGC/2009).

Art. 38 RGC/2009 que, además, incorpora la expresa referencia a la disp. adic. Tercera LTSV en cuanto al lugar en el que se encuentra la definición de conductor profesional a efectos del régimen más beneficioso a efectos de la nueva obtención de la autorización por pérdida de vigencia.

Las previsiones del RGC/2009 se completan, en lo que aquí interesa, con los efectos que se derivan de la declaración de pérdida de vigencia del (art. 40.3 RGC/2009), ya sea por la pérdida total de puntos o por haber sido condenado a la pena de privación del derecho a conducir vehículos de motor y ciclomotores por tiempo superior a dos años, declaración que afectará a todas las clases del permiso o licencia de conducción 
de que sea titular, así como a cualquier otro certificado, autorización administrativa o documento cuyo otorgamiento dependa de la vigencia de la clase o de las clases del permiso o licencia de conducción objeto del procedimiento, tal y como se establece en el art. 40.3 RGC/2009. De igual manera, y por las idénticas razones se determina, en ese mismo precepto que, una vez obtenido nuevamente un permiso o licencia de conducción de la misma clase de la que era titular, siguiendo el procedimiento establecido en su caso, también se obtendrán de nuevo, siempre que no haya transcurrido el plazo de vigencia otorgado cuando le fueron expedidos, los certificados, autorizaciones administrativas o documentos cuyo otorgamiento dependan de la vigencia de la clase o de las clases del permiso o licencia de conducción recuperados.

La redacción realizada en el RGC/2009 presenta, ciertamente, una sistemática más adecuada y rellena, sobre el mismo planteamiento que se había efectuada por medio del RD 62/2006, de 27 de enero, algunas de las fisuras del sistema, pero, al tiempo, muestra las mismas carencias de la regulación previa, en particular en la definición formal del procedimiento de pérdida de vigencia y su terminación que parece vedar, de inicio, toda posibilidad de defensa del interesado.

\section{R) La Ley 18/2009, de 23 de noviembre, de modificación del régimen sancionador de la LTSV}

La Ley 18/2009, de 23 de noviembre, va a suponer una modificación de la Ley de Tráfico y Seguridad Vial en materia sancionadora.

La modificación afecta a 40 artículos de la LTSV, supone la incorporación de un buen número de disposiciones adicionales y finales, la incorporación de dos Anexos... pero, sobre todo, la total mutación del Título de la Ley que, hasta ese momento, había recibido la denominación "de las infracciones y sanciones, de las medidas cautelares y de la responsabilidad" y que recibe nueva redacción bajo esa nueva denominación de "Régimen sancionador" con una estructura íntegramente nueva diferente y un planteamiento totalmente diferentes.

Esta norma, en cuanto al procedimiento sancionador en materia de tráfico, se constituye en la regulación actual y, por ello, tanto su análisis como su crítica, han de ser realizados ya no como evolución y desarrollo de la originaria Ley de Tráfico y Seguridad Vial, sino como su vigente regulación.

No es óbice para ello que la Ley de Tráfico y Seguridad Vial haya seguido recibiendo, con posterioridad a la reforma efectuada por medio de la Ley 18/2009, de 23 de 
noviembre, alguna modificación que, en todo caso, son cuestiones que se integran en el modelo definido por esa Ley ${ }^{303}$.

${ }^{303}$ Tras la Ley 18/2009, de 23 de noviembre, la LTSV se ha vistió afectada por diversas modificaciones y desarrollos con el siguiente alcance:

- Ley 25/2009 de 22 de diciembre, Ley Ómnibus, que modifica los arts. 5 y 60.2 y suprime al apartado 4 del Anexo III.

- RD 170/2010, de 19 de febrero, por el que se aprueba el Reglamento de centros de reconocimiento destinados a verificar las aptitudes psicofísicas de los conductores.

- Orden INT/3022/2010 de 23 de noviembre, que desarrolla art. 59 bis.

- Orden INT/3215/2010 de 3 de diciembre, que desarrolla art. 9 bis.

- RD 303/2011 de 4 de marzo, que añade el párrafo 2ㅇ inciso 2ㅇ al Anexo II.

- Ley 17/2012 de 27 de diciembre, que añade los arts. art. 18.3 y $69.1 \mathrm{~g}$ ). 


\title{
Capítulo II
}

\section{LA COMPETENCIA PARA SANCIONAR LAS INFRACCIONES DE TRÁFICO Y SEGURIDAD VIAL}

\begin{abstract}
SUMARIO: I. COMPETENCIA SANCIONADORA: A) La evolución de la norma general de atribución de la competencia para sancionar las infracciones en materia de tráfico y seguridad vial; B) Ubicación de la regulación de la competencia sancionadora (art. 71 LTSV). II. ATRIBUCIÓN Y DISTRIBUCIÓN DE LA POTESTAD SANCIONADORA EN MATERIA DE TRÁFICO Y SEGURIDAD VIAL: A) Sobre la diversidad de titulares a los que se atribuye la potestad sancionadora; $B$ ) Sobre la distribución de la potestad sancionadora: 1. LA NORMA GENERAL POR LA QUE SE ATRIBUYE a LOS JefES PROVINCIALES DE tRÁfICO LA COMPETENCIA PARA SANCIONAR (AdMinistración General del Estado): a) La atribución de la competencia sancionadora; b) Delimitación. 2. COMUNIDADES AUTÓNOMAS CON COMPETENCIAS EN MATERIA DE TRÁFICO Y SEGURIDAD VIAL: a) La Comunidad Autónoma del País Vasco; b) La Comunidad Autónoma de Cataluña; c) La Comunidad Foral de Navarra. 3. LAS COMPETENCIAS MUNICIPALES EN LA ORDENACIÓN DEL TRÁFICO DE VEHÍ́CULOS Y PERSONAS EN LAS VÍAS URBANAS; 4. COMPETENCIA SANCIONADORA POR RAZÓN DE LA MATERIA (PUBLICIDAD DE LOS VEHÍCULOS); 5. El ESTRAMBótICO SUPUESTO DE LA COMPETENCIA PARA IMPONER LA SANCIÓN DE SUSPENSIÓN DEL PERMISO O LICENCIA DE CONDUCCIÓN O CIRCULACIÓN. III. SOBRE LA DELEGACIÓN DE LA COMPETENCIA PARA SANCIONAR LAS INFRACCIONES DE TRÁFICO Y SEGURIDAD VIAL Y OTROS SUPUESTOS DE SU DESPLAZAMIENTO: A) La genérica previsión; B) La delegación de la competencia sancionadora atribuida a los Jefes Provinciales de Tráfico: 1. Los REQUISITOS DE LA DELEGACIÓN; 2. LA DELEGACIÓN EN EL DiReCtor del CENTRO de tRatamiento de denunCias automatizadas. C) La delegación de la competencia sancionadora de las Comunidades Autónomas; D) La delegación de la competencia sancionadora Municipal; E) La delegación de competencias del Director General de Tráfico; F) La asunción de competencias municipales; G) La delegación de competencias entre diferentes Administraciones; $\mathrm{H}$ ) El ejercicio de la competencia por el órgano delegado.
\end{abstract}

\section{COMPETENCIA SANCIONADORA}

\section{A) La evolución de la norma general de atribución de la competencia para sancionar las infracciones en materia de tráfico y seguridad vial}

La LTSV, en el ámbito de las competencias de la Administración General del Estado, atribuye a los Jefes Provinciales de Tráfico la competencia para sancionar las infracciones en materia de tráfico y seguridad vial, lo que supone, a su vez, determinar 
el ámbito territorial al que se extiende esa competencia, el de la circunscripción provincial en el que ejercen sus funciones.

Esta es la regla general que, en la actualidad, encontramos recogida en la LTSV. Pero no siempre ha sido así. De hecho, esta determinación que residencia en los Jefes Provinciales de Tráfico la competencia para sancionar es bastante reciente y se introduce en la LTSV por medio de la disp. final Primera.Uno de la Ley Orgánica 15/2007, de 30 de noviembre, de modificación del Código Penal en materia de seguridad vial.

La redacción originaria de la LTSV establecía, en el art. 68.1, que "la competencia para sancionar corresponde en el marco de lo dispuesto en la presente Ley, al Gobernador Civil de la provincia en que se haya cometido la infracción". Hay que tener presente que en 1990, al tiempo de dictarse la LTSV, ni siquiera se había promulgado la LOFAGE, por lo que, en ese momento convivían normas que mantenían la regulación de los Gobernadores Civiles con las que habían creado, y empezaban a regular, la figura del Delegado del Gobierno en las Comunidades Autónomas.

En lo que aquí interesa, y en cuanto a la atribución de la competencia para sancionar las infracciones en materia de tráfico y seguridad vial, se pueden diferenciar una serie de períodos o fases temporales:

- El primero de estos períodos abarca el espacio de tiempo comprendido entre la entrada en vigor de la LTSV y la sustitución de la LPA por la LRJ - PAC.

- El segundo alcanza desde la entrada en vigor de la LRJ - PAC hasta la promulgación de la LOFAGE.

- El tercero sería incluiría el periodo de tiempo comprendido entre la entrada en vigor de la LOFAGE y la Ley 4/1999, de 13 de enero, de modificación de la LRJ PAC.

- El cuarto se iniciaría con la referida modificación de la LRJ - PAC, efectuada por la Ley 4/1999, de 13 de enero, y se cerraría con la modificación de la LTSV efectuada por medio de la Ley Orgánica 15/2007, de 30 de noviembre, de modificación del Código Penal en materia de seguridad vial, momento que, como hemos señalado anteriormente, el legislador aprovecha para residenciar, de manera general, la competencia sancionadora en materia de tráfico y seguridad vial en los Jefes Provinciales de Tráfico.

- El quinto sería el espacio comprendido entre la modificación de la LTSV por la Ley Orgánica 15/2007, de 30 de noviembre, y la entrada en vigor de la modificación operada en la LTSV por medio de la Ley 18/2009, de 23 de noviembre.

- $Y$, el sexto y último, que es el estadio en el que actualmente nos encontramos tras la redacción que la LTSV ha recibido de la Ley 18/2009, de 23 de noviembre. 
Con todo hay que tener presente que el gran cambio, en cuanto a la evolución de la competencia para sancionar las infracciones tipificadas en la LTSV, se produce fuera de las normas reguladoras del tráfico y la seguridad vial, cuando por medio de la Ley 4/1999, de 13 de enero, se elimina del art. 127.2 LRJ - PAC el inciso final que prohibía la delegación de las potestades sancionadoras (“...sin que pueda delegarse en órgano distinto", en términos de la originaria redacción LRJ - PAC).

\section{B) Ubicación de la regulación de la competencia sancionadora (art. 71 LTSV)}

Tras la reforma efectuada en la LTSV por la Ley 18/2009, de 23 de noviembre, que da nueva redacción a la totalidad de las previsiones que componen el régimen sancionador, la regulación de la competencia para sancionar las infracciones en materia de tráfico y seguridad vial se encuentra recogida en el art. 71 LTSV, precepto que, bajo la rúbrica "competencias", se encuentra ubicado en el capítulo que la Ley destina a la ordenación del procedimiento sancionador, lo que supone el emplazamiento en un lugar distinto al que, hasta entonces y desde la promulgación de la LTSV, había ocupado, ya que la redacción originaria había situado las cuestiones relativas a la competencia para sancionar en el art. 68 LTSV y dentro del capítulo que se destinaba a la regulación de infracciones y sanciones.

Potestad sancionadora y concreta atribución de competencia para sancionar no forman parte, de manera estricta, del procedimiento sancionador, aunque, sin lugar a dudas, la competencia se constituye en elemento esencial del mismo, en cuanto presupuesto para su ejercicio.

La competencia, tal y como establece el art. 12.1 LRJ - PAC "es irrenunciable y tendrá que ser ejercida, precisamente, por los órganos administrativos que la tengan atribuida como propia", salvo, como añade ese mismo precepto, los casos de delegación o avocación y siempre que se efectúe en los términos establecidos por la ley. A ello se añade, por el art. 127.2 LRJ - PAC, que el ejercicio de la potestad sancionadora corresponde a los órganos administrativos que la tengan expresamente atribuida, por disposición de rango legal o reglamentario. Esa relación ente órgano y competencia es la que determina que el art. 62 LRJ - PAC sancione con la nulidad de pleno derecho los actos dictados por órgano manifiestamente incompetente por razón de la materia o del territorio, lo que resulta especialmente trascedente dado el reparto que el art. 71 LTSV realiza entre las diferentes Administraciones públicas de la potestad para sancionar las infracciones de la LTSV. 


\section{ATRIBUCIÓN Y DISTRIBUCIÓN DE LA POTESTAD SANCIONADORA EN MATERIA DE TRÁFICO Y SEGURIDAD VIAL}

\section{A) Sobre la diversidad de titulares a los que se atribuye la potestad sancionadora}

La potestad sancionadora en materia de tráfico y seguridad vial ha sido objeto de reparto entre las diferentes Administraciones públicas territoriales. La redacción originaria de la LTSV no resultaba especialmente precisa en este ámbito al hacer uso de una medida ambigüedad resultado de la mezcla de declaraciones expresas y reconocimientos tácitos.

Así, en la redacción originaria del art. 68 LTSV, se hacía cumplida referencia a los Alcaldes sin que, en cambio, se realizara mención alguna a las Comunidades Autónomas. Mientras, en el art. 5 de la propia LTSV se atribuían competencias al Ministerio del Interior señalando, ahí sí, expresamente, que ello se hacía sin perjuicio de las que tuvieran asumidas las Comunidades Autónomas en sus propios Estatutos, competencias entre las que se señalaba, en la letra i), "la vigilancia y disciplina del tráfico en toda clase de vías interurbanas y en travesías cuando no exista Policía local, así como la denuncia y sanción de las infracciones a las normas de circulación y de seguridad en dichas vías". Por su parte, el art. 7 LTSV realizaba expresa atribución de competencias a los Municipios sin que existiera un precepto equivalente en el que se regularan las que habían de corresponder a las Comunidades Autónomas con competencias en la materia que, haberlas, como tendremos ocasión de analizar, las había.

Más de diez años habrán de transcurrir hasta que, con la primera gran reforma de la LTSV, la efectuada por medio de la Ley 19/2001, de 19 de diciembre, se modifique el art. 68 LTSV y se establezca, expresamente, que "en las Comunidades Autónomas que tengan transferidas competencias ejecutivas en materia de tráfico y circulación de vehículos a motor, serán competentes para sancionar los órganos designados por sus respectivos Consejos de Gobierno" (art. 68.1 párrafo Cuarto LTSV) y que "los Delegados o Subdelegados del Gobierno, en su caso, y en las Comunidades Autónomas que tengan transferidas las competencias ejecutivas en materia de tráfico y circulación de vehículos a motor, los órganos competentes que correspondan, asumirán esa competencia cuando, por razones justificadas o por insuficiencia de los servicios municipales, no pueda ser ejercida por los Alcaldes".

Ello no significa que, entre tanto, las Comunidades Autónomas con competencias en el ámbito del tráfico y la seguridad vial, no hubieran ejercido esas competencias sancionadoras, sencillamente se trataba de un desajuste formal en el texto normativo, de una falta de reconocimiento expreso de la realidad, situación que con el tiempo, el progresivo traspaso de servicios del Estado a las Comunidades Autónomas y de 
transferencia de competencias ejecutivas y el normal ejercicio de esas competencias se ha ido progresivamente organizando.

El caso de la Administración Local ha sido diferente. Su establecimiento se debía, por una parte, a ese reconocimiento que el art. 140 CE realiza de la autonomía municipal y que, de manera previa a la promulgación de la LTSV, se había plasmado, con base en la innegable tradición histórica existente en esta materia, en la atribución, en todo caso, a los Municipios de la competencia de ordenación del tráfico de vehículos y personas en las vías urbanas, plasmado en el art. 25.1 b) LBRL.

Nos enfrentamos a una potestad sancionadora que se encuentra repartida entre varios titulares, una fragmentación subjetiva (activa) de los titulares de la potestad en la acertada visión de $\mathrm{NIETO}^{1}$, de la que se deriva la necesaria atribución de la parte cuyo ejercicio corresponde a cada uno de ellos.

\section{B) Sobre la distribución de la potestad sancionadora}

El art. 71 LTSV determina los diferentes titulares de la potestad sancionadora en materia de tráfico y seguridad vial y el ámbito al que se ciñe el ejercicio de esa potestad sancionadora. Para ello se determinan las Administraciones y se señalan, o se ponen las bases para que sea determinado por quien tiene la competencia para hacerlo, los órganos a los que se atribuye el ejercicio de la facultad para sancionar las infracciones cometidas contra lo establecido en la LTSV en su respectivo ámbito de competencia.

1. La nORMa general por la QUe se atribuye a los Jefes provinCiales de tráfico la COMPETENCIA PARA SANCIONAR (ADMINISTRACIÓN GENERAL DEL ESTADO)

\section{a) La atribución de la competencia sancionadora}

La vigente regulación de la LTSV (y desde la reforma en ella realizada por la Ley Orgánica 15/2007, de 30 de noviembre) atribuye la competencia para sancionar las infracciones a lo dispuesto en la LTSV a los Jefes Provinciales de Tráfico, siendo el criterio delimitador, entre unos y otros, el del lugar (la provincia) de la comisión de la infracción. A ellos, a los Jefes Provinciales de Tráfico, y en cuanto a las competencias sancionadoras que se les atribuyen, quedan equiparados los Jefes Locales de Tráfico de las Ciudades Autónomas de Ceuta y Melilla en virtud de la expresa previsión efectuada en el art. 71.9 LTSV.

\footnotetext{
${ }^{1}$ NiETO, A., Derecho Administrativo Sancionador, Madrid, Tecnos, 2012, 5a ed., pág. 154.
} 
El hipotético conflicto sobre la determinación de la competencia, para aquellos supuestos en los que la infracciones se hubieran cometido en el territorio de más de una provincia, se resuelve mediante atribución de esa competencia (conflicto que, para poder existir, requeriría de la formulación de más de una denuncia), como criterio delimitador, al Jefe de Tráfico de la provincia en la que la infracción hubiera sido denunciada en primer lugar.

El art. 71.1 LTSV establece la regla general sobre la que se asienta el sistema y que se corresponde con la propia organización de la Administración General del Estado en el ámbito del tráfico sobre la base de la circunscripción provincial (Jefaturas Provinciales de Tráfico $^{2}$ ).

\section{b) Delimitación}

El art. 71.1 LTSV se reduce a establecer la competencia sancionadora de los Jefes Provinciales de Tráfico, y las normas que permiten determinar a cuál de ellos, en concreto, corresponde sancionar una determina infracción, pero sin que en ese precepto se señalen el resto de límites al que queda sometida esa competencia por estar atribuida a otro sujetos, algo que sin duda se desprende de las previsiones que, sobre las competencias en el ámbito del tráfico y la seguridad vial, se realizan en los arts. 4 a 7 de la propia LTSV.

No corresponde a los Jefes Provinciales de Tráfico, por estar atribuía a otras Administraciones Públicas o a otros organismos dentro de la propia Administración General del Estado:

- La competencia para sancionar las infracciones cometidas en las Comunidades Autónomas que tengan transferidas las funciones y servicios en materia de tráfico (País Vasco, Cataluña y el especial caso de Navarra)

- La competencia para sancionar las infracciones cometidas en vías urbanas, que corresponde a los respectivos Municipios, salvo que se trate de infracciones en materia de autorizaciones administrativas, de infracciones cometidas en travesías o que se den los supuestos establecidos para que se produzca la asunción de esa competencia municipal

- La competencia para sancionar las infracciones en materia de publicidad de vehículos (art. 52 LTSV) que corresponde al Director General de Tráfico o al órgano que tenga atribuida la competencia en las Comunidades Autónomas

\footnotetext{
${ }^{2}$ La Organización periférica del Organismo estará integrada por cincuenta Jefaturas Provinciales de Tráfico con sede en cada una de las capitales de provincia españolas, y dos Locales, una en Ceuta y otra en Melilla, tal y como establecía el art. 11.4.1 Decreto 986/1974, de 5 de abril, en la redacción del RD 1908/1982, de 23 de julio, precepto derogado por el Real Decreto 901/1990, de 13 de julio, por el que reestructura la Subsecretaría del Ministerio del Interior y los Centros Directivos dependientes de ella.
} 
que tengan transferidas las funciones y servicios en materia de tráfico y seguridad vial

En esa delimitación competencial si les corresponde:

- La sanción de las infracciones cometidas en vías urbanas que tengan la consideración de travesías ${ }^{3}$

- La sanción de infracciones cometidas en vías urbanas cuando hayan asumido la competencia sancionadora municipal

\section{COMUNIDADES AUtÓNOMAS CON COMPETENCIAS EN MATERIA DE TRÁFICO Y SEGURIDAD VIAL}

El art. 71.3 LTSV se limita a establecer la competencia sancionadora de las Comunidades Autónomas sometida a la condición de que tengan transferidas las funciones y servicios en materia de tráfico y seguridad vial. En ese caso, el órgano competente para sancionar las infracciones en materia de tráfico y seguridad vial será el determinado por la propia normativa autonómica.

Hay que destacar que, en el marco general de atribución de competencias (art. 4 a 7 LTSV) no existe un precepto reservado a las Comunidades Autónomas (como sucede para las competencias municipales con el art. 7 LTSV), si bien tanto el art. 4 LTSV, al determinar las competencias de la Administración General del Estado, como el art. 5 LTSV delimitar las que corresponden al Ministerio del Interior, establecen que esas atribuciones de competencias se realizan "sin perjuicio de las que tengan asumidas las Comunidades Autónomas en sus propios Estatutos".

A falta de una expresa concreción de las Comunidades Autónomas con competencias para sancionar las infracciones cometidas en materia de tráfico y seguridad vial resulta adecuado hacer un análisis, por somero que este sea, sobre cuáles son y en que normas se encuentra esa regulación competencial a la que hace referencia el inciso final del art. 71.3 LTSV.

\section{a) La Comunidad Autónoma del País Vasco}

El Real Decreto 3256/1982, de 15 de octubre, de traspaso de servicios del Estado en materia de ejecución de la legislación estatal sobre tráfico y circulación de vehículos ${ }^{4}$,

\footnotetext{
${ }^{3}$ El concepto de "travesía" se encuentra en el apartado 65 del Anexo I LTSV 65 que, a los efectos de esta norma, la define como "el tramo de carretera que discurre por poblado", a lo que se añade que "no tendrán la consideración de travesías aquellos tramos que dispongan de una alternativa viaria o variante a la cual tiene acceso". En cuanto a lo que ha de entenderse por "carretera", concepto del que se hace uso en la definición de travesía, el apartado 78 del propio Anexo I LTSV establece, que a efectos de esta ley, es "toda vía pública pavimentada situada fuera de poblado, salvo los tramos en travesía".
} 
contiene el acuerdo en el que se establece que como consecuencia de lo dispuesto en el art. 17 del Estatuto de Autonomía para el País Vasco (Ley Orgánica 3/1979, de 18 de diciembre, cuyo desarrollo se inició a través del Real Decreto 2903/1980, de 22 de diciembre, y del reconocimiento expreso del Estado a unos antecedentes históricos debidamente actualizados, corresponde a la Comunidad Autónoma del País Vasco las funciones que en este acuerdo se citan, de ejecución de la legislación del Estado en materia de tráfico y circulación de vehículos (apartado A del Anexo).

En virtud de ello, y a partir de la entrada en vigor del Real Decreto aprobatorio del presente acuerdo de la Comisión Mixta de Transferencias, la Comunidad Autónoma del País Vasco asume la facultad de sancionar establecida en el Código de la Circulación, correspondiendo al órgano competente de la Comunidad Autónoma la imposición de todas las sanciones previstas en el Código de la Circulación y disposiciones complementarias, con exclusión de las delegadas en los Alcaldes, la suspensión del permiso de conducción y anulación de la licencia de conducción, facultad que implica la de instruir el expediente, así como la de dictar la resolución que le ponga término y hacerla ejecutar, percibiendo, en su caso, el importe de las multas ${ }^{5}$.

En cuanto a la concreta determinación del órgano competente para sancionar, en el ámbito de la Comunidad Autónoma del País Vasco, y conforme determina el inciso final del art. 71.2 LTSV, que se remite a la regulación autonómica, se hace preciso señalar el Decreto del País Vasco 194/2013, de 9 de abril, por el que se establece la estructura orgánica y funcional del Departamento de Seguridad ${ }^{6}$ y en el que se regula, como órgano central, dentro de la Viceconsejería de Seguridad, la Dirección de Tráfico (art. 2.2.3) que se define como el órgano encargado de elaborar y gestionar las políticas de seguridad vial en la Comunidad Autónoma del País Vasco (art. 16.1).

En ese art. 16 del Decreto del País Vasco 194/2013, de 9 de abril, se establece que:

- En el ejercicio de las potestades de autorización, inspección y sanción previstas en la normativa sobre tráfico y seguridad vial, le corresponden, a la Dirección de Tráfico (del País Vasco), la instrucción y resolución de los expedientes sancionadores que se incoen por infracciones cometidas contra la normativa de

\footnotetext{
${ }^{4}$ Publicado en el Boletín Oficial del Estado de 30 de noviembre de 1982 y en el Boletín Oficial del País Vasco de 29 de enero de 1983.

${ }^{5}$ Cfr. los apartados A), B). 1 a) y 2 a) del Anexo del Real Decreto 3256/1982, de 15 de octubre, de traspaso de servicios del Estado en materia de ejecución de la legislación estatal sobre tráfico y circulación de vehículos. El apartado B).2 a) del Anexo se añadía, además, que "la Comunidad Autónoma, cuando se trate de infracciones que puedan dar lugar, además de la sanción pecuniaria, a la suspensión del permiso de conducción o anulación de la licencia de conducción, remitirán a la Jefatura Provincial de Tráfico competente los expedientes sancionadores a los efectos de dicha suspensión o anulación".

La competencia sancionadora se asumía en el marco de un conjunto de competencias referidas, todas ellas, a la ejecución de la legislación del Estado en materia de tráfico y circulación de vehículos.

${ }^{6}$ Publicado en el Boletín Oficial del País Vasco de 18 de abril de 2013.
} 
tráfico, circulación de vehículos a motor y seguridad vial, y disposiciones complementarias, conforme determina el art. $16.2 \mathrm{a}$ )

- Que la facultad relacionada en el art. 16.2 a) será ejercida por los órganos correspondientes de las Oficinas Territoriales de Tráfico y por la persona responsable del "Centro Automatizado de Tramitación de Infracciones de Tráfico" en sus respectivos ámbitos competenciales (art. 16.2)

- Que a los efectos previstos en la normativa que regula el procedimiento sancionador en materia de tráfico, circulación de vehículos a motor y seguridad vial, será el Instructor o la Instructora de cada Oficina Territorial de Tráfico o el Instructor o la Instructora del "Centro Automatizado de Tramitación de Infracciones de Tráfico" (CATIT), los órganos encargados de la instrucción de los expedientes sancionadores, siendo los competentes para sancionar los Responsables Territoriales de Tráfico o el o la Responsable del "Centro Automatizado de Tramitación de Infracciones de Tráfico (CATIT)" (art. 16.2)

En relación al "Centro Automatizado de Tramitación de Infracciones de Tráfico" al que se hace referencia en el art. 16 del Decreto del País Vasco 194/2013, de 9 de abril, hay que señalar que fue creado por el Decreto del País Vasco 87/2001, de 22 de mayo, por el que se regula el Sistema de Gestión del Tráfico Interurbano en la Comunidad Autónoma de Euskadi y crea el Centro de Gestión de Tráfico de Euskadi, con el objeto de ejercer la potestad sancionadora en relación a las infracciones detectadas directamente por el Centro de Gestión de Tráfico de Euskadi a través de medios de captación y reproducción de imágenes que permitan la identificación del vehículo en los términos que se expresan en el art. 10 del propio Decreto del País Vasco 87/2001, de 22 de mayo ${ }^{7}$.

${ }^{7}$ El art. 10 del Decreto del País Vasco 87/2001, de 22 de mayo, en la redacción recibida del Decreto 10/2012, de 7 de febrero, establece que:

1. El responsable o la responsable del Centro Automatizado de Tramitación de Infracciones de Tráfico será competente para sancionar las siguientes infracciones a la normativa de tráfico y seguridad vial:

a) Infracciones leves, graves y muy graves por incumplimiento de la normativa de tráfico y seguridad vial detectadas directamente por el Centro de Gestión de Tráfico de Euskadi a través de los medios de captación y reproducción de imágenes que permitan la identificación del vehículo.

b) las infracciones por incumplimiento de la obligación de identificar verazmente al conductor responsable de las infracciones referidas en la letra anterior.

c) las infracciones por incumplimiento de la obligación de impedir que el vehículo sea conducido por quienes nunca hubieran obtenido el permiso o la licencia de conducción correspondiente, cuando se haya cometido alguna de las infracciones previstas en la letra a) del presente artículo.

2. En tales casos será el Instructor o Instructora del Centro Automatizado de Tramitación de Infracciones de Tráfico el órgano encargado de la instrucción de los correspondientes expedientes sancionadores.

3. Las resoluciones sancionadoras que dicte el o la responsable del Centro Automatizado de Tramitación de Infracciones de Tráfico ponen fin a la vía administrativa, y contra las mismas 
En el ámbito de la Comunidad Autónoma del País Vasco es preciso tener en cuenta la existencia de una regulación específica que, con rango de Ley, establece unas reglas generales sustantivas válidas para la aplicación de cualquier régimen sancionador sectorial y fijar un procedimiento con unas reglas generales y un iter formal igualmente hábiles para el ejercicio de la potestad sancionadora respecto de cualquier materia. Se trata de la Ley del País Vasco 2/1998, de 20 de febrero, de la potestad sancionadora de las Administraciones Públicas de la Comunidad Autónoma del País Vasco, norma que en el art. 23.2 determina la jerarquía normativa en cuanto a las normas que han de regir los procedimientos sancionadores y que se regirán por los principios establecidos en el Capítulo II del Título IX (principios del procedimiento sancionador) de la LRJ - PAC o la legislación estatal que la sustituya, por la propia Ley del País Vasco 2/1998, de 20 de febrero y las normas que la desarrollen, siendo aplicables, en defecto de éstas, las normas del procedimiento común establecidas en la LRJ - PAC.

\section{b) La Comunidad Autónoma de Cataluña}

La Ley Orgánica 6/1997, de 15 de diciembre, de transferencia de Competencias Ejecutivas en Materia de Tráfico y Circulación de Vehículos a Motor a la Comunidad Autónoma de Cataluña, sobre la base de la competencia en materia de seguridad ciudadana (que se señala que "la tradición administrativa vincula a la de tráfico, y dispone además de una policía autonómica que constituye la infraestructura indispensable para el ejercicio de las funciones de ejecución de la legislación del Estado") transfirió a la Comunidad Autónoma de Cataluña las facultades de ejecución de la legislación del Estado en materia de tráfico, circulación de vehículos y seguridad vial $^{8}$, que sería asumido por la Comunidad Autónoma en el momento que tenga efectividad la transferencia de los medios personales y materiales y presupuestarios precisos, instrumentado, mediante acuerdo de la Comisión Mixta de Transferencias Estado-Generalidad de Cataluña, y el correspondiente Real Decreto de traspaso de servicios (arts. 1 y 3 ).

podrá interponerse recurso de reposición con carácter potestativo ante el mismo órgano que dictó la resolución sancionadora.

${ }^{8}$ Competencias de las que quedaban expresamente excluidas por el art. 1 de la Ley Orgánica 6/1997, de 15 de diciembre, las siguientes:

a) La facultad de expedir, revisar y canjear los permisos y licencias para conducir vehículos a motor y ciclomotores, así como su anulación, intervención, revocación y, en su caso, suspensión, derivada de expedientes de sanción o en vía cautelar.

Igualmente se excluye la verificación de las pruebas reglamentarias establecidas para la obtención del permiso de conducción y de las licencias de conducción para ciclomotores.

b) La matriculación y la expedición de los permisos o licencias de circulación, así como la anulación, intervención y revocación de dichos permisos o licencias, y por su consecuencia la autorización de transferencias, duplicados y bajas de vehículos a motor y ciclomotores, así como la expedición de permisos temporales. 
Vigente ya, por tanto, la LTSV, el Real Decreto 391/1998, de 13 de marzo, sobre traspaso de servicios y funciones de la Administración del Estado a la Generalidad de Cataluña en materia de tráfico y circulación de vehículos a motor ${ }^{9}$, por el que se traspasan los servicios adscritos a las siguientes funciones de ejecución, de la Administración del Estado (apartado B.1)

- La vigilancia y control del tráfico, tránsito y circulación de vehículos en las vías públicas interurbanas y en travesías cuando no exista policía local comportando la realización a los conductores de las pruebas reglamentarias establecidas (apartado B.1 a)

- La facultad de denuncia y sanción de las infracciones a las normas de circulación y de seguridad en las vías interurbanas, travesías que no tengan características exclusivas de vías urbanas, y urbanas que no correspondan a los alcaldes, de acuerdo con la normativa aplicable en la materia y demás normas complementarias. Esta facultad implica la de instruir el expediente, así como la de dictar la resolución que le ponga término y hacerla ejecutar, percibiendo, en su caso, el importe de las multas (apartado B.1 b)

- Igualmente se transfieren las facultades sancionadoras correspondientes al régimen sancionador específico que regula la publicidad en relación a vehículos, así como el referido a la Ley sobre Responsabilidad Civil y Seguro en la Circulación de Vehículos a Motor (apartado B.1 a b 2ª̣)

- La denuncia y sanción por el incumplimiento de la obligación de someterse a la inspección técnica de vehículos, así como a las prescripciones derivadas de la misma (apartado B.1 f)

- La realización material de las funciones policiales derivadas de las medidas de intervención que respecto a los procesos de nulidad, anulabilidad, suspensión y pérdida de vigencia de permisos y licencias adopten las autoridades competentes (apartado B.1 g)

- La concesión, extinción, suspensión o revocación de autorizaciones de apertura y funcionamiento de centros de formación de conductores, su inspección y régimen sancionador (apartado B.1 h)

Sobre los órganos competentes para sancionar en materia de tráfico y seguridad vial en el ámbito de las facultades de la Comunidad Autónoma de Cataluña resulta preciso tener en cuenta que por medio de la Ley del Parlamento de Cataluña 14/1997, de 31 de diciembre, de Creación del Servicio Catalán de Tráfico, se procedió a la creación del referido organismo autónomo, de carácter administrativo, adscrito al Departamento de Gobernación (art. 1.1). Este último, el Departamento de Gobernación, es el responsable de la ejecución de las competencias de la Generalidad en materia de tráfico, circulación de vehículos y seguridad viaria, que deben ser ejercidas mediante el

\footnotetext{
${ }^{9}$ Publicado en el BOE de 2 de abril de 1998 y en el Diario Oficial de la Generalidad de Cataluña de 2 de abril de 1998 .
} 
Servicio Catalán de Tráfico y los órganos del Departamento de Gobernación que se determinen por reglamento (art. 2.1).

Son funciones que se atribuyen, en el ámbito del ejercicio de la potestad sancionadora, al Servicio Catalán de Tráfico, conforme determina el art. 2.4 de la Ley del Parlamento de Cataluña 14/1997, de 31 de diciembre:

- Instruir y resolver los expedientes sancionadores que se incoen por infracciones cometidas contra la normativa de tráfico, circulación de vehículos y seguridad viaria, objeto de transferencia (letra a)

- Ejercer las relativas a la apertura, funcionamiento, inspección y régimen sancionador de las autoescuelas, así como a la formación y homologación del profesorado y dirección de las mismas (letra b)

- Controlar la publicidad relacionada con el tráfico y seguridad de la circulación viaria (letra q)

Por otra parte, en los arts. 5 y 11 de la propia Ley del Parlamento de Cataluña 14/1997, de 31 de diciembre, en el marco de la regulación del Director del Servicio Catalán de Tráfico y la competencia sancionadora que se le atribuye, establecen como funciones del Director:

- Resolver los expedientes sancionadores que se incoen por infracciones cometidas contra la normativa de tráfico, la circulación de vehículos y la seguridad vial a las vías interurbanas y travesías, sin perjuicio de las competencias municipales (art. $5 \mathrm{~g}$ )

- Resolver los expedientes sancionadores que se incoen y asumir la competencia sancionadora por infracciones cometidas en vías urbanas de los municipios que hayan firmado un convenio (arts. $5 \mathrm{~h}$ y 11.4)

- Resolver los expedientes sancionadores relativos a las autoescuelas y a los centros de reconocimiento de aptitudes psicotécnicas de los conductores (art. 5 i)

- Resolver los recursos administrativos (art. $5 \mathrm{j}$ )

- Imponer multas y sanciones en materia de tráfico, circulación de vehículos y seguridad vial, sin perjuicio de las competencias municipales (art. 11.1)

- Las sanciones en materia de publicidad (art. 11.3)

c) La Comunidad Foral de Navarra

Mucho se ha escrito sobre la existencia o inexistencia de la competencia de la Comunidad Foral de Navarra en materia de tráfico y seguridad vial. Lo cierto es que, en 
muchas ocasiones mezclando este título, el del tráfico, con otros, como es el caso del transporte y seguridad pública ${ }^{10}$.

Lo cierto es que, al margen de cuál fuera el alcance de las competencias históricas, no se ha realizado la correspondiente transferencia de competencias en materia de tráfico y seguridad vial, y ello independientemente, como se ha indicado, del ejercicio de determinadas competencias en ese entorno.

El hecho de contar con un cuerpo policial propio (Policía Foral) que, en el fondo, es el gran argumento del que se hace uso para transferir al País Vasco y a Cataluña competencias ejecutivas en materia de Tráfico y Circulación, y que el ejercicio de estas sea práctica habitual, motivo por el cual las referencias a las competencias en materia de tráfico y seguridad vial sean constantes.

Baste con citar, a título de ejemplo, que el art. 9 f) de la Ley Foral 8/2007, de 23 de marzo, de Policías de Navarra, señala, entre las funciones de la Policía Local la de "la ordenación del tráfico dentro del territorio de la Comunidad Foral de Navarra, conforme a los convenios de delimitación de competencias en la materia concluidos con el Estado y vigentes en cada momento, salvo que correspondan legalmente a las Policías Locales" y que el Decreto Foral 113/2005, de 12 de septiembre, por el que se aprueba el Reglamento de Organización y Funcionamiento de la Escuela de Seguridad de Navarra, que en párrafo cuarto de su Exposición de Motivos señala que la Policía Foral de Navarra se encuentra "inmersa en un proceso de reorganización y crecimiento, que deberá concretarse en la consolidación del ejercicio de funciones en materia de seguridad ciudadana y policía judicial y en la asunción de las que le corresponderán como consecuencia de la transferencia de las competencias de tráfico a la Comunidad Foral de Navarra". Entre tanto, la Policía Foral ejerce las funciones propias a la vigilancia y control del tráfico de vehículos en las vías públicas interurbanas, en travesías cuando no exista policía local y la realización de las pruebas reglamentarias establecidas, así como la denuncia y sanción de las infracciones a las normas de circulación y de seguridad en las vías interurbanas, travesías que no tengan características exclusivas de vías urbanas, y urbanas que no correspondan a los alcaldes, de acuerdo con la normativa aplicable en la materia y demás normas complementarias.

\footnotetext{
${ }^{10}$ A ello se refieren quienes se han detenido en estudiar el marco competencial de la Comunidad Foral de Navarra. Es el caso de M. PULIDO QUECEDO en "Las competencias de Navarra en materia de ordenación de transportes por carretera", Revista Jurídica de Navarra, № 2, julio - diciembre 1986, págs. 31 - 49 o de T. CANO CAMPOS, El régimen jurídico - administrativo del tráfico, Madrid, Civitas, 2010, 2a ed., págs. 228 a 233.
} 
3. LAS COMPETENCIAS MUNICIPALES EN LA ORDENACIÓN DEL TRÁFICO DE VEHÍCULOS Y PERSONAS EN LAS VÍAS URBANAS

El art. 71.3 LTSV establece la competencia municipal para la sanción de las infracciones que, en materia de tráfico y seguridad vial, sean cometidas en las vías urbanas, competencia sancionadora que se residencia en el Alcalde.

La delimitación de la competencia municipal para sancionar las infracciones en materia de tráfico y seguridad se fundamenta en la autonomía municipal, en la potestad sancionadora atribuida por el art. $4.1 \mathrm{f}$ ) LBRL a los municipios y en el hecho del sitio, del tipo de lugar, en el que se comete la infracción, de ahí que el art. 7 a) LTSV establezca que "se atribuyen a los Municipios, en ámbito de esta Ley, la competencia de la ordenación y el control del tráfico en las vías urbanas de su titularidad, así como su vigilancia por medio de agentes propios, la denuncia de las infracciones que se cometan en dichas vías y la sanción de las mismas cuando no esté expresamente atribuida a otra Administración".

Un análisis de esta premisa permite entender que queden al margen de la competencia sancionadora municipal los siguientes supuestos:

- Las infracciones en materia de autorizaciones administrativas (art. 71.6 LTSV), en la medida en que no necesitan de una vía urbana para ser cometidas ni se distinguen por ello

- Las infracciones cometidas en travesías ${ }^{11}$ en tanto no tengan la consideración de vías urbanas (art. 71.6 LTSV) dado que el concepto sobre el que se asienta la competencia es, precisamente que la infracción se produzca en vías de naturaleza urbana

- Las infracciones en materia de publicidad de los automóviles (art. 71.8 LTSV), cuestión sobre la que los municipios no tienen competencia alguna

Las características propias del tráfico sobre vías urbanas y su neta diferenciación del realizado en vías interurbanas justifican la existencia de una competencia municipal establecida en el marco de la Ley 7/1985, de 2 de abril, reguladora de Bases del Régimen Local (LBRL), que el municipio ha de ejercer en todo caso en materia de ordenación del tráfico de vehículos en las vías urbanas, tal y como establece el art. 25.2 b) LBRL.

Movilidad y ordenación de los diferentes usos de los espacios urbanos y una regulación específica, como respuesta a las necesidades concretas que el tráfico supone en las vías urbanas que lleva al establecimiento de la regulación mediante Ordenanzas municipales, como se prescribe en el art. 38.4 LTSV en el marco de la regulación del régimen de parada y estacionamiento, de la posible adopción de medidas

\footnotetext{
${ }^{11}$ Sobre el concepto de travesía vide supra la nota 3 en este mismo capítulo.
} 
provisionales, en especial la de retirada y depósito del vehículo, vinculada a la comisión de infracciones en vías urbanas -arts. 7 c) y 85 LTSV- y de unas previsiones específicas en el marco de la LBRL en cuanto a tipificación de infracciones y sanciones.

Especial mención merece la previsión efectuada en el art. 71.5 LTSV conforme a la que esa competencia sancionadora de los Alcaldes puede ser asumida por los Jefes Provinciales de Tráfico o, en su caso por los órganos competentes de las Comunidades Autónomas con competencias en materia de tráfico y circulación de vehículos a motor, en aquellos supuestos en los que por razones justificadas o por la insuficiencia de medios, no pueda ser ejercida por los municipios, cuestión cuyo análisis se efectúa junto con el resto de supuestos en los que se produce un desplazamiento de la competencia sancionadora ${ }^{12}$.

\section{COMPETENCIA SANCIONADORA POR RAZÓN DE LA MATERIA (PUBLICIDAD DE LOS VEHÍCULOS)}

Al lado de la distribución territorial de la competencia para sancionar las infracciones en materia de tráfico y seguridad vial efectuada entre Administración del Estado, Comunidades Autónomas (en su caso) y Municipios, se encuentran otras normas. Es el caso de la que atribuye la específica competencia para la sanción de las infracciones previstas en el art. 52 LTSV precepto en el que se prohíbe "la publicidad en relación con vehículos a motor que ofrezca en su argumentación escrita o verbal, en sus elementos sonoros o en sus imágenes, incitación a la velocidad excesiva, a la conducción temeraria, a situaciones de peligro o cualquier otra circunstancia que suponga una conducta contraria a los principios de esta Ley o cuando dicha publicidad induzca al conductor a una falsa o no justificada sensación de seguridad".

El art. 71.8 LTSV distribuye la competencia para sancionar esa publicidad prohibida entre la Administración General del Estado y las Comunidades Autónomas haciendo uso del criterio, ya conocido, de Comunidades Autónomas con competencias transferidas en materia de tráfico y seguridad vial. De esta forma se designa, como órgano competente en el Estado, al Director General de Tráfico y, en las Comunidades Autónomas, limitada, eso sí, a su ámbito geográfico de competencia, al respectivo órgano que tenga atribuía la competencia por las normas autonómicas ${ }^{13}$.

\footnotetext{
12 Véase, el al final de este capítulo, el análisis de los diferentes supuestos en los que se desplaza el ejercicio de la competencia sancionadora para ser ejercida por órgano distinto al que, inicialmente, la tiene atribuida por el art. 71 LTSV y, en particular, el apartado III.F) sobre "La asunción de competencias municipales".

${ }^{13}$ Véase, a este respecto, el apartado sobre las competencias sancionadoras de las Comunidades Autónomas. Como allí se señala, en el caso de la Comunidad Autónoma del País Vasco el RD 3256/1982, de 15 de octubre, es previo a la promulgación de la LTSV, de forma que lo que se asume es la facultad de sancionar establecida en el Código de la Circulación de 1934, correspondiendo al órgano competente de la Comunidad Autónoma del País Vasco la imposición de todas las sanciones previstas en el Código de la Circulación y disposiciones complementarias, y el art. 16.2 a) del Decreto del País Vasco 194/2013, de 9
} 
Esta infracción, establecida por la LTSV en el marco del espacio dedicado a "otras normas de circulación", ubicación extraña para una disposición ciertamente peculiar, como lo es la propia regulación de la materia sobre la que recae, en cuanto que prevé que "esta publicidad estará sometida al régimen de autorización administrativa previa, de acuerdo con lo establecido en la legislación reguladora de la publicidad" ${ }^{14}$ (art. 52 LTSV) y que fuera del cuadro general de infracciones se determine sobre este tipo de infracciones que "se sancionarán en la cuantía y a través del procedimiento establecido en la legislación sobre defensa de los consumidores y usuarios" (art. 66 LTSV), lo que, en principio, parece una remisión al Real Decreto Legislativo $1 / 2007$, de 16 de noviembre, por el que se aprueba el texto refundido de la Ley General para la Defensa de los Consumidores y Usuarios y otras leyes complementarias ${ }^{15}$, norma que destina los arts. 46 a 52 a la potestad sancionadora, y que, aunque en su Exposición de Motivos (párrafo noveno del apartado II), señala que "El título IV contiene las disposiciones en materia de procedimiento sancionador e infracciones y sanciones", determinando la cuantía de las sanciones en el art. $51.1^{16}$ si bien no se detalla un procedimiento administrativo sancionador más allá de referirse al art. 130.2 LRJ - PAC y señalar que, conforme a lo previsto en ese precepto, podrá exigirse la reposición de la situación y la indemnización de daños y perjuicios probados al consumidor,

de abril, establece que a la Dirección de Tráfico de esa Comunidad Autónoma le corresponde La instrucción y resolución de los expedientes sancionadores que se incoen por infracciones cometidas contra la normativa de tráfico, circulación de vehículos a motor y seguridad vial, y disposiciones complementarias.

Para el caso de la Comunidad Autónoma de Cataluña la transferencia de esta facultad sancionadora se llevo a efecto por medio del apartado B). 1 b) 2a del Anexo del RD 391/1998, de 13 de marzo, y la competencia para imponer las sanciones en materia de publicidad está atribuida, por el art. 11.3 de la Ley del Parlamento de Cataluña 14/1997, de 24 de diciembre, al Director del Servicio Catalán de Tráfico.

${ }^{14}$ Referencia que nos sitúa en el art. 5.1 de la Ley 34/1988, de 11 de noviembre, General de Publicidad, precepto que establece que:

"La publicidad de materiales o productos sanitarios y de aquellos otros sometidos a reglamentaciones técnico-sanitarias, así como la de los productos, bienes, actividades y servicios susceptibles de generar riesgos para la salud o seguridad de las personas o de su patrimonio, o se trate de publicidad sobre juegos de suerte, envite o azar, podrá ser regulada por sus normas especiales o sometida al régimen de autorización administrativa previa. Dicho régimen podrá asimismo establecerse cuando la protección de los valores y derechos constitucionalmente reconocidos así lo requieran".

${ }^{15}$ Publicado en el Boletín Oficial del Estado de 30 de noviembre de 2007.

${ }^{16}$ Precepto que establece:

“1. Las infracciones en materia de defensa de los consumidores y usuarios previstas en esta Norma serán sancionadas por las Administraciones públicas competentes con multas de acuerdo con la siguiente graduación:

a) Infracciones leves, hasta $3.005,06$ euros.

b) Infracciones graves, entre $3.005,07$ euros y $15.025,30$ euros, pudiendo rebasar dicha cantidad hasta alcanzar el quíntuplo del valor de los bienes o servicios objeto de la infracción.

c) Infracciones muy graves, entre $15.025,31$ y 601.012,10 euros, pudiendo rebasar dicha cantidad hasta alcanzar el quíntuplo del valor de los bienes o servicios objeto de infracción". 
previsiones que no vienen a encajar, demasiado bien, con el tipo previsto en el art. 52 LTSV $^{17}$.

Diferente es si esa remisión ha de entenderse efectuada, por la naturaleza del tipo infractor, al régimen establecido en el marco de la regulación de la publicidad ${ }^{18}$, cuestión a la que, efectivamente, se refiere la Exposición de Motivos del referido Real Decreto Legislativo 1/2007, de 16 de noviembre, al señalar en la ya citada Exposición de Motivos que no forman parte de refundición efectuada este Real Decreto Legislativo otras normas que instrumentan regímenes jurídicos muy diversos y que regulan ámbitos sectoriales específicos alejados del núcleo básico de la protección de los consumidores y usuarios, como es la Ley 34/1988, de 11 de noviembre, General de Publicidad $^{19}$.

Ley General de Publicidad que en el art. 2 define lo que ha de entenderse por publicidad y en el art. 3, entre los supuestos de publicidad ilícita, señala, en el apartado d), que lo es "la que infrinja lo dispuesto en la normativa que regule la publicidad de determinados productos, bienes, actividades o servicios". Así, para el caso de los productos, bienes, actividades y servicios susceptibles de generar riesgos para la salud o seguridad de las personas (supuesto en el que cabría encuadrar la publicidad a la que se refiere el art. 52 LTSV) esa publicidad podrá ser regulada por sus normas especiales o sometida al régimen de autorización administrativa previa (que es lo que aquí sucede) y el incumplimiento de esas normas especiales "tendrá consideración de infracción a los efectos previstos en la Ley General para la Defensa de los Consumidores y Usuarios y en la Ley General de Sanidad (apartados 1 y 5 del art. 5 Ley General de Publicidad).

Sobre esta cuestión, y en cuanto al ámbito del ejercicio de esta potestad sancionadora, es preciso señalar que la prohibición realizada en el art. 52 LTSV no se limita a la publicidad que esté referida a los vehículos de motor y alcanza a cualquier tipo de publicidad que tenga relación con vehículos a motor, sea cual sea el producto o servicio anunciado, e independientemente de que se trate o no de un vehículo ${ }^{20}$.

\footnotetext{
17 El art. 48 del Real Decreto Legislativo 1/2007, de 16 de noviembre, establece, literalmente que "conforme a lo previsto en el artículo 130.2 de la Ley 30/1992, de 26 de noviembre, de Régimen Jurídico de las Administraciones Públicas y del Procedimiento Administrativo Común, en el procedimiento sancionador podrá exigirse al infractor la reposición de la situación alterada por la infracción a su estado original y, en su caso, la indemnización de daños y perjuicios probados causados al consumidor que serán determinados por el órgano competente para imponer la sanción, debiendo notificarse al infractor para que en el plazo de un mes proceda a su satisfacción, quedando, de no hacerse así, expedita la vía judicial".

${ }^{18}$ Aunque esta parece ser la dirección adecuada cabría preguntarse la razón de que la referencia que se realiza en el art. 66 LTSV lo sea, de manera específica, a la legislación sobre defensa de consumidores y usuarios, y no a la legislación reguladora de la publicidad como se hace desde el art. 52 LTSV.

${ }^{19}$ Cfr. los párrafos séptimo y undécimo de la Exposición de Motivos del Real Decreto Legislativo 1/2007, de 16 de noviembre.

${ }^{20}$ En este sentido la STS de Madrid de 22 de septiembre de 2004 señala, sobre el art. 52 LTSV, que:
} 
De no aceptarse la presente interpretación bastaría con efectuar la publicidad de un determinado producto, no relacionado con el mundo del vehículo del motor, en el que apareciese, sin embargo, como centro argumental éste, con la marca que se pretendiese anunciar, para eludir, cualquiera que fuese actividad o conducta reflejada, la responsabilidad derivada del producto comentado. Se trata de evitar situaciones de riesgo circulatorio.

5. El ESTRAMBÓtico SUPUESTO DE LA COMPETENCIA PARA IMPONER LA SANCIÓN DE SUSPENSIÓN DEL PERMISO O LICENCIA DE CONDUCCIÓN O CIRCULACIÓN

Contiene el art. 71.7 LTSV una previsión sobre atribución de competencia para la imposición de una determinada sanción que la vigente regulación de la LTSV en materia de sanciones ha dejado fuera de lugar.

Señala el art. 71.7 LTSV que "la competencia para imponer la suspensión del permiso o licencia de conducción o de circulación corresponde, en todo caso, al Jefe Provincial de Tráfico". Se trata de una previsión que carece de sentido desde el momento que la Ley 18/2009, de 23 de noviembre, eliminó de la LTSV la suspensión de autorizaciones administrativas como sanción. Es cierto que en el marco de la propia regulación de las autorizaciones administrativas establecidas por la LTSV se establece la posibilidad de su suspensión y que, en concreto, el art. 64 LTSV permite, como posibilidad, la suspensión cautelar de la autorizaciones administrativas en el curso de los procedimientos de declaración de nulidad o lesividad y pérdida de vigencia, pero se trata de una medidas que no tienen naturaleza sancionadora ${ }^{21}$.

Pero desde el momento que en el art. 67 LTSV, precepto en el que se establecen y regulan las diferentes sanciones administrativas que a las infracciones en materia de tráfico y seguridad vial les pudieran corresponder, no figura la suspensión de autorizaciones administrativas, algo que sucede tras la modificación operada por la Ley

\footnotetext{
“El artículo 52 reseñado no prohíbe tan sólo la publicidad referida a vehículos de motor, sino que, como se desprende inequívocamente de su tenor literal. «Se prohíbe la publicidad en relación con vehículos a motor», por ello, lo realmente prohibido es toda publicidad en la que, con total independencia del producto anunciado, aparezca como argumentación de la misma un vehículo a motor y a través de ella se incurra en alguna de las conductas en el precepto. De no aceptarse la presente interpretación bastaría con efectuar la publicidad de un determinado producto, no relacionado con el mundo del vehículo del motor, en el que apareciese, sin embargo, como centro argumental éste, con la marca que se pretendiese anunciar, para eludir, cualquiera que fuese actividad o conducta reflejada, la responsabilidad derivada del producto comentado. Se trata de evitar situaciones de riesgo circulatorio".
}

\footnotetext{
${ }^{21}$ Cuestión distinta es la privación de la autorización para conducir por haber perdido su titular todos los puntos asignados y la naturaleza que a ello se deba atribuir, asunto al que se destina el capítulo con el que se cierra esta obra.
} 
18/2003, de 19 de noviembre, que elimina las previsiones que, hasta ese momento, regulaban la suspensión de autorizaciones como sanción, no cabe hablar de sanción de suspensión del permiso o licencia de conducción y circulación y, por lo tanto la referencia a la atribución de competencia para su imposición es extravagante y su presencia en el art. 71 LTSV está fuera de todo lugar, ya que no existiendo, como sanción, la suspensión de autorizaciones, difícilmente (ya que es imposible) puede atribuirse la competencia para imponerla ${ }^{22}$.

\section{SOBRE LA DELEGACIÓN DE LA COMPETENCIA PARA SANCIONAR LAS INFRACCIONES DE TRÁFICO Y SEGURIDAD VIAL Y OTROS SUPUESTOS DE SU DESPLAZAMIENTO}

\section{A) La genérica previsión}

Una vez eliminada la prohibición de delegación del ejercicio de la potestad sancionadora (tras la reforma efectuada en el art. 127.2 LRJ - PAC por la Ley 4/1999, de 13 de enero) desaparece el obstáculo que impedía al órgano administrativo que la tenía atribuida desplazar su competencia, tal y como previene el art. 13 LRJ - PAC, a otros órganos de la misma Administración, aun cuando no sean jerárquicamente dependientes, o de las entidades de derecho público vinculadas o dependientes de aquéllas.

El art. 71 LTSV establece de manera expresa esta posibilidad. Así, encontramos referencias en relación a los Jefes Provinciales de Tráfico y a los Alcaldes, sin que nada impida que, en el resto de los supuestos, se haga uso de esta posibilidad en el marco, eso sí, de la regulación que le corresponda.

Se hace preciso determinar las diferentes posibilidades que se plantean, los diferentes requisitos con los que, en cada supuesto, es preciso cumplir, así como las consecuencias de esa traslación de la competencia, ya que la delegación de las

\footnotetext{
${ }^{22}$ La suspensión del permiso de conducir no está prevista en el ámbito de la LTSV. Sin embargo, la Ley Orgánica 1/1992, de 21 de febrero, de Seguridad Ciudadana (LOSC) dispone en el art. 28.2 que "Ias infracciones previstas en el artículo 25 podrán ser sancionadas, además, con la suspensión del permiso de conducir vehículos de motor hasta tres meses y con la retirada del permiso o licencia de armas, procediéndose desde luego a la incautación de las drogas tóxicas, estupefacientes o sustancias psicotrópicas", art. 25 LOSC en el que se establece que "constituyen infracciones graves a la seguridad ciudadana el consumo en lugares, vías, establecimientos o transportes públicos, así como la tenencia ilícita, aunque no estuviera destinada al tráfico, de drogas tóxicas, estupefacientes, o sustancias psicotrópicas, siempre que no constituya infracción penal, así como el abandono en los sitios mencionados de útiles o instrumentos utilizados para su consumo" y que "las sanciones impuestas por estas infracciones podrán suspenderse si el infractor se somete a un tratamiento de deshabituación en un centro o servicio debidamente acreditado, en la forma y por el tiempo que reglamentariamente se determine".
} 
competencias no supone la transferencia de la titularidad de la competencia, sino solamente de su ejercicio.

\section{B) La delegación de la competencia sancionadora atribuida a los Jefes Provinciales de Tráfico}

\section{LOS REQUISITOS DE LA DELEGACIÓN}

El art. 71 LTSV presta especial atención a la posibilidad de delegación de la competencia atribuida a los Jefes Provinciales de Tráfico, algo que no debe de extrañar dado el carácter medular que, en materia sancionadora, cumplen estos órganos de la Jefatura Central de Tráfico.

Así, el art. 71.2 LTSV establece que la competencia que tienen atribuida los Jefes Provinciales de Tráfico podrá ser delegada "en la medida y extensión que estimen conveniente", expresión esta que, a pesar de los términos empleados, no puede suponer el total poder de disposición de los Jefes Provinciales de tráfico sobre la competencia que les atribuye el art. 71.1 LTSV, capacidad de delegación que, como no puede ser de otra manera se encuentra sometida a los límites establecidos en el ordenamiento jurídico, de forma que ha de interpretarse en el sentido de establecer que la LTSV como norma de atribución de esa potestad sancionadora no impone más límites a la facultad de su delegación que los establecidos en las normas que, de manera general, regulan la delegación de competencias, sin que, como señalamos, la LTSV añada ningún otro límite ni requisito adicional.

De esta forma, la delegación de la competencia para sancionar las infracciones en materia de tráfico y seguridad vial tiene que cumplir con lo establecido en el art. 13 LRJ - PAC:

- Esa delegación se puede efectuar (y únicamente se puede producir) en "otros órganos de la misma Administración, aun cuando no sean jerárquicamente dependientes, o de las entidades de derecho público vinculadas o dependientes de aquéllas.

- En relación con la prohibiciones efectuadas en el art. 13.2 LRJ - PAC únicamente habrá que tener presente la contenida en la letra c) y relativa a que, en ningún caso, podrán ser objeto de delegación la resolución de recursos en los órganos administrativos que hayan dictado los actos objeto de recurso

- Esa delegación de la competencia sancionadora (y en su caso la revocación) tiene que publicarse en el Boletín Oficial correspondiente, que en el caso de la delegación de la competencia sancionadora de atribuida a los Jefes Provinciales de Tráfico será el de la respectiva Provincia, que en el caso de las Comunidades Autónomas uniprovinciales, será en el Diario Oficial de esa Comunidad 
Autónoma. En el supuesto de los Jefes Locales de Tráfico de Ceuta y Melilla habría de publicarse en el Boletín Oficial de la Correspondiente Ciudad Autónoma.

- La delegación como excepción al principio general de ejercicio por el órgano que tiene atribuida la competencia, y con más razón si cabe en el caso de que el objeto de esa delegación recaiga sobre competencias sancionadoras, ha de ser concreta y precisa, por lo que no cabe interpretación extensiva alguna sobre el alcance de la competencia sancionadora delegada

De ellos merece especial atención el referido a la prohibición de delegación establecida en el art. 13.2 c) LRJ - PAC. Bien es cierto que esta previsión parece especialmente dirigida a impedir que el órgano al que compete el conocimiento y resolución de un recurso de alzada pueda delegar esa competencia en el órgano que ha dictado la resolución que se pretende recurrir mediante ese recurso. Algo de todo punto razonable. Pero el caso, aquí, es distinto, ya que tras la reforma efectuada por la ley 18/2009, de 23 de noviembre, se eliminó, del régimen sancionador en materia de tráfico y seguridad vial, la posibilidad de recurrir las resoluciones sancionadoras mediante el recurso de alzada ante el superior jerárquico de manera que, desde ese momento, y conforme establece el art. 82.2 LTSV, "contra las resoluciones sancionadoras, podrá interponerse recurso de reposición, con carácter potestativo, en el plazo de un mes contado desde el día siguiente al de su notificación". Recurso de reposición que, como señalan tanto el art. 82.2 párrafo segundo LTSV como el art. 116.1 LRJ - PAC, se interpondrá ante el mismo órgano que dictó la resolución y que será el competente para resolverlo.

De la integración de estas normas se desprende que, aunque pudiera parecer que el recurso de reposición ha de ser interpuesto y resuelto, en todo caso, ante el órgano autor de la resolución que se pretende recurrir, la prohibición efectuada en el art. 13.2 c) LRJ - PAC es, en este punto, taxativa, expresa y no realiza distinción algún en función del tipo de recurso. De ello se ha de entender que ni los Jefes Provinciales de Tráfico pueden delegar la competencia para resolver los recursos de reposición y que efectuada la delegación de la competencia para sancionar el conocimiento de los recursos de reposición que se interpongan frente a las resoluciones dictadas por el órgano en el que se ha delegado esa competencia seguirá siendo de la Jefatura Provincial de Tráfico.

La delegación de la competencia sancionadora que el art. 71.1 LTSV atribuye a los Jefes Provinciales de Tráfico no puede recaer sobre la resolución de los recursos de reposición, ni se puede entender que se extienda a ello. Nula de pleno derecho sería la delegación efectuada en esos términos e, igualmente, nulas de pleno derecho serían las resoluciones dictadas, resolviendo los recursos de reposición, por el órgano delegado. 
Esta delegación de la competencia sancionadora puede ser revocada por el Jefe Provincial de Tráfico en cualquier momento, tal y como determina el art. 13.6 LRJ PAC.

\section{LA DELEGACIÓN EN EL DIRECTOR DEL CENTRO DE TRATAMIENTO DE DENUNCIAS AUTOMATIZADAS}

El art. 71.2 LTSV hace referencia a una posibilidad concreta de delegación de la competencia sancionadora de los Jefes Provinciales de Tráfico al señalar que "en particular podrán delegar en el Director del Centro de Tratamiento de Denuncias Automatizadas $^{23}$ la de las infracciones que hayan sido detectadas a través de medios de captación y reproducción de imágenes que permitan la identificación del vehículo".

Se trata de un supuesto de delegación de competencia de un órgano periférico del Organismo Autónomo Jefatura Central de Tráfico (Jefe Provincial de Tráfico) en otro órgano (Director del Centro de Tratamiento de Denuncias Automatizadas) integrado en la estructura orgánica de la Subdirección General de Normativa y Recursos, de la Dirección General de Tráfico, de la que depende orgánica y funcionalmente.

Esta previsión, la de que los jefes Provinciales de tráfico deleguen su competencia sancionadora en el Director del Centro de Tratamiento de Denuncias Automatizadas, tiene como objetivo cuadrar dos elementos establecidos por la propia LTSV, como son, la posibilidad de denunciar hechos de los que se ha tenido conocimiento a través de medios de captación y reproducción de imágenes que permitan la identificación del vehículo como supuesto que, además, habilita la notificación de la denuncia en un momento posterior al hecho denunciado (art. 76 LTSV) con la competencia de base territorial (circunscripción provincial) atribuida a los Jefes Provinciales de Tráfico (art. 71.1 LTSV).

La previsión que, de manera particular, se efectúa sobre esta posible delegación del Jefe Provincial de Tráfico en el Director del Centro de Tratamiento de Denuncias Automatizadas toma en consideración los medios técnicos de detección, la tramitación de ese tipo de procedimientos sancionadores y los medios con los que cuenta el referido Centro, previsión que se orienta hacia la delegación de la competencia sancionadora cuando se haya tenido conocimiento de los hechos a través de esos medios que permiten la identificación del vehículo y que no requieren de notificación en el acto, es decir, a la referida previsión del art. 76.1 c) LTSV que, no se olvide, no

\footnotetext{
${ }^{23}$ Órgano creado por la Orden INT/2035/2007, de 2 de julio (Boletín Oficial del Estado de 10 de julio de 2007), que se integra en la estructura orgánica de la Subdirección General de Normativa y Recursos, de la Dirección General de Tráfico, de la cual depende funcional y orgánicamente, y que ejercerá funciones de apoyo telemático y administrativo para la tramitación de las infracciones cuya detección se produzca mediante el empleo de medios técnicos (art. 2 de la referida Orden).
} 
distingue entre instrumentos ubicados en instalaciones fijas de los que lo están (entre radares fijos y móviles, en definitiva).

Este es el marco de referencia en el que, en la práctica, se realiza la delegación de competencias supuesto al que también suele acompañar el de la sanción por incumplir la obligación de identificar al conductor responsable de la infracción cuando dicho incumplimiento se produzca durante la tramitación de un procedimiento sancionador instruido por una infracción sobre las que se ha delegado la competencia sancionadora ${ }^{24}$.

En los términos que están redactados los apartados 1 y 2 del art. 72 LTSV cabe plantearse si no hubiera sido más correcto, desde un punto de vista práctico, atribuir directamente determinadas competencias sancionadoras al Director del Centro de Tratamiento de Denuncias Automatizadas, que podrían con las que se le están delegando, de manera sistemática y ordenada, desde las Jefaturas Provinciales, solución, ésta, que coincide con la llevada a la práctica, en su ámbito de competencia, por la Comunidad Autónoma del País Vasco en relación al Director del Centro Automatizado de Tramitación de Infracciones de Tráfico, algo que se antoja más razonable y, sobre todo, más acorde con lo expuesto en la propia explicación que se ofrece en la propia Orden INT/2035/2007 por la que se crea el Centro de Tratamiento de Denuncias Automatizadas.

\footnotetext{
${ }^{24}$ De hecho este es el contenido prototípico de delegación de Resolución por la que un Jefe de Tráfico delega competencias sancionadoras en materia de tráfico y circulación de vehículos en el Director del Centro de Tratamiento de Denuncias Automatizadas y que se corresponden con un modelo homogéneo y uniforme (como es el caso de la Resolución de 15 de septiembre de 2011, por la que el Jefe Provincial de Tráfico de Asturias delega competencias sancionadoras en materia de tráfico y circulación de vehículos en el Director del Centro de Tratamiento de Denuncias Automatizadas, publicada en el BOPA de 22 de septiembre de 2011 o la de idéntica fecha del Director Provincial de Tráfico de Murcia publicada en el BORM de 5 de octubre de 2011).

Primero.-Delegar en el Director del Centro de Tratamiento de Denuncias Automatizadas las siguientes competencias:

1. Para sancionar las infracciones a lo dispuesto en el texto articulado de la Ley sobre Tráfico, Circulación de Vehículos a Motor y Seguridad Vial, aprobado por el Real Decreto legislativo 339/1990, de 2 de marzo, (en adelante Ley de Seguridad Vial), cuando se haya tenido conocimiento de los hechos a través de medios de captación y reproducción de imágenes que permitan la identificación del vehículo y que estén ubicados en instalaciones fijas.

2. Para sancionar las infracciones por exceder los límites de velocidad reglamentariamente establecidos, cuando se haya tenido conocimiento de los hechos a través de medios de captación y reproducción de imágenes que permitan la identificación del vehículo que no estén ubicados en instalaciones fijas, y no se haya producido la parada e identificación del conductor del vehículo.

3. Para sancionar las infracciones por el incumplimiento por parte del titular del vehículo de la obligación de identificar al conductor responsable de la infracción, prevista en el artículo 9 bis de la Ley de Seguridad Vial, cuando dicho incumplimiento se haya producido durante la tramitación de un procedimiento sancionador instruido por una infracción de las previstas en los números anteriores.
} 


\section{C) La delegación de la competencia sancionadora de las Comunidades Autónomas}

Son competentes para sancionar, como ya se ha analizado en el correspondiente apartado, aquellas Comunidades Autónomas que tengan transferidas las funciones y servicios en materia de tráfico y seguridad vial.

En el caso del País Vasco la competencia para sancionar se ejerce (art. 16.2 Decreto 194/2013, de 9 de abril) por los órganos correspondientes de las Oficinas Territoriales de Tráfico y por la persona responsable del Centro Automatizado de Tramitación de Infracciones de Tráfico en sus respectivos ámbitos competenciales, que para el Centro Automatizado determina el art. 10 del Decreto 87/2001, de 22 de mayo.

En este caso, a diferencia de lo que sucede en el marco de la Administración General del Estado, la competencia sancionadora para las infracciones detectadas por medios de captación y reproducción de imágenes que permitan la identificación del vehículo, está directamente atribuida al Director del Centro Automatizado de Tramitación de Infracciones de Tráfico, sin que resulte necesario sugerir su delegación (como hace el art. 72.2 de la LTSV a los Directores Provinciales de Tráfico).

Por otra parte, nada impide la delegación de la competencia sancionadora por los órganos que la tienen atribuida, que resulta posible en los términos y condiciones establecidos en la LRJ - PAC.

La Comunidad Autónoma de Cataluña atribuye, en su ámbito territorial y en el ejercicio de sus competencias, la facultad de sancionar las infracciones de tráfico y seguridad vial al Director del Servicio Catalán de Tráfico (arts. 5 y 11 de la Ley 14/1997, de de 24 de diciembre).

El art. 8 de la Ley 26/2010, de 3 de agosto, de Procedimiento Administrativo de Cataluña, coincidente con los establecido en el art. 13 LRJ - PAC, no impide la delegación de esas competencias ${ }^{25}$.

\footnotetext{
${ }^{25}$ En relación a la posibilidad de delegación de las competencias del Director del Servicio Catalán de Tráfico nada señala, expresamente el art. 5 de la Ley 14/1997, de 24 de diciembre, a diferencia de lo que ocurre con las competencias de la Presidencia de ese Organismo autónomo, ya que en el art. 4.2 de esa misma Ley se establece que "la Presidencia puede delegar expresamente sus funciones en la Dirección, de acuerdo con la normativa vigente". Teniendo en cuenta que las normas que regulan la delegación lo que prescriben es la prohibición de delegación en las materias en que así se determine por una norma con rango de Ley, no existe obstáculo para que, en su caso, se pudiera realizar esa delegación de la competencia sancionadora.
} 


\section{D) La delegación de la competencia sancionadora Municipal}

El art. 71.4 LTSV establece, al tiempo de atribuir la competencia sancionadora por las infracciones cometidas en vías urbanas a los Alcaldes, que esta competencia podrá ser delegada conforme a la legislación que resulte aplicable.

La remisión nos ubica en las atribuciones Alcalde del art. 21 LBRL y en la previsión efectuada en el apartado 3 del referido artículo que establece que el Alcalde puede delegar el ejercicio de sus atribuciones siempre que ello no esté prohibido. La posibilidad de desplazar el ejercicio de las competencias sancionadoras no se encuentra entre las prohibidas, por lo que resulta posible su delegación.

Esta delegación habrá de realizarse, necesariamente, mediante el correspondiente Decreto de la Alcaldía que tendrá que contener el ámbito al que se refiere la delegación, las facultades que se delegan y las condiciones específicas del ejercicio de las mismas, tal y como se establece en el art. 44.1 del Reglamento de Organización, Funcionamiento y Régimen Jurídico de las Entidades Locales ${ }^{26}$. Añade ese precepto, en el apartado 2, que los efectos de la delegación surtirán efectos al día siguiente al de la fecha de ese Decreto, salvo que en él se dispusiera otra cosa, sin perjuicio de la preceptiva publicación de ese Decreto de la Alcaldía en el Boletín Oficial de la Provincia (que será el Diario Oficial de la Comunidad Autonóma en el caso de las uniprovinciales) y, caso de que existiera, en el Diario Oficial Municipal.

La delegación de la competencia sancionadora requiere de la forma establecida, sin que pueda establecerse mediante otro procedimiento por otra norma ${ }^{27}$.

\footnotetext{
${ }^{26}$ Aprobado por RD 2568/1986, de 28 de noviembre y publicado en el Boletín Oficial del Estado de 22 de diciembre de 1986.

${ }^{27}$ La STSJ de Andalucía - Málaga de 30 de septiembre de 2009 determinó, sobre la atribución mediante Reglamento del Gobierno al Subinspector Jefe de la Policía Local de la competencia para sancionar las infracciones de tráfico y seguridad vial en la Ciudad Autónoma de Melilla, lo siguiente (F. 7):

La competencia para imponer sanciones en materia de tráfico viene atribuida por el R.D. Legislativo 339/1990, de 2 de marzo, que aprueba el Texto Articulado de la Ley sobre Tráfico, Circulación de Vehículos a Motor y Seguridad Vial, en su art. 68.4 a favor de los Alcaldes.

Conforme a dicho precepto "la sanción por infracción de normas de circulación cometida en vías urbanas corresponderá a los respectivos Alcaldes, los cuales podrán delegar esta facultad de acuerdo con la legislación aplicable".

Por su parte el precepto que a nuestra consideración se somete, es decir el art. 7.1 del Reglamento de Gobierno y de la Administración de la Ciudad Autónoma de Melilla, establece la competencia sancionadora del Subinspector Jefe de la Policía Local en cuya virtud el mismo puede imponer sanciones en materia de tráfico sin una delegación expresa, concreta y motivada del órgano de dicha ciudad que legalmente tiene la atribución legal de competencia.

Como ha razonado y concluido el Juzgador a quo dicha atribución de competencia sancionadora en materia de tráfico al Subinspector Jefe de la Policía Local debe considerarse ilegal porque como dice la Sentencia de que trae causa esta cuestión la Ciudad Autónoma, entidad local con un estatuto especial, y más concretamente su Asamblea no puede aprobar un Reglamento mediante el cual se alteren competencias que por ley correspondan a su Presidente que en la Ciudad de Melilla ostenta también la condición de Alcalde.
} 


\section{E) La delegación de competencias del Director General de Tráfico}

Sobre la posibilidad de delegar la competencia que el art. 71.8 LTSV atribuye al Director General de Tráfico para sancionar las infracciones que, sobre relación con vehículos a motor, el art. 52 LTSV declara ilícita, habría de estarse al régimen general establecido en el art. 13 LRJ - PAC (y que se ha detallado para el supuesto de delegación de competencias de los Jefes Provinciales de Tráfico).

Ningún obstáculo se presenta para que el Director General de Tráfico, como titular de esa competencia sancionadora en materia de publicidad, proceda, en esos términos, a su delegación.

\section{F) La asunción de competencias municipales}

Entre las previsiones que, en materia de competencia sancionadora, realiza el art. 71 LTSV se encuentra la efectuada en el apartado 5 que prevé la posibilidad de que los Jefes Provinciales de Tráfico $o$, en su caso, los órganos competentes de las Comunidades Autónomas con competencias en materia de tráfico y seguridad vial, puedan llegar a asumir las competencias de los Alcaldes.

Para que ello suceda, y se asuma la competencia de los Alcaldes, el propio art. 71.5 LTSV establece que ello habrá de ser "cuando, por razones justificadas o por insuficiencia de los servicios municipales, no pueda ser ejercida por éstos", redacción que coincide con la que, de manera previa, se efectuaba en el art. 68 LTSV.

Se trata de una cuestión que, desde la promulgación de la LTSV, ha dado lugar a controversias y sobre la que se existen resoluciones judiciales que abordan los diferentes matices que presenta previsión legal.

La primera de esas cuestiones es, sin duda, cual sea la naturaleza de esa previsión ya que no se puede entender que se trate de una delegación de competencias del Alcalde al delegado del Gobierno, sino que ex lege se atribuye al Jefe Provincial de Tráfico o, en su caso, al órgano competente de la Comunidad Autónoma que pueda asumir dichas competencias si bien supeditándolo a que se den unas determinadas circunstancias,

$Y$ ha de considerarse ilegal el controvertido precepto por vulnerar el régimen competencial atribuido por el R.D. Legislativo 339/1990, en su art. 68.4 y el art. 15 del R.D. 320/1994, de 25 de febrero que aprueba el Reglamento de Procedimiento Sancionador en materia de Tráfico, Circulación de Vehículos a Motor y Seguridad Vial.

Sus normas atribuyen, como se ha dicho, la competencia sancionadora a los Alcaldes, exceso del reglamento analizado que -como bien dice la Sentencia del Juzgador melillense- lo vicia de nulidad. 
esto es, que por razones justificadas o por insuficiencia de los servicios municipales, no pueda ser ejercida por los Alcaldes ${ }^{28}$.

Lo esencial en el supuesto es la concurrencia de razones justificadas o la insuficiencia de los servicios municipales que impidan el ejercicio de la competencia sancionadora por el Alcalde. El hecho de que no se acrediten las circunstancias o de que se trate de supuestos en los que, por la naturaleza del municipio (con entidad suficiente), no se pueda presuponer esa insuficiencia de medios, invalida el ejercicio por parte de la Administración estatal o autonómica ${ }^{29}$, siendo preciso que consten las razones motivadas o justificadas por las que ha declinado la Administración Local la tramitación y resolución del expediente sancionador a favor de la Administración General del Estado ${ }^{30}$.

Se requiere, por tanto, para que se pueda asumir esa competencia sancionadora atribuida a los Alcaldes que haya una prueba de esas razones justificadas o insuficiencia de medios, como puede ser la insuficiencia de agentes municipales acreditada en el expediente administrativo ${ }^{31}$ o la petición efectuada por propio Ayuntamiento, supuesto en el que poca duda cabe de que la competencia sancionadora se vendría a ejercitar precisamente a la petición manifestada por la autoridad municipal sin que por tanto pueda entenderse se haya incumplido las previsiones del art. 71.5 LTSV $^{32}$.

La asunción de la competencia municipal sin que concurran las causas que lo justifican determina la nulidad de pleno derecho de los actos dictados por órganos manifiestamente incompetentes por razón del territorio, y acarrea la nulidad de la sanción $^{33}$.

Todo ello no impide que la denuncia de infracciones puede ser efectuada por Agentes de cuerpos diferentes a los que designe el Ayuntamiento Policía Local (como, por

\footnotetext{
${ }^{28}$ Cfr. la JCA Oviedo (Asturias), núm. 1, sentencia núm. 476/2007 de 23 noviembre (JUR 2008, 102091) que si bien se refiere a los Delegados del Gobierno por tratarse de un supuesto bajo la regulación del art. 68 LTSV es perfectamente equiparable.

${ }^{29}$ Sentencias como la del Tribunal Superior de Justicia de Castilla y León, Valladolid, de 21 noviembre (RJCA 2001, 209) que considera que no ha sido acreditado que se dieran en el caso enjuiciado y que de todas formas no parece que sean predicables del caso de una ciudad como Zamora; o Sentencias como la del TSJ Galicia 6 abril de abril de 2001 (JUR 2001, 209822), la del TSJ de la Comunidad Valenciana de 18 abril de 2001 (JUR 2001, 301509), la del TSJ Andalucía, Sevilla de 15 mayo 2000 (JUR 2001, 35854) o la STSJ Aragón de 14 febrero de 2002 (JUR 2002, 196115) que consideran que el Ayuntamiento no se encuentra desasistido en ese menester.

${ }^{30}$ Como señala la STSJ de Extremadura de 19 septiembre 2000 (RJCA 2000, 2486).

${ }^{31}$ STSJ Castilla y León, Valladolid de 16 junio de 2006 (JUR 2006, 215375).

${ }^{32}$ SJCA Oviedo núm. 1 de 23 noviembre de 2007 (JUR 2008, 102091).

${ }^{33}$ Así lo establecen las Sentencias del TSJ de Extremadura en sentencia de 21 de enero de 1999 (RJCA 1999, 100) y del TSJ Cataluña de 18 enero de 2005 (JUR 2005, 120254).
} 
ejemplo, la Guardia Civil), si bien esas denuncias tendrán igual valor, y los mismos efectos, que la cualquier otro ciudadano ${ }^{34}$.

\section{G) La delegación de competencias entre diferentes Administraciones}

El art. 71.2 LTSV se cierra con un inciso que más que una disposición parece contener un consejo sobre posibilidades de actuación en el ámbito del ejercicio de la potestad sancionadora y su delegación al señalar que "asimismo los órganos de las diferentes Administraciones Públicas podrán delegar el ejercicio de sus competencias sancionadoras mediante convenios o encomiendas de gestión o a través de cualesquiera otros instrumentos de colaboración previstos en la legislación de procedimiento administrativo común".

Teniendo en cuenta su ubicación, tras la previsión ("particular" en términos de la propia LTSV) de posible delegación de la competencia sancionadora atribuida al Jefe Provincial de Tráfico en el Director del Centro de Tratamiento de Denuncias Automatizadas de las infracciones que hayan sido detectadas por medios que permitan la identificación del vehículo, lo dispuesto parece una sugerencia al resto de Administraciones Públicas (por si alguien no se hubiera dado cuenta) de la posibilidad de acudir a la delegación de sus competencias sancionadoras mediante los diferentes instrumentos que permiten la colaboración conforme a lo establecido en la LRJ - PAC.

Dos parecen ser los casos más plausibles (en el sentido de admisibles o recomendables, ya que ese parece ser el objetivo de la disposición). Por una parte la delegación de la competencia sancionadora de Comunidades Autónomas y Ayuntamientos en el Centro de Tratamiento de Denuncias Automatizadas de las infracciones detectadas por medios que permiten la identificación del vehículo. De otra, la delegación de las competencias municipales (en todo o en parte) a favor de la Jefatura Provincial de Tráfico o de las Comunidades Autónomas que tiene competencias en materia de tráfico y seguridad vial. Ello sin descartar otras posibles opciones como la cesión de su competencia por parte de los Ayuntamientos hacia las Diputaciones Provinciales o a otros organismos administrativos o Entidades de derecho público.

El inciso, que no pasa de una mera declaración, eso sí, en el marco de la LTSV, es una sugerencia puesto que ni autoriza nada que no estuviera permitido ni produce innovación normativa alguna. Los medios de colaboración entres las diferentes Administraciones públicas son los que son y su regulación es la que es. La decisión de hacer uso de los diferentes instrumentos regulados en la LRJ - PAC hubiera existido igual con esta norma que sin ella, norma que utiliza, y mezcla, los conceptos

\footnotetext{
${ }^{34}$ SJCA Salamanca núm. 1 de 14 marzo de 2007 (JUR 2008, 103954).
} 
delegación, convenio, encomienda y cualesquiera otros medios de colaboración previstos sin indicar la manera precisa y los cometidos para los que esas técnicas de colaboración interadministrativa pudiera emplearse en el concreto ámbito del ejercicio de la potestad sancionadora en el tráfico y la seguridad vial.

\section{H) El ejercicio de la competencia por el órgano delegado}

La delegación de la competencia sancionadora supone una serie de consecuencias que es preciso tener presentes.

En primer lugar hay que tener en cuenta que las resoluciones sancionadoras, aunque dictadas por el órgano que ha recibido esa delegación (órgano delegado), tendrán la consideración de haber sido emitidas por el órgano delegante (art. 13.4 LRJ - PAC), puesto que lo que se transmite con la delegación no es la titularidad de la competencia, que es indisponible en sí misma, lo que se transmite es el ejercicio de esa competencia en cuanto que ese desplazamiento esté permitido por el ordenamiento jurídico como excepción al principio establecido en el art. 12 LRJ - PAC de que "la competencia es irrenunciable y se ejercerá, precisamente, por los órganos administrativos que la tengan atribuida como propia", ya que, como se ha señalado por el Tribunal Supremo, la delegación de atribuciones no define las competencias, sino que afecta sólo a su ejercicio, por lo que permaneciendo invariable la titularidad de las mismas en el órgano legalmente investido, la delegación para su ejercicio carece de contenido normativo ${ }^{35}$.

La delegación es una excepción a ese principio, pero la decisión adoptada acordada por ese órgano delegado es, y así se considera a todos los efectos, como si hubiera sido dictada por el órgano delegante, lo que es preciso tener en cuenta a la hora de determinar quién ha de conocer los recursos, tanto administrativos como jurisdiccionales, que contra ese acto adoptado por delegación, pudieran interponerse.

Esta es la razón por la que, en el caso de la delegación de la competencia sancionadora, como la que puede ser efectuada por los Jefes Provinciales de Tráfico en el Director del Centro de Tratamiento de Denuncias Automatizadas, el recurso de reposición que se interpusiera contra la resolución dictada por este último habría de sustanciarse por el Jefe Provincial de Tráfico delegante que tiene proscrita la delegación de las resolución de recursos en los órganos administrativos en los órganos administrativos que hayan dictado los actos objeto de recurso, conforme a la prohibición efectuada en el art. 13.2 c) LRJ - PAC.

\footnotetext{
${ }^{35}$ Como se puede leer en STS de 12 de junio de 1991 (RJ 1991, 6694).
} 
En toda resolución adoptada por delegación resulta obligado la expresa indicación de esa circunstancia (art. 13.4 LRJ - PAC), omisión que, se ha considerado, no es susceptible de subsanación con la posterior acreditación ${ }^{36}$.

La delegación de la competencia sancionadora en materia de tráfico y seguridad vial no puede ser objeto de de sucesiva delegación por el órgano delegado (o subdelegación) dado que no existe autorización expresa en norma con rango de ley que es el requisito establecido, a tal efecto, por el art. 13.5 LRJ - PAC para que pueda procederse a la delegación del ejercicio de competencias que, a su vez, hubieran sido recibidas por delegación.

\footnotetext{
${ }^{36}$ Así, la STSJ de Baleares de 23 de junio de 1998 (RJCA 1998, 2064) determina que "la competencia para resolver el expediente sancionador correspondía a la Alcaldía, de manera que, aún siendo delegable, la resolución por delegación, que es lo que en el caso se dio, debió indicarse expresamente -art. 13.4 LRJ PAC-, lo que no se hizo, de manera que, aún acreditado con la documental acompañada a la contestación a la demanda que la delegación existía, la infracción del ordenamiento antes indicada permanece".
} 


\section{Capítulo III}

\section{RESPONSABILIDAD POR LA COMISIÓN DE INFRACCIONES DE TRÁFICO}

SUMARIO: I. DE LA RESPONSABILIDAD POR AUTORÍA A LA RESPONSABILIDAD SIN AUTORÍA (LA CULPABILIDAD COMO PROBLEMA): A) Autoría y responsabilidad: De la aparente simplicidad de las cosas; B) Sobre el dogma de la culpabilidad. II. DE LA RESPONSABILIDAD EN LA LTSV: A) De la terminología del art. 69 LTSV; B) El principio general de la responsabilidad por autoría de la infracción: 1. UNA REFLEXIÓN INICIAL; 2. EL AUTOR Y EL RESPONSABLE DE LAS INFRACCIONES DE TRÁFICO Y SEGURIDAD VIAL; 3. EL CONDUCTOR; 4. LOS OCUPANTES DE LOS VEHÍCULOS; 5. EL TITULAR DEL VEHÍ́CULO Y LA EQUIPARACIÓN QUE AL ÉL SE REALIZA DEL ARRENDATARIO A LARGO PLAZO: a) La necesidad de ubicar esta norma en su contexto histórico; b) La vigente configuración del titular y del arrendatario del vehículo; 6. LOS CICLISTAS; 7. OTROS POSIBLES AUTORES. C) LOS supuestos especiales de responsabilidad: 1. DE LA ACUMULACIÓN DE SUPUESTOS (Y SOBRE LA CONFUSIÓN DEL "NO OBSTANTE"); 2. RESPONSABILIDAD DEL CONDUCTOR: a) Responsabilidad del conductor por la no utilización por el ocupante del casco de seguridad; b) Responsabilidad del conductor por transportar menores con edad inferior de la establecida para ello; c) Responsabilidad del conductor por la no de los preceptivos sistemas de retención infantil; 3. RESPONSABILIDAD POR LAS INFRACCIONES COMETIDAS POR LOS MENORES: a) La previsión del art. 69.1 b) LTSV; b) Integración en el propio sistema establecido en el art. 69.1 LTSV; 4. LA RESPONSABILIDAD POR LA INFRACCIÓN COMETIDA POR CONDUCTOR NO IDENTIFICADO AL MOMENTO DE LA COMISIÓN DE LA INFRACCIÓN: a) Vehículos que no tuvieran designado conductor habitual (titular y arrendatario a largo plazo); b) Vehículos que tuvieran designado conductor habitual; c) Arrendamientos a corto plazo y depositarios de vehículos; d) Infracciones de estacionamiento e impago de peajes; e) Efectos de la declaración de responsabilidad; f) Requisitos y efectos la identificación. 5. LA RESPONSABILIDAD POR LAS INFRACCIONES RELATIVAS AL VEHÍCULO; 6. RESPONSABILIDAD Y PERSONAS JURÍDICAS. D) Responsabilidad por el impago de multas. 


\section{DE LA RESPONSABILIDAD POR AUTORÍA A LA RESPONSABILIDAD SIN AUTORÍA (LA CULPABILIDAD COMO PROBLEMA)}

\section{A) Autoría y responsabilidad: De la aparente simplicidad de las cosas}

La Ley de Tráfico y Seguridad Vial contiene, dentro del Título normativo del Régimen sancionador, un capítulo específico bajo la denominación "de la responsabilidad", capítulo integrado por un único artículo, el 69 LTSV, bajo la rúbrica "personas responsables".

El precepto se abre con una declaración tan diáfana como axiomática "la responsabilidad por infracciones a lo dispuesto en esta Ley recaerá directamente en el autor". Si ello fuera así pocas líneas más habría que dedicar a este apartado que se agotaría en el análisis de la identidad que, de esos términos, responsable y autor, se realiza en el precepto.

Lamentablemente tras esa dogmática afirmación siguen dos palabras que impiden cerrar, de forma rauda, este capítulo y que van a exigir alguna explicación adicional. Esas palabras son un "no obstante" (seguido de dos puntos) que en realidad suponen un "pero". Un "sí, pero" que obliga a realizar el análisis de determinar en lo que queda ese principio general de identidad entre responsable y autor. Lástima que las cosas aparentemente sencillas pocas veces lo sean.

\section{B) Sobre el dogma de la culpabilidad}

Mucho se podría escribir sobre la culpabilidad como requisito para la imposición de una sanción administrativa. Todo lo que aquí se escribiera sería, esencialmente, superfluo. $Y$ ello por diversos motivos de los que considero necesario resaltar tres. El estudio de esa cuestión en el ámbito del derecho administrativo sancionador está realizado de forma completa, rigurosa y, sobre todo, consistente. Seguir y reproducir aquí (intentarlo, sin siquiera conseguirlo, sería afirmación más precisa) el análisis de NIETo sería, además de un plagio, una pérdida deliberada de tiempo ${ }^{1}$. Abordar un estudio de la responsabilidad por la comisión de infracciones a la Ley de Tráfico y seguridad Vial, requeriría del correspondiente análisis exhaustivo de las normas, previsiones y tipos, lo que supera el objeto de análisis que para esta obra se ha

\footnotetext{
${ }^{1} \mathrm{Y}$ no porque no existan otras obras en este ámbito. Afortunadamente han pasado esos tiempos de escasez en los que todo se limitaba a la obra de CARRETERo PÉREZ y CARRETERo SÁnCHEZ (EDERSA, 1992). Obra hay. Publicaciones en la materia han proliferado, como señala el propio NIETO, que se refiere a algunas de ellas, guardando silencio sobre otras, algunas de ellas muy significativas. Así me parece, por ejemplo, el que guarda sobre El Manual de Derecho Administrativo Sancionador que en 2a edición y en dos Tomos ha realizado la Abogacía General del ESTAdo - DiRECCIÓn DEL SERVICIO JURídico del Estado bajo la dirección de JOAQUín DE FUENTES BARDAJí y sobre una publicación esencial como, a mi juicio lo es, el número monográfico sobre La potestad sancionadora de las Administraciones Públicas, Documentación Administrativa, no $280-281,2008$.
} 
propuesto, donde la responsabilidad es un presupuesto y no un fin en sí mismo. Es por ello, que para el objetivo de esta obra enfocada al procedimiento sancionador, resulta suficiente con escarbar con las manos sobre el terreno por el que NiETo ha pasado con su maquinaria pesada de obra pública, con una profundidad ciertamente menor y enfocada al tráfico y la seguridad vial, reino del riesgo y paraíso del peligro abstracto. Así pues, me "limitaré" a tomarlo como norte y citarlo repetidamente.

El análisis sobre las formas de culpabilidad y lo que NieTo denomina el "giro administrativo de la culpabilidad" que no se ha detenido en el distanciamiento del dolo y la magnificación de la culpa, sino que ha llegado al mero incumplimiento recogido en el inciso final del art. 130.1 LRJ - PAC cuando se dispone únicamente se puede sancionar a quienes resulten responsables de los hechos constitutivos de infracciones "aun a título de mera inobservancia" ${ }^{2}$ y la conclusión que de ello se deriva, ya que "tal como aparece en el art. 130 LRJ - PAC esta figura excluye ya el elemento culpabilidad expresado en la palabra "mera»" ya que "mero significa que con el incumplimiento basta" y "de no ser así, carecería de sentido este adjetivo" ${ }^{3}$.

El principio de culpabilidad, como dogma, todo lo complica y en un mundo más imperfecto y sobre todo vulgar, como es el derecho administrativo sancionador (en comparación con el edén de la perfección que es el derecho penal), resulta preciso encontrar una solución para atribuir la responsabilidad por hechos ajenos.

La conclusión, el corolario, es que en el ámbito de la culpabilidad el Derecho Administrativo Sancionador ha de regirse por reglas propias liberándose del derecho Penal ${ }^{4}$.

\footnotetext{
2 Nieto, A., Derecho Administrativo Sancionador, Madrid, Tecnos, 2012, 5a ed., pág. 342. Sobre la exigencia de culpabilidad en el ámbito administrativo sancionador y la ambigüedad" del art. 130 LRJ PAC resultan especialmente interesantes las observaciones de CUETO PÉREZ en "Los principios de potestad sancionadora de las Administraciones Públicas. Tipicidad y responsabilidad", Documentación Administrativa, 2010, no 280 - 281, enero - agosto 2008, págs. 95 - 117 y la obra DE PALMA TESO, El principio de culpabilidad en el derecho administrativo sancionador, Tecnos, 1996.

${ }_{3}^{3}$ Nieto, A., Derecho Administrativo Sancionador, Madrid, Tecnos, 2012, 5a ed., pág. 349.

${ }^{4}$ Ibidem, pág. 428. Para llegar a esa conclusión, y las proposiciones que la preceden, hace uso NiETo de dos instrumentos de los que, por muy diferentes razones, preciso dejar constancia. De un lado de una norma con rango de ley, la única en nuestro país de esas características y que, lamentablemente, está limitada a su correspondiente ámbito territorial autonómico, que realiza un planteamiento calificable de integro sobre esta cuestión. Me refiero a la Ley del País Vasco 2/1998, de 20 de febrero, de la potestad sancionadora de las Administraciones Públicas de la Comunidad Autónoma del País Vasco que resuelve está cuestión mediante la consideración, mediante una ficción legal, de la consideración como autor de quien no lo es. Solución que seguro encuentra sus detractores pero que ofrece una solución práctica y flexible. De otra el uso de un ejemplo ilustrativo sobre el art. 278 del Código de la Circulación. la STC 219/1988, de 22 de noviembre (F. 3) y un libro inédito de IGNACIO BORRAJO titulado Las actas de la policía de Tráfico. Se trata, por cierto, de la obra presentada en el segundo ejercicio a Cátedra de Derecho Administrativo en la Universidad Pública de Navarra que el citado Profesor gano y que, curiosamente, concluyó el mismo día en el que se publico en el BOE la LRJ - PAC (27 de noviembre de 1992).
} 


\section{DE LA RESPONSABILIDAD EN LA LTSV}

\section{A) De la terminología del art. 69 LTSV}

Tanto el art. 69 LTSV como su predecesor (el art. 72 LTSV hasta la reforma efectuada por medio de la Ley 17/2005, de 19 de julio) se han limitado al uso de los conceptos "autor" y "responsable". La Ley no tiene problemas en diferenciar ambos conceptos, pero parece que el Estado no busca culpables, ni siquiera autores, sino responsables, hasta el punto que a la mera inobservancia se corresponde la mera responsabilidad ${ }^{5}$.

Desde la redacción originaria de la LTSV se ha hecho uso, como rúbrica del precepto, de la expresión "personas responsables" y hasta la referida reforma del año 2005 el art. 72 LTSV se limita a la identificación de ambas figuras en la medida que el autor es responsable. $Y$ así la previsión dogmática era (y es) que "la responsabilidad por las infracciones a lo dispuesto en esta Ley recaerá directamente en el autor del hecho en que consista la infracción".

Sobre esa redacción originaria del art. 72.1 LTSV conviene tener en cuenta que, por una parte, se trata de una previsión anterior en el tiempo a la que se efectuará en el art. 130.1 LRJ - PAC y, por otra, que se corresponde, y se tiene que corresponder, con la efectuada en la Ley 18/1989, de 25 de julio, de Bases, sobre Tráfico, Circulación de vehículos y Seguridad Vial, que en la Base Octava, apartado 5, establece como principio y criterio que "será responsable directo de las infracciones el autor del hecho que dé lugar a las mismas".

Sobre esta estructura se van introduciendo cambios en las conductas que se regulan, en los tipos administrativos que llevan, en la reforma de 2005, a tener que destruir esa completa identidad conceptual entre autor y responsable introduciendo, un matiz al dogma, que se cumplía "excepto" en determinado supuesto en el que se hacía responsable de la infracción (la consistente en no hacer uso del casco por el ocupante de una motocicleta) no al autor de la misma (el ocupante) sino al conductor de esa motocicleta, que no era el autor de la infracción.

Roto el paradigma de la responsabilidad por autoría era cuestión de tiempo que empezaran a surgir una importante cosecha de anomalías al dogma, al haberse adosado un importante número de excepciones, tras la formula "no obstante".

Pero el legislador arrepentido de tanta apostasía y reniego frente al dogma advierte que todo ello, que todo lo dispuesto en el art. 69 LTSV (lo que incluye desde el dogma hasta sus excepciones), se entenderá a los únicos efectos de la determinación de la responsabilidad en el ámbito administrativo por las infracciones determinadas en la propia LTSV.

\footnotetext{
${ }^{5}$ De nuevo NiETo, de nuevo en la misma obra, que en el mismo inicio de su planteamiento sobre la culpabilidad y dentro de su planteamiento crítico hace esta consideración.
} 


\section{B) El principio general de la responsabilidad por autoría de la infracción}

1. UNA REFLEXIÓN INICIAL

La norma establecida por el art. 69.1 LTSV, como ya se ha señalado, es que la responsabilidad por las infracciones a lo dispuesto en la LTSV recae, como principio general (y aparentemente cuasi absoluto) en el autor del hecho en el que consista la infracción.

No hace falta un análisis exhaustivo ni ningún sesudo estudio para establecer que la normativa que regula el tráfico y la seguridad vial ha puesto los puntos en el conductor del vehículo. En él se han centrado de manera especial, y casi absoluta, las reglas, órdenes y mandatos, lo que en el ámbito de la fijación de normas y la tipificación de infracciones ha supuesto que el infractor prototípico sea el conductor. La práctica totalidad de las normas de comportamiento en la circulación a él se dirigen y, en consecuencia, su cumplimiento e incumplimiento a él tienen como actor principal.

Tampoco lo requiere, sobre este planteamiento, sustituir el término infractor por el de conductor para determinar que ese es el autor que buscamos y que nuestro modelo de responsable es el conductor del vehículo.

Pero el problema de pisar sobre el mismo suelo, año tras año, sin preguntarse lo que hay debajo, sobre todo cuando cambian los que habitan esa casa y llegan nuevos moradores, es que el día menos esperado se pueden empezar a oír crujidos. Si levantamos nuestro suelo lo que encontramos es que el sistema se ha mantenido durante mucho tiempo sobre ideas, convertidas en verdaderos axiomas, que, sin duda, fueron ciertas, pero que hace tiempo que dejaron de serlo. No se trata, en muchos casos, siquiera, de cuestiones jurídicas, pero sí que están en la base del sistema. Se trata de cuestiones como (a título meramente enunciativo y sin ánimo alguno de taxatividad) de la ruptura del binomio relación conductor - propietario del vehículo, que nos ha dejado con un estatuto del conductor pero a falta de un estatuto del propietario del vehículo, de la quiebra temporal del trinomio comisión de la infracción - identificación del conductor - notificación de la denuncia, de la regulación de normas y tipos que ya no se fijaban en comportamientos del conductor, de la incorporación de los menores al tráfico, como conductores, como destinatarios de normas sin necesidad de ser conductores, de la necesidad de imponer obligaciones a unas personas sobre el comportamiento de otras, de que las personas jurídicas habían pasado de ser una anécdota a un protagonista con una destacada presencia... demasiado peso para un sistema asentado en el dogmático principio de "la responsabilidad por las infracciones recaerá directamente en el autor del hecho en que consista la infracción".

El sustrato, el terreno que pisamos, no soporta la carga que le estamos poniendo encima y ese armazón requiere de una importante reforma estructural. 


\section{EL AUTOR Y EL RESPONSABLE DE LAS INFRACCIONES DE TRÁFICO Y SEGURIDAD VIAL}

La imposición de normas supone la existencia de personas que puedan transgredirlas. Las normas de tráfico y seguridad vial han sido, tradicionalmente, normas de circulación. $Y$ siguen siéndolo, aunque el cambio ha venido, precisamente, por la incorporación de normas, y las correspondientes infracciones, que regulaban otros elementos del tráfico y la seguridad vial.

Las normas de la Ley de Tráfico y Seguridad Vial toman en consideración la existencia de diferentes tipos de sujetos. Significativo es, en ese sentido, la rúbrica de la que hace uso el artículo con el que se inicia la regulación de las normas de comportamiento en la circulación, que emplea los términos "usuarios, conductores y titulares de los vehículos", tanto por la variedad de términos empleados como por no agotar en esa descripción todos los que después utiliza en el texto del artículo, ya que a ellos es preciso añadir a los "ocupantes del vehículo" y a los "arrendatarios de los vehículos", como derivación, estos últimos, en su caso, de los titulares de los vehículos.

Estos pueden ser los sujetos que transgredan las normas establecidas y cometan una infracción de las tipificadas en la LTSV.

Pero ya hemos señalado, en palabras de NiETo, que el Estado no busca culpables, ni siquiera autores, sino responsables, hasta el punto que a la mera inobservancia se corresponde la mera responsabilidad. De ahí que el art. 69 LTSV haga uso de los términos que emplea y lo haga en el sentido que lo hace. La LTSV señala responsables, el capítulo del régimen sancionador se denomina "de la responsabilidad" y el art. 69 LTSV recibe la rúbrica "personas responsables".

Así, será en la norma impuesta y en la que se establece el tipo infractor donde habrá que buscar respuesta a quién sea ese autor y responsable. Si coincide con el autor, perfecto. Todo es más sencillo. Si conocemos al autor, mejor. Pero cuando, no obstante, no se conoce ese autor, siempre se puede fijar un responsable. El problema es cómo se realice esa determinación de responsabilidad.

\section{EL CONDUCTOR}

El conductor ${ }^{6}$, como destinatario de las normas de comportamiento en la circulación, es el autor de la inmensa mayoría de las infracciones $y$, en consecuencia, el

\footnotetext{
${ }^{6}$ El concepto de lo que ha de entenderse por "conductor" está establecido en el número 1 del ANEXO LTSV. Se trata de una definición legal expansiva respecto a lo que por tal normalmente se entiende ("guiar en vehículo automóvil" en términos del DRAE) al establecer que:
} 
responsable de las mismas. Un gran parte de los tipos establecidos en el art. 65 LTSV comienzan por "conducir" y por "circular" porque el conductor es el protagonista más común de las acciones u omisiones contrarias a la Ley (art. 65 LTSV). Mencionar al autor de la infracción, en el ámbito de la regulación sobre tráfico y seguridad vial y por la propia naturaleza y contenidos de sus normas, es referirse, en la mayoría de los casos, al conductor.

El conductor, como autor de una infracción, presente muchas ventajas a la hora de atribuirle la responsabilidad por ese hecho. Siempre se le puede reprochar, de una manera directa, la conducta. No resulta preciso usar el término culpabilidad para que se sobreentienda. La conducción de vehículos (a motor y ciclomotores) está sometida a autorización. El conductor, para obtener esa autorización, tiene que haber mostrado la capacidad, los conocimientos y las habilidades, de manera que, cuando el conductor transgrede una norma, está faltando a una obligación que (se supone) conoce y con la que tiene que cumplir.

La norma general de comportamiento, la norma básica de circulación, contenida en el art. 9.2 LTSV (y art. 3 del RGC) establece que "los conductores deben utilizar el vehículo con la diligencia, precaución y no distracción necesarias para evitar todo daño, propio o ajeno, cuidando de no poner en peligro, tanto a sí mismos como a los demás ocupantes del vehículo y al resto de usuarios de la vía"7 lo que había llevado a señalar, como responsables de los hechos de la circulación que "en estos casos, en principio, sólo puede ser el conductor que cometió la infracción de que se trata, y no,

"Conductor: Persona que, con las excepciones del párrafo segundo del apartado 2 de este artículo, maneja el mecanismo de dirección o va al mando de un vehículo, o a cuyo cargo está un animal o animales. En vehículos que circulen en función de aprendizaje de la conducción, es conductor la persona que está a cargo de los mandos adicionales".

${ }^{7}$ Previsión normativa a la que, desde la reforma efectuada por la Ley 18/2009, de 23 de noviembre, ya no se le adosa el inciso final "queda terminantemente prohibido conducir de modo negligente o temerario". Esta norma, la contenida en el art. 9.2 LTSV ( $y$ en los concordantes art. 3 del RGC) ha sido la penas sobre la que se ha ubicado la responsabilidad extracontractual derivada de accidentes de tráfico para culpar y hacer responsable al conductor por los daños causados. En términos de la Sala Primera del Tribunal Supremo:

“Conforme al art. 3 del Real Decreto Legislativo 1428/2003, de 21 de noviembre que establece en su párrafo segundo que se deberá conducir con la DILIGENCIA y precaución necesarias para evitar todo daño, propio o ajeno, cuidando de no poner en peligro, tanto al mismo conductor como a los demás ocupantes del vehículo y al resto de los usuarios de la vía. De la prueba practicada en el acto del juicio ha quedado acreditado por la propia declaración del demandado que simplemente "no le vio", que el mismo se incorporaba a la carretera, pero que no percibió que había una motocicleta circulando por la carretera a la que se incorporaba, sin que haya prueba alguna de la posible negligencia o culpabilidad del actor, que conducía correctamente por la vía, como así han declarado los testigos. En conclusión debe apreciarse una conducción no diligente por parte del demandado, y por tanto debe considerarse responsable de la colisión" (STS de 19 de mayo de 2011, RJ 2011, 4517).

Precepto continuamente empleado por las Audiencias Provinciales. Por citar laguna sentencias reciente, SAP A Coruña, de 16 de diciembre de 2011, JUR 2012, 8469, AP Sevilla de 27 de noviembre de 2012, JUR 2013, 146750, AP Valencia de 9 de noviembre de 2012, JUR 2013, 119209... 
por tanto, el titular del vehículo, y ello como consecuencia del principio de personalidad de las penas o de responsabilidad de las infracciones" ${ }^{8}$.

El modelo de actuación va a consistir en imponer obligaciones. En el art. 9.2 LTSV se añade a la diligencia y precaución el deber de "no distracción" y se impone una obligación adicional, un poco extraña (incluso sorprendente) conforme a la que "el conductor deberá verificar que las placas de matrícula del vehículo no presentan obstáculos que impidan o dificulten su lectura e identificación". A ello añade el art. 11 LTSV las normas que, de manera general, incumben a los conductores, precepto que contiene una serie de obligaciones y prohibiciones (incluyendo excepciones) en las que se mezcla lo genérico con lo específico ${ }^{9}$.

La conducción de vehículos (vehículos a motor y ciclomotores) se encuentra sometida a la previa obtención de la correspondiente autorización administrativa. Sobre esta cuestión es preciso tener en cuenta la existencia de supuestos en los que, para la obtención tanto del permiso como de la licencia de conducción, no resulta preciso la mayoría de edad ${ }^{10}$. Por ello nos podemos encontrar con titulares de autorizaciones

\footnotetext{
${ }^{8}$ Alonso Segovia, B., "Tráfico y Seguridad Vial" en Abogacía General del Estado - Dirección del Servicio JURídico DEL ESTADO, Manual de derecho Administrativo Sancionador, Cizur Menor, Aranzadi, 2009, 2a edición, Tomo II, pág. 804. En este comentario, realizado de manera previa a la modificación realizada en la LTSV por medio de la Ley 18/2009, de 23 de noviembre, los términos empleados por la autora ("en principio", "personalidad de las penas o responsabilidad de las infracciones") ya denotan algo extraño en esa construcción normativa.

${ }^{9}$ Es el caso de obligaciones genéricas impuestas al conductor como "estar en todo momento en condiciones de controlar sus vehículos" o estar "obligado a mantener su propia libertad de movimientos, el campo necesario de visión y la atención permanente a la conducción, que garanticen su propia seguridad, la del resto de ocupantes del vehículo y la de los demás usuarios de la vía". Prohibiciones como la de utilizar "durante la conducción de dispositivos de telefonía móvil y cualquier otro medio o sistema de comunicación (excepto cuando el desarrollo de la comunicación tenga lugar sin emplear las manos ni usar cascos, auriculares o instrumentos similares" y obligaciones como la de "utilizar el cinturón de seguridad, cascos y demás elementos de protección y dispositivos de seguridad en las condiciones y con las excepciones que, en su caso, se determinen reglamentariamente".
}

6. Se prohíbe que en los vehículos se instalen mecanismos o sistemas, se lleven instrumentos o se acondicionen de forma encaminada a eludir la vigilancia de los agentes de tráfico, y que se emitan o hagan señales con dicha finalidad."

${ }^{10}$ La LTSV no contiene los requisitos que es preciso cumplir, de manera específica y concreta, para la obtención del permiso y de la licencia de conducción. Las diferentes clases de autorizaciones que habilitan la conducción y los requisitos se desarrollan en el Reglamento General de Conductores (RGCon, aprobado por el RD 818, 2009, de 8 de mayo, publicado en el BOE de 8 de junio de 2009). En lo que aquí nos interesa, la posibilidad de conducir de los menores de edad amparados en la correspondiente autorización administrativa, resulta preciso tener presente que:

- La edad mínima para obtener el permiso de la clase AM es de quince años y que habilita para conducir ciclomotores de dos o tres ruedas y cuadriciclos ligeros (aunque podrá estar limitado a la conducción de ciclomotores de tres ruedas y cuatriciclos ligeros), art. 4.2 a) RGCon

- La edad mínima para obtener el permiso de la clase A1 es de dieciséis años yt que autoriza para conducir motocicletas con una cilindrada máxima de $125 \mathrm{~cm}^{3}$ (con una potencia máxima de 11 kW y una relación potencia/peso máxima de $0,1 \mathrm{~kW} / \mathrm{kg}$ y triciclos de motor cuya potencia máxima no exceda de $15 \mathrm{~kW}$, art. 4.2 b) RGCon. 
administrativas para conducir que, cumpliendo con los requisitos establecidos para ello, son menores de edad, y, de igual manera, con personas que realizan la actividad de conducir sin estar provistos de la preceptiva autorización, supuesto que también puede efectuarse por personas que no han alcanzado la mayoría de edad.

A ello hay que añadir los problemas que surgen desde el momento en que al conductor se le hace responsable de hechos que no ha cometido y entonces todas estas sencillas y sólidas construcciones sobre la personalidad de las penas y el dogma de la culpabilidad pierden solvencia para explicar lo que está sucediendo, algo que corresponde analizar ya no en el marco de la responsabilidad por autoría, sino, precisamente, en las quiebra de ese principio general.

A esta figura, la del conductor, como persona que realiza la actividad de guiar un vehículo al momento de la comisión de la infracción, se une, tras la reforma efectuada por la Ley 18/2009, de 23 de noviembre, la del "conductor habitual"11. El que lo conduce y el que usualmente lo suele conducir, que puede coincidir, o no, con aquél. Traslación, en definitiva, de la disociación entre "titular del vehículo" y "conductor" y designación, con su correspondiente inscripción en el Registro de Vehículos, de ese dato, con las consecuencias que se explican en los apartados siguientes y que suponen que, de existir designado, para un concreto vehículo, una persona física como "conductor habitual", a él se le trasladan determinadas obligaciones que, en principio corresponden al propietario del vehículo.

\section{LOS OCUPANTES DE LOS VEHÍCULOS}

Las personas que, transportadas en el vehículo, no tiene la condición de conductor, también son destinatarias de normas que, por lo tanto, pueden incumplir.

Se trata, en particular, de las normas que regulan su posición en el vehículo y el uso de los elementos de seguridad determinados para cada tipo de vehículo. Normas dirigidas a los ocupantes y que, por tanto, pueden dar lugar a su incumplimiento por personas que son mayores de edad y por menores. Además, es preciso tener presente, que se

- La edad mínima para obtener la licencia de conducción para conducir vehículos para personas de movilidad reducida será de catorce años cumplidos, art. 6.1 a) RGCon

- La edad mínima obtener la licencia de conducción para conducir vehículos especiales agrícolas autopropulsados y sus conjuntos cuya masa o dimensiones máximas autorizadas no excedan de los límites establecidos para los vehículos ordinarios o cuya velocidad máxima por construcción no exceda de $45 \mathrm{~km} / \mathrm{h}$ es de dieciséis años cumplidos.

11 El concepto de "conductor habitual", introducido por la Ley 1872009, de 23 de noviembre, se encuentra definido (a los exclusivos efectos previstos en la LTSV) en el apartado 1.bis Anexo I LTSV como "la persona que, contando con el permiso o licencia de conducción necesario, que estará inscrito en el Registro de Conductores e Infractores, ha sido designada por el titular de un vehículo, previo su consentimiento, en virtud de lo dispuesto en el art. 9 bis, por ser aquella que de manera usual o con mayor frecuencia conduce dicho vehículo". 
mezclan aquí normas que, regulando obligaciones que tienen que cumplir los ocupantes de un vehículo, pueden estar impuestas al propio ocupante o a la persona que conduce el vehículo, los que nos ubicaría de nuevo en la figura del conductor.

5. El Titular del Vehículo y la equiparación QUe al él SE REAliza del arRendatario a largo PLAZO

\section{a) La necesidad de ubicar esta norma en su contexto histórico}

El titular del vehículo, la persona a cuyo nombre figura inscrito el vehículo en el Registro oficial correspondiente ${ }^{12}$ (número 3 del Anexo I LTSV) puede cometer infracciones y responder de ellas como autor. Se le imponen obligaciones específicas, de manera que el titular del vehículo puede no observar normas que a él le corresponde cumplir y que son independientes de la condición de conductor, aunque la rudimentaria redacción original de la LTSV no las ubique en las normas generales, precepto que en principio tiene por rúbrica la de "usuarios y conductores", redacción en la que no se introducirá la reseña a los titulares de los vehículos hasta la reforma efectuada por la Ley 18/2009, de 23 de noviembre.

Aunque en la redacción originaria de la LTSV existen referencias al titular del vehículo $^{13}$, no se disocian, completamente, "conductor" y "titular del vehículo". La interpretación que se efectúa (socialmente y desde los destinatarios de la norma) del conjunto normativo es que el conductor de un vehículo atrae para sí, por el hecho de la conducción, los deberes de la titularidad, al tiempo que ese titular queda liberado de toda obligación sobre el vehículo que se desplaza a quien lo conduce. Por supuesto que la norma no dice eso y configura (afirmación generosa, ya que más que configurar, permite llegar a extraerlo por adición de previsiones asistemáticas y dispersas) un tosco estatuto del titular del vehículo de entre las cuales destaca la establecida en el

\footnotetext{
12 Que es el Registro de Vehículos del art. 2 del Reglamento General de Vehículos (aprobado por el RD 2822/1998, de 23 de diciembre, BOE de 26 de enero de 1999), registro de carácter puramente administrativo por lo que y los datos que figuren en él no prejuzgarán las cuestiones de propiedad, cumplimientos de contratos $y$, en general, cuantas de naturaleza civil o mercantil puedan suscitarse respecto a los vehículos (art. 2.1 párrafo tercero RGV) y que estará encaminado preferentemente a la identificación del titular del vehículo, al conocimiento de las características técnicas del mismo y de su aptitud para circular, a la comprobación de las inspecciones realizadas, de tener concertado el seguro obligatorio de automóviles y del cumplimiento de otras obligaciones legales, a la constatación del Parque de Vehículos y su distribución, y a otros fines estadísticos (art. 2.1 párrafo segundo RGV).

${ }^{13}$ En la redacción originaria de la LTSV ninguna se efectúa en el Título relativo a las normas de comportamiento en la circulación, que se centra en el elemento subjetivo del tráfico, en el conductor. Si aparecen referencia a él, por razones obvias, al regular las autorizaciones de los vehículos (arts. 60.2 y 62.4 LTSV). Se distingue perfectamente al titular del vehículo en relación a las medida cautelar de retirada del vehículo de la vía pública (art. 71.2 LTSV) y llegado el momento de determinar su responsabilidad por determinadas infracciones (art. 72.2 LTSV) y como obligado a la identificación del conductor (art. 72.3 LTSV, infracción no recogida en el cuadro general del art. 65) y domicilio de notificaciones y obligación de notificar los cambios de ese domicilio (art. 78.1 LTSV).
} 
art. 72.3 LTSV y conforme a la que se le impone que, ni más ni menos, "debidamente requerido para ello, tiene el deber de identificar al conductor responsable de la infracción y si incumpliere esta obligación en el trámite procedimental oportuno sin causa justificada, será sancionado pecuniariamente como autor de falta grave". Así se explica la belicosidad frente a esta norma, constantemente combatida, tachada de contar con todo tipo de defectos que la hacían inviable jurídicamente, por desbordar todos los criterios de razonabilidad exigibles... dudas que alcanzaron a los responsables de impartir Justicia, hasta el punto que esa norma fue objeto del planteamiento de diversas cuestiones de inconstitucionalidad por las Salas de lo Contencioso Administrativo de diversos Tribunales Superiores de Justicia que planteaban, por este cauce, que se aclarara la constitucionalidad del art. 72.3 LTSV, previsión normativa que termino siendo declarada conforme a la Constitución ${ }^{14}$.

\section{b) La vigente configuración del titular y del arrendatario del vehículo}

Como se acaba de señalar, no es hasta la reforma realizada en la LTSV por la Ley 18/2009, de 23 de noviembre, que se modifica el art. 9 LTSV y se incluye en él un nuevo apartado 3 en el que se impone un deber de diligencia al titular del vehículo, por el hecho de serlo, que se fundamenta en el riesgo que supone su uso, y que se concreta en las obligaciones de "mantenerlos en las condiciones legal y reglamentariamente establecidas", "someterlos a los reconocimientos e inspecciones que correspondan" e "impedir que sean conducidos por quienes nunca hubieren

\footnotetext{
${ }^{14}$ La STC 197/1995, de 21 de diciembre, desestimó las cuestiones de inconstitucionalidad planteadas por la Sección Quinta de la Sala de lo Contencioso - Administrativo del Tribunal Superior de Justicia de Cataluña, la Sala de lo Contencioso - Administrativo del Tribunal Superior de Justicia de Cantabria y la Sala de lo Contencioso - Administrativo del Tribunal Superior de Justicia de Castilla - León con sede en Burgos, respectivamente, por supuesta inconstitucionalidad del art. 72.3 LTSV, al vulnerar supuestamente el art. 24.2 CE, resolución que cuenta con un voto particular discrepante formulado por Vicente Gimeno Sendra y al que se adhiere Rafael de Mendizábal Allende en el que se plantea el problema de la autoincriminación y que la conversión de la obligación de identificar al autor responsable por la del conductor en el momento de cometer la infracción supone un elemento por el que debería haberse estimado el recurso.

Se trata, sin duda, de un tema atractivo, lo que ha dado lugar a un importante número de estudios. Es el caso, entre otros, de los realizados por MANTECA VALDELANDE, VíctoR: "Alegaciones e identificación del conductor en los expedientes", Actualidad Administrativa, no 11/2004, La Ley, págs. 1378 - 1386, ARTETXe Palomar, Eugenio: "El deber de identificación del conductor: análisis del art. 72.3 del Texto Articulado de la Ley de Seguridad Vial", Revista Vasca de Administración Pública, núm. 42, 1995, págs. 9 - 34, ATIenZa López, José IGNACIO: "Multa de tráfico: identificación de conductor", CEF Legal: Revista práctica de derecho. Comentarios y casos prácticos, ํo. 148, 2013, págs. 35 - 38, MAGRO SERVET, VICENTE: "La necesaria identificación exacta del conductor infractor por el titular del vehículo como garantía de exculpación", Tráfico y Seguridad Vial, no. 146, 2011, La Ley, págs. 7 - 16, PINAGLIA - VILLALóN Y GAVIRA, JUAN IGNACIO: “Análisis jurisprudencial del incumplimiento por el titular de un vehículo de la obligación de facilitar a la Administración la identificación del conductor del vehículo en el momento de ser cometida una infracción", Revista de responsabilidad civil, circulación y seguro, no. 7/2012, págs. $29-41 \ldots$ Entre todos ello resulta preciso destacar, y al que me remito, CASINO RUBIO, MIGUEL: La increíble historia del deber de identificar al conductor infractor, Civitas, 2010, 245 págs.
} 
obtenido el permiso o la licencia de conducción correspondiente". Art. 9 LTSV en el que, además, se equipara al titular del vehículo, a efectos de las obligaciones que se le imponen, con el arrendatario del vehículo (vehículos de alquiler) caso de existir, figura, la del arrendatario en la que cabe desde el alquiler por unas horas o días hasta el arrendamiento financiero de larga duración (leasing o renting).

A eso se añade un artículo específico, el art. 9 bis LTSV (precepto cuya entrada en vigor se demora hasta transcurrido un año de su publicación en el BOE) en el que se establece un pequeño catálogo de las obligaciones correspondientes al titular del vehículo, al arrendatario y al conductor habitual.

El titular de un vehículo, el que así figure en el Registro de Vehículos, adquiere por ese hecho las siguientes obligaciones:

- Identificar al conductor del vehículo del que es titular cuando sea requerido por la Administración

- Impedir su conducción por quien nunca hubiere obtenido autorización para conducir (ese tipo de vehículo)

A cambio, al titular del vehículo se le confiere la posibilidad (derecho) de poder designar un conductor habitual que, con esa condición, la de ser la persona que de manera usual o con mayor frecuencia conduce dicho vehículo, quedará inscrito en el Registro de Vehículos de la Dirección General de Tráfico en los términos que se determinen por Orden del Ministro del Interior ${ }^{15}$, quedando, en ese caso, exonerado el titular de las obligaciones anteriores, que se trasladarán al conductor habitual.

Por otra parte, el art. 9 bis. 3 LTSV establece que, para el caso de que sobre el vehículo se establezca un contrato de arrendamiento a largo plazo, sobre el titular recae el deber de comunicar al Registro de Vehículos los datos que identifiquen al arrendatario, lo que supone que los deberes de identificación del conductor y de impedir la conducción del vehículo por quien nunca hubiera obtenido la autorización necesaria para hacerlo recaen en el arrendatario, para lo que resulta preciso la constancia de ello en el Registro de Vehículos, lo que supone el cumplimiento del deber de comunicación que se impone al titular del vehículo en el art. 9 bis.4 LTSV. Ese

\footnotetext{
${ }^{15}$ La regulación del conductor habitual ha sido realizada por medio de la Orden INT/3215/2010, de 3 de diciembre, por la que se regula la comunicación del conductor habitual y del arrendatario a largo plazo al Registro de Vehículos (publicada en el BOE 15 de diciembre de 2010).

La SAN de 18 de abril de 2012 (RJCA 2012, 700) desestimó el recurso interpuesto contra la Orden INT/3215/2010, de 3 de diciembre y declaró la conformidad a Derecho de la misma en los concretos extremos que ha sido examinada. El recurso había fundamentado su pretensión procesal en la nulidad de pleno derecho de la Orden impugnada por infracción de la legalidad material por estimar que la precitada Orden Ministerial era nula de pleno derecho al estar dictada sin habilitación legal, en la nulidad del art. 2 de la Orden por infracción del art. 62.2 LRJ - PAC, en la nulidad del art. 2 de la Orden por infracción de los arts. 59 bis y 77 LTSV, en nulidad del art. 2 de la orden por infracción de la Ley Orgánica 15/1999 de 13 de diciembre, de Protección de Datos de Carácter Personal y en la nulidad de art. 3 de la Orden por por vulneración del principio de seguridad jurídica.
} 
arrendatario a largo plazo dispone, a su vez, de la posibilidad de designar en el Registro de Vehículos a un conductor habitual.

\section{LOS CICLISTAS}

Aunque la definición de conductor les incluiría, puesto el apartado 1 del Anexo no especifica que se trate de de vehículos a motor o ciclomotores, los ciclistas ${ }^{16}$ han sido objeto de un tratamiento diferenciado que, aunque centrado más en su protección, también ha ido incorporando obligaciones y les ha convertido en posibles autores de infracciones.

Es el caso de las previsiones que se efectúan sobre el uso del arcén, normas generales de prioridad de paso, uso del casco de protección, obligación de someterse a las pruebas de detección alcohólica, así como la expresamente calificada como leve en el art. 65.3 LTSV cuando señala que "en particular es falta leve no hacer uso por parte de los usuarios de bicicletas de los elementos y prendas reflectantes, de acuerdo con lo dispuesto en esta Ley".

Los ciclistas son usuarios de las vías, pero en la medida en la que la regulación ha ido incidiendo progresivamente en la regulación de su presencia en las vías públicas y se han ido introduciendo preceptos en la LTSV que, en la mayoría de los casos imponen obligaciones a los conductores de vehículos (y a otros usuarios) para garantizar una mayor seguridad de los ciclistas, parece adecuado individualizarlos como posibles autores de infracciones en materia de tráfico y seguridad vial.

\section{OTROS POSIBLES AUTORES}

El art. 1.2 b) LTSV señala que la Ley regula tanto las normas de circulación para los vehículos como aquellas otras que "por razón de seguridad vial han de regir para la circulación de peatones y animales por las vías de utilización general; estableciéndose a tal efecto los derechos y obligaciones de los usuarios de dichas vías".

Al lado de los expuestos surgen otros autores (actores de reparto en el tráfico y la seguridad vial), aunque algunos de ellos no carezcan de trascendencia. Así, hemos de tener presente a:

\footnotetext{
${ }^{16}$ El Anexo I LTSV establece definiciones para "ciclo" (apartado 5), "bicicleta" (apartado 6) y otros conceptos relacionados con el tránsito de las bicicletas, como son los conceptos de "vía ciclista" (apartado 69), "carril - bici" (apartado 70), carril - bici protegido (apartado 71), acerra - bici (apartado 72), pista - bici (apartado 73) y senda ciclable (apartado 74), pero no hace lo propio con "ciclista" que, en todo caso, es la persona que conduce la bicicleta (o el ciclo).
} 
- Peatones ${ }^{17}:$ Usuarios que transitan a pie por las vías y a los que, como se acaba de señalar, se dirige la regulación de la LTSV. Aunque hay normas, no son muchas (por ejemplo, el lugar por el que han de transitar en la vía, la prohibición de caminar por autopistas, la obligación de respetar las señales, obligación de uso de elementos luminosos o autoreflectantes para la circulación nocturna), y su nivel de exigencia, en cuanto a la amenaza de sanción, no es elevado, a lo que se une que las normas que les imponen o prohíben conductas no suelen estar calificadas por lo que, en su caso (y en virtud de lo establecido en el art. 65.3 LTSV), estaríamos ante infracciones leves a las que le corresponderían (conforme a lo establecido en el art. 67.1 LTSV) multas de hasta $100 €$.

- Usuarios de la vía: Término genérico capaz de dar cobijo, de forma residual, a todos aquellos supuestos que no se encuadran, en relación al tráfico, en un tipo específico de sujeto. Personas que con su conducta pueden influir en el tráfico y la seguridad vial. A ello se refiere el art. 9.1 LTSV estableciendo la genérica obligación de "comportarse de forma que no entorpezcan indebidamente la circulación, ni causen peligro, perjuicios o molestias innecesarias a las personas, o daños a los bienes", el art. 12.2 LTSV cuando determina que están obligados a someterse a las pruebas de detección de alcohol "los demás usuarios de la vía cuando se hallen implicados en algún accidente de circulación", el art. 51.1 LTSV al señalar que "los usuarios de las vías que se vean implicados en un accidente de tráfico, lo presencien o tengan conocimiento de él, estarán obligados a auxiliar o solicitar auxilio para atender a las víctimas, si las hubiere, prestar su colaboración para evitar mayores peligros o daños, restablecer, en la medida de lo posible, la seguridad de la circulación y esclarecer los hechos" o el art. 53.1 LTSV al establecer que todos los usuarios "están obligados a obedecer las señales de la circulación que establezcan una obligación o una prohibición y a adaptar su comportamiento al mensaje del resto de las señales reglamentarias que se encuentren en las vías por las que circulan".

- Centros de enseñanza y centros de reconocimiento: La LTSV y su desarrollo reglamentario contienen normas sobre su régimen de autorización y funcionamiento, estableciéndose infracciones en el art. 65.5 e) LTSV

- Instalación de instrumentos prohibidos: Como es el caso de los inhibidores, estando sancionado, además de la conducción de vehículos (art. 65.5 h LTSV), la instalación de los mismos (art. 65.6 d LTSV)

- Personas que no siendo usuarios de la vía: Pero que pueden desarrollar actividades que influyan en el tráfico y la seguridad vial. Realizar obras, arrojar

\footnotetext{
${ }^{17}$ A los que el apartado 2 Anexo I LTSV define como "personas que, sin ser conductor, transitan a pie por las vías o terrenos a que se refiere el art. 2 LTSV", condición que se extiende a "quienes empujan o arrastran un coche de niño o de impedido o cualquier otro vehículo sin motor de pequeñas dimensiones, los que conducen a pie un ciclo o ciclomotor de dos ruedas, y los impedidos que circulan al paso en una silla de ruedas, con o sin motor".
} 
objetos, poner obstáculos, realizar inmisiones en las proximidades de la vía que puedan afectar al tránsito (piénsese, por ejemplo en una quema de rastrojos)

\section{C) Los supuestos especiales de responsabilidad}

\section{De la acumulación de supuestos (Y SObRe la confusión del “No obstante”)}

Esa armonía (y tranquilidad) que a buen seguro suponía para el legislador el monocorde y rotundo principio de la responsabilidad por autoría establecido en la regulación originaria de la LTSV se ve resquebrajado por las sucesivas modificaciones del entonces art. 72 LTSV que van reconfigurando este artículo hasta que ya, en la reforma realizada por medio de la Ley 17/2005, de 19 de julio, se establece un supuesto excepcional, y aunque se mantiene ese principio general ya se reconoce que eso no es así para un caso, "excepto en el supuesto de los pasajeros de los vehículos que estén obligados a utilizar el casco de protección en los casos y en las condiciones que reglamentariamente se determinan, en que la responsabilidad por la infracción recaerá en el conductor".

La Ley 18/2009, de 23 de noviembre, que traslada las normas de determinación de personas responsables al art. 69 LTSV, mantiene ese principio conforme al que "la responsabilidad por las infracciones a lo dispuesto en esta Ley recaerá directamente en el autor del hecho en que consista la infracción" y añade (sustituyendo al término "excepto") un "no obstante" del que en la actualidad cuelgan hasta siete supuestos ${ }^{18}$.

$Y$ es que, no obstante, a partir de ese "no obstante" lo que viene es la confusión. Porque en un uso normal de los términos, ese al que, se supone, venimos obligados todos, lo que incluye al legislador, el uso de esta locución conjuntiva debería significar que lo que se va a señalar, tras de esa expresión (de ese "no obstante"), se hace "sin que estorbe ni perjudique para algo" a lo que se ha señalado previamente. Es decir, que se van a señalar una serie de supuestos en los que el responsable por la infracción no es el autor del hecho, que es lo que precisamente sucedía cuando (en la redacción previa) se hacía referencia a una excepción (la del no uso, siendo preceptivo, del casco de seguridad por el ocupante, infracción de la que se responsabilizaba al conductor aunque no fuera su autor).

Sin embargo (que también es locación conjuntiva con equivalente significado al de no obstante), tras ese "no obstante" figuran muy variados supuestos en cuanto a la atribución, eso sí, de la responsabilidad.

\footnotetext{
${ }^{18}$ La redacción que el art. 69 LTSV recibe de la Ley 18/2009, de 23 de noviembre, cuenta con seis apartados en forma de letras, desde la a) hasta la f). El séptimo de los que conforman la actual redacción, la letra g), fue incorporada por medio de la Ley 17/2012, de 27 de enero, de Presupuestos generales del Estado para 2013, con efectos desde el 1 de enero de 2013.
} 


\section{RESPONSABILIDAD DEL CONDUCTOR}

El apartado a) del art. 69.1 LTSV hace responsable al conductor del vehículo del incumplimiento de las normas establecidas por los ocupantes, lo que puede suceder tanto en el caso de motocicletas y ciclomotores (o vehículos equivalentes en cuanto a la obligación del uso del casco) como en otros tipos de vehículos.

a) Responsabilidad del conductor por la no utilización por el ocupante del casco de seguridad

El primer inciso del párrafo primero del art. 69.1 a) LTSV determina que la responsabilidad por el hecho de que el ocupante de un vehículo no utilice el casco de seguridad, cuando está obligado a hacerlo, no es del autor de la infracción (ocupante) sino del conductor de ese vehículo.

En realidad (en el mundo real) el conductor es responsable de que el ocupante del vehículo que él guía haga uso de las medidas de seguridad establecidas. Es una derivación de la obligación impuesta en el art. 9.2 LTSV de ese especial deber de cuidado de no poner en peligro ni a él mismo ni al resto de ocupantes del vehículo en la que se debe de incluir el uso de los elementos de seguridad, y ello independientemente de que el art. 11.4 LTSV prescriba la responsabilidad personal de cada uno de los sujetos obligados al establecer que "los conductores y los ocupantes de los vehículos están obligados a utilizar el cinturón de seguridad, cascos y demás elementos de protección y dispositivos de seguridad en las condiciones y con las excepciones que, en su caso. Se determinen reglamentariamente".

En esta línea señala CANO CAMPOS que "la Ley atribuye al conductor una posición de garante, dando así lugar a un supuesto de comisión por omisión", de manera que "el responsables es, únicamente, el conductor de tales vehículos, no el pasajero", para inmediatamente afirmar "aunque el principio de personalidad de las sanciones excluye la responsabilidad por "hecho ajeno", no es contrario a dicho principio la posibilidad de que sujetos diversos al autor material de la infracción se consideren autores de la misma por no haberla impedido pudiendo -y debiendo legalmente hacerlo-"19.

Siendo cierto el argumento de la garantía, en base a los deberes que la propia LTSV impone al conductor y de tratarse del hecho de una medida de seguridad básica, no parece que esta sea la posición adecuada. $Y$ más esa inmediatez por reconvertir a autoría lo que no lo es.

\footnotetext{
${ }^{19}$ CANo CAMPOS, T., El régimen jurídico - administrativo del tráfico, 2ª ed., Madrid, Civitas, 2010, 2a ed., pág. 508.
} 
Si el conductor incumple un deber, el de permitir que, en el vehículo que él conduce, un pasajero ${ }^{20}$ no haga e uso del preceptivo elemento de seguridad (el casco), esa es una infracción que se comete a título de autor, en la que coincidirían autor y responsable en la misma persona, el conductor de la motocicleta (o vehículo equivalente), con pleno respeto al principio de personalidad de las sanciones (que tanto preocupa). Pero esa infracción sería una conducta distinta de la realizada por el ocupante.

Con el argumento del garante estamos borrando una infracción que existe como norma de conducta (art. 11.4 LTSV) y que está tipificada en el art. 65.4 h) LTSV (que no distingue entre conductores y ocupantes) y le estamos atribuyendo la responsabilidad de ese hecho al conductor. Si lo que se quiere es atribuir al conductor la autoría de la no utilización de casco por parte del ocupante no hace falta más que establecer ese tipo, "conducir un vehículo para el que se exija el uso del casco por conductor y pasajero sin que el pasajero hago uso del mismo", del mismo modo que se hace, como veremos, en el art. 65.4 i) LTSV al establecer como infracción "el circular con menores de doce años como pasajeros de ciclomotores o motocicletas" (objeto de análisis en el apartado siguiente).

Pero es que, además, en la base de esta atribución de la responsabilidad, tal y como se realiza, pudiera haber otros elementos mucho más cotidianos y menores que la discusión sobre si se quiebra o no el principio de personalidad de las penas. La práctica demuestra que en la mayoría de los casos existen indicios sobre la solvencia económica del conductor (posible identidad conductor - titular del vehículo) de los que se carece respecto del ocupante. Piénsese, además, en la hipótesis de denuncia sin detener al vehículo (si el responsable fuera el infractor habría que identificarlo). En fin, recuérdese, una vez más, el pensamiento de NIETO, ese de "parece que el Estado no busca culpables, ni siquiera autores, sino responsables, hasta el punto que a la mera inobservancia se corresponde la mera responsabilidad".

Ni la ordenación del conjunto norma - tipo infractor - responsabilidad está, a mi juicio, técnicamente bien configurada, ni hay que buscar más allá de lo que hay. El conductor no ha observado la norma que se le impone y responde por la infracción del ocupante.

Y, a partir de ahí, complíquese el supuesto todo lo que se quiera. Con conductor y ocupantes ambos mayores de edad, ambos menores, el conductor menor y el ocupante mayor (que hasta podría ser su padre) y viceversa... Y por si ello no resultara suficiente todavía puede discutirse sobre el alcance de esa responsabilidad en cuanto a la consecuencia accesoria de la detracción de puntos por una infracción ajena, puesto que mientras el art. 69.1 b) LTSV limita la responsabilidad solidaria a la estrictamente

\footnotetext{
${ }^{20} \mathrm{Y}$ se hace uso consciente del indeterminado "un" en lugar del determinado "el" empleado en el art. 69.1 a) párrafo primero LTSV dado que es posible que una motocicleta haya más de un pasajero, dada la existencia de las motocicletas con sidecar.
} 
pecuniaria derivada de la multa impuesta en el art. 69.1 a) LTSV nada se señala al respecto, de manera que la responsabilidad puede serlo por la sanción y sus consecuencias, si bien el número 18 del Anexo II LTSV, al determinar las infracciones que llevan aparejada la pérdida de puntos, hace uso de los términos "no hacer uso del cinturón de seguridad, sistemas de retención infantil, casco y demás elementos de seguridad" lo que plantea la duda del alcance de la previsión efectuada en el art. 69.1 a) LTSV en cuanto a la aplicación de esta consecuencia al conductor de del vehículo por la infracción cometida por el ocupante. Del texto del art. 69.1 a) LTSV parece desprenderse que el conductor responde de la infracción y que lo hace con todas sus consecuencias, la sanción económica y la detracción de puntos. De los términos del número 18 del Anexo II LTSV podría inferirse lo contrario, ya que es la consecuencia (la detracción de puntos) para limitarse a quién personalmente no hace uso del elemento de seguridad. Se trata (una vez más) de una incoherencia normativa que, en todo caso, debe ser interpretada en el sentido más favorable al responsable, por lo que la duda generada por la LTSV debe resolverse a favor de entender que la responsabilidad establecida en el art. 69.1 a) LTSV debe quedar limitada, al igual que como sucede en el caso del art. 69.1 b) LTSV, a la estrictamente pecuniaria derivada de la multa impuesta sin que la conducta del pasajero pueda acarrearle la pérdida de puntos ${ }^{21}$.

\section{b) Responsabilidad del conductor por transportar menores con edad inferior de la establecida para ello}

En segundo término, el art. 69.1 a) párrafo primero LTSV establece, como responsabilidad del conductor, el hecho de transportar menores de 12 años en ciclomotores o motocicletas (norma general recogida en el art. 11.5 LTSV, y siempre que no se trate de mayores de siete años que vayan de ocupantes en un vehículo conducido por su padre, madre, tutor o persona mayor de edad autorizada por ellos).

La característica de este supuesto está en la prohibición de transportar a menores de doce años (cuya edad varía y se rebaja a 7 años en función de la existencia de permiso o autorización de la persona a la que corresponda otorgarlo).

Pero en este caso el tipo infractor del art. 65.4 i) LTSV es, precisamente "circular con menores de doce años como pasajeros de ciclomotores o motocicletas". La infracción es que el conductor transporte a un menor y, por lo tanto, es el conductor el autor de la infracción, y no el menor transportado como pasajero. El criterio empleado en la norma (art. 11.5 LTSV) y en el tipo infractor del art. 65.4 i) LTSV es el de la edad y ninguna consideración se hace preciso realizar para justificar que esa decisión queda en la absoluta esfera del conductor al que corresponde la decisión de realizar esa

\footnotetext{
${ }^{21}$ Algo que sería perfectamente posible pero para lo que entiendo que sería necesario la expresa determinación de la LTSV en ese sentido.
} 
conducta prohibida (algo que resultaría aplicable al supuesto anterior, el del no uso del casco, en personas de edad equivalente). Por ello entiendo que la posición de garante de la seguridad del menor se integra en el propio tipo que el conductor realiza a título de autor.

c) Responsabilidad del conductor por la no de los preceptivos sistemas de retención infantil

El art. 69.1 a) párrafo segundo LTSV atribuye al conductor del vehículo la responsabilidad por la no utilización de los sistemas de retención infantil, cuestión regulada en el art. 117 del Reglamento General de Circulación (RGC).

La propia terminología empleada en el RGC (niños) y en la determinación del tipo infractor del art. 65.4 h) LTSV, "no hacer uso ... sistema de retención infantil", evidencian que el autor de la infracción es el conductor del vehículo. Y ello es así hasta el punto que una sosegada lectura de lo establecido en el art. 69.1 a) párrafo segundo LTSV permite determinar que el conductor no responde en todos los casos por el no uso de los sistemas de retención, sino únicamente en cuanto se trate de sistemas de retención infantiles, de los destinados para niños, ya que el art. 117.2 b) 1 o RGC establece, respecto de los asientos traseros del vehículo, el uso obligatorio de sistemas de retención "a las personas cuya estatura no alcance los 135 centímetros" sin realizar distinción alguna por edad, algo que sí realiza el art. 69.1 a) párrafo segundo LTSV al determinar la responsabilidad del conductor únicamente por la no utilización de los sistemas de retención "infantil". Sin entrar en disquisiciones sobre cual haya de ser el exacto alcance del término en cuanto a edad del usuario si es claro que en el supuesto de un mayor de edad obligado a usar un dispositivo de retención, al igual que sucede con la obligación de hacer uso del cinturón de seguridad, la responsabilidad no recae en el conductor, sino en el autor de la infracción.

En la misma línea se encuentra la excepción a la responsabilidad del conductor por la no utilización de los preceptivos sistemas de retención infantil para el caso de los conductores profesionales. Lo que plantea la excepción es que el conductor de un taxi no resulta responsable de la falta de uso del sistema de retención infantil, sin aclarar si existe otro responsable $\mathrm{o}$, sencillamente, no hay responsabilidad ${ }^{22}$.

\footnotetext{
${ }^{22}$ Curiosa forma esta, de entender la seguridad vial y la utilización de las medidas de seguridad relajando (eliminado) la norma en el caso de los conductores profesionales. Al mismo padre se le sanciona por no hacer uso en su vehículo de un sistema de retención para su hijo y, en cambio, la obligación se diluye cuando se monta en un taxi con él. Sin desconocer la razones de orden práctico que hay detrás de esta excepción, que las hay, si parece que tengan más peso que las de seguridad vial que imponen el uso de esas mismas medidas de seguridad y que existan otras alternativas capaces de conjugar los diferentes intereses que, en este caso, se vislumbran
} 


\section{RESPONSABILIDAD POR LAS INFRACCIONES COMETIDAS POR LOS MENORES}

a) La previsión del art. 69.1 b) LTSV

El párrafo primero del apartado b) del art. 69.1 LTSV establece que "cuando la autoría de los hechos cometidos corresponda a un menor de dieciocho años, responderán solidariamente con él sus padres, tutores, acogedores y guardadores legales o de hecho, por este orden, en razón al incumplimiento de la obligación impuesta a éstos que conlleva un deber de prevenir la infracción administrativa que se impute a los menores" ${ }^{23}$, responsabilidad solidaria que el párrafo segundo de ese mismo apartado limita "estrictamente a la pecuniaria derivada de la multa impuesta".

Este planteamiento, tal y como se efectúa, poco o nada tiene que ver con la previsión general de responsabilidad por la autoría de las infracciones. Parece que lo que la norma persigue es garantizarse la efectividad de la sanción económica, en definitiva, el cobro de la multa, mediante la designación de un responsable solidario ante la hipótetica falta de solvencia económica de ese menor - infractor. En este supuesto si encontramos unos garantes que, siéndolo legalmente del menor, lo son de la sanción económica (que no de la infracción) que se le pudiera imponer.

Diseño normativa que se asienta y corresponde con la previsión efectuada en el art. 130.3 párrafo segundo LRJ - PAC en sede de responsabilidad como principio de la potestad sancionadora, precepto en el que se establece que "serán responsables subsidiarios o solidarios por el incumplimiento de las obligaciones impuestas por la Ley que conlleven el deber de prevenir la infracción administrativa cometida por otros, las personas físicas y jurídicas sobre las que tal deber recaiga, cuando así lo determinen las Leyes reguladoras de los distintos regímenes sancionadores ${ }^{24}$.

\footnotetext{
${ }^{23}$ Téngase en cuenta que ya la redacción originaria del Código de la Circulación de 1934 establecía, en el art. 284, que "son responsables de las infracciones cometidas por los menores contra lo dispuesto en el presente Código los padres o tutores de estos; castigándose, la primera vez, con multa de 2 pesetas; la segunda vez, con multa de 4 pesetas, y las demás reincidencias con multa de 5 pesetas y dando cuenta al Juzgado."

${ }^{24}$ Sobre este precepto han tenido oportunidad de pronunciarse los Tribunales (tal es el caso de la STSJ de Cataluña de 30 de noviembre de 2011, JUR 2011, 404929, que reproduce lo que ya se había manifestado en las Sentencias del propio TSJ de Cataluña de 8 de noviembre de 2007, JUR 2007, 1401120 y de 23 de noviembre de 2009, RJCA 2010, 345) y señalar que:

“El trascrito precepto, que forma parte del Capítulo Primero del Título IX de la referida Ley, dedicado a los principios de la potestad sancionadora, establece pues la posibilidad de responder, por quien ostente la condición de garante de un tercero, de las acciones y omisiones de este último, constitutivas de una infracción administrativa, y ello, entiende parte de la doctrina, sin quiebra del principio de culpabilidad, por cuento "no se exige responsabilidad al garante por la infracción cometida por el autor material, a quien debía vigilar, sino por su propia participación en los hechos (de modo que) la infracción ha sido posible porque él ha incumplido la obligación legal de prevenirla (y por tanto) su conducta omisiva le hace cooperador necesario" (A. de Palma del Teso); si bien, otra doctrina sostiene en definitiva que "se es infractor por haber realizado el tipo y se es responsable porque así lo declara la ley", que "la autoría o imputación de la infracción exige culpabilidad, pero no así la imputación de
} 
Lo que se ha señalado sobre la responsabilidad solidaria de padres, tutores, acogedores y guardadores legales o de hecho establecida en la LTSV es que "se fija así, mediante norma con rango de ley, la responsabilidad de los garantes, respecto de los infractores menores de edad, en el ámbito del tráfico, deslindando por cierto la responsabilidad de los primeros, «referida estrictamente a la pecuniaria derivada de la multa impuesta», de la infractora en sentido estricto, que corresponde a los autores materiales, mejorando con ello el sistema, ciertamente más confuso, del art. 130 LRJ $\mathrm{PAC}^{\prime 25}$.

Los garantes legales del menor responden porque así lo establece la Ley, el art. 69.1 b) LTSV. Y responden de las consecuencias económicas de la infracción que ha cometido el menor, que es el autor de la infracción, porque el legislador ha querido garantizarse la efectividad de la sanción económica impuesta.

\section{b) Integración en el propio sistema establecido en el art. 69.1 LTSV}

Pudiera parecer que esta previsión de responsabilidad de padres, tutores, acogedores y guardadores legales o de hecho (y por este orden) resuelve los supuestos que pudieran plantearse en cuanto a la responsabilidad sobre la sanción económica impuesta. Pero tal vez no sea tan sencillo y ello sin necesidad de salir del propio art. 69 LTSV.

La puesta en relación de las previsiones efectuadas en los apartados a) y b) del art. 69.1 LTSV permiten percibir supuestos en los que no está claro quién responde.

Es el caso, a mi entender, del supuesto en el que dos menores de edad circulen en una motocicleta o ciclomotor (conductor y pasajero). Conductor con casco y pasajero que no hace uso del mismo. Parece claro que conforme al art. 69.1 a) LTSV es el conductor el que responde de la infracción del pasajero, responsabilidad del conductor que es

responsabilidad realizada ex lege", y que "los responsables por imperativo legal que no son jurídicamente autores de la infracción no se encuentran protegidos por el principio de la exigencia de culpabilidad" (A. Nieto).

En cualquier caso, sí resulta pacífico que la regla o título de imputación, afectante al garante, derivada del art. 130.3.2 LRJ - PAC, está sujeta a la reserva de norma con rango de ley, de manera que sólo se responde por la acción u omisión de un tercero, en el ámbito sancionador administrativo, en los términos del precepto, "cuando así lo determinen las Leyes reguladoras de los distintos regímenes sancionadores" (al respecto, S. de esta Sala y Sección no 52/2006, de 12 de enero (JUR 2006, 84828), rec. 1229/2002 , FJ 3ㅇ ; S. de la Sala de lo Contencioso del TSJ de Castilla-La Mancha de 30-12-2004 (JUR 2005, 50272), rec. 219/2001 , FJ 6ㅇ).

${ }^{25}$ En varias Sentencias del TSJ de Cataluña (las citadas en la nota anterior), y no de forma directa sino al hilo de la regulación mediante Ordenanza Municipal de la posibilidad de desplazar a los responsables de su potestad o tutela el pago de las sanciones impuestas a menores, por la comisión de infracciones, se analiza el supuesto concreto recogido en la LTSV que se considera con lo previsto en el art. 130 LRJ PAC por tener la cobertura legal de la que carecen la previsiones incluidas en las Ordenanzas. Cuestión que también es objeto de análisis por la STSJ de Madrid de 29 de noviembre de 2012 (RJCA 2013, 66). 
derivada, en el aspecto económico a sus padres (o garante correspondiente), pero al lado está la norma del art. 61.1 b) LTSV que puede hacer pensar (por ejemplo, al garante de ese conductor) que la responsabilidad de los garantes por autoría es norma preferente a la de la responsabilidad del conductor. Dos normas, un supuesto, dos soluciones distintas, y dos padres alegando que la responsabilidad corresponde al otro. Y ciertamente es así. Ambas posturas son defendibles. La de considerar preferente al norma de responsabilidad del conductor sobre la de la responsabilidad del garante por la autoría del menor.

Frente al argumento de la aplicación de la norma del art. 69.1 a) LTSV por ser específica para el supuesto resulta oponible que la del art. 69.1 b) LTSV está la de la responsabilidad por garantía.

Creo que pudieran darse las circunstancias para establecer la inaplicabilidad de la norma por no cumplir con el requisito de la necesaria claridad y precisión. Si la duda es razonable, y parece que pudiera serlo, el resultado de tanto intento de minuciosidad sería, curiosa y precisamente, el de impedir la declaración de responsabilidad de ninguno de los implicados. Ni el pasajero que no hacía uso del casco, ni el conductor del vehículo, ni los padres (o garantes) de uno y otro podrían ser declarados responsables de la infracción ante la imposibilidad de conocer el sentido, para ese caso, de las normas.

4. LA RESPONSABILIDAD POR LA INFRACCIÓN COMETIDA POR CONDUCTOR NO IDENTIFICADO AL MOMENTO DE LA COMISIÓN DE LA INFRACCIÓN

El art. 69.1 LTSV contiene diversas normas en cuanto a la responsabilidad para aquellos supuestos en los que no se detuviera al vehículo al momento de la comisión de la infracción y no se procediera a la identificación del conductor y notificación en el acto de la denuncia por concurrir alguno de los casos previstos en el art. 76.2 LTSV que así lo permiten ${ }^{26}$.

\footnotetext{
${ }^{26}$ Art. 76 LTSV, objeto de estudio en el análisis de la denuncia y su notificación, que establece el principio de notificación en el acto y los supuestos en los que, no obstante, puede efectuarse la notificación con posterioridad por concurrir alguna de las siguientes circunstancias:

- Que la denuncia se formule en circunstancias en que la detención del vehículo pueda originar un riesgo para la circulación. En este caso, el Agente deberá indicar los motivos concretos que la impiden.

- Que la denuncia se formule estando el vehículo estacionado, cuando el conductor no esté presente.

- Que la autoridad sancionadora haya tenido conocimiento de los hechos a través de medios de captación y reproducción de imágenes que permitan la identificación del vehículo.
} 
Los diferentes supuestos previstos en el art. 69.1 LTSV determinan la relación entre, de un lado, las diversas personas que pueden estar vinculadas con el vehículo y, de otro, el conductor que no ha sido identificado al momento de la comisión de la infracción.

El sistema se asienta en las obligaciones establecidas, por el art. 9 bis LTSV, para el titular, el arrendatario a largo plazo y el conductor habitual, figuras que han sido objeto de análisis en cuanto a autores de infracciones en materia de tráfico y seguridad vial. Obligaciones que deberían coincidir, y así parece que debiera ser, aunque la redacción empleada en los diferentes apartados del art. 69.1 LTSV pudiera generar alguna duda.

En todos estos casos la historia comienza igual. Se comete una infracción sin que se practique la notificación en el acto de la denuncia al no producirse la detención del vehículo (o no estar el conductor en el supuesto de la infracción por estacionamiento). Y tramitada la denuncia comienzan las labores de identificación del autor de la infracción, que habrán de comenzar por el Registro de Vehículos y los datos que en él consten.

a) Vehículos que no tuvieran designado conductor habitual (titular y arrendatario a largo plazo)

En aquellos casos en los que en el Registro de Vehículos figure el titular y, en su caso, el arrendatario a largo plazo sin que haya sido designado persona alguna como conductor habitual, se procederá a solicitar que procedan a identificar al conductor del vehículo al momento de la comisión de la infracción, persona que puede coincidir, o no, con el requerido.

El titular o arrendatario a largo plazo así requerido tiene el deber, establecido en el art. 9 bis.1 a) LTSV de facilitar esa identificación y de hacerlo cumpliendo con los requisitos establecidos en cuanto a que esa identificación sea veraz y que hace que, conforme a lo prevenido en el art. 69.1 d) LTSV, sea responsable el conductor identificado por el titular o el arrendatario a largo plazo.

b) Vehículos que tuvieran designado conductor habitual

Cuando al consultar el Registro de Vehículos apareciera designado, en relación al vehículo con el que se ha cometido la infracción, un conductor habitual, a él habría de dirigirse, pues conforme determina el art. 9 bis.2 LTSV en este caso, cuando se ha designado un conductor habitual (que figura inscrito en el Registro de Vehículos) "el titular quedara exonerado de las obligaciones anteriores (entre las que figura la de identificar al conductor), que se trasladarán al conductor habitual". 
Y así debería ser. Pero el art. 69.1 c) LTSV se expresa en otros términos, que difieren de la mera traslación de responsabilidad, al señalar que "en los supuestos en que no tenga lugar la detención del vehículo y éste tuviese designado un conductor habitual, la responsabilidad por la infracción recaerá en éste, salvo en el supuesto de que acreditase que era otro el conductor o la sustracción del vehículo", redacción que no coincide con la del supuesto en la que no hay designado conductor habitual, puesto que aquí se parte de que el responsable de la infracción es ese conductor habitual ${ }^{27}$.

Parece que el conductor habitual (por el hecho de figurar designado como tal) pasa a ocupar ya no la posición del titular (o arrendatario a largo plazo), sino la del conductor identificado como tal en el momento de cometerse la infracción, a no ser que acredite la conducción en ese momento por otra persona o la sustracción del vehículo. De los términos empleados se infiere que ya no se trata de identificar, como acción consistente en facilitar unos datos que permitan la identificación. No, aquí, los términos empleados para que el conductor habitual desplace a otro conductor la responsabilidad es "que acredite", lo que parece estar un estadio por encima de "que identifique", que es el deber impuesto al titular o al arrendatario.

De esta forma los términos en los que se establece la responsabilidad del conductor habitual se presentan como superiores a los del titular o arrendatario, algo que no se desprende de la redacción utilizada por el art. 9 bis.2 LTSV que se limita a trasladar el deber de identificación, "que se trasladarán al conductor habitual", en términos de ese art. 9 bis. 2 LTSV.

A pesar de los términos empleados por el art. 69.1 c) LTSV no se alcanza a percibir razón alguna que justifique un trato diferente que dejaría, al "conductor habitual", en peor posición que al titular del vehículo. No existe motivo alguno para que se establezcan presunciones diferentes entre las establecidas para el titular del vehículo y las que se determinen para el conductor habitual en cuanto al alcance y configuración del deber de identificar al conductor al momento de la infracción, y hacerlo en la forma y con los requisitos previstos en el art. 9 bis. 1 a) LTSV ${ }^{28}$.

\footnotetext{
27 Algo que recuerda mucho esa presunción de culpabilidad a la que se refieren NiETo (Derecho Administrativo Sancionador, Madrid, Tecnos, 2012, 5a ed., pág. 342) y, en especial, CASINO en "Presunción legal de culpabilidad versus prueba indiciaria de la autoría en las infracciones de tráfico", $R A P, \mathrm{n}$ 182, mayo - agosto 2010, págs. $85-120$.

${ }^{28}$ Téngase en cuenta, en este sentido, que la STC 63/2007, de 27 de marzo, señala que "lo que desde luego no puede, en ningún caso, a su juicio, so pena de vulnerar el derecho a la presunción de inocencia, es sancionar al propietario del vehículo como autor de la infracción de tráfico cometida por el simple hecho de serlo y sin antes haber apurado todas las posibilidades de identificación facilitadas por el propietario, aunque sean incompletas o, incluso, inverosímiles" (F. 2).
} 


\section{c) Arrendamientos a corto plazo y depositarios de vehículos}

El art. 69.1 e) LTSV establece, en los alquileres de vehículos a corto plazo, la responsabilidad del arrendatario. En el caso de tratarse de una persona jurídico, o siendo física no fuera el conductor al momento de la infracción, se habrá de estar a lo previsto para el titular del vehículo y el deber de identificación.

Idéntica solución se previene para de el caso de las infracciones cometidas por vehículos que, en ese momento estuvieran depositados en talleres mecánicos o establecimientos de compraventa de vehículos, correspondiendo la responsabilidad a sus titulares $y$, en los mismos términos el deber de identificación.

\section{d) Infracciones de estacionamiento e impago de peajes}

El art. $69.1 \mathrm{~g}$ ) LTSV establece la responsabilidad para el caso de infracciones por estacionamiento en las que la denuncia se formula no estando presente el conductor y la correspondiente al impago de peajes (supuesto, este último, introducido en la LTSV por la Ley 17/2012, de 27 de diciembre, de Presupuestos para 2013, con efectos desde 1 de enero de 2013).

Para estos casos, y como sucede en los otros supuestos, se declara la responsabilidad del conductor habitual, cuando figure en el Registro de Vehículos, por delante de la de arrendatario, caso de existir, y de manera previa a la del titular vehículo. Responsabilidad que podrá ser derivada al conductor - infractor en la forma y con los requisitos establecidos en el art. 9 bis.1 a) LTSV. De nuevo, los términos empleados en la LTSV vienen a señalar la existencia de un responsable a no ser que se indique a otra persona $^{29}$.

\section{e) Efectos de la declaración de responsabilidad}

Estas declaraciones de responsabilidad resultan, en los propios términos empleados, confusas. Si volvemos los ojos al principio general establecido en el art. 69.1 LTSV y releemos aquello de "la responsabilidad por infracciones a lo dispuesto en esta Ley recaerá directamente en el autor, el "no obstante" y todos estos supuestos en los que no se ha identificado al conductor - infractor, pudiera parecer que de lo que se hace responsable al titular, arrendatario, conductor habitual, es de la infracción cometida, mediante el iter infracción - autor - responsable. Pero por la lectura de otros preceptos de la LTSV sabemos que ello no es así. Que del incumplimiento del deber de

\footnotetext{
${ }^{29}$ Véase supra, en este sentido, lo señalado para el supuesto del art. 69.1 c) LTSV, en la nota 27 de este mismo Capítulo, sobre el conductor habitual en los supuestos de no detención del vehículo al momento de comisión de la infracción.
} 
identificar que se les impone a determinados sujetos, por su relación con el vehículo con el que sea cometido la infracción, se deriva la comisión de una infracción distinta y diferente a la que origina ese deber de identificación. El incumplimiento del deber de identificar hace que esa infracción inicial se diluya junto con el anonimato del autor de lo que se hace responsable a quien la LTSV atribuye la obligación de saber quién era ese conductor e identificar.

El declarado como responsable no lo es de la infracción cometida por un conductor desconocido. Lo es de ese deber de identificar. Cumplir con ese deber es su responsabilidad. Y si incumple ese deber, o lo cumple de manera defectuosa, comete la infracción muy grave de "el incumplimiento por el titular o el arrendatario del vehículo con el que se haya cometido la infracción de la obligación de identificar verazmente al conductor responsable de dicha infracción, cuando sean debidamente requeridos para ello en el plazo establecido" prevista en el art. 65.5 j) LTSV ${ }^{30}$.

\section{f) Requisitos y efectos la identificación}

El deber de identificar al conductor que ha cometido una infracción por los que son declarados responsables de hacerlo ha sido dotado, tras la reforma efectuada por la Ley $18 / 2009$, de 23 de noviembre, de unos contornos más precisos y definidos. Para que ese deber de identificación se entienda cumplido hay que facilitar los datos que permitan la identificación de ese conductor. Así, el art. 9 bis.1 a) LTSV distingue entre conductores que figuran inscritos en el Registro de Conductores e Infractores y los que no lo están ${ }^{31}$, y exige que:

- Que los datos facilitados incluyan el número del permiso o licencia de conducción que permita la identificación en el Registro de Conductores e Infractores

- Que si el conductor no figura inscrito en el Registro de Conductores e Infractores, el titular deberá disponer de copia de la autorización administrativa que le habilite a conducir en España y facilitarla a la Administración cuando le sea requerida, que en el caso de las empresas de alquiler de vehículos sin conductor podrá sustituirse por la copia del contrato de arrendamiento.

\footnotetext{
30 Infracción que la LTSV tipifica como una "infracción autónoma", como han señalado las SSTC 197/1995, de 21 de diciembre, FF. 6 A) y 8 y 67/2003, de 27 de marzo, F. 2).

${ }^{31}$ La distinción se viene a corresponder con titulares de permisos expedidos en nuestro país y permisos expedidos por otros países, si bien es cierto que en determinados supuestos está prevista la inscripción de permisos expedidos por otros Estados en el Registro de Conductores e Infractores, como es el caso de la inscripción voluntaria de los permisos de conducción expedidos en cualquiera de los Estados miembros de la Unión Europea de titulares que hubieran adquirido la residencia en España (art. 16.1 RGCon) o para obtener el permiso internacional de conducir (art. 32 RGCon).
} 
El precepto legal configura un deber de colaboración del titular de un vehículo con la Administración que resulta inherente al hecho de ser propietario, lo cual comporta, con la lógica consecuencia de su disponibilidad continuada, ciertas obligaciones, entre ellas la de saber, dentro de lo razonablemente posible, la persona que lo maneja en un determinado momento, debido, esencialmente, al riesgo potencial que la utilización del automóvil entraña para la vida, salud e integridad de las personas. De ahí que la carga del titular del vehículo de participar a la Administración quién lo conducía al tiempo de producirse una supuesta infracción de tráfico y cuando no hubiera sido posible su identificación en el acto de formularse la denuncia no se presenta como excesiva o desproporcionada. Se comprende, por lo demás, que sin la colaboración en tales casos del titular del vehículo, la obligada intervención de los poderes públicos en el mantenimiento de la seguridad de la circulación vial resultaría notablemente dificultada ${ }^{32}$.

En definitiva, el titular de un vehículo tiene un doble deber o carga: en primer lugar, adoptar la diligencia debida para saber quien conduce o está en disposición de manejar su vehículo; en segundo lugar, el deber de comunicar este extremo cuando con ocasión de denuncias que no pueden notificarse directamente al conductor es requerido por la Administración para ello ${ }^{33}$.

La identificación, para serlo, ha de cumplir con esos requisitos y permitir la individualización de ese conductor. Por eso la infracción muy grave del art. 65.5 j) LTSV establece, y exige, que esa obligación lo es de "identificar verazmente" al conductor que ha cometido la infracción ${ }^{34}$.

\section{LA RESPONSABILIDAD POR LA INFRACCIONES RELATIVAS AL VEHÍCULO}

El apartado f) del art. 69.1 LTSV hace responsable al titular del vehículo o, caso de existir, al arrendatario a largo plazo, por la comisión de determinadas infracciones

\footnotetext{
${ }^{32}$ Cfr., entre otras, las SSTC 197/1995, de 21 de diciembre y 63/2007, de 27 de marzo.

${ }^{33}$ Entre otras en SJCA Oviedo, núm. 5, de 23 de enero (JUR 2008, 120726) y SJCA Bilbao, núm. 2, de 24 de mayo de 2013 (JUR 2013, 219608)

${ }^{34}$ La doctrina del Tribunal Constitucional se mueve entre la necesidad de que esa identificación sea correcta y verosímil, de manera que "forzoso es concluir que la defectuosa o incorrecta identificación del conductor supuestamente responsable califica un incumplimiento susceptible de arriesgar el reproche sancionador previsto en el art. 72.3 LSV" (SSTC 63/2007, de 27 de marzo) y que la de la obligación de identificar verazmente al conductor, existen diversas Sentencias del Tribunal Constitucional que consideran suficiente, para cumplir con ese deber, que se comunique el nombre, apellidos y domicilio del supuesto responsable, datos que habían sido considerado insuficientes por la Administración al considerar indispensable la comunicación del número del documento nacional de identidad (DNI) o del permiso de conducir del responsable para cumplimentar la identificación requerida (SSTC 30/2013, de 11 de febrero y 45/2013, de 25 de febrero). Pero téngase en cuenta que, en estas últimas resoluciones aunque cercanas en el tiempo, se interpreta sobre la normativa anterior que no exigía, como ahora hace de manera expresa el art. 9 bis a), los datos correspondientes a la autorización administrativa para conducir.
} 
relacionadas con las autorizaciones, documentación, inspecciones y estado de conservación.

De ello se deriva que es al titular (o arrendatario a largo plazo) al que corresponde tener en orden la documentación que se exige para la circulación del vehículo. El permiso de circulación (o licencia de circulación, en el caso de los ciclomotores), la tarjeta de inspección técnica (o el certificado de características técnicas en el supuesto de ciclomotores), pasar en plazo las inspecciones técnicas establecidas y que es el responsable de que el vehículo mantenga afecten a las condiciones de seguridad del vehículo.

Sobre esta documentación, que la LTSV establece como obligatoria para la circulación de los vehículos, se imponen tres obligaciones, al establecer el art. 59.2 LTSV (y el concordante art. $26 \mathrm{RGV}$ ) que el conductor de un vehículo queda obligado a estar en posesión y llevar consigo, así como a exhibir ante los agentes de la autoridad que se lo soliciten la documentación correspondiente al vehículo. De ello se deriva que la LTSV establece diversas obligaciones sobre la obligación de los vehículos. El hecho de tenerlas es responsabilidad del titular del vehículo. El de portarlas y exhibirlas de quien lo conduzca. Son responsabilidades diferentes por infracciones distintas.

La línea que divide las responsabilidades que, sobre un vehículo, corresponden al titular y al conductor, no son tan claras como pudiera parecer. No basta pensar con el vehículo como elemento para atribuirle toda la responsabilidad al titular (o arrendatario). Piénsese, de un lado, en el los deberes impuestos al titular (o arrendatario) en el art. 9.3 LTSV de mantenerlos en las condiciones legal y reglamentariamente establecidas, someterlos a los reconocimientos e inspecciones que correspondan e impidiendo que sean conducidos por quienes nunca hubieren obtenido el permiso o la licencia de conducción correspondiente.

Pero en ese mismo artículo se ubica, de manera deslavazada y asistemática, ya que no se encuentra en las normas generales de los conductores, la previsión realizada en el art. 9.2 párrafo segundo por la que "el conductor deberá verificar que las placas de matrícula del vehículo no presentan obstáculos que impidan o dificulten su lectura e identificación", como solución para evitar la tentación del conductor (de manera independiente del titular) de eludir la identificación del vehículo en el caso de que se cometiera alguna infracción. Esta norma, tipificada como infracción grave en el art. 65.4 p) LTSV es digna de mención (e incluso de elogio) por ser una de las pocas soluciones prácticas a un mandato que escondido en el art. 131.2 LRJ - PAC establece, en el marco del principio de proporcionalidad, que el establecimiento de sanciones pecuniarias deberá prever que la comisión de las infracciones tipificadas no resulte más beneficios para el infractor que el cumplimiento de las normas infringidas, principio que no se suele tomar en consideración al establecer la estructura de los regímenes sancionadores. 


\section{RESPONSABILIDAD Y PERSONAS JURÍDICAS}

Al perspicaz legislador no se le escapan dos hechos absolutamente relevantes en el ámbito de tráfico y la seguridad vial como son que el conductor es (siempre) persona física pero que hay otros casos (titular del vehículo, arrendatario, talleres mecánicos, establecimientos de compraventa) en el que esas posiciones pueden ser ocupadas por personas jurídicas. Perfectamente consciente de ello establece distintas regulaciones y requisitos, en base a ello, al momento de expedir documentos a las personas físicas, como es el caso del art. 59 bis 5 LTSV, que obliga a designar un domicilio electrónico cuando el titular de una autorización es una persona física.

El art. 69.1 e) LTSV contiene referencia específica a las personas jurídicas, algo que no se realiza en otros apartados en los que este caso es perfectamente posible, como son los supuestos de las letras c), f) y g) del propio art. 69.1 LTSV.

A las personas jurídicas que fueran titulares, arrendatarios u ocuparen cualesquiera otra posición de las previstas en la LTSV les corresponden las mismas obligaciones establecidas para las personas físicas.

No se trata aquí de realizar un análisis sobre personas jurídicas y derecho administrativo sancionador como de dejar constancia que en el ámbito del tráfico y seguridad vial, tan centrado en el conductor, la incidencia de las personas jurídicas es, cuantitativamente, mucho más elevada de lo que, en principio, pudiera aparecer. El aumento de vehículos cuyo titular no se corresponde con una persona física es un fenómeno que, en nuestro país no ha hecho más que seguir las tendencias de los Estados que nos rodean. A la titularidad de vehículos por personas jurídicas se une el uso mediante otras figuras contractuales diferentes de la compraventa, como son leasing y renting. Son fenómenos que ya trascienden la regulación pero sobre los que, tal vez, sea preciso detenerse para encajar este hecho en el marco del régimen sancionador establecido para el tráfico y la seguridad vial.

\section{D) Responsabilidad por el impago de multas}

Al margen de la determinación de la persona responsable por la comisión de las infracciones se sitúa la responsabilidad por el pago de la sanción económica impuesta como consecuencia de la infracción en caso de que sobre quien recae esa obligación no cumpla con ella.

El art. 91 LTSV determina la responsabilidad subsidiaria del titular del vehículo con el que se haya cometido la infracción, y lo hace como norma general, de manera que el 
titular es responsable salvo que concurra una de las circunstancias (excepciones) que, legalmente establecidas, le exoneran de esa carga.

Los supuestos de exención de responsabilidad (subsidiaria) previstos en el art. 91.1 LTSV se concretan en:

- Los supuestos de usos e contra de voluntad del titular, entre los que se señalan, de manera expresa, el robo y el hurto del vehículo pero sin que estos supuestos sean los únicos que determinen la ruptura del nexo de responsabilidad ya que el art. 91.1 a) LTSV añade la expresión "o cualquier otro uso" siempre que, eso sí, quede acreditado "que el vehículo fue utilizado en contra de su voluntad".

- En el caso de que el titular sea una empresa de alquiler de vehículos sin conductor, sin que en este caso se establezca, de manera expresa, quien asume esa responsabilidad subsidiaria, ya que el art. 91.1 b) LTSV se limita a exonerar a este tipo de propietarios sin que se indique que esa posición de garante es asumida por el arrendatario, algo que si se establece en el art. $91.1 \mathrm{c}$ ) LTSV en los arrendamientos a largo plazo respecto a ese arrendatario

- El conductor habitual, caso de estar designado, será quien asuma esa posición, quedando liberado el titular, tal y como dispone el art. $91.1 \mathrm{~d}$ ) LTSV

La propia definición, como responsabilidad subsidiaria, difiere del supuesto de responsabilidad solidaria previsto en el art. 69.1 b) LTSV para los garantes de los menores (padres, tutores, acogedores, guardadores legales o de hecho) y, por ello, las consecuencias también son diferentes, de manera que el art. 91.3 LTSV establece el derecho de reembolso del titular del vehículo respecto del responsable originario ${ }^{35}$.

El art. 91.2 LTSV dispone que el procedimiento derivado de esta declaración de responsabilidad, lo que alcanza a la propia declaración de responsabilidad subsidiaria, las consecuencias que de ello se derivan y las medidas cautelares a adoptar, se regirá por las normas establecidas en la legislación tributaria con expresa remisión a lo previsto en nuestro ordenamiento en la Ley General Tributaria y al Reglamento General de Recaudación.

\footnotetext{
${ }^{35}$ Para el que la LTSV emplea el término infractor y no el de "responsable de la infracción" como sucede en el art. 69.1 LTSV.
} 


\section{Capítulo IV}

\section{LAS FASES DEL PROCEDIMIENTO ADMINISTRATIVO SANCIONADOR EN MATERIA DE TRÁFICO Y SEGURIDAD VIAL}

SUMARIO: I. DE LA INICIACIÓN DEL PROCEDIMIENTO ADMINISTRATIVO SANCIONADOR EN MATERIA DE TRÁFICO Y SEGURIDAD VIAL: A) LOS presupuestos previos: 1. EL PRESUPUESTO DE HECHO; 2. EL CONOCIMIENTO DE LOS HECHOS; 3. LA NECESIDAD DE DAR UN PASO ATRÁS: EL PELIGRO DE LA SENSACIÓN DE IMPUNIDAD Y SUS CONSECUENCIAS. B) El inicio: 1. INCOACIÓN DE OFICIO: a) Inicio e iniciativa; b) Regulación y práctica. 2. LA DENUNCIA COMO ACTO DE INICIACIÓN: a) Denuncia formulada por los agentes de la autoridad encargados de la vigilancia del tráfico; b) Que la denuncia sea notificada en el acto; c) Sobre lo extraordinario de este modo de iniciación del procedimiento sancionador y sus efectos. 3. EL CONOCIMIENTO TELEMÁTICO DE LOS HECHOS: a) La incorporación de instrumentos; b) La mutación tecnológica; c) El procedimiento administrativo sancionador con uso de elementos electrónicos. II. LA DENUNCIA: A) Concepto y clases; B) La denuncia como deber: las denuncias obligatorias. C) El contenido de las denuncias: 1. FINALIDAD; 2. El CONTENIDO NECESARIO DE TODA DENUNCIA: a) El carácter imprescindible de los requisitos previstos en el art. 74.2 LTSV; b) La identificación del vehículo con el que se hubiese cometido la supuesta infracción del art. 74.2 a) LTSV; c) La identidad del denunciado, si fuere conocida del art. 74.2 b) LTSV; d) Una descripción sucinta del hecho, con expresión del lugar o tramo, fecha y hora del art. 74.2 c) LTSV; e) El nombre y domicilio del denunciante o, si fuera un Agente de la Autoridad, su número de identificación profesional del art. 74.2 d) LTSV; f) El incumplimiento del contenido necesario de las denuncias y sus efectos. 3. EL CONTENIDO DE LAS DENUNCIAS NOTIFICADAS EN EL ACTO: a) Sobre su finalidad y diferentes efectos; b) La calificación infracción y sus consecuencias; c) El órgano competente para imponer la sanción y la norma que le atribuye tal competencia; d) En función de si el denunciado procede, o no, al abono de la sanción señalada; e) El domicilio que, en su caso, indique el interesado a efectos de notificaciones; f) El incumplimiento del contenido de las denuncias notificadas en el acto y sus efectos. 4. El CONTENIDO dE LAS DENUNCIAS POR HECHOS AJENOS A LA CIRCULACIÓN. 5. SOBRE LAS DENUNCIAS VOLUNTARIAS. III. LA NOTIFICACIÓN DE LA DENUNCIA: A) Momento de la notificación: 1. LA NORMA GENERAL DE NOTIFICACIÓN EN EL ACTO; 2. EXCEPCIONES A LA NORMA GENERAL: CIRCUNSTANCIAS QUE PERMITEN LA NOTIFICACIÓN EN UN MOMENTO POSTERIOR: a) Que la denuncia se formule en circunstancias en que la detención del vehículo pueda originar un riesgo para la circulación; b) Que la denuncia se formule estando el vehículo estacionado, cuando el conductor no esté presente; c) Que la autoridad sancionadora haya tenido conocimiento de los hechos a través de medios de captación y reproducción de imágenes que permitan la identificación del vehículo; 3. EFECTOS DEL INCUMPLIMIENTO DE LA NORMA GENERAL QUE OBLIGA A LA NOTIFICACIÓN EN EL ACTO DE LAS DENUNCIAS. B) Práctica de la notificación de las denuncias (en momento posterior): 1. Presupuestos a Considerar SObRE LA DENUNCIA NO NOTIFICADA EN EL ACTO; 2. El SISTEMA DE NOTIFICACIÓN DE DENUNCIAS NO ENTREGADAS EN EL 
ACTO Y DE DEMÁS NOTIFICACIONES A QUE DÉ LUGAR EL PROCEDIMIENTO SANCIONADOR: a) Una aproximación al sistema de notificaciones de los arts. 77 y 78 LTSV; b) La Dirección Electrónica Vial (DEV); c) La notificación en el domicilio del interesado; d) El Tablón Edictal de Sanciones de Tráfico (TESTRA). 3. UNA VALORACIÓN DEL SISTEMA DE NOTIFICACIONES DE LA LTSV. IV. LA PRUEBA: A) Regulación; B) El Valor probatorio de las denuncias de los Agentes de la Autoridad: 1. DE LOS TÉRMINOS EMPLEAdOS EN EL ART. 75 LTSV; 2. DE LOS EFECTOS DE LA PREVISIÓN DEL ART. 75 LTSV, 3. DeL ALCANCE DEL VALOR PROBATORIO DE LAS DENUNCIAS DE LOS AGENTES. V. INSTRUMENTOS DE MEDICIÓN: A) Introducción; B) Cuestiones comunes a los instrumentos, aparatos o medios y sistema de medida que sean utilizados para la formulación de denuncias por infracciones a la normativa de tráfico; C) La medición en las infracciones de velocidad: 1. EL PLANTEAMIENTO DE LA LTSV; 2. LOS ERRORES MÁxIMOS PERMITIDOS EN LOS INSTRUMENTOS UTILIZADOS PARA MEDIR LA VELOCIDAD DE LOS VEHÍCULOS A MOTOR: a) Sobre la existencia de diferentes tipos de cinemómetros; b) De los diferentes errores máximos permitidos para cada tipo de cinemómetro; 3 . EFECTOS DE LOS MÁRGENES DE ERROR PERMITIDOS; D) La medición en las infracciones por haber ingerido bebidas alcohólicas y conducir con tasas superiores a las que reglamentariamente se establezcan: 1. LA INFRACCIÓN EN LA LTSV Y LA DETERMINACIÓN REGLAMENTARIA DE LOS LÍMITES; 2. MÁRGENES DE ERROR Y EFECTOS; E) La determinación de las infracciones por conducción bajo los efectos de estupefacientes, psicotrópicos, estimulantes y otras sustancias análogas; F) Otras mediciones. VI. MEDIOS DE CAPTACIÓN DE IMÁGENES: A) Una delimitación necesaria; B) El supuesto y sus requisitos. VI. ACTUACIONES ADMINISTRATIVAS Y PENALES: A) La concurrencia de ilícitos administrativos y tipos penales (como presupuesto): 1 . TIPIFICACIÓN ADMINISTRATIVA Y PENAL; 2. EL PRINCIPIO NON BIS IN IDEM; 3. DE LA PLURALIDAD DE TIPIFICACIONES Y DE LA DIVERSIDAD DE SANCIONES: a) De las genéricas previsiones sobre tipos administrativos y penales; b) La distribución del ius puniendi en materia de tráfico y seguridad vial; c) Previsiones administrativas al margen de la LTSV; B) La preferencia de la Jurisdicción Penal: 1. LA PREVISIÓN NORMATIVA; 2. PREVISIÓN Y EFECTOS; 3. LA OPCIÓN ESTABLECIDA ENTRE POSIBLES ALTERNATIVAS.

\section{DE LA INICIACIÓN DEL PROCEDIMIENTO SANCIONADOR EN MATERIA DE TRÁFICO}

\section{C) Los presupuestos previos}

\section{EL PRESUPUESTO DE HECHO}

Para que la maquinaria procedimental se ponga en movimiento resulta precisa la comisión de una infracción, la realización de un hecho que, al menos, tenga la apariencia de corresponderse con un tipo administrativo de los previstos en la Ley de Tráfico y Seguridad Vial.

Pero ello, por sí mismo, tampoco es suficiente. La comisión de unos hechos constitutivos de infracción (por claro y evidente que sea esa correspondencia entre realidad fáctica y previsión normativa del ilícito administrativo) no produce de manera automática el arranque del procedimiento administrativo sancionador. Y más en un ámbito, como lo es el del tráfico y la seguridad vial, en el que una parte considerable de las infracciones no dejan el menor rastro una vez consumadas. Es preciso, en 
términos del art. 73.1 LTSV que se tenga noticia de esos hechos y que esa percepción se realice por alguien que tenga la obligación de actuar 0 , al menos, de alguien que se tome la molestia y quiera (haga ese esfuerzo) ponerlos en conocimiento de quién sí tenga esa obligación. Porque la probabilidad, estadística, de que una infracción sea detectada es, ciertamente, muy baja, posibilidad, que en el ámbito del tráfico, raya con la casualidad ${ }^{1}$.

Por ello, y para que el procedimiento administrador comience, es preciso que la autoridad competente llegue a tener conocimiento de esos hechos susceptibles de ser constitutivos de infracción administrativa. En otro caso, aunque la infracción se haya producido, se ignora su existencia, al menos por quien tiene capacidad para poner en marcha el instrumento destinado a depurar las correspondientes responsabilidades e imponer la sanción que, en su caso, proceda.

\section{EL CONOCIMIENTO DE LOS HECHOS}

Es la necesaria suma de todos esos elementos (sujetos, hechos e instrumentos) la que puede dar lugar inicio del procedimiento cuando la autoridad competente tenga noticia de esos hechos que puedan ser constitutivos de infracciones en materia de tráfico y seguridad vial.

Ese es el elemento desencadenante, el que va a distinguir que frente, a unos hechos, la autoridad reaccione poniendo en marcha el procedimiento y que, en otros casos, eso no ocurra. Es necesario el conocimiento de los hechos.

Esta idea, la de la necesidad de conocer los hechos para que, en un caso concreto, se proceda a la incoación del procedimiento administrativo sancionador, se encuentra en la base de una preocupación que, maliciosamente, se opone a la justicia del caso concreto. Cuál sea la razón que justifique que la persecución y sanción de una infracción y que otras, equivalentes, queden sin castigo ${ }^{2}$.

\footnotetext{
${ }^{1}$ Alejandro Nieto señala que "sólo una mínima parte de las infracciones que se cometen llegar a ser castigadas: en materia de tráfico, alimentación seguridad en el trabajo o urbanismo de seguro que no llegan al uno por mil" (Derecho Administrativo Sancionador, Madrid, Tecnos, 2012, 5a ed., pág. 100). Lorenzo MARTín - RETORTILLO se refería a ello realizando una serie "consideraciones, a modo de reflexión sotto voce, sobre lo aleatorio y lábil de las sanciones administrativas" "Las sanciones administrativas en relación con la defensa de los consumidores, con especial referencia a la publicidad de las mismas", RAP, no 126, Madrid, 1991, pág. 144).

${ }^{2}$ Este es al argumento que de manera, tan persistente como pertinaz, se opone por el infractor detectado que alega la injusticia de la persecución de su caso cuando "todo el mundo sabe que en otros muchos supuestos equivalentes o iguales no pasa absolutamente nada".
} 
El tráfico, como fenómeno de masas, afecta y envuelve cada día a millones de ciudadanos, a millones de vehículos, por cientos de miles kilómetros de carreteras $^{3}$ y supone la comisión un gran número de conductas que podrían ser calificadas (que deberían serlo) como infracciones. Y si no lo son es porque no se conocen. Porque es imposible que las Administraciones con competencia para controlar y, en su caso, sancionar esas conductas lleguen a conocerlas, porque "los medios humanos de vigilancia y disciplina del tráfico son siempre finitos" y "no es posible contar con agentes de la autoridad asentados permanentemente en cada tramo de la carretera" ${ }^{4}$.

De esta nimiedad se desprenden dos consecuencias que no son, precisamente, menores. La primera, en el plano teórico - jurídico, es que no se puede pretender la injustica del sistema por ese hecho incuestionable de que únicamente se sancionen las infracciones conocidas y, las otras, las no conocidas, queden impunes. Esto es algo que jurídicamente ha sido objeto de suficiente debate y que está resuelto mediante la comprensión de que el principio de igualdad no puede actuar al margen de la legalidad. La segunda, en el terreno de lo práctico - jurídico, supone la necesidad de incorporar al tráfico y la seguridad vial mecanismos de control y detección que rompen con la tradición de los medios de vigilancia empleados durante el pasado siglo y que haciendo uso de las tecnologías disponibles (las nuevas en cada momento) no requieren de la presencia de un agente que perciba, con la inmediatez de sus sentidos, la existencia de unos hechos que pudieran resultar constitutivos de una infracción a las previsiones efectuadas en la LTSV para que se ponga en marcha el procedimiento sancionador.

\footnotetext{
${ }^{3}$ A finales del año 2011 había más de 26 de millones de conductores y más 31 millones de vehículos (fuente DGT a 31 de diciembre de 2011). En el año 2008 había en España 681.298 km, de los cuales $15.152 \mathrm{Km}$ eran autopistas (fuente The World Factbook).

El Ministerio de Fomento (Dirección General de Carreteras) publica, anualmente (y desde 1960), los Mapas de Tráfico en los que se recogen los datos de circulación. El dato más relevante es la intensidad media diaria medida en vehículos/día IMD), junto con otros como son el porcentaje de vehículos pesados y motor y la intensidad diaria de vehículos extranjeros. En la edición correspondiente al año 2012 los apartados básicos de estudio son, junto con los Mapas de Tráfico, la evolución del tráfico 2000 - 2012, velocidades 2000 - 2012, tráfico en los años 2011, 2012 y 2013, velocidades y accidentes en los años 2011, 2012 y 2013, las previsiones de tráfico y el estudio de accidentes en la red de carreteras del Estado. Todos estos datos pueden consultarse en: http://www.fomento.es/MFOM/LANG CASTELLANO/DIRECCIONES GENERALES/CARRETERAS/ TRAFICO VELOCIDADES/

4 Ledesma MuÑIZ, R.,: Decálogo para la correcta gestión de las sanciones de los radares de velocidad, Pons, 2013, pág. 68.
} 
3. LA NECESIDAD DE DAR UN PASO ATRÁS: EL PELIGRO DE LA SENSACIÓN DE IMPUNIDAD Y SUS CONSECUENCIAS

El análisis encaminado a construir y colocar en el ordenamiento el sistema normativo más adecuado requiere de valoraciones previas que no proceden ni se asientan en cuestiones jurídicas.

Por ello, sobre las consideraciones realizadas previamente, se hace preciso tener en cuenta las consecuencias que la baja represión de infracciones, sabiendo de su existencia, puede tener sobre la sociedad. Y el efecto directo es que, si establecida una norma de conducta que prevé la imposición de una sanción, para el que la incumpla, se produce una continua trasgresión de la misma, sin reproche social, ello deriva en una sensación de impunidad. Impresión que se convierte en percepción de que la norma no existe, porque no es exigida, y que cuando, por la concurrencia conjunta de todas esas circunstancias que derivan en que se denuncie una infracción, supongan un sentimiento de sinrazón en el infractor denunciado que percibe el procedimiento administrativo sancionador y la sanción no como la consecuencia previsible de su acción sino como fruto del azar, de una lotería, en la que le ha tocado, con total arbitrariedad $^{5}$, una sanción. Lo que puede llevar a la siguiente percepción del ejercicio facultativo, por parte de la Administración, de la potestad sancionadora que tiene atribuida, incrementando esa sensación de arbitrariedad.

Arbitrariedad que no existe porque la Administración no actúe cuando desconoce los hechos, pero en la que, sin lugar a dudas, incurriría si conocidos esos hechos no se actuara en consecuencia o se diera distinto tratamiento a idénticos hechos conocidos ${ }^{6}$.

Por ello es preciso adaptar las normas a las necesidades sociales, incorporar en el sistema los nuevos mecanismos y soluciones que permitan hacerlo más eficaz y eficiente. Pero en ningún caso resulta legítimo saltarse las normas para alcanzar el fin perseguido. La exigencia de responsabilidades requiere del cumplimiento de todas las garantías establecidas en nuestro ordenamiento. El fin, por loable que sea, no justifica los medios. Los medios tienen que ser, y tienen que serlo siempre, lícitos. La norma, la regulación en este caso del procedimiento administrativo sancionador encaminado a la

\footnotetext{
${ }^{5}$ Como percepción, insisto, del ciudadano afectado. Sobre el concepto de arbitrariedad resulta imprescindible acudir a la obra de TOMÁs - RAMÓN FERNÁNDEZ, De la arbitrariedad de la Administración, Civitas, 2008, 5a edición ampliada, págs. 145 - 153. Sobre esta obra, y su desarrollo a través del tiempo, resulta imprescindible FERNÁNDEZ TORRES, JUAN RAMÓN: “Arbitrariedad y discrecionalidad, dos décadas después”, Administración y justicia: un análisis jurisprudencial: liber amicorum Tomás-Ramón Fernández (coord. por Eduardo García de Enterría Martínez - Carande, Ricardo Alonso García), Vol. 1, 2012, págs. 1111-1146.

${ }^{6}$ Sobre la posibilidad o interdicción del ejercicio facultativo de la potestad sancionadora puede verse Alejandro NiETo, Derecho Administrativo Sancionador, Madrid, Tecnos, 2012, 5a ed., págs. 100 - 109. Análisis que también efectúa LOZANO CUTANDA en "El principio de oficialidad de la acción sancionadora administrativa y las condiciones necesarias para garantizar su efectividad", RAP, no 161, mayo - agosto 2003, en especial págs. $88-92$.
} 
depuración de responsabilidades por la comisión de infracciones a lo establecido en la Ley de Tráfico y Seguridad Vial, tiene que respetar todas y cada una de las garantías establecidas para el presunto infractor. De no ser así la norma pierde su valor, y pasa de cobertura a obstáculo como medio de garantizar, en este caso, la seguridad vial.

\section{D) El inicio}

\section{INCOACIÓN DE OFICIO}

a) Inicio e iniciativa

Para que el procedimiento sancionador en materia de tráfico y seguridad vial comience tiene que ser iniciado, y esa iniciativa, la de la incoación, corresponde a la autoridad competente. Así lo establece el art. 73.1 LTSV al disponer que "el procedimiento sancionador se incoará de oficio por la autoridad competente que tenga noticia de los hechos que puedan constituir infracciones tipificadas en esta Ley".

Tanto el art. 73.1 LTSV como el art. 11 del Reglamento del Procedimiento para el Ejercicio de la Potestad Sancionadora (REPEPOS) establecen que los procedimientos sancionadores se iniciarán siempre de oficio por quien tenga atribuida la competencia para ello, algo que puede ocurrir por diferentes motivos, ya que no hay que confundir (ni, por tanto, equiparar) los términos "inicio" con "iniciativa". El "inicio" corresponde, por así estar atribuido, al órgano competente que puede actuar movido por una "iniciativa" que puede ser propia o ajena”.

En cuando esas posibilidades de iniciativa, el propio art. 73.1 LTSV señala tres: "por iniciativa propia o mediante denuncia de los Agentes encargados del servicio de

\footnotetext{
${ }^{7}$ Que es a lo que se refieren los términos "por iniciativa propia o mediante" del art. 73.1 LTSV y o los de "bien por propia iniciativa o como consecuencia de" empelados por el art. 11.1 REPEPOS.

Sobre esta cuestión conviene recordar que la redacción originaria (previa al REPEPOS) del entonces art. 75.1 LTSV establecía que "el procedimiento sancionador se incoará de oficio por la Autoridad competente que tenga noticias de los hechos que puedan constituir infracciones a los preceptos de esta Ley o mediante denuncia que podrá formular cualquier persona que tenga conocimiento directo de los mismos", de lo que parecía desprenderse que la denuncia de un particular ocasionaba, por si misma, el inicio del procedimiento sancionador, algo realmente difícil de asimilar en nuestro sistema. Este problema terminológico se quiso resolver con la promulgación del RPSTSV que, para llevar las aguas al cauce de la lógica establecía, en el art. 3, que:

“El procedimiento sancionador se incoará de oficio por la autoridad competente que tenga noticias de los hechos que puedan constituir infracciones a los preceptos del Texto Articulado de la Ley sobre Tráfico, Circulación de Vehículos a Motor y Seguridad Vial o mediante denuncia formulada por los agentes de la autoridad encargados de la vigilancia y seguridad del tráfico. Asimismo se podrá incoar un procedimiento por la autoridad competente como consecuencia de denuncia formulada por cualquier persona que tenga conocimiento de los hechos mencionados".

Algo muy razonable, eso sí, ignorando que se pretendía la corrección de la previsión legal mediante una norma reglamentaria.
} 
vigilancia de tráfico y control de la seguridad vial o de cualquier persona que tenga conocimiento de los hechos", redacción que difiere de la utilizada para la forma de iniciación del procedimiento en el referido art. 11.1 REPEPOS, ya que, en este precepto, se contienen otras posibilidades que pueden dar lugar a la incoación del procedimiento, como son "como consecuencia de orden superior" o "petición razonada de otros órganos".

Sobre lo que haya de entenderse por cada una de estas circunstancias, como iniciativas que dan lugar al inicio del procedimiento administrativo sancionador, es algo que no se encuentra recogido en el texto de la LTSV, ni tampoco lo ha estado en el Reglamento de procedimiento sancionador en materia de tráfico, circulación de vehículos a motor y seguridad (RPSTSV), pero cuyas definiciones se encuentran en el art. 11.1 del REPEPOS $^{8}$.

\section{b) Regulación y práctica}

Pero el procedimiento sancionador en materia de tráfico y seguridad vial presenta particularidades desde su propia iniciación, peculiaridades que están presentes tanto en las previsiones normativas como en su ejecución práctica.

A la forma de iniciación y las posibles iniciativas señaladas en el art. 73.1 LTSV que, como se ha señalado en el apartado anterior, vienen a coincidir con lo establecido en

\footnotetext{
${ }^{8}$ Precepto que en el que se señala que a efectos del presente Reglamento (REPEPOS), se entiende por:
}

a) Propia iniciativa: La actuación derivada del conocimiento directo o indirecto de las conductas o hechos susceptibles de constituir infracción por el órgano que tiene atribuida la competencia de iniciación, bien ocasionalmente o por tener la condición de autoridad pública o atribuidas funciones de inspección, averiguación o investigación.

b) Orden superior: La orden emitida por un órgano administrativo superior jerárquico de la unidad administrativa que constituye el órgano competente para la iniciación, y que expresará, en la medida de lo posible, la persona o personas presuntamente responsables; las conductas o hechos que pudieran constituir infracción administrativa y su tipificación; así como el lugar, la fecha, fechas o período de tiempo continuado en que los hechos se produjeron.

c) Petición razonada: La propuesta de iniciación del procedimiento formulada por cualquier órgano administrativo que no tiene competencia para iniciar el procedimiento y que ha tenido conocimiento de las conductas o hechos que pudieran constituir infracción, bien ocasionalmente o bien por tener atribuidas funciones de inspección, averiguación o investigación.

Las peticiones deberán especificar, en la medida de lo posible, la persona o personas presuntamente responsables; las conductas o hechos que pudieran constituir infracción administrativa y su tipificación; así como el lugar, la fecha, fechas o período de tiempo continuado en que los hechos se produjeron.

d) Denuncia: El acto por el que cualquier persona, en cumplimiento o no de una obligación legal, pone en conocimiento de un órgano administrativo la existencia de un determinado hecho que pudiera constituir infracción administrativa.

Las denuncias deberán expresar la identidad de la persona o personas que las presentan, el relato de los hechos que pudieran constituir infracción y la fecha de su comisión y, cuando sea posible, la identificación de los presuntos responsables. 
el art. 11 REPEPOS, se opone una previsión especial, en cuanto que propia y característica, del procedimiento sancionador en materia de tráfico, disposición que se introduce mediante la locución adverbial "no obstante", conforme a la que, y a pesar de lo que se ha señalado sobre la iniciación del procedimiento sancionador, esto es, que corresponde al órgano que tiene atribuida la competencia para ello, conforme a la que "no obstante, la denuncia formulada por los Agentes de la autoridad encargados del servicio de vigilancia del tráfico y notificada en el acto al denunciado, constituye el acto de iniciación del procedimiento sancionador, a todos los efectos" ${ }^{\prime 9}$.

Esta peculiar forma de entender iniciado el procedimiento sancionador no hace sino trasladar al texto de la LTSV la práctica que en el ejercicio de la potestad se produce. Durante mucho tiempo la forma habitual de dar inicio a un procedimiento sancionador en materia de tráfico y seguridad vial era la denuncia efectuada por los agentes ${ }^{10}$. Es tan corriente que se llega a considerar la forma ordinaria de iniciativa para la incoación del procedimiento administrativo hasta el punto que, primero en el RPSTSV (1994) y después en la LTSV (reforma 2009) se trasmite a los agentes esa facultad de darlo por iniciado a todos los efectos, si bien es cierto que para que ello sea así, esa denuncia tiene que cumplir con determinados requisitos.

\section{LA DENUNCIA COMO ACTO DE INICIACIÓN}

El art. 73.2 LTSV no atribuye a todas las denuncias, de manera indiscriminada, el que se constituyan en acto de iniciación del procedimiento sancionador en materia de tráfico.

\footnotetext{
${ }^{9}$ Previsión que aunque no es introducido en el texto de la LTSV hasta la reforma efectuada por medio de la Ley 18/2009, de 23 de noviembre, tal y como señala TOMAS CANO, no supone novedad al ser algo ya previsto en el RPSTSV, lugar en el que se establecía que "el procedimiento sancionador se incoará de oficio por la autoridad competente que tenga noticias de los hechos que puedan constituir infracciones a los preceptos del Texto Articulado de la Ley sobre Tráfico, Circulación de Vehículos a Motor y Seguridad Vial o mediante denuncia formulada por los agentes de la autoridad encargados de la vigilancia y seguridad del tráfico" (art. 3) y que "como norma general, las denuncias de carácter obligatorio, formuladas por agentes de la autoridad encargados de la vigilancia del tráfico, se notificarán en el acto a los denunciados, haciendo constar en las mismas los datos a que hace referencia el artículo 5 del Reglamento, así como que con ellas quedan incoados los correspondientes expedientes..." (art. 10.1). Cfr. CANo CAmpos, T., El régimen jurídico - administrativo del tráfico, 2a ed., Madrid, Civitas, 2010, pág. 522.

${ }^{10}$ Hasta el punto que en la Ley de Bases se señala que "el procedimiento se iniciará mediante denuncia y no se podrá dictar resolución sin conceder previamente audiencia al interesado" (Base Novena, apartado 1, párrafo segundo), términos de los que pareciera derivarse que esta (la denuncia) fuera la única manera posible de dar comienzo al procedimiento sancionador en materia de tráfico y seguridad vial, algo que es preciso entender como la traslación a la previsión normativa de lo "habitual", y no como la "exigencia" de que ello tenga que ser siempre, y necesariamente, así.

Algo que, sin duda, tiene su origen en la propia regulación que del inicio del procedimiento sancionador se hacía en el art. 287 del Código de la Circulación de 1934, que establecía que "las multas consignadas en este Código, por infracción de sus preceptos, serán consecuencia de denuncias hechas ante las Jefaturas de Obras públicas, las que trasladarán a las de Industria las que a estas correspondan".
} 
Para que ello sea así, y para que, a todos los efectos, se pueda entender que una denuncia supone la incoación del procedimiento sancionador en materia de tráfico y seguridad vial tiene que cumplirse con una serie de requisitos.

Las primeras de esas condiciones se encuentran explicitadas en el propio art. 73.2 LTSV, que impone dos exigencias en cuanto a su origen y comunicación.

Esa denuncia tiene que ser formulada por los Agentes de la autoridad encargados del servicio de vigilancia del tráfico y esa denuncia tiene que ser notificada en el acto al denunciado.

a) Denuncia formulada por los agentes de la autoridad encargados de la vigilancia del tráfico

Cuando en el art. 11.1 d) REPEPOS se define lo que ha de entenderse por denuncia, se establece que ese acto de poner en conocimiento un determinado hecho que pudiera ser constitutivo de infracción administrativa puede ser realizado por cualquier persona. Pero al art. 73.2 LTSV no le basta con la existencia de una denuncia, y exige la concurrencia de un requisito en el autor de esa denuncia, al requerir que sea formulada por "agente de la autoridad encargado del servicio de la vigilancia del tráfico". No por cualquier persona, es más, ni siquiera por cualquier agente de la autoridad, sino precisamente por el que tiene encomendada esa misión, la de la vigilancia del tráfico. A lo que resulta preciso añadir un requisito que se encuentra implícito en esa designación, y es que esos agentes de la autoridad encargados del servicio del tráfico lo sean de la Administración competente en cada caso, por lo que hay que poner en relación agentes de la autoridad con la distribución de la potestad sancionadora que entre Administración General del Estado, Comunidades Autónomas (con competencias en la materia) y Administración Local se realiza por la propia LTSV, cada una de las cuales cuenta, para su respectivo ámbito de competencia, con sus agentes, con su cuerpo policial al que corresponde el control y vigilancia del tráfico.

Lo expuesto supone que tiene que tratarse de agentes de autoridad, que tengan atribuida esa misión y que la ejerzan en su ámbito de competencia ${ }^{11}$. Un guardia civil de la Agrupación de Tráfico en una carretera o travesía, pero no en una vía urbana; un agente de los Cuerpos de Policía Autonómicos (Ertzaintza ${ }^{12}$ o Mossos d'Escuadra ${ }^{13}$ ) en

\footnotetext{
11 Téngase en cuenta, sobre esta cuestión lo expuesto, como presupuesto del procedimiento administrativo sancionador, en el capítulo correspondiente de esta obra dedicado a "La competencia para sancionar las infracciones de tráfico y seguridad vial" y, en particular, el apartado sobre la atribución y distribución de la potestad sancionadora en materia de tráfico y seguridad vial.

${ }^{12}$ Véase, a este respecto la regulación de la Ley del País Vasco 4/1992, de 17 de julio, de Policías del País Vasco, publicada en el Boletín Oficial del País Vasco de 11 de agosto de 1992 y en el Boletín Oficial del Estado de 15 de febrero de 2012).
} 
el ámbito de sus respectiva Comunidad Autónoma; un agente de la Policía Local en el territorio de sus respectivo Municipio (a salvo de lo previsto, especialmente, en el art. 71.5 LTSV sobre la asunción de las competencias de los Alcaldes por los Jefes Provinciales de Tráfico y los órganos competentes de las Comunidades Autónomas con competencia en materia de tráfico y seguridad vial ${ }^{14}$ ).

$\mathrm{Ni}$ cumplen con la condición de agentes de la autoridad los controladores o vigilantes de las zonas reguladas de aparcamiento (Ordenanzas reguladoras del aparcamiento) salvo que sean miembros de la Policía Local ${ }^{15}$, ni la tienen los que, siendo agentes de la autoridad encargados del servicio de vigilancia del tráfico, actúan fuera de su ámbito de competencia (Agentes de la Guardia Civil en vías urbanas, por ejemplo ${ }^{16}$ ).

En definitiva, no basta con la condición de Agentes de la autoridad. Es necesario que, además, a esos Agentes les haya sido encomendada, por quien tiene competencia para ello, la misión del servicio de vigilancia del tráfico y el control de la seguridad vial, competencia que queda enmarcada y limitada al correspondiente ámbito territorial de competencia, conforme la delimitación realizada en el art. 71 LTSV.

\footnotetext{
${ }^{13}$ Véase, sobre ello, la Ley del Parlamento de Cataluña 10/1994, de 11 de julio, de Mossos d'Escuadra, publicada en el Diario Oficial de la Generalidad de Cataluña de 28 de octubre de 1994 y en el Boletín Oficial del Estado de 12 de agosto de 1994.

${ }^{14}$ Véase, en el capítulo correspondiente de esta obra dedicado a "La competencia para sancionar las infracciones de tráfico y seguridad vial" el específico apartado sobre la asunción de competencias municipales.

${ }^{15}$ La STS de 23 de noviembre de 1993 (RJ 1993, 8883) resolviendo recurso de casación en interés de la Ley establece que "en general, los controladores o vigilantes de dichas zonas en otros municipios donde exista implantado dicho régimen de estacionamiento de vehículos, no tienen la consideración de agentes de la Autoridad, salvo cuando sean miembros de la Policía Local, ni tampoco pueden tener la cualidad de auxiliares de ésta, al sólo poder existir tales auxiliares en Municipios de menos de 5.000 habitantes donde no exista dicha Policía Local. Esta es, además, la doctrina ya establecida por STS 1 de octubre de 1991 (RJ 1991, 7639), en la que se sienta de forma clara y explícita la negación de la consideración de agentes de la Autoridad a los aludidos controladores o vigilantes de la denominada ORA, y por ello, como se añade en la precitada sentencia, «su simple denuncia equivale a la denuncia de un particular, $y$ al no ser adverada por pruebas posteriores, no tienen fuerza suficiente para acreditar los hechos denunciados»".

${ }^{16}$ En este caso se ha señalado que "en consecuencia, a la vista del expediente administrativo y de la normativa mencionada, se ha de concluir que en lo que respecta a la denuncia, si bien no le correspondía en este caso a la Guardia civil las funciones de vigilancia y control de la circulación vial en las vías urbanas, pues tales competencias le corresponden a las personas que designe el Ayuntamiento, no estando la Guardia civil encargada en este caso de velar por la seguridad del tráfico en esas vías, sin embargo nada impide que sus miembros puedan denunciar la infracción, al igual que lo puede hacer cualquier otro ciudadano que tenga conocimiento directo de los hechos que puedan constituir infracciones, teniendo en este caso la denuncia del guardia civil igual valor que la cualquier otro ciudadano, no concediéndosele el valor probatorio de presunción de veracidad prevista en el art. 76 del Texto articulado mencionado y en el art. 14 del Reglamento del procedimiento sancionador en materia de tráfico, que establece la presunción de veracidad de las denuncias efectuadas por los agentes de la autoridad encargados de la vigilancia del tráfico" (SJCA Salamanca, núm.1, de 14 de mayo de 2007, JUR 2008, 103954).
} 
Cumplido el requisito del autor de la denuncia expuesto en el apartado anterior (agente de la autoridad encargado de la vigilancia del tráfico y seguridad vial en su concreto ámbito de competencia) resulta preciso, además, que esa denuncia formulada sea comunicada en el acto al supuesto infractor.

El art. 73.2 LTSV exige el cumplimiento de la regla general establecida en el art. 76.1 LTSV conforme al que las denuncias (salvo que concurran circunstancias que lo justifiquen) tienen que ser notificadas en el acto al denunciado.

En lo que aquí interesa, y como requisito para que la denuncia se constituya en acto de iniciación del procedimiento (el análisis de la notificación en el acto se realiza en el apartado correspondiente de esta obra ${ }^{17}$ ), se trata de un requisito de inmediatez que precisa, para ser cumplido, de la realización sucesiva y de forma continua, sin solución de continuidad, entre los hechos, formulación de la denuncia y comunicación de la misma al denunciado, que permite a las partes (Administración con competencia para sancionar y denunciado) el conocimiento de toda la información que precisan para intervenir en el procedimiento administrativo sancionador y hacerlo con todas las garantías, para lo cual resulta necesario la concurrencia de un tercer requisito que, aunque no enunciado de forma expresa, se infiere del propio art. 73.2 LTSV, como es que la denuncia formulada por el Agente de la autoridad, y que se notifica al denunciado, cumpla con las condiciones establecidas para que pueda ser tenida como tal, para lo cual tiene que cumplir con todos los requisitos que, para ese supuesto concreto, el de las denuncias notificadas en el acto, prescribe el art. 74.3 LTSV que, además de los genéricamente establecidos para cualquier tipo de denuncia (art. 74.2 LTSV), impone otros con la finalidad, precisamente, de poder dar por iniciado el procedimiento administrativo sancionador, siempre y cuando pueda afirmarse, de esa denuncia, que está "correctamente extendida y notificada al infractor"18.

\section{c) Sobre lo extraordinario de este modo de iniciación del procedimiento sancionador y sus efectos}

El hecho de que la denuncia sea, en sí misma y sin necesidad de que así lo decida el órgano con competencia para ello, acto de iniciación del procedimiento sancionador a todos los efectos es, ciertamente, una situación peculiar ${ }^{19}$.

\footnotetext{
${ }^{17}$ Véanse, sobre la denuncia y su notificación, los apartados II y III de este mismo capítulo.

${ }^{18}$ Términos empleados por la STS de 4 de junio de 2004 (no de recurso 49/2003, EDJ 2004/60708).

${ }^{19}$ La STSJ de Castilla - La Mancha de 27 de septiembre de 2012 (JUR 2012, 359298), que reproduce los señalado en el mismo sentido por ese Tribunal en otra anteriores, se refiere a esta previsión como "una regla peculiar y aun extravagante y excepcional en relación con el panorama procedimental general, y en cualquier caso dictada para un procedimiento particular" y que "esto contradice lo establecido en
} 
El dar por iniciado el procedimiento sancionador sin intervención del órgano competente supone la compresión en un limitado espacio de tiempo (el que media desde que los agentes observan los hechos, los califican, formulan la denuncia y se la notifican al denunciado) a toda la fase de iniciación sin que, como se ha señalado, el órgano competente haya intervenido.

Hay una sustitución (delegación o traslación ${ }^{20}$ ), mediante una previsión legal que así lo establece, de la competencia para la iniciación del procedimiento sancionador en materia de tráfico y seguridad vial. Desplazamiento que lleva consigo, de manera ínsita, la propia decisión de iniciar el procedimiento, la valoración de si concurren las circunstancias que justifican esa iniciación, que es lo que sucede en el resto de ámbito de actividad cuando recibida la denuncia el órgano competente valora hechos y circunstancias, los califica (incluso con la posibilidad de realizar, de manera previa y con carácter preliminar, unas actuaciones previas) e incluso pondera, a la vista de los hechos, la necesidad de adoptar alguna medida de carácter provisional.

Aquí, cuando la denuncia de los Agentes es notificada en el acto, empieza y concluye la fase de iniciación. El procedimiento ha comenzado, y ya está iniciado, algo que se produce, como señala el inciso final del art. 73.2 LTSV, "con todos los efectos", es

general por el art. 69 LRJ - PAC, según el cual, aunque pueda estar motivada por denuncia, la incoación se efectúa siempre "por acuerdo del órgano competente», sin que un agente de la autoridad pueda reputarse, desde luego, "órgano administrativo»" y que rechaza una interpretación extensiva (y aun analógica) a otros ámbitos (transportes) que el TS había realizado (SSTS de 15 de noviembre de 2000, RJ 2000, 10064 y de 23 de mayo de 2001, RJ 2001, 4287). Interpretación que perdió su validez (para ese ámbito, el del transporte) una vez que la Ley 29/2003, de 8 de octubre, dio nueva redacción al art. 146 LOTT, e introdujo en dicho precepto una regla que estaba ausente del mismo en la redacción anterior sobre la cual se dictaron las sentencias del Tribunal Supremo, y que vino a establecer, ya sin duda alguna, que la única forma de incoación en esta materia, a diferencia de la de tráfico y seguridad vial, es la que coincide con la regla general establecida en el art. 69 LRJ - PAC, según el cual, aunque pueda estar motivada por denuncia, la incoación se efectúa siempre "por acuerdo del órgano competente".

Ahora bien, la reforma realizada en ese art. 146 LOTT por la Ley 9/2013, de 4 de julio, establece, como redacción para el párrafo sexto de su apartado 2 que:

"No obstante, las denuncias formuladas por los Servicios de Inspección del Transporte Terrestre o por las fuerzas encargadas de la vigilancia del transporte en carretera, entregadas en el acto al denunciado, constituirán la iniciación del procedimiento sancionador y la notificación de la denuncia, siempre que aquél pague voluntariamente la sanción en ese mismo momento, teniendo este pago las mismas consecuencias que las establecidas en el procedimiento ordinario. El referido pago deberá efectuarse en metálico en euros o utilizando una tarjeta de crédito"

Lo que supone un reconocimiento expreso de la posibilidad de iniciación del procedimiento sancionador por denuncia que, eso sí, queda sometido a unos requisitos más exigentes que los del art. 72.3 LTSV al requerir del denunciado que "pague voluntariamente la sanción en ese mismo momento", pero que, en todo caso, supone el expreso reconocimiento de que el inicio del procedimiento sancionador se produzca por la denuncia (y no como consecuencia de una denuncia).

${ }^{20}$ Tomas CANO CAMPOS señala que "en el sector del tráfico se traslada a los agentes de la autoridad encargados del tráfico una competencia que, en el resto de sectores, corresponde al órgano competente para iniciar el procedimiento, que es quién, además, valora si las denuncias son o no fundadas y si es preciso o no abrir un trámite de actuaciones previas para determinar si concurren o no las circunstancias que justifican la iniciación del procedimiento", El régimen jurídico - administrativo del tráfico, 2a ed., Madrid, Civitas, 2010, 2a ed., pág. 522. 
decir, como si esa decisión la hubiera tomado el órgano al que la LTSV atribuye la competencia para incoar procedimiento.

El mandato que se contiene en esa previsión, ahora incluido en la LTSV de forma expresa (y que antes únicamente se podía encontrar, de manera explícita, en el art. 10.1 RPSTSV) es que no hace falta esperar, "sin que haya razón alguna para que la iniciación del procedimiento quede diferida a un momento posterior a voluntad de la propia Administración" y ello porque concurren todas las circunstancias que permiten que ello sea así sin que ello genere indefensión alguna para el interesado en ese expediente sancionador. Porque si, como se ha señalado, la denuncia está "correctamente extendida y notificada al infractor" ambas partes, Administración sancionadora, por medio de Agente específico para ese ámbito, y denunciado (autor de la infracción) tienen desde el momento en que esa denuncia es comunicada por el denunciante al denunciado todos "Ios elementos y datos necesarios para el ejercicio de sus competencias y la defensa de sus intereses respectivamente" y por eso no hace falta esperar a que el órgano competente reciba la denuncia y comunique al infractor que se acuerda el inicio del procedimiento sancionador, y así lo entendió la Sentencia del TS de 4 de junio de $2004^{21}$.

Que la denuncia formulada por los Agentes constituya acto de iniciación del procedimiento constituye una posibilidad excepcional para el caso en el que se cumpla la condición de la denuncia formulada por Agente de la Autoridad encargado del servicio de vigilancia del tráfico que en el ámbito de su competencia notifique esa denuncia en el mismo momento de la comisión de la infracción y que esa denuncia este correctamente extendida y notificada al denunciado. Previsión que siendo excepcional (es decir, una salvedad a la norma general de iniciación del procedimiento por la autoridad competente para ello) en el régimen de la LTSV, es una previsión absolutamente extraordinaria en el marco de los procedimientos administrativos y de la regla establecida en el art. 69 LRJ - PAC.

\footnotetext{
${ }^{21}$ Resolución que, por su fecha, se refería al art. 10 RPSTSV y de la que se han extraído los entrecomillados que figuran en el texto. La redacción de la referida Sentencia del TS se corresponde con los siguientes términos:

"El que la denuncia correctamente extendida y notificada al infractor suponga el comienzo del plazo para el procedimiento sancionador -tal como se contempla en el artículo 10 del Reglamento del Procedimiento Sancionador en materia de Tráfico, Circulación de Vehículos a Motor y Seguridad Vial, y como ha sido aplicado en materia de transportes terrestres-, se asienta sobre la base de que ambas partes, Administración sancionadora y sujeto responsable de la infracción, poseen a partir de ese momento los elementos y datos necesarios para el ejercicio de sus competencias y la defensa de sus intereses respectivamente. La Administración puede proceder al ejercicio de la potestad sancionadora en defensa de la seguridad vial y de los intereses generales asociados a la misma, puesto que tiene los datos necesarios para la instrucción del expediente, sin que haya razón alguna para que la iniciación del procedimiento quede diferida a un momento posterior a voluntad de la propia Administración. El infractor, por su parte, ha quedado notificado de la infracción supuestamente cometida y sabe que la Administración ha iniciado un expediente sancionador, por lo que queda excluida toda posible indefensión".
} 
Que ello es posible por la incorporación de los datos que, para ese caso, el de la notificación de la denuncia efectuado en el acto, establece el art. 74.3 LTSV, y que suponen la puesta a disposición del denunciado de todos los elementos que necesita para realizar alegaciones y, en su caso, articular los medios de prueba que a su derecho convenga. La celeridad de la actuación, la aceleración en esa fase inicial del procedimiento sancionador, se articula mediante la adopción de las medidas que permiten garantizar los derechos del denunciado.

Que, por otra parte y desde la perspectiva de la actuación de la Administración sancionadora, esa cesión de la facultad de iniciar el procedimiento sancionador encuentra su fundamento en principios básicos, de forma que su actuación se sustenta en criterios de eficiencia y servicio a los ciudadanos. Iniciación que se produce "a todos los efectos", con todas sus consecuencias, "incluida la iniciación del plazo de caducidad, sin que esa iniciación pueda aplazarse, a conveniencia de la Administración" ${ }^{22}$.

El hecho de que el procedimiento esté iniciado impide que se puedan practicar actuaciones previas (de las revistas en el art. 12 REPEPOS). Difícilmente se puede acordar la realización de algo de manera previa al comienzo del procedimiento cuando ese procedimiento sancionador ya ha sido iniciado a todos los efectos.

En cambio, sí es preciso tener presente la posibilidad de la adopción de medidas de carácter provisional. Las medidas provisionales (y otras medidas) se encuentran reguladas en los arts. 83 a 87 LTSV. En lo que aquí nos interesa el art. 83 LTSV establece dos previsiones muy distintas. Así, mientras en el primero de sus apartados determina que el órgano que haya acordado la incoación del procedimiento sancionador tiene la posibilidad adoptar, mediante acuerdo motivado, las medidas provisionales que aseguren la eficacia de la resolución que, finalmente, pudiera recaer en ese procedimiento, en el apartado segundo limita, únicamente, a la medida de inmovilización del vehículo la medida provisional que los Agentes de la Autoridad encargados de la vigilancia del tráfico la que estos pueden adoptar ${ }^{23}$.

Al lado de estas consideraciones, y para concluir, se hace preciso señalar que esta previsión realizada durante años, y hasta su inclusión en la LTSV por medio de la Ley 18/2009, de 23 de noviembre, bajo la cobertura del RPSTSV, encuentra mucho mejor acomodo en la Ley dada su excepcionalidad frente al régimen general establecido en el art. 69 LRJ - PAC. De hecho, y aunque la previsión efectuada en el art. 10 RPSTSV

\footnotetext{
${ }^{22}$ Como determinó las STS de 15 de noviembre de 2000 (RJ 2000, 10064).

${ }^{23}$ Traslación específica al ámbito del procedimiento sancionador en materia de tráfico y seguridad vial de las previsiones efectuadas por el art. 15 REPEPOS que establece, como norma general, la competencia para la adopción de las medidas provisionales que fueran necesarias para garantizar la eficacia de la resolución que pudiera recaer al órgano competente para resolver y permite, de manera excepcional, que el órgano competente para iniciar el procedimiento sancionador o el órgano instructor adopte las que fuera preciso adoptar por razones de urgencia inaplazable.
} 
lograra mantenerse en el ordenamiento jurídico, su existencia fue discutida llegándose a plantear que "la norma reglamentaria de tráfico podría ser cuestionada incluso en su misma adecuación a derecho, pues contradice una regla general de rango legal y aun un principio general común al derecho sancionador y al derecho procesal penal, cual es el de que la denuncia es mera notitia criminis" ${ }^{24}$.

Por ello se presenta como solución, sin duda mucho más adecuada, que con la reforma del régimen sancionador esta previsión haya sido integrada en el texto de la propia LTSV y figure en ella de manera expresa.

\section{El CONOCIMIENTO TELEMÁtICO DE LOS HECHOS}

\section{a) La incorporación de instrumentos}

En el ámbito del tráfico y la seguridad vial la denuncia formulada por los agentes de la autoridad, ya diera origen al inicio del procedimiento sancionador por ser notificada en el acto o ya fuera la causa de que el órgano competente incoara el ese procedimiento sancionador, era la forma de actuación ordinaria y pareciera, en definitiva, que la denuncia tuviera el monopolio del procedimiento sancionador, de manera que costaba pensar en un procedimiento sancionador que tuviera su origen (como inicio o como iniciativa) en otra fórmula distinta a la de la denuncia ${ }^{25}$.

El régimen sancionador se asentaba sobre la percepción que, de manera directa, tuvieran los Agentes de la Autoridad a quienes se encomendaba la vigilancia y el control del tráfico y la seguridad vial. Conocimiento por medio de sus propios sentidos. Y así, se establecía y se establece, que los Agentes de la Autoridad encargados del servicio de vigilancia de tráfico deberán denunciar las infracciones que observen cuando ejerzan funciones de vigilancia y control de la circulación vial.

El control de determinadas normas agregó el uso de medios o instrumentos que, con el paso del tiempo, fueron incorporando los avances tecnológicos, en especial en relación a las infracciones que eran susceptibles de ser medidas (caso de la velocidad ${ }^{26}$ y del consumo de alcohol) y de aquellas cuya realización podía ser documentada mediante una imagen (entre otras las relativas a paradas y estacionamientos).

Pero en todos estos supuestos el instrumento utilizado era un soporte para realizar la denuncia, un medio de acreditar (o descartar) su existencia. La denuncia seguía siendo realizada por el Agente de la Autoridad que la observaba y percibía con ayuda de esos

\footnotetext{
${ }^{24}$ Así lo señalaba la STSJ Castilla - La Mancha de 27 de septiembre de 2012 (JUR 2012, 359298) a la que ya nos hemos referido (véase nota 19 en este mismo capítulo).

${ }^{25}$ Vide supra nota 10 de este mismo capítulo.

${ }^{26}$ Sobre los cambios sufridos para la medición de la velocidad puede consultarse Carlos Nicolás Fraile, "Radares: una historia a toda velocidad" en Tráfico y Seguridad Vial, núm. 204, 2010, págs. 38 a 41.
} 
aparatos instrumentos que le permitían determinar si unos hechos podían ser constitutivos de infracción a la LTSV. La medición de la velocidad mediante un radar (cinemómetro), la tasa de alcohol en sangre o en aire espirado (alcoholímetros y etilómetros) o el uso de imágenes (fotografías). Se trataba de pruebas para acreditar la existencia de la infracción objeto de denuncia.

El cambio se produce cuando la tecnología da soporte a la detección, a la observación, de hechos constitutivo de infracciones $y$, como señala el art. 76.2 c) LTSV, al determinar como uno de los supuestos que habilita la notificación en momento posterior a la comisión de la infracción, "que la autoridad sancionadora haya tenido conocimiento de los hechos a través de medios de captación y reproducción de imágenes que permitan la identificación del vehículo", sin la presencia inmediata de un Agente de la autoridad.

Se trata de un supuesto, el de la detección de infracciones mediante sistemas de captación de imágenes, inicialmente enfocado a las infracciones de exceso de velocidad, tanto de las que se producen en un punto concreto como de las que consisten en la superación de la velocidad media en un tramo, pero que se puede extender, y de hecho así está ocurriendo, a otras tipos de infracciones, como es el caso, por ejemplo, de las relativas a los semáforos, y que puede ser utilizado para tener conocimiento y probar en el procedimiento sancionador la comisión de una infracción. Pero para ello es necesario que todo ello se haga conforme al procedimiento establecido y con respeto de las garantías de quienes se encuentran formando parte de ese procedimiento sancionador.

\section{b) La mutación tecnológica}

Es en este momento cuando el procedimiento cambia. Cuando se pasa de la denuncia del agente de la autoridad, que se apoya en un prueba instrumental (la realizada por medio de un instrumento, medio, aparato o sistema), a que la detección de la infracción se haya producido por medios técnicos, o en términos de la propia LTSV, "que la autoridad sancionadora haya tenido conocimiento de los hechos a través de medios de captación y reproducción de imágenes que permitan la identificación del vehículo".

$\mathrm{Y}$ el procedimiento administrativo sancionador tiene que adaptarse a las nuevas circunstancias, y tiene que mutar en la misma medida que los medios de los que dispone para el control han cambiado.

Y entonces tenemos que volver la vista hacia la Ley 11/2007, de 22 de junio, de Acceso Electrónico de los Ciudadanos a los Servicios Públicos (LAE), cuya existencia hemos podido ignorar hasta ahora. 
El análisis de situación ha de comenzar por el impacto y determinación del marco jurídico y la aplicación de la LAE al procedimiento sancionador en materia de tráfico. Ninguna duda cabe de ello dado el carácter de la regulación en la LAE cuyo objetivo es el de "actualizar el contenido, muy diferente al de 1992, de la regulación básica que esté hoy a la altura de las nueva exigencias" ${ }^{27}$. La propia LAE establece, que la regulación que en ella se hace sobre la gestión electrónica de los procedimientos (arts. 33 a 39 LAE) será de genérica aplicación al establecer, de manera expresa (disp. adic. Cuarta LAE), la aplicación de lo en ella dispuesto a los procedimientos especiales, a esos que en las disposiciones adicionales de la LRJ - PAC se determina que se regularán por su normativa específica ${ }^{28}$.

Sin pretender un estudio exhaustivo de esta cuestión ${ }^{29}$, que aquí no corresponde por quedar limitado a los propios confines de nuestro objeto de análisis, sí resulta adecuado señalar los ámbitos que quedan afectados por la regulación efectuada en la LAE sobre los procedimientos administrados gestionados electrónicamente, sentido en el que resulta conveniente señalar que no se trata (en este momento) de

\footnotetext{
${ }^{27}$ Cfr. el último párrafo del apartado II de la Exposición de Motivos de la Ley 11/2007, de 22 de junio, de Acceso Electrónico de los Ciudadanos a los Servicios Públicos (LAE).

${ }^{28}$ Sobre esta cuestión hay que tener en cuenta que aunque la disp. adic. Cuarta LAE no hace expresa referencia al procedimiento sancionador en materia de tráfico y seguridad vial no hay que olvidar que, por su fecha (2007), es anterior a la incorporación de la disp. adic. Octava bis al texto de la LRJ - PAC (adición que se produce por medio de la Ley 18/2009, de 23 de noviembre). La referida disp. adic. Cuarta LAE señala, literalmente, que "la aplicación de lo dispuesto en el Título Tercero de esta Ley a los procedimientos en materia tributaria, de Seguridad Social y desempleo y de régimen jurídico de los extranjeros en España, se efectuará de conformidad con lo establecido en las disposiciones adicionales quinta, sexta, séptima y decimonovena LRJ - PAC", procedimientos, todos ellos, calificados en esas disposiciones adicionales de la LRJ - PAC como "normativa específica". La ubicación de la disp. adic. Octava entre esas disposiciones y el uso de la expresión "legislación específica" hace pensar que para el legislador (e independientemente de las consideraciones que ello merezca y de que ello sea realmente así) el procedimiento sancionador en materia de tráfico y seguridad vial es un procedimiento específico al que ha de alcanzar lo previsto en la LAE sobre la gestión electrónica de los procedimientos de igual manera que al resto de procedimientos comunes o especiales, sin que resulte preciso acudir a que el "procedimiento administrativo en materia de tráfico y seguridad vial está entre los que podríamos denominar de procedimiento común y, por tanto, sin especialidad alguna" y que "esta consideración nos permite entender que cuando la Administración Pública actúa en este ámbito utilizando medios electrónicos o informáticos tiene, ineludiblemente, que cumplir con las prescripciones que establece la LAE", como ALBERTO PALOMAR OLMEDA en un pionero artículo en el que aborda minuciosamente todos los elementos implicados en la integración de los medios electrónicos en el procedimiento sancionador en materia de Tráfico y Seguridad Vial El procedimiento sancionador en tráfico y seguridad vial (a propósito de las cámaras en los semáforos que formará parte del "Liber Amicorum" con el que se rinde merecido homenaje a JUAN ALFONSO SANTAMARÍA PASTOR, artículo en el que traslada al ámbito del tráfico los planteamiento efectuados en un estudio monográfico anterior "La actividad administrativa efectuada por medios electrónicos", Aranzadi, 2007, en el que ya advierte de los problemas que se pueden presentar sobre este tipo de actividad de la Administración.

${ }^{29}$ Numerosos han sido los estudios que se han llevado a efecto y han visto la luz sobre la LAE. Tanto los que la abordan desde una visión completa y general como aquellos otros que acometen la observación de cuestiones concretas. De entre los primeros especial mención merece, a mi juicio, los Comentarios dirigidos por Gamero CASAdo y Valero Torrijos, la Ley de Administración Electrónica, 3a ed., Cizur Menor, Aranzadi, 2010, en el que el tratamiento de las cuestiones relativas a la "Gestión electrónica de los documentos" corresponde a PALOMAR OLMEDA.
} 
procedimientos administrativos gestionados en su totalidad electrónicamente (art. 37.1 LAE), que está prevista la iniciación por medios electrónicos (aunque referida al supuesto en que así se haga a solicitud del interesado, art. 35.1 LAE) y que no existe previsión específica sobre la iniciación del procedimiento por medios electrónicos, aunque la primera cuestiones que se determina es que "la gestión electrónica de la actividad administrativa respetará la titularidad y el ejercicio de la competencia por la Administración Pública, órgano o entidad que la tenga atribuida y el cumplimiento de los requisitos formales y materiales establecidos en las normas que regulen la correspondiente actividad (art. 33.1 LAE).

Además, y fuera de la regulación que se hace de la gestión electrónica de los procedimientos, la LAE contiene disposiciones que no pueden ser obviadas. Al margen de los derechos establecidos en los arts. 6 a 9 LAE y en el marco de las disposiciones que sobre el régimen jurídico de la administración electrónica se realizan (arts. 10 a 32 $\mathrm{LAE}$ ) nos encontramos con la regulación de las comunicaciones y notificaciones electrónicas, lugar en el que se establece, en lo que aquí más interesa, el elenco de derechos y condiciones que han de cumplirse para la utilización de los medios electrónicos y que, a su vez, ha supuesto uno de los cambios de mayor calado entre los efectuados en el nuevo régimen sancionador configurado en la LTSV tras la Ley $18 / 2009$, de 23 de noviembre, y configuran el sistema de notificación en el marco del procedimiento sancionador en materia de tráfico y seguridad (arts. 76 a 78 LTSV) objeto de análisis específico.

\section{c) El procedimiento administrativo sancionador con uso de elementos electrónicos}

El cambio es claro y las consecuencias también. Nos encontramos ante procedimientos sancionadores que pretenden apoyarse en la detección (observación) automatizada de infracciones y ello requiere de la previa determinación, para su posterior cumplimiento, de los requisitos exigidos por nuestro sistema normativo y en este sentido es preciso tener en cuenta que el art. 39 LAE establece que "en caso de actuación automatizada ${ }^{30}$ deberá establecerse previamente el órgano u órganos competentes, según los casos, para la definición de las especificaciones, programación, mantenimiento, supervisión y control de calidad y, en su caso, auditoría del sistema de información y de su código fuente. Asimismo, se indicará el órgano que debe ser considerado responsable a efectos de impugnación".

\footnotetext{
30 El apartado a) del Anexo de la LAE define "Actuación administrativa automatizada" como la "actuación administrativa producida por un sistema de información adecuadamente programado sin necesidad de intervención de una persona física en cada caso singular. Incluye la producción de actos de trámite o resolutorios de procedimientos, así como de meros actos de comunicación".
} 
Para Palomar es preciso considerar quién, y cómo, realiza esa actuación material de comprobación $^{31}$. Si es, o no, la propia Administración con competencias sancionadoras en materia de tráfico y seguridad vial, y de quién son (bajo el control efectivo de quién se encuentran) los medios que permiten esa detección automatizada mediante la que es posible percibir una infracción e identificar el vehículo con el que se ha cometido. Análisis del que se desprende que el problema no es el "qué", sino el "cómo", y que en definitiva resulta posible siempre y cuando se cumpla con los requisitos establecidos que, en definitiva, constituyen la garantía que el procedimiento debe asegurar a los que en ellos resulten interesados.

No se trata, a mi juicio, de nuevos problemas. Más bien nos enfrentamos a la manifestación de cuestiones que, siendo perfectamente conocidas, requieren de ser encajadas con nuevos modelos de actuación ${ }^{32}$. No se trata de un nuevo procedimiento y de nuevas garantías. Se trata de trasladar las garantías que para la actuación administrativa en general, y para los procedimientos sancionadores en materia de tráfico en particular, se han ido cristalizado con el tiempo, y constatar que el impacto de la tecnología puede ser incorporado, adoptando, y adaptando, las medidas adicionales que del uso de esas nuevas formas de actuar se derivan. Es, en definitiva, el permanente deambular del derecho tras los avances de la técnica que hoy permiten hacer lo que ayer ni siquiera se podía imaginar.

En el ámbito del procedimiento sancionador en materia de tráfico suponen la existencia de nuevas formas de actuar en hitos esenciales del mismo. Al lado de la detección de infracciones sin la presencia de un Agente de la Autoridad, la Administración electrónica incide, como ya se ha señalado, en notificación y comunicación. Cada uno de los impactos que permite el uso de los avances tecnológicos es analizado, y se integra, en el correspondiente espacio destinado el estudio específico de cada cuestión, porque se configura como parte del propio procedimiento.

Aquí, en el marco del inicio del procedimiento, se hace preciso considerar el cambio que esas nuevas formas de observar, que otorgan el don de la ubicuidad a la Administración sancionadora, y cómo influyen en la puesta en marcha del procedimiento sancionador, acostumbrados, como estábamos, a que los hechos llegaban a conocimiento de la autoridad por medio de la denuncia efectuada, en la inmensa mayoría de los casos, por los Agentes encargados del servicio de la vigilancia

\footnotetext{
${ }^{31}$ Alberto Palomar, Alberto, El procedimiento sancionador en tráfico y seguridad vial (a propósito de las cámaras en los semáforos en un artículo en fase de publicación y al que ya se ha hecho referencia, vide supra nota 28 de este mismo capítulo.

32 En este sentido, y como señala MARTín Delgado, "el acto administrativo adoptado de forma automatizada no deja de ser acto administrativo y que el empleo de las TIC no influye en el reparto competencial, aquél ha de reunir todos y cada uno de los requisitos y condiciones que la LPC exige para la completa validez y eficacia de los actos administrativos" en "Naturaleza, Concepto y régimen jurídico de la actuación administrativa", RAP, no 180, septiembre - diciembre 2009, págs. 371 a 372.
} 
del tráfico y del control de la seguridad vial, y cuando creíamos resueltos todos (o una parte importante) de los problemas que habían ido surgiendo nos encontramos con nuevas posibilidades de actuación que pretendemos encajar con enseres antiguos y que requieren de la nuevas herramientas jurídicas encarnadas por la regulación contenida en la LAE. Y, cegados por el hábito, queremos mantener al agente validando infracciones detectadas a través de medios de captación y reproducción de imágenes (telecaptadas) como solución a ese cambio, sencillamente porque no lo acabamos de entender bien. Y esa solución es, en cuanto a los problemas de la iniciación - iniciativa del procedimiento, más sencilla, puesto que "Ilegados a este punto cabe, de nuevo plantearse si no sería más razonable la iniciación del procedimiento de oficio -sin implicar a los agentes- sobre la base de documentos administrativos que, fruto de la función de comprobación administrativa, puedan servir para el ejercicio de la función sancionadora" ${ }^{33}$. Ahí radica el problema y esa es la solución ${ }^{34}$.

\section{LA DENUNCIA}

\section{A) Concepto y clases}

El art. 11.1 d) REPEPOS define la denuncia como "el acto por el que cualquier persona, en cumplimiento o no de una obligación legal, pone en conocimiento de un órgano administrativo la existencia de un determinado hecho que pudiera constituir infracción administrativa". Se trata, por tanto, de una acción de comunicación mediante la que se pone en conocimiento de la Administración un suceso que puede ser calificado como ilícito administrativo.

En el ámbito del tráfico la denuncia se ha constituido en la forma ordinaria en la que encuentra su origen el procedimiento administrativo y sobre la base de las previsiones efectuadas en la propia LTSV se puede establecer los siguientes tipos de denuncias:

- Por el deber de formularlas pueden ser "obligatorias" o "voluntarias": El criterio delimitar se asienta en la existencia de un obligación legal en la formulación de la denuncia pues, como señala la definición del art. 11.1 REPEPOS la Ley puede imponer, a determinados sujetos, la obligación

\footnotetext{
33 Ibídem.

34 Particularmente me preocupa la inexistencia de norma específica (expresa) en la LAE sobre los requisitos que la Administración ha de cumplir para poder iniciar un procedimiento de oficio por medios electrónicos, limitándose la referencia de la LAE (art. 35.1) a "la iniciación de un procedimiento administrativo a solicitud del interesado". El tiempo, sin duda, completará la previsión que, como mandato general y primigenio, se efectúa en el primer inciso del art. 33.1 LAE al establecer que "Ia gestión electrónica de la actividad administrativa respetará la titularidad y el ejercicio de la competencia por la Administración Pública, órgano o entidad que la tenga atribuida y el cumplimiento de los requisitos formales y materiales establecidos en las normas que regulen la correspondiente actividad", que es lo que, a mi juicio, precisamente no hacía falta señalar, pues si hay algo evidente es que el "medio" (tradicional o electrónico) no puede alterar el "fin" (el procedimiento).
} 
denunciar (de ahí la denominación) las infracciones que observen. Esto es lo que sucede, en el tráfico y la seguridad vial, con los Agentes de la Autoridad, pero no con todos, únicamente con aquellos cuya labor consista en la vigilancia del tráfico y control de la seguridad vial, por habérselo encomendado el órgano con competencia para ello (estatal, autonómico o local). El resto de sujetos no están sometidos a esa obligación, de manera que cuando perciben una infracción queda en su esfera de voluntad el denunciarlo o no hacerlo, de ahí que reciban la calificación de "voluntarias". Los efectos que la LTSV atribuye a las denuncias varía en función de si es "obligatoria" o "voluntaria".

- Por el contenido de los hechos objeto de denuncia pueden ser "por hechos de la circulación" o "por hechos ajenos a la circulación": La inmensa mayoría de las normas establecidas y de los tipos infractores previstos en la LTSV se corresponden con conductas en el tráfico, en la circulación. Pero la LTSV también regula cuestiones que suceden fuera del tráfico de vehículos, como es el caso de las escuelas y de los centros de reconocimiento de conductores. En el art. 74 LTSV se determina el contenido de las denuncias, de manera expresa y detallada para las que se formulen "por hechos de la circulación" y, de manera finalística (mediante la cláusula "los datos necesarios para su descripción", art. 74.4 LTSV), para las que se efectúen "por hechos ajenos a la circulación".

- Por el momento en el que se efectúe su notificación en relación a la comisión de los hechos que las originan pueden ser "notificadas en el acto" o "con posterioridad": Las denuncias pueden ser notificadas en el acto, de forma inmediata y coetánea a la comisión de la infracción, o con posterioridad, sin continuidad temporal con los hechos que la originan.

- Por los medios empleados para su observación y detección pueden ser "personales" o "automatizadas 35 ": Las denuncias de carácter personal son las que tienen su origen en la percepción de unos hechos realizados por una persona, que es quien la formula, las que se originan en medios materiales automatizados y de las que se tiene conocimiento a través de medios de captación y reproducción de imágenes

Los elementos que dan lugar a estas clasificaciones se encuentran en el origen del análisis que se efectúa en los siguientes apartados sobre el contenido y la notificación de las denuncias formuladas en materia de tráfico y seguridad vial.

\footnotetext{
35 O electrónica, como la denominan algunos autores, Es el caso de CASADO CADARSO, M. T. y VILA MUNTAL, M. A. en la "denuncia electrónica", véase, por ejemplo, "la denuncia electrónica" en Administración electrónica: la Ley/2007, de 22 de junio, de acceso electrónico de los ciudadanos a los Servicios Públicos y los retos jurídicos del e-gobierno en España (obra coordinada por COTINO HUESO, L. y VALERO TORRIJOS, J.), 2010, Tirant lo Blanch, 2010, págs. 469-488
} 


\section{B) La denuncia como deber: las denuncias obligatorias}

Tal y como señala el art. 11.1 d) REPEPOS el acto de poner en conocimiento de la autoridad competente la existencia de unos hechos susceptibles de ser constitutivos de infracción puede deberse a una acción voluntaria o, por el contrario, como consecuencia de que esa persona, el denunciante está cumpliendo con un obligación que se le ha impuesto de actuar de esa manera y tener que formular una denuncia cuando perciben hechos que sean constitutivos de infracciones. Eso es lo que exactamente hace el art. 74.1 LTSV cuando establece que "los Agentes de la Autoridad encargados de la vigilancia del tráfico deberán denunciar las infracciones que observen cuando ejerzan funciones de vigilancia y control de la seguridad vial" ${ }^{36}$.

Siendo, como lo es, la función y misión de los Agentes de la Autoridad que tienen encomendada, por el titular de la potestad sancionadora, vigilar y controlar el tráfico como garantía de la seguridad vial, de su calificación de Agentes de la autoridad y la misión que se les atribuye se deriva que, en su caso, la denuncia de de las infracciones que observen se constituya en obligación.

\section{C) El contenido de las denuncias}

\section{FINALIDAD}

El contenido de la denuncias viene determinado, y así tiene que ser, por su propia finalidad. Ya sea como medio que dé lugar al inicio del procedimiento administrativo sancionador o como inicio mismo del mismo, en la denuncia han de constar los elementos que, en todo caso, permitan presuponer la existencia de una infracción para que, llegado el caso, se determine que así es (o que no lo es).

Si en el sistema establecido de manera general la denuncia formulada por el Agente es lo que va a ocasionar la incoación del procedimiento administrativo sancionador, ello supone que tiene que contener los elementos necesarios para que el órgano competente esté en condiciones de adoptar esa decisión que, trasladada el denunciado, le permita, a este, el ejercicio de su defensa, alegando y proponiendo las pruebas que a su derecho convengan. Con más razón en el ámbito de tráfico y la seguridad vial donde, como se ha señalado, es posible que la denuncia constituya, por sí misma, el acto de iniciación del procedimiento sancionador.

Por este motivo, la LTSV determina el contenido que, de manera necesaria, habrá de contener toda denuncia (sea del tipo que sea) al que se le añaden una serie de

\footnotetext{
${ }^{36} \mathrm{Y}$ ello en los términos que hemos tenido la oportunidad de determinar al analizar, en el marco de $l a$ denuncia como acto de iniciación del procedimiento, la formulada por los agentes de la autoridad encargados de la vigilancia del tráfico, en el apartado I. A) 2 a) de este mismo capítulo.
} 
elementos para el caso de que se trate de denuncias obligatorias que sean notificadas en el acto al denunciado (es decir, para el supuesto del art. 73.2 LTSV).

\section{EL CONTENIDO NECESARIO DE TODA DENUNCIA}

a) El carácter imprescindible de los requisitos previstos en el art. 74.2 LTSV

El art. 74.2 LTSV determina el contenido de las denuncias por hechos de la circulación. Los diferentes elementos que se establecen son imprescindibles, por lo que el precepto determina que esa información "deberá constar en todo caso". Esta expresión, que no deja margen de duda alguna sobre la imprescindibilidad de todos y cada uno de los requisitos que se establecen, es más tajante que la establecida de manera previa (hasta la reforma efectuada por la Ley 18/2009, de 23 de noviembre) en el art. 75.3 LTSV que se limitaba a la primera parte de la expresión actual ("deberá constar"), de forma que, frente a la redacción anterior, el inciso "en todo caso" denota la imposibilidad de excepción alguna respecto al régimen establecido, por lo que para que estemos en presencia de una denuncia ésta tiene que recoger toda esa información y tiene que hacerlo en la forma establecida.

Los cuatro elementos que se señalan en el art. 74.2 LTSV, como contenido necesario que debe constar en toda denuncia, presentan diferentes características en cuanto a la forma en la que tienen que ser recogidos en la denuncia para que se entienda cumplido con lo establecido. Análisis que es necesario realizar y que, trasladado al caso concreto, permitirá determinar si una denuncia cumple con los requisitos establecidos como obligatorios e indispensables, ya que, en caso contrario, no podrá ser considerada como denuncia.

b) La identificación del vehículo con el que se hubiese cometido la supuesta infracción del art. 74.2 a) LTSV

El art. 74.2 LTSV parece limitar las denuncias por hechos de circulación a las infracciones en las que hubiera intervenido (que se hubieran cometido con) un vehículo, de ahí que se exija, como primer elemento que ha de constar en toda denuncia, los datos que permitan la identificación del vehículo. De los términos empleados se podría inferir que las prescripciones realizadas en este art. 74.2 LTSV no resultan aplicables, ni por tanto exigibles, para las infracciones en las que no interviene 
un vehículo, como es el caso de las realizadas por peatones ( $y$ animales), y ello aunque la propia LTSV se refiera a estos, y a su tránsito por las vías, como "circulación" 37 .

Así pues, y en todo caso, se requiere que, de estar involucrado un vehículo en los hechos constitutivos de infracción, en la denuncia consten los datos que permitan su identificación.

La redacción empleada en este art. 74.2 a) LTSV requieren de dos precisiones, que recaen sobres los términos "vehículo" e "identificación".

El precepto hace uso del término "vehículo", mucho más general que otros de los que podría haberse hecho uso, como "vehículo motor" y "ciclomotores", a los que engloba y supera, al dar cabida, además, a bicicletas, vehículos de tracción animal, tractores y maquinaria ( $y$, en general a todo tipo de vehículos especiales), caravanas, remolques y semirremolques... e, incluso, a los tranvías.

Por ello, y puesto el concepto "vehículo" al lado del de su "identificación", en seguida se percibe que la forma ordinaria de identificación sea la de hacer constar su número de matrícula ${ }^{38}$ como forma de individualizar el vehículo con el que se dice cometida la infracción. Pero no todos los vehículos, con los que se puede cometer una infracción, tienen la obligación de portar una matrícula y, en la práctica, pueden presentarse casos en los que determinados vehículos a motor no lleven matrícula ${ }^{39} \mathrm{o}$, incluso, que la infracción objeto de denuncia esté relacionada, precisamente, con el hecho de que el vehículo no lleva las placas de matrícula (teniendo obligación de hacerlo) o esas placas de matrícula no cumplen con los requisitos establecidos en cuanto a la

\footnotetext{
${ }^{37}$ Así, el art. 1.2 b) LTSV se refiere a las normas "que por razón de seguridad vial han de regir para la circulación de peatones y animales por las vías de utilización general" (y en el concordante art. 1.2 a RGC). También se hace uso del término circulación en la propia definición de conductas prohibidas como es el caso del art. 48.3 LTSV cuando prescribe que "queda prohibida la circulación de peatones por autopistas" o en las rúbricas de los arts. 121, 122 y 123 RGC que se refieren, respectivamente, y en relación a los peatones, a "circulación por zonas peatonales", "circulación por la calzada o el arcén" o circulación nocturna. Y lo mismo sucede con la rúbrica del Capítulo IV (arts. 126 a 128 RGC) que hace uso de los términos "circulación de animales".

$38 \mathrm{El}$ art. 62.1 LTSV establece que "para poner en circulación vehículos a motor, así como remolques de peso máximo superior al que reglamentariamente se determine, será preciso matricularlos y que lleven las placas de matrícula con los caracteres que se les asigne del modo que se establezca" y que "esta obligación será exigida a los ciclomotores de acuerdo con lo que reglamentariamente se determine", sobre lo que el art. 25.1 RGV precisa que "para poner en circulación vehículos de motor, así como remolques y semirremolques de masa máxima autorizada superior a 750 kilogramos, será preciso matricularlos y que lleven las placas de matrícula con los caracteres que se les asigne, del modo que se establece en el anexo XVIII" y que "esta obligación será exigida a los ciclomotores de acuerdo con lo que se determina en el artículo 28 del presente Reglamento".

${ }^{39}$ Es el caso de los vehículos que participan en pruebas deportivas y que fuera de los tramos en los que, propiamente, se desarrolla la competición y que están cerrados al tráfico, están sometidos a las normas establecidas en le regulación del tráfico y la seguridad vial. Su identificación, caso de no llevar matrícula, puede realizarse mediante el número asignado por la organización, a la que habrá que dirigirse la Administración competente estando aquél obligado a facilitar los datos de quien, bajo ese número, figure inscrito para participar en ese prueba deportiva. En este sentido el Anexo II RGC regula "Ias pruebas deportivas, marchas ciclistas y otros eventos".
} 
posibilidad de su lectura e identificación, como es el caso de la infracción grave prevista en el art. 65.4 p) LTSV ("incumplir la obligación de todo conductor de verificar que las placas de matrícula del vehículo no presentan obstáculos que impidan o dificulten su lectura e identificación", que se corresponde con la norma prevista en el art. 9.2 párrafo segundo LTSV).

La denuncia debe incluir, en todo caso, los datos que permitan la identificación de ese vehículo en el sentido de poder individualizarlo y particularizarlo, de forma que pueda ser distinguido del resto (de vehículos) y, por lo tanto, ser singularizado, pues caso de no hacerlo no se estará cumpliendo con el primero de los requisitos establecidos como contenido necesario de la denuncia por hechos de la circulación.

\section{c) La identidad del denunciado, si fuere conocida del art. 74.2 b) LTSV}

El art. 74.2 b) LTSV determina la necesidad de que en la denuncia conste "la identidad del denunciado si fuera conocida". Aunque los términos parecen claros de ellos pudiera derivarse alguna confusión, por lo que parece preciso determinar qué es lo que requiere la LTSV y delimitarlo de lo que no exige.

El art. 74.2 b) LTSV no precisa que en la denuncia se identifique a un denunciado. Lo que la LTSV exige es que la denuncia tiene que hacerlo en aquellos casos en los que al momento de su formulación el denunciante pueda realizar de forma precisa (esté en condiciones de hacerlo) esa identificación, lo que apunta a los supuestos de las denuncias obligatorias notificadas en el acto en los que, observados por los Agentes de la Autoridad unos hechos que, a su juicio, son constitutivos de infracción a lo establecido en la LTSV, se procede a la identificación del supuesto infractor (denunciado), mediante los documentos que toda persona (o conductor) tiene la obligación de portar para acreditar su identidad, datos que tienen que constar en la denuncia.

Y ese es el matiz que diferencia una denuncia de lo que, con esa apariencia, no lo es, por no cumplir con los requisitos establecidos. La denuncia es válida aunque no esté identificada la persona del denunciado cuando éste (el supuesto infractor) no es conocido. Pero una denuncia no cumple con los requisitos establecidos cuando teniendo que figurar los datos correspondientes al denunciado, por ser conocido y estar identificado como tal, no se hayan incluido en la denuncia. En este último caso se estaría incumpliendo con el contenido que el art. 74.2 LTSV declara como necesario en todo caso. 
La identidad del denunciado, cuando es conocida, y no cuando se trata de una mera sospecha, conjetura o posibilidad ${ }^{40}$, tiene que estar incorporada en la denuncia, ya que en caso contrario no se cumple con lo establecido en la LTSV en cuanto al contenido que, en todo caso, debe figurar en las denuncias ${ }^{41}$.

d) Una descripción sucinta del hecho, con expresión del lugar o tramo, fecha y hora del art. 74.2 c) LTSV

El art. 74.2 c) LTSV exige que, de esos hechos, que pudieran ser constitutivos de una infracción a lo establecido en la LTSV, quede cumplida constancia en la denuncia.

La expresión de la que hace uso el art. 74.2 c) LTSV es que en la denuncia deberá constar en todo caso "una descripción sucinta del hecho, con expresión del lugar o tramo ${ }^{42}$, fecha y hora", cuestión sobre la que hay que destacar, en primer lugar, que son términos distintos a los que, hasta la reforma efectuada por medio de la Ley $18 / 2009$, de 23 de noviembre, figuraban en relación a la misma cuestión y que señalaban que en las denuncias habría de figurar "una relación circunstanciada del hecho, con expresión del lugar, fecha y hora" (art. 75.3 LTSV y art. 5 RPSTSV, que coincidían con la efectuada, previamente, en el art 281 CCirc). Se trata de términos ciertamente similares, pero que no parecen tener el mismo significado (de una forma exacta e idéntica).

La redacción previa, la que establecía como requisito la necesidad de que en la denuncia hubiera "una relación circunstancias del hecho" fue, a lo largo del tiempo, objeto de oportunas interpretaciones. Así se consideró que se había omitido con esa

\footnotetext{
${ }^{40}$ La realidad, mucho más rica en casos que lo que se pueda imaginar, deja supuestos que pueden plantear problemas en este caso. De un lado la identificación del denunciado que no aporta documentación alguna y no colabora con ese deber de identificarse. De otro, y a título de ejemplo, el caso del conductor que ha cometido unos hechos que pueden ser constitutivos de infracción y al que se le notifica en el acto la comisión de esa infracción, con lo cual ya está identificado, y que al abandonar el lugar, una vez se ha procedido por los Agentes de la Autoridad a notificar personalmente y en el acto esa denuncia, comete una nueva infracción percibida por esos mismos Agentes que, en este caso, no tiene posibilidad de practicar la notificación en el acto, pero no cabe la menor duda (y no estamos hablando de conjeturas) de que es el mismo sujeto, dado que la infracción se ha cometido al lado de los Agentes que acaban de denunciarle.

${ }^{41}$ En este sentido, por ejemplo, la STSJ Asturias de 6 de septiembre de 1996 (RJCA 1996, 2188) señala que "de lo anteriormente reseñado se deduce que no se cumple con lo establecido como necesario para que el boletín de denuncia adquiera validez, y por ello eficacia, ya que se omite en dicho boletín de denuncia la identidad del denunciado, pudiendo haberse cumplido ese trámite obligatorio, toda vez que el agente denunciante reconoce haberse relacionado con el denunciado en varias ocasiones, no notificándosele el boletín de denuncia pudiendo hacerlo; y por ello que ante la existencia de tales defectos formales procede estimar el presente recurso".

${ }^{42}$ La reforma efectuada por la Ley 18/2009, de 23 de noviembre, introdujo la expresión "con expresión del lugar o tramo", que supone la adición del término "tramo" como medio de identificar el punto en el que se comete la infracción. De la propia LTSV se puede desprender que "tramo" es una parte de una carretera, arts. 5 n), 22 o $30 \ldots$ LTSV).
} 
obligación cuando "no hacen constar los hechos concretos que se le imputan, no pudiendo admitirse el argumento del recurrente de que cuanto menos concreta y extensa sea la redacción del cargo, más fácil resulta al interesado poder rebatirlo" ${ }^{43} \mathrm{y}$ que no se ha cumplido por la denuncia cuando señalada una infracción se remite a un informe que no se adjunta y en que debiera contener la totalidad de las circunstancias que rodearon la comisión de la infracción y que finalmente se imputa al denunciado en cuanto que vulnera los derechos del denunciado ${ }^{44}$.

La modificación efectuada en cuanto sustitución de la expresión "una relación circunstanciada del hecho" por la de "descripción sucinta del hecho" enfrenta dos términos (sucinta por circunstanciada) que no resultan identificables. Frente a la previsión anterior en la que se le pedía a la denuncia que incluyera los hechos y que lo hiciera circunstanciadamente, es decir, "con toda menudencia, sin omitir ninguna circunstancia o particularidad", la regulación vigente determina que basta con una descripción sucinta del hecho, lo que supone que es suficiente con que en la denuncia sean recogidos de una forma breve o compendiosa.

No se trata de previsiones (la anterior y la actual) que, en los términos en los que se encuentran redactados, resulten equiparables. Pero, en todo caso, la recepción de los hechos en la denuncia, como causa que la origina, debe atender a la finalidad que la denuncia cumple en el procedimiento que, como se ha puesto de manifiesto, debe permitir el adecuado ejercicio de la competencia sancionadora por el órgano que la

\footnotetext{
43 Tal y como señala la STS de 10 de marzo de 1990 (RJ 1990, 1867).

${ }^{44}$ La STSJ de Madrid de 6 de febrero de 2013 (JUR 2013, 123272) resuelve un recurso contencioso administrativo en el que la normativa aplicable se corresponde con la que, en ese momento, se establecía en el art. 5 RPSTSV. En dicha resolución se señala que:

"En efecto, para ello bastará con tener en cuenta que en la denuncia que da origen al expediente sancionador que nos ocupa se alude como hecho denunciado "NO OBEDECER AL AGENTE", y reseñándose en el boletín de denuncia que "SE ADJUNTA INFORME". En el expediente no hay rastro alguno de dicho informe.

En todo el expediente no existe referencia alguna a los hechos motivadores de la denuncia distintos a la lacónica frase de "NO OBEDECER AL AGENTE", y a ella se refiere la resolución impugnada. No existiendo referencia alguna al contenido de la orden supuestamente desobedecida, cuáles fueran las razones que se tuvieron en cuanta para darla, cuáles eran las circunstancias que concurrían, cuál fue la reacción del sancionado frente a ellas, etc...

La omisión de tales capitales hechos y circunstancias vienen a infringir, de forma clara y manifiesta, el contenido mínimo de la denuncia referido en el art. 5 del Real Decreto 320/1994, de 25 de febrero, por el que se aprueba el Reglamento de Procedimiento Sancionador en Materia de Tráfico, circulación de Vehículos a Motor y Seguridad Vial, que establece que la misma deberá incluir "una relación circunstanciada del hecho», siendo evidente que tal capital requisito no es cumplido por la denuncia que nos ocupa, y de ahí, obviamente, que el propio agente denunciante exponga en la misma que se acompaña el correspondiente informe.

Dicho informe adquiere así plena y total relevancia, en cuanto que debiera contener la totalidad de las circunstancias que rodearon la comisión de la infracción y que finalmente se imputa al denunciado. Su omisión adquiere relevancia constitucional en la medida que viene así a interferir el derecho fundamental del denunciado "a ser informados de la acusación formulada contra ellos», según dispone el art. 24.2 de la CE, incidiendo así negativamente en su derecho de defensa".
} 
tiene atribuida y la posibilidad de ejercer, al denunciado, su derecho de defensa y de hacerlo con todas las garantías que nuestro ordenamiento jurídico le ofrece.

La exigencia de descripción de los hechos que el art. 74.2 LTSV impone a la denuncias como parte integrante de su contenido no excluye que ello se haga con economía de medios, ni que se realice de una manera escueta, es decir, sucinta. No es posible confundir brevedad con inexistencia. La exigencia es que los hechos estén y que aparezcan recogidos de una forma clara y precisa. Con ello se cumple con lo establecido, de igual manera que una extensa redacción de los hechos no resultaría suficiente si a pesar de una dilatada redacción con ella no se pueden determinar ni los hechos ni las circunstancias que lo rodean. Una descripción precisa de los hechos no tiene porque requerir de largas explicaciones y no tiene porqué resultar incompatible con la brevedad y concisión ${ }^{45}$.

e) El nombre y domicilio del denunciante o, si fuera un Agente de la Autoridad, su número de identificación profesional del art. 74.2 d) LTSV

El art. 74.2 d) LTSV exige que en la propia denuncia consten los datos de la persona que la formula y diferencia entre las realizadas por Agentes de la Autoridad o por personas en las que no concurra esta condición.

Ha de notarse, en primer lugar, que la distinción que se efectúa no lo es entre denuncias obligatorias y voluntarias. El art. 74.2 d) LTSV se refiere a los "Agentes de la Autoridad" y no, de una forma concreta y específica como hace en otros lugares de la propia LTSV, a los "Agentes encargados del servicio de vigilancia de tráfico y control de la seguridad vial”.

Para el caso de los Agentes de la Autoridad es suficiente con la aportación de su número de identificación profesional, sin que resulte preciso ningún dato adicional, de los que dispone, en su caso, la autoridad de la que depende ese Agente.

En el resto de casos se exige que en la denuncia conste, en todo caso, el nombre y domicilio de la persona que efectúa la denuncia. Y ello es independiente de que la actividad profesional del denunciante esté, precisamente, vinculada al control del tráfico. Es el caso del personal destinado a la vigilancia y control de lo establecido en las Ordenanzas municipales de regulación del aparcamiento que, salvo en aquellos

\footnotetext{
45 Lo que mantengo (por si no se ha notado) es que resulta trasladable la doctrina que sobre la motivación escueta, breve y sucinta se ha mantenido tanto por el Tribunal Supremo como por el Tribunal Constitucional (por todas la STS de 28 de febrero de 2011, RJ 2001, 1859 con cita de doctrina del Tribunal Constitucional). Lo realmente relevante es que esa descripción cumpla, y lo haga de manera real y efectiva, con la finalidad por la que viene impuesta. Y que si precisa estar acompañada de un informe, porque así lo aconsejan las concretas circunstancias que concurren en el caso concreto, que lo esté.
} 
casos en los que los denunciantes reúnan la condición de Agentes de la Autoridad (por ejemplo, que se trate de Policías Locales) tendrán que incorporar los datos exigidos, sin que esa información pueda ser sustituida por una indicación numérica (como es el caso de números de identificación profesional) de la que carecen, de manera que la no inclusión de los datos establecidos en el art. 74.2 d) LTSV ("el nombre y domicilio del denunciante") podría determinar el incumplimiento de los requisitos establecidos y que, en todo caso, se exige que deben constar en la denuncia y de las consecuencias que de ello se pudieran derivar, cuestión que es objeto de análisis en el siguiente apartado.

\section{f) El incumplimiento del contenido necesario de las denuncias y sus efectos}

La obligación que el art. 74.2 LTSV impone en cuanto al contenido que, en todo caso, debe constar en las denuncias por hechos de la circulación, tiene que ser puesta en relación con el fin que esa información cumple en el procedimiento, tanto para la Administración titular de la potestad sancionadora como, y sobre todo, en relación a los derechos del denunciado.

La ausencia de esa información puede impedir que el interesado tenga la posibilidad de ejercer, en forma adecuada, sus derechos frente a esa denuncia. Pero es en ese caso, y únicamente en ese caso, cuando el incumplimiento de los requisitos establecidos en cuanto al contenido necesario de la denuncia imposibilita el ejercidio de sus derechos de defensa al denunciado, que la inobservancia de esa obligación despliega sus efectos. Por ello, y teniendo en cuenta que "al vicio de forma o de procedimiento no se le reconoce siquiera con carácter general virtud anulatoria de segundo grado, anulabilidad, salvo aquellos casos excepcionales en que el acto carezca de los requisitos indispensables para alcanzar su fin, se dicte fuera de plazo previsto, cuando éste tenga carácter esencial, o se produzca una situación de indefensión", de ello se desprende que "sólo en el supuesto de que de la omisión se siguiera indefensión para el administrado, condición ésta que comporta la necesidad de comprobar si la indefensión se produjo", nos encontraríamos con motivos suficientes para anular esa actuación ${ }^{46}$.

Doctrina que, trasladada al concreto ámbito del contenido necesario de las denuncias de tráfico y seguridad vial, determina que "quien invoca la anulabilidad por motivos formales tiene que hacer lo propio con la indefensión y la justificación de la forma para alcanzar el fin del acto" por lo que cuando "el recurrente ha ejercido su derecho de defensa y contradicción plenamente, pues ha alegado lo que consideró oportuno,

\footnotetext{
${ }^{46}$ Conforme a lo establecido por el Tribunal Supremo sobre la teoría de la nulidad los actos y la necesidad de que los defectos formales, para que sean tomadas en consideración tienen que causar indefensión (Cfr. entre otras muchas, SSTS de 20 de julio de 1992, RJ 1992, 6511, de 12 de noviembre de 2009, RJ 2009, 8001, 30 de septiembre de 2010, RJ 2010, 6910).
} 
luego subsanó cualquier defecto en la notificación de la denuncia ya que pasó a cuestionar el fondo de la cuestión discutida" 47 , ni tampoco puede oponerse la propia conducta del denunciado ${ }^{48}$.

Sin embargo, y en sentido contrario, se ha exigido que la modificación de esos datos en el propio boletín de denuncia vaya acompañada de las oportunas aclaraciones del Agente, pues, en caso contrario, se ha determinado la invalidez de la denuncia por no cumplir con los requisitos establecidos ${ }^{49}$.

\section{EL CONTENIDO DE LAS DENUNCIAS NOTIFICADAS EN EL ACTO}

\section{a) Sobre su carácter adicional, finalidad y diferentes efectos}

Al lado del contenido necesario que el art. 74.2 LTSV establece para toda denuncia por hechos de la circulación, en el apartado siguiente de ese mismo artículo (74.3 LTSV) se determinan una serie de contenidos, adicionales a los allá establecidos, para el supuesto de que la denuncia, habiendo sido formulada por Agente de la Autoridad, sea notificada en el acto al denunciado.

La previsión efectuada en el art. 74.3 LTSV se asienta, por tanto, sobre una serie de previsiones previas que actúan como presupuestos:

${ }^{47}$ STSJ Andalucía - Málaga, de 16 de marzo de 2000, RJCA 2000, 1215.

${ }^{48}$ Como pone de manifiesto la STSJ Castilla - La Mancha, de 4 de noviembre de 2002, JUR 2003, 30240, al señalar que:

"También ha de rechazarse la existencia de defectos de forma en la formulación de la denuncia que determinaran la nulidad de la resolución, tal como se sostiene por el actor por no haberse notificado en el acto la denuncia y no contener las causas que lo motivaron. Los defectos de forma que se invocan son inexistentes. Por un lado, el vehículo sí se detuvo, se identificó al conductor y de él se recabaron los datos necesarios para la formalización de la denuncia por lo que materialmente su pudieron recabar in situ los datos a los que hace referencia el art. 75 LTSV. Si no se entregó copia en el instante fue por un motivo que afectaba directamente al actor, su prisa, y así se recoge debidamente en la denuncia y es un extremo que se ratifica expresamente en la denuncia".

49 Sobre esta cuestión la STSJ Región de Murcia de 2 de junio de 1999 (JUR 1999, 171984) ha señalado que:

“Concurren en este caso circunstancias peculiares en torno a la notificación del acto iniciador del expediente sancionador, que, tal como se desprende del expediente, fue la propia denuncia formulada contra el interesado. En la denuncia se aprecia cómo se redactó teniendo en cuenta que el conductor estaba ausente y que después se rectificó para hacer constar la entrega al denunciado y que éste se negó a firmar.

Por el recurrente se alega que, al existir enmendados en el boletín, no deben tenerse en cuenta los datos a él incorporados.

Ciertamente la existencia de rectificaciones en el boletín hacía necesario que por el agente denunciante se aclarase porqué se hicieron éstas, sin que baste con que la Administración, en sede judicial, haga esa función en sus escritos de alegaciones, por lo que se estima que existe infracción de lo establecido en los artículos 10 y 12 R.D. 320/94 en relación con el 63.2 de la Ley 30/92, puesto que, formalmente, se ha privado al interesado de la posibilidad de formular alegaciones, sin que se haya probado que, materialmente, dispusiese de esa oportunidad. 
- Se trata de contenidos adicionales a los previamente establecidos en el art. 74.3 LTSV, y este tipo de denuncias tendrá que cumplir con todos ellos.

- La referencia a "las denuncias de los Agentes de la autoridad" efectuada en este art. 74.3 LTSV habrá de entenderse realizada a los Agentes de la Autoridad encargados del servicio de vigilancia del tráfico y control de la seguridad vial, pues son los únicos a los que el art. 72.2 LTSV atribuye la posibilidad de que las denuncias que notifiquen en el acto al denunciado constituyen acto de iniciación del procedimiento sancionador (que es a lo que se refiere la letra d) de este apartado, siendo, por tanto, la única interpretación posible conforme a lo establecido en el propio art. 74.3 LTSV).

- El contenido adicional que, para este tipo de denuncias notificadas en el acto se exige, se asocia, precisamente, a la consecuencia establecida en el art. 72.2 LTSV de tener por iniciado el procedimiento sancionador

De manera que las previsiones efectuadas hacen confluir causa y efecto. El art. 74.3 LTSV exige la presencia en la denuncia de un mayor número de elementos por razón de su notificación en el acto al denunciado y para garantizar que sea posible tener por iniciado el procedimiento sancionador ya que no resultaría viable darlo por iniciado si en la denuncia figurase, únicamente, el contenido previsto en el art. 74.2 LTSV.

\section{b) La calificación infracción y sus consecuencias}

El primero de los contenidos que, de manera adicional se determina en el art. 74.3 a) LTSV consiste en que el Agente de la Autoridad tiene que dejar expresa constancia de "la infracción presuntamente cometida, la sanción que pudiera corresponder y el número de puntos cuya pérdida lleve aparejada la infracción, conforme a lo dispuesto en esta Ley".

Esta prescripción supone la exigencia, dirigida al Agente de la Autoridad denunciante ( $y$, no lo olvidemos, se trata de un Agente de la Autoridad que, de manera especial, está encargado del servicio de vigilancia del tráfico y control de la seguridad vial), de que proceda a la calificación, de manera específica y concreta, de la conducta observada y de la atribución de las consecuencias que a esos hechos corresponde. Esta previsión, la de incorporar en la propia denuncia notificada en el acto al denunciado la calificación jurídica de los hechos denunciados, lejos de suponer vulneración de derechos del interesado se convierten en garantía ya que "ciertamente no puede negarse que se facilita la defensa, cuando desde el pliego de cargos se hace ya una determinada calificación jurídica" ${ }^{50}$.

\footnotetext{
${ }^{50}$ Tal y como señalan las SSTS de 17 de noviembre de 1993 (RJ 1993, 8367) y de 12 de febrero de 2003 (RJ 2003, 1084).
} 
El que señalemos que al Agente de la Autoridad se le exige una "calificación específica y concreta" radica en que, de manera previa a la redacción del boletín de denuncia, ese Agente ya ha realizado una calificación (que podría denominarse "genérica"). De otro modo no estaría denunciando esos hechos.

Hay, por tanto, una primera calificación que se corresponde con el momento en el que el Agente de la Autoridad observa unos hechos que considera susceptibles de constituir una infracción. Pero, en esa fase, la calificación acaba ahí y se viene a corresponder con ese deber con el que tiene que cumplir toda denuncia de realizar "una descripción sucinta del hecho". Y hasta ahí se le pide al Agente que llegue, salvo que nos encontremos en el supuesto de que esa denuncia va a ser notificada en el acto al denunciado, que requerirá de pasar a un segundo nivel de calificación.

En ese segundo estadio se tendrá que encajar el hecho observado, y que se ha considerado constitutivo de infracción, en el marco de alguno de los tipos previstos por la propia LTSV y, además, indicar las consecuencias que de ello pudiera derivarse (sanción económicas y, en su caso, detracción de puntos). Es decir, se está exigiendo al Agente que realice la calificación jurídica que, en el caso de las denuncias que no son notificadas en el acto, corresponde efectuar al instructor de procedimiento administrativo sancionador de manera previa a la práctica de la correspondiente notificación de esa denuncia ${ }^{51}$ y que se viene a corresponder con lo establecido en el art. 13.1 b) REPEPOS, precepto en el que se establece que, dentro de contenido mínimo del inicio del procedimiento administrativo sancionador, habrán de indicarse "los hechos sucintamente expuestos que motivan la incoación de procedimiento, su posible calificación y las sanciones que pudieran corresponder, sin perjuicio de lo que resulte de la instrucción", previsión que, a su vez, enlaza con los principios del procedimiento sancionador establecidos en la LRJ - PAC y, en particular, con el art. 135 LRJ - PAC, precepto que garantiza al presunto responsable el derecho "a ser notificado de los hechos que se le imputen, de las infracciones que tales hechos puedan constituir y de las sanciones que, en su caso, se les pudiera imponer..." ${ }^{52}$.

\footnotetext{
${ }^{51}$ Algo que, en mi opinión, no supone problema alguno dada la suficiente capacidad con la que cuentan los Agentes de la Autoridad encargados de la vigilancia del tráfico y control de la seguridad vial. Los problemas, y así lo muestran los conflictos ante los Juzgados y Tribunales, son más comunes en el estricto ámbito de "la descripción sucinta del hecho" que en el de la "calificación". A modo de simple ejemplo, es más común la falta de concreción en el hecho (lo que nos sitúa en la norma de conducta) que en la calificación (la determinación de la infracción cometida dentro de las establecidas en el art. 65 LTSV). Es más fácil que se describa un estacionamiento en zona prohibida, sin indicar el supuesto concreto del art. 39.2 LTSV (lo que supone falta de la necesaria concreción), y señale sin problema alguno el art. 65.4 d) LTSV.

${ }^{52}$ Así, la STSJ Comunidad Valenciana de 22 de junio de 2002 (JUR 2002, 269967) señala la que no consignación en el boletín de denuncia del importe de la sanción a imponer evidentemente origina en el interesado una auténtica indefensión y que, en consecuencia, es forzoso concluir que se ha producido la violación del art. 135 LRJ - PAC.
} 
La notificación de los hechos que se imputan al denunciado es la garantía sobre la que se asienta el derecho a la defensa. Sin conocer el alcance fáctico y jurídico de los hechos resulta difícil (por no decir imposible) ejercer ese derecho con garantías, cuando se desconocen los hechos que se le imputan, la calificación efectuada a los mismos y sus consecuencias ${ }^{53}$.

Desde un punto de vista formal la dificultad se encuentra en que, en ese paso, el que media desde la "descripción sucinta del hecho" hasta "la infracción presuntamente cometida", se realice con la necesaria claridad y concreción, puesto que, como se ha señalado, esa calificación que se exige ha de caracterizarse, necesariamente, por ser precisa y determinada, ya que, en caso contrario, se estaría dando lugar a una indeterminación proscrita en el derecho sancionador porque impide o limita los medios de defensa ${ }^{54}$. Así, de no ser lo suficientemente clara y precisa, no se estará cumpliendo con el requisito establecido en el art. 74.3 a) LTSV.

La determinación de la sanción que pudiera corresponder a la infracción que se señala no debiera presentar problemas teniendo en cuenta los términos del art. 67 y de los Anexos II y IV LTSV. Siempre puede haber errores materiales e, incluso, interpretaciones que, de haberlas, procederán de la calificación del tipo infractor, puesto que, como se señala, la determinación de las sanciones ha derivado en una aplicación casi automatizada, dados los términos en los que la Ley 18/2009, de 23 de noviembre, fijó la redacción del referido art. 67 LTSV y que la detracción de puntos se asocia a la comisión de determinados tipos.

De todas maneras se trata de cuestiones que, en sí mismo, pueden ser objeto de conflicto. $Y$ aunque forman del análisis del tipo de procedimiento por el que se realice

\footnotetext{
${ }^{53}$ En este sentido la STEDH de 25 de julio de 2000 (Caso Matoccia contra Italia) sostiene que el acusado tiene derecho a una información detallada sobre la naturaleza y causa de la acusación que posibilite su defensa. Doctrina que se reitera, entre otras, en la STEDH de 1 de marzo de 2001 (Caso Dallos contra Hungria, TEDH 2001, 197) donde se razona que "el artículo 6.3 a) del Convenio reconoce al acusado el derecho a ser informado no sólo del «motivo» de la acusación, es decir, de los hechos materiales de los que se le acusa, sino también de la calificación jurídica dada a estos hechos y esto de manera detallada (Pélissier y Sassi c. Francia [TEDH 1999, 10] , [GS], núm. 254444/1994, ap. 51, TEDH 1999-II)"; y en la STEDH de 21 de febrero de 2002 (Caso Sipavicius contra Lituania, TEDH 2002, 8) si bien, esta última sentencia, nos enseña que "la equidad del procedimiento debe ser valorada con respecto al procedimiento en su conjunto", y no aisladamente. Por su parte la STC 31/1986, de 20 de febrero razona que "el derecho a ser informado de la acusación, como principio establecido en el art. $24 \mathrm{CE}$, no es exclusivo del orden penal, sino que tiene su vigencia frente a todas las instancias públicas represivas". Doctrina que reitera en su STC 29/1989, de 6 de febrero, entre otras. De la anterior doctrina se infiere que lo esencial es valorar si el presunto responsable ha tenido un cabal conocimiento de los hechos que se le imputan, de forma que haya podido realizar una adecuada defensa de sus intereses (SAN de 15 de noviembre de 2002, RJCA 2003, 14).

${ }^{54}$ Así lo pone de manifiesto la STSJ Madrid de 7 de junio de 2012 (RJCA 2012, 585) al establecer que "los motivos del recurso han de ser estimados toda vez que, en efecto, en el boletín de denuncia extendido por el agente de la autoridad no consta fehacientemente si la infracción presuntamente cometida consistía en "conducir utilizando dispositivo de telefonía móvil" o "cualquier otro que exija el empleo de las manos", ya que se hacen constar las dos expresiones lo cual constituye una indeterminación proscrita del derecho sancionador porque impide o limita los medios de defensa".
} 
la tramitación del procedimiento, sí conviene dejar constancia aquí de una idea muy simple. Cuando la denuncia da lugar a un procedimiento ordinario en la instrucción del mismo habrá lugar a discutir todos los elementos, incluida la calificación de los hechos y sus consecuencias, sin que ello presente mayores dificultades. No sucede lo mismo, sin embargo, cuando esa calificación errónea se sustancia por el procedimiento sancionador abreviado ${ }^{55}$.

c) El órgano competente para imponer la sanción y la norma que le atribuye tal competencia

El art. 74.3 b) LTSV impone la obligación de incluir en la denuncia "el órgano competente para imponer la sanción y la norma que le atribuye tal competencia", previsión que viene a coincidir con la establecida en el primer inciso del art. $13.1 \mathrm{~d}$ ) REPEPOS como uno de los elementos que ha de estar presente en la iniciación del procedimiento administrativo sancionador.

Se trata, de nuevo, de un requisito que se convierte en básico al tomar en consideración que las denuncias notificadas en el acto al denunciado constituyen acto de iniciación del procedimiento sancionador y que se asienta sobre el derecho del presunto responsable a ser notificado y a conocer tanto la titularidad de la potestad sancionadora como la norma que la atribuye (art. 135 LRJ - PAC), conocimiento que se extiende a la indicación, en su caso, del ejercicio de esa competencia por delegación, tal y como determina el art. 13 LRJ - PAC que exige su publicación en el correspondiente Diario Oficial, así como que las resoluciones administrativas que se adopten por delegación tendrán que indicarlo expresamente, considerándose dictadas por el órgano delegante ${ }^{56}$.

\footnotetext{
${ }^{55}$ El planteamiento se corresponde con que el Agente de la Autoridad califique los hechos en un tipo inferior al que le debiera corresponder (por ejemplo, grave en lugar de muy grave) y el denunciado dé por buena esa calificación y sus consecuencias (inferiores a las que debieran haberle correspondido) y proceda a efectuar el pago voluntario de la multa impuesta, con lo que, conforme establece el art. $80 \mathrm{c}$ ) LTSV "se tendrá por concluido el procedimiento sancionador con... la terminación del procedimiento, sin necesidad de dictar resolución expresa, el día que se realice el pago", cuestión sin duda problemática y cuyo análisis ha de efectuarse en el marco del examen del procedimiento sancionador abreviado.

${ }^{56}$ Véase el Capítulo dedicado a "La competencia para sancionar las infracciones de tráfico y seguridad vial" y, en particular, la sección que en él se dedica a la delegación de la competencia para sancionar (apartado III).
} 
d) En función de si el denunciado procede, o no, al abono de la sanción señalada

\section{$\underline{\text { La posición del denunciante }}$}

Frente a la denuncia formulada por Agente de la Autoridad y notificada en el acto al denunciado, éste puede actuar de diversas formas, y ello supondrá diferentes implicaciones en cuanto al contenido que habrá de figurar en el la denuncia.

El hecho diferencial radica en que el denunciado proceda a realizar, o no, el pago de la sanción que el Agente hubiera consignado en la denuncia, conforme a la obligación que, en este sentido, establece el art. 74.3 a) LTSV.

Hay, por tanto, una configuración, que podríamos denominar abierta, en cuanto al contenido que debe de constar en las denuncias formuladas por los Agentes de la Autoridad y que son notificadas en el acto, puesto que junto a determinados elementos que deberán constar, en todo caso, se configuran otros, de carácter alternativo, que tendrán que figurar en función de determinadas circunstancias.

Todo ello se sustenta, aunque nada se señale de manera expresa, en el régimen sancionador y el procedimiento establecido para ello en la LTSV, sobre la base de lo establecido en el art. 8 REPEPOS que permite resolver el procedimiento administrativo sancionador si se produce el pago voluntario de la multa por el imputado, sin perjuicio de la posibilidad de interponer los recursos procedentes y siendo posible aplicar reducciones sobre el importe de la sanción propuesta, que deberán estar determinadas en la notificación de la iniciación del procedimiento.

La información que deberá constar en la denuncia es, por tanto, diferente en función de que el denunciado proceda, o no, a abonar en el acto la sanción establecida.

Los términos empleados en la LTSV son claros en cuanto al resultado y los efectos que el pago en el acto produce, pero no sucede lo mismo en cuanto a la forma.

\section{Cuando el denunciado procede al pago en el acto}

Formalizada la denuncia por el Agente de la Autoridad, y una vez calificados los hechos y fijada la sanción económica ( $y$, en su caso, puntos a detraer), el denunciado puede optar por proceder al pago en el acto de la sanción.

Si opta por proceder al abono de la sanción, esa multa ya no será la fijada por el Agente, pues ese pago en el acto conlleva un beneficio del 50 por cierto del importe fijado, porque en realidad lo que está haciendo el denunciado es optar por el 
procedimiento sancionador abreviado con las consecuencias que ello supone, la primera de las cuales es, precisamente, la reducción de la sanción económica fijada ${ }^{57}$.

En lo que aquí importa, en cuanto a la determinación del contenido que ha de constar en la denuncia, si el denunciado opta por el abono de la sanción que se ha establecido (que se está estableciendo, en puridad), en ese caso la consecuencia del pago será que en la denuncia se tendrá que recoger la cantidad entregada en concepto de pago de esa sanción por el denunciante y que ese pago, al suponer la tramitación de la denuncia por el procedimiento sancionador abreviado, supone las consecuencias establecidas en el art. 80 LTSV:

- La renuncia a formular alegaciones. En el caso de que fuesen formuladas se tendrán por no presentadas.

- La terminación del procedimiento, sin necesidad de dictar resolución expresa, el día en que se realice el pago.

- El agotamiento de la vía administrativa siendo recurrible únicamente ante el orden jurisdiccional contencioso - administrativo.

- El plazo para interponer el recurso contencioso - administrativo se iniciará el día siguiente a aquel en que tenga lugar el pago.

- La firmeza de la sanción en la vía administrativa desde el momento del pago, produciendo plenos efectos desde el día siguiente.

- La sanción no computará como antecedente en el Registro de Conductores e Infractores, siempre que se trate de infracciones graves que no lleven aparejada pérdida de puntos.

Todo ello debe constar en la denuncia y todo ello debería ser puesto en conocimiento del denunciado de manera previa a realizar el pago. Pago que, conforme señala el art. 80 c) LTSV supone la terminación del procedimiento, sin necesidad de dictar resolución expresa, el día que se realice el pago.

\section{Cuando el denunciado no procede al abono de la sanción en el acto}

El denunciado, que debería saber los efectos que el pago en el acto produce (aunque nada se señala expresamente a este respecto en el art. 74.3 LTSV), puede optar por no proceder al pago de la sanción en el acto. En cualquier caso, si el denunciado no realiza el pago de la sanción en el acto (ya sea porque no se le ofrece o porque, ofrecido, no lo realiza), de ello se deriva que en el boletín de denuncia habrá de constar que constituye acto de iniciación del procedimiento sancionador y, como consecuencia de ello, en la propia denuncia tiene que figurar:

\footnotetext{
${ }^{57}$ El procedimiento sancionador abreviado y sus consecuencias es objeto de análisis en el Capítulo que en esta obra se destina al examen de "Las clases de procedimientos sancionadores".
} 
- Que dicha denuncia inicia el procedimiento sancionador

- Que dispone de un plazo de veinte días naturales para efectuar el pago ${ }^{58}$, con la reducción y las consecuencias establecidas en el art. 80 LTSV, o para formular las alegaciones y proponer las pruebas que estime convenientes

- Los lugares, oficinas o dependencias donde puede presentar, en su caso, las alegaciones a esa denuncia

- Que si en el plazo señalado de veinte días no se formulan alegaciones ni se procede al abono de la multa, la denuncia surtirá el efecto de resolución sancionadora y la sanción en ella establecida podrá ejecutarse a los treinta días naturales a contar desde la notificación de la denuncia.

\section{Formulación y notificación de la denuncia}

De los términos literales en los que se encuentra redactado el art. 74.3 LTSV no se desprende cual ha de ser la posición del Agente de la Autoridad denunciante en cuanto a la actuación a realizar. En realidad el problema consiste en que los requisitos, en cuanto a la información que ha de constar en la denuncia, son claros, pero no sucede lo mismo con el procedimiento a seguir, puesto que carece de linealidad.

Mientras que las letras a), b) y c) del art. 74.3 LTSV muestran una continuidad en la actuación del agente denunciante ese trazo se desvanece pierde en las letras d) y e).

Se puede entender la intención del legislador, pero ello no significa que la norma esté bien redactada. Se mezcla el contenido necesario de la denuncia notificada en el acto, con las alternativas del denunciado $y$, todo ello, a su vez, con situaciones que superan el marco de la propia denuncia, como sucede con los efectos de la inactividad del denunciado (que ni paga ni alega). La sencillez del sistema, que lo es, se pierde en una redacción inadecuada ${ }^{59}$.

\footnotetext{
${ }^{58}$ Conviene señalar sobre este plazo de veinte días naturales para efectuar el pago, con el beneficio de reducción, o formular alegaciones que no coincide con el establecido, para el mismo fin (formular alegaciones) por el art. 81.1 LTSV que establece que "notificada al denuncia, el interesado dispondrá de quince días naturales para formular las alegaciones que tenga por conveniente y proponer o aportar las pruebas que estime oportunas". Tratándose de un plazo para articular la defensa en el procedimiento habrá que estar al más favorable para el interesado que es el más largo de los señalados.

${ }^{59}$ Frente a la alegación de quien defienda la claridad normativa y para ello se apoye, como muestra palpable de que la intención del legislador se entiende por clara y meridiana, en que a diario se ponen denuncias (y muchas), opongo que eso no es más que una prueba evidente de la buena voluntad de los Agentes de la Autoridad que hacen lo que pueden con lo que se les da. La redacción del artículo (que se entiende, sí) no responde a la forma en la que tiene que actuar el Agente. Si formulada la denuncia, y rellenado el correspondiente boletín, pretende proceder a su notificación, esa denuncia estará incompleta, pues desconoce la intención del denunciado en cuanto al pago (realizarlo o no realizarlo). La única manera de "cumplir" sería dando por hecho que el denunciado no va a proceder a realizar el pago y, en ese caso, no estaría ofreciendo la posibilidad del pago voluntario en el acto... Sí, no es tan complicado, pero no conforme a la letra del art. 73.4 LTSV. La denuncia notificada en el acto se
} 


\section{e) El domicilio que, en su caso, indique el interesado a efectos de notificaciones}

Concluye el art. 74.3 LTSV con un elemento que ha de figurar en la denuncia en caso de que así sea indicado por el denunciado, ya que se le ofrece la posibilidad de que señale un domicilio a efecto de notificaciones para las que hubiera que realizar en ese procedimiento administrativo sancionador.

Sin perjuicio del análisis, que se efectúa en el apartado correspondiente a las notificaciones y su práctica, resulta preciso realizar una serie de consideraciones sobre lo establecido en esta disposición.

En primer término hay que señalar que el art. 74.3 f) LTSV recoge el derecho del denunciado a fijar un domicilio a efecto de notificaciones en ese procedimiento y que la única limitación que a ese derecho se establece es que esa designación no se tendrá en cuenta (se tendrá a todos los efectos por no realizada) en el caso de que el denunciado tuviera asignada una Dirección Electrónica Vial ${ }^{60}$ que, regulada en el art. 59 bis LTSV, y en lo que aquí interesa, es obligatoria para las personas jurídicas y voluntaria para las físicas, ya que conforme previene citado art. 59 bis.5 LTSV "si el titular es una persona física sólo se le asignará una Dirección Electrónica Vial cuando así lo solicite voluntariamente".

En segundo lugar hay que tener en cuenta que el hecho de tener asignada una Dirección Electrónica Vial (de forma obligatoria o voluntaria) no impide, que conforme determina el art. 28.4 de la Ley 11/2007, de 22 de junio, de Acceso Electrónico de los Ciudadanos a los Servicios Públicos (LAE), "durante la tramitación del procedimiento el interesado podrá requerir al órgano correspondiente que las notificaciones sucesivas no se practiquen por medios electrónicos, utilizándose los demás medios admitidos en el art. 59 LRJ - PAC" excepto en los casos previstos en el art. 27. 6 de la propia LAE que permite imponer la obligatoriedad de comunicarse con la Administración utilizando sólo medios electrónicos, pero siempre que se trate de personas jurídicas o colectivos de personas físicas que por razón de su capacidad económica o técnica, dedicación profesional u otros motivos acreditados tengan garantizado el acceso y disponibilidad de los medios tecnológicos precisos.

Y que, además, ese derecho a señalar el domicilio a efectos de notificaciones determina el lugar en el que han de ser practicadas por delante de los domicilios que, para ese denunciado, figuren en los diferentes Registros de la Dirección General de

convierte en una transacción entre denunciante y denunciado. Exigirle al Agente de la Autoridad que rellene con ingenio y mano izquierda los vacíos de la norma no es de recibo.

${ }^{60}$ Véase, en este mismo capítulo, el apartado III.B) 2 b) sobre la Dirección Electrónica Vial (DEV). 
Tráfico (Conductores e Infractores, Vehículos...) y en otras Administraciones (Ayuntamientos, Agencia Estatal de la Administración Tributaria.... $)^{61}$.

\section{f) El incumplimiento del contenido que han de contener las denuncias notificadas en el acto y sus efectos}

Al igual que sucede con el contenido que, de manera general, tiene que integrar cualquier tipo de denuncia (por hechos de la circulación), nos encontramos a previsiones que cumplen con el fin de garantizar el derecho de defensa del denunciado. Lo señalado para la denuncias vale para las denuncias notificadas en el acto.

Cuestión diferente son los efectos que se producen sobre el procedimiento sancionador cuando la omisión de esos elementos causa indefensión al denunciado. $Y$ ello porque la denuncia notificada en el acto por los Agentes de la Autoridad constituye acto de iniciación del procedimiento administrativo sancionador, de forma que si la denuncia no cumple con las exigencias impuestas por el art. 74.3 LTSV no podrá considerarse como acto de iniciación del procedimiento y el órgano competente deberá proceder a su notificación, pues ni esa denuncia se puede tener por notificada ni, por tanto, ese procedimiento sancionador se puede tener por iniciado ${ }^{62}$. Y ese contenido que se establece como necesario tiene que estar recogido en el propio documento de la denuncia ${ }^{63}$, no siendo suficiente con que se señalen de manera verbal al denunciado al momento de la notificación, pues ello no cumple con las garantías que persigue el art. 74 LTSV $^{64}$.

\footnotetext{
${ }^{61}$ En cuestión de "domicilio de notificaciones" la regulación de la LTSV no es homogénea ni coherente. Al lado de la prescripción que el art. $74.3 \mathrm{~g}$ ) LTSV realiza se encuentran otras previsiones como son las realizadas en los arts. 59 bis y 77 LTSV cuya integración puede generar cierto grado de confusión.

${ }^{62}$ Tal y como señala, por ejemplo, la STSJ de la Región de Murcia de 19 de mayo de 1999 (JUR 1999, 174666) "se aprecia que, efectivamente, el interesado no ha tenido oportunidad de participar en la tramitación del procedimiento, puesto que se comprueba que, tal como alega, el boletín de denuncia no cumple con las exigencias impuestas por el art. 10 RPSTSV, por lo que no puede considerarse como acto de iniciación del procedimiento".

${ }^{63}$ La STSJ de Madrid de 30 de abril de 2009 (JUR 2009, 366089) señala que "en el presente supuesto, la Sala comparte la fundamentación jurídica del Juez a quo, toda vez que si bien consta en el expediente administrativo, que el sancionado rehusó firmar la notificación del boletín policial de denuncia, no consta que se le informara de su derecho a formular alegaciones en el plazo de 15 días, por lo que faltando el requisito fundamental de la Audiencia exigido en todo procedimiento administrativo sancionatorio, la sanción ha de ser considerada nula por lo que procede la desestimación del presente recurso".

64 La STSJ de Galicia de 3 de julio de 2000 (JUR 2000, 294152) señala que, sobre la necesidad de hacer constar en las denuncias que con ellas quedan incoados los correspondientes expedientes y que disponen de un plazo de 15 días para que aleguen cuanto consideren conveniente a su defensa y propongan las pruebas que estimen oportunas, "si bien dando crédito al informe obrante al folio 2 (que en todo caso no ratificado), se puede entender que verbalmente se hicieron al denunciado las citadas advertencias, las mismas no aparecen recogidas en el impreso de boletín de denuncia, ni lógicamente en
} 
Así pues, el incumplimiento de los requisitos establecidos en relación al contenido de las denuncias notificadas en el acto por los Agentes de la Autoridad, y en cuanto ese defecto coloque en una situación de indefensión al denunciado, supone que se ha prescindido del procedimiento establecido, con las consecuencias que a ello atribuye el art. 62 LRJ - PAC 65 .

\section{EL CONTENIDO EN LAS DENUNCIAS POR HECHOS AJENOS A LA CIRCULACIÓN}

El art. 74.4 LTSV establece que en las denuncias por hechos ajenos a la circulación se especificarán todos los datos necesarios para su descripción, lo que supone que, para estos casos, las denuncias no se encuentran sometidas, en cuanto al contenido que en ellas debe de constar, a lo establecido en los apartados 2 y 3 del propio art. 74 LTSV.

La cuestión, aquí, radica en determinar de manera previa que ha de entenderse por "hechos ajenos a la circulación". Atendiendo a la propia estructura y sistemática de la LTSV se podría establecer que son aquellas infracciones que se encuentran recogidas fuera del apartado destinado a las normas de comportamiento en la circulación (Título II, art. 9 a 52 LTSV). Quedaría, de esa manera, determinado un ámbito que, con determinados matices, se correspondería con la regulación de señalización, actividades que pudieran incidir sobre le vía, autorizaciones, régimen de centros de formación y reconocimiento de conductores y actividades en materia de seguridad vial ${ }^{66}$.

Pero el mayor problema en cuanto a la concreción de lo que haya de entenderse y, por tanto, como tenga que interpretarse la expresión "hechos ajenos a la circulación" no se encuentra en la delimitación con "hechos de la circulación" del art. 74.2 LTSV ni en el ámbito de la regulación de tráfico y seguridad vial. El problema se ubica extra muros, y ello porque la práctica se ha empeñado en demostrar la existencia de "hechos ajenos a la circulación" que, aunque afectan al tráfico, no quedan sometidos a la regulación, ni al régimen sancionador establecido en la LTSV, y ello por se requiere "una relación directa en el hecho cometido y la norma sancionadora que al mismo se le aplica". Esta es la doctrina que impide que la obstaculización del tráfico rodado por una concentración de protesta (manifestación) sea sancionada por medio del régimen

\footnotetext{
la copia que se le entregó, lo que es tanto como confiar la garantía de sus derechos a la mejor o peor memoria que pudiera conservar de las advertencias recibidas de palabra".

${ }^{65}$ Como señala la STSJ de Madrid de 30 de abril de 2009 (JUR 2009, 366089) al indicar que "en el presente supuesto, la Sala comparte la fundamentación jurídica del Juez a quo, toda vez que si bien consta en el expediente administrativo, que el sancionado rehusó firmar la notificación del boletín policial de denuncia, no consta que se le informara de su derecho a formular alegaciones en el plazo de 15 días, por lo que faltando el requisito fundamental de la Audiencia exigido en todo procedimiento administrativo sancionatorio, la sanción ha de ser considerada nula por lo que procede la desestimación del presente recurso.".

${ }^{66}$ Con cierto margen de imprecisión en cuanto a la ubicación de determinadas infracciones que correspondiendo a este ámbito se ubican en el de hechos de la circulación, como es el caso de las infracciones en materia de autorizaciones.
} 
establecido en la Legislación de Tráfico y Seguridad Vial ya que se trata de "hechos en los que, en su caso, existiría una infracción a los preceptos reguladores del derecho de manifestación, que serían sancionables, si resultaba procedente, según la legislación de orden público" ${ }^{67}$.

Se trata, en definitiva, de un supuesto de falta de relación directa entre la norma en que la sanción se basa y el hecho sancionado, lo que supone un uso indebido por la Administración de su potestad sancionadora y consecuentemente la nulidad del acto impugnado.

\section{SOBRE LAS DENUNCIAS VOLUNTARIAS}

El art. 73.1 LTSV no descarta la posibilidad de que el procedimiento sancionador en materia de tráfico y seguridad pueda tener su origen en la denuncia formulada por particulares, e incluso se refiere a ello expresamente, al indicar que "el procedimiento sancionador se incoará de oficio... mediante denuncia... de cualquier persona que tenga conocimiento de los hechos", ya que la denuncia, como puesta en conocimiento de la autoridad de un determinado hecho que pudiera constituir infracción, es un acto que puede ser realizado por cualquier persona, conforme la definición establecida en el art. 11.1 e) REPEPOS.

\footnotetext{
${ }^{67}$ Como así se estableció en un importante número de Sentencias del Tribunal Supremo como las de 11 de febrero de 1993(RJ 1993, 705), de 22 de febrero de 1993 (RJ 1993, 844) y 24 de abril de 1993 (RJ 1993, 2732) en las que se establecía que:

"El Derecho administrativo sancionador, al que deben aplicarse, aunque con matices, los principios inspirados del Derecho penal [SSTS 29 septiembre y 21 octubre 1980 (RJ 1980, 3464 y RJ 1980, 3761) y STC 18/1981, de 8 junio (RTC 1981, 18)], es de interpretación restrictiva, por lo que se distorsiona cuando no existe una directa relación entre el hecho cometido y la norma sancionadora que al mismo se aplica. En el presente supuesto no se produce esa directa relación, ya que se han sancionado como contrarios al Código de la Circulación, y aplicando el Cuadro de Multas que en él se contiene, hechos en los que, en su caso, existiría una infracción a los preceptos reguladores del derecho de manifestación, que serían sancionables, si resultaba procedente, según la legislación de orden público.

La Administración ha utilizado la potestad sancionadora de que le inviste el Código de la Circulación para fines ajenos a los que dicho texto protege, imponiendo la multa anulada por la sentencia apelada por unos hechos que constituían expresión del derecho de manifestación. En razón de ello, tal multa, impuesta conforme al Real Decreto 142/1978 que es objeto del presente proceso, no corresponde al hecho sancionado, que -debemos repetirlo- constituía expresión del derecho de manifestación y, en su caso, debió ser castigado aplicando la legislación de orden público. Esta falta de relación directa entre la norma en que la sanción se basa (el Código de la Circulación) y el hecho sancionado y el consiguiente uso indebido que la Administración ha hecho de su potestad sancionadora, determinan la nulidad de tal multa, y, por consecuencia, de los acuerdos en cuya virtud se impuso, como ha dispuesto la sentencia impugnada, por lo que, en definitiva, procede desestimar el recurso de apelación interpuesto por el señor Abogado del Estado".
} 
Sobre las denuncias efectuadas por particular han de tenerse en cuenta una serie de consideraciones que las diferencian de las obligatorias formuladas por los Agentes de la Autoridad, y así:

- En cuanto al contenido de la denuncia, en ella tienen que constar los datos establecidos de manera general, para todo tipo de denuncia, en el art. 74.2 LTSV, resultando preceptiva, por tanto, la identificación de la persona que efectúa esa denuncia, del denunciante, mediante la inclusión de su nombre y domicilio, y aunque nada se diga de manera expresa, esa indicación deberá incluir el documento identificativo de esa persona (DNI, Pasaporte o documento equivalente) ${ }^{68}$.

- En relación a los hechos contenidos en ellas, carecen del valor probatorio atribuido a los hechos constatados por los funcionarios a los que se reconoce la condición de autoridad y que hayan sido formalizados en documento público observando los requisitos establecidos (art. 137.3 LRJ - PAC y 75 LTSV). No son, por sí mismas, pruebas de cargo suficientes, lo que implica la necesidad del acreditar los hechos integrantes de la denuncia ${ }^{69}$.

- No imponen al órgano competente la incoación del procedimiento sancionador, ya que las posibilidades de actuación de un particular, respecto a las actuaciones de la autoridad administrativa titular de la potestad sancionadora o disciplinaria se agotan en la denuncia de la infracción cometida $^{70}$.

- El denunciante no adquiere, por el hecho de formular la denuncia voluntaria, la condición de interesado en ese procedimiento administrativo sancionador, aun cuando pueda tener reconocida cierta intervención en el procedimiento. Pero no es parte (salvo que se trate de un interesado), ni está legitimación para crear la obligación del órgano sancionador de investigar la concreta situación del hecho denunciado. El denunciante es un tercero simple, carece por tanto de la cualidad de parte legítima $y$, en consecuencia, resulta inviable procesalmente su pretensión de impugnar la resolución que se dicte en el expediente sancionador ${ }^{71}$. Necesitaría de ese interés. Del hecho de que la imposición de la sanción al presunto infractor pudiera producirle un efecto

\footnotetext{
${ }^{68}$ En este sentido resulta más clara y concreta la expresión empleada en el art. 11.1 d) REPEPOS al establecer, en su párrafo segundo, que "las denuncias deberán expresar la identidad de la persona o personas que las presentan...". Los términos del art. 74.2 d) LTSV "el nombre y domicilio del denunciante" y los utilizados en el art. 5 RPSTSV "el nombre, profesión y domicilio del denunciante" resultan, sin duda, mas imprecisos.

${ }^{69}$ Cfr. STSJ País Vasco de 29 de junio de 2000 (RJCA 2000, 2113), STSJ Cantabria de 15 de marzo de 1999 (RJCA 1999, 564), STSJ de Madrid de 8 de noviembre de 2000 (RJCA 2007, 863) y STS de 25 de marzo de 1988 (RJ 1988, 2516).

${ }^{70}$ Cfr. SSTS de 20 de marzo de 1992 (RJ 1992, 3113) y de 15 de enero de 1993 (RJ 1993, 113) y STSJ de Cataluña de 30 de abril de 2001 (JUR 2001, 232672)

${ }^{71}$ Cfr. SSTS de 12 de marzo de 1991 (RJ 1991, 6306), de 30 de octubre de 1991 (RJ 1991, 9176) y de 26 de octubre de 2000 (RJ 2000, 8582
} 
positivo en la esfera jurídica del denunciante o puede eliminar una carga o gravamen de su esfera ${ }^{72}$.

En particular es preciso tener en cuenta que la denuncia exige la identificación del denunciado como parte del contenido que ha de constar en la denuncia, lo que excluye la posibilidad de las denuncias anónimas, cuestión sobre la que nada se señala, de manera expresa, en la LTSV y sobre la que el art. 9.2 RPSTSV señalaba que "sin perjuicio de que los órganos competentes puedan comprobar los hechos a que se refieran, en los casos en que puedan suponer un riesgo para la seguridad vial, las denuncias de carácter anónimo serán archivadas sin que deban efectuarse ulteriores trámites al respecto". El problema radica en determinar el equilibrio entre la puesta en conocimiento de unos hechos susceptibles de ser constitutivos de infracción sin que conste la identidad del denunciado (requisito establecido entre los que han de integrar en todo caso el contenido de la denuncia) y la posibilidad de que esa forma de conocimiento, por parte de la Administración competente para sancionar, pueda originar el comienzo del procedimiento administrativo o la realización de actuaciones previas para determinar si ha lugar a su inicio.

\section{LA NOTIFICACIÓN DE LA DENUNCIA}

\section{A) Momento de la notificación}

\section{LA NORMA GENERAL DE NOTIFICACIÓN EN EL ACTO}

El art. 76.1 LTSV no puede ser más conciso y claro al determinar que "las denuncias se notificarán en el acto al denunciado", disposición que lleva implícita la referencia a las denuncias formuladas por los Agentes de la autoridad ${ }^{73}$ y supone el establecimiento de una norma o principio general ${ }^{74}$.

La justificación del establecimiento de la notificación de las denuncias en el acto como norma general no requiere de grandes explicaciones, en razón de la seguridad jurídica y de la garantía de los derechos del presunto responsable, algo que sin duda se logra de una manera mucho más efectiva mediante la inmediatez de la denuncia, a lo que, además, se une la identificación del infractor.

Pero lo realmente importante es que la norma general de la notificación en el acto de las denuncias obligatorias supone que, caso de no concurrir ninguna de las

\footnotetext{
${ }^{72}$ Cfr. SSTS de 26 de septiembre de 1997 (RJ 1997, 6934) y 2 de julio de 1999 (RJ 1999, 6829).

${ }^{73}$ Precisión que figuraba en el art. 77.1 LTSV hasta la modificación del régimen sancionador efectuada por la Ley 18/2009, de 23 de noviembre. El referido artículo señalaba que "como norma general, las denuncias de carácter obligatorio, formuladas por agentes de la autoridad, se notificarán en el acto al denunciado,".

${ }^{74}$ Expresión esta, la de que "como norma general" de la que también se ha prescindido tras la reforma realizada por la Ley 18/2009, de 23 de noviembre.
} 
circunstancias que, legal y específicamente previstas, permiten la notificación en un momento posterior, por considerar que suponen causa suficiente para que se excepcione ese principio general, si no hay un motivo (de los legalmente establecidos), esa notificación posterior no será válida y, por tanto, impedirá la tramitación del procedimiento sancionador contra el responsable de esa infracción.

2. EXCEPCIONES A LA NORMA GENERAL: CIRCUNSTANCIAS QUE PERMITEN LA NOTIFICACIÓN EN UN MOMENTO POSTERIOR

Desde la reforma efectuada por la medio de la Ley 19/2001, de 19 de diciembre ${ }^{75}$, las causas que habilitaban la notificación de la denuncia en un momento posterior se han articulado en torno a tres supuestos o circunstancias, lo cual no significa que, en algunos casos, esas excepciones no hayan evolucionado y hayan sido objeto de modificación, y que en el régimen vigente se encuentra ubicadas en el art. 76.2 LTSV (bajo esa locución adverbial de "no obstante" que tanto gusta de usar el legislador de la Ley de Tráfico y Seguridad Vial).

a) Que la denuncia se formule en circunstancias en que la detención del vehículo pueda originar un riesgo para la circulación

El art. 76.2 a) LTSV establece, como primera circunstancias que permite la notificación con posterioridad, "que la denuncia se formule en circunstancias en que la detención del vehículo pueda originar un riesgo para la circulación" siendo necesario, en ese caso, que "el Agente deberá indicar los motivos concretos que la impiden".

La estructura de la excepción se articula sobre un supuesto abierto, como es que detener al vehículo suponga un riesgo para la circulación (y no cualquier tipo de riesgo), siendo necesario que el Agente lo concrete y lo recoja en la propia denuncia y que, al mismo tiempo, ese motivo cumpla con la previsión normativa. Es preciso que esa razón justifique que detener el vehículo infractor, en esas concretas circunstancias, suponía un riesgo para la circulación, un riesgo concreto para la seguridad vial.

La forma en la que se establece esta circunstancia que, de manera excepcional, exime de la obligación de notificar en el acto la denuncia formulada por los Agentes de la Autoridad, difiere de la regulación que para este supuesto se establecía hasta la reforma efectuada por la Ley 18/2009, de 23 de noviembre, ya que hasta ese

\footnotetext{
${ }^{75}$ No es hasta ese momento que se comienzan a sistematizar las excepciones a la norma general de la notificación en el acto de la denuncia. Hasta entonces el inciso final art. 77 LTSV mantenía la redacción originaría en la que se establecía que "Por razones justificadas que deberán constar en la propia denuncia, podrá notificársele la misma con posterioridad".
} 
momento el art. 77.1 párrafo primero contenía una relación abierta de supuestos ${ }^{76}$ que habilitaban para realizar, posteriormente, la notificación de la denuncia. Algo que no sucede con la vigente redacción del art. 76.2 a) LTSV que establece como única causa, de manera genérica, que la detención del vehículo con el que se ha cometido la infracción origine un riesgo para la seguridad vial, peligro que hay que precisar y que tiene que cumplir con la condición establecida.

En definitiva, es preciso que concurra la circunstancia habilitante de que la detención del vehículo originara un riesgo para la seguridad vial, que esa causa concreta ${ }^{77}$ que justifica que no se detuviera el vehículo y que no se realizara la notificación en el acto conste en la denuncia ${ }^{78}$, que esa causa que se indica en la denuncia cumpla de manera genérica con el requisito establecido ${ }^{79}$ y que esa causa dote de contenido y llene, en el

\footnotetext{
${ }^{76}$ La regulación anterior procedía de la Ley 19/2001, de 19 de diciembre, y que la Ley 17/2005, de 19 de julio, había mantenido, y en ella se establecía que "será causa legal que justifique la notificación de la denuncia en momento posterior el hecho de formularse en momentos de gran intensidad de circulación o cuando concurran factores meteorológicos adversos, obras u otras circunstancias en que la detención del vehículo también pueda originar un riesgo concreto".

${ }^{77}$ Sobre la concreción de esas causas se señalo, por ejemplo que "por causas específicas y concretas no deben entenderse las genéricas de encontrarse detenidos otros vehículos, sino que es preciso que se especifiquen y concreten cuáles son esos vehículos para poder verificar en su caso la realidad de esa afirmación" (STSJ Extremadura de 15 de julio de 1999, RJCA 1999, 2427), "sin que quepa asumir, sin más, que cualquier alusión genérica y en abstracto a la misma resulta suficiente para obviar el requisito legal de notificación inmediata" (STSJ Comunidad Valenciana de 28 de mayo de 1998, RJCA 1998, 2773) y que "Si se observa el boletín de denuncia, se comprueba que, en efecto consta la expresión ya transcrita. Esta Sala ya ha tenido ocasión de señalar que esta fórmula no se aproxima siquiera a las "razones justificadas" a que se refiere el art. 77 de la Ley de Tráfico y Seguridad Vial. Esta interpretación encontró respaldo mediante la aprobación por la propia Administración del Real Decreto 320/94, de 25 de Febrero, del Reglamento del Procedimiento sancionador en materia de Tráfico, cuyo art. 10.2 resulta explícito cuando reclama la constancia de las "causas concretas y específicas" de la no detención del vehículo, lo que desde luego no puede identificarse con una fórmula como la que consta en la denuncia, pues la atención a los usuarios de la vía es uno de los cometidos genéricos de la Guardia Civil de Tráfico; viniendo el carácter estampillado de la mención a corroborar que la misma no es sino una forma imperfecta y genérica de cubrir una exigencia que se caracteriza por su concreción y especificidad, como hemos visto" (STSJ Castilla - La Mancha de 3 de octubre de 2003, JUR 2004, 48356).

78 "En el supuesto estudiado en la denuncia no se hizo constar la causa por la que no se detuvo el vehículo, y tampoco se intentó notificar después la denuncia cuando se localizó al conductor. En efecto, en el apartado correspondiente a la notificación, existente en los boletines de denuncia, no se hace mención alguna a que se intentase notificar la denuncia, ni figura la firma del denunciado, encontrándose sin cumplimentar las casillas correspondientes al intento de notificación, de lo que se desprende que el policía denunciante tomó los datos de la persona identificada a posteriori y redactó la denuncia con posterioridad, sin entregar copia al denunciado en el acto, lo que supone una vulneración de lo establecido en el art 77 LTSV" (SJCA no 1 de Ciudad Real de 6 de marzo de 2007, JUR 2008, 105244)

79 "En el presente caso, según el boletín de denuncia, no se hizo entrega de copia del mismo al recurrente con la indicación "en ruta». Tal indicación no cumple con la exigencia de cita de las causas concretas y específicas por las que no fue posible detener el vehículo conducido por el recurrente pues la misión de quienes ostentan competencia sobre la regulación del tráfico es el control del mismo, lo que comprende la detención de los infractores salvo supuestos concretos en que es posible denunciar sin detener siempre que ello resulte especialmente injustificado, modo de proceder que, al no ocurrir en el presente caso, invalida la denuncia origen del procedimiento así como el resto de actuaciones que le siguen" (SJCA no 6 Murcia de 8 de octubre de 2007, JUR 2008, 103015)
} 
caso concreto, la previsión de "riesgo para la circulación" establecida en el art. 76.2 a) LTSV $^{80}$.

b) Que la denuncia se formule estando el vehículo estacionado, cuando el conductor no esté presente.

La segunda circunstancia parte de la inexistencia del conductor al momento de ser observados los hechos constitutivos de infracción, de manera que el art. 76.2 b) LTSV establece "que la denuncia se formule estando el vehículo estacionado, cuando el conductor no esté presente", por lo que no hay denunciado al que notificarle la denuncia en el momento en que esta es formulada.

El supuesto de hecho sobre el que actúa este supuesto que exime de la notificación en el acto se encuentra rodeado de ciertas circunstancias que lo constituyen en peculiar. El supuesto prototípico (no el único, pero sí el más común) de infracción por estacionamiento se produce en vías urbanas que se encuentran sometidas a Ordenanzas Reguladoras de Aparcamiento, situación que supone competencia sancionadora municipal, intervención de denunciantes que no reúnen la condición de Agentes de la autoridad, posibilidad de hacer uso de la medida provisional de retirada y depósito del vehículo... otro universo ${ }^{81}$.

c) Que la autoridad sancionadora haya tenido conocimiento de los hechos a través de medios de captación y reproducción de imágenes que permitan la identificación del vehículo.

La tercera circunstancia contemplada para que no resulte necesaria la notificación en el acto de la denuncia es que el conocimiento de los hechos se haya producido a través de medios de captación y reproducción de imágenes que permitan la identificación del vehículo, prevista en el art. 76.2 c) LTSV.

\footnotetext{
${ }^{80}$ En el presente supuesto, si bien en la denuncia se hizo constar como causa para la notificación de la denuncia en el acto ser peligrosa la detención para la circulación, es lo cierto, sin embargo, que no concurría causa para la notificación de la denuncia en un momento posterior, pues de la fotografía obrante en el expediente administrativo (folio 4) no resulta esa situación de peligro por tratarse de un tramo recto con buena visibilidad sin apenas circulación en el momento que se captó por el cinemómetro la velocidad del recurrente. Procede, en consecuencia, estimar el recurso y anular la resolución recurrida (SJCA n1 de Cáceres de 13 de febrero de 2007, JUR 2008, 96724).

${ }^{81}$ Incluso desde la perspectiva del procedimiento administrativo sancionador, ya que la reglas, en la práctica, son diferentes a las establecidas en la LTSV y se encuentran en el menos conocido mundo de las Ordenanzas Municipales y las previsiones que en ellas se realizan.

La posibilidad de evitar el inicio de un expediente que, no ha comenzado, dado que, por lo general, se trata de denuncias voluntarias efectuadas por Agentes de la ORA, mediante el pago de cantidades que suponen una reducción muy considerable (y en todo caso muy superior al 50 por 100 previsto en la LTSV), nos ubica en procedimientos administrativos muy diferentes a los previstos en la LTSV.
} 
Los términos en los que se encuentra redactado el art. 76.2 c) LTSV, en principio claros, se dirigen a permitir que todas las infracciones de las que se tiene conocimiento por medios que capten las imágenes de esos hechos y que permitan identificar el vehículo con el que se ha cometido la infracción pueden ser notificadas con posterioridad, lo que supone recabar del titular (conductor habitual o arrendatario) que identifique al conductor del vehículo al momento de ser cometida la infracción, conforme a lo establecido en los arts. 9 bis y 69 LTSV $^{82}$.

Pero la redacción del art. 76.2 c) LTSV que, como se acaba de señalar, en principio parece clara, puede presentar un problema en cuanto a la interpretación de la extensión que deba darse a esos términos $y$, en consecuencia, al alcance de la exención de notificación en el acto de la denuncia.

Nótese que la expresión utilizada ("que la autoridad sancionadora haya tenido conocimiento de los hechos a través de medios de captación y reproducción de imágenes que permitan la identificación del vehículo") hace referencia a una acción acabada en el pasado ${ }^{83}$, por lo que la norma parece referirse a aquellos supuestos en los que la autoridad sancionadora conoce unos hechos que ya han ocurrido, es decir, tiene conocimiento de unos hechos a posteriori, y es en ese momento que se pone en marcha el procedimiento administrativo sancionador. Se trata de una previsión normativa en la que encuentra perfecto encaje la captación de una infracción mediante un sistema automatizado que funciona (trabaja) en modo desasistido y remoto $^{84}$, y que constituye una "actuación administrativa automatizada" en los términos que para este concepto se establece en el apartado a) del Anexo de la Ley 11/2007, de 22 de junio, de Acceso Electrónico de los Ciudadanos a los Servicios Públicos (LAE) ${ }^{85}$.

Pero al lado de este tipo de sistemas de captación de hechos constitutivos de infracciones se encuentra el supuesto en el que al lado del instrumento que permite la captación hay una persona en la que, además, concurre la condición de Agente de la autoridad encargada del servicio de vigilancia del tráfico y control de la seguridad vial,

\footnotetext{
${ }^{82}$ Véase, sobre ello, el Capítulo que en esta obra se destina al análisis de la "Responsabilidad por la comisión de infracciones de tráfico".

${ }^{83}$ El tiempo y modo verbal empleado, pretérito perfecto de subjuntivo, expresa acción acabada en el pasado. Se trata de un "tiempo que denota ser ya pasada la significación del verbo", como señala la acepción que, para "pretérito perfecto" ofrece el Diccionario de la Real Academia Española.

${ }^{84}$ Los términos utilizados lo son para explicar la situación, y quieren definir aquellos casos en que los medios de captación y reproducción de imágenes han sido instalados en una ubicación determinada, con cierto grado de fijeza o continuidad, que una vez conectado o puesto en marcha funciona por sí solo y que, por lo tanto (aunque sea una reiteración) no necesita de una persona para realizar su función. Se trata de una mezcla de conceptos en la que se incorporan usos comunes en el campo de las tecnologías. ${ }^{85}$ Que, como ya se ha señalado en otro lugar de esta obra, se define como la "actuación administrativa producida por un sistema de información adecuadamente programado sin necesidad de intervención de una persona física en cada caso singular. Incluye la producción de actos de trámite o resolutorios de procedimientos, así como de meros actos de comunicación".
} 
que observa, percibe y tiene conocimiento de esos hechos constitutivos de infracción en el mismo instante en que se producen y se captan.

Así planteado surge la duda de si este supuesto puede quedar incluido en la excepción, que a la norma general de notificación de las denuncias en el acto al denunciado, se establece en el art. 76.2 c) LTSV.

Se trata, y por simplificar la cuestión objeto de análisis, de la contraposición entre sistemas fijos, los que no requieren para su funcionamiento y en los que no está presente una persona física para la captación de las imágenes que permiten constatar la existencia de una infracción, y aquellos otros que realizan esa función acompañados de un Agente de la autoridad. Instalaciones fijas frente a instrumentos en manos de Agentes $^{86}$, siendo el caso más significativo el de los cinemómetros ${ }^{87}$ (aunque no el único $\left.{ }^{88}\right)$.

$Y$ de esa contraposición no parece que deban tener el mismo tratamiento las denuncias obtenidas mediante un sistema que funciona de forma autónoma, cuya actividad está automatizada y sin colaboración de persona alguna, con aquellas otras que son captadas por un sistema en el que está presente un agente de la autoridad.

En las primeras hay un sistema que tiene que cumplir con una serie de garantías (técnicas y jurídicas) que permite determinar (y probar) la existencia de unos hechos constitutivos de infracción. Nada que objetar a la aplicación de la tecnología a la detección de infracciones, siempre y cuando se cumplan con los requisitos que para ello se establezcan en aras a las garantías que el procedimiento administrativo sancionador tiene que ofrecer al responsable de una infracción.

\footnotetext{
${ }^{86}$ Téngase en cuente que, de propósito, no se contraponen cinemómetros (o radares) fijos frente a móviles. Esa no es la cuestión, dado que un cinemómetro puede ser colocado en un trípode al borde de la carretera (o funcionar desde un coche que permanece estático, sin moverse) y no cumpliría con la condición de ser una instalación fija funcionando en modo desasistido sin la intervención, colaboración o compañía de un Agente. La distinción parte de la forma de funcionamiento y uso.

${ }^{87}$ Sobre estos aparatos debemos tener presente que su regulación se efectúa por medio de la Orden ITC/3123/2010, de 26 de noviembre, por la que se regula el control metrológico del Estado de los instrumentos destinados a medir la velocidad de circulación de vehículos a motor (publicada en el Boletín Oficial del Estado de 3 de diciembre de 2010) que en su art. 1.2 establece que "se entiende por cinemómetro aquel instrumento o sistema de medida destinado a determinar la velocidad de circulación de vehículos a motor junto con sus dispositivos complementarios destinados a registrar, y conservar los resultados de las medidas efectuadas. Están concebidos bien para funcionar situados en edificios u otras construcciones, postes o pórticos de carretera, bien para hacerlo en soportes provisionales tipo trípode o sobre vehículos terrestres, detenidos o en movimiento, o aéreos, denominados en adelante "cabinas»". Esta Orden, a efectos de los márgenes de error (errores máximos permitidos) distingue entre instalaciones "fijas o estáticas" y "móviles" (ANEXO II), además de los instalados en "aeronaves" (ANEXO III) o los destinados "a medir la velocidad media de circulación de los vehículos a motor sobre tramos de distancias conocidas" (ANEXO IV).

88 Al lado de los cinemómetros estáticos colocados en instalaciones (edificios u otro tipo de construcciones) van apareciendo otros sistemas que pretenden la captación de imágenes que permitan constatar otro tipo de infracciones (ya sean instantáneas o continuas), como pueden ser, entre otras, "no respetar la luz roja de un semáforo" o "incumplir la obligación de asegurar los vehículos".
} 
Pero en el segundo caso, cuando hay un Agente de la Autoridad "de por medio", entre la infracción detectada por medios de captación de imágenes y la autoridad sancionadora no está tan claro que la excepción del art. 76.2 c) LTSV dé cobertura, por sí misma (y sin la concurrencia de otras circunstancias), para que la notificación puede ser notificada en un momento posterior, ya que la infracción es constatada en el acto por un Agente de la Autoridad que, si es de los encargados de la vigilancia del tráfico y control de la seguridad vial, puede poner en marcha, de forma inmediata el correspondiente procedimiento administrativo sancionador, algo para lo que le habilita (mediante una norma absolutamente extraordinaria en nuestro sistema jurídico) el art. 73.2 LTSV. Ese Agente de la Autoridad está cumpliendo su función en el marco del funcionamiento de la Administración que tiene atribuida la competencia para la vigilancia y disciplina del tráfico y tiene el deber de denunciar las infracciones que observe (art. 74.1 LTSV), y a no ser que concurra la circunstancia establecida en el art. 76.2 a) LTSV y que ello se haga constar en la denuncia, no hay razón para que no tenga que proceder a la notificación en el acto de esa denuncia, sin que pueda alegarse cualquier otra causa como motivo suficiente para no proceder a realizar esa notificación en el acto, como pudiera ser "que el agente denunciante se encuentre realizando labores de regulación del tráfico y carezca de medios para proceder a la persecución del vehículo infractor" ${ }^{\prime 89}$.

A ello se debe añadir que la mera existencia de una duda sobre cuál deba ser el alcance de la norma nos debe conducir, en este caso, a una interpretación restrictiva ya que se trata de una norma que supone una excepción al deber general de notificación de las denuncias en el acto al denunciado en el marco de un procedimiento sancionador. La medida ambigüedad de los términos utilizados para determinar una excepción no puede permitir que sea la forma de introducir en ella situaciones que no pueden, ni deben, encontrar amparo en una excepción a la norma general que impone que las denuncias se notificarán en el acto al denunciado.

\footnotetext{
${ }^{89}$ Señalamos de manera concreta esta causa (a titulo ejemplificativo) por tratarse de un supuesto adicional que el Ayuntamiento de Madrid pretendió introducir en la Ordenanza de Movilidad como causa para que la denuncia pudiera ser notificada en un momento posterior al de su comisión y que fue anulada por el Tribunal Superior de Justicia de Madrid porque "dicha causa no está prevista en el art. 76 LTSV, y careciendo de cobertura legal, debe ser anulada" (STSJ Madrid de 8 de marzo de 2012, RJCA 2012, 392). Téngase en cuenta, además, que este resolución judicial tiene como objeto la modificación de la Ordenanza de Movilidad del Ayuntamiento de Madrid efectuada por Acuerdo del Pleno del Ayuntamiento de Madrid de 30 de noviembre de 2010, es decir, ya vigente el régimen establecido en la LTSV tras la reforma efectuada por la Ley 18/2009, de 23 de noviembre.
} 
3. EFECTOS DEL INCUMPLIMIENTO DE LA NORMA GENERAL QUE OBLIGA A LA NOTIFICACIÓN EN EL ACTO DE LAS DENUNCIAS

El sistema de notificación dispuesto en el art. 76 LTSV establece, para la notificación de las denuncias de tráfico y seguridad vial, una norma general, la notificación en el acto, que puede ser excepcionada en determinadas circunstancias.

Excepciones legalmente tasadas y que son, por tanto, los únicos supuestos que, de estar presentes, permiten realizar la notificación con posterioridad al momento en el que se comete la infracción objeto de denuncia.

Si no concurren las circunstancias establecidas, o concurriendo no se cumple con los requisitos que se establecen para acreditar la existencia de esas circunstancias, la notificación realizada posteriormente no es válida, que es lo que se establecía en el art. 10.2 RPSTSV precepto que señalaba que "las denuncias formuladas por los agentes de la autoridad sin parar a los denunciados no serán válidas a menos que consten en las mismas y se les notifique las causas concretas y específicas por las que no fue posible detener el vehículo", de modo que "la trascendencia anulatoria de la omisión es clara , y se funda en la consideración de la notificación en el acto como garantía del encartado en un expediente sancionador, consideración que conduce a la necesidad de asegurar que la omisión de aquélla garantía sólo tiene lugar por causas concretas y justificadas, interpretación que conduce directamente a que la resolución sancionadora pierde su base y origen y debe ser anulada" ${ }^{90}$.

\section{B) Práctica de la notificación de las denuncias (en momento posterior)}

\section{Presupuestos a considerar sobre la denUnCia no NOTIFICADA EN EL ACtO}

Formulada la denuncia por el Agente de la Autoridad, y notificada la misma en el acto al denunciado, el procedimiento administrativo sancionador ha de entenderse iniciado a todos los efectos, eso sí, siempre y cuando esa denuncia notificada en el acto cumpla con todos los requisitos establecidos para ello en los apartados 2 y 3 del art. 74 LTSV.

En el caso de que la denuncia no haya sido notificada en el acto la Administración correspondiente (estatal, autonómica o local) titular de la competencia sancionadora se encontrará con esa denuncia y deberá proceder a su notificación.

Pero antes de proceder a practicar esa notificación deberá proceder a iniciar el procedimiento y ello requiere del análisis de diferentes aspectos que es preciso, cuando menos, enunciar aquí, pues de ellos depende que se practique, o no, esa

\footnotetext{
${ }^{90}$ Cfr. STSJ Castilla - La Mancha de 3 de octubre de 2003, JUR 2004, 48356.
} 
notificación, y que se viene a corresponder con lo que el art. 9 RPSTSV denominaba "tramitación de denuncias".

Una vez recibida la denuncia, el órgano instructor procederá:

- A calificar los hechos y la graduación de la multa o a la verificación de la calificación y multa consignadas en la misma por el agente denunciante

- Proponer (a la autoridad competente) se declare la inexistencia de infracción en los casos de que los hechos denunciados no fuesen constitutivos de la misma, la improcedencia de imponer sanción, en los supuestos en que no pueda identificarse a su autor, o el impulso del procedimiento en sus siguientes trámites

- Se debería, aunque nada se señale en ese punto de forma expresa, comprobar el cumplimiento del resto de requisitos que se han de cumplir para continuar con la tramitación como es que la denuncia cumple con todos los requisitos establecidos, la inexistencia de prescripción de la infracción o de la caducidad del procedimiento, que no se trate de hechos que ofrezcan la apariencia de delitos o faltas perseguibles de oficio y, en lo que aquí más interesa, que no se ha incumplido con el régimen de notificación porque existe causa que habilita la notificación posterior y que esa causa es suficiente en ese caso concreto

Analizados todos los elementos, determinada la viabilidad jurídica de la denuncia, iniciado el procedimiento, habrá que determinar qué hay que notificar, a quién hay que notificárselo y cómo (y por qué medio) ha de practicarse esa notificación.

Antes de pasar a analizar el régimen de notificación establecido en la Ley de Tráfico y seguridad Vial es preciso realizar dos advertencias adicionales.

La primera de ellas es señalar la necesidad de comprobar, en las denuncias que ya hayan sido notificadas en el acto, que cumplen con todos los requisitos establecidos en el art. 74 LTSV ya que, se entiende, que el procedimiento sancionador ya se ha iniciado (art. 73.2 LTSV). Pero ello no sería así en el caso de que la denuncia fuera defectuosa. Es cierto que, en ese caso, se reconoce la posibilidad de que el denunciado subsane con su actuación esos defectos, pero en correcta técnica administrativa sería preciso (y en la medida que ello sea posible) subsanar esos defectos y proceder a una correcta (y en ese caso real) incoación del procedimiento administrativo sancionador.

La segunda cuestión a considerar es que, llegado el momento de practicar la notificación, se determine de forma adecuada el destinatario de la misma, conforme a lo establecido, en sede de responsabilidad, por el art. 69 LTSV, no estando de más, y en 
relación a la advertencia realizada en el párrafo anterior, comprobar que la persona a la que se le notificado la denuncia es el destinatario de la misma ${ }^{91}$.

En ese punto, procede practicar la notificación de la denuncia, lo que se llevará a efecto conforme se establece en el art. 77 LTSV (para la denuncia y el resto de notificaciones a las que dé lugar el procedimiento sancionador).

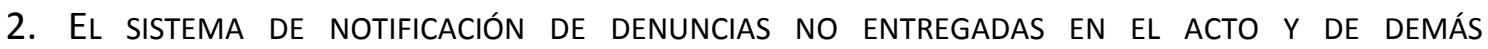
NOTIFICACIONES A QUE DÉ LUGAR EL PROCEDIMIENTO SANCIONADOR

Una de las mayores innovaciones introducidas en la LTSV por la Ley 18/2009, de 23 de noviembre, es el establecimiento de "un sistema de notificaciones adaptado a la realidad actual" ${ }^{92}$ que diverge, y de forma muy importante, del previsto en la LRJ PAC.

Se incorpora una Dirección Electrónica Vial (DEV), se mantiene la notificación en el domicilio para las personas físicas que no opten voluntariamente por la notificación electrónica y se sustituyen la notificación mediante anuncios en los Tablones de Anuncios de Ayuntamientos y en los Boletines Oficiales por un Tablón Electrónico (TESTRA).

\section{a) Una aproximación al sistema de notificaciones de los arts. 77 y 78 LTSV}

La LTSV establece un sistema de notificaciones que se aleja del sistema tradicional de notificación (sin abandonarlo completamente, eso sí) y que, sobre la base de las nuevas posibilidades establecidas por la Ley 11/2007, de 22 de junio, de Acceso Electrónico de los Ciudadanos a los Servicios Públicos (LAE), introduce medios de

\footnotetext{
${ }^{91}$ Este reflexión, que puede parecer paradójica, tiene como misión la de prevenir frente a situaciones que, por extrañas, pueden pasar desapercibidas. Es el caso de determinadas infracciones cuya responsabilidad se atribuye por la LTSV al titular del vehículo, y no al conductor del mismo al momento de la denuncia, como son "las infracciones relativas a la documentación del vehículo, a los reconocimientos periódicos y a su estado de conservación, cuando las deficiencias afecten a las condiciones de seguridad del vehículo". Cfr. sobre esta cuestión la STSJ Andalucía de 27 de diciembre de 2000 (RJCA 2001, 484).

92 De ello se advierte en la Exposición de Motivos (párrafo quinto del apartado V) de la Ley 18/2009, de 23 de noviembre, en la que se señala que:

“El segundo de los elementos característico del nuevo procedimiento sancionador es la creación de un sistema de notificaciones adaptado a la realidad actual. Las notificaciones en boletines oficiales pueden efectivamente ofrecer "garantías formales» de que la notificación ha sido practicada. Sin embargo, no ofrecen «garantía material» alguna al ciudadano de que tenga siempre conocimiento de los procedimientos que contra él se dirigen. En estas circunstancias se crean la Dirección Electrónica Vial (DEV) y el Tablón Edictal de Sanciones de Tráfico, en formato digital".
} 
comunicación electrónicos que sustituyen, en algunos casos en todo, en otros en parte, a los previstos en la LRJ - PAC.

Aunque se establece como norma general la notificación electrónica (art. 77.1 LTSV), ello únicamente es así para quienes tengan la Dirección Electrónica Vial (DEV), que únicamente es obligatoria para las personas jurídicas que sean titulares de una autorización administrativa de las previstas en la LTSV, tal como establece el art. 59 bis.5 LTSV, siendo potestativa para las personas físicas, que dispondrán de ella cuando la soliciten voluntariamente (art. 59 bis.5 LTSV).

Al lado de la notificación en la Dirección Electrónica Vial (DEV) se ubica la notificación en el domicilio del interesado, en términos equivalentes a los establecidos en la LRJ PAC, si bien es cierto que la LTSV permite determinar un domicilio a efecto de notificaciones (art. $74.3 \mathrm{f}$ LTSV), los domicilios que figuren en los Registros de la Dirección General de Tráfico (art. 77.1 LTSV) y los domicilios de los que tengan constancia otras Administraciones (art. 59 bis.1 LTSV) ${ }^{93}$.

Por otra parte, la LTSV rompe con el sistema tradicional de notificación edictal. Ni el tablón de anuncios del Ayuntamiento del último domicilio conocido del interesado ni la publicación de anuncios en los Diarios Oficiales (previsiones del art. 59.5 LRJ - PAC) figuran entre los medios establecidos en la LTSV para notificar las denuncias que no han sido entregadas en el acto ni el resto de notificaciones a que dé lugar el procedimiento sancionador.

La LTSV establece la siguiente prelación de medios para la práctica de notificaciones:

- Dirección Electrónica Vial (DEV)

- En ausencia de Dirección Electrónica Vial el domicilio indicado por el interesado a efecto de notificaciones (para ese procedimiento)

- En ausencia de ellos en el domicilio que figure en los Registros de la Dirección General de Tráfico

- Cuando no se pueda practicar la notificación en la Dirección Electrónica Vial (DEV) o en domicilio, la notificación se practicará en el Tablón Edictal de Sanciones de Tráfico (TESTRA)

\section{b) La Dirección Electrónica Vial (DEV)}

El medio preferente de comunicación de denuncias no notificadas en el acto y del resto de notificaciones a que haya lugar en el procedimiento administrativo sancionador es, en caso de que el destinatario disponga de ella, la Dirección

\footnotetext{
${ }^{93}$ Un auténtico lío de "domicilios", sobre todo si se tiene en cuenta lo que, en puridad y por oposición al concepto "residencia", ha de entenderse por tal.
} 
Electrónica Vial (DEV), que el art. 59 bis LTSV declara obligatoria para las personas jurídicas que sean titulares de una autorización administrativa de las previstas en la LTSV y voluntaria para las personas físicas, a las que se les asignará cuando, voluntariamente, así lo soliciten ${ }^{94}$.

Esta previsión encuentra su soporte en el art. 27.6 LAE, en cuanto la posibilidad de imponer la obligatoriedad de comunicación por medios electrónicos a las personas jurídicas, así como que los ciudadanos tienen el derecho a elegir la forma de comunicarse con las Administraciones Públicas (y cambiar esa elección) y que las Administraciones Públicas pueden utilizar las comunicaciones electrónicas para relacionarse con los ciudadanos siempre que estos así lo hayan solicitado o consentido expresamente. La solicitud y el consentimiento podrán, en todo caso, emitirse y recabarse por medios electrónicos (art. $27 \mathrm{LAE}$ ).

Por ello, esta norma general de notificación no supone, en estos momentos, la forma en la que por lo común se practican esas notificaciones ${ }^{95}$.

El sistema consiste en la asignación de una dirección electrónica a la que se envían todas las notificaciones relativas a ese titular. Cuando se deposita alguna notificación el propio sistema envía un mensaje (al correo electrónico o móvil indicado por el titular de esa DEV) advirtiéndole que hay un mensaje en su DEV. El titular puede acceder a esa notificación, rechazarla o ignorarla. En este último caso el trascurso de

\footnotetext{
94 Téngase en cuenta que la Orden INT /3215/2010, de 3 de diciembre, por la que se regula la comunicación del conductor habitual y del arrendatario a largo plazo al Registro de Vehículos establece, en el art. 3, la obligación de que el titular del vehículo comunique al Registro de Vehículos en relación al arrendatario a largo plazo una serie de datos para proceder a su inscripción entre los que se encuentran el domicilio o la Dirección Electrónica Vial (esta última obligatoria para las personas jurídicas y voluntaria para las físicas). De igual forma, en el art. 2 se establece la posibilidad de que el titular o el arrendatario a largo plazo comuniquen al Registro de Vehículos, para su inscripción, los datos del conductor habitual (con el consentimiento de esa persona física), entre los que pueden figurar un Dirección Electrónica Vial. La disp. transit. Única de la Orden INT /3215/2010, de 3 de diciembre, establece que "los titulares de vehículos cedidos en régimen de arrendamiento a largo plazo cuyos contratos estén vigentes en la fecha de entrada en vigor de la orden, dispondrán de un plazo de seis meses para comunicar al Registro de Vehículos los datos del arrendatario que se indican en el artículo 3 de esta orden" y que "para la inclusión de los datos del arrendatario en el Registro de Vehículos no será obligatoria la asignación de una Dirección Electrónica Vial".

95 Sin embargo, no hay que ignorar que un importante número de vehículo tiene como titular a una persona jurídica y que, de igual manera el parque de vehículos que funciona en régimen de arrendamiento (leasing, renting, alquiler sin conductor) no es desdeñable.

En este sentido LEDESMA MuÑIz, R. advierte que "es cada vez más frecuente en el uso de las cosas que estas no se adquieran en propiedad, sino que simplemente se pague por el uso que de ellas se haga durante un cierto tiempo. Con los vehículos ocurre así. Esta circunstancia provoca que la tradicional asociación de ideas titular del vehículo-conductor del mismo vaya desapareciendo. La matriculación de vehículos a nombre de personas jurídicas (cerca ya del 40\%), y la creciente introducción de la figura del renting o arrendamiento a largo plazo del vehículo obligan a configurar el Registro de Vehículos contemplando estas realidades, permitiendo de este modo que las administraciones se dirijan en el procedimiento sancionador contra quien realmente es el "usuario habitual" del vehículo", ("El nuevo procedimiento sancionador", Documentación Administrativa, no 284 - 285, mayo - diciembre 2009, pág. 15).
} 
diez días naturales implicará que ha sido rechazada, lo que supondrá que esa notificación se tendrá, a todos los efectos, por realizada.

El sistema supone la traslación de la tradicional notificación postal previsto en la LRJ PAC y con los parámetros y requisitos que determina la LAE a un sistema de notificación electrónico en el que, por la propia naturaleza de los medios empleados, queda constancia de todas las actuaciones realizadas tanto por la Administración notificadora como por el destinatario, así como el momento en que esa actuaciones se realizan (puesta a disposición, contenido, actividad del destinatario en cuanto a acceso, rechazo o desidia).

En el caso de que la notificación enviada sea rechazada se hará constar en el expediente ese rechazo y el trámite de notificación se tendrá por efectuado, entendiéndose, a estos efectos, que si transcurren diez días sin que se acceda al contenido de la notificación habiendo constancia de su recepción se entenderá que la notificación ha sido rechazada (a no ser que "de oficio o a instancia del destinatario se compruebe la imposibilidad técnica o material del acceso"), conforme se determina en el art. 77.2 párrafo tercero LTSV.

La Dirección Electrónica Vial (DEV), en caso de existir es el medio preferente que la Administración ha de utilizar para comunicar las denuncias no notificadas ${ }^{96}$. Sobre esta preferencia hay que tener presente, además, que en el caso de las denuncias notificadas en el acto se establece, entre el contenido necesario de las mismas, en el art. 74.3 f) LTSV, que conste el domicilio que, en su caso, indique el interesado a efectos de notificaciones, y que en ese mismo lugar se determina que "ese domicilio

\footnotetext{
96 La disp. transit. Segunda de la Ley 18/2009, de 23 de noviembre, establecía en su redacción originaria que "el Organismo Autónomo Jefatura Central de Tráfico y los órganos de las Comunidades Autónomas con competencias ejecutivas en materia de tráfico y circulación de vehículos a motor, vendrán obligados a efectuar las notificaciones telemáticas a la entrada en vigor de la presente Ley" y que "las Administraciones locales con competencias en materia de tráfico vendrán obligadas a efectuar las notificaciones telemáticas a la Dirección Electrónica Vial en el plazo de dos años a partir de la entrada en vigor de la presente Ley". Esta previsión transitoria fue modificada por la Ley 37/2010, de 15 de noviembre que la dejaba en los siguientes términos:

“Las Administraciones locales se incorporarán progresivamente a efectuar las notificaciones telemáticas y la publicación en el Tablón Edictal de Sanciones de Tráfico, en función de la disponibilidad de sus medios técnicos. En todo caso, vendrán obligadas a practicarlas en el plazo de dos años a partir de la entrada en vigor de la presente Ley".

Plazo de dos años que se aplicaría "en la medida en que sean compatibles con lo dispuesto en la disposición final tercera de la Ley 11/2007, de 22 de junio", es decir, en función de sus disponibilidades presupuestarias y medios técnicos.

El Real Decreto Ley 19/2012, de 25 de mayo, primero, y la Ley 12/2012, de 26 de diciembre, después, fijaron esa obligación en los siguientes términos:

“Las administraciones locales practicarán las notificaciones en la Dirección Electrónica Vial o, en su caso, en el Tablón Edictal de Sanciones de Tráfico antes del 25 de mayo de 2014, siempre que lo permitan sus disponibilidades presupuestarias y sus medios técnicos".
} 
no se tendrá en cuenta si ese denunciado tuviese asignada una Dirección Electrónica Vial, ello sin perjuicio de lo previsto en el art. 28.4 LAE", precepto, este último, que dispone que "durante la tramitación del procedimiento el interesado podrá requerir al órgano correspondiente que las notificaciones sucesivas no se practiquen por medios electrónicos, utilizándose los demás medios admitidos en el art. 59 LRJ - PAC" salvo en aquellos casos en los que la obligatoriedad del uso de los medios electrónicos venga impuesto para ese sujeto.

Si tenemos en cuenta que las denuncias notificadas en el acto suponen, a todos los efectos, la iniciación del procedimiento sancionador, encontramos que el art. $74.3 \mathrm{f}$ ) LTSV no permite lo que el art. 27.1 LAE establece como un derecho, que es el cambio del medio de comunicarse con la Administración y la posibilidad de optar por un medio distinto del inicialmente elegido, lo que supondría que la persona física que voluntariamente hubiera solicitado la asignación de una Dirección Electrónica Vial (DEV) puede, para un procedimiento concreto, escoger la comunicación por medio de notificaciones postales en un domicilio designado a tal efecto. Conforme al art. 27.1 LAE puede hacerlo "en cualquier momento", pero resulta que no pueda hacerlo a la iniciación del procedimiento sancionador en materia de tráfico y seguridad vial, y caso de hacerlo, la Administración, porque así lo establezca el art. 74.3 f) LTSV, practicará las notificaciones a las que hubiera lugar en la Dirección Electrónica Vial (DEV) porque esa opción, "ese domicilio no se tendrá en cuenta", sin que nada se señale respecto a la posibilidad de que se posible modificar esa opción en un momento posterior de ese mismo procedimiento, algo que, por otra parte, no ofrece lugar a dudas que el interesado puede realizar.

No parece que los términos empleados por el art. 74.3 f) LTSV sean muy afortunados. Impiden a quien voluntariamente (persona física) hubiera optado por la Dirección Electrónica Vial (DEV) cambiar el medio de comunicación para las sucesivas notificaciones a que dé lugar ese procedimiento sancionador (ya que el procedimiento ya está iniciado, conforme al art. 73.2 LTSV) y, en cambio, permite a quienes se les ha impuesto ese cauce electrónico (personas jurídicas) salirse de ese medio de comunicación en las siguientes comunicaciones que se hayan de producir en ese procedimiento. Sorprendente, desde una perspectiva que parecía pretender "que las comunicaciones con las personas jurídicas tuvieran lugar en todo caso mediante el canal electrónico" ${ }^{97}$, como es el caso de la previsión efectuada en el art. 81.2 LTSV que establece, en el marco de la regulación del procedimiento sancionador ordinario y para el caso de que no se hubiese producido la detención del vehículo que la identificación del conductor responsable de la infracción (por el titular, el arrendatario a largo plazo

\footnotetext{
${ }^{97}$ Tal y como señala GAMERO CASADO, E., "El régimen de notificaciones: la dirección electrónica vial (DEV) y el tablón edictal de sanciones de tráfico (TESTA)" en Documentación Administrativa, no 284 - 285, mayo - diciembre 2009, pág. 45, que añade "pero el contenido material que finalmente se ha dado a los preceptos no permite llegar a esa conclusión. Este orden de cosas puede arruinar el efecto pretendido por la reforma -un incremento en la eficacia de gestión de los procedimientos sancionadores-".
} 
o el conductor habitual) "se efectuará por medios telemáticos si la notificación se hubiese efectuado a través de la Dirección Electrónica Vial".

\section{c) La notificación en el domicilio del interesado}

El art. 77.1 párrafo segundo LTSV establece que en el caso de que el denunciado no tuviese Dirección Electrónica Vial (DEV) la notificación "la notificación se efectuará en el domicilio que expresamente hubiese indicado para el procedimiento, y en su defecto, en el domicilio que figure en los Registros de la Dirección General de Tráfico", previsión que, emparentada con la que se efectúa en el art. 59.2 LRJ - PAC, consigue superar el despropósito de la regulación establecida de manera general en la LRJ PAC.

Sin discutir la oportunidad de que el interesado señale, de forma expresa, una dirección en la que recibir las notificaciones que se hayan de practicar en un determinado procedimiento, por la seguridad que ello ofrece tanto a ese interesado como a la propia Administración notificadora, a partir de ahí reina la confusión.

En primer lugar, y en el plano terminológico, porque el art. 77.1 párrafo segundo LTSV hace uso de la expresión "domicilio que expresamente hubiera indicado para el procedimiento" en lugar de la empleada en el art. 59.2 LRJ - PAC "en el lugar que este haya señalado a tal efecto en la solicitud" ${ }^{\prime 98}$.

De ahí se pasa, y en el caso de que el interesado no hubiera indicado de manera expresa el lugar en el que quiere recibir las notificaciones a que diera lugar ese procedimiento, al domicilio que figure en los Registros de la Dirección General de Tráfico. Que puede ser uno o varios, que, caso de ser varios, pueden coincidir entre sí,

\footnotetext{
98 Es cierto que existe una larga tradición en hacer uso de la denominación "domicilio a efecto de notificaciones" posible mente originada en la redacción del art. 80.1 de la Ley de Procedimiento Administrativo de 17 de julio de 1958 que determinaba que "las notificaciones se realizarán mediante oficio, carta, telegrama o cualquier otro medio que permita tener constancia de la recepción, de la fecha y de la identidad del acto notificado, y se dirigirá en todo caso al domicilio del interesado o al lugar señalado por éste para las notificaciones".

La expresión de la que hace uso la LTSV ("el domicilio que expresamente hubiese indicado para el procedimiento") aparece en otras normas. Es el caso del Real Decreto Legislativo 1/1994, de 20 de junio, que recibe esta expresión, para la disp. adic. quincuagésima, de la Ley 32/2010, de 5 de agosto, de protección de trabajadores autónomos o de la disp. adic. tercera del Real decreto Ley 10/2011, de 26 de agosto, Medidas urgentes para la promoción del empleo de los jóvenes, el fomento de la estabilidad en el empleo y el mantenimiento del programa de recualificación profesional de las personas que agoten su protección por desempleo.

La expresión "domicilio a efectos de notificaciones" y su presencia en la Ley Hipotecaria de 1946 y en la LEC de 1881 es otra historia y, por tanto, debe ser contada en otro momento.
} 
o ser diferentes, y que, a su vez, pueden no corresponderse con el domicilio actual del denunciado.

Por si ello no fuera suficiente, en el marco de la regulación de las autorizaciones administrativas se profundiza sobre esta cuestión del domicilio y así, en el art. 59 bis.1 LTSV (incorporado al texto de la Ley por la Ley 18/2009, de 23 de noviembre, misma norma que dio nueva redacción a la totalidad del régimen sancionador), se establece que "el titular de una autorización administrativa para conducir o de circulación de vehículo comunicará a los Registros de la Dirección General de Tráfico su domicilio", que "este domicilio se utilizará para efectuar las notificaciones respecto de todas las autorizaciones de que disponga" y que "estos efectos, los Ayuntamientos y la Agencia Estatal de Administración Tributaria podrán comunicar a la Dirección General de Tráfico los nuevos domicilios de que tengan constancia".

Lo cual puede dar lugar a múltiples domicilios sin que resulte claro, dado que nada se especifica al respecto, por cuál de esas "direcciones" hay que optar para considerar cumplido con el requisito de la notificación practicada en el domicilio del interesado.

La propia LTSV parece ignorar (al tiempo que desautorizar) la previsión efectuada en el art. 10 RGCon, precepto en el que se establece que "cualquier variación de los datos que figuran en el permiso o licencia de conducción, así como la del domicilio de su titular, deberá ser comunicada por éste dentro del plazo de quince días, contados desde la fecha en que se produzca, a la Jefatura Provincial de Tráfico". Es cierto que nada se indica ni en la LTSV ni en el RGCon acerca de las consecuencias del incumplimiento de ese deber, de esa obligación de tener actualizado el domicilio en el Registro de Conductores e Infractores ${ }^{99}$.

Resultaría más fácil, sin duda alguna, una regulación menos abierta a tal cantidad de posibilidades en cuanto al domicilio del denunciado que lo único que produce es inseguridad en cuanto al resultado ${ }^{100}$.

Reproducir el régimen previsto en la LRJ - PAC y mejorarlo (me refiero al caótico y anacrónico método de notificación postal) introduciendo un sistema de multiplicidad

\footnotetext{
${ }^{99} \mathrm{El}$ art. 77 a) RGCon determina que "en el Registro de conductores e infractores figurarán los siguientes datos:

a) Nombre, apellidos, nacionalidad y domicilio del titular de la autorización, el Número de su Documento Nacional de Identidad si es español o, en su caso, el Número de Identidad de Extranjero".

Detalle, por otra parte importante, el del domicilio del titular de la licencia de conducción, dado que en el art. 37.3 del propio RGCon, precepto que regula el procedimiento para la declaración de pérdida de vigencia por la pérdida total de los puntos asignados, se establece que "la competencia para declarar la pérdida de vigencia corresponde al Jefe de Tráfico de la provincia correspondiente al domicilio del titular de la autorización".

${ }^{100}$ Regulación que se convierte en algo más próximo a un juego de azar que a lo que debiera regular un procedimiento y que, eso sí, es causa de enorme satisfacción para quien quiere eludir una notificación, que encuentra en este punto el apoyo normativo necesario para hacerlo "con todas las de la Ley".
} 
domiciliaria no puede deparar más que problemas que resultan perfectamente conocidos. Esta parte del procedimiento no puede funcionar adecuadamente. $Y$ no se trata de un pronóstico, es un diagnóstico ${ }^{101}$.

En nada altera la situación que se mantenga, como se ha hecho, el doble intento de notificación dentro de los tres días siguientes al primer intento fallido, o que no se exija que ese segundo intento haya de efectuarse en hora distinta, o que el rechazo del interesado $^{102}$ se haga constar en el expediente y se tenga por realizado el trámite, continuándose con el procedimiento (art. 77.3 LTSV). El despropósito de la LRJ - PAC no hace sino incrementarse en la regulación de la LTSV ${ }^{103}$.

En el caso de que no se puede practicar en el domicilio del interesado, se procederá a practicar esa notificación de forma edictal.

Por otra parte es preciso tomar en consideración que el art. 92.2 LTSV dispone que la notificación interrumpe el plazo de prescripción al que se encuentran sometidas las infracciones ${ }^{104}$.

\section{d) El Tablón Edictal de Sanciones de Tráfico (TESTRA)}

En el caso de que la notificación personal, ya sea la enviada, caso de existir, a la Dirección Electrónica Vial (DEV) o a ese domicilio del denunciado, no logre el objetivo de toda comunicación, esto es, la entrega y recepción por su destinatario, se tendrá

\footnotetext{
101 “Frente a este carácter nuclear de las notificaciones administrativas, la realidad es que en el último cuarto de siglo su práctica viene representando un verdadero tormento para los tramitadores de los procedimientos" GAMERO CASADO, E., "El régimen de notificaciones: la dirección electrónica vial (DEV) y el tablón edictal de sanciones de tráfico (TESTA)" en Documentación Administrativa, no 284 - 285, mayo diciembre 2009, pág. 34.

Sobe ello, y de manera previa a la promulgación de la Ley 18/2009, de 23 de noviembre, ya me manifesté con ocasión de las SSTC 32/2008, de 25 de febrero y 128/2008, de 27 de octubre en "Las notificaciones en el procedimiento sancionador en materia de tráfico (Teoría y práctica de un despropósito en la teoría y en la práctica)" en Actualidad Jurídica Aranzadi, no 767/2008.

102 Matiz curioso este, el de señalar de forma específica que "si estando el interesado en el domicilio rechazase la notificación..." (art. 77.3 párrafo tercero LTSV), que difiere de los establecido en el régimen general, que establece que "cuando el interesado o su representante rechace la notificación..." (art. 59.4 LRJ - PAC). Ello puede dar lugar a que se rechace la recepción de la notificación por persona distinta del interesado en su domicilio, sin que ello suponga rechazo a efectos del procedimiento, lo que puede dar a un equívoco de esos que tanto gustan a los que buscan el doblez el resquicio procedimental.

${ }^{103}$ Resulta difícil encontrar justificación a que la Ley 18/2009, de 23 de noviembre, no optara por una regulación más adecuada para la notificación personal por medios tradicionales (por oposición a los electrónicos). Pero lo que ya es de todo punto inexplicable es que habiendo mantenido la estructura general no lo haga de manera total. Para lo que se ha hecho una sencilla remisión hubiera sido suficiente y mucho más efectivo.

${ }^{104}$ Dispone el art. 92.2 LTSV que "la prescripción se interrumpe por cualquier actuación administrativa de la que tenga conocimiento el denunciado o esté encaminada a averiguar su identidad o domicilio y se practique con otras Administraciones, Instituciones u Organismos. También se interrumpe por la notificación efectuada de acuerdo con los artículos 76, 77 y 78".
} 
por efectuado ese trámite de notificación y se procederá a su publicación en el Tablón Edictal de Sanciones de Tráfico (TESTRA). Lo que no incluye el rechazo de la notificación (ya sea electrónica o postal), ya que, en ese caso, se hará constar en el expediente ese rechazo y el trámite de notificación se tendrá por efectuado, continuándose con el procedimiento, tal y como establecen el 77.2 LTSV para la notificación electrónica y el art. 77.3 LTSV para la notificación en el domicilio físico.

Toda la cicatería que el legislador ha regateado en cuanto al diseño, planteamiento y formulación de soluciones de notificación que se adapten a la realidad actual, se despliegan para el caso de tener que llegar a una notificación edictal ${ }^{105}$.

El Tablón Edictal de Sanciones de Tráfico (TESTRA), al que se refieren los arts. 77 y 78 LTSV, se encuentra regulado en la Orden INT/3022/2010, de 23 de noviembre ${ }^{106}$, que establece que su objeto es ser "medio oficial de publicación a través de edictos de las notificaciones a que dé lugar el procedimiento sancionador como consecuencia de la comisión de infracciones a la normativa sobre tráfico, circulación de vehículos a motor y seguridad vial, que no se hayan podido practicar en la Dirección Electrónica Vial, en las equivalentes de las Comunidades Autónomas con competencias ejecutivas en materia de tráfico, o en el domicilio del interesado" (art. 1). Objeto que muestra lo inadecuado de la denominación que recibe este medio de comunicación, ya que en él tiene cabida todo tipo de notificaciones y no, únicamente, las resoluciones sancionadoras, como pudiera desprenderse del nombre que recibe.

El Tablón Edictal de Sanciones de Tráfico es, por tanto, el medio electrónico oficial de comunicación de los edictos a que den lugar los procedimientos sancionadores en materia de tráfico y seguridad vial ubicado en la sede electrónica del Organismo Autónomo Jefatura Central de Tráfico, accesible permanentemente de forma universal y gratuita, respetando el estándar de protección de datos establecido en nuestro ordenamiento jurídico y que, adaptado a lo establecido en la Ley 11/2007, de 22 de junio, de Acceso Electrónico de los Ciudadanos a los Servicios Públicos (LAE), garantice

\footnotetext{
105 Téngase presente que para que el sistema que se establece en cuanto a la notificación edictal electrónica sea válido es preciso que, hasta llegar a él, se hayan cumplido con los requisitos establecidos previamente, que suponen respetar la regulación prevista para la notificación en la Dirección Electrónica Vial (DEV) y para la notificación en el "domicilio" del interesado. Incumplir las obligaciones establecidas deja sin valor y eficacia la publicación edictal por medios electrónicos, de la misma forma que antes sucedía con la publicación en el tablón de edictos del Ayuntamiento de su último domicilio o en el Diario Oficial correspondiente.

106 Publicada en el Boletín Oficial del Estado de 25 de noviembre de 2010 y que es el desarrollo de la previsión de la disp. final séptima de la Ley 18/2009, de 23 de noviembre, en cuanto que en ella se establecía la entrada en vigor de la redacción que se efectuaba para los arts. 77 y 78 LTSV en el plazo de un año desde su publicación (de la Ley 18/2009, de 23 de noviembre, que fue publicada en el Boletín Oficial del Estado de 24 de noviembre de 2009).
} 
la autenticidad e integridad de los contenidos en él publicados, y el resto de protecciones que se imponen a este tipo de sistemas.

La publicación de los edictos en el Tablón Edictal de Sanciones de Tráfico se realizará durante veinte días naturales (art. 78.1 LTSV y art. 10 Orden INT/3022/2010). Finalizado ese plazo la notificación se tendrá por realizada (art. 10.5 Orden INT/3022/2010) y se pondrá a disposición de la Administración emisora del edicto una diligencia acreditativa de la publicación firmada electrónicamente, en la que figurarán los datos del edicto y las fechas en que ha permanecido expuesto en estado vigente (art. 11 Orden INT/3022/2010).

\section{UNA VALORACIÓN DEL SISTEMA DE NOTIFICACIONES DE LA LTSV}

El régimen de notificaciones establecido en la Ley de Tráfico y Seguridad Vial tanto para la notificación de la denuncia como para el resto de notificaciones a las que dé lugar ese procedimiento sancionador y que procede de la reforma efectuada por la Ley $18 / 2009$, de 23 de noviembre, conforman un conjunto peculiar de disposiciones que a duras penas consiguen tejer un sistema.

Roto el cordón umbilical con la LRJ - PAC mediante la declaración de independencia del procedimiento sancionador en materia de tráfico y seguridad vial respecto del sistema general no se configurado un conjunto de reglas o principios sobre esta materia que, racionalmente enlazados entre sí, puedan ser calificados de un todo. Los avances son notables, se han injertado órganos nuevos de una calidad genética muy elevada. Pero por desgracia no todo está al nivel del sistema edictal electrónico. Esa parte sí configura un auténtico sistema (subsistema). Pero el sistema que se quiere configurar (que se crea en términos de la Exposición de Motivos de la Ley 18/2009, de 23 de noviembre) sigue lastrado por una notificación en un punto indeterminado que se califica de "domicilio" y que empeora la situación ya de por sí mala de la LRJ - PAC.

La notificación y, en especial, de aquellas cuestiones que ningún ciudadano le gusta conocer, sigue siendo una de las mayores carencias del procedimiento sancionador en materia de tráfico y del procedimiento administrativo en general.

Hecha esta consideración sería injusto no reconocer el avance que ha supuesto ese sistema que se ubica al lado del tradicionalmente más efectivo y que, sin lugar a dudas, es el de los asuntos tributarios.

Queda recorrido, y la incorporación de los medios que la tecnología pone a disposición de la sociedad y de la Administración sin duda han de permitir avanzar y crear un sistema que permita la comunicación y relación entre Administración con todas las garantías, para el ciudadano y también para la Administración. 


\section{LA PRUEBA}

\section{A) Regulación}

La regulación que del procedimiento sancionador efectúa la Ley de Tráfico y Seguridad Vial no contiene demasiadas referencias a la prueba, sus medios y práctica.

La LTSV, como la LRJ - PAC, es muy escueta en este sentido. En la LTSV ni siquiera hay una regulación sistemática que agrupe en un conjunto de preceptos o en un artículo (como sucede con el art. 17 REPEPOS) las diferentes disposiciones sobre esta materia. Existen, sí, referencias dispersas a lo largo de todo el articulado de la LTSV sobre cuestiones relativas a la prueba ${ }^{107}$ y menciones sobre aspectos específicos en la propia regulación del procedimiento administrativo sancionador, como son las realizadas sobre el uso de instrumentos, aparatos o medios y sistemas de medida empleados para la formulación de denuncias (art. 70.2 LTSV), la necesidad de respetar la declaración de hechos probados en el procedimiento penal (art. 72.3 LTSV), en el marco de la denuncia (art. $74.3 \mathrm{~d}$ LTSV), el valor probatorio de las denuncias de los Agentes de la Autoridad (art. 75 LTSV), la posibilidad de su práctica en el procedimiento (art. 79.1 LTSV) y en procedimiento sancionador ordinario (art. 81 LTSV).

A pesar de la capital importancia que la prueba tiene en cualquier procedimiento, y más cuando lo que se dirime es la imposición de una sanción, nos tenemos que conformar con expresiones formularias utilizadas a modo de coletillas ${ }^{108}$ o con el recordatorio de la facultad del instructor de acordar las que tenga por convenientes para el procedimiento. Ni siquiera nos encontramos en la LTSV con esa mención con la que se abre el artículo destinado en la LRJ - PAC a los medios y período de prueba conforme a la que "los hechos relevante para la decisión del procedimiento podrán acreditarse por cualquier medio de prueba admisible en derecho" (art. 80.1 LRJ - PAC).

\footnotetext{
107 Es el caso de las pruebas que se establecen para la detección de alcohol y sustancias prohibidas que se efectúan en los arts. 4 e), 5 o), 7 e), 10.6, 12.2 y 3, 65.5 d) LTSV, sobre el valor probatorio de las denuncias de los Agentes de la Autoridad en el art. 75 LTSV.

${ }^{108}$ Los arts. 74.3 d), 79.1 y 81 LTSV hacen uso, prácticamente, de los mismos términos al señalar, en relación al denunciado, de la disponibilidad de un plazo “... para formular las alegaciones y proponer las pruebas que estime convenientes", “... para formular las alegaciones y proponer o aportar las pruebas que estime oportunas" y “... para formular las alegaciones que tenga por conveniente y proponer o aportar las pruebas que estime oportunas".

Y en el RPSTSV, más de lo mismo, al margen de la sintética regulación del período de prueba efectuada en el art. 13, al señalar que “...para que aleguen cuanto consideren conveniente a su defensa y propongan las pruebas que estimen oportunas" (art. 10.1), que "...para que alegue cuanto considere conveniente a su defensa y proponga las pruebas que estime oportunas" (art. 12.1) y reiterar el valor probatorio, respecto de los hechos denunciados de las denuncias efectuadas por los agentes de la autoridad encargados de la vigilancia del tráfico (art. 14).
} 
$Y$ es que la prueba cumple una finalidad, como es acreditar un hecho. Pero no cualquier hecho. Tiene que tratarse de un hecho que resulte relevante para la decisión que en ese procedimiento se haya de adoptar y sobre el que no exista acuerdo entre las partes, "cuando la Administración no tenga por cierto los hechos alegados por los interesados o la naturaleza del procedimiento lo exija" (art. 80.2 LRJ - PAC). Por ello, para que se realice, la prueba tiene que ser "objetivamente necesaria"109, de manera que el derecho a utilizar los medios de prueba pertinentes no comprende un hipotético derecho a llevar a cabo una actividad probatoria ilimitada en virtud de la cual las partes estén facultadas para exigir cualesquiera pruebas que tengan a bien proponer, sino que atribuye sólo el derecho a la recepción y práctica de las que sean pertinentes $y$, puesto que se trata de un derecho de configuración legal, es preciso que la prueba se haya solicitado en la forma y momento legalmente establecidos ${ }^{110}$.

El art. 13 RPSTSV contiene una serie de disposiciones, bajo la rúbrica "período de prueba" sobre el presupuesto para su práctica, el plazo, los requisitos para su denegación y la atribución de los gastos en los que, por la práctica de esa prueba, se pudiera incurrir $^{111}$.

\footnotetext{
${ }^{109}$ Cfr. García de Enterría, E. y Fernández Rodríguez T.-R., Curso de Derecho Administrativo, Tomo II, 11ạ ed., Madrid, Civitas, 2008, pág. 508.

${ }^{110}$ En las SSTS de 30 de diciembre de 2003 (RJ 2004, 3153), SSTS de 21 de enero de 2004 (RJ 2005, 5665) y 31 de mayo de 2012 (RJ 2012, 9150), entre otras muchas, se resume y sintetiza la doctrina del Tribunal Constitucional sobre el derecho a la utilización de los medios de prueba pertinente, en las que se hace referencia, entre otras, a las SSTC 165/2001, de 16 de julio, F. 2, 168/2002, de 30 de septiembre, F. 3 y $131 / 2003$, de 30 de junio, F. 3.

${ }^{111}$ La Ley 18/2009, de 23 de noviembre, establecía, en su disp. final sexta, que "el Gobierno, a propuesta del Ministro del Interior, aprobará las normas necesarias para el desarrollo de esta Ley" y que, "n todo caso, en el plazo de seis meses desde que entre en vigor esta Ley, se dictará un nuevo reglamento de procedimiento sancionador en materia de tráfico, circulación de vehículos a motor y seguridad vial", sin que en la disp. derogatoria se hiciera referencia expresa alguna al RPSTSV que quedaba sometido a la derogatoria tácita que en ella se establecía.
}

Reproducimos aquí el contenido del art. 13 RPSTSV, cuya redacción originaria había sido objeto de modificación por el RD 137/2000, de 4 de febrero, y por el RD 318/2003, de 14 de marzo.

Artículo 13. Período de prueba

1. Cuando fuera necesario para la averiguación y calificación de los hechos o para la determinación de las posibles responsabilidades, el instructor acordará la apertura de un período de prueba, por un plazo no superior a treinta días ni inferior a diez, a fin de que puedan practicarse cuantas sean adecuadas.

El instructor del procedimiento sólo podrá rechazar mediante resolución motivada las pruebas propuestas por los interesados, cuando sean improcedentes.

En los casos en que, a petición del interesado, deban efectuarse pruebas cuya realización implique gastos que no deba soportar la Administración, ésta podrá exigir el anticipo de los mismos, a reserva de la liquidación definitiva, una vez practicada la prueba. La liquidación de los gastos se practicará uniendo los comprobantes que acrediten la realidad y cuantía de los mismos.

2. Una vez concluida la instrucción del procedimiento y practicada la audiencia al interesado por el órgano correspondiente, salvo cuando no figuren en el procedimiento ni sean tenidos en cuenta en la resolución otros hechos y otras alegaciones y pruebas que las aducidas por el interesado, el instructor elevará propuesta de resolución al órgano que tenga atribuida la competencia sancionadora para que dicte la resolución que proceda. 
EL RPSTSV reproduce las previsiones efectuadas en la LRJ - PAC sobre que el instructor acordará la apertura de un período de prueba, por un plazo no superior a treinta días ni inferior a diez, a fin de que puedan practicarse cuantas sean adecuadas (art. 13.1 RPS y art. 80.2 LRJ - PAC), que el instructor del procedimiento sólo podrá rechazar mediante resolución motivada las pruebas propuestas por los interesados cuando sean improcedentes ${ }^{112}$ y añade una previsión conforme a la cual la Administración puede exigir el anticipo de los gastos (a reserva de la liquidación definitiva) que se deriven de las pruebas que impliquen gastos que no deba soportar la Administración.

La cláusula de subsidiariedad establecida en el art. 70.2 LTSV nos conduce a la LRJ PAC y al REPEPOS, que tampoco contienen, como se ha señalado, una regulación detallada y que se limita a lo establecido en los arts. 80, 81 y 137.4 LRJ - PAC y en los arts. 16 y 17 REPEPOS.

Nada establece la LRJ - PAC sobre los medios de prueba en el procedimiento administrativo, que se limita, como ya se ha señalado, a indicar que "los hechos podrán acreditarse por cualquier medio de prueba admisible en Derecho", previsión que nos sitúa en las disposiciones generales del Código Civil (CC, arts. 1.214 - 1.256), las efectuadas por la Ley de Enjuiciamiento Civil (LEC, arts. 281 - 386) y las que se puedan encontrar en la Ley de la Jurisdicción Contencioso - Administrativa (LCA, arts. $60-61)$.

Sobre la carga de la prueba ${ }^{113}$, y teniendo en cuenta el básico principio de que incumbe al que afirma y no al que niega (en la ya derogada redacción del art. 1.214 CC y del vigente art. 217 LEC), a cada parte corresponde probar el supuesto de hecho de la norma cuyas consecuencias jurídicas invoca a su favor, lo que supone que ha de ser la Administración la que soporte la carga de probar la realización de la conducta que integra la infracción que pretende sancionar, y esta conclusión se ve aquí profundamente reforzada por virtud de la presunción de inocencia que establecida en

3. Cuando, por razón de la posible sanción de suspensión de la autorización administrativa para conducir, la Administración General del Estado deba conocer del expediente resuelto por las autoridades competentes de la Administración local o autonómica que hayan impuesto la sanción de multa correspondiente, estas autoridades, una vez que haya adquirido firmeza su resolución, remitirán el expediente a la autoridad competente de la Administración General del Estado. Esta última autoridad notificará la propuesta de resolución que contemple la suspensión del permiso o licencia de conducción que se pueda acordar y dará traslado ésta en trámite de audiencia, por 15 días, al interesado.

112 Eliminado, eso sí, la mención "o innecesarias" que efectúa el art. 80.3 LRJ - PAC.

113 Como señalan las SSTS de 22 de enero de 2000 (RJ 2000, 1044) y de 17 de mayo de 2012 (RJ 2012, 6828) "la carga de la prueba es un concepto no demasiado perfilado en el proceso contencioso, que se limita a ser tributario de la doctrina civilista nacida de los arts. 1.214 y siguientes del Código Civil. La importancia del expediente administrativo en nuestra jurisdicción explica la falta de relevancia de este tema. La carga de la prueba, paradójicamente tiene interés sólo cuando hay falta o ausencia de prueba de hechos relevantes. En ese caso, el Tribunal debe hacer la imputación lógica a la parte que quebrantó el onus probandi". 
el art. 24 CE, ha de operar plenamente en el ámbito de la potestad sancionadora de la Administración ${ }^{114}$.

Todo ello nos conduce, en el ámbito del procedimiento sancionador en materia de tráfico y seguridad vial a los medios de prueba, y en particular a determinados medios, a la forma en la que deben articularse y al valor, consideración y alcance que deba darse a determinados a determinados hechos probados ${ }^{115}$ y a determinadas pruebas, entre las que, sin duda, especial referencia merecen las denuncias de los Agentes de la autoridad, así como los instrumentos, aparatos o medios y sistemas de medida que sean utilizados para la formulación de denuncias por infracciones a la normativa de tráfico.

\section{B) El Valor probatorio de las denuncias de los Agentes de la Autoridad}

\section{De LOS TÉRMINOS EMPLEAdOS EN EL ART. 75 LTSV}

Bajo esta rúbrica el art. 75 LTSV establece que "las denuncias formuladas por los Agentes de la Autoridad encargados de la vigilancia del tráfico darán fe, salvo prueba en contrario, de los hechos denunciados y de la identidad de quienes los hubieran cometido, así como, en su caso, de la notificación de la denuncia, sin perjuicio del deber de aquéllos de aportar todos los elementos probatorios que sean posibles sobre el hecho denunciado".

La redacción actual, procedente de la Ley 18/2009, de 23 de noviembre, difiere de la precedente, la originaria, ubicada en el art. 76 LTSV $^{116}$, en varios aspectos.

De un lado, el uso de los términos "darán fe" en lugar de los de "harán fe". De otro la extensión de ese efecto a "los hechos denunciados y de la identidad de quienes los hubieran cometido, así como, en su caso, de la notificación de la denuncia", que

\footnotetext{
${ }^{114}$ Cfr. STS de 26 de diciembre de 1990 (RJ 1990, 10258) que recoge la doctrina establecida por las SSTS sentencias de 30 de marzo de 1987 (RJ 1987, 4162), de 26 de mayo de 1987 (RJ 1987, 5850), de 22 de febrero de 1988 (RJ 1988, 1378), de 31 de diciembre de 1988 (RJ 1988, 10278), de 20 de diciembre de 1989 (RJ 1989, 9222), de 20 de junio (RJ 1990, 5218) y de 25 de septiembre de 1990 (RJ 1990, 7386).

Y de forma específica en el procedimiento sancionador en materia de tráfico y seguridad vial, por ejemplo, las STSJ Cataluña de 2 de noviembre de 2001 (JUR 2002, 92724) y de 16 de noviembre de 2001 (JUR 2002, 93249).

${ }^{115}$ Algo especialmente relevante dado que el art. 72.3 LTSV establece que "la resolución que se dicte deberá respetar, en todo caso, la declaración de hechos probados en dicho procedimiento penal", en referencia al procedimiento administrativo sancionador que se suspende por haberse puesto de manifiesto hechos que ofrezcan apariencia de delito o falta perseguible de oficio y queda la espera del resultado de ese proceso penal.

${ }^{116}$ Esta cuestión se contenía en el art. 76 LTSV que no sufrió cambio hasta la reforma efectuada por la Ley 18/2009, de 23 de noviembre, y en el que se disponía "Las denuncias efectuadas por los Agentes de la Autoridad encargados de la vigilancia del tráfico harán fe, salvo prueba en contrario, respecto de los hechos denunciados, sin perjuicio del deber de aquéllos de aportar todos los elementos probatorios que sean posibles sobre el hecho denunciado".
} 
anteriormente únicamente se señalaba (de manera expresa) "respecto de los hechos denunciados".

La sustitución de la expresión "harán fe" por la de "darán fe" resulta, desde una perspectiva semántica, acertada y correcta, ya que por "dar fe" se entiende "asegurar algo que se ha visto", mientras "hacer fe" significa "ser suficiente o tener los requisitos necesarios para que se crea lo que se dice o ejecuta", lo que hace mucho más precisos, en relación al efecto que se quiere señalar, a los términos ahora utilizados que a los empleados con anterioridad. No se trata, como ha puesto de manifiesto CANO CAMPOS $^{117}$, de una presunción de certeza o veracidad, se trata del valor que se atribuye, en el procedimiento sancionador en este caso, a la declaración realizada por el Agente de la Autoridad.

\section{De LOS EFECTO DE LA PREVISIÓN DEL ART. 75 LTSV}

El art. 75 LTSV atribuye un valor probatorio a las denuncias formuladas por los Agentes de la Autoridad encargados de la vigilancia del tráfico (y no a cualquier tipo de Agente de la Autoridad).

El valor que, como prueba, se atribuye al contenido de las denuncias formuladas por los Agentes de la Autoridad no supone, por sí mismo, la destrucción de la presunción de inocencia del denunciado (algo que ha preocupado, y mucho, a muchos autores). Es una prueba aportada por la Administración y lo que hace el legislador es establecer una regla legal de valoración de esa prueba que, para llegar a destruir la presunción de inocencia, habrá de cumplir con una serie de condiciones ${ }^{118}$ y "en tal sentido, el derecho a la presunción de inocencia comporta que la sanción esté basada en actos o medios probatorios de cargo o incriminadores de la conducta reprochada; que la carga de la prueba corresponde a quien acusa, sin que nadie esté obligado a probar su propia inocencia, y que cualquier insuficiencia en el resultado de las pruebas practicadas, libremente valorado por el órgano sancionador, debe traducirse en un pronunciamiento absolutorio"119, por lo que "resulta de todo punto aplicable al procedimiento administrativo sancionador la exigencia de un acervo probatorio suficiente, recayendo sobre la Administración pública actuante la carga probatoria

\footnotetext{
${ }^{117}$ Véase, en particular, CANO CAMPOS, T., El régimen jurídico - administrativo del tráfico, 2a ed., Madrid, Civitas, 2010, 2a ed., pág. 524 y, de manera general, Presunciones y valoración legal de la prueba en el derecho administrativo sancionador, Civitas, 2008, 242 págs.

${ }^{118}$ CANO CAMPOS, que estudia profusamente esta cuestión señala que "se trata de una regla legal de valoración de la prueba que no hace más que positivizar las «reglas de la sana crítica» o «las máximas de experiencia» que la Administración o el Juez, en virtud del principio de libre valoración de la prueba, aplicaría generalmente a tales documentos a la hora de determinar su fuerza probatoria y su virtualidad como medios de prueba para destruir en el ámbito sancionador el derecho fundamental de inocencia ( $E I$ régimen jurídico - administrativo del tráfico, 2a ed., Madrid, Civitas, 2010, 2a ed., pág. 525). NIETo hace un análisis sobre la carga de la prueba y su redistribución a través de las resoluciones del TC y del TS (Derecho Administrativo Sancionador, Madrid, Tecnos, 2012, 5a ed., págs. 370 a 372).

${ }^{119}$ SSTC 76/1990, de 26 de abril, F. 8 b) y 169/1998, de 21 de julio, F. 2.
} 
tanto de la comisión del ilícito como de la participación del acusado, sin que a éste pueda exigírsele una probatio diabolica de los hechos negativos" ${ }^{\prime 20}$.

En esa valoración (reconocer, estimar o apreciar el valor o mérito de alguien o algo) se determinará si el contenido acredita los dos elementos que se le exigen para destruir la presunción de inocencia, "comisión del ilícito" y "participación del acusado", extremos sobre los que, efectivamente el art. 75 LTSV ofrece una regla de valoración sobre "los hechos denunciados" y "la identidad de quienes los hubieran cometido". En la medida en que la denuncia reúna esos requisitos se desvirtuará la presunción de inocencia y, de igual manera, si esa denuncia no se desprende prueba suficiente no se podrá imponer la sanción por no haberse desvirtuado ese derecho del denunciado.

Pasar de lo que se ha señalado resulta complicado. No porque no se pueda explicar perfectamente en el plano teórico ${ }^{121}$, sino por la confusión que impera en la práctica.

\section{Del alCANCE del Valor PROBAtorio de LAS denUnCias de los AgenteS}

Si nos abstraemos del entorno y nos centramos en la disposición (lo que señala el art. 75 LTSV) y su ámbito de aplicación (en el procedimiento sancionador en materia de tráfico y seguridad vial) lo que encontramos es un precepto que ubicado tras el que regula la denuncia pretende determinar el valor que debe atribuirse a su contenido.

El art. 75 LTSV establece que las denuncias de esos Agentes de la Autoridad darán fe de determinadas cuestiones ( $y$ no de todas las que pudieran aparecer en esa denuncia). Así, las denuncias, "darán fe", en el sentido de asegurar, sobre el hecho, sobre la identidad (si figura en la denuncia) de la persona denunciada (no se utiliza el término "autor") y, caso de haberse realizado, de la notificación de la denuncia.

Pero el artículo 75 LTSV no se agota en esas previsiones, y establece que ello no exime al Agente de la autoridad de aportar todos los elementos probatorios que sean posibles sobre el hecho denunciado, que es su deber, es decir, de dotar a ese acto de puesta en conocimiento de un hecho constitutivo de infracción de la estructura que le de soporte, que dependerá del tipo de infracción y de las circunstancias concurrentes.

Es más, si la LTSV no dispusiera nada, si no atribuyera a las denuncias de los Agentes el valor probatorio que le confiere... esas denuncias seguirían teniendo valor probatorio en cuanto se trata de documentos públicos expedidos por Agentes de la Autoridad en el ejercicio de sus funciones y en la medida que contuvieran los elementos necesario

\footnotetext{
${ }^{120}$ SSTEDH Caso Messegué y Jabardo contra España, de 6 diciembre 1988, Caso John Murray contra el Reino Unido, de 8 febrero 1996 y Caso Telfner contra Austria, Sentencia de 20 marzo 2001 y SSTC 182/1989, de 3 de noviembre, F. 2 y 45/1997, de 11 de marzo, F. 4.

${ }^{121}$ CANO CAMPOS describe de manera exhaustiva y precisa esa denominada "presunción de veracidad", su relación con la "presunción de inocencia" (sobre la que señala que tampoco es presunción), la inexistencia de "inversión de carga de la prueba"... pero en la práctica se dicen otras muchas cosas (EI régimen jurídico - administrativo del tráfico, 2aㅡ ed., Madrid, Civitas, 2010, 2a ed., págs. 523 a 534).
} 
para constituirse en prueba de cargo suficiente para destruir la presunción de inocencia del denunciado, conforme a lo establecido en el art. 137.4 LRJ - PAC (precepto que bajo la rúbrica "presunción de inocencia" se enmarca en los principios del procedimiento administrativo sancionador), y por ello, las denuncias habrían de producir exactamente los mismos efectos ${ }^{122}$.

\section{INSTRUMENTOS DE MEDICIÓN}

\section{A) Introducción}

En ocasiones los tipos administrativos previstos en la LTSV son susceptibles de ser medidos, es decir, de "comparar una cantidad con su respectiva unidad"123. En realidad la existencia de una transgresión de la norma (conducta) se determina en función de una escala mensurable, de manera que la infracción se produce al sobrepasarse un punto de una escala. Tal es el caso de las previsiones efectuadas en el ámbito de la "velocidad" y de "las tasas de alcohol". Se permite, se tolera, conducir a determinada velocidad o con determinada tasa de alcohol, pero se prohíbe hacerlo por encima (o incluso por debajo) de determinada velocidad, o con determinada tasa de alcohol.

En estos supuestos la referencia entre lo que está permitido y lo que está prohibido se hace en relación a una escala: kilómetros/hora en el caso de la velocidad y gramos de alcohol/litro de sangre o miligramos alcohol/litro de aire espirado para las bebidas alcohólicas..

La constatación de estas infracciones exige medir, y que los hechos se ubiquen en el espacio prohibido de esa escala, para poder determinar la propia existencia de la conducta proscrita.

El art. 70.2 LTSV dispone que "los instrumentos, aparatos o medios y sistema de medida que sean utilizados para la formulación de denuncias por infracciones a la normativa de tráfico estarán sometidos a control metrológico en los términos establecidos por la Ley 3/1985, de 18 de marzo, de Metrología y su normativa de desarrollo", norma en la que se dispone que "están sujetos a control metrológico del Estado todos los objetos y elementos de aplicación en metrología, así como las mediciones que reglamentariamente se determinen", tal y como señala el art. 6 Ley 3/1985, de 18 de marzo, de Metrología (LM).

Nos encontramos con una previsión normativa, introducida por la Ley 18/2009, de 23 de noviembre, que, hasta ese momento, no había sido recogida de manera expresa ni

\footnotetext{
${ }^{122}$ Tal y como señala CANO CAMPOS como corolario de su análisis (El régimen jurídico - administrativo del tráfico, 2a ed., Madrid, Civitas, 2010, 2a ed., pág. 534)

${ }^{123}$ Primera de las acepciones que, para el término "medir" ofrece el Diccionario de la Real Academia Española.
} 
en el texto de la LTSV ni en la normativa que la desarrollaba. Y, ciertamente, han existido y existen (como hemos señalado), infracciones que requieren para su determinación, por su propia naturaleza y la forma en la que están tipificadas, de su medición.

De esta forma, la LTSV se remite a la normativa correspondiente, la Ley de Metrología y su normativa de desarrollo. En este sentido es preciso señalar que el art. 149.1.12a CE otorga al Estado competencia exclusiva ${ }^{124}$ en esta materia (legislación sobre pesas y medidas), concepto, éste, sobre el que la propia introducción que antecede al articulado de la Ley $3 / 1985$, de 18 de marzo, de Metrología, señala que "el antiguo concepto de "pesas y medidas» ha sido sustituido, en las nuevas legislaciones, por el de «metrología», como así ya se recogió en el primer Documento Internacional de la Organización Internacional de Metrología Legal, denominado «Ley de Metrología», a la que España se halla adherida". De igual manera no se puede ignorar el impacto que, sobre este ámbito normativo, han tenido, y tienen, las disposiciones emanadas de la Unión Europea sobre "aproximación de las legislaciones de los Estados miembros sobre las disposiciones comunes a los instrumentos de medida y a los métodos de control metrológico".

La redacción originaria de la Ley de Metrología ha sufrido varias modificaciones y ha sido ampliamente desarrollada. De esos diferentes ámbitos en los que se ha desarrollado la Ley interesan, muy especialmente, los que de manera directa pueden

${ }^{124}$ Cuestión distinta es como hemos de entender este título competencial. Y ello por haber sido objeto de discusión desde que se realizaran los primeros desarrollos reglamentarios de la Ley 3/1985, de 18 de marzo, de Metrología.

Un estupendo y sintético resumen de esta cuestión se encuentra en los párrafos 20 y 30 de la introducción que antecede al RD889/2006, de 21 de julio, que regula el control metrológico del Estado sobre instrumentos de medida, lugar en el que se puede leer el siguiente texto:

“La Ley 3/1985, de 18 de marzo, de Metrología, fue desarrollada, en relación con el control metrológico del Estado de instrumentos, aparatos, medios y sistemas de medida, por los Reales Decretos 1616/1985, de 11 de septiembre, por el que se establece el control metrológico que realiza la Administración del Estado; 1617/1985, de 11 de septiembre, por el que se establece el procedimiento para la habilitación de laboratorios de verificación metrológica oficialmente autorizados; 1618/1985, de 11 de septiembre, por el que se establece el Registro de Control Metrológico, derogado por el Real Decreto 914/2002, de 6 de septiembre, y el Real Decreto $597 / 1988$, de 10 de junio, por el que se regula el Control Metrológico CEE.

Por otro lado, el Tribunal Constitucional en sus sentencias de 13 de mayo (STC 100/1991, de 13 de mayo) y 12 de diciembre de 1991 (STC 236/1991, de 12 de diciembre), emitió sendos fallos sobre el recurso de inconstitucionalidad planteado por la Comunidad Autónoma de Cataluña y sobre diversos conflictos positivos de competencias planteados igualmente por las Comunidades Autónomas de Cataluña, País Vasco y Andalucía contra la legislación metrológica anteriormente mencionada, declarando que corresponde a las Comunidades Autónomas citadas la titularidad de las competencias ejecutivas previstas en los Reales Decretos $1616 / 1985,1617 / 1985$, y 1618/1985, todos ellos de 11 de septiembre, y el Real Decreto $597 / 1988$, de 10 de junio".

Que, por otra parte, es la razón por la que las Comunidades Autónomas han establecido un gran número de disposiciones en este ámbito. Sin ánimo de ser exhaustivos existe regulación autonómica sobre órganos competentes en materia de control metrológico, medios para la ejecución del control metrológico, verificación y reparación de instrumentos. 
afectar a las infracciones en materia de tráfico y seguridad vial que, como hemos señalado, son los relativos a determinar la velocidad de los vehículos y a comprobar las tasas de alcohol. Se trata, por un lado, de la Orden ITC/3123/2010, de 26 de noviembre, por la que se regula el control metrológico del Estado de los instrumentos destinados a medir la velocidad de circulación de vehículos a motor ${ }^{125} \mathrm{y}$, de otro, la Orden ITC/3707/2006, de 22 noviembre, por la que se regula el control metrológico del Estado de los instrumentos destinados a medir la concentración de alcohol en el aire espirado ${ }^{126}$.

\section{B) Cuestiones comunes a los instrumentos, aparatos o medios y sistema de medida que sean utilizados para la formulación de denuncias por infracciones a la normativa de tráfico}

La interacción que se produce entre determinación de la existencia de una infracción (en materia de tráfico y seguridad vial) y la medición utilizada para formular la denuncia por esa infracción requiere de un análisis detallado.

Una parte importante de ese análisis se muestra, de manera expresa, en la propia formulación que, como ya hemos puesto de manifiesto, la LTSV realiza en el art. 70.2 al señalar que "los instrumentos, aparatos o medios y sistema de medida que sean utilizados para la formulación de denuncias por infracciones a la normativa de tráfico estarán sometidos a control metrológico en los términos establecidos por la Ley 3/1985, de 18 de marzo, de Metrología y su normativa de desarrollo".

Se trata de una remisión desde la norma que ocupa la cúspide del ordenamiento normativo en materia de tráfico y seguridad vial (la LTSV) hacia un grupo normativo concreto, el que regula la "metrología", encabezado por la Ley 3/1985, de 18 de marzo, de Metrología ${ }^{127}$, que, a su vez, tiene su correspondiente desarrollo normativo.

\footnotetext{
${ }^{125}$ Publicada en el Boletín Oficial del Estado de 3 de diciembre de 2010 y por la que se deroga la Orden ITC/3699/2006, de 22 noviembre, de control metrológico del Estado sobre instrumentos de medida de velocidad de vehículos a motor, que, a su vez, había derogado Orden derogó la Orden del Ministerio de Obras Públicas, Transporte y Medio Ambiente, de 11 de febrero de 1994, por la que se regulaban los cinemómetros destinados a medir la velocidad de circulación de vehículos a motor.

${ }^{126}$ Publicada en el Boletín Oficial del Estado de 7 de diciembre de 2006 y por la que se procedió a la derogación de la Orden de 27 julio 1994, que establecía el control metrológico del Estado para los instrumentos destinados a medir la concentración de alcohol en el aire espirado.

${ }^{127}$ Esta forma de remisión, la aquí utilizada por el legislador, no parece la más adecuada. La norma se remite a una norma identificándola de manera concreta y determinada. Considero mucho más adecuado que estas remisiones se realicen de forma genérica a la norma o normas que regulan un sector, en este caso se me antoja preferible que la referencia se hubiera realizado "a las normas que regulan la metrología". Frente a la falta de determinación concreta, inherente a este tipo de fórmulas, se produce la ventaja que, ante un cambio normativo, como podría ser la derogación de la Ley 3/1985, de Metrología, no se plantearía la duda de si nos hallamos ante una remisión estática o dinámica. Si mañana cambia la Ley de Metrología no sabremos si el espíritu de la LTSV es mantener la remisión a la norma derogada o, por el contrario, se prefiere entender que la remisión lo es, a partir de ese momento, a la nueva norma.
} 
Poner de manifiesto, esta remisión de manera expresa, es correcto, puesto que de no hacerlo tendríamos que entender que existe (y no puede ser de otra manera) una remisión tácita, salvo que el legislador se tomara la inútil e innecesaria molestia de crear un sistema normativo (en este caso sobre metrología) específico para el concreto ámbito de las infracciones en materia de tráfico y seguridad vial. Luego se ha adoptado lo solución más adecuada.

Ahora bien, haber actuado correctamente no es óbice para que, en el mundo de los hechos, se planteen una serie de problemas que, tal y como indicábamos al principio de este mismo apartado no son más que las consecuencias, en la práctica, de "la acción que se ejerce recíprocamente" (que es la definición que el RAE otorga a interacción) entre un sector regulado concreto, como es el de la "metrología" y un terreno específico como es el de "las denuncias por infracciones a la normativa de tráfico y seguridad vial".

El punto a partir del cual se establece la existencia de infracción a las normas de tráfico, como ocurre tanto en el ámbito de la velocidad como en el de la alcoholemia, se basa en valores objetivos. Superar la velocidad o sobrepasar una determinadas tasas de alcohol constituyen el presupuesto de la comisión de la infracción ${ }^{128}$.

Las normas, en sí mismas, parecen claras (como tendremos ocasión de analizar en los apartados dedicados específicamente a cada una de ellas). La infracción de velocidad, art. 65.4 a) y b) y 5 a) y b) se remite al Anexo IV de la propia LT (no respetar los límites de velocidad establecidos reglamentariamente, ya sea en un punto concreto o de velocidad media superior en un tramo, "de acuerdo con lo recogido en el Anexo IV). Para el supuesto de la ingesta de alcohol se hace referencia a que esas tasas de alcohol sean superiores a las que reglamentariamente se establezcan, lo que nos conduce al art. 20 RGC.

Pero lo cierto es que, en ambos casos, la determinación de la infracción requiere, tal y como previene el art. 70.2 LTSV de "instrumentos, aparatos o medios y sistema de medida", lo que nos sitúa en el grupo normativo que regula la metrología.

Y aquí, es preciso entender los requisitos que la metrología, desde el punto de vista de la seguridad jurídica, exige en la realización de mediciones, y ponerlo en relación, situarlo, en el concreto y estricto ámbito del derecho administrativo sancionador

\footnotetext{
${ }^{128}$ El art. 12.1 LTSV dispone que "no podrá circular por la vías objeto de esta Ley, el conductor de vehículos o bicicletas con tasas superiores a las que reglamentariamente se establezcan de bebidas alcohólicas" y el art. 65.5 c) LTSV establece que "la conducción por las vías objeto de esta Ley habiendo ingerido bebidas alcohólicas con tasas superiores a las que reglamentariamente se establezcan...", tasas que concreta el art. 20 RGC.

Sin querer pecar de reiterativo es preciso señalar que el art. 19.2 LT hace referencia a "velocidad máxima y mínima" y el art. 49 RGC establece que "se prohíbe la circulación en autopistas y autovías de vehículos a motora una velocidad inferior a 60 kilómetros por hora, y en las restantes vías, a una velocidad inferior a la mitad de la genérica señalada para cada categoría de vehículos de cada una de ellas en este Capítulo, aunque no circulen otros vehículos".
} 
como procedimiento que, por sus consecuencias, supone una especial intromisión en la esfera de derechos, y por tanto de garantías, del ciudadano, que no por ser infractor (o presunto infractor) queda desposeído del resguardo que nuestro ordenamiento jurídico le otorga.

El sistema de normas que regulan la metrología va a imponer una serie de condiciones y requisitos a esos instrumentos y aparatos en aras de garantizar que el resultado de la medición efectuada es correcto ${ }^{129}$. De esta manera el art. 7 LM, establece, en lo que aquí interesa, que "los instrumentos, aparatos, medios y sistemas de medida que sirvan para pesar, medir o contar y que sean utilizados en aplicaciones de medida por razones de ... sanciones administrativas ... estarán sometidos al control metrológico del Estado, cuando esté establecido, o se establezca, por reglamentación específica” ${ }^{130}$. Este es el motivo que obliga a la remisión desde la LTSV (que el art. 70.2 manifiesta de manera expresa) al grupo normativo que regula la metrología.

Es en el ap. 2 del propio art. 7 LM, el lugar en el que encontramos la concreción de lo que hemos de entender por estar "sometidos al control metrológico del Estado" y que se identifica con la "evaluación" y "control" de esos instrumentos, aparatos o medios a los que se refiere el art. 70.2 LTSV. Se trata de dos funciones que, con un mismo objeto, se realizan de una forma genérica, y previa ${ }^{131}$, antes de que entre en funcionamiento el tipo de aparato y de una forma específica, sobre cada aparato en concreto, una vez que han entrado en funcionamiento ${ }^{132}$.

\footnotetext{
${ }^{129}$ En términos de la introducción que antecede al cuerpo de la Ley 3/1985, de 18 de marzo, de Metrología, "se establece el control metrológico por parte del Estado, con el fin de velar por la corrección y exactitud de las medidas" (inciso inicial del párr. 40 de la referida introducción)

${ }^{130}$ La redacción íntegra del art. 7.1 de la Ley 3/1985, de 18 de marzo, de Metrología, establece que "Los instrumentos, aparatos, medios y sistemas de medida que sirvan para pesar, medir o contar y que sean utilizados en aplicaciones de medida por razones de interés público, salud y seguridad pública, orden público, protección del medio ambiente, protección de los consumidores y usuarios, recaudación de impuestos y tasas, cálculo de aranceles, cánones, sanciones administrativas, realización de peritajes judiciales, establecimiento de las garantías básicas para un comercio leal y todas aquellas que puedan determinarse con carácter reglamentario, estarán sometidos al control metrológico del Estado, cuando esté establecido, o se establezca, por reglamentación específica".

Ello supone que, en realidad son varios los supuestos o razones que pudieran centrar nuestra atención. Hemos destacado "sanciones administrativas" por entender que es la causa que, de una manera más específica, se adapta a nuestro caso, pero ello no nos debe hacer ignorar otras de las razones expresamente mencionadas como pudieran ser el interés público, la seguridad pública, el orden público, así como la genérica cláusula de cierre "y todas aquellas que puedan determinarse con carácter reglamentario".

${ }^{131}$ Aunque el art. 7.2 de la Ley 3/1985, de 18 de marzo, de Metrología (que se trascribe en la siguiente nota), no explicita, de una forma totalmente clara, que ese control será previo a su puesta en servicio, el art. 3.3 del RD889/2006, de 21 de julio, que regula el control metrológico del Estado sobre instrumentos de medida así lo manifiesta claramente al señalar que "La fase de control metrológico del Estado desarrollada en este capítulo será aplicable a los instrumentos de medida con carácter previo a su puesta en servicio, en base a los procedimientos de evaluación de la conformidad..."

${ }^{132}$ Los dos párrafos que integran el art. 7.2 de la Ley 3/1985, de 18 de marzo, de Metrología, están redactados en los siguientes términos:
} 
Sobre esta base, y como desarrollo específico en un ámbito de medición concreto, las órdenes que establecen la regulación del control metrológico del Estado de los cinemómetros (Orden ITC/3123/2010, de 26 de noviembre) y de los etilómetros (Orden ITC/3707/2006, de 22 noviembre) establecen, y por lo tanto exigen, unos determinados estándares de fiabilidad, o lo que es lo mismo determinan los errores máximos permitidos.

Esto supone que para que un modelo concreto de instrumento o aparato medidor reciba la evaluación de conformidad, es decir, la autorización previa para ser comercializado tiene que ser lo suficientemente preciso y no desviarse más allá de los límites establecidos para ese tipo de aparatos. Se le está concediendo un pequeño margen de error, una tolerancia. En eso consiste el "error máximo permitido".

La admisión de este concepto en el marco de la determinación de las infracciones y del correspondiente procedimiento sancionador supone, sencillamente, desplazar el punto de la escala en el mismo valor que se admite como "error máximo permitido", de forma que el valor que habrá de superarse para que se pueda considerar cometida la infracción será el fijado en la normativa de tráfico incrementado en el mismo valor que se concede como margen de error al aparato o instrumento de medición. Actuar de otra manera supondría transgredir el principio constitucional de presunción de inocencia aplicable en el derecho administrativo sancionador puesto que sería admitir una posibilidad de error en la forma de constatar infracciones y no asumir esa misma posibilidad de error (en el mismo grado) en las conductas infractoras.

Cuáles son esos espacios en los que según la letra de la norma existe infracción y en los que conforme a la integración de las normas que rigen el derecho administrativo sancionador en materia de tráfico y seguridad vial con las que regulan la metrología no se puede asegurar de forma absoluta la existencia de infracción y, por lo tanto, debe prevalecer el principio de presunción de inocencia, son objeto de análisis específico en el marco de los apartados destinados al examen de las concretas infracciones susceptibles de ser determinadas con instrumentos, aparatos o medios y sistemas de medida que sean utilizados para la formulación de denuncias por infracciones a la normativa de tráfico y seguridad vial que, en todo caso, habrán de corresponderse con instrumentos reconocidos en nuestro sistema para realizar esas mediciones con todas las garantías.

“El control previsto en el apartado anterior comprenderá la fase de evaluación de la conformidad, que comprueba el cumplimiento de los requisitos que deberán satisfacer a efectos de su comercialización y puesta en servicio.

Igualmente comprenderá, en su caso, la fase de control metrológico de instrumentos en servicio, que puede efectuarse mediante verificación periódica o después de reparación o modificación, que tiene por objeto comprobar y confirmar que un instrumento o sistema de medida en servicio mantiene las características metrológicas originales". 


\section{C) La medición en las infracciones de velocidad ${ }^{133}$}

\section{EL PLANTEAMIENTO DE LA LTSV}

Las infracciones en materia de velocidad suponen, cuantitativamente, la mayor parte de las que se denuncian en el ámbito del tráfico y seguridad vial y, cualitativamente, una de las tres causas (las otras dos son conducción bajo los efectos del alcohol y no usar los dispositivos de seguridad) que más repercusión tienen en la siniestralidad del tráfico de vehículos ${ }^{134}$.

De igual manera es digno de mención que uno de los mayores esfuerzos en la evolución de la LTSV y, en particular, de la reforma efectuada por medio de la Ley $18 / 2009$, de 23 de noviembre, se dirige a objetivar, mediante la indicación precisa de la sanción correspondiente en una cantidad exacta, las consecuencias de estas infracciones $^{135}$.

La consecuencia es que la tipificación de las infracciones, graves y muy graves, en materia de velocidad, ya sea por "no respetar los límites de velocidad", ya sea por "circular en un tramo a una velocidad media superior a los límites establecidos" se asocia, en cuanto a sus consecuencias, a lo establecido en el Anexo IV de la propia LT ("de acuerdo con lo recogido en el Anexo IV" en los términos que emplea la LT).

El Anexo IV consiste en un "cuadro de sanciones y puntos por exceso de velocidad" (y así se denomina) para el caso de infracciones sobre exceso de velocidad captado por cinemómetro", cuadro que pone en relación los límites de velocidad con los excesos sobre esos mismos límites, de manera que a un exceso concreto sobre un límite concreto se le asocia una consecuencia determinada y que, por lo tanto, al estar prefijada es perfectamente conocible "a priori" por el conductor.

\footnotetext{
133 La evolución de los medios por los que, a lo largo del tiempo, se han controlado y denunciado las infracciones en materia de velocidad puede comprobarse en "Radares: Una historia de toda velocidad" en Tráfico y Seguridad Vial, no 204, 2010, págs. 38 a 41.

134 La Comunicación de la Comisión Programa de acción europeo de seguridad vial, documento $\operatorname{COM(2003)} 311$ final, de 2 de junio de 2003, señalaba que todos los estados miembros se enfrentan a los mismos problemas de seguridad vial y que se conocen perfectamente las principales causas de accidentes, siendo la primera de ellas la velocidad excesiva e inadaptada que es la causante de aproximadamente un tercio de los accidentes mortales y graves, siendo además factor determinante de la gravedad de las lesiones.

135 El Preámbulo de la Ley 18/2009, de 23 de noviembre, tras describir como la misma infracción en materia de velocidad daba lugar a sanciones diferentes, señala en el párr. 4ㅇ del apartado IV que "Ias anteriores situaciones descritas han motivado que se proceda ahora a definir la cuantía de la multa en una cantidad exacta", lo que, evidentemente, produce una mayor seguridad jurídica en cuanto al resultado de las conductas transgresoras.
} 
El contenido del Anexo IV de la LT tal y como lo introdujo la Ley 18/2009, de 23 de noviembre, es el siguiente:

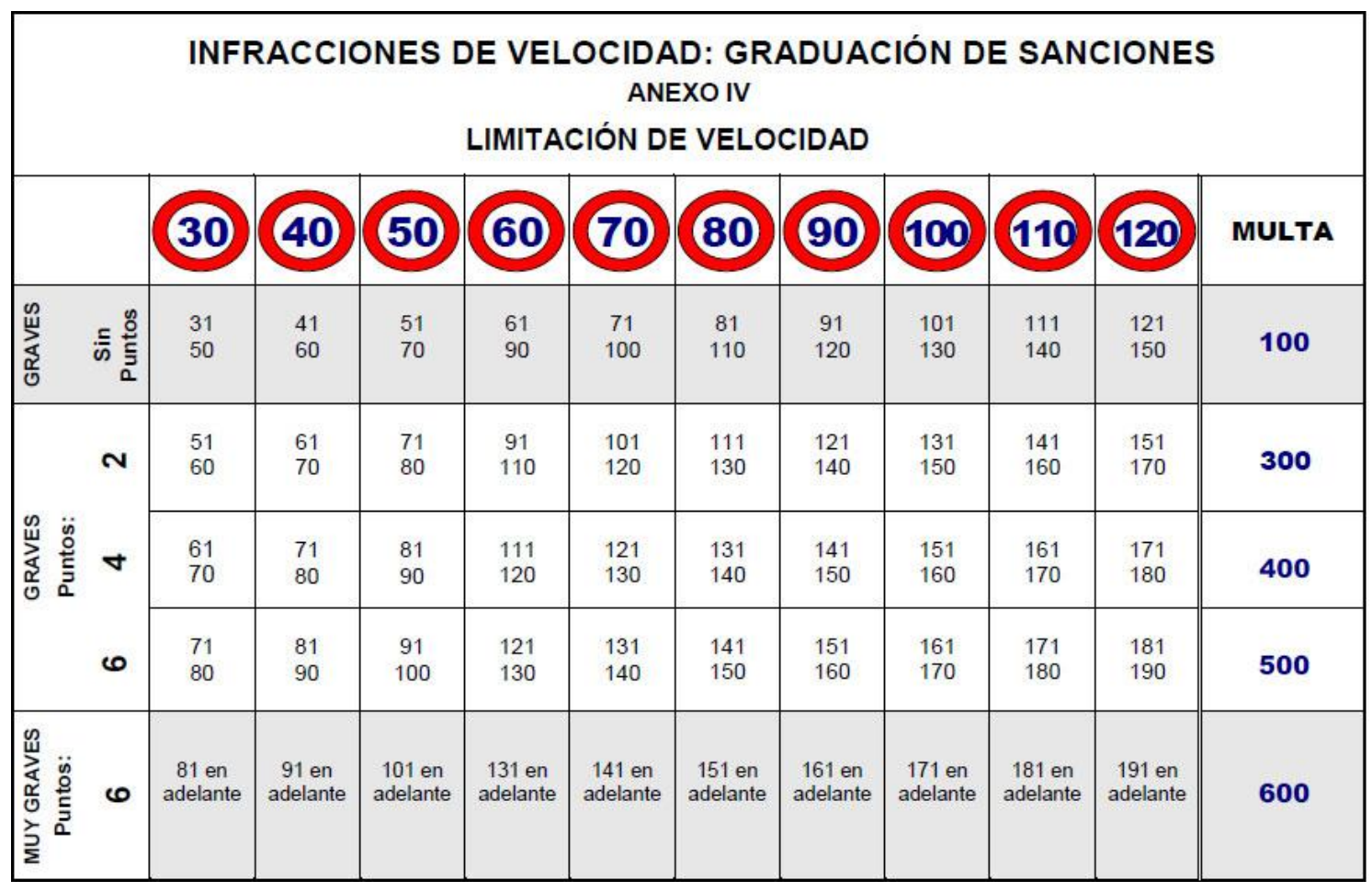

En los tramos de autovías y autopistas interurbanas de acceso a las ciudades en que se hayan establecido límites inferiores a $100 \mathrm{~km} / \mathrm{h}$, los excesos de velocidad se sancionarán con la multa económica correspondiente al cuadro de sanciones del anexo IV. El resto de los efectos administrativos y penales sólo se producirá cuando superen los $100 \mathrm{~km} / \mathrm{h}$ y en los términos establecidos para este límite.

El examen de la tabla permite determinar que, aunque aparentemente se refleja en la misma la realidad de la LTSV, eso no es cierto. La aplicación de los márgenes de error, los "errores máximo permitidos" a los cinemómetros desvirtúan en la práctica las previsiones efectuadas en este Anexo IV. Al menos sería preciso haber introducido una nota general que especificara que los números que se indican en la tabla están sometidos a los propios márgenes de error (errores máximos permitidos) establecidos en la Orden ITC/3123/2010, de 26 de noviembre, por la que se regula el control metrológico del Estado de los instrumentos destinados a medir la velocidad de circulación de vehículos a motor.

2. LOS ERRORES MÁXIMOS PERMITIDOS EN LOS INSTRUMENTOS UTILIZADOS PARA MEDIR LA VELOCIDAD DE LOS VEHÍCULOS A MOTOR

a) Sobre la existencia de diferentes tipos de cinemómetros

El art. 9 de la Orden ITC/3123/2010, de 26 de noviembre, por la que se regula el control metrológico del Estado de los instrumentos destinados a medir la velocidad de 
circulación de vehículos a motor establece que "los errores máximos permitidos en la verificación después de reparación o modificación serán los establecidos para cada instrumento en sus correspondientes anexos de requisitos esenciales a los que se refiere el artículo 3 de la presente Orden", precepto, este último que se remite a los Anexos III, IV y V, y ello en función del tipo de cinemómetro. Luego, y para empezar nos vamos a encontrar con márgenes de error diferentes para cada tipo de instrumento de medición de velocidad.

Puede tratarse de "cinemómetros destinados a medir la velocidad instantánea de circulación de los vehículos a motor desde emplazamientos estáticos o a bordo de vehículos" (Anexo III), o de "cinemómetros destinados a medir la velocidad de circulación de los vehículos a motor desde aeronaves" (Anexo IV) o, por último, de "cinemómetros destinados a medir la velocidad media de circulación de los vehículos a motor sobre tramos de distancias conocidas" (Anexo V), lo que hace preciso analizar de forma separada cada uno de estos tres supuestos dado que los márgenes de error aplicables a cada uno de estas clase de cinemómetros es diferente lo que hace, a su vez, variar las consecuencias.

\section{b) De los diferentes errores máximos permitidos para cada tipo de cinemómetro}

De lo dispuesto en los Anexos de la Orden ITC/3123/2010, de 26 de noviembre, por la que se regula el control metrológico del Estado de los instrumentos destinados a medir la velocidad de circulación de vehículos a motor, se desprende la existencia de los diferentes errores máximos permitidos:

Cinemómetros destinados a medir la velocidad instantánea de circulación de los vehículos a motor desde emplazamientos estáticos o a bordo de vehículos (Anexo III Orden ITC/3123/2010, de 26 de noviembre)

- En examen de modelo y verificación de producto

\begin{tabular}{|c|c|c|}
\hline & \multicolumn{2}{|c|}{ Errores máximos permitidos } \\
\hline Tipo de instalación & $\begin{array}{l}\text { Para ensayos en laboratorio } \\
\text { (por simulación de señales) }\end{array}$ & $\begin{array}{l}\text { Para ensayos en carretera } \\
\text { (tráfico real) }\end{array}$ \\
\hline Instalación fija o estática. & \multirow[t]{2}{*}{ $\pm 2 \mathrm{~km} / \mathrm{h}$} & $\begin{array}{c} \pm 3 \mathrm{~km} / \mathrm{h}, \text { para } v \leq 100 \mathrm{~km} / \mathrm{h} \\
\pm 3 \%, \text { para } v>100 \mathrm{~km} / \mathrm{h} \\
\pm 1 \mathrm{~km} / \mathrm{h}^{1}\end{array}$ \\
\hline Instalación móvil. & & $\begin{array}{c} \pm 5 \mathrm{~km} / \mathrm{h}, \text { para } v \leq 100 \mathrm{~km} / \mathrm{h} \\
\pm 5 \%, \text { para } v>100 \mathrm{~km} / \mathrm{h}\end{array}$ \\
\hline
\end{tabular}


- En verificación después de reparación o modificación

\begin{tabular}{|c|c|c|}
\cline { 2 - 3 } \multicolumn{1}{c|}{} & \multicolumn{2}{c|}{ Errores máximos permitidos } \\
\hline Tipo de instalación & $\begin{array}{c}\text { Para ensayos en laboratorio } \\
\text { (por simulación de señales) }\end{array}$ & $\begin{array}{c}\text { Para ensayos en carretera } \\
\text { (tráfico real) }\end{array}$ \\
\hline \multirow{2}{*}{ Instalación fija o estática. } & & $\begin{array}{c} \pm 4 \mathrm{~km} / \mathrm{h}, \text { para } v \leq 100 \mathrm{~km} / \mathrm{h} . \\
\pm 4 \%, \text { para } v>100 \mathrm{~km} / \mathrm{h} .\end{array}$ \\
\cline { 3 - 3 } & $\begin{array}{c} \pm \mathrm{km} / \mathrm{h}, \text { para } v \leq 200 \mathrm{~km} / \mathrm{h} . \\
\pm 3 \mathrm{~km} / \mathrm{h}, \text { para } v>200 \mathrm{~km} / \mathrm{h} .\end{array}$ & $\begin{array}{c} \pm 6 \mathrm{~km} / \mathrm{h}, \text { para } v \leq 100 \mathrm{~km} / \mathrm{h} . \\
\pm 6 \%, \text { para } \mathrm{v}>100 \mathrm{~km} / \mathrm{h}\end{array}$ \\
\hline
\end{tabular}

- En verificación periódica

\begin{tabular}{|c|c|c|}
\cline { 2 - 3 } \multicolumn{1}{c|}{} & \multicolumn{2}{c|}{ Errores máximos permitidos } \\
\hline Tipo de instalación & $\begin{array}{c}\text { Para ensayos en laboratorio } \\
\text { (por simulación de señales) }\end{array}$ & $\begin{array}{c}\text { Para ensayos en carretera } \\
\text { (tráfico real) }\end{array}$ \\
\hline Instalación fija o estática. & & $\begin{array}{c} \pm 5 \mathrm{~km} / \mathrm{h}, \text { para } v \leq 100 \mathrm{~km} / \mathrm{h} . \\
\pm 5 \%, \text { para } v>100 \mathrm{~km} / \mathrm{h} .\end{array}$ \\
\cline { 3 - 3 } Instalación móvil. & $\begin{array}{l} \pm \mathrm{km} / \mathrm{h} \text {, para } v \leq 200 \mathrm{~km} / \mathrm{h} . \\
\pm 3 \mathrm{~km} / \mathrm{h}, \text { para } v>200 \mathrm{~km} / \mathrm{h} .\end{array}$ & $\begin{array}{c} \pm 7 \mathrm{~km} / \mathrm{h}, \text { para } v \leq 100 \mathrm{~km} / \mathrm{h} . \\
\pm 7 \%, \text { para } v>100 \mathrm{~km} / \mathrm{h}\end{array}$ \\
\hline
\end{tabular}

Cinemómetros destinados a medir la velocidad instantánea de circulación de los vehículos a motor desde aeronaves (Anexo IV Orden ITC/3123/2010, de 26 de noviembre)

Para la posición y medida de distancias: $\pm 3 \%$.

Valor mínimo del Error máximo permitido: $5 \mathrm{~m}$.

Para el tiempo transcurrido: $\pm 0,1 \%$.

Valor mínimo del Error máximo permitido: 0,2 s.

Para la medida de velocidad: $\pm 10 \%$

Cinemómetros destinados a medir la velocidad instantánea de circulación de los vehículos a motor sobre tramos de distancias conocidas (Anexo $\mathrm{V}$ Orden ITC/3123/2010, de 26 de noviembre)

Para la posición y medida de distancias: $\pm 2 \%$.

Para el tiempo transcurrido en recorrido de distancia: $\pm 0,1 \%$.

Valor mínimo del Error máximo permitido: 0,2 s.

Para la medida de velocidad: $\pm 5 \%$. 


\section{EFECTOS DE LOS MÁRGENES DE ERROR PERMITIDOS}

La determinación normativa de unos márgenes de error permitidos supone la existencia de un espacio en el no se puede afirmar la existencia de la infracción, espacio que viene determinado por la adición del margen de error determinado al punto en el que comienza la infracción ${ }^{136}$ y que será diferente para cada supuesto en función del tipo instrumento con el que se hubiera realizado la medición y el concreto margen al que se encuentre sometido ${ }^{137}$.

El efecto no solo se produce para determinar si se puede afirmar la existencia o no de infracción. Lo mismo sucede para delimitar si la medición efectuada permite determinar la existencia de una infracción grave, de las previstas en el art. 65.4 a) y b) LTSV o de una muy grave de las del art. 65.5 a) y b) LTSV e, incluso, si nos encontramos ante un tipo penal del previsto en el art. $379.1 \mathrm{CP}$ cuando se establece que "el que condujere un vehículo a motor o ciclomotor a velocidad superior en 60 kilómetros por hora en vía urbana o en 80 kilómetros por hora en vía interurbana a la permitida reglamentariamente.

\section{D) La medición en las infracciones por haber ingerido bebidas alcohólicas y conducir con tasas superiores a las que reglamentariamente se establezcan}

\section{LA INFRACCIÓN EN LA LTSV Y LA DETERMINACIÓN REGLAMENTARIA DE LOS LÍMITES}

La constatación de la infracción consistente en circular bajo los efectos de bebidas alcohólicas requiere del uso de los instrumentos destinados a medir la concentración de alcohol en el aire espirado, cuya regulación se efectúa por la Orden ITC/3707/2006, de 22 noviembre, por la que se regula el control metrológico del Estado de los instrumentos destinados a medir la concentración de alcohol en el aire espirado, los etilómetros, que como dispone el art. 1 de la referida Orden se utilizan como medio para la imposición de sanciones, realización de pruebas judiciales o aplicación de normas o reglamentaciones que exijan su uso.

El art. 65.5 c) LTSV tipifica como infracción muy grave "la conducción por las vías objeto de esta Ley habiendo ingerido bebidas alcohólicas con tasas superiores a las

\footnotetext{
${ }^{136}$ Así, para una un límite de $100 \mathrm{~km} / \mathrm{h}$ y un margen de error permitido en el aparato con el que se ha efectuado la medición del $5 \%$, sólo podrá afirmarse la existencia de infracción a partir de mediciones que den como resultado, al menos, $105 \mathrm{~km} / \mathrm{h}$.

${ }^{137}$ Es preciso conocer el tipo de cinemómetro y sus circunstancias, pues los márgenes, para un mismo aparata, varían desde su puesta en funcionamiento y posteriores verificaciones, a través de las diferentes fases del control metrológico al que el cinemómetro se encuentra sometido a lo largo de su vida útil.
} 
que reglamentariamente se establezcan", colaboración reglamentaria que se efectúa por medio del art. $20 \mathrm{RGC}^{138}$.

\section{MÁRGENES DE ERROR Y EFECTOS}

El art. 9 de la Orden ITC/3707/2006, de 22 de noviembre, por la que se regula el control metrológico del Estado de los instrumentos destinados a medir la concentración de alcohol en el aire espirado dispone que "los errores máximos permitidos en la verificación después de reparación o modificación serán los indicados en el Anexo II de esta Orden".

El apartado 2.3 de ese Anexo II establece que los errores máximos permitidos para los etilómetros en servicio son:

- $0,030 \mathrm{mg} / \mathrm{l}$ para todas las concentraciones menores o iguales a $0,400 \mathrm{mg} / \mathrm{l}$;

- $7,5 \%$ del valor verdadero de la concentración para toda concentración mayor de 0,400 $\mathrm{mg} / \mathrm{l}$ y menor o igual de $1 \mathrm{mg} / \mathrm{l}$;

- $20 \%$ del valor verdadero de la concentración para toda concentración mayor de 1 $\mathrm{mg} / \mathrm{l}$.

Lo cual supone que no podrá afirmarse la comisión de la infracción hasta que se alcance el punto resultante de sumar la tasa establecida y el margen de tolerancia (de error) permitido a los instrumentos de medida. Tal y como está establecida la infracción y determinada la tasa en $0,25 \mathrm{mg} / \mathrm{l}$, si a eso le sumamos el margen de error permitido para mediciones inferiores a $0,40 \mathrm{mg} / \mathrm{l}$, que es de $0,3 \mathrm{mg} / \mathrm{l}$, arroja como resultado que las mediciones de hasta $0,28 \mathrm{mg} / \mathrm{l}$ no permiten constatar la existencia de la infracción.

Y lo mismo sucede para determinar la frontera entre la infracción muy grave del art. 65.5 c) LTSV y el tipo del art. $379.2 \mathrm{CP}$, puesto que habrá que tener en cuenta lo establecido sobre los márgenes de error permitidos. En este caso, y al estar fijado la tasa penal en $0,60 \mathrm{mg} / \mathrm{l}$, el margen de error aplicable será del 7,5\%, el resultado de la prueba de detección alcohólica tendrá que ser superior a 0,645 mg/l para poder asegurar la comisión del tipo penal.

Los márgenes de error actúan sobre los instrumentos destinados a medir el grado de concentración alcohólica en aire espirado, sin que ello alcance a los resultados obtenidos por análisis de sangre ni, por supuesto, nada tenga que ver con las

\footnotetext{
${ }^{138}$ Precepto que establece, como límite para la infracción, de manera genérica "una tasa de alcohol en sangre superior a 0,5 gramos por litro, o de alcohol en aire espirado superior a 0,25 miligramos por litro", tasa que se reduce, en determinados supuestos a "una tasa de alcohol en sangre superior a 0,3 gramos por litro, o de alcohol en aire espirado superior a 0,15 miligramos por litro" (conducción de vehículos destinados al transporte de mercancías con una masa máxima autorizada superior a 3.500 kilogramos, vehículos destinados al transporte de viajeros de más de nueve plazas, o de servicio público, al transporte escolar y de menores, al de mercancías peligrosas o de servicio de urgencia o transportes especiales y conductores noveles, durante los dos años siguientes a la obtención del permiso o licencia que les habilita para conducir).
} 
apreciaciones realizadas por los Agentes sobre el estado de quien se niega a cumplir con la obligación de someterse a las pruebas.

\section{E) La determinación de las infracciones por conducción bajo los efectos de de estupefacientes, psicotrópicos, estimulantes y otras sustancias análogas}

Aunque hasta el momento no se ha desarrollado ningún medio de prueba concreto para la determinación de este tipo de infracción muy grave, se trata de un supuesto diferente por mucho que comparta ubicación con la prohibición de conducir con tasas superiores a las establecidas reglamentariamente.

En este caso, el de la infracción de la conducción bajo los efectos de las sustancias prohibidas, la norma no prevé, a diferencia de lo que ocurre con el alcohol, una tasa a partir de la cual se produzca la infracción. El tipo administrativo de las sustancias prohibidas se produce con cualquier cantidad, lo que supone que no hay un margen de tolerancia que dé lugar a una conducta permitida.

El problema, caso de existir, vendría determinado por la posibilidad de resultados que constituyeran "falsos positivos". Pero frente a la existencia de una escala y de unos valores tolerados y una medición en la que haya de tomarse en consideración determinados márgenes de error en los instrumentos empleados para realizar esa comprobación, en el caso de las pruebas de detección de sustancias prohibidas lo trascedente, a efectos de la existencia de infracción, es la presencia o ausencia de la sustancia, no siendo relevante, a efectos de la infracción, la cantidad resultante.

Cuestión que, a su vez, nos lleva a un segundo conflicto, puesto que la infracción administrativa prevista en el art. 65.5 c) LTSV ("la conducción bajo los efectos de estupefacientes, psicotrópicos, estimulantes y cualquier otra sustancia de efectos análogos") y el tipo penal del art. 379.2 CP ("el que condujere un vehículo de motor o ciclomotor bajo la influencia de drogas tóxicas, estupefacientes, sustancias psicotrópicas") no presentan diferencias (más allá del uso de la expresión "bajo los efectos" frente a la de "bajo la influencia") que permitan establecer, a priori, la delimitación entre una y otra, y nos sitúa en el ámbito de la interpretación de los límites que a cada una corresponda.

\section{F) OTRAS MEDICIONES}

El hecho de que en el ámbito del tráfico las infracciones susceptibles de ser medidas sean, por antonomasia, las relativas a velocidad y alcohol, no significa que no existan otras para cuya determinación sea necesario el uso de instrumentos, aparatos o medios y sistemas de medida. 
Hay otros supuestos en los que la LTSV (por sí misma o con la colaboración reglamentaria) determinan ilícitos administrativos en relación a escalas de medida.

Sin trata aquí de realizar aquí una lista que contenga todas esas infracciones sí pueden señalarse algunos ejemplos. Tal es el caso de:

- Dimensiones de la carga (art. 15 RGC)

- Espacio máximo empleado para adelantar (art. 36.3 RGC)

- Distancia entre vehículos (54.2 RGC)

- Recorrido máximo marcha atrás (art. 80.2 RGC)

- Distancia lateral en adelantamiento (art. 85 RGC)

- Distancia entre vehículos en túneles (art. 95.6 RGC)

De igual forma, existen prescripciones sobre elementos susceptibles de ser medidos. El art. 10.5 LTSV prohíbe la emisión de perturbaciones electromagnéticas, ruidos, gases y otros contaminantes en las vías objeto de esta Ley, por encima de las limitaciones que reglamentariamente se establezcan, que el art. 7 RGC remite al Anexo I del Reglamento General de Vehículos (RGV), ámbito en el que existen las oportunas normas que regulan los correspondientes controles metrológicos ${ }^{139}$.

\section{MEDIOS DE CAPTACIÓN DE IMÁGENES}

\section{A) Una delimitación necesaria}

Es fácil (y tentador) tratar conjuntamente los instrumentos de medición (algunos de ellos, en concreto) con la captación de imágenes. No resulta difícil mezclar la medición efectuada con la imagen en la que se recoge esa medición. Y no es extraño que así se haga porque en la infracción más común, al de velocidad, el sistema combina ambos elementos, de manera que no resulta difícil caer en esa confusión.

El hecho de que para la constatación de ese tipo de infracciones se unan ambos elementos y que la "medición" quede reflejada en el "medio de captación" no supone que eso, la confluencia de ambos elementos, tenga que darse para otro tipo de infracciones. El hecho de que en las infracciones de velocidad resulte necesario la identificación del vehículo, mediante la imagen, y que el sistema introduzca el resto de datos fácticos sobre esa imagen, no supone que la constatación de otras infracciones necesite de esa misma estructura documental. Hay infracciones, muchas, la mayoría,

\footnotetext{
139 Es el caso, por ejemplo, de normas como la Orden ITC/3700/2006, de 22 noviembre RCL 2006\2163, que regula el control metrológico del Estado de los manómetros dotados, total o parcialmente, de componentes electrónicos, provistos o no de dispositivos de predeterminación, destinados a medir la presión de los neumáticos de los vehículos a motor o la Orden ITC/3722/2006, de 22 noviembre RCL 2006\2187, que regula el control metrológico del Estado en la fase de instrumentos en servicio sobre los instrumentos destinados a medir las emisiones de los gases de escape de los vehículos equipados con motores de encendido por chispa (gasolina).
} 
en la que su constatación no requiere de medida, por no estar sometida a ella. Infracciones que por su propia naturaleza, diversa de las de velocidad, una imagen (o imágenes) puede llegar a constituirse en elemento probatoria de la comisión de la infracción.

Y la delimitación se hace necesaria en tanto que la practica muestra que los medios de medición, por su propia naturaleza, suelen estar acompañados de la potestad sancionadora. Y así, cinemómetros y etilómetros, son elementos que forman, y se conforman, como parte de la actividad administrativa. En cambio, la obtención de imágenes, no requiere, por sí misma un gran componente tecnológico ni la necesidad que requieren aquellos instrumentos de homologaciones, revisiones y controles metrológicos y, por ello, son susceptibles de un uso que puede quedar dentro o fuera del control de la Administración, lo que requiere del análisis de los requisitos para su uso como elemento probatorio de la comisión de infracciones.

\section{B) El supuesto y sus requisitos}

No son pocas las infracciones que pueden acreditarse mediante la aportación de una imagen. Casos muy variados, como pudieran ser una agente de la autoridad fotografiando vehículos que circulan sin hacer uso del preceptivo alumbrado en un túnel o en un carril habilitado para la circulación el sentido contrario; o un agente de la autoridad fotografiando a un vehículo mal estacionado o un agente de la ORA haciendo lo propio con un vehículo infringiendo la normativa de aparcamiento; o un sistema obteniendo imágenes de vehículos que no respetan la luz roja de un semáforo.

Aparentemente se trata de infracciones y de una prueba fotográfica de la comisión de las mismas. Pero, en realidad, de supuestos que pueden ser muy diferentes y que pueden dar lugar a la necesidad de cumplir con requisitos muy diversos.

Cuando el art. 75 LTSV enuncia el valor probatorio de las denuncias de los Agentes de la Autoridad no atribuye "una presunción de veracidad" al Agente. Y prueba de ello es que ese valor probatorio lo es "sin perjuicio del deber de aquellos de aportar todos los elementos probatorios que sean posibles sobre el hecho denunciado". Afirmar que con un determinado vehículo se ha cometido una infracción y, además, adjuntar una fotografía dota de mayor consistencia a esa denuncia y dificulta, en mayor medida, la destrucción de esa afirmación, de esa prueba. Que esa misma prueba la aporte un Agente de la Autoridad o lo haga quien no reúne esa condición conlleva efectos distintos, ya que el art. 137.3 LRJ - PAC reconoce valor probatorio a los hechos constatados por los Agentes de la Autoridad que se formalicen en documentos público siempre que se observen los requisitos legales pertinentes. No es indiferente quien lo haga. 
$Y$ aquí es donde pueden surgir los problemas, como ha señalado, de manera certera y precisa, PALOMAR ${ }^{140}$. Y por eso conviene distinguir entre instrumentos de medición y medios de captación y reproducción de imágenes, que a veces, como hemos señalado, van juntos, y el control del instrumento de medida arrastra el de todos los elementos del sistema (que es el caso de los cinemómetros), pero en otros, como el caso de las cámaras en los semáforos, allí ubicadas con el objeto de constatar la infracción de pasar ese semáforo en rojo, se limita a una imagen y el proceso puede no cumplir con los requisitos establecidos.

Cuando se trata de una simple fotografía, y ya no de un sistema que requiere de un control metrológico, con todo lo que ello supone, todo se puede simplificar, y la tentación de hacerlo es muy elevada, hasta el punto de que esa actividad ya no sea realizada directamente por una Administración de las que poseen la competencia para sancionar las infracciones en materia de tráfico y seguridad vial y se ponga en manos de particulares.

Y es en este caso donde surge el problema, pues como señala PALOMAR ni se cumple con la condición de autoridad del art. 137.3 LRJ - PAC ni responde al patrón exigido por la LAE para la actividad administrativa automatizada, lo que va a suponer que las posibilidades de actuación encuentran importantes obstáculos para la tramitación de ese procedimiento sancionador con las garantías exigidas por nuestro sistema jurídico, ya que no se tiene una denuncia de Agente de la Autoridad con el soporte adicional de una imagen, ni se tiene un documento electrónico (la imagen) que cumpla con las garantías que se establecen y exigen para tenerlo como tal. En esa tesitura pedirle a un Agente de la Autoridad que denuncie sobre la base de una imagen que no sabe como ha sido obtenida y de la que no puede asegurar su integridad, autenticidad y veracidad, más que la solución se convierte en una garantía de fracaso por, y precisamente, la ausencia de las garantías a tal efecto establecidas.

Frente a la tentación de la simplicidad que ofrece el intentar acreditar la comisión de infracciones mediante imágenes obtenidas y gestionadas sin garantía alguna es preciso oponer la necesidad de de actuar cumpliendo los mismos requisitos y ofreciendo las mismas garantías que se precisan cuando se trata de obtener medios de prueba que, por su propia naturaleza ya se encuentran sometidos al control metrológico y a la actuación administrativa automatizada.

\footnotetext{
${ }^{140}$ ALBERTO PALOMAR, ALBERTO, El procedimiento sancionador en tráfico y seguridad vial (a propósito de las cámaras en los semáforos en un artículo en fase de publicación y al que ya se ha hecho referencia, vide supra la nota 28 en este mismo capítulo.
} 


\section{ACTUACIONES ADMINISTRATIVAS Y PENALES}

\section{A) La concurrencia de ilícitos administrativos y tipos penales (como presupuesto)}

\section{TIPIFICACIÓN ADMINISTRATIVA Y PENAL}

Hay un punto de conexión, cuando no de roce, entre derecho administrativo sancionador y derecho penal desde el momento en que infracciones administrativas y delitos son dos figuras normativas que están a libre disposición del legislador que puede calificar a su arbitrio una acción como delito o como infracción, de tal manera que puede hacer que lo que ayer eran infracciones administrativas, se conviertan mañana en delitos y lo que eran ilícitos penales se conviertan de pronto en infracciones administrativas ${ }^{141}$.

En el caso del tráfico y la seguridad vial al lado de los ilícitos administrativos previstos en la LTSV se encuentra la tipificación de los delitos contra la seguridad vial efectuada en los arts. 379 a 385 ter CP, situación que supone que determinadas conductas aparezcan recogidas en ambos escenarios, lo que da lugar a tener que determinar cuál sea el reproche social que, en un determinado caso, merecen unos hechos ${ }^{142}$.

\section{EL PRINCIPIO NON BIS IN IDEM}

En el trasfondo de esta previsión normativa se encuentra el principio non bis in idem ${ }^{143}$ o, en términos del art. 133 LRJ - PAC, el que "no podrán sancionarse los hechos que

\footnotetext{
${ }^{141}$ La intercambiabilidad de delitos e infracciones a la que se refiere NIETO (Derecho Administrativo Sancionador, Madrid, Tecnos, 2012, 5a ed., pág. 128).

Sobre esta cuestión GARCÍA AMADO advierte sobre el hecho común de diferenciar y graduar las sanciones en razón del grado de importancia de los ilícitos y su ubicación en el sistema (penas y sacniones) y sew pregunta, no sin razón, "si el juicio sobre la gravedad de esta o aquella sanción se puede y se debe hacer desde patrones objetivos o si, por contra, debe tomarse en consideración total o parcial el sentimiento subjetivo del ciudadano sancionado o de los ciudadanos en su conjunto" y señalando las "incongruencias del sistema" cuando se pretende hacer uso de clasificaciones objetivas ("Sobre el ius puniendi: su fundamento, sus manifestaciones y sus límites", Documentación Administrativa, no 280 281, 2008, págs. $11-41$ ).

${ }^{142}$ Es "la eterna carencia de encaje o de sutura entre los extremos fronterizos del derecho penal y Administrativo", como señala ToliVAR AlAS ("Concurrencia de sanciones: una construcción inacabada", Documentación Administrativa, № 280 - 281, 2008, págs. 133 - 158).

${ }^{143}$ No es momento de discutir sobre la naturaleza de este principio y su carácter de principio general de derecho, de derecho fundamental o de regla jurídica. La interpretación efectuada por el Tribunal Constitucional y Tribunal Supremo es que la prohibición de "non bis in idem" ha sido elevada a la categoría de principio constitucional ya que "si bien no se encuentra recogido expresamente en los arts. 14 a 30 de la Constitución... va íntimamente unido a los principios de legalidad y tipicidad de las infracciones recogidos principalmente en el art. 25 CE" y que "por otro lado es de señalar que la tendencia de la legislación española reciente, en contra de la legislación anterior, es la de recoger expresamente el principio de referencia" (tal como afirma la STC 2/1981, de 30 de enero, F. 4). Esta Resolución del Tribunal Constitucional que es uno de los comentarios (Julián SÁNCHEZ MELGAR, "El principio "non bis in idem" ante el Tribunal Constitucional") que integra la obra Veinticinco años de
} 
hayan sido sancionados penal o administrativamente, en los casos en los que se aprecie identidad de sujeto, hecho y fundamento" ${ }^{144}$.

Los términos en los que el art. 133 LRJ - PAC recoge el non bis in idem, como principio de la potestad sancionadora, no impiden que sea compatible la ilicitud penal y la ilicitud administrativas (ATC 355/1991, de 25 de noviembre, F. 5 y STS de 3 de febrero de 1997, RJ 1997, $1344^{145}$ ) ya que la prohibición de doble sanción se establece para los supuestos de "identidad de sujeto, hecho y fundamento", lo que supone que no se trasgrede por el hecho de dos sanciones (una penal y otra administrativa, o ambas administrativas) en el caso de que no concurra esa triple identidad.

jurisprudencia constitucional. 25 sentencias fundamentales comentadas, Difusión Jurídica y temas de Actualidad, 2007, (Coord. Alberto Dorrego de Carlos).

Véase, por todos, el análisis de NiETo (Derecho Administrativo Sancionador, Madrid, Tecnos, 2012, 5a ed., págs. 438 - 439) y las reflexiones de MARTín ReBOLLo (anotación al art. 133 LRJ - PAC en Leyes Administrativas, Aranzadi).

144 Señala NiETo que "con la Ley 30/1992, cuyo art. 133, y bajo la rúbrica de «concurrencia de sanciones», en su número 1 (sic), aborda puntualmente la cuestión de una manera contundente, aunque desgraciadamente rudimentaria, puesto que pasa por alto todos sus aspectos conflictivos" (Derecho Administrativo Sancionador, Madrid, Tecnos, 2012, 5a ed., págs. 445).

${ }^{145}$ El Fundamento de derecho Cuarto de esta Sentencia señala, con expresa cita del ATC 335/1991, de 25 de noviembre, señala que:

“El que considera como segundo motivo de revisión -la prescripción de la infracción objeto de la sanción que los Tribunales del Orden Contencioso-Administrativo han considerado ajustada a Derecho- no está comprendida en ninguno de los supuestos del artículo 102, c) de la Ley Jurisdiccional. Aunque tan evidente consideración sería suficiente para rechazar este segundo motivo, no estará de más añadir aquí, de un lado, que la sentencia de la Sala de lo ContenciosoAdministrativo del Tribunal Supremo examina y rechaza tal argumento por estimar que, pese a las consideraciones contenidas en la sentencia del orden Penal, la prescripción de la infracción administrativa imputada al recurrente no había llegado a producirse, y de otra, que en la providencia del Tribunal Constitucional que acuerda la inadmisión del recurso de amparo se contienen las siguientes consideraciones: «este Tribunal ha señalado en repetidas ocasiones que la apreciación en cada caso concreto de la concurrencia o no de la prescripción es una cuestión de legalidad que corresponde decidir a los Tribunales ordinarios (SSTC 157/1982, $255 / 1988$ y $83 / 1989$, entre otras). Finalmente, no puede admitirse en la realidad jurídica que algo es y no es y que unos mismos hechos ocurrieron y no ocurrieron (SSTC 24/1984, 62/1984 y $158 / 1985)$, pero ello no tiene nada que ver con la posibilidad de que unos mismos hechos sean examinados desde la perspectiva de los diferentes órdenes jurisdiccionales con el riesgo de que éstos extraigan consecuencias jurídicas distintas de ellos. No se trata en estos casos de afirmar un hecho que haya sido negado por otro órgano jurisdiccional, sino de distintas interpretaciones judiciales que no violan el derecho a la tutela judicial efectiva (SSTC 70/1989 y $116 / 1989$ y AATC 61/1992 y 105/1992). A mayor abundamiento, el principio "non bis in idem" (artículo $25.1 \mathrm{CE}$ ) no impide que sea compatible la licitud penal y la ILICITUD administrativa de unos mismos hechos (ATC 355/1991)»". 


\section{DE LA PLURALIDAD DE TIPIFICACIONES Y DE LA DIVERSIDAD DE SANCIONES}

a) De las genéricas previsiones sobre tipos administrativos y penales

Si centramos el análisis en las cuestiones de orden práctico, y recorriendo el camino inverso, es claro que no habría lugar a esta cuestión (el non bis in idem como problema) si a unos hechos correspondiera, en su caso, una única tipificación (penal o administrativa) con un única consecuencia sancionadora. En este caso nunca se plantearía el problema, hipótesis que así se encuentra formulada por la Ley del País Vasco 2/1998, de 20 de febrero, de la potestad sancionadora de las Administraciones Públicas de la Comunidad Autónoma del País Vasco, que dispone que "en la configuración de los regímenes sancionadores se evitará la tipificación de infracciones con idéntico supuesto de hecho e idéntico fundamento que delitos o faltas ya establecidas en las leyes penales o que infracciones ya tipificadas en otras normas administrativas sancionadoras" (art. 4.2) ${ }^{146}$.

Pero la realidad, como opción del legislador, se impone, y al lado de las infracciones administrativas a lo dispuesto en la LTSV encontramos los delitos contra la seguridad vial tipificados en el los arts. 279 a 385 ter CP. Y, por otra parte, con infracciones y sanciones administrativas que, de alguna manera, confluyen con las previsiones efectuadas en la LTSV.

\section{b) La distribución del ius puniendi en materia de tráfico y seguridad vial}

La tipificación de conductas como ilícitos administrativos o tipos penales queda en la esfera de decisión del legislador. Al Legislador compete, en cada momento histórico, el diseño estructural del ius puniendi (general y en un ámbito determinado), le corresponde determinar la posición de los tipos en una y otro ámbito (administrativo sancionador y penal) y hacerlo con todas las consecuencias que ello supone.

Hay veces que esa distribución resulta fácilmente aprehensible, en especial cuando un bloque entero queda excluido del ámbito penal. Incluso puede no resultar difícil captar el esquema, la estructura, aunque las conductas se distribuyan entre esos dos ámbitos. Pero también es cierto que, en ocasiones, no resulta fácil aprehender el sistema construido, lo que pude ser debido a su propia complejidad o, sencillamente, a la existencia de errores (cometidos voluntaria o involuntariamente) al diseñar o modificar el sistema.

\footnotetext{
146 Hermosa declaración de intenciones que, por desgracia, se queda en eso. La tipificación de infracciones es tentación de la que resulta muy difícil escapar. A título de ejemplo, en el propio ámbito del País Vasco, el art. 55.1 Ley 2/2001, de 17 de marzo, de Caza del País Vasco, tipifica como infracción muy grave "cazar especies amenazadas" que se parece bastante al tipo del art. 334.1 CP cuando establece "el que cace o pesque especies amenazadas...".
} 
El diseño del ius puniendi del que se hace uso en el ámbito del tráfico y seguridad vial se ha ubicado, tradicionalmente y sin lugar a dudas, en el terreno de lo complejo y discutible.

La opción a la que se ha llegado supone un reparto en el que las conductas tipificadas en el CP se corresponden con algunas de las previstas como infracciones administrativas graves y muy graves en la LTSV, sin que exista ninguna que, en todo caso, sea constitutivo del tipo penal. Así, y de manera sintética, se debe tener en cuenta que:

- El tipo penal de exceso de velocidad se cuantifica en función en función de la superación cuantitativa del límite establecido y del tipo de vía. Lo mismo sucede con la conducción bajo la influencia de bebidas alcohólicas, en cuanto que el tipo penal se produce a partir de una determinada tasa.

- Al lado de esa determinación cuantitativa se ubican otros supuestos, como la conducción bajo la influencia de sustancias prohibidas, o la negativa a someterse a las pruebas de detección alcohólica o de sustancias prohibidas, que coinciden con la del ilícito administrativo. Y la de la conducción temeraria en la que se introducen elementos para la tipificación penal (que lo sea de forma "manifiesta", con "manifiesto desprecio por la vida de los demás", "con o sin - puesta en concreto peligro de la vida o la integridad de las personas", "con resultado lesivo").

- Por otra parte, el tipo penal de conducir sin la correspondiente autorización, requieren que se trate de supuestos concretos (pérdida de vigencia por pérdida total de puntos, privación judicial o no haberla obtenido nunca). El de colocación de obstáculos en la vía y el de no restablecer la seguridad de la vía, cuando haya obligación de hacerlo, coinciden, parcialmente, con el ilícito muy grave del art. 65.6 LTSV.

El sistema, globalmente considerado, al que se ha llegado a través de sucesivas adiciones, innovaciones y reformas, da lugar a que una serie de conductas (genéricamente consideradas) puedan caer en uno u otro ámbito punitivo, siendo las circunstancias concurrentes las que determinen el resultado final, circunstancias susceptibles de interpretación y discusión, lo que puede dar lugar a que iniciado el procedimiento sancionador se considere que su objeto, esos hechos, puede ser constitutivo (por ofrecer esa apariencia) de un delito o falta perseguible de oficio.

\section{c) Previsiones administrativas al margen de la LTSV}

Al lado de la concurrencia, junto a las previsiones efectuadas por la LTSV, de tipificación penal, pueden encontrarse otras disposiciones administrativas que, fuera de la LTSV, pueden suponer interferencias con lo previsto en ella. 
Al margen de las consideraciones efectuadas en materias a las que la LTSV se remite (como es el caso de infracciones en materia de publicidad, art. 66 LTSV y seguro, art. 65.7 LTSV) se ubican otras a las que resulta preciso hacer referencia, por sumaria que esta sea.

La primera de ellas supone la vinculación real entre transporte por carretera y tráfico y seguridad vial, que se traslada a la tipificación en el art. 65.5 i) LTSV, como infracción muy grave, del "exceso en más del 50 por 100 en los tiempos de conducción o la minoración en más del 50 por 100 en los tiempos de descanso establecidos en la legislación sobre transporte terrestre", infracción que en el ámbito de la legislación de transportes se encuentra en el art. 140.37.1 de la Ley 16/1987, de 30 de julio, de Ordenación de los Transportes Terrestres (LOTT), lugar en que se califica, como infracción muy grave, "El exceso igual o superior al 50 por ciento en los tiempos máximos de conducción diaria, así como la disminución de los descansos diarios por debajo de cuatro horas y media"147.

De forma distinta la Ley Orgánica 1/1992, de 21 de febrero, sobre Protección de la Seguridad Ciudadana, (LOSC), hace uso, como sanción de la suspensión del permiso de conducir al establecer que "las infracciones previstas en el artículo 25 podrán ser sancionadas, además, con la suspensión del permiso de conducir vehículos de motor hasta tres meses y con la retirada del permiso o licencia de armas, procediéndose desde luego a la incautación de las drogas tóxicas, estupefacientes o sustancias psicotrópicas" (art. 28.2 LOSC), lo que supone que eliminada de la LTSV la suspensión de las autorizaciones que habilitan la conducción de vehículos como sanción se mantiene fuera de su ámbito de aplicación ${ }^{148}$.

\section{B) La preferencia de la jurisdicción penal}

1. LA PREVISIÓN NORMATIVA

Sea como fuere el art. 72.1 LTSV recoge de manera expresa la preferencia del orden jurisdiccional penal al establecer que "cuando en un procedimiento administrativo de

\footnotetext{
${ }^{147}$ Ciertamente que se trata de una cuestión más compleja ya que en el ámbito de la LOTT la regulación y tipificación sobre tiempos de conducción y descanso se configura en torno a diferentes tipos, y, al lado de que aquí se ha señalado, se encuentran "el exceso igual o superior al 25 por ciento en los tiempos máximos de conducción semanal o bisemanal" (art. 140.37.2 LOTT), "el exceso superior a dos horas en los tiempos máximos de conducción diaria, salvo que deba calificarse conforme a lo dispuesto en el apartado 37.1" (art. 140.37.3 LOTT), "la conducción durante más de seis horas sin respetar las pausas reglamentariamente exigidas (art. 140.37.4 LOTT), "la disminución del descanso diario normal en más de dos horas y media o del reducido o fraccionado en más de dos horas, incluso cuando se realice conducción en equipo, salvo que deba calificarse conforme a lo dispuesto en el apartado 37.1" (art. 140.37.5 LOTT) y "la disminución del descanso semanal normal en más de nueve horas o del reducido en más de cuatro" (art. 140.37.6 LOTT) y de las correlativas infracciones graves del art. 141.24 LOTT.

${ }^{148}$ Tal y como se señalaba en el estudio de la competencia para sancionar las infracciones de tráfico y seguridad vial al analizar la extraña disposición contendía en el art. 71.7 LTSV.
} 
carácter sancionador se ponga de manifiesto un hecho que ofrezca apariencia de delito o falta perseguible de oficio, la Autoridad administrativa lo pondrá en conocimiento del Ministerio Fiscal, por si hubiere lugar al ejercicio de la acción penal y acordará la suspensión de las actuaciones".

Se requiere, por tanto, la previa existencia de un procedimiento administrativo sancionador (o al menos de unas actuaciones previas) en el que, una vez iniciado, se perciba que los hechos que han dado lugar a su incoación pueden ser constitutivos de "un delito o falta perseguible de oficio", percepción que da lugar a dos consecuencias. De un lado, a la puesta en conocimiento del Ministerio Fiscal de esos hechos y, de otro, a suspender las actuaciones de ese procedimiento sancionador.

Este modo de actuación supone, además del reconocimiento de la preferencia y prioridad penal, el quedar a la espera de lo que de esa intervención se pueda deparar, para, llegado el caso, actuar en consecuencia.

\section{PREVISIÓN Y EFECTOS}

El art. 72 LTSV somete al procedimiento sancionador a las actuaciones penales que tienen preferencia y prioridad sobre las administrativas, de manera que le procedimiento administrativo sancionador queda condicionado a aquellas, a priori y $a$ posteriori.

En un primer momento al ordenarse la paralización del procedimiento ya que, constatada la posibilidad de que los hechos sean constitutivos de delito o falta perseguible de oficio, el instructor lo pondrá en conocimiento del Ministerio Fiscal y procederá a acordar la suspensión del procedimiento sancionador.

El procedimiento, suspendido, queda en estado latente a la espera de lo que ocurra en ese proceso penal. Si de esos hechos se deriva sentencia condenatoria se procederá al archivo del procedimiento sin declaración de responsabilidad, puesto que ya se ha procedido, en el ámbito penal, a castigar esa conducta, por lo que la hipotética sanción administrativa quebrantaría la prohibición de non bis in idem (art. 72.2 párrafo primero LTSV).

Pero también puede suceder que ese proceso penal termine sin declaración de responsabilidad, lo que permite reactivar ese procedimiento sancionador (iniciarlo o continuarlo) contra quien no hubiera sido condenado en vía penal siempre y cuando, eso sí, la resolución penal no estuviera fundada en la inexistencia del hecho ${ }^{149}$,

\footnotetext{
${ }^{149}$ Advierte NIETO que "Ias dificultades crecen aún más cuando ya no se trata de hechos declarados en la sentencia sino que ésta se limita a declarar que no fueron probados pero sin negar la posibilidad de su existencia". Y como tradicionalmente se había entendido que "la Administración puede indagar con sus propios medios la existencia de los hechos y sancionar si consigue probarlos", y que ello era así hasta
} 
supuesto en el que se entiende que no hay base para sanción de tipo alguno (art. 72.2 párrafo segundo LTSV). A este caso hay que equiparar, aunque nada diga el art. 72 LTSV a aquellos casos en los que, paralizado el procedimiento y remitido al Ministerio Fiscal, se considere por este que los hechos no son constitutivos de delito o falta.

Pero, en todo caso, la declaración de hechos probados que se efectúe en el proceso penal vincularán a la Administración (art. 72.3 LTSV), algo que también dispone el art. 137.2 LRJ - PAC, precepto que además señala que esas resoluciones judiciales han de ser firmes.

Sobre esta suspensión de las actuaciones administrativas es preciso tener presente la existencia de una norma específica sobre la caducidad del procedimiento sancionador ya que el art. 92.3 párrafo segundo LTSV previene que "cuando la paralización del procedimiento se hubiera producido a causa del conocimiento de los hechos por la jurisdicción penal, el plazo de caducidad se suspenderá y, una vez haya adquirido firmeza la resolución judicial, se reanudará el cómputo del plazo de caducidad por el tiempo que restaba en el momento de acordar la suspensión", lo que supone que, en su caso, el procedimiento sancionador seguiría disponiendo de un año efectivo para alcanzar la resolución final, eliminado el problema del tiempo consumido en las actuaciones penales como parte del período de tiempo previsto (un año) para que se produzca la caducidad del procedimiento.

Pero esta previsión normativa (fruto de la perspicacia del legislador y con el objeto de garantizarse el tiempo necesario para tramitar y resolver), se encuentra con un problema de orden práctico desde el momento en que el legislador no ha previsto una norma equivalente para el plazo de prescripción de las infracciones. El art. 92.1 LTSV que establece un plazo de seis meses para la prescripción de infracciones graves y muy graves, a contar "a partir del mismo día en que los hechos se hubieran cometido" no contiene entre sus cautelas ninguna sobre la interrupción de ese plazo por el conocimiento de los hechos por la jurisdicción penal ${ }^{150}$, y estando, como estamos, ante previsiones en materia sancionadora no parece que pueda establecerse interpretación analógica o extensiva que, en todo caso, lo sería en perjuicio del denunciado.

que la STS de 22 de febrero de 2011 (RJ 2011, 2257) interpreta que "no había quedado suficientemente probado" supone que "había sido suficientemente probado que no se habían producido daños" (Derecho Administrativo Sancionador, Madrid, Tecnos, 2012, 5a ed., pág. 460 - 461).

${ }^{150} \mathrm{El}$ art. 92.2 LTSV dispone que:

"La prescripción se interrumpe por cualquier actuación administrativa de la que tenga conocimiento el denunciado o esté encaminada a averiguar su identidad o domicilio y se practique con otras Administraciones, Instituciones u Organismos". También se interrumpe por la notificación efectuada de acuerdo con los artículos 76,77 y $78^{\prime \prime}$

Artículos, éstos (76 a 78 LTSV) que se refieren a la notificación de la denuncia. 


\section{LA OPCIÓN ESTABLECIDA ENTRE POSIBLES ALTERNATIVAS}

No parece oportuno dar por cerrada esta cuestión sin dejar constancia que la opción elegida por el legislador de, ante las actuaciones penales, acordar la suspensión del procedimiento sancionador, es una de las posibles. Y que esa preferencia penal podía articularse, desde el procedimiento sancionador, de diferentes formas, como de hecho así se ha hecho en otros momentos.

De hecho, la redacción originaria de la LTSV se limitaba a la mención de "cuando, como consecuencia de un proceso penal, se hubiera abstenido la Administración de actuar para sancionar posibles infracciones a los preceptos de esta Ley" (art. 74.1 LTSV) y es tras la reforma efectuada por medio de la Ley 19/2001, de 19 de diciembre, que cuando, por tener apariencia de delito o falta perseguible de oficio, se pusiera un hecho en conocimiento del Ministerio Fiscal " "no se ordenará la suspensión de las actuaciones del procedimiento administrativo que continuará tramitándose hasta el momento en que el procedimiento esté pendiente de resolución en que se acordará la suspensión" (art. 74.2 LTSV).

Ambas previsiones, la vigente y la previa, permiten entender el contexto en el que se produce la situación y los diferentes intereses en presencia de la actuación administrativa. Mientras que suspender las actuaciones garantiza conocer los hechos probados en la jurisdicción penal y actuar en consecuencia, se penalizan los tiempos de reacción de esa actividad administrativa que puede encontrarse no tanto con la caducidad del procedimiento como con la prescripción de la infracción. Avanzar en el procedimiento y llegar hasta que esté pendiente de la resolución para, en ese momento, proceder a la suspensión, deja preparado el procedimiento para, llegado el caso, resolver de forma muy rápida, a cambio, eso sí, de encontrarse con un trabajo realizado pero que no vale en aquellos casos de resolución penal condenatoria o que establezca la inexistencia de los hechos.

La tensión a la que, la amenaza del non bis in idem y la prioridad penal, pueden someter al procedimiento sancionador, unido a la defectuosa regulación (en cuanto prevé la suspensión del plazo de caducidad del procedimiento pero no de la interrupción del de prescripción de la infracción para este caso), ponen en peligro la propia viabilidad del procedimiento sancionador. 


\section{Capítulo V}

\section{CLASES DE PROCEDIMIENTOS SANCIONADORES}

SUMARIO: I. DE LA DETERMINACIÓN DE PROCEDIMIENTOS: CUESTIONES GENERALES Y DELIMITACIÓN: A) La previsión de dos procedimiento sancionadores; B) Delimitación y elección del procedimiento sancionador. C) Prescripciones generales sobre presentación de escritos. II. EL PROCEDIMIENTO SANCIONADOR ORDINARIO: A) Cuestiones generales: 1. ÁMBITO OBJETIVO DEL PROCEDIMIENTO SANCIONADOR ORDINARIO; 2. PRESUPUeStOS O PUNTOS DE PARTIDA del PROCEDIMIENTO SANCIONADOR ORDINARIO; 3. OTROS ASPECTOS FORMALES SOBRE LA REGULACIÓN DEL PROCEDIMIENTO SANCIONADOR ORDINARIO EN LA LTSV. B) Sobre el inicio del procedimiento sancionador: 1. LA TRAMITACIÓN DEL PROCEDIMIENTO; 2. CONTENIDO del ACTO DE INICIACIÓN DEL PROCEDIMIENTO; 3. AdOPCIÓN DE MEDIDAS PROVISIONALES; 4. IDENTIFICACIÓN DEL "CONDUCTOR RESPONSABLE": a) El cumplimiento del deber de identificación; b) Los efectos de la identificación; c) Tramitación por el procedimiento sancionador ordinario. C) Alegaciones: 1. LAS OPCIONES DEL INFRACTOR - DENUNCIADO; 2. CONTENIDO; 3. PLAZO; 4. INCOMPATIBILIDAD CON EL PAGO VOLUNTARIO DE LA MULTA; 5. INEXISTENCIA DE FORMULACIÓN DE alegaciones; 6. Sobre el traslado de las alegaciones al Agente denunciante y su informe. D) Prueba: 1. Alegaciones y prueba; 2. Plazo; 3. Medios de prueba; 4. Denegación; E) Propuesta de resolución: 1. FINAL DE LA FASE DE INSTRUCCIÓN Y PROPUESTA DE RESOLUCIÓN; 2. SUPUESTOS EN LOS QUE PROCEDE EL TRASLADO DE LA PROPUESTA DE RESOLUCIÓN AL INTERESADO; 3. EL CONTENIDO DE LA PROPUESTA DE RESOLUCIÓN; F) Resolución: 1. REQUISITOS PREVIOS; 2. CONTENIDO dE LA RESOLUCIÓN: a) Resolución sancionadora o que declare la inexistencia de responsabilidad por la infracción; b) La resolución deberá de ser motivada; c) La resolución decidirá todas las cuestiones planteadas por los interesados y aquellas otras derivadas del procedimiento; d) La resolución no podrá tener en cuenta hechos distintos de los determinados en la fase de instrucción del procedimiento, sin perjuicio de su diferente valoración jurídica; 3. LA FORMA DE LA RESOlución SANCIONADORA; 4. PLAZO DE TIEMPO A LOS QUE SE ENCUENTRA SOMETIDA: a) El plazo de tiempo para dictar la resolución (sancionadora); b) El plazo de tiempo para dictar la resolución desde que recibe la propuesta de resolución del órgano instructor; G) Supuesto en el que el denunciado ni realiza alegaciones ni procede al pago de la multa (los supuestos recogidos en el art. 81.5 LTSV): 1) EL SUPUESTO: a) La inactividad del denunciado (notificado o dado por tal); b) El período de tiempo establecido; c) La consecuencia o el resultado; 2) EfECTOS (SOBRE EL PROCEDIMIENTO Y SOBRE LA SANCIÓN); 3) SUPUESTOS A LOS QUE SE APLICA Y A LOS QUE NO SE APLICA. H) Otras causas de terminación (inexistencia o extinción de la responsabilidad): 1. LA OBLIGACIÓN DE RESOLVER EL PROCEDIMIENTO SANCIONADOR ORDINARIO; 2. DE LA PRESCRIPCIÓN DE LAS INFRACCIONES: a) Sobre la evolución de la regulación de prescripción de las infracciones y sus plazos; b) Sobre la actual regulación tras la reforma de la LTSV por la Ley 18/2009, de 23 de noviembre; c) Sobre el cómputo de la prescripción de las infracciones de tráfico y seguridad vial; d) Sobre la interrupción de la prescripción de las infracciones de tráfico y seguridad vial; e) Sobre las actuaciones administrativas de las que tiene conocimiento el denunciado; f) Sobre las actuaciones administrativas para averiguar la identidad o el domicilio del denunciado; g) Sobre la práctica de la notificación de la propia denuncia; h) Sobre la reanudación del plazo de prescripción de las infracciones de tráfico y seguridad vial; i) La resolución como límite de la prescripción; 3. DE LA CADUCIDAD DEL PROCEDIMIENTO SANCIONADOR: a) De las previsiones específicamente establecidas en la LTSV; b) Sobre algunas cuestiones previstas en el régimen general; c) Del supuesto de paralización del procedimiento sancionador por actuaciones penales; d) La resolución como límite de la caducidad del procedimiento. 4. DE LAS PRESCRIPCIÓN DE LAS SANCIONES: a) Enfoque y tratamiento (legal) de la cuestión; b) Los plazos de prescripción de las sanciones. I) Impugnación de la resolución sancionadora: 1. DE LA NECESIDAD DE 
RESOLUCIÓN SANCIONADORA Y DE SUS EFECTOS; 2. LA IMPUGNACIÓN EN VÍA ADMINISTRATIVA: a) recurSO de reposición y sus efectos; b) Comunidades Autónomas y Administración Local; 3. LA IMPUGNACIÓN ANTE LA JURISDICCIÓN CONTENCIOSO - ADMINISTRATIVA. III. EL PROCEDIMIENTO SANCIONADOR ABREVIADO: A) Ubicación de este procedimiento en el marco del procedimiento sancionador en materia de tráfico; B) El pago de la multa en el plazo de quince días naturales como presupuesto del procedimiento sancionador abreviado: 1. EL PAGO DE LA MULTA COMO PRESUPUESTO; 2. EL PAGO DE LA MULTA COMO ELECCIÓN Y FIN DEL PROCEDIMIENTO. C) Las consecuencias: 1 . LA REDUCCIÓN DEL 50 POR CIENTO DEL IMPORTE DE LA SANCIÓN DE MULTA: a) ¿Consecuencia o presupuesto?; b) Beneficio económico transaccional; c) Alcance del beneficio de reducción del 50 por ciento; 2. LA RENUNCIA A FORMULAR ALEGACIONES QUE, EN CASO DE QUE FUESEN FORMULADAS, SE TENDRÁN POR NO PRESENTADAS; 3. LA TERMINACIÓN DEL PROCEDIMIENTO, SIN NECESIDAD DE DICTAR RESOLUCIÓN EXPRESA, EL DÍA EN QUE SE REALICE EL PAGO: a) Forma: "La terminación del procedimiento, sin necesidad de dictar resolución expresa,..."; b) Dies a quo: "La terminación del procedimiento... el día en que se realice el pago". 4. EL AGOTAMIENTO DE LA VÍA ADMINISTRATIVA SIENDO RECURRIBLE ÚNICAMENTE ANTE EL ORDEN JURISDICCIONAL CONTENCIOSO-ADMINISTRATIVO; 5. RECURRIBILIDAD EN EL ORDEN JURISDICCIONAL CONTENCIOSO - ADMINISTRATIVO Y PLAZO PARA INTERPONER EL RECURSO CONTENCIOSO-ADMINISTRATIVO SE INICIARÁ EL DÍA SIGUIENTE A AQUEL EN QUE TENGA LUGAR EL PAGO; 6. LA FIRMEZA DE LA SANCIÓN EN LA VÍA ADMINISTRATIVA DESDE EL MOMENTO DEL PAGO, PRODUCIENDO PLENOS EFECTOS DESDE EL DÍA SIGUIENTE; 7. LA SANCIÓN NO COMPUTARÁ COMO ANTECEDENTE EN EL REGISTRO DE CONDUCTORES E INFRACTORES, SIEMPRE QUE SE TRATE DE INFRACCIONES GRAVES QUE NO LLEVEN APAREJADA PÉRDIDA DE PUNTOS. D) A modo de conclusiones: Una valoración en conjunto de las consecuencias establecidas para las denuncias (expedientes sancionadores) tramitadas por el procedimiento sancionador abreviado.

\section{DE LA DETERMINACIÓN DE PROCEDIMIENTOS: CUESTIONES GENERALES Y DELIMITACIÓN}

\section{A) La previsión de dos procedimientos sancionadores}

La Ley de Tráfico y Seguridad Vial determina la existencia de dos clases de procedimientos sancionadores a través de los que se pueden depurar las responsabilidades derivadas de las infracciones en materia de tráfico y seguridad vial, y así, el art. 79 LTSV hace referencia al "procedimiento sancionador abreviado" (al que se destina el art. 80 LTSV) y al "procedimiento sancionador ordinario" (que se regula en el art. 81 LTSV).

La propia forma en la que se enuncia la existencia de dos procedimientos situando, en primer plano, y por delante del que recibe la calificación de ordinario, al que se denomina como procedimiento abreviado, es una declaración de intenciones, y así hay que entenderlo, sobre la forma en la que se configura, de manera general, el procedimiento como instrumento para sancionar la conductas que infrinjan lo establecido en la LTSV.

El art. 79 LTSV contiene, además, una serie de disposiciones sobre la determinación de la elección del concreto procedimiento sancionador a seguir en cada caso, así como alguna genérica prescripción sobre la presentación de los escritos que, en su caso, los interesados pueden presentar a lo largo del procedimiento. 


\section{B) Delimitación y elección del procedimiento sancionador}

El art. 79.2 LTSV determina la existencia de supuestos en los que, en todo caso, la tramitación habrá de efectuarse por medio del procedimiento sancionador ordinario, ya que el procedimiento sancionador abreviado no será de aplicación a las infracciones previstas en el art. 65 , apartados $5 . \mathrm{h})$, j) y $6^{1}$.

Al lado de estos supuestos que, en todo caso, se dirigen al procedimiento sancionador ordinario, se establece que la infracción consistente en el incumplimiento de la obligación de asegurar el vehículo "podrá sancionarse conforme a uno de los dos procedimientos sancionadores que se establecen en esta Ley"² (art. 79.3 LTSV).

El uso del término "podrá" no ayuda, precisamente, a determinar lo que el legislador ha querido hacer con este supuesto. Hay que entender que esta redacción es, en sí misma, superflua y que este tipo de infracciones, al igual que todas aquellas que cuya tramitación queda específicamente reservada al procedimiento sancionador ordinario pueden ser tramitadas por ambos procedimientos, lo que dependerá de actuación del denunciado.

El resto de infracciones (incluidas, por tanto, las relativas al incumplimiento de asegurar los vehículos a motor) podrán ser tramitadas tanto por el procedimiento sancionador ordinario como por el abreviado, elección que no corresponde a la Administración sancionadora, ni se encuentra en su ámbito de decisión, puesto que la

\footnotetext{
${ }^{1}$ Estas infracciones se detallan al determinar el ámbito objetivo del procedimiento sancionador ordinario y se corresponden con la conducción de vehículos que lleven instalados inhibidores, la no identificación del conductor responsable de la infracción y las que, agrupadas en el art. 65.6 LTSV, son calificadas "asimismo" como infracciones muy graves.

2 Disposición extraña, la contenida en el art. 79.3 LTSV. De un lado, por sus propios términos y el uso del "podrá" en referencia a la posibilidad de tramitar este tipo de infracciones por uno u otro procedimiento. De otro, porque nada se señala sobre el resto de infracciones (salvo en los casos en los que se establece la necesaria tramitación por el procedimiento sancionador ordinario). Cuestiones que la convierten, en este sentido, en una disposición superflua.

Pero es que, además, en el art. 65.7 LTSV se dispone que "las infracciones derivadas del incumplimiento de la obligación de asegurar los vehículos a motor se regularán y sancionarán con arreglo a su legislación específica", lo cual puede resultar un poco desconcertante.

La explicación es relativamente sencilla, siempre que se tenga en cuenta que la Ley 18/2009, de 23 de noviembre, que dio nueva redacción a todo el régimen sancionador de la LTSV, al mismo tiempo, modifico el art. 3 de la Ley sobre Responsabilidad Civil y Seguro en la Circulación de Vehículos a Motor, aprobado por Real Decreto Legislativo 8/2004, de 29 de octubre, fijando la redacción de los apartados segundo y tercero del referido art. 3 en los siguientes términos:

“2. Para sancionar la infracción serán competentes los Jefes Provinciales de Tráfico o, en las Comunidades Autónomas que tengan transferidas competencias ejecutivas en materia de tráfico y circulación de vehículos a motor, los órganos previstos en la normativa autonómica, en los términos establecidos en el artículo 71 del Texto Articulado de la Ley sobre Tráfico, Circulación de Vehículos a Motor y Seguridad Vial, aprobado por Real Decreto Legislativo 339/1990, de 2 de marzo.

3. La infracción se sancionará conforme a uno de los procedimientos sancionadores previstos en el Texto Articulado de la Ley sobre Tráfico, Circulación de Vehículos a Motor y Seguridad Vial.
} 
determinación del procedimiento a seguir depende de la actuación del denunciado, siendo éste, por tanto, quien elige el procedimiento por el que van a ser tramitados los hechos constitutivos de infracción.

Tal y como establece el art. 79.1 párrafo segundo LTSV, si el denunciado efectúa el pago voluntario de la multa en el plazo establecido, se seguirá el procedimiento sancionador abreviado y, caso de no hacerlo, la tramitación se realizará conforme a lo establecido para el procedimiento sancionador ordinario.

Es el denunciado (con su acción, la de proceder al pago voluntario o la de no hacerlo) el que, en definitiva, determina el procedimiento que se va a seguir y es, por lo tanto, el propio denunciado el que escoge, la forma en la que se va a tramitar el procedimiento sancionador, quedando la Administración a la expectativa de lo que haga y la forma en la que actúe el denunciado.

\section{C) Prescripciones generales sobre presentación de escritos}

El art. 79 LTSV se cierra con un apartado, el cuarto, que contiene dos previsiones sobre la presentación de "las alegaciones, escritos y recursos que se deriven de los procedimientos sancionadores en materia de tráfico".

La primera de establece la posibilidad de que para la presentación de todos esos escritos podrá hacerse uso tanto en los lugares que expresamente se designen por la Administración como en los establecidos, de manera general en el art. 38 LRJ - PAC.

La segunda se limita a recordar, más que a disponer, ya que señala que "cuando se presenten en los registros, oficinas o dependencias no designados expresamente, éstos los remitirán a los órganos competentes en materia de tráfico a la mayor brevedad posible", lo que no deja de ser una reiteración del deber de los órganos administrativos de cursar sin dilación a sus destinatarios los escritos presentados en sus registros, conforme a lo establecido en el referido art. 38.2 LRJ - PAC.

Por todo ello no parece estar de más recordar que la previsión efectuada en el art. 38.4 LRJ - PAC "es precisamente un instrumento al servicio de ese acercamiento, pues permite a los ciudadanos presentar sus solicitudes, escritos y comunicaciones, dirigidos a los órganos de las Administraciones públicas, tanto en el registro del órgano administrativo a que se dirijan [apartado a)], como en los registros de cualquier órgano de la Administración General del Estado o de cualquier Administración de las Comunidades Autónomas [apartado b)]"3 .

\footnotetext{
${ }^{3}$ Cfr. STS de 14 de mayo de 2013 (RJ 2013, 4232).
} 


\section{EL PROCEDIMIENTO SANCIONADOR ORDINARIO}

\section{A) Cuestiones generales}

La LTSV establece un procedimiento sancionador ordinario para la tramitación de los expedientes sancionadores por infracción de las normas establecidas en materia de tráfico y seguridad vial.

De manera previa al análisis del iter procedimental resulta preciso determinar el ámbito objetivo sobre el que puede actuar este procedimiento sancionador ordinario así como los presupuestos previos del mismo.

\section{1. ÁMBITO OBJETIVO DEL PROCEDIMIENTO SANCIONADOR ORDINARIO}

El art. 79 LTSV determina dos clases de procedimientos sancionadores, dejando, en principio y como norma general, la decisión de cuál va ser el cauce de tramitación por el que se va a sustanciar el expediente sancionador en la esfera de decisión del denunciado, puesto que éste puede, conforme a lo establecido en el apartado 1 del referido art. 79 LTSV o "realizar el pago voluntario con reducción del sanción de multa" o "formular las alegaciones y proponer o aportar las pruebas que estime oportunas".

En el primer caso (pago voluntario con reducción del 50 por 100 del importe de la sanción inicialmente prevista) el expediente sancionador se tramitará por el procedimiento sancionador abreviado y en segundo supuesto (que el infractor denunciado no proceda al pago voluntario, formule o no alegaciones) se solventará por el procedimiento sancionador ordinario. Esta prescripción general debe ser anotada en el sentido de que el art. 79.2 LTSV excluye la posibilidad de tramitar por el procedimiento sancionador abreviado una serie de infracciones, en concreto las consistentes en:

- Conducir vehículos que tengan instalados inhibidores de radar o cualesquiera otros mecanismos encaminados a interferir en el correcto funcionamiento de los sistemas de vigilancia del tráfico, del art. 65.5 h) LTSV

- El incumplimiento por el titular o el arrendatario del vehículo con el que se haya cometido la infracción de la obligación de identificar verazmente al conductor responsable de dicha infracción, cuando sean debidamente requeridos para ello en el plazo establecido. En el supuesto de las empresas de alquiler de vehículos sin conductor la obligación de identificar se ajustará a las previsiones al respecto del artículo 9 bis, del art. 65.5 j) LTSV 
- Realizar en la vía obras sin la autorización correspondiente, así como la retirada, ocultación, alteración o deterioro de la señalización permanente u ocasional, del art. 65.6 a) LTSV

- No instalar la señalización de obras o hacerlo incorrectamente, poniendo en grave riesgo la seguridad vial, del art. 65.6 b) LTSV

- Incumplir las normas, reglamentariamente establecidas, que regulan las actividades industriales que afectan de manera directa a la seguridad vial, del art. 65.6 c) LTSV

- Instalar inhibidores de radar en los vehículos o cualesquiera otros mecanismos encaminados a interferir en el correcto funcionamiento de los sistemas de vigilancia del tráfico. No constituirán infracción los sistemas de aviso que informan de la posición de los sistemas de vigilancia del tráfico, del art. 65.6 d) LTSV

- Incumplir las normas sobre el régimen de autorización y funcionamiento de los centros de enseñanza y formación y de los centros de reconocimiento de conductores autorizados por el Ministerio del Interior o por los órganos competentes de las Comunidades Autónomas, que afecten a la cualificación de los profesores o facultativos, al estado de los vehículos utilizados en la enseñanza, o a elementos esenciales que incidan directamente en la seguridad vial, del art. 65.6 e) LTSV

De esta manera, lo establecido en el art. 79.2 LTSV supone que los expedientes sancionadores que tengan su origen en este tipo de infracciones serán tramitados, siempre y en todo caso, por el procedimiento sancionador ordinario.

$\mathrm{Y}$, de igual manera, seguirán la tramitación correspondiente al procedimiento sancionador ordinario todos aquellos expedientes en los que el denunciado proceda a formular alegaciones (sin efectuar el pago) o aquellos en los que no haga nada, es decir, ni proceda al pago ni formule alegaciones

Estos dos conjuntos de supuestos, el de los de la segunda opción establecida en el art. 79.1 LTSV (o que deja transcurrir el tiempo sin hacer nada) y el de los específicamente predeterminados por la Ley (art. 79.2 LTSV), conforma el ámbito sobre el que el procedimiento sancionador ordinario va a desplegar sus efectos.

\section{PREsUPUESTOS O PUNTOS DE PARTIDA DEL PROCEDIMIENTO SANCIONADOR ORDINARIO}

El procedimiento sancionador ordinario, al igual que el abreviado parte de un presupuesto habilitante con el que se inicia la redacción del art. 81 LTSV, al señalar "notificada la denuncia...". Esto supone que la denuncia ha sido efectivamente notificada o que, en su caso, se ha seguido el procedimiento que permite entender 
que, a los efectos de la Ley, esa notificación ha sido practicada, es decir, que se han realizado todas las acciones previstas en la LTSV para darse por cumplido dicho trámite y que se continúa con el procedimiento sancionador ${ }^{4}$.

La LTSV no es especialmente precisa (ni afortunada) en este punto, al establecer, como forma de iniciación del procedimiento la denuncia y su notificación. Tal y como determina el art. 73 LTSV la incoación del procedimiento puede venir determinada por iniciativa propia o mediante denuncia. El art. 81 LTSV (al igual que el art. 79 LTSV) se asienta sobre un planteamiento que considera a la denuncia como la única forma de iniciación del procedimiento. Es cierto que la denuncia se ha constituido, durante mucho tiempo, en la forma habitual y normal de iniciación del procedimiento sancionador, hasta el punto de que las notificadas en el acto constituyen acto de iniciación del procedimiento. Pero el hecho de que la denuncia haya tenido, en la práctica, casi el monopolio de la iniciación del procedimiento es algo que no debiera confundirse, como parece que ocurren en los términos de la LTSV, con la única posibilidad de iniciación, algo que, la propia práctica, se puede encargar de desvirtuar desde el momento en que la autoridad sancionadora puede tener conocimiento de los hechos a través de medios de captación y reproducción de imágenes que permitan la identificación del vehículo, tal y como previene el art. 76.2 c) de la propia LTSV, sin que ello necesite, por sí mismo, de denuncia para que se incoe el correspondiente procedimiento sancionador ${ }^{5}$.

3. OTROS ASPECTOS FORMALES SOBRE LA REGULACIÓN DEL PROCEDIMIENTO SANCIONADOR ORDINARIO EN LA LTSV

Conviene destacar, por la trascendencia (teórica y práctica) que para el entendimiento de las previsiones que la LTSV realiza sobre el procedimiento sancionador ordinario, una realidad formal sobre la propia regulación efectuada. Y ello aunque esta advertencia recaiga sobre algo que resulta absolutamente evidente.

La regulación del procedimiento sancionador ordinario que realiza la LTSV se hace, de forma directa, en un artículo, el 81 LTSV, si bien es cierto que de forma incidental o indirecta se requieren de más preceptos legales de la propia Ley.

Es evidente que, como apreciación previa, resulta muy difícil que los cinco apartados en los que está estructurado ese art. 81 LTSV contengan todas las previsiones necesarias para la tramitación de un procedimiento sancionador por este cauce que, por su denominación, deberíamos (o podríamos) entender que es curso normal que deben de seguir los expedientes sancionadores en materia de tráfico y seguridad vial.

\footnotetext{
${ }^{4}$ Véanse en el capítulo sobre las fases del procedimiento administrativo sancionador en materia de tráfico y seguridad vial los apartados correspondientes a la denuncia (II) y su notificación (III).

${ }^{5}$ Sobre esta cuestión véase el apartado sobre la iniciación del capítulo sobre las fases del procedimiento administrativo sancionador en materia de tráfico y seguridad vial y, en particular, la nota 10 del referido capítulo.
} 
Tomar estos dos enunciados como afirmaciones es errar en el genuino (al tiempo que intrínseco) planteamiento de la LTSV en los términos que ésta recibe de la Ley 18/2009, de 23 de noviembre.

La LTSV tiene, precisamente, ese rango, el de Ley (Real Decreto Legislativo). La versión original ha sido objeto de diversas modificaciones. La última de ellas, la que más nos interesa aquí por ser la causa de "la configuración del nuevo procedimiento sancionador en materia de tráfico... mediante la nueva redacción de los Títulos $\mathrm{V}$ y $\mathrm{VI}$ (infracciones y sanciones, y procedimiento sancionador de tráfico) del texto articulado de la Ley sobre Tráfico, Circulación de Vehículos a Motor y Seguridad Vial”6.

La propia naturaleza de la Ley presupone concisión regulatoria que, en el caso de la LTSV, alcanza el carácter de parquedad. Es cierto que el procedimiento sancionador ordinario no agota su regulación en el art. 81 LTSV, por mucho que así pudiera desprenderse de la propia rúbrica del artículo. El precepto está relacionado con el art. 79 LTSV, en el que encontramos, bajo la denominación "clases de procedimientos sancionadores", normas de carácter general; de igual forma ocurre con el art. 82 LTSV que, bajo el apelativo "recursos en el procedimiento sancionador ordinario", se inicia con una referencia a "la resolución sancionadora" que pone fin al procedimiento, cuestión que no se aborda en el estricto marco del art. 81 LTSV. Y, de igual manera con el art. 70.1 LTSV, que abre el Capítulo III, sobre el "procedimiento sancionador" y en el que se anuncia que el procedimiento sancionador en materia de tráfico se instruirá con arreglo a lo dispuesto en este Capítulo y en su desarrollo reglamentario y, de forma supletoria, por las disposiciones generales de la LRJ $-\mathrm{PAC}^{7}$.

El art. 81 LTSV establece el esquema del procedimiento sancionador ordinario y se complementa con un importante número de remisiones (expresas unas, tácitas otras) a diferentes preceptos de la propia LTSV, así como al sistema general del procedimiento administrativo sancionador contenido en la LRJ - PAC y en su

\footnotetext{
${ }^{6}$ Cfr. en este sentido, el inciso inicial del apartado II del Preámbulo de la Ley 18/2009, de 23 de noviembre.

${ }^{7}$ Conviene tener presente el tenor literal del art. 70.1 LTSV que, en la redacción recibida de la Ley 18/2009, de 23 de noviembre, establece que "no se podrá imponer sanción alguna por las infracciones tipificadas en esta Ley sino en virtud de procedimiento instruido con arreglo a lo dispuesto en el presente Capítulo y en las disposiciones reglamentarias que lo desarrollen y, supletoriamente, por lo dispuesto en la Ley 30/1992, de 26 de noviembre, de Régimen Jurídico de las Administraciones Públicas y del Procedimiento Administrativo Común".

La referencia que este art. 70.1 LTSV efectúa es muy precisa en cuanto al carácter supletorio, en esta materia, de la LRJ - PAC, pero no lo es tanto, nada en realidad, en cuanto al desarrollo reglamentario de la propia LRJ - PAC, de manera que, incluso, podrían plantearse dudas (que aquí se descartan) en cuanto a la posibilidad de integrar en su caso, supletoriamente, el RD 1398/1993, de 4 de agosto, por el que se aprueba el Reglamento del Procedimiento para el ejercicio de la potestad sancionadora (REPEPOS). Tal vez el Reglamento al que se refiere el propio art. 70.1 LTSV, y que tendrá que sustituir (debería haberlo hecho ya, hace tiempo, conforme a lo establecido en la disp. final Sexta.2 de la Ley 18/2009, de 23 de noviembre) al RD 320/1994, de 25 de febrero, por el que se aprobó Reglamento de Procedimiento Sancionador en materia de Tráfico, Circulación de Vehículos a Motor y Seguridad Vial, clarifique la cuestión.
} 
Reglamento para el Ejercicio del Procedimiento para el Ejercicio de la Potestad Sancionadora (REPEPOS).

\section{B) Sobre el inicio del procedimiento sancionador}

1. LA TRAMITACIÓN DEL PROCEDIMIENTO

Al momento de comenzar el procedimiento sancionador en materia de tráfico y seguridad vial, ya sea por denuncia del Agente de la autoridad notificada en el acto o por la iniciativa de la autoridad competente, se desconoce (en la inmensa mayoría de los casos) el procedimiento que se va a seguir en su tramitación. Algo evidente, dado que (y excepto en los casos establecidos en el art. 79.2 LTSV en los que se excluye la tramitación por el procedimiento abreviado) la LTSV entrega esa decisión al denunciado que dispone de la posibilidad de elección del tipo de procedimiento a seguir.

De ello se deriva que la Administración ha de comenzar todos los procedimientos como si fueran a tramitarse por el cauce ordinario, a la espera de la forma en la que actúe el denunciado.

La tramitación por el procedimiento sancionador ordinario requiere de la previa notificación al denunciado ("notificación de la denuncia", en la letra del 81.1 LTSV), ya sea por haber sido notificada la denuncia en el acto o por haberse cumplido con los trámites que permiten determinar que el denunciado ha sido notificado ${ }^{8}$.

El procedimiento sancionador se ha iniciado y seguirá por la tramitación del ordinario en tanto que no se produzca el pago voluntario en el período establecido para ello y en este propio acto de iniciación se plantean una serie de cuestiones que resulta preciso tener presentes.

El art. 81 LTSV parte de la notificación de la denuncia al interesado y de que este dispone de un plazo para formular alegaciones y proponer o aportar pruebas.

En ese aspecto resultaban más precisas las previsiones realizadas en el art. 11.1 RPSTSV en cuanto que en él se señalaba que una vez recibida la denuncia se procedería "a la calificación de los hechos y graduación de la multa o a la verificación de la calificación y multa consignadas en la misma por el agente denunciante", es decir, a realizar el correspondiente análisis jurídico y la comprobación de que concurren las circunstancias que justifican y dan fundamento a la iniciación (si es que ya no está iniciado, caso de las denuncias notificadas en el acto) del procedimiento sancionador.

De todas esas circunstancias es preciso hacer especial referencia a:

\footnotetext{
${ }^{8}$ Véanse en el capítulo sobre las fases del procedimiento administrativo sancionador en materia de tráfico y seguridad vial los apartados correspondientes a la denuncia (II) y su notificación (III).
} 
- Que los hechos son constitutivos (tienen la apariencia) de infracción

- Que la denuncia contiene toda la información exigida en el art. 74 LTSV

- Que caso de no haber sido notificada en el acto concurren las circunstancias que permiten la notificación posterior

- Que si ha sido notificada en el acto en ella constan los requisitos adicionales requeridos para ese caso en el art. 74.3 LTSV

- Que no ha transcurrido el plazo de tiempo que determine la prescripción de la infracción

La inexistencia de cualquiera de estas circunstancias supondría la necesidad de proceder al archivo de las actuaciones practicadas por no concurrir las circunstancias necesarias para continuar o iniciar el procedimiento sancionador.

\section{CONTENIDO DEL ACTO DE INICIACIÓN DEL PROCEDIMIENTO}

La iniciación del procedimiento sancionador se basa en la existencia de una denuncia (aunque no tenga porque ser así, necesariamente). Pero dado que la notificación en el acto de la denuncia por el Agente de la Autoridad tiene como consecuencia, a todos los efectos, que esa denuncia se constituye en acto de iniciación del procedimiento sancionador (art. 73.2 LTSV) y que, en ese supuesto, está taxativamente determinado el contenido que "deberá constar" en esas denuncias (apartados 2 y 3 del art. 74 LTSV), se puede establecer el contenido mínimo del acto de iniciación del procedimiento (medie, o no, denuncia).

Esas previsiones se parecen a las efectuadas en el art. 13 REPEPOS, precepto en el que se regula el contenido mínimo con el que se formalizará la iniciación de los procedimientos sancionadores. Pero entre las diferencias entra las previsiones efectuadas en la LTSV y el régimen general se encuentra la necesidad de incluir la determinación del Instructor del procedimiento.

Nada señala la LTSV sobre el "instructor" del procedimiento sancionador". Así pues el primer problema al que nos enfrentamos es el de determinar su propia existencia en el procedimiento sancionador y las normas a las que se encuentra sometido.

De la propia LTSV se infiere la existencia de instructor, pero, a diferencia del régimen general (LRJ - PAC y REPEPOS), no se realizan referencias expresas a esta figura. Frente al silencio que, sobre esta cuestión, guarda la LTSV, encontramos expresa referencia a ello en el art. 13.1 c) REPEPOS y en el art. 135 párrafo segundo LRJ - PAC como elementos que han de integrar el contenido mínimo de la iniciación del procedimiento

\footnotetext{
${ }^{9}$ A lo largo del articulado de la LTSV se realizan, únicamente, cuatro referencias al instructor. Las dos que figuran en el art. 81.3 LTSV, la realizada en el art. 81.4 LTSV al órgano instructor y la realizada en el art. 77.2 LTSV en sede de notificación de denuncias.
} 
sancionador ${ }^{10}$. La cuestión ha sido objeto de múltiples resoluciones judiciales que en modo alguno permiten determinar ni la necesidad del cumplimiento de este requisito en el procedimiento sancionador en materia de tráfico ni, en su caso, la forma en que debiera entenderse cumplido. Así, el casuismo abarca las resoluciones en las que se considera que esta falta de determinación del instructor del procedimiento sancionador es un defecto formal que no tiene mayor trascendencia salvo que se pruebe que ello ha ocasionado indefensión al interesado ${ }^{11}$, lo que no es obstáculo para poder encontrar resoluciones que mantienen lo contrario y que sostienen la necesidad de cumplir con la determinación del Instructor ${ }^{12}$.

\section{ADOPCIÓN DE MEDIDAS PROVISIONALES}

Ninguna referencia se contiene, de manera expresa, a la posibilidad de adoptar, en el marco de la específica regulación del procedimiento sancionador en materia de tráfico (arts. 70 a 82 LTSV), medidas de carácter provisional.

Pero, ciertamente, en el apartado destinado dentro de la regulación del régimen sancionador a tratar "de las medidas provisionales y de otras medidas" (arts. 83 a 87 LTSV), se establece que "el órgano competente que haya ordenado la incoación del procedimiento sancionador podrá adoptar mediante acuerdo motivado, en cualquier momento de la instrucción del procedimiento sancionador, las medidas provisionales

\footnotetext{
${ }^{10}$ El art. 135 párrafo segundo LRJ - PAC señala, como derechos del presunto responsable, el "ser notificado de los hechos que se le imputen, de las infracciones que tales hechos puedan constituir y de las sanciones que, en su caso, se les pudieran imponer, así como de la identidad del instructor, de la autoridad competente para imponer la sanción y de la norma que atribuya la competencia" y el art. 13.1 c) REPEPOS incluye en el contenido mínimo al "Instructor y, en su caso, Secretario del procedimiento, con expresa indicación del régimen de recusación de los mismos".

${ }^{11}$ Así, desde las resoluciones que entienden que la LTSV "no prevé el nombramiento de instructor y secretario en este concreto procedimiento sancionador" (STSJ Cantabria de 30 de abril de 1997, RJCA $1997,840)$, las que consideran que basta con la indicación de quien sea el encargado de la tramitación del expediente y que el interesado puede en todo caso impugnar su designación (STSJ Castilla - La Mancha de 6 de mayo de 1999, RJCA 1999, 1431), aquella otras para las que la falta de identificación concreta de la persona que encarnaba el órgano encargado de la instrucción del procedimiento sancionador, se considera una irregularidad sin la suficiente entidad para determinar la invalidez de los actos impugnados cuando se pueda deducir y no se determine la existencia de alguna causa que pudiera dar lugar a la abstención o recusación de dicha persona (STSJ Región de Murcia, de 6 de mayo de 1999, RJCA 1999, 1846) y que en todo casos se requiere que ello haya producido indefensión para el interesado (STSJ Castilla y León - Valladolid, de 30 de abril de 2001, JUR 2001, 211694) (STSJ Región de Murcia de 8 de enero de 1999, JUR 1999, 256580), admitiéndose que se cumple con el requisito de identificación al señalar como Instructor a "la Unidad de sanciones de la Jefatura de Tráfico (STSJ Aragón de 26 de mayo de 2000, JUR 2000, 282161).

${ }^{12} \mathrm{Y}$ que consideran que la aplicación del art. $13.1 \mathrm{c}$ ) REPEPOS al procedimiento sancionador en materia de tráfico, en todo aquello no previsto en el PRSTSV, lo que impone a la Administración la obligación de comunicar a los afectados la designación del instructor de los expedientes sancionadores a fin de que aquéllos puedan ejercer el derecho a recusarlo si concurriere causa legal, incumplimiento que invalida el procedimiento (STSJ La Rioja de 8 de abril de 1999, RJCA 1999, 900).
} 
que aseguren la eficacia de la resolución final que pudiera recaer en el procedimiento sancionador".

Un somero análisis de los términos en los que se encuentra redactada la previsión normativa permite detectar su carácter ciertamente peculiar.

En primer lugar por la referencia al "órgano competente que haya ordenado la incoación" que nos ubica en la previsión de la denuncia formulada por Agente de la Autoridad y notificada en el acto al denunciado y en segundo término por la limitación a la que se somete la propia adopción de medidas provisionales en cuanto que su finalidad no puede ser otra que la de que "aseguren la eficacia de la resolución final que pudiera recaer en el procedimiento sancionador", resolución que, en todo caso, puede suponer la imposición de una multa (art. 67 LTSV) y asegurar su eficacia, por tanto, es el que esa multa se haga efectiva, de ahí que se haya señalado que "no cabe adoptar, como medida provisional, por ejemplo, la suspensión del permiso de conducir o el de circulación" ${ }^{\prime 3}$.

De esta forma una cosa es la adopción de las medidas provisionales previstas (inmovilización y retirada y depósito del vehículo) y otra su aplicación en el procedimiento sancionador para asegurar la eficacia de la resolución que pudiera recaer.

De hecho los supuestos de inmovilización del vehículo previstos en el art. 84.1 LTSV impiden que esta se mantenga una vez desaparezca la causa que la motivó ya que el propio art. 84.1 LTSV dispone que "la inmovilización se levantará en el momento en que cese la causa que la motivó".

Quiero ello decir que fuera del momento en el que se produce la infracción, más allá del momento en que el Agente de la Autoridad observa los hechos, formula la denuncia y lo notifica al denunciado, no se alcanza a ver supuesto alguno que permita al órgano instructor la adopción de medida provisional alguna y en ese punto es donde adquiere toda su relevancia la previsión realizada en el art. 83.2 LTSV conforme a la que "los Agentes de la Autoridad encargados de la vigilancia del tráfico como consecuencia de presuntas infracciones a lo dispuesto en esta Ley únicamente podrán adoptar la inmovilización del vehículo en los supuestos previstos en el art. 84 LTSV".

Y la medida de inmovilización del vehículo prevista en ese art. 84 LTSV presenta, en lo que aquí interesa, las siguientes características:

- Se trata de una medida provisional que puede ser adoptada en el marco de un procedimiento sancionador en materia de tráfico

\footnotetext{
${ }^{13}$ CAno CAMPoS, T., El régimen jurídico - administrativo del tráfico, 2a ed., Madrid, Civitas, 2010, 2a ed., págs. $536-537$.
} 
- Su adopción requiere de la existencia de una infracción (presunta infracción)

- Su adopción está limitada en los supuestos legalmente previstos

- Su adopción ha de cesar en el momento que cesa la causa que la ha originado

Pero es fuera de las previsiones del art. 84 LTSV y de la concreta regulación de las medidas provisionales donde se encuentra la única inmovilización del vehículo que, como medida provisional dentro del procedimiento sancionador, tiene sentido, ya que en el marco de la regulación de las sanciones el art. 67.4 LTSV dispone la posibilidad de inmovilización ( $y$, en su caso, de traslado) en el caso de infractores que no acrediten su residencia legal en territorio español y no depositen el importe de la multa fijada por el Agente denunciante.

Cuestión distinta es la adopción de medidas provisionales en procedimientos de otra naturaleza, pero en el ámbito sancionador las condiciones para la adopción de estas medidas han de cumplir con lo que aquí se ha señalado.

\section{IDENTIFICACIÓN DEL “CONDUCTOR RESPONSABLE"}

Cuando la denuncia no hubiera sido notificada en el acto la primera labor del instructor será la de identificar al responsable de la infracción. Para ello se dirigirá, caso de haberlo, a quien aparezca designado como conductor habitual en el Registro de Vehículos, en su defecto, y si figurara como tal, al arrendatario a largo plazo, y, en defecto de estos, al titular del vehículo ${ }^{14}$.

Se trata de un trámite previo puesto que el destinatario de ese requerimiento puede, 0 no, coincidir con el responsable de la infracción, y será tras esa identificación que el procedimiento se dirija contra el responsable de la infracción o, caso de incumplimiento del deber establecido en el art. 9 bis a) LTSV de "facilitar esa identificación", que se produzca otra infracción, diferente de la que dio lugar a ese requerimiento, que da lugar a un procedimiento distinto con un responsable (infractor) diferente por la comisión de la infracción muy grave prevista en el art. 65.5 j) LTSV.

\footnotetext{
${ }^{14}$ Los términos en los que se encuentra redactado el art. 81.1 LTSV no lo señalan así. En el referido precepto se establece que "en el supuesto de que no se hubiese producido la detención del vehículo, el titular, el arrendatario a largo plazo o el conductor habitual, en su caso, dispondrán de un plazo de quince días naturales para identificar al conductor responsable de la infracción contra el que se iniciará el procedimiento sancionador", pero resulta preciso tener presente lo dispuesto en los arts. 9 bis y 69 LTSV, de los que se deriva un orden en cuanto a las personas, que caso de existir en relación al vehículo con el que se ha cometido la infracción, hay que dirigir el requerimiento de identificación del conductor al momento de comisión de la infracción.
} 
Así, sobre la identificación del conductor responsable de la infracción original resulta preciso, en el marco de la tramitación del procedimiento sancionador, realizar una serie de consideraciones.

\section{a) El cumplimiento del deber de identificación}

La previsión efectuada en el art. 81.2 LTSV se limita a indicar al necesidad de dirigirse a las personas que, vinculadas con el vehículo con el que se ha cometido la infracción, tienen el deber de identificar a la persona que lo conducía en ese momento, estableciendo, eso sí, un plazo de quince días naturales, y que cuando ese requerimiento haya sido realizado a través de la Dirección Electrónica Vial (DEV) será obligatorio que el requerido cumpla con ese deber de identificación haciendo uso de medios telemáticos.

El contenido de ese deber de identificación se corresponde con la infracción prevista en el art. 65.5 j) LTSV que determina la "obligación de identificar verazmente" a ese conductor $^{15}$, lo cual nos ubica en el contenido de la forma de cumplir con ese deber en los términos establecidos en el art. 9 bis LTSV que exigen, para que se entienda cumplimentado, que los datos facilitados incluyan "el número del permiso o licencia de conducción que permita la identificación en el Registro de Conductores e Infractores" o, en el caso de conductores que no posean una autorización administrativa expedida en nuestro país, de "copia de la autorización administrativa que le habilite a conducir en España y facilitarla a la Administración cuando le sea requerida", bastando, en el caso de las empresas de alquiler de vehículos sin conductor, con "la copia del contrato de arrendamiento" ${ }^{\prime 16}$.

\section{b) Los efectos de la identificación}

La LTSV determina la forma en la que tiene que ser realizada esa identificación y los efectos de su incumplimiento, que califica como infracción muy grave, art. 65.5 j) LTSV, con efectos diferentes en función de la propia calificación de la infracción originaria ${ }^{17}$.

\footnotetext{
15 Infracción que, como ya se ha señalado en otro lugar, la LTSV tipifica como una "infracción autónoma", tal y como han señalado las SSTC 197/1995, de 21 de diciembre, FF. 6 A) y 8 y 67/2003, de 27 de marzo, F. 2).

16 Téngase en cuenta que la Ley 18/2009, de 23 de noviembre, modifico sustancialmente los términos en los que, previamente, se establecía el deber de identificación que, contenido en el art. 72.3 LTSV, no contemplaba los requisitos documentales que ahora se recogen en el art. 9 bis.1 LTSV en cuanto a la forma. Véase, en este sentido el apartado correspondiente del capítulo destinado a la responsabilidad por la comisión de las infracciones de tráfico.

17 La Ley 18/2009, de 23 de noviembre, introdujo una importante modificación conceptual al determinar, en el marco de las sanciones, una norma especial conforme a la que "la multa por la infracción prevista en el artículo 65.5.j) será el doble de la prevista para la infracción originaria que la motivó, si es infracción leve, y el triple, si es infracción grave o muy grave", previsión que parece muy
} 
Pero nada señala respecto al supuesto en el que quien resulte identificado como conductor niegue su participación en los hechos y ser el conductor del vehículo al momento de comisión de la infracción.

Eludir el deber de identificación mediante la designación de un ciudadano extranjero o de una persona que no guarda relación con los hechos se habían constituido en prácticas mucho más habituales de lo que se pudiera imaginar.

A estas situaciones pretende enfrentarse la vigente redacción que une al requisito de "veracidad" el de datos que es preciso facilitar, el número de permiso en el caso de autorizaciones nacionales y copia de los permisos en el caso de estar expedidos en otro país ${ }^{18}$.

Se trata de una cuestión compleja en la que la regulación y la práctica en la tramitación han tenido que virar y cambiar para adaptarse a la realidad con la que se encontraban los procedimientos. En esa práctica procedimental la identificación realizada por el denunciado se daba por buena, de manera que una persona podía encontrarse con que había sido identificado como conductor al momento de la comisión de una infracción. En ese caso, ahora y antes, no puede darse por buena una identificación en la que el sujeto identificado como conductor niegue serlo. Es más, la cuestión a analizar es la determinación de la responsabilidad en la que pudiera incurrir quien pretende cumplir el deber de identificación señalando, a sabiendas, a quien no lo era, lo cual, además, puede ocurrir con conocimiento o desconocimiento de la persona que se señala como conductor.

\section{c) Tramitación por el procedimiento sancionador ordinario}

En todo caso cuando se incumpla, o no se cumpla adecuadamente, el deber de identificar al conductor al momento de la infracción, ello dará lugar a la iniciación de un procedimiento diferente que se incoará de oficio por iniciativa propia al cometer el titular (arrendatario a largo plazo o conductor habitual) el tipo previsto en el art. 65.5 j) LTSV.

$Y$, en este caso, el instructor se encontrará ante uno de los supuestos a los que, conforme previene de manera específica el art. 79.2 LTSV, no le será de aplicación el

acertada en cuanto que toma en consideración, y pone en relación, el incumplimiento del deber de identificación con la conducta y su gravedad a efectos de calificación.

${ }^{18}$ La Ley 17/2005, de 19 de julio, dio nueva redacción al entonces art. 72.3 LTSV pasando de "tiene el deber de identificar al conductor responsable de la infracción" a "tienen el deber de identificar verazmente al conductor responsable de la infracción", al tiempo que se modificaba la calificación de la infracción de grave a muy grave. La Ley 18/2009, de 23 de noviembre, introdujo la vigente redacción como deber del titular o del arrendatario del vehículo en el art. 9 bis.1 LTSV, precepto en el que no figura el conductor habitual al que, no obstante, si se hace referencia en el art. 69.1 c) LTSV (Véase, sobre ello, el apartado II.B).4.c) sobre vehículos que tuvieran designado conductor habitual en el capítulo Responsabilidad por la comisión de infracciones de tráfico. 
procedimiento sancionador abreviado, por lo que será preciso, en todo caso, tramitarlo por el procedimiento sancionador ordinario.

\section{C) Alegaciones}

1. LAS OPCIONES DEL INFRACTOR - DENUNCIADO

Llegados a este punto nos encontramos ante la tramitación de un expediente sancionador en materia de tráfico y seguridad vial por el procedimiento sancionador ordinario. El infractor - denunciado ha renunciado a desentenderse del asunto (pagar y olvidar) y ha optado o bien por presentar las alegaciones (formular lo que tenga por conveniente y proponer o aportar las pruebas que estime oportunas) o bien por no hacer nada frente a la notificación de la denuncia.

El pago voluntario de la sanción lleva a la tramitación por el procedimiento abreviado y la pasividad frente a las actuaciones desemboca, de una u otra manera, en la resolución sancionadora ${ }^{19}$. Interesa aquí la evolución del expediente en el caso de que el infractor - denunciado opte por formular alegaciones frente a la notificación de la denuncia y la actuación, que en ese caso, tiene que desarrollar el instructor del expediente sancionador por el específico cauce del procedimiento sancionador ordinario.

Varias son las hipótesis a las que se pueden reducir las prescripciones realizadas en este sentido por la LTSV y que pueden ser sintetizadas en los siguientes supuestos que se derivan de que en esas alegaciones se aporten, o no, "datos nuevos o distintos de los constatados por el Agente denunciante" y que el interesado solicite o no la práctica de prueba.

\section{CONTENIDO}

Formular alegaciones y proponer y aportar pruebas son derechos básicos del denunciado reconocidos como tal en el art. 135 LRJ - PAC.

El acto de iniciación del procedimiento debe recoger estos derechos, tal y como se establece, de manera general en el art. $13.1 \mathrm{f}$ ) REPEPOS $y$, de forma específica en el ámbito del procedimiento sancionador en materia de tráfico, en el art. 74.3 d) LTSV como elemento que necesariamente ha de constar en las denuncias notificadas en el acto al denunciado. Su carácter esencial, como parte de derecho de defensa, está fuera de toda duda y, por ello, su ausencia determina la nulidad de las actuaciones practicadas.

El objeto de las alegaciones, como plasmación del derecho que asiste al denunciado, es la posibilidad de exponer las razones que sirven de fundamento a su derecho, a las

\footnotetext{
${ }^{19}$ Cuestión que es objeto de análisis en el apartado C) 5 de este mismo capítulo.
} 
realizadas en la denuncia. Alegaciones que pueden requerir de la correspondiente prueba

Denuncia y alegaciones conforman los elementos sobre los que el Instructor del procedimiento sancionador tiene que conformar su opinión para trasladarla a la propuesta de resolución.

\section{PLAZO}

La LTSV no establece de una forma clara y congruente el espacio de tiempo del que dispone el denunciado para formular alegaciones. Es preciso partir del hecho de que ese plazo es el que la LTSV ofrece, de manera común, al denunciado para realizar las alegaciones o proceder al pago de la sanción fijada.

El problema surge desde el momento en que las referencias que a ese plazo se hacen en diferentes artículos de la LTSV no coinciden en cuanto a la duración del mismo. Así, mientras que en los arts. 79.1, 80 y 81.1 LTSV se fija un plazo de quince días naturales $^{20}$, el art. 74.3 d) LTSV lo establece en veinte días naturales ${ }^{21}$.

Tal discrepancia normativa sobre cuál sea el plazo del que dispone el denunciado, ya sea para proceder al pago voluntario (con el beneficio de reducción) o para formular las alegaciones que a su derecho convenga, debe ser resuelta en favor del de mayor extensión de los indicados (veinte días naturales), y ello por la propia naturaleza del trámite a desarrollar en él, al tratarse de un espacio de tiempo que la Ley pone a disposición del denunciado para el ejercicio de sus derechos, y ello por mucho que el plazo de quince días naturales aparezca en más lugares de la LTSV o, incluso, resulte coincidente con el establecido en el art. 16.1 REPEPOS y en el art. 10.1 RPSTSV.

\footnotetext{
${ }^{20}$ El art. 79.1 LTSV señala que "notificada la denuncia, el denunciado dispondrá de un plazo de quince días naturales para realizar el pago voluntario con reducción de la sanción de multa, o para formular alegaciones y proponer o aportar las pruebas que estime oportunas", el art. 80 LTSV prescribe que "una vez realizado el pago voluntario de la multa, ya sea en el acto de entrega de la denuncia o dentro del plazo de quince días naturales contados desde el día siguiente al de su notificación...", el art. 81.1 LTSV dispone que "notificada la denuncia, el interesado dispondrá de un plazo de quince días naturales para formular las alegaciones que tenga por conveniente y proponer o aportar las pruebas que estime oportunas" y el art. 81.5 LTSV que "si el denunciado no formula alegaciones ni abona el importe de la multa en el plazo de quince días naturales siguientes al de la notificación de la denuncia, ésta surtirá el efecto de acto resolutorio del procedimiento sancionador".

${ }^{21}$ El primer inciso del art. 74.3 c) LTSV establece que "en el caso de que no se proceda al abono en el acto de la sanción, deberá indicarse que dicha denuncia inicia el procedimiento sancionador y que dispone de un plazo de veinte días naturales para efectuar el pago, con la reducción y las consecuencias establecidas en el artículo 80, o para formular las alegaciones y proponer las pruebas que estime convenientes" y en la letra d) del mismo apartado se señala que "Si en el plazo señalado en el párrafo anterior no se hubiesen formulado alegaciones o no se hubiese abonado la multa, se indicará que el procedimiento se tendrá por concluido el día siguiente a la finalización de dicho plazo, conforme se establece en el art 81.5".
} 
Por ello, e independientemente de lo que figure en determinados preceptos (art. 79.1, 80 y 81.1 LTSV y 10.1 RPSTSV), hay que entender que el interesado dispone de un plazo de veinte días naturales para formular las alegaciones que tenga por conveniente y proponer o aportar las pruebas que estime oportunas. Alegaciones que podrán ser presentadas, tal y como se establece en el art. 79.4 LTSV, tanto en los lugares que se indiquen expresamente en la notificación de la denuncia como en los demás registros, oficinas y dependencias previstos en el art. 38 LRJ - PAC.

Las alegaciones formuladas fuera de ese plazo de veinte días naturales serán extemporáneas y se "podrán tener" por no efectuadas. En caso de ser admitidas (aun siendo extemporáneas) y de que el procedimiento continúe su curso hasta alcanzar la propuesta de resolución y la resolución final, no podrá ser alegado, posteriormente, ese hecho como defecto que invalide su admisión en el procedimiento.

\section{INCOMPATIBILIDAD CON EL PAGO VOLUNTARIO DE LA MULTA}

El plazo del que dispone el denunciado para formular las alegaciones o para realizar el pago voluntario con reducción de la sanción de multa ofrece al interesado la posibilidad de elegir una de esas opciones (junto con la posibilidad de no hacer nada, ni pagar, ni alegar).

Se trata de opciones alternativas y excluyentes. Así lo dispone el art. 80 b) LTSV que establece, entre las consecuencias del pago voluntario de la multa, "la renuncia a formular alegaciones" y que "en el caso de que fueran formuladas se tendrán por no presentadas".

Se trata de una previsión legal que ofrece al interesado la posibilidad de elegir entre dos alternativas y que, en el marco del planteamiento efectuado por la LTSV, resulta congruente con el resultado atribuido al pago en el art. 80 c) LTSV de tramitación por el procedimiento abreviado y terminación del procedimiento sin necesidad de dictar resolución expresa, por lo que, establecido que el procedimiento sancionador ha finalizado ya no resulta posible la realización de trámite alguno en él. Desde esta perspectiva, la de entender, conforme dispone el art. 80 c) LTSV, que el pago voluntario (con la correspondiente reducción) supone la terminación del procedimiento sancionador, ni siquiera resulta posible la formulación de alegaciones, con posterioridad a ese pago, aunque en ellas se indicara de manera expresa con esa actuación se quería invalidar el pago realizado. Ambas partes. Administración y denunciado, se encontrarían vinculados a sus actos, el pago con descuento y su aceptación, con los efectos señalados de tener por terminado el procedimiento sancionador.

Se trata de una previsión que, introducida por la Ley 18/2009, de 23 de noviembre, pretende terminar con los problemas que las regulaciones realizadas previamente, en la LTSV y en el RPSTSV, habían originado en cuanto a la compatibilidad entre realizar el 
pago acogiéndose al beneficio de reducción de la multa fijada y la presentación de alegaciones ${ }^{22}$.

Nada se señala, en cambio, sobre la posibilidad de proceder al pago total de la multa, es decir, sin acogerse al derecho de reducción y proceder a formular alegaciones, posibilidad que resulta compatible tanto con la letra como con el espíritu de la Ley ${ }^{23}$.

\section{INEXISTENCIA DE FORMULACIÓN DE ALEGACIONES}

Al lado de las opciones que el art. 79.1 LTSV ofrece al denunciado, la del pago voluntario con la correspondiente reducción de la multa fijada y la de formular alegaciones y proponer $\mathrm{y}$ aportar pruebas, aparece una tercera posibilidad que, aunque no prevista en ese art. 79.1 LTSV, sí se encuentra recogida en otros lugares de la LTSV.

Así, en el art. 81.5 LTSV se establece que, en ese caso, la denuncia "surtirá el efecto de acto resolutorio del procedimiento sancionador".

Sin perjuicio del análisis de esta cuestión en el marco de la resolución sancionadora, ya que a ello se deriva la ausencia de alegaciones cuando no se ha procedió al pago voluntario, es preciso anticipar que el propio art. 81.5 LTSV limita este efecto, el de convertir la denuncia en acto resolutorio, a determinados supuestos:

- Las infracciones leves, art. 81.5 a) LTSV

- Las infracciones graves que no detraigan puntos, art. 81.5 b) LTSV

- Las infracciones graves y muy graves cuya notificación se efectuase en el acto de la denuncia, art. 81.5 c) LTSV

\section{Sobre el tRASLAdo de LAS ALEgACIONES AL AgENTE DENUNCIANTE Y SU INFORME}

La modificación operada en la LTSV por medio de la Ley 18/2009, de 23 de noviembre, ha supuesto una importante modificación en el recorrido establecido para la tramitación del expediente sancionador.

\footnotetext{
${ }^{22}$ Véase en el Capítulo sobre la evolución de la regulación del procedimiento sancionador en materia de tráfico y seguridad vial la partes destinada al análisis de la Ley 19/2001 (arts. 67.1 y 77.2 LTSV), del RD 318/2003 (art. 12.2 RPSTSV) y STS de 27 de octubre de 2004 (RJ 2005, 14) y de la Ley 17/2005 (art. 77.2 LTSV).

${ }^{23}$ Lejos de tratarse de una hipótesis irrealizable es una posibilidad que, en determinados supuestos, puede presentarse como la más razonable para el infractor. En el caso de la notificación en el acto a infractor que no acredite su residencia legal en territorio español y que se ve obligado (art. 67.4 LTSV) a depositar el importe de la multa, bajo amenaza de inmovilización, puede optar por reservarse el derecho a formular alegaciones y proponer o aportar pruebas, para lo cual tiene que realizar el pago de la totalidad de la multa fijada por el Agente de la Autoridad sin acogerse al beneficio de reducción, lo que supondría la terminación del procedimiento sancionador.
} 
En la redacción anterior se establecía que, en la fase de tramitación, "de las alegaciones del denunciado se dará traslado al denunciante para que informe en el plazo de quince días" (art. 79.2 LTSV). Ello suponía que, fuera cual fuera, el contenido de las alegaciones realizadas por el denunciado estas tenían que ser puestas en conocimiento del denunciado que tenía que realizar un informe al respecto.

La vigente redacción del art. 81.3 LTSV plantea un escenario sustancialmente diferente al establecer, en el párrafo primero, que "si las alegaciones formuladas aportasen datos nuevos o distintos de los constatados por el Agente denunciante, y siempre que se estime necesario por el instructor, se dará traslado de aquéllas al Agente para que informe en el plazo de quince días naturales".

El cambio es drástico desde el momento en que queda en manos del instructor decidir sobre la necesidad de solicitar al denunciante que informe sobre las alegaciones formuladas por el denunciado.

Esa decisión, la de recabar el informe del Agente denunciante, queda en el ámbito de decisión del instructor, al establecer la LTSV que se podrá hacer "siempre que se estime necesario por el instructor" (art. 81.3 LTSV), y siempre que esas "alegaciones formuladas aportasen datos nuevos o distintos de los constatados por el Agente denunciante".

La formulación legal pasa (en relación a la redacción anterior a la Ley 18/2009, de 29 de noviembre) de un supuesto preestablecido conforme al cual la mera formulación de alegaciones por el denunciado suponía que estas tenían que ser informadas por el Agente denunciante, a una previsión en la que, para que las alegaciones tengan que ser informadas, tienen o bien contener "datos nuevos o distintos de los constatados por el Agente denunciante" o bien que el contenido de esas alegaciones requiera de un contraste con el denunciante.

En definitiva, la situación se invierte de manera que con la redacción ahora vigente se tienen que cumplir una serie de requisitos (objetivos o subjetivos) para que el instructor tenga la obligación de solicitar el informe del Agente denunciante, petición que, por otra parte, el instructor podrá realizar cuando así lo tuviera por conveniente (lo estime necesario, en términos del art. 81.3 LTSV).

Por otra parte cabe indicar que el plazo establecido para que el Agente informe se reduce, puesto que los quince días previstos en el régimen anterior (hábiles, al no especificarse otra cosa) se convierten en naturales.

\section{D) Prueba}

\section{Alegaciones y prueba}

Dentro del ámbito de actuación del instructor se inserta, en este momento del procedimiento sancionador ordinario, la fase probatoria. $Y$ se hace en la doble 
vertiente que comprende, de un lado, las que desde su propia posición necesite o precise (o quiera) realizar y, de otro, la decisión sobre la oportunidad y pertinencia de las propuestas por el denunciado.

El derecho del denunciado a participar en el procedimiento administrativo sancionador le atribuye el de poder proponer y aportar las pruebas que a su derecho convengan. El derecho del denunciado a hacer uso de los medios de prueba tiene relevancia constitucional $^{24}$, si bien no se trata de un derecho absoluto e incondicional al uso de los medios de prueba ${ }^{25}$, ya que no supone el derecho a practicar todas las pruebas que se propongan, sino tan solo a las que sean pertinentes o necesarias ${ }^{26}$.

Por ello, la prueba en el procedimiento sancionador en materia de tráfico y seguridad vial tiene que tener por objeto hechos que "sean relevantes para la decisión de un procedimiento" (art. 80.1 LRJ - PAC) y estar destinada a esclarecer los hechos sobre los que, a su vez, no exista acuerdo y, por ello será procedente "cuando la administración no tenga por cierto los hechos alegados por los interesados o la naturaleza del procedimiento lo exija" (art. 80.2 LRJ - PAC).

La prueba puede ser propuesta y aportada por el interesado en el plazo que para ello se le ofrece $y$, de igual manera, el instructor del procedimiento puede acordar la práctica de aquellas pruebas que estime pertinentes para la averiguación y calificación de los hechos y para la determinación de las posibles responsabilidades (art. 81.3 párrafo segundo LTSV y, en los mismos términos, en el art. 13.1 RPSTSV), disposición que se corresponde con lo establecido en el art. 17.3 REPEPOS, precepto en el que se encuentra el concepto de las que, para este supuesto, hay que entender por las que "estime pertinentes", ya que en él se especifica que son "aquellas distintas de los documentos que los interesados puedan aportar" y que ello se puede realizar "en cualquier momento de la tramitación del procedimiento".

Sobre las pruebas practicadas a instancia del Instructor es importante tener presente las consecuencias que originan en otras fases del procedimiento, y que, en este sentido, el inciso final del art. 81.4 LTSV dispone, como supuestos que, de manera excepcional, dan lugar a la obligación de trasladar la propuesta de resolución al interesado, el de aquellos casos en los que figuren "en el procedimiento o se hubiesen tenido en cuenta en la resolución otros hechos $u$ otras alegaciones y pruebas diferentes a las aducidas por el interesado", algo que resulta preciso tener en cuenta puesto que de ello se podría derivar indefensión lo que puede ser causa de nulidad de las actuaciones por prescindir del procedimiento establecido.

\footnotetext{
${ }^{24}$ Cfr. ATC 320/1986, de 9 de abril, F. 6 y SSTC 2/1987, de 21 de enero, F. 6, y 190/1987, de 1 de diciembre, F. 3.

${ }^{25}$ Cfr. SSTC 2/1987, de 21 de enero, F. 6, y 22/1990, de 15 de febrero, F.5

${ }^{26}$ Cfr. STC 192/1987, de 2 de diciembre, F. 2.
} 


\section{PLAZO}

El art. 81.1 LTSV establece "un plazo de quince días naturales para formular las alegaciones que tengan por conveniente y proponer o aportar las pruebas que estime oportunas", plazo al que, como ya hemos tenido la oportunidad de señalar, la propia LTSV atribuye otra extensión en el art. 74.3 d) LTSV, lugar en el que se determina que el denunciado "dispone de veinte días naturales... para formular las alegaciones y proponer las pruebas que estime convenientes".

Por ese motivo, y ante la falta de congruencia de la que da muestras la propia LTSV a la hora de determinar este plazo y teniendo en cuenta que se trata de un derecho para el denunciado, habrá que estar al más extenso de entre los establecidos en la LTSV y, por tanto, entender que el plazo del que dispone el denunciado para alegar y proponer o aportar prueba es de veinte días naturales y no de quince, como señala el art. 81.1 LTSV $^{27}$.

\section{Medios DE PRUEBA}

La prueba está condicionada a su pertinencia y necesidad en relación con el propio objeto del procedimiento sancionador $y$, aunque nada se establece en la LTSV, esos hechos podrán ser acreditados por cualquier medio de prueba admisible en derecho ${ }^{28}$ (art. 80.1 LRJ - PAC).

Pero una cosa es esa posibilidad de acreditar por cualquier medio admisible en derecho y otra que, en la práctica, el uso de los medios de prueba suela quedar limitado, de entre las posibles, a la documental. $Y$ en este marco resulta especialmente importante entender el sentido de la prueba en el procedimiento sancionador en materia de tráfico y seguridad vial y aprehender su uso en función de su finalidad, pues es la única forma de ubicar el valor probatorio del contenido de la denuncia (en cuanto a los hechos denunciados que en ella se contienen) y la forma en la que la prueba se pueda y deba articular.

No es el medio de prueba el que, en sí mismo, determina una mayor o menor adecuación al procedimiento $y$, por tanto, a la necesidad de su realización. La pertinencia de una determinada prueba viene definida por lo que con ella se pretende probar y no por el medio que para ello se emplea. Si lo que se pretende poner de manifiesto tiene trascendencia para la resolución a adoptar poco importa el medio a utilizar (siempre que esté admitido en derecho). Ni todas las documentales tienen porqué ser admitidas ni todas las testificales (interrogatorios) tienen porqué ser rechazadas. Ese no es (no tiene que ser) el criterio que determine la admisión o rechazo de la prueba propuesta. Es la utilidad o inutilidad de la prueba para los fines

\footnotetext{
${ }^{27}$ Véase, en este sentido, lo señalado en el apartado II.C de este mismo capítulo.

${ }^{28}$ Lo que nos sitúa, además de en las previsiones generales realizadas en los arts. 80 y 81 LRJ - PAC, en lo establecido en los arts. 1214 a 1256 CC, en los arts. 281 a 386 LEC y en los arts. 60 y 61 LCA.
} 
del procedimiento lo que ha de determina su pertinencia. Tan inútil pretender como prueba el informe del agente en relación a las preguntas que se le hacían sobre el cinemómetro cuando esa información consta en el certificado que ya se ha remitido ${ }^{29}$ o la testifical del acompañante del denunciado que, por sí misma, no acredita que de su testimonio pudieran determinarse conclusiones fácticas de trascendencia ${ }^{30}$ como necesario puede resultar el interrogatorio personal de testigos en una infracción de tipo instantáneo en la que la única prueba es, precisamente, la denuncia del agente ${ }^{31}$.

Es el fin concreto y determinado que se persigue con el uso de un determinado medio de prueba, lo que se quiere probar, la idoneidad de ese medio y su directa relación con los hechos relevantes, su calificación y la determinación de responsabilidades, lo que convierte a una concreta prueba en útil y pertinente para la resolución del procedimiento sancionador $y$, lo que en definitiva, acredita, en ese caso concreto, el derecho del interesado a hacer uso de ese medio de prueba, pues la denegación de su práctica le produciría, de manera real y efectiva, indefensión.

\section{DENEGACIÓN}

En el inciso final del segundo párrafo del art. 81.3 LTSV se establece que "la denegación de la práctica de las pruebas deberá ser motivada, dejando constancia en el expediente administrativo". En definitiva, no se impone a la autoridad

${ }^{29}$ Cfr. STSJ Navarra de 8 de mayo de 2002 (JUR 2002, 187392).

30 Cfr. SAN 19 de junio de 2003 (JUR 2006, 274449).

${ }^{31}$ Muy interesante, en este sentido, resoluciones como las SSTSJ Castilla - La Mancha de 17 de octubre de 2005 (JUR 2006, 11347), y las que en ella se citan, que señalan que:

"La Sentencia de instancia afirma que en el procedimiento administrativo sancionador no existe un derecho a interrogar personalmente a los testigos, sino que hay que conformarse con que declaren por escrito. Esta afirmación es totalmente inasumible, como ya hemos reiterado en las Sentencias de esta Sala recaídas en recurso de apelación 105/03, 106/03, 9/04, 10/04 y 11/04 en las que se ha dicho que no es preciso recordar las normas que establecen que en el procedimiento administrativo son utilizables todos los medios de prueba admisibles en derecho. Pues bien, uno de ellos es la declaración testifical, sin que en ninguna norma procesal vigente (y a ellas habrá que acudir para saber cuáles son los medios de prueba admisibles en derecho) se establezca que el solicitante de la prueba testifical deba someterse a practicar la misma por escrito cuando no haya una causa poderosa que impida su prestación verbal y espontánea, con la posibilidad de solicitar sobre la marcha las aclaraciones que procedan al testigo a las respuestas que vaya dando. Por otro lado, es claro que cuando la Ley 30//1992, de 26 de noviembre, de Procedimiento Administrativo Común establece que se debe comunicar el lugar y hora de la práctica de las pruebas está pensando en la posibilidad de practicar pruebas orales sujetas a la inmediación del instructor y de las partes.

El argumento del Juez a favor de la "no-oralidad" de esta prueba, según el cual ello deriva del art. 12.3 del Reglamento de Procedimiento sancionador en materia de tráfico, circulación de vehículos a motor y seguridad vial, no es aceptable. Es cierto que este prcepto se refiere a un informe escrito cuando señala que "De las alegaciones del denunciado salvo que no aporten datos nuevos o distintos de los inicialmente constatados por el denunciante, se dará traslado a éste, para que informe en el plazo máximo de quince días", pero no lo es menos que éste es un trámite en todo caso obligatorio, al que precisamente sucede, en su caso, la apertura de la fase probatoria, que debe desarrollarse con las debidas garantías" 
administrativa la obligación de practicar las pruebas propuestas, pero sí la de razonar, en su caso, la denegación ${ }^{32}$.

De nuevo se hace preciso acudir a la LRJ - PAC y, en este sentido, es preciso tener presente que el art. 137.4 LRJ - PAC establece, en su primer párrafo, que "se practicarán de oficio o se admitirán a propuesta del presunto responsable cuantas pruebas sean adecuadas para la determinación de hechos y posibles responsabilidades", y en su segundo párrafo que "sólo podrán declararse improcedentes aquellas pruebas que por su relación con los hechos no puedan alterar la resolución final a favor del presunto responsable".

Del específico tratamiento que la LTSV realiza de la prueba no se pueden extraer demasiadas conclusiones. La regulación se agota con el hecho de establecer la garantía formal de que la denegación tiene que ser motivada y expresa (dejar constancia en el expediente). De esta manera el instructor cumple con incorporar al expediente administrativos los motivos en los que funda su decisión de denegar la práctica de la prueba solicitada (o aportada) por el denunciado.

Así, la primera cuestión a considerar es, y aunque pueda parecer obvio, que para que algo pueda ser denegado es preciso que, de manera previa, se produzca la solicitud, lo que en este caso supone que el interesado proponga o aporte las pruebas en el momento establecido para ello $y$, en ese sentido, no es lo mismo que la solicitud realizada se limite a señalar que se tenga por propuesta la apertura de período probatorio a que en esa petición se inste la práctica de una o varias pruebas concretas. En el primer supuesto no hay denegación de prueba puesto que ninguna prueba se llega a proponer ${ }^{33}$.

Así, solicitada la práctica de una prueba es preciso entender la naturaleza del trámite y su trascendencia procedimental que, por su relevancia constitucional en cuanto que manifestación del derecho de defensa, adquiere el carácter de trámite esencial ${ }^{34}$.

Pero dado que, como ya se ha puesto de manifiesto, no existe un derecho absoluto a la prueba, la prueba no es necesaria en todos los casos, y su pertinencia viene determinada por su utilidad para la averiguación y calificación de los hechos o para la determinación de las posibles responsabilidades.

Por ello, la denegación de la prueba propuesta tiene que ser motivada, y tiene que serlo porque así lo exige el art. 54.1 a) LRJ - PAC, dado que se está limitando un

\footnotetext{
${ }^{32}$ Cfr. SSTSJ de Aragón de 10 de mayo de 2000 (RJCA 2000, 2452) y de 20 de mayo de 2002 (JUR 2002, 208161).

${ }^{33}$ Así, la STSJ Andalucía - Sevilla de 22 de julio de 2000 (JUR 2000, 297318) establece que "la actora no propuso prueba alguna en el escrito de alegaciones, sino que solicitó que se tuviera por propuesta la apertura de periodo probatorio, que no es lo mismo que solicitar la práctica de una o unas pruebas concretas, por lo que la Administración no le ha denegado la práctica de ninguna prueba".

${ }^{34}$ Así se señala que "vemos, por lo tanto, que se han infringido trámites esenciales del procedimiento con indefensión, en tanto que no se practicaron todas las pruebas solicitadas ni se motivó su denegación" (STSJ Extremadura de 27 de septiembre de 2001 (JUR 2001, 292308).
} 
derecho subjetivo o interés legítimo y por ello el órgano instructor viene obligado a efectuar un pronunciamiento razonado sobre la necesidad de la práctica de la prueba propuesta, sin que sea disponible por dicho órgano la práctica de dicha prueba, cual si se tratara de una facultad discrecional de aquél. Muy al contrario el juicio a realizar por la Administración ha de efectuarse ponderando la necesidad de la utilización de los medios probatorios propuestos en función de los elementos de cargo y convencimiento que ya obren ${ }^{35}$.

Siendo claro, por tanto, el criterio que permite al instructor proceder a la denegación de la prueba solicitada (su innecesariedad), y la exigencia de motivar esa denegación, resulta preciso determinar lo que deba de entenderse por "dejar constancia en el expediente sancionador" de los motivos que llevan al instructor del procedimiento a denegar la práctica de la prueba solicitada.

La expresión de la que se hace uso en el inciso final del art. 81.3 LTSV no parece demasiado afortunada, ya que esta referencia no se antoja excesivamente fina en cuanto a la fórmula en la que tiene que realizarse la denegación motivada de la prueba solicitada por el denunciado.

Una vez más el régimen general es bastante más preciso y elocuente que lo que nos encontramos en la LTSV, ya que el art. 17.2 REPEPOS establece que "en el acuerdo, que se notificará los interesados, se podrá rechazar de forma motivada la práctica de aquellas pruebas que, en su caso, hubiesen propuesto aquellos cuando sean improcedentes de acuerdo con lo dispuesto en el art. 137.4 LRJ - PAC ${ }^{\prime 36}$.

La lógica jurídica, en garantía de los derechos del denunciado, impone que la forma en la que han de entenderse los términos "dejando constancia en el expediente sancionador" trasciendan el interior del mismo y produzcan una manifestación externa de la decisión del instructor que permita al interesado, en este caso denunciado, tener conocimiento tanto del hecho de que el instructor ha tomado la decisión de denegar la práctica de la prueba solicitada, como de los motivos que le han llevado a adoptar, y

\footnotetext{
${ }^{35}$ Como señalan las SSTSJ de Navarra de 15 de abril de 2002 (JUR 2002, 165881) y de 22 de abril de 2002 (JUR 2002, 167285) en las que, además, se advierte que "la Administración debe efectuar, conforme a lo razonado, una valoración de la necesidad de la práctica de la prueba, siendo esta resolución susceptible de revisión jurisdiccional, supuesta la negativa a su práctica, o en otro caso de considerarse relevante la misma llevarla materialmente a efecto".

${ }^{36}$ A este respecto téngase en cuenta lo establecido en la propia LRJ - PAC no solo en el referido art. 137.4, también lo dispuesto, de manera genérica para todo tipo de procedimientos, en el art. 80 LRJ $\mathrm{PAC}$, en sede de medios de prueba en la instrucción del procedimiento, al señalar que "el instructor del procedimiento sólo podrá rechazar las pruebas propuestas por los interesados cuando sean manifiestamente improcedentes o innecesarias, mediante resolución motivada", previsión legal que se encuentra relacionada con lo establecido en el art. 54.1 de la propia LRJ - PAC sobre motivación de los actos administrativos, lugar en el que se indica que "serán motivados" tanto "los actos que limiten derechos subjetivos o intereses legítimos" como "los que se dicten en el ejercicio de potestades discrecionales, así como los que deban serlo en virtud de disposición legal o reglamentaria expresa".
} 
justifican, esa decisión ${ }^{37}$. Y por ello, no se produce una indefensión de relevancia constitucional cuando la inadmisión de una prueba se ha producido debidamente en aplicación estricta de normas legales cuya constitucionalidad no se pone en duda, ni tampoco cuando las irregularidades procesales que se hayan podido producir en la inadmisión de alguna prueba no han llegado a causar un efectivo y real menoscabo del derecho de defensa ${ }^{38}$.

Ahora bien, la práctica muestra una modulación en la forma de interpretar esa "denegación motivada" y "su constancia en el expediente sancionador", de la que es preciso dejar constancia, ya que no se entiende que, a pesar de la letra del art. 81.3 LTSV, la Administración pueda denegar las pruebas de manera tácita y que no motivar expresamente la denegación de la práctica de las pruebas solicitadas ${ }^{39}$, aunque se reconoce que eso es lo deseable ${ }^{40}$, anteponiéndose la inexistencia de indefensión por considerarse que se trata de un defecto subsanable, lo que lleva incluso a considerar que no existe indefensión cuando denegada la prueba en el procedimiento sancionador el interesado recurre en vía contencioso - administrativa y en ella no solicita la práctica de las pruebas que en vía administrativa le habían sido denegadas y que, por lo tanto, esa denegación de pruebas se constituye en irregularidad formal que carecen de trascendencia invalidante ${ }^{41}$. Interpretación en la que, entendiendo la

37 Como ha señalado el Tribunal Constitucional "sólo tiene relevancia constitucional por provocar indefensión la denegación de pruebas que, siendo solicitadas en el momento y la forma oportunas, no resultase razonable y privase al solicitante de hechos decisivos para su pretensión" (STC 149/1987, de 30 de septiembre, F. 3).

${ }^{38}$ Cfr. STC 212/1990, de 20 de diciembre, F. 3.

${ }^{39}$ Se ha señalado que "en el supuesto enjuiciado, se denegaron tácitamente las pruebas propuestas por el interesado, consistentes en el interrogatorio del agente denunciante así como en la incorporación al expediente del certificado de homologación del alcoholímetro utilizado para la verificación de la prueba de determinación de alcohol en aire espirado. Y, si bien es cierto que hubiera sido deseable una específica argumentación de los motivos que condujeron al instructor a considerar innecesarias dichas pruebas, no cabe entender que tal omisión constituya una irregularidad generadora de efectiva indefensión, habida cuenta que el informe de los agentes intervinientes únicamente viene contemplado en el art. 12.2 del RD 320/94 para los supuestos en los que se aporten por el denunciado datos nuevos u otros elementos fácticos de los constatados en el boletín de denuncia" STSJ Cataluña de 14 de febrero de 2005 (JUR 2005, 172932).

${ }^{40}$ Tal y como se señala en la STSJ Castilla - La Mancha de 22 de diciembre de 2000 (JUR 2001, 80822) "si bien la Administración debería sin duda en todo caso motivar expresamente la denegación, en su caso, de la práctica de las pruebas que deniega, lo cierto es que tal omisión sólo habrá de producir la nulidad del acto recurrido en caso de que éstas fuesen relevantes y pertinentes, pues, en otro caso, aun existiendo una infracción, ésta no puede entenderse que cause indefensión y, por tanto, no pasa de ser defecto formal no invalidante (art. 63.2 LRJ - PAC)“.

${ }^{41}$ Es el caso de resoluciones judiciales que establecen que "es por tanto indudable que en éste último caso no se ha producido indefensión del recurrente pues ésta recurrió las sanciones en vías administrativa y en esta sede judicial y aquí ha tenido oportunidad de practicar las pruebas que le hayan parecido oportunas, pese a lo cual se ha remitido a estos efectos únicamente a lo que consta en el expediente administrativo" (SSJCA Murcia no 6 de 20 de marzo de 2007, JUR 2008, 103936, de 9 de mayo de 2007, JUR 2008, 103674 y de octubre de 2007, JUR 2008, 102962) y que "ahora bien, dichas irregularidades formales carecen de trascendencia invalidante pues no generan una indefensión material, es decir, una disminución real, efectiva y trascendente de garantías, toda vez que el interesado, además de las alegaciones iniciales, pudo alegar en vía judicial, con pleno conocimiento de 
necesidad de que la negativa a practicar las pruebas cause indefensión efectiva al interesado, se hace realmente difícil entender que las formas exigidas de manera expresa por la Ley se diluyan hasta el punto de no requerirlas en modo alguno, y que parece confundir la posibilidad del control jurisdiccional del procedimiento con la necesidad de que en ese procedimiento se cumpla con lo establecido por la Ley.

Una interpretación más ajustada a lo establecido por el inciso final del art. 87.3 párrafo segundo LTSV es la de entender que el instructor del procedimiento sancionador sólo podrá rechazar mediante resolución motivada las pruebas propuestas por los interesados, cuando sean improcedentes, y que en el caso de que proponga prueba el denunciante el instructor debe pronunciarse sobre su admisión o no a través de resolución expresa y motivada ${ }^{42}$.

\section{E) Propuesta de Resolución}

\section{FINAL DE LA FASE DE INSTRUCCIÓN Y PROPUESTA DE RESOLUCIÓN}

Notificada la denuncia, formuladas las alegaciones y practicada, en su caso, la correspondiente prueba, la instrucción del procedimiento concluye con la formulación de la propuesta de resolución.

El art. 81.4 LTSV se limita a realizar dos prescripciones sobre la propuesta de resolución como resultado, y consecuencia, de darse por concluida, por el instructor, la fase de instrucción del procedimiento sancionador ordinario.

De un lado, la necesidad de remitir al órgano competente para imponer la sanción la propuesta de resolución y, de otro, los supuestos en los que, en su caso, es preciso trasladar al denunciado esa propuesta de resolución con el objeto de que pueda realizar las alegaciones que tuviera por conveniente.

El inciso inicial del art. 81.4 LTSV aborda de una forma ciertamente sintética las cuestiones relativas a la propuesta de resolución, puesto que el texto legal se limita a señalar que "concluida la instrucción del procedimiento, el órgano instructor elevará propuesta de resolución al órgano competente para sancionar para que dicte la resolución que proceda". Fuera de esta mención del art. 81.4 LTSV no aparece referencia alguna a la propuesta de resolución que tiene que realizar el instructor del procedimiento sancionador ordinario.

Nada añadía el RPSTSV sobre los requisitos de la propuesta de resolución remitida por el instructor al órgano titular de la competencia sancionadora y, de esta manera, no

todo lo actuado, lo que estimó pertinente. Igual consideración merece la denegación de pruebas innecesarias incluso para el actor, que de estimarlas fundamentales para su defensa hubiese solicitado su práctica en el proceso, lo cual no hizo" (STSJ Galicia de 31 de octubre de 2007, JUR 2009, 22591).

42 Tal es el caso de lo señalado por la SJCA no 6 de Murcia de 21 de junio de 2007 (JUR 2008, 111368), interpretación que considero aplicable aunque por motivos temporales recayera sobre el art. 13.1 RPSTSV y que se refería a las pruebas improcedentes. 
encontramos en el marco de la propia LTSV explicación alguna sobre el contenido, formal y material, con los que habría de cumplir de la propuesta de resolución ${ }^{43}$.

\section{SUPUESTOS EN LOS QUE PROCEDE EL TRASLADO DE LA PROPUESTA DE RESOLUCIÓN AL INTERESADO}

Dispone el art. 81.4 LTSV que únicamente se dará traslado de la propuesta al interesado, para que pueda formular nuevas alegaciones en el plazo de quince días naturales, si figuran en el procedimiento o se hubiesen tenido en cuenta en la resolución otros hechos u otras alegaciones y pruebas diferentes a las aducidas por el interesado.

Ello supone establecer, y hacerlo legalmente, que la norma general de actuación consiste en que el órgano instructor traslada (eleva) su propuesta de resolución sancionadora al órgano titular de la competencia para sancionar sin dar cuenta de ello al interesado (inciso primero del art. 81.4 LTSV). Esta es la regla general y, lo contrario, trasladar la propuesta de resolución al denunciado, se convierte en la excepción, en casos estrictamente tasados que se encuentran recogidos en el inciso final del propio art. 81.4 LTSV.

Estos casos excepcionales en los que el instructor tiene la obligación de dar traslado de la propuesta de resolución sancionadora al interesado, que el texto de la LTSV explicita mediante un clarísimo "únicamente... si", como condición imprescindible, se concretan en "si figuran el procedimiento o se hubiesen tenido en cuenta en la resolución otros hechos u otras alegaciones y pruebas diferentes a las aducidas por el interesado".

No parece que los términos empleados en este inciso final del art. 81.4 LTSV, simple traslación del art. 13.2 RPSTSV (en redacción RD 137/2000, de 4 de febrero ${ }^{44}$ ), resulte especialmente afortunada.

\footnotetext{
${ }^{43}$ De hecho el art. 81.3 LTSV (procedente de la Ley 18/2009, de 23 de noviembre) es más concreto que el art. 13.2 RPSTSV ya que, sobre esa base y en el caso de que se preciso el traslado de la propuesta de resolución al interesado, éste dispone de un plazo de quince días para formular alegaciones, algo a lo que ni siquiera se hacía expresa referencia en el RPSTSV.

${ }^{44}$ Antes, y en la redacción originaria, el art. 13.2 RPSTSV establecía que "una vez concluida la instrucción del expediente y formulada su propuesta de resolución, se dará traslado de la misma a los interesados para que, en un plazo no inferior a diez días ni superior a quince y con vista del expediente, puedan alegar lo que estimen pertinente y presentar los documentos que tengan por oportuno", lo que venía a suponer, como regla general, que la propuesta de resolución del instructor se trasladaba en todo caso al interesado que tenía la oportunidad de realizar las alegaciones que tuviera por conveniente a la vista de esa propuesta de resolución sancionadora.

En el art. 79.3 LTSV se mantuvo la misma redacción hasta la reforma efectuada por la Ley $18 / 2009$, de 23 de noviembre señalando que "transcurridos los plazos señalados en los números anteriores, a la vista de lo alegado y probado por el denunciante y el denunciado y tras la eventual práctica de la prueba y ulterior audiencia a los interesados, en los casos en que ello fuera estrictamente necesario para la averiguación y calificación de los hechos, se dictará la resolución que proceda", redacción de por sí ambigua.
} 
Esta redacción, en términos que vienen a respetar la esencia de lo establecido (de forma ambigua) en la redacción originaria de la LTSV y modificado, únicamente, a nivel reglamentario (la modificación que por medio del RD 137/2000, de 4 de febrero se realiza, como hemos señalado, del RPSTSV), determina los casos en los que resulta obligado para el órgano instructor poner en conocimiento del interesado (denunciado) la propuesta de resolución antes de trasladar la misma al órgano que tiene atribuida la competencia para sancionar, planteamiento que viene a reproducir la previsión efectuada en los arts. 13.2 y 19.2 REPEPOS $^{45}$.

Se trata, por tanto, de poner en relación los términos en los que se plantea la necesidad, o no, de trasladar la propuesta de resolución al denunciado y ofrecerle, por tanto, el trámite de audiencia para que tenga la oportunidad de alegar lo que a su derecho convenga de manera previa a la adopción de la resolución sancionadora, con el papel que la esa propuesta de resolución y el trámite de audiencia cumplen en el procedimiento y las garantías que tienen que ofrecerse al interesado.

El trámite de audiencia en la propuesta de resolución (y la puesta de manifiesto del procedimiento, como señala el art. 19.1 REPEPOS) ha sido la forma en la que tradicionalmente se ha informado de la acusación al interesado ${ }^{46}$ ya que "sin ningún género de dudas, el derecho a conocer la propuesta de resolución de un expediente sancionador claramente estipulado en las normas del procedimiento administrativo, forma parte de las garantías que establece el art. $24.2 \mathrm{CE}$, pues sin él no hay posibilidades reales de defensa en el ámbito del procedimiento" ${ }^{47}$.

\footnotetext{
${ }^{45}$ Si bien el art. 19.2 REPEPOS la expone en negativo "se podrá prescindir del trámite de audiencia cuando no figuren en el procedimiento ni sean tenidos en cuenta otros hechos ni otras alegaciones y pruebas que las aducidas, en su caso, por el interesado...", al igual que hacía el art. 13.2 párrafo primero RPSTSV al indicar que "una vez concluida la instrucción del procedimiento y practicada la audiencia al interesado por el órgano correspondiente, salvo cuando no figuren en el procedimiento ni sean tenidos en cuenta en la resolución otros hechos y otras alegaciones y pruebas que las aducidas por el interesado...", mientras que el art. 81.4 LTSV lo hace en positivo. De ello se infiere que en el sistema general la norma es trasladar la propuesta de resolución y la excepción, cuando concurran las circunstancias establecidas, no hacerlo, mientras que en la LTSV la norma general es no conceder el trámite de audiencia salvo en determinados supuestos.

${ }^{46}$ El art. 137.1 de la Ley de Procedimiento Administrativo disponía que "contestado el pliego de cargos o transcurrido el plazo para hacerlo, el Instructor formulará propuesta de resolución, que se notificará a los interesados para que en el plazo de ocho días puedan alegar cuanto consideren conveniente a su defensa".

${ }^{47}$ Como señala la STC 29/1989, de 6 de febrero, F.6. Nótese que esta resolución es por su fecha y cuestión que resuelve anterior a la LRJ - PAC, REPEPOS, LTSV y RPSTSV. Sobre la base de la regulación de la Ley de Procedimiento Administrativo de 1958 el Tribunal Supremo ya había diferenciado entre esa función de anunciar una sanción y otorgar la posibilidad de alegar en su defensa lo que estimara por conveniente (elemento esencial) y la simple concreción de la cuantía de la sanción (sin entidad suficiente para provocar la nulidad) en Sentencia de 11 de mayo de 1981 (RJ 1981, 1960), no hubiera cambios antes y después de la formulación del pliego de cargos en Sentencia de 15 de enero de 1993 (RJ $1993,114)$, lo que derivo en una construcción doctrinal que entendía que no había indefensión "cuando el hecho imputado no ha sufrido alteración alguna a lo largo de la tramitación del expediente administrativo" de la que son muestra SSTS como las de 3 de marzo de 1979 (RJ 1979, 837), de 5 de
} 
Sobre esta base, el hecho de que se colocara al interesado en posición de indefensión y la regulación efectuada por la LRJ - PAC ${ }^{48}$, el Tribunal Supremo desarrollo una doctrina conforme a la que "el derecho a ser informado de la acusación, que con la categoría de fundamental se garantiza en el art. 24.2 CE, se satisface normalmente en el procedimiento administrativo sancionador a través de la notificación de la propuesta de resolución, pues es en ésta en donde se contiene un pronunciamiento preciso acerca de la responsabilidad que se imputa, integrado, cuando menos, por la definición de la conducta infractora que se aprecia, y su subsunción en un concreto tipo infractor, y por la consecuencia punitiva que a aquélla se liga en el caso de que se trata" y que "excepcionalmente, aquel trámite podrá dejar de ser imprescindible, desde la óptica de la plena satisfacción del derecho fundamental citado, si en un trámite anterior se notificó aquel pronunciamiento preciso" ${ }^{\prime 49}$.

Entendido de esta manera, el que no se traslade la propuesta de resolución sancionadora cuando el denunciado dispone de todos los elementos que dan forma y configuran esa propuesta del instructor, no parece presentar mayores problemas. Incluso el hecho de que le art. 81.4 LTSV convierta en regla general lo que en el sistema general se supone la excepción se encuentra justificado en el conocimiento previo, por parte del denunciado, de los hechos que se le imputan, la calificación que se les atribuye y la consecuencia que de ellos se derivan.

El problema se plantea cuando se producen cambios en esos elementos sin que, para ello, hayan concurrido otras alegaciones o pruebas que las formuladas por el denunciado. Puede suceder que el instructor califique los hechos de manera distinta de la efectuada por el Agente, sin que ello requiera de alegaciones o pruebas nuevas, calificación que puede llevar asociada una sanción diferente. Parece claro que, en estos casos, y en especial si la situación inicial, y conocida por el denunciado, cambia a peor, éste debería tener conocimiento de esa propuesta de resolución y la

mayo de 1987 (RJ 1987, 5229) y de 3 de marzo de 1998 (RJ 1998, 2289). Así ha ocurrido en nuestro caso: no solamente el hecho, sino también la calificación jurídica como infracción grave no ha experimentado modificación alguna".

${ }^{48}$ Diferente a la que formulaba la LPA en el art. 137.1 (vide supra nota 46), ya que el art. 135 LRJ - PAC no establecía la necesidad de trasladar de propuesta de resolución sino el derecho del presunto responsable "a ser notificado de los hechos que se le imputen, de las infracciones que tales hechos puedan constituir y de las sanciones que, en su caso, se les pudieran imponer...", lo que formalmente es diferente y permite la entrada de la previsión de efectuada en los arts. 13.2, 16.3 y 19.2 REPEPOS.

${ }^{49}$ A lo que se añade que "el estudio del art. 137.1 de la Ley de Procedimiento Administrativo de 17 julio 1958, aplicable en defecto de otras normas especiales según el art. 1.2 de la misma Ley, y de la Sentencia del Tribunal Constitucional número 29/1989, de 6 febrero, conducía ya inequívocamente a la afirmación que se ha hecho, a la que también conducen hoy las normas contenidas en la LRJ - PAC, en especial las de su art. 135, y en el Real Decreto 1398/1993, de 4 agosto, en especial las de sus artículos 13.2, 18 y 19", doctrina contenida en la STS de 30 de julio de 1997 (RJ 1997, 6331, que da forma a lo expuesto en anteriores como las Sentencias de 21 abril, 2 junio y 6 junio 1997, RJ 1997, 3335, RJ 1997, 5434 y RJ 1997, ) y, a partir de ella, en otras muchas como son las de de 21 de abril y 2 y 6 de junio de 1997 (RJ 1997, 3335, 5434 y 5437), 27 de abril de 1998 (RJ 1998, 3646) y 24 de abril, 28 de abril y 6 y 26 de mayo de 1999 (RJ 1999, 3300, 3689 y 3949). 
oportunidad de manifestarse sobre ello ${ }^{50}$, y ello por no cumplirse con el presupuesto del conocimiento preciso que, como se ha expuesto, debe conforma el derecho a ser informado de la acusación.

\section{EL CONTENIDO DE LA PROPUESTA DE RESOLUCIÓN}

Nada dispone el art. 81 LTSV sobre el contenido de la propuesta de resolución que, el órgano instructor, tiene que elevar al órgano competente para sancionar para que, por este, se dicte la resolución que proceda.

Este vacío (tampoco señalaba nada al respecto el RPSTSV), tiene que ser rellenado, conforme a la cláusula de supletoriedad establecida, en el art. 70.1 de la propia LTSV, con lo dispuesto en el art. 138 LRJ - PAC y en el desarrollo reglamentario efectuado por el art. 18 REPEPOS.

El art. 18 REPEPOS, bajo la rúbrica propuesta de resolución, determina, de manera sucinta, eso sí, que "el órgano instructor del procedimiento formulará propuesta de resolución en la que se fijarán de forma motivada los hechos, especificándose los que se consideren probados y su exacta calificación jurídica, se determinará la infracción que, en su caso, aquéllos constituyan y la persona o personas que resulten responsables, especificándose la sanción que propone que se impongan y las medidas provisionales que se hubieran adoptado, en su caso, por el órgano competente para iniciar el procedimiento o por el instructor del mismo; o bien se propondrá la declaración de no existencia de infracción o responsabilidad".

De la lectura de este precepto se desprenden la existencia de dos posibilidades, en función de que de la instrucción se compruebe que haya lugar, o no, a la sanción. En el caso de que la instrucción determine la inexistencia de infracción o responsabilidad la propuesta de resolución tendrá que contener una declaración en ese sentido. En caso contrario, se establece el contenido de esa propuesta de resolución fijando unos elementos que, en todo caso, tendrán que estar presentes $y$, otros, que pueden o no, según los casos, aparecer en la propuesta de resolución.

Los elementos que, en todo caso, tienen que aparecer en la propuesta de resolución son:

- Los hechos de forma motivada y especificándose los que se consideren probados

- Exacta calificación jurídica de los hechos

\footnotetext{
${ }^{50}$ Sentido en el que se manifiesta CANO CAMPOS, T., El régimen jurídico - administrativo del tráfico, 2 a ed., Madrid, Civitas, 2010, 2a ed., págs. 539.
} 
- Determinación de la infracción que los hechos constituyan

- La persona o personas que resulten responsables

- La sanción que propone que se impongan

De igual manera, y en el caso de que se hubieran adoptado, la propuesta de resolución deberá contener referencia a las medidas provisionales que se hubieran tomado, ya fueran adoptadas por el órgano competente para iniciar el procedimiento o por el instructor del mismo.

\section{F) ResoluCión}

\section{REQUISITOS PREVIOS}

El procedimiento sancionador ordinario termina con la resolución sancionadora adoptada por el órgano que tiene la competencia para imponer la sanción ${ }^{51}$.

Como culminación del procedimiento administrativo (sancionador), la resolución sancionadora requiere de la tramitación del procedimiento conforme a las prescripciones legalmente establecidas (en el art. 81 LTSV) y, supletoriamente por lo señalado en la LRJ - PAC (dado la previsión efectuada, en este sentido por el art. 70.1 LTSV).

Así pues, y tal y como establece el art. 81.4 LTSV el órgano competente ${ }^{52}$ para sancionar procederá a dictar "la resolución que proceda" una vez "concluida la instrucción del procedimiento", resolución que puede tener un contenido sancionador o declarar la inexistencia de responsabilidad.

\section{CONTENIDO DE LA RESOLUCIÓN}

Nada señala la LTSV sobre el contenido concreto de la resolución sancionadora que pone fin a la vía administrativa. Ninguna mención puede encontrarse en el texto de la LTSV entre la prescripción contenida en el art. 81.4 LTSV conforme a la cual "concluida la instrucción del procedimiento, el órgano instructor elevará propuesta de resolución al órgano competente para sancionar para que dicte la resolución que proceda" y la disposición del art. 82.1 LTSV que señala que "la resolución sancionadora pondrá fin a la vía administrativa". De esta manera entre la propuesta de resolución que recibe el

\footnotetext{
${ }^{51}$ Así lo señala el art. 82.1 LTSV al disponer que "la resolución sancionadora pondrá fin a la vía administrativa" si bien, como pone de manifiesto el art. 15.1 RPSTSV, ello también podría suceder por la resolución que declare la inexistencia de responsabilidad por la infracción. Aquí se parte del supuesto normal que es que el órgano competente dicta la resolución sancionadora.

${ }^{52}$ Véase el Capítulo correspondiente a Las competencias para sancionar las infracciones de tráfico y seguridad vial.
} 
órgano competente para sancionar y la resolución sancionadora que tiene que emitir lo único que encontramos, en cuanto a regulación, es la nada.

Ninguna novedad supone, en este sentido, la redacción que la LTSV ha recibido de la Ley $18 / 2009$, de 23 de noviembre, puesto que la versión anterior establecía que el órgano instructor "elevará propuesta de resolución al órgano que legal o reglamentariamente tenga atribuida la competencia sancionadora para que dicte la resolución que proceda" (art. 79.3 in fine ${ }^{53}$ ).

El art. 15 RPSTSV desarrollaba reglamentariamente esta cuestión en cuanto a la resolución del órgano competente.

Al momento de ser modificada la LTSV por la Ley 18/2009, de 23 de noviembre, la redacción del art. 15 RPSTSV contenía siete prescripciones sobre la resolución que había de dictar el órgano competente para sancionar.

- En primer lugar (inciso primero del art. 15.1 RPSTSV) se determinaba que esa resolución podía, o no, tener carácter sancionador, puesto que podía declarar la responsabilidad por la infracción o declarar la inexistencia de responsabilidad.

- En segundo lugar (inciso segundo del art. 15.1 RPSTSV) se hacía referencia a la forma de esa resolución que podía ser escrita o verbal.

- En tercer lugar (inciso tercero del art. 15.1 RPSTSV) se establecía el plazo de tiempo en el que esa resolución debía de ser puesta en conocimiento del interesado.

- En cuarto lugar (inciso tercero del art. 15.1 RPSTSV) se imponía la obligación de que la resolución fuera motivada ("deberá ser motivada" en los términos del propio reglamento).

- En quinto lugar (inciso tercero del art. 15.1 RPSTSV) se señalaba el ámbito de la resolución que tiene que extenderse a todas y cada una de las cuestiones planteadas por los interesados así como a todas aquellas que se derivaran del propio procedimiento sancionador.

- En sexto lugar (art. 15.2 RPSTSV) se establecía un límite en cuanto a los hechos a tomar en consideración por la resolución que no podrán ser distintos de los determinados en la propia instrucción del procedimiento, eso sí, permitiendo que, esos hechos, fueran merecedores en la resolución de una diferente valoración jurídica.

\footnotetext{
53 La redacción anterior a la introducida por la Ley 18/2009, de 23 de noviembre, procedía de la Ley 19/2001, de 19 de diciembre (RCL 2001, 3131) que había procedido a modificar la redacción originaria del ap. 3 del art. 79 LTSV que se limitaba a señalar que “... se dictará la resolución que proceda".
} 
- Y en último lugar (art. 15.3 RPSTSV) se posibilitaba la delegación de la competencia para sancionar.

Por ello resulta preciso determinar el contenido que, la resolución sancionadora que pone fin al procedimiento sancionador ordinario, debe comprender para que pueda ser considerada como tal.

a) Resolución sancionadora o que declare la inexistencia de responsabilidad por la infracción

\section{Sobre la necesidad de la resolución}

El art. 15.1 RPSTSV se abría con unos términos inequívocos en cuanto la propia necesidad de la resolución (sancionadora o no) que había de poner fin al procedimiento administrativo sancionador al indicar los órganos en los que se encontraba residencia la competencia para sancionar ${ }^{54}$ "dictarán resolución".

Y no podía ser de otra manera. El mismo carácter imperativo se encuentra en el art. 20.2 REPEPOS ("el órgano competente dictará resolución...") que deriva de la obligación genéricamente establecida en el art. 42 LRJ - PAC, precepto que establece que "la Administración está obligada a dictar resolución expresa en todos los procedimientos y a notificarla cualquiera que sea su forma de iniciación" y de la prescrita, de una forma tan específica como tácita, en el concreto ámbito del ejercicio de la potestad sancionadora por medio del art. 138.1 de la propia LRJ - PAC que determina que "la resolución que ponga fin al procedimiento habrá de ser motivada y resolverá todas las cuestiones planteadas en el expediente".

La resolución tiene (debe) que existir. El órgano competente tiene que emitir esa resolución, tiene la obligación de dictar esa resolución, sancionadora o no (declarando la inexistencia de responsabilidad) so pena de que ese procedimiento incurra en caducidad y, por tanto fenezca, en el caso de que esa resolución no hubiera sido adoptada en el plazo de un año desde la iniciación del procedimiento administrativo sancionador (art. 16 RPSTSV).

\footnotetext{
${ }^{54}$ Sobre esta particular la redacción del art. 15.1 RPSTSV no tuvo más remedio que evolucionar con el paso del tiempo pasando la referencia originaria a "los Gobernadores Civiles y los Alcaldes" a ser a "Ios Delegados o Subdelegados del Gobierno, en su caso, y los Alcaldes" por medio del RD 137/2000, de 4 de febrero (RCL 2000, 473).
} 


\section{Sobre el carácter de la resolución}

Una vez determinada la necesidad de que el órgano competente para sancionar dicte la pertinente resolución es preciso señalar que esa resolución puede ser de dos tipos: o "sancionadora" o declarativa de "la inexistencia de responsabilidad por la infracción".

Ello significa que la consecuencia natural (o esperable) del procedimiento administrativo sancionador es que se dicte la correspondiente resolución sancionadora, pero ésta no es la única posibilidad pues el procedimiento puede concluir con una resolución que, sin ser sancionadora, declare, y tal posibilidad está prevista como tal, "la inexistencia de responsabilidad por la infracción".

Sea, o no, sancionadora la resolución, lo cierto es que órgano titular de la competencia para sancionar tiene la obligación, como deber legal, de dictar esa resolución. Y, además, ese órgano tiene que cumplir con una serie de plazos que alcanzan tanto al tiempo máximo para dictarla desde el inicio del expediente sancionador, al tiempo que puede transcurrir entre la recepción, por el órgano competente para sancionar, de la propuesta de resolución remitida por el órgano instructor y al espacio de tiempo del que dispone el órgano titular de la competencia para sancionar para poner en conocimiento, para notificar, la resolución adoptada al interesado.

El art. 81 LTSV guarda silencio al respecto, puesto que se limita a establecer, en el primer inciso del apartado 4 del referido artículo, que "concluida la instrucción del procedimiento, el órgano instructor elevará propuesta de resolución al órgano competente para sancionar para que dicte la resolución que proceda". A esto únicamente se añade, en el art. 82.1 LTSV que "la resolución sancionadora pondrá fin a la vía administrativa...", lo que supone la existencia, implícita, eso sí, sobre la necesidad, y por lo tanto obligación, en cuanto a que esa resolución sancionadora sea dictada por el órgano que tiene atribuida la competencia.

Ante el silencio de la LTSV sobre el marco temporal al que debe de encontrarse sometida la propia aparición de la resolución sancionadora se hace preciso buscar y hacerlo conforme a las prescripciones establecidas (a tal efecto) en el art. 70.1 de la propia LTSV, primero de los artículos destinados por la propia LTSV a la regulación del procedimiento sancionador, precepto que se refiere, y por este orden, a "las disposiciones reglamentarias que lo desarrollen" (el procedimiento instruido en la propia LTSV, se entiende) " $y$, supletoriamente, por lo dispuesto en la Ley 30/1992, de 26 de noviembre, de Régimen Jurídico de las Administraciones Públicas y del Procedimiento Administrativo Común". 


\section{b) La resolución deberá de ser motivada}

Aunque nada establece, de manera expresa, la LTSV sobre la necesidad de motivación de la resolución que ponga fin a la vía administrativa, ya sea sancionadora o declarativa de la inexistencia de responsabilidad por la infracción, resulta evidente que la resolución, para poder ser tomada como tal, tiene que cumplir con esta condición, la de ser una resolución motivada.

Así, el inciso tercero del art. 15.1 RPSTSV, imponía la obligación de que la resolución fuera motivada ("la resolución... deberá ser motivada" en los términos del propio reglamento ${ }^{55}$ ).

La LRJ - PAC establece a este respecto prescripciones tanto generales (para los actos administrativos) como específicas (para las resoluciones sancionadoras). Así, el art. 54 LRJ - PAC dispone que "serán motivados, con sucinta referencia de hechos y fundamentos de derecho: ... a) Los actos que limiten derechos subjetivos o intereses legítimos" $y$, en el concreto ámbito del ejercicio de la potestad sancionadora, el art. 138.1 LRJ - PAC, señala que "la resolución que ponga fin al procedimiento habrá de ser motivada".

La motivación de las resoluciones sancionadoras en materia de tráfico y seguridad vial ha sido objeto de discusión y análisis en multitud de resoluciones judiciales en las que se estudia tanto el requisito exigido de manera general en el art. 54 LRJ - PAC, la motivación como la causa jurídica tenida en cuenta como base de la medida adoptada por la Administración, como en relación a determinadas cuestiones que se han presentado de manera específica en este tipo de resoluciones, cuyo fin no es otro que el de poner término motivadamente a un expediente sancionador, determinando razonadamente la existencia o no de unos hechos subsumibles en un injusto típico, la justificación en ellos de la persona sometida a expediente y la consecuencia sancionadora en el caso de que fuera procedente ${ }^{56}$, puesto que la resolución

55 Téngase en cuenta que la redacción transcrita se corresponde con la vigente al momento de publicarse la Ley 18/2009, de 23 de noviembre. Pero esos términos no eran, exactamente, los que aparecían en la redacción originaria del RPSTSV. A su entrada en vigor, y hasta que fue modificado por el RD 137/2000, de 4 de febrero, el art. 15.1 RPSTSV tenía la siguiente redacción literal:

"Los Gobernadores civiles y los Alcaldes dictarán resolución sancionadora o resolución que decrete, la inexistencia de la infracción, sucintamente motivada, en el plazo de seis meses a contar desde que se inició el procedimiento y decidirán todas las cuestiones planteadas por los interesados y aquellas otras derivadas del procedimiento".

De esta manera los términos empleados originalmente mutaron de "resolución... sucintamente motivada" hacia que "la resolución... deberá ser motivada".

${ }^{56}$ STSJ Castilla y León - Burgos de 4 de abril de 2000 (RJCA 2000, 696) y SSTSJ Canarias - Santa Cruz de Tenerife (entre otras) de 13 de enero de 2000 (RJCA 2000, 719), 7 de septiembre de 2001 (JUR 2002, 38588) y 8 de mayo de 2002 (JUR 2002, 259099). 
sancionadora, carente de auténticos antecedentes fácticos y de fundamentos jurídicos, está desprovista de la más elemental motivación ${ }^{57}$.

La resolución sancionadora requiere de motivación, pues sólo a través de ella es como se puede conocer si la actuación merece la conceptuación de objetiva por adecuarse al cumplimiento de sus fines, sin que tal motivación se pueda cumplir con fórmulas convencionales sino dando la razón plena del proceso lógico y jurídico que determine la decisión, porque la motivación es necesaria para el debido conocimiento de los interesados y para la posible defensa de sus derechos, y la misma debe darse con la amplitud necesaria para tal fin, pues sólo expresando las razones que justifiquen la decisión, es cómo puede el interesado después alegar cuanto le convenga para su defensa, sin subsumirse en la manifiesta indefensión que proscribe el art. 24.1 CE, también extensivo a las resoluciones administrativas ${ }^{58}$.

El cumplimiento del requisito de la motivación no exige una argumentación extensa, bastando con que sea "racional y suficiente" y contenga una referencia de hechos y fundamentos de derecho, pero siendo esto así se ha señalado que ello no se concibe mediante resoluciones contenidas en un documento en el que figura un listado de resoluciones sancionadoras, y solamente se dedica una línea a cada resolución ${ }^{59}$, aunque la utilización de modelos impresos o formularios estereotipados no implican necesariamente una falta o insuficiencia de motivación ${ }^{60}$, sin que ello exima de de un razonamiento concreto sobre el supuesto de hecho, que no se cumple con el uso de cláusulas de estilo, válidas para cualquier caso e insuficiente por tanto para todos ${ }^{61}$.

\footnotetext{
${ }^{57}$ Así, se ha señalado que "la resolución sancionadora, carente de auténticos antecedentes fácticos y de fundamentos jurídicos, es decir, desprovista de la más elemental motivación, se limita a imponer la sanción que tuvo por conveniente y como si los argumentos del interesado no hubiesen existido" (SSTSJ Canarias - Las Palmas de 30 de abril de 1998 (RJCA 1998, 2531), de 16 de abril de 1999 (RJCA 1999, 892) y de 2 de febrero de 2001(JUR 2001, 146561).

${ }^{58}$ Cfr. STC de 36/1982, de 16 de junio (F. 8), SSTS 14 de noviembre de 1986 (RJ 1986, 8081) y 17 de noviembre de 1988 (TJ 1988, 9099) y STSJ Canarias - Las Palmas de 15 de diciembre de 2000 (JUR 2001, 111860).

59 SSTSJ Región de Murcia de 13 de octubre de 1998 (RJCA 1998, 3711), 2 de noviembre de 1999 (JUR 2000, 21120), 14 de enero de 2000 (JUR 2000, 65538) y 29 de noviembre de 2000 (JUR 2001, 13393), entre otras.

${ }^{60}$ Entre otras en SSTSJ Castilla y León - Burgos de 18 de enero de 1999 (RJCA 1999, 1692) y de 4 de abril de 2000 (RJCA 2000, 696), SSTSJ Castilla y León - Valladolid de 28 de septiembre de 2000 (JUR 2001, 7013) y 13 de septiembre de 2002 (JUR 2002, 272531) y SJCA de León, núm. 2, de 28 de septiembre de 2007 (JUR 2008, 110918), todas ellas con cita de la STC 128/1996, de 9 de julio (que se refiere a esta cuestión en su Fundamento 10).

${ }^{61}$ Se ha señalado que "a pesar de la profusión de los argumentos que expuso el recurrente en su recurso ordinario, la resolución de la Dirección General de Tráfico, lejos de subsanar el defecto señalado, se limita a confirmar automáticamente el acto impugnado, acudiendo a fórmulas vacías de contenido concreto, tan abstractas y genéricas que pueden ser extrapoladas a cualquier caso en que esté en juego la misma infracción por la que ha sido sancionada la recurrente. No hay un razonamiento concreto en torno al supuesto de hecho, sino cláusulas de estilo, válidas para cualquier caso e insuficiente por tanto para todos" (SSTSJ Canarias - Las Palmas de 30 de abril de 1998 (RJCA 1998, 2531), de 2 de febrero de 2001 (JUR 2001, 146561) y 12 de mayo de 2006 (JUR 2006, 243067).
} 
La existencia motivación, como requisito necesario de las resoluciones sancionadoras en materia de tráfico y seguridad vial, ha sido discutida en aquellos casos en los que se dicta una única resolución para un conjunto de sanciones, mediante una refundición que, aunque prevista en el art. 55.3 LRJ - PAC para "cuando deba dictarse una serie de actos de la misma naturaleza, tales como nombramientos, concesiones o licencias", se trata de una previsión que no parece que se compadezca con la posibilidad de dar cobertura a diferentes resoluciones sancionadoras, algo que no está previsto ni en la LRJ - PAC, ni en el REPEPOS, ni en la normativa de Tráfico y Seguridad Vial ${ }^{62}$. Refundición que da lugar a una resolución colectiva que pretenden sancionar a una serie de personas con la simple mención de un precepto normativo y una sanción, sin tener en cuenta los hechos que han concurrido, las circunstancias personales o de cualquier otra clase $e^{63}$.

En todo caso la resolución, sancionadora o no, pero con especial incidencia en las que tengan una naturaleza sancionadora, tienen que cumplir con el requisito de la motivación como garantía ínsita al mismo, so pena de nulidad en cuanto que produzca indefensión al interesado ${ }^{64}$.

c) La resolución decidirá todas las cuestiones planteadas por los interesados y aquellas otras derivadas del procedimiento

La resolución, como elemento final en la que desemboca el procedimiento administrativo (sancionador en este caso), tiene decidir todas las cuestiones planteadas por los interesados y aquellas otras derivadas del procedimiento.

Sobre este punto no hay divergencia, ni puede haberla. De esta manera el inciso final del art. 15.1 RPSTSV que "la resolución... decidirá todas las cuestiones planteadas por los interesados y aquellas otras derivadas del procedimiento" que no es más que una reproducción de lo indicado por el art. 20.2 REPEPOS, que indica que la "resolución... decidirá todas las cuestiones planteadas por los interesados y aquellas otras derivadas del procedimiento", redacción que, a su vez, es una transcripción de los términos empleados de forma general en el art. 89.1 LRJ - PAC que sobre el contenido de la resolución establece que "el órgano competente dictará resolución que será motivada y decidirá todas las cuestiones planteadas por los interesados y aquellas otras derivadas del procedimiento" y de manera específica en el ámbito del procedimiento sancionador en el art. 138.1 LRJ - PAC, lugar en el que determina que "la resolución

\footnotetext{
${ }^{62}$ Así se pone de manifiesto en las STSJ de la Región de Murcia (entre otras muchas) de 8 de abril de 1999 (RJCA 1999, 1067), 15 de septiembre de 1999 (JUR 1999, 241991), 11 de octubre de 2000 (JUR 2000, 310218) y de 20 de noviembre de 2002 (RJCA 2002, 1193).

${ }^{63}$ Cfr. STSJ Navarra de 9 de abril de 2001, JUR 2002, 171977.

${ }^{64}$ STSJ Castilla - La Mancha de 16 de septiembre de 2002 (JUR 2002, 272751).
} 
que ponga fin al procedimiento habrá de ser motivada y resolverá todas las cuestiones planteadas en el expediente".

Nos encontramos ante una cuestión básica del procedimiento y que, por lo tanto, tiene que recibir (y recibe) el mismo tratamiento para el procedimiento general, en la regulación el procedimiento sancionador general y en la ordenación de los procedimientos sancionadores especiales como, en este caso, es el tráfico y la seguridad vial.

Se trata, en definitiva, de cumplir con el requisito de la congruencia entre los límites determinados en el procedimiento (sancionador en este caso) y la terminación del mismo mediante la correspondiente resolución. Especial relevancia tiene (puede tener y la tiene) en el ámbito del procedimiento sancionador en materia de tráfico la correspondencia, la más que exacta, adecuada y necesaria, entre lo alegado por el interesado, el denunciado como presunto infractor en su caso, y la contestación que, finalmente, se da al procedimiento sancionador por medio de la correspondiente resolución. Además de la necesidad, ya analizada, de la existencia de la resolución, es preciso que esa resolución sea congruente con lo planteado por el interesado y es, en el caso del tráfico, dado el carácter masivo de procedimientos y la práctica formularia que se ha ido imponiendo, como medio de hacer frente por la propia Administración competente a esa ingente cantidad de procedimientos sancionadores, que en el supuesto concreto la resolución se adapte, sea congruente con lo planteado y resuelva todas las cuestiones que, insisto, sean objeto de ese concreto procedimiento. Las contestaciones formularias pueden ocasionar, y de hecho en la práctica ello sucede, que se obvien en la resolución cuestiones que han sido puestas en el marco del procedimiento, lo que desencadenará, mediante los mecanismos oportunos que se pueda llegar a decretar la nulidad de esa resolución por no cumplir con el requisito, legalmente impuesto, de la congruencia.

Sobre esta cuestión ya se ha señalado, al hilo de la necesidad de cumplir con el requisito de motivación, que la utilización de modelos impresos o formularios estereotipados no implican necesariamente una falta o insuficiencia de motivación ${ }^{65}$, y sin que ello el "automatismo burocrático" constituya, por sí mismo y en abstracto vulneración de derechos fundamentales, sino más bien proyección del principio de eficacia de las Administraciones Públicas para velar por los intereses de la seguridad vial, que refiere el art. $103 \mathrm{CE}^{66}$, siempre, eso sí, que esa forma de actuación respete los principios a los que la resolución sancionadora se encuentra sometida y contenga, por tanto, motivación suficiente y conteste a todas las cuestiones planteadas en el procedimiento.

\footnotetext{
${ }^{65}$ Vide supra nota 60 de este mismo capítulo con referencia a la STC 128/1996, de 9 de julio, F. 10.

${ }^{66}$ Como señala la STSJ Cataluña de 16 de enero de 2003 (RJCA 2003, 219).
} 
d) La resolución no podrá tener en cuenta hechos distintos de los determinados en la fase de instrucción del procedimiento, sin perjuicio de su diferente valoración jurídica

La LTSV no hace referencia expresa a esta limitación de la resolución a adoptar por el órgano competente para sancionar que, el art. 15.2 RPSTSV recoge de manera literal al indicar que "la resolución no podrá tener en cuenta hechos distintos de los determinados en la fase de instrucción del procedimiento, sin perjuicio de su diferente valoración jurídica".

En este sentido el art. 20.3 REPEPOS, en su primer inciso, determina que "en la resolución no se podrán aceptar hechos distintos de los determinados en la fase de instrucción del procedimiento, salvo los que resulten, en su caso, de la aplicación de lo previsto en el número 1 de este artículo, con independencia de su diferente valoración jurídica" ${ }^{67}$.

Son, por lo tanto, dos las previsiones que se efectúan en el art. 20.3 REPEPOS y ambas son recogidas por el art. 15.2 RPSTSV. Por un lado, y en primer lugar, se limita el alcance de la resolución en cuanto a los hechos que no podrán ser distintos de los determinados en la fase de instrucción del procedimiento. De otro se permite la posibilidad de que la resolución realice una valoración jurídica, de esos hechos determinados en la fase de instrucción, y que esa valoración jurídica (sobre esos mismos hechos) no coincida con la realizada en la instrucción.

Aunque, y a diferencia de lo establecido en el art. 30 REPEPOS, ninguna previsión se realiza en el art. 15 RPSTSV sobre la forma de proceder en el caso de que el órgano competente para sancionar considere que la infracción reviste una mayor gravedad de la establecida en la propuesta de resolución entiendo que la previsión efectuada en el segundo inciso del art. 20.3 REPEPOS resulta plenamente aplicable y que, ante la ausencia de regulación del RPSTSV, lo allí establecido determina la forma en la que se

\footnotetext{
${ }^{67}$ Téngase en cuenta que, en este sentido, el apartado 1, al que se hace referencia en este art. 20.3 REPEPOS señala que:

“Antes de dictar resolución, el órgano competente para resolver podrá decidir, mediante acuerdo motivado, la realización de las actuaciones complementarias indispensables para resolver el procedimiento.

El acuerdo de realización de actuaciones complementarias se notificará a los interesados, concediéndoseles un plazo de siete días para formular las alegaciones que tengan por pertinentes. Las actuaciones complementarias deberán practicarse en un plazo no superior a quince días. El plazo para resolver el procedimiento quedará suspendido hasta la terminación de las actuaciones complementarias. No tendrán la consideración de actuaciones complementarias los informes que preceden inmediatamente a la resolución final del procedimiento".
} 
debe actuar. De esta manera, y conforme a lo establecido en el referido segundo inciso del art. 20.3 REPEPOS "no obstante, cuando el órgano competente para resolver considere que la infracción reviste mayor gravedad que la determinada en la propuesta de resolución, se notificará al inculpado para que aporte cuantas alegaciones estime convenientes, concediéndosele un plazo de quince días".

En cualquier caso, y como ya hemos tenido oportunidad de analizar al estudiar la propuesta de resolución, no hay duda sobre que el derecho de defensa presupone el derecho a conocer los cargos antes de la imposición de la sanción, ya que en caso contrario, la defensa no puede ser eficaz. Pero, las garantías impuestas por el derecho a ser informado de la acusación, en los términos antes expuestos, no alcanzan a impedir que se produzca un cambio en la calificación de los hechos imputados, en cuanto se trata de una operación jurídica de subsunción del hecho en la norma, pero no una modificación sustancial de los fundamentos fácticos de la acusación y posterior sanción ${ }^{68}$, por lo que aunque no resulta posible la alteración de los hechos que sirven de base a la acusación, sin embargo, esa prohibición no alcanza a la valoración jurídica de tales hechos no puede decirse lo mismo, de forma que el órgano encargado de resolver el expediente sancionador no se encuentra vinculado por las calificaciones y ponderaciones que se contengan en el pliego de cargos y en la propuesta de resolución, y tiene plena libertad de juicio para determinar la calificación jurídicoadministrativa que corresponda a los hechos

\section{LA FORMA DE LA RESOLUCIÓN SANCIONADORA}

Nada detalla la LTSV sobre la forma que debe de adoptar la resolución sancionadora, como requisito de los actos administrativos que, en estos casos, suponen la imposición de una sanción para el interesado.

El RD 137/2000, de 4 de febrero (RCL 2000, 473) modificó el art. 15.1 RPSTSV estableciendo que:

“Los Delegados o Subdelegados del Gobierno, en su caso, y los Alcaldes, dictarán resolución sancionadora o resolución que declare la inexistencia de responsabilidad por la infracción. Dicha resolución se dictará por escrito conforme previene el art. 55.1 LRJ - PAC, salvo que los órganos administrativos ejerzan su competencia de forma verbal, en cuyo caso el titular de la competencia deberá autorizar una relación de las que haya dictado de forma verbal con expresión de su contenido conforme previene el art.ículo 55.2 de la referida Ley. La resolución habrá de notificarse en el plazo de un año desde que se inició el procedimiento, deberá ser motivada y decidirá todas las cuestiones planteadas por los interesados y aquellas otras derivadas del procedimiento".

Con esta redacción se mantenía, en cuanto a la producción de la resolución (sancionadora o declarativa de la inexistencia de responsabilidad), la forma escrita como manera general u ordinaria en línea a lo establecido en el art. 55.1 LRJ - PAC.

\footnotetext{
${ }^{68}$ Cfr. STC 160/1994, de 23 de mayo.
} 
Pero al mismo tiempo, y mediante la cláusula "salvo que", se establecía la posibilidad de la forma oral para esas resoluciones, con referencia, para este supuesto, al propio art. 55.2 de la propia LRJ - PAC.

La adopción de esta decisión, como posibilidad, no estuvo exenta de polémica desde el mismo instante en que fue introducida. Algo lógico, puesto que la forma de los actos administrativos, como garantía, puede resultar en entredicho al hacerse uso de la forma verbal como sistema de adopción de resoluciones que, en la mayoría de los casos, suponen la imposición de una sanción administrativa.

La discusión no se centra tanto en la posibilidad de que las resoluciones sancionadores puedan adoptar la forma oral, cuestión que, efectivamente, se encuentra reconocida y amparada, de manera general, por el art. 55.2 LRJ - PAC y, en el específico ámbito de las resoluciones sancionadoras en materia de tráfico y seguridad vial, por el art. 15.1 RPSTSV en la redacción que, como ya se ha puesto de manifiesto, recibió este precepto del RD 137/2000, de 4 de febrero. El debate surge entorno a la propia existencia de la resolución que, se dice, ha sido adoptada por el órgano competente de forma verbal.

Esa duda desaparece, es más, ni siquiera llega a existir, cuando la resolución sancionadora se ha producido por escrito, puesto que la propia forma en la que se documenta viene a determinar su propia existencia. La forma oral induce al interesado a plantearse preguntas y a dudar sobre si esa resolución, que se le notifica ha sido adoptada por el órgano competente para sancionar, ha llegado a producirse de manera efectiva y real.

$\mathrm{Ni}$ que decir tiene que siempre resulta mucho más verosímil y creíble la constancia escrita de un acto administrativo, tangible y palpable (al menos aparentemente), que el tener que recurrir a la fe del interesado al que resulta ciertamente muy fácil caer en la tentación de la duda.

Este, y no otro, es el trasunto que inspira la redacción del art. 55.1 LRJ - PAC cuando prescribe que "los actos administrativos se producirán por escrito a menos que su naturaleza exija o permita otra forma más adecuada de expresión y constancia", no siendo posible confundir la forma verbal de producción con su constancia por escrito ${ }^{69}$.

Cualquier análisis del contenido de este precepto nos conduce a la conclusión de que al lado del establecimiento, como norma general, del principio de exigencia de la forma escrita para los actos administrativos, como garantía para los ciudadanos, se establece una excepción que, en los términos en los que se establece ("a menos que su naturaleza exija o permita otra forma más adecuada de expresión y constancia"), es muy difícil de poder concretar en la práctica. $Y$ lo es porque encontrar supuestos

\footnotetext{
${ }^{69}$ García de Enterría, E. y Fernández Rodríguez T.-R., Curso de Derecho Administrativo, Tomo I, 14ạ ed., Madrid, Civitas, 2008, pág. 570.
} 
hipotéticos en los que la naturaleza del acto administrativo exija o permita una forma más adecuada de expresión o constancia se nos antoja una labor complicada y ardua.

Es cierto que la combinación de términos utilizados en ese inciso final del art. 55.1 in fine LRJ - PAC puede llevar a minimizar la expresión en "a menos que su naturaleza permita otra forma más adecuada de expresión".

Y es en este terreno donde surgen todos los problemas. Ni existe previsión específica, en el ámbito sancionador (ni en el general, ni en el concreto del tráfico y la seguridad vial) para hacer uso de la refundición de actos de la misma naturaleza, ni esta parece la forma más adecuada cuando de lo que se trata es de diversidad de resoluciones sancionadoras, algo que, como ya se expuso al analizar el requisito de la motivación, no se compadece en demasía con las garantías que debe recibir el interesado.

Pero es que, además, la adopción de la resolución sancionadora de forma verbal no puede ser completada con una resolución posterior, de quien carece de la competencia sancionadora, que pretenda rellenar los vacíos de aquella. No nos hallaríamos, en ese caso, ante una resolución verbal de la que se da constancia por escrito. La complicación surge porque, en ese caso, nos encontramos con dos actos. El primero de ellos adoptado por el órgano competente para sancionar y con forma verbal carece de motivación y es inválido. El segundo, al no limitarse a la constatación, es un acto distinto, que adopta la forma escrita y está motivado, pero dictado por órgano incompetente ${ }^{70}$.

$Y$ ello sin ignorar que los propios términos en los que se encuentra redactada la previsión del art. 55.1 LRJ - PAC podrían ser, por sí mismos, suficiente razón para

\footnotetext{
${ }^{70}$ Así, por ejemplo, en la STSJ Navarra de 9 de abril de 2001 (JUR 2002, 171977) en la que se señala que "en el presente caso la Resolución adoptada no es una Resolución individual, sino colectiva, en la que se acuerda sancionar a una serie de personas sin tener en cuenta los hechos que han concurrido, las circunstancias personales o de cualquier otra clase. Hay una mera remisión a un precepto del R.G.C y una multa. La Resolución dictada con la misma fecha por la Jefa de la unidad de sanciones, dice que le da traslado de la Resolución dictada por el Delegado del Gobierno. Pero no es así. Esta Resolución es distinta y en ella se recogen sucintamente hechos y razonamientos jurídicos, pero es evidente que estamos ante dos resoluciones distintas. Una inmotivada e inválida dictada por el órgano competente. Otra dictada por órgano incompetente y ajustada al procedimiento" y en diferentes resoluciones del TSJ de Andalucía - Granada en las que, sin poner obstáculo a la adopción verbal de resoluciones sancionadoras, sin embargo se manifiesta que "La motivación, que según exige el artículo 89.3, deberá de contenerse en la propia resolución, sólo podrá entenderse cumplida mediante la aceptación de previos informes o dictámenes, cuando los mismos se incorporen al texto de la resolución. De donde resulta obvio que las garantías de motivación que son exigibles a la resolución sancionadora no se cumplen en las que son dictadas de forma verbal y ello, pese a que del tenor literal del citado artículo 55.2 de la Ley 30/1 992, pueda colegirse que no existe inconveniente en que, incluso tratándose de resoluciones sancionadoras su dictamen pueda ser acordado de esa forma verbal, porque como acaba de razonarse aquí, en esta forma resolutoria no es posible incorporar el texto de su motivación que, desde luego, no puede ser sustituido por el de la propuesta evacuada por el Jefe Provincial de Tráfico" (SSTSJ Andalucía - Granada de 10 de marzo de 2003, JUR 2003, 131731, y 17 de noviembre de 2003, JUR 2004, 27588)
} 
cuestionar que la forma verbal en una resolución sancionadora sea la más adecuada para cumplir con las garantías establecidas para este tipo de procedimientos.

No obstante, frente al inciso del art. 15.1 RPSTSV (en la redacción recibida del RD $137 / 2000$, de 4 de febrero) que disponía que los órganos competentes dictarían la resolución sancionadora, o la que declarase la inexistencia de responsabilidad por la infracción, por escrito, "salvo que los órganos administrativos ejerzan su competencia de forma verbal, en cuyo caso el titular de la competencia deberá autorizar una relación de las que haya dictado de forma verbal con expresión de su contenido conforme previene el art. 55.2 LRJ - PAC", se planteo cuestión de ilegalidad sobre la que el Tribunal Supremo entendió que "no se ha tenido en cuenta que el art. 55.2 LRJ PAC - del que el precepto reglamentario cuya legalidad se cuestiona es mera aplicación en el concreto sector de la administración vial- está habilitando a la Administración pública para utilizar una técnica de racionalización y simplificación del trabajo administrativo, y que, en modo alguno, el empleo de esa técnica en el procedimiento sancionador de tráfico implica disminución de garantía alguna de los administrados", desestimando la cuestión de ilegalidad que había sido planteada ${ }^{71}$.

\section{Plazo de tiempo a los QUe SE ENCUENTRA SOMETIDA}

\section{a) El plazo de tiempo para dictar la resolución (sancionadora)}

Nada señala, de manera expresa, el art. 81 LTSV (como tampoco lo hacía el art. 15 RPSTSV), al abordar las cuestiones relativas a la resolución, sobre el plazo de tiempo del que dispone el órgano competente para dictar la resolución sancionadora. Pero ello no quiere decir que no se encuentre sometida a condiciones temporales. Es en sede de regulación de la caducidad, art. 92.3 LTSV (16 RPSTSV), el lugar en el que encontramos la prescripción normativa que aquí interesa.

El art. 92.3 LTSV (que viene a coincidir con lo establecido en la regulación anterior ${ }^{72}$ y en el art. 16.1 RPSTSV) dispone que "si no se hubiera producido la resolución sancionadora transcurrido un año desde la iniciación del procedimiento, se producirá

\footnotetext{
${ }^{71}$ La cuestión fue planteada por Auto del JCA de Cádiz no 5 de 30 de julio de 2002 (RJCA 2002, 432) y desestimada por STS de 15 de noviembre de 2002 (RJ 2003, 624).

72 La Ley 19/2001, de 19 de diciembre, incorporó al art. 81.2 LTSV esta previsión, coincidente con la establecida en el art. 16.1 RPSTSV y a la que la redacción originaria no hacía referencia alguna. La redacción originara del art. 16 RPSTSV prescribía la caducidad del procedimiento "si no hubiese recaído resolución transcurridos treinta días desde la finalización del plazo de seis meses desde la iniciación del procedimiento", redacción que fue modificada por el RD 137/2000, de 4 de febrero, para establecer su redacción en "si no hubiese notificado la resolución transcurridos seis meses desde la iniciación del procedimiento, se producirá la caducidad de éste y se procederá al archivo de las actuaciones" y nuevamente enmendada por el RD 318/2003, de 14 de marzo, que fijó sus términos en "Si no hubiera recaído resolución sancionadora transcurrido un año desde la iniciación del procedimiento, se producirá la caducidad de éste y se procederá al archivo de las actuaciones".
} 
su caducidad y se procederá al archivo de las actuaciones, a solicitud de cualquier interesado o de oficio por el órgano competente para dictar resolución.

La regulación es clara (al menos en apariencia) e impone la necesidad de que la resolución sancionadora sea adoptada en el plazo de un año a contar desde la fecha de iniciación del procedimiento. El análisis de esta cuestión, tal y como está regulada, de manera general y las excepciones a ese genérico planteamiento son objeto de estudio y análisis en el apartado correspondiente a la caducidad del procedimiento (apartado II.H.3 en este mismo capítulo).

En lo que aquí interesa baste con señalar que existe un marco temporal, que se concreta en un año, a contar desde la iniciación del propio procedimiento sancionador. Plazo que, por otra parte, es específico del procedimiento sancionador en materia de tráfico y seguridad vial, puesto que el art. 20.6 REPEPOS establece uno distinto, que es de "seis meses desde la iniciación", con unas normas de interpretación también diferentes para su cómputo para el caso de las excepciones que en ese mismo precepto se contemplan.

b) El plazo de tiempo para dictar la resolución desde que recibe la propuesta de resolución del órgano instructor

Ninguna previsión normativa, a este respecto, encontramos en el ámbito de la regulación del Tráfico y la Seguridad Vial, ni en la LTSV ni en el RPSTSV.

Sin embargo, en el desarrollo reglamentario de la regulación general para el ejercicio de la potestad sancionadora, encontramos (ciertamente escondida) una referencia a esta cuestión, ya que el último párrafo (el tercero) de los que componen el art. 20.2 REPEPOS se establece que "la resolución se adoptará en el plazo de diez días, desde la recepción de la propuesta de resolución y los documentos, alegaciones e informaciones obrantes en el procedimiento, salvo lo dispuesto en los puntos 1 y 3 de este artículo".

Los supuestos a los que hace referencia el art. 20.2 REPEPOS son "la realización de las actuaciones complementarias indispensables para resolver el procedimiento" (art. 20.1 REPEPOS que, eso sí, requiere de acuerdo motivado) y que se proceda a dar audiencia al interesado (art. 20.3 REPEPOS).

Nos encontramos con una determinación de carácter general en la que se fija, como espacio de tiempo en el que el órgano titular de la competencia para sancionar tiene el deber de dictar la correspondiente resolución ( $y$, por lo tanto, resolver), un plazo de diez días que empiezan a computarse desde que el órgano, que tiene que dictarla, recibe la propuesta de resolución, norma general que no es absoluta, desde el 
momento en que queda sometida, en algunos casos, a la presencia de determinadas vicisitudes que pueden ocasionar la extensión de ese plazo de diez días prefijado como norma general.

Esta previsión ha de ser puesta en relación con la establecida en el art. 63.3 LRJ - PAC conforme a la que "la realización de actuaciones administrativas fuera del tiempo establecido para ellas sólo implicará la anulabilidad del acto cuando así lo imponga la naturaleza del término o plazo" por lo que "debe estimarse que se trata de plazos aceleratorios, cuyo incumplimiento constituye una irregularidad no invalidante" ${ }^{\prime 73}$.

Y siempre que, eso sí, que esa demora en dictar la resolución no suponga superar los plazos establecidos tanto para la prescripción de las infracciones (art. 92.1 LTSV) como para la caducidad del procedimiento (art. 92.3 LTSV).

\section{G) Supuesto en el que el denunciado ni realiza alegaciones ni procede al pago de la multa (los supuestos recogidos en el art. 81.5 LTSV)}

\section{EL SUPUESTO}

El art. 81.5 LTSV establece previsiones frente a la inactividad del denunciado que, en su primer inciso, contiene tres elementos perfectamente diferenciables: supuesto o previsión, plazo y efecto o resultado.

\section{a) La inactividad del denunciado (notificado o dado por tal)}

La premisa o previsión normativa se centra en el supuesto en el que "el denunciado no formula alegaciones ni abona el importe de la multa". El denunciado, al que se le notifica la denuncia (o se entiende que la ha recibido), ni ha procedido al pago de la sanción prevista, caso de que sea posible con el descuento establecido del 50 por ciento, ni ha formulado las alegaciones. Es decir, ha desechado el pago (y elegir de manera expresa) el procedimiento sancionador abreviado y guarda silencio frente a la actuación de la Administración sancionadora.

El denunciado escoge, de entre las tres opciones posibles, la tercera: ni paga, ni alega... simplemente se limita a quedarse a la espera de los acontecimientos.

\footnotetext{
${ }^{73}$ Así lo ha entendido el Tribunal Supremo en multitud de sentencias en el propio ámbito del derecho administrativo sancionador y la emisión, por tanto de resoluciones sancionadoras, como son, entre otras, las dictadas en 24 de septiembre de 2001 (RJ 2002, 3122), 1 de octubre de 2001 (RJ 2002, 3124), 15 de octubre de 2001 (RJ 2002, 10190), 9 de abril de 2002 (RJ 2002, 3458), 29 de septiembre de 2006 (RJ 2006, 6461) y 4 de diciembre de 2012 (RJ 2013, 1014)
} 


\section{b) El período de tiempo establecido}

El art. 85.1 LTSV acota un espacio temporal para esa falta de actividad del denunciado, al establecer, y al menos aparentemente de forma precisa, que cantidad de tiempo tiene que transcurrir y desde cuando se inicia el cómputo de ese plazo. Si el denunciado no hace nada (ni paga, ni alega) "en el plazo de quince días naturales siguientes al de la notificación de la denuncia".

El problema, sobre la determinación de este plazo de tiempo, se complica desde el momento en que, como hemos tenido oportunidad de señalar, las referencias en la propia LTSV a este espacio de tiempo no son congruentes ni fijan, en todos los casos, la misma duración. Por ello, y aunque el art. 81.5 LTSV establece un plazo de quince días naturales, hay que entender que, en realidad, el denunciado dispone de veinte días naturales y que, por lo tanto, es necesario dejar transcurrir ese tiempo sin que se realice el pago voluntario o se presenten alegaciones para que la Administración pueda entender que el denunciado ha optado por la inactividad en relación con la denuncia ${ }^{74}$.

Ahora bien, es preciso tener en cuenta que puede transcurrir ese plazo de tiempo, de veinte días naturales, y la Administración sancionadora, en ese instante, puede no conocer (todavía) que el denunciado ha procedido a realizar el pago de la multa. Será ese hecho, el pago voluntario realizado en el plazo marcado, el que lo determine, y no el hecho de que esa acción del interesado sea confirmado por la Administración antes o después de finalizar el plazo de veinte días naturales.

La práctica se empeña en demostrar que son cosas diferentes el instante en el que se realiza el pago y el momento en el que ese hecho se incorpora al conocimiento de la Administración.

Por otra parte no debe resultar extraño la defensa del carácter antiformalista con el que debemos de entender ese plazo de veinte días naturales, pues lo que realmente importa es el acto del interesado para proceder al pago del importe de la sanción, con la reducción del cincuenta por ciento, en cuanto manifestación de su voluntad. Por ello defiendo que, en tanto en cuanto no se haya puesto en marcha el mecanismo de la Administración para tramitar el expediente por el procedimiento sancionador ordinario debería prevalecer el hecho del pago con esa bonificación del cincuenta por ciento en el importe de la sanción sobre una lectura milimétrica y formalista del plazo.

En este sentido todo intento de acotar cuál deba de ser el plazo de tiempo en el que, una vez superados esos veinte días naturales, pueda entenderse que el pago por el interesado produce las consecuencias establecidas en el art. 80 LTSV, parece, por sí mismo, estéril. Intentar afirmar, y justificar en derecho, que el entendimiento antiformalista del plazo alcanza a los 10 o a los 20 días naturales siguientes (o a

\footnotetext{
${ }^{74}$ Véase, en este mismo capítulo, el apartado destinado, dentro de las alegaciones, al plazo.
} 
cualquier otro espacio de tiempo que se pudiera señalar) al del propio plazo de tiempo establecido carece de sentido. Es por ello que será la propia actuación de la Administración sancionadora la que dé por terminado ese plazo de tiempo en cuanto a la posibilidad que legalmente se ofrece al interesado.

Esta forma en la que ha de entenderse, de una manera flexible, el plazo del que dispone el denunciado para proceder al pago encuentra apoyo en el inciso final del propio párrafo primero del art. 81.5 LTSV establece, para este supuesto que "la sanción podrá ejecutarse transcurridos treinta días naturales desde de la notificación de la denuncia". Tomando esta referencia de manera recta, este puede ser el plazo objetivo con el que, en la práctica, podemos entender el plazo de tiempo del que dispone el denunciado, considerado desde una perspectiva antiformalista, para proceder al pago. Entrar en la discusión de si este plazo es el doble del inicialmente previsto de quince días naturales, plazo que, como se ha puesto de manifiesto queda en entredicho teniendo que entender que es de veinte días naturales por lo que ya no es el doble, es lo de menos. Caso de que se quiera objetivar se podría entender que hasta transcurridos treinta días naturales la Administración no puede proceder a ejecutar la sanción, por lo que en tanto que no se proceda a la ejecución el interesado está a tiempo de acogerse a ese beneficio de pago bonificado.

Cualquier pago que se realice después de que la Administración se haya puesto en marcha para ejecutar cierra de por sí, al denunciado, la posibilidad de acogerse a los beneficios establecidos. Que ese momento se determine por la fecha de la actuación de la Administración o por aquella en la que el interesado tiene conocimiento de esa actuación, mediante la correspondiente notificación, puede ser objeto de discusión. Lo que resulta evidente es que, en todo caso, si la Administración pone en marcha el procedimiento ordinario y exterioriza al interesado su actuación, con puesta en conocimiento, es claro que esa noticia supone la preclusión para el interesado de esa posibilidad de paccionar con la Administración. En este caso, y al tratarse de la ejecución de una sanción, entiendo que la mera puesta en marcha del procedimiento de apremio es suficiente para dar por precluido el espacio de tiempo en el que pudo ser realizado el pago voluntario, y ello independientemente de que el interesado tenga un conocimiento ulterior de esa actividad administrativa.

\section{c) La consecuencia o el resultado}

La consecuencia que la LTSV anuda a la pasividad del interesado en el plazo de tiempo establecido, es que la denuncia (que se ha notificado o que la propia LTSV entiende que produce esos mismos efectos) "surtirá el efecto de acto resolutorio del procedimiento sancionador". 
Esta disposición supone que la denuncia se convierte en resolución sancionadora. Ya no en propuesta de resolución, que elevar al titular de la competencia sancionadora para que proceda a dictar la correspondiente resolución sancionadora, como estaba previsto en el régimen anterior y en el REPEPOS (arts. 16 y 19), sino en "acto resolutorio del procedimiento sancionador" siempre y cuando, eso sí, concurran determinadas circunstancias.

Se establece, por tanto, que en ese supuesto de inactividad del interesado en el plazo legalmente establecido la denuncia se convierte en resolución sancionadora. Se trata, ni más ni menos, que de una mutación genética legalmente prevista por el mero transcurso de un plazo de tiempo (sic) sin que el interesado de señales de vida. En este caso el ADN jurídico de la denuncia como medio de iniciación del expediente sancionador se altera (ope legis) y se transforma en resolución sancionadora, de ahí surge la importancia, para que el ser resultante de la mutación, esa resolución sancionadora, sea jurídicamente viable, que la denuncia originaria conste con todos y cada uno de los elementos que la hagan susceptible de convertirse en acto administrativo sancionador capaz de poner fin a un procedimiento administrativo sancionador ${ }^{75}$.

\section{EFECTOS (SOBRE EL PROCEDIMIENTO Y SOBRE LA SANCIÓN)}

En los supuestos en los que se perfeccione la previsión legal establecida en el art. 80.5 LTSV se producen, por asociación, dos efectos que se contienen en el último párrafo del propio precepto. Por una parte se pone fin a la vía administrativa y, por otra, se podrá ejecutar la sanción transcurridos treinta días naturales desde la notificación de la denuncia. Cara y cruz de la misma moneda, pues difícilmente es ejecutable algo que no está terminado, y viceversa.

La posibilidad de ejecutar, por el hecho de darse por terminado el procedimiento administrativo sancionador, aparece recogida en el inciso final del párrafo primero del art. 80.5 LTSV y reiterada en el inciso final del último párrafo de ese mismo apartado.

El art. 82 LTSV se inicia con la genérica previsión de que "la resolución sancionadora pondrá fin a la vía administrativa y la sanción se podrá ejecutar desde el día siguiente a aquél en que se notifique al interesado, produciendo plenos efectos...", claro que, inmediatamente, se añade que "o, en su caso, una vez haya transcurrido el plazo indicado en el último apartado del artículo anterior", referencia esta que, precisamente, se dirige a la previsión que aquí se analiza.

\footnotetext{
${ }^{75}$ Se hace necesario, por tanto, determinar el contenido de la denuncia, conforme se ha analizado en el capítulo sobre Las fases del procedimiento administrativo sancionador en materia de tráfico y seguridad vial en el apartado destinado a la denuncia y su contenido (II).
} 
La LTSV requiere, como norma general, de una resolución sancionadora que necesita de la manifestación expresa del depositario de la competencia para sancionar como consecuencia de un procedimiento sancionador tramitado con todas las garantías para el interesado.

En este caso la LTSV establece previsiones conforme a las cuales no va a existir una resolución sancionadora. Lo que se hace es convertir otro acto administrativo (la denuncia) en resolución sancionadora como respuesta legal al desinterés y dejación del denunciado, de manera que, con base en el aforismo que "quien calla, otorga"76, se eleva a categoría resolutoria una mera denuncia.

Lo preocupante de esta prescripción (al igual que sucede con las previsiones realizadas en el marco del procedimiento abreviado) es que pueden no darse las garantías previstas en nuestro sistema para imponer una sanción. Para los supuestos en los que esta previsión actúa (que, como veremos, no son todos) no hay órgano instructor, ni instrucción, ni propuesta de resolución, ni interviene el titular de la competencia sancionadora. Y ello podría suponer, en ciertos casos y bajo determinadas circunstancias, que la denuncia se llegara a convertir en una sanción de plano por el hecho de que el denunciado ni paga ni alega.

Evidentemente esta situación no se plantearía si transcurrido el plazo establecido el órgano instructor elevara propuesta de resolución en base a la denuncia al órgano competente para sancionador y este dictara la resolución que tuviera por conveniente. Nótese que ambos pasos se pueden automatizar ${ }^{77}$, pero ha de hacerse con todas las garantías exigidas, y así, frente a eventuales errores, formales o materiales, en la denuncia, el órgano instructor, como garante que es, actuaría de oficio en interés de ley. Errores que pueden producirse en ambos sentidos, tanto en contra del denunciado como a favor del mismo (algo que resulta preciso tener presente).

Pero la previsión convierte la denuncia en acto resolutorio del procedimiento sancionador $y$, en el caso de que ulteriormente se detectara un error (por ejemplo, que la calificación efectuada era inferior a la legalmente prevista) no se podría rectificar, puesto que habría que recurrir a los mecanismos establecidos, de manera general en la LRJ - PAC para corregir ese defecto en la tramitación del expediente sancionador.

\footnotetext{
76 Sobre esta cuestión, y la supervivencia de este aforismo jurídico "como parte de nuestro subconsciente jurídico colectivo", véase el artículo de GEMA TOMÁs MARTínEz "Fuentes jurídicas del principio "qui tacet, consentire videtur". Realidad jurídica versus difusión social", Revue internationale des droits de l'antiquité, no 50, 2003, págs. 383 - 400, que se cierra con la expresión entrecomillada en esta nota.

${ }^{77}$ Algo que nos ubica en la "actuación administrativa automatizada" del apartado a) del Anexo de la LAE y a lo que nos hemos referido en el apartado I.B.3.C) del capítulo sobre Las fases del procedimiento administrativo sancionador en materia de tráfico y seguridad vial en el que se analiza "El procedimiento administrativo sancionador con uso de elementos electrónicos".
} 
En cuanto a la ejecución, la previsión es mera consecuencia de la terminación del procedimiento sancionador. Parece importante señalar aquí que el plazo, reiteradamente fijado en el art. 80.5 LTSV, de treinta días naturales, a contar desde la propia notificación de la denuncia que el interesado ignora, es el momento a partir del cual se puede proceder a la ejecución de la sanción inicialmente prevista en la propia denuncia y, por lo tanto, sin descuento y con los recargos que le correspondan por así estar establecido.

Aquí interesa destacar que la puesta en marcha de la ejecución de la sanción prevista en la denuncia, "la sanción que pudiera corresponder..." en términos del art. 74.2 a) LTSV sobre contenido de las denuncias notificadas en el acto, puede, y a mi juicio así debe ser considerado, como trámite preclusivo del plazo de tiempo del que ha dispuesto el denunciado para resolver el expediente sancionador por el procedimiento sancionador abreviado, como medio pactado para tramitar el expediente sancionador correspondiente a esa denuncia.

\section{SUPUESTOS A LOS QUE SE APLICA Y A LOS QUE NO SE APLICA}

El propio art. 80.5 LTSV establece el ámbito de aplicación de las prescripciones establecidas. La LTSV opta por establecer el ámbito de actividad de manera positiva al señalar que "lo dispuesto anteriormente será de aplicación únicamente" en determinados casos, enumerando, con letras, los siguientes:

- Infracciones leves (letra a)

- Infracciones graves que no detraigan puntos (letra b)

- Infracciones graves y muy graves cuya notificación se efectuase en el acto de la denuncia (letra c)

A la vista de esta redacción tal vez hubiera sido más sencillo haber explicado los supuestos a los que no se les puede aplicar este supuesto. Tal vez redactar en negativo (por una vez) hubiera sido más claro puesto que contrario sensu parece que quedan fuera de la aplicación de este supuesto:

- Las infracciones graves y muy graves cuya notificación no hubiera sido practicada en el acto, $y$

- Las infracciones graves (y muy graves) que detraigan puntos (hayan o no sido notificadas en el acto)

Sea lo que fuere, los términos empleados no parecen demasiado afortunados a la vista de las dudas que se generan de su simple lectura. 
Resulta evidente que las infracciones leves, notificadas en el acto o no, forman parte del supuesto.

$\mathrm{Y}$, de igual manera (a pesar de los términos de la redacción de la Ley) parece claro que las infracciones graves y muy graves no notificadas en el acto (independientemente de que lleven o no asociada la consecuencia de pérdida de puntos) están excluidas y no forman parte del alcance de las previsiones de este supuesto.

En el medio nos queda una previsión que genera dudas, puesto que, en cuanto a la previsión expresa "infracciones graves que no detraigan puntos", el sentido, y delimitación, parece diáfano: no se pueden aplicar las prescripciones establecidas a las "infracciones graves que sí detraigan puntos"... pero nada se establece sobre las infracciones muy graves que sí detraigan puntos y que, conforme a lo establecido en siguiente letra c), fueran notificadas en el acto.

Resulta extraño el diferente tratamiento que, parece ser, se establece para las infracciones graves y las muy graves en función de la posibilidad de detracción de puntos y el momento de la notificación. Es incongruente que en las "las infracciones graves no notificadas en el acto y que detraigan puntos" la inactividad del denunciado no convierta la denuncia en resolución sancionadora, mientras que en las "infracciones muy graves notificadas en el acto", siempre y en todo caso, la inactividad del denunciado supone que la denuncia sí se convierte en resolución sancionadora, lo cual parece un contrasentido en sí mismo.

De igual manera las infracciones graves, notificadas en el acto, que detraigan puntos parecen excluidas por el art. 81.5 b) LTSV, pero incluidas conforme a la previsión dl art. 81.5 c) LTSV.

No resulta fácil encontrar cual sea el criterio establecido por el legislador para delimitar los supuestos en los que a la inactividad del denunciado frente a la notificación de la denuncia se le atribuye ese efecto de convertir en resolución sancionadora ("acto resolutorio del procedimiento sancionador", en términos de la Ley). Y ello se puede deber, tal vez, a que tal criterio, simplemente, no existe.

\section{H) Otras causas de terminación (inexistencia o extinción de la responsabilidad)}

\section{LA OBLIGACIÓN DE RESOLVER EL PROCEDIMIENTO SANCIONADOR ORDINARIO}

Al lado de la resolución sancionadora se sitúa la posibilidad de que el procedimiento concluya mediante una resolución sancionadora que declare la inexistencia de responsabilidad.

Nada señala expresamente la LTSV que se refiere, únicamente, a la resolución sancionadora (art. 82.1 LTSV) si bien el art. 15.1 RPSTSV establecía que se dictará 
"resolución sancionadora o resolución que declare la inexistencia de responsabilidad por la infracción".

El sistema se asienta en el principio dispuesto de manera general (art. 42 LTSV) conforme al que la Administración está obligada a dictar resolución expresa en todos los procedimientos y a notificarla a quienes resulten interesados, norma que se traslada al procedimiento sancionador ordinario regulado en el art. 81 LTSV $^{78}$ y que supone que ha de dictarse resolución expresa en todo caso y no solo cuando se concluya la existencia de responsabilidad.

De los diferentes supuestos que, conforme a lo establecido en los arts. 87 a 92 LRJ PAC, dan lugar a la terminación del procedimiento nos interesan aquí las resoluciones que no sean sancionadoras y la caducidad del procedimiento ${ }^{79}$. Entre las primeras, las resoluciones que declaren la inexistencia de responsabilidad, encontraremos las que determinen que no se cumplen con las condiciones establecidas para determinar la existencia de infracción y aquellas otras en las que habiendo existido infracción se ha producido la prescripción por haber transcurrido el plazo establecido para ello. Este supuesto y el de la caducidad del procedimiento son los que aquí nos interesan, lo que nos ubica en las previsiones efectuadas en el art. 92 LTSV precepto en el que se pretende regular la prescripción de infracciones (al mismo tiempo que la de las sanciones) y la caducidad del procedimiento. A estas cuestiones, desde la perspectiva del procedimiento sancionador ordinario, dedicaremos un sumario análisis en los siguientes apartados.

\section{DE LA PRESCRIPCIÓN DE LAS INFRACCIONES}

a) Sobre la evolución de la regulación de prescripción de las infracciones y sus plazos

A pesar de tratarse de cuestiones ciertamente diferentes, como son la prescripción, la caducidad y la cancelación de antecedentes, la LTSV las trata, de manera conjunta en el Capítulo VI del Título V (arts. 92 y 93).

Hay que tener en cuenta que, además, bajo el concepto de prescripción se encuentra tanto la regulación correspondiente a la "prescripción de la infracciones" como a la "prescripción de las sanciones".

Sobre la prescripción de las infracciones establecidas en la Ley interesan los dos primeros apartados del referido art. 92 LTSV.

\footnotetext{
${ }^{78}$ Algo que señalamos intencionadamente dado que el art. 80 c) LTSV dispone, como consecuencia del procedimiento sancionador abreviado, que realizado el pago voluntario de la multa se tendrá por concluido el procedimiento sancionador sin necesidad de dictar resolución expresa.

79 Previsiones entre las que también se encuentra la efectuada en el art. 88 LRJ - PAC sobre la terminación convencional del procedimiento y que se relaciona con las previsiones efectuadas para el procedimiento sancionador abreviado.
} 
Los términos empleado, en el párrafo primero del art. 92.1 LTSV, para establecer el plazo de prescripción de las infracciones son claros y precisos, al señalar que "el plazo de prescripción de las infracciones previstas en esta Ley será de tres meses para las infracciones leves y de seis meses para las infracciones graves y muy graves".

Así pues, pocas son las matizaciones que, a este respecto, pueden realizarse ante los términos empleados. Sin embargo se hace preciso realizar una serie de consideraciones en relación a la vigente regulación que fue introducida en el texto de la LTSV por medio de la Ley 18/2009, de 23 de noviembre.

La primera observación de la que parece oportuno dejar constancia es la modificación de los plazos de prescripción que la actual regulación supone respecto del régimen anterior. Hasta la promulgación de la Ley 18/2009, de 23 de noviembre, la prescripción de las infracciones se encontraba regulada en el art. 81.1 LTSV, precepto este que había visto modificada su redacción en diversas ocasiones.

En la redacción originaria del art. 81.1 LTSV se establecía un mismo plazo de tiempo, fijado en dos meses, para sancionar cualquier tipo de infracción en materia de tráfico y seguridad vial ${ }^{80}$. La elección de ese plazo de tiempo, dos meses, y no otro, se encuentra en que, al momento de la redacción de la LTSV, el Código Penal vigente en ese momento establecía ese mismo espacio de tiempo para la prescripción de las faltas $^{81}$. De esta manera parece hoy, como debió parecerlo entonces, un referente adecuado, lo establecido en el art. 112 CP/1973, de manera que resultaba muy difícil justificar que una infracción administrativa pudiera quedar sometida a un plazo de prescripción superior al establecido para las faltas penales.

Nótese que, en lo que aquí interesa, se establecía un plazo de dos meses que era mimético, como ya se ha puesto de manifiesto, al establecido para las faltas en el $\mathrm{CP} / 1973$, siendo único y uniforme para cualquier tipo de infracción, ya fueran leves, graves o muy graves ${ }^{82}$.

Pero por mucho que estuviera claro la motivación, y su origen, que habían impulsado al legislador (recordemos que la LTSV fue tramitada como Real Decreto legislativo, con todo lo que ello supone) a adoptar esta decisión, y acompasar el plazo de prescripción de las infracciones de tráfico y seguridad vial al establecido, de manera previa, en el marco del CP/1973 para las faltas, ello no fue óbice para que con el paso del tiempo ese regulación fuera sucesivamente mutando.

\footnotetext{
${ }^{80}$ La redacción originaria del primer inciso del art. 81.1 LTSV lo era en los siguientes términos:

"La acción para sancionarlas infracciones prescribe a los dos meses, contados a partir del día siguiente a aquél en que se hubiesen cometido".

${ }^{81}$ Cuando se promulga la LTSV se encontraba vigente el CP/1973 (Decreto 3096/1973, de 14 de septiembre). El párrafo sexto de art. 113 CP/1973 establecía, en ese momento, en el marco de las causas que extinguen la responsabilidad penal, que "las faltas prescriben a los dos meses".

${ }^{82}$ Téngase en cuenta a este respecto que ya la redacción originaria del art. 65.2 LTSV, establecía que "las infracciones a las que hace referencia el número anterior se clasifican en leves, graves y muy graves".
} 
El primero de esos cambios se produjo por medio de la Ley 5/1997, de 24 de marzo ${ }^{83}$. Hay que tener presente que en el momento de la promulgación de esta modificación de la LTSV, se había producido la derogación del CP/1973, que, como se ha señalado, había sido tomado como referencia para establecer el plazo de prescripción de las infracciones en materia de tráfico y seguridad vial. En ese momento ya está vigente el $\mathrm{CP} / 1995$ y, ciertamente, el cambio de Código Penal ha supuesto la modificación del plazo de prescripción de las faltas que ha pasado a ser de seis meses ${ }^{84}$.

En esa situación la LTSV procede a modificar la regulación de la prescripción de las infracciones en materia de tráfico y seguridad vial que, desde ese momento, se establece en tres meses ${ }^{85}$, cuestión sobre la que nada se señala en la Exposición de Motivos de la Ley 5/1997, de 24 de marzo ${ }^{86}$.

La solución adoptada supone que, en cuanto a la prescripción de las infracciones a la LTSV, se implantaba un plazo de tres meses (ampliación en un mes respecto a la regulación originaria de la LTSV, pasando de dos a tres meses), que ese plazo de tiempo era inferior al previsto en ese momento para las faltas en el CP/1995 (tres meses frente a seis meses o la mitad del establecido penalmente, como se quiera ver), siendo un plazo de tiempo único y uniforme para cualquier tipo de infracción administrativa en materia de tráfico y seguridad, ya se tratara de infracciones leves, graves o muy graves ${ }^{87}$.

Con todo el cambio trascendente en cuanto a la regulación de la prescripción de las infracciones en materia de tráfico y seguridad vial estaba por llegar. La verdadera transformación se produce por medio de la Ley 17/2005, de 19 de julio, que, por una

\footnotetext{
${ }^{83}$ Esta Ley reforma la LTSV y se dirige, esencialmente, a introducir "las modificaciones normativas necesarias para reforzar la autoridad municipal en materia de tráfico y seguridad vial", tal y como señala el párrafo cuarto de su propia Exposición de Motivos, a lo que se añade, en el párrafo quinto de esa misma Exposición de Motivos que "ante la confusión jurídica que se ha venido observando en esta materia, la única solución posible es la realización de una reforma legislativa que diese cobertura legal a la actuación municipal mediante la reforma" de la LTSV.

${ }^{84}$ La redacción originaria, que en cuanto a este apartado no ha sido objeto de modificación alguna, del art. 131.2 del CP/1995 (Ley Orgánica 10/1995, de 23 de noviembre [RCL 1995, 3170]) determina que, en el marco de las causas que extinguen la responsabilidad criminal, que "las faltas prescriben a los seis meses".

${ }^{85}$ La redacción que, por medio de la Ley 5/1997, de 24 de marzo, se introduce en el primer inciso del art. 81.1 LTSV lo es con la siguiente redacción:

"La acción para sancionarlas infracciones prescribe a los tres meses, contados a partir del día en que los hechos se hubieren cometido".

${ }^{86}$ Esta Ley se orientaba hacia el ajuste normativo en el ámbito de las competencias municipales en materia de tráfico y seguridad vial y aunque el último párrafo de la Exposición de Motivos de la propia Ley 5/1997, de 24 de marzo, se refiere a que "por otra parte se estima oportuno modificar" otros preceptos, únicamente se hace referencia a los arts. 65 y 67 LTSV, sin que en momento alguno se dé cuenta del cambio efectuado en el plazo de la prescripción de las infracciones y, mucho menos aún, se expliquen las razones que justifican la ampliación de ese espacio de tiempo.

87 Téngase en cuenta que la Ley 5/1997, de 24 de marzo, no modificó el art. 65.2 LTSV (Vide supra nota 85) pero que al momento de llevare a cambio esta alteración en el texto de la LTSV ya estaba vigente, a diferencia de lo que ocurría al momento de la promulgación de la LTSV, la LRJ - PAC.
} 
parte, va a extender el plazo de tiempo establecido y, por otra, va a disponer plazos de prescripción diferentes en función de que se trate de infracciones leves, graves o muy graves, de manera que se mantiene el plazo de tres meses para la prescripción de las infracciones leves, se extiende a seis meses para las infracciones graves y se amplía a un año tanto para las infracciones muy graves como para las previstas en el art. 67.2 $\mathrm{LT}^{88}$.

La Ley $17 / 2005$, de 19 de julio, fue la norma con la que se introdujo en nuestro sistema el permiso y la licencia de conducción por puntos ${ }^{89}$. En la Exposición de Motivos de la propia Ley $17 / 2005$, de 19 de julio, se da cuenta de todos y cada uno de los cambios que se introducen en el texto de la LTSV, pero ello no se realiza de igual forma en todos los casos. Mientras que hay modificaciones que se explican con cierto grado de detalle, en otras se pasa de puntillas sobre ellas. Y esta última forma de actuar es la que mejor parece definir el comportamiento de la Exposición de Motivos sobre la modificación y extensión de los plazos de prescripción de las infracciones. El asunto se despacha con una simple mención a que era preciso adaptar la regulación de la prescripción y cancelación de antecedentes para adaptar su contenido a las previsiones del permiso por puntos y a las modificaciones realizadas en los arts. 65 y 67 LTSV $^{90}$, sin que se ofrezca ninguna razón de fondo que permita entender las auténticas razones que han llevado a la adopción de esa decisión.

\footnotetext{
${ }^{88}$ La redacción introducida en el art. 81.2 LTSV por medio de la Ley 17/2005, de 19 de julio, lo es en los siguientes términos:

“El plazo de prescripción de las infracciones previstas en esta Ley será el de tres meses para las infracciones leves, seis meses para las infracciones graves y un año para las infracciones muy graves y para las infracciones previstas en el art. 67.2 de esta Ley".

La redacción del último inciso de este precepto se me antoja especialmente desafortunada al tiempo que ejemplo (uno más) de nefasta técnica legislativa. La referencia con la que finaliza el párrafo primero del art. 81.1 LTSV en la redacción recibida de la Ley 17/2005, de 19 de julio, determina que el plazo de prescripción será el de "un año para las infracciones muy graves y para las infracciones previstas en el art. 67.2 de esta Ley". Ese lugar de la Ley de Tráfico, el art. 67.2 LTSV, se corresponde con un artículo que recibe la rúbrica de "sanciones" y cuya redacción procedía de la propia Ley 17/2005, de 19 de julio. El precepto establecía sanciones especiales con límites económicos en las multas superiores a los establecidos, de manera genérica en el art. 67.1 LTSV. Pero todas las previsiones se efectúan sobre infracciones que ya de por sí tienen la calificación de muy graves. De esta manera ningún sentido tiene una prescripción de estas características que nada añade a la previsión de que el plazo de prescripción de las infracciones muy graves será, a partir de ese momento, el de un año.

${ }^{89}$ Cfr. la Exposición de Motivos de la propia Ley 17/2005, de 19 de julio, y, en particular el primero de sus párrafos en el que se indica que "se pretende con esta Ley establecer un sistema que ha dado en denominarse "permiso y licencia de conducción por puntos» y que, incidiendo sobre las autorizaciones administrativas para conducir, sea la combinación de dos elementos esenciales".

${ }^{90}$ De esta manera, el párrafo 28 de la Exposición de Motivos de la Ley 17/2005, de 19 de julio se limita a señalar que:
}

"Dentro del Capítulo III sobre la prescripción y cancelación de antecedentes, se modifica el párrafo primero del apartado 1 del artículo 81, para adaptar su contenido a las previsiones del permiso por puntos y a las modificaciones realizadas en los artículos 65 y 67 ". 
El resultado con el que nos encontramos es que la modificación efectuada por medio de la Ley $17 / 2005$, de 19 de julio, supone un escenario totalmente distinto al que existía previamente. El plazo de prescripción difiere en función de la calificación que la infracción administrativa recibe en la propia LTSV. El plazo, hasta ese momento establecido, de tres meses, que es la mitad del previsto por el CP/1995 para la prescripción de las faltas, únicamente se mantiene para las infracciones leves. Por su parte las infracciones graves tienen a partir de este instante un plazo de prescripción de seis meses, que es el mismo que el CP/1995 establece para las faltas. Y las infracciones muy graves pasan a estar sometidas a un plazo de prescripción de un año, lo que supone la implantación de un sistema en el que determinadas infracciones administrativas, las calificadas como muy graves por la LTSV, tardan en prescribir el doble que las conductas que para el CP/1995 merecen la consideración de faltas.

Tan afortunado se antoja establecer plazos de prescripción diferentes en función de la calificación de las infracciones como desatinado que, para algún supuesto, como es el caso de las infracciones muy graves, ese plazo de prescripción se extienda de una forma tan desmesurada, puesto que la fijación de un año es, a mi entender, un espacio de tiempo demasiado largo tanto en términos absolutos como, y sobre todo, en términos relativos por comparación con lo determinado en el ámbito penal.

Es una extraña situación. A mi juicio una auténtica paradoja desde la perspectiva del poder punitivo del Estado, que conductas no alojadas en el Código Penal tengan un plazo de prescripción superior al previsto para transgresiones que sí merecen un reproche más contundente. Afortunadamente, dado que se trataba de un evidente error de concepción jurídico, esta situación ha desaparecido tras la modificación de la LTSV llevada a efecto por medio de la Ley 18/2009, de 23 de noviembre.

Para completar la comparación con el CP/1995 se hace preciso señalar que, ciertamente, el art. 131.1 CP/1995 establece (tras la reforma efectuada por la Ley Orgánica 5/2010, de 22 de junio ${ }^{91}$ ) un plazo de prescripción, para los delitos menos graves, de cinco años, lo que supone que los tipos penales que se corresponden con las infracciones administrativas tienen previsto un plazo mucho mayor para la extinción de la responsabilidad criminal ${ }^{92}$.

Pero es que la paradoja se extiende en el marco de la propia regulación, globalmente considerada, de la LTSV. Y ello como fruto del resultado que se produce al integrar y conjugar las normas que regulan la prescripción de las infracciones, y en particular en

\footnotetext{
${ }^{91}$ Hasta ese momento el plazo de prescripción previsto en el art. 131.1 párrafo quinto $\mathrm{CP} / 1995$ era de tres años para los delitos menos graves.

92 Plazo que puede ser mayor, ya que "la privación del derecho a conducir vehículos a motor y ciclomotores por tiempo superior a ocho años" tiene la consideración, conforme al art. 33.2 e) CP/1995, de pena grave, algo que puede suceder conforme a lo establecido en el art. $381 \mathrm{CP} / 1995$ (conducción con temeridad manifiesta y manifiesto desprecio por la vida de los demás), lo que supone un plazo de prescripción de 10 años.
} 
lo relativo a las calificadas como muy graves, con las prescripciones que la propia LTSV efectúa sobre la caducidad del procedimiento sancionador. La Ley 17/2005, de 19 de julio, que mantuvo la redacción que había sido introducida en la LTSV por la Ley 19/2001, de 19 de diciembre, establecía, en el art. 81.2 LTSV que "si no hubiese recaído resolución sancionadora transcurrido un año desde la iniciación del procedimiento, se producirá su caducidad y se procederá al archivo de las actuaciones, a solicitud de cualquier interesado o de oficio por el órgano competente para dictar la resolución". De esta manera nos podríamos encontrar ante supuestos en los que una infracción (muy grave) no hubiera prescrito pero el procedimiento hubiera fenecido por caducidad. Y todo ello por la perversión de fijar un plazo de prescripción, el de un año, que, sin lugar a dudas, era demasiado extenso.

El desatino de la regulación efectuada era tan evidente y sus consecuencias tan palmariamente perniciosas que la regulación establecida en la LTSV a partir de la Ley $17 / 2005$, de 19 de julio, en cuanto al plazo de prescripción de las infracciones en materia de tráfico y seguridad vial, que estaba abocado a su revisión, lo cual no impidió su pervivencia en el mundo jurídico durante casi un lustro ${ }^{93}$.

b) Sobre la actual regulación tras la reforma de la LTSV por la Ley 18/2009, de 23 de noviembre

La vigente redacción de la procede de la Ley 18/2009, de 23 de noviembre, que fija la redacción del art. 92.1 LTSV en los siguientes términos: "el plazo de prescripción de las infracciones previstas en esta Ley será de tres meses para las infracciones leves y de seis meses para las infracciones graves y muy graves".

El cambio es sustancial puesto que aunque se diferencia el plazo de prescripción en función de la calificación otorgada por la propia LTSV se establece el ya conocido de tres meses para las infracciones leves y otro común, de seis meses, tanto para las infracciones graves como para las muy graves. Esta fórmula supone reconducir la anterior previsión del plazo de un año de prescripción para las infracciones muy graves

\footnotetext{
93 La forma imprecisa de la que aquí se hace uso en cuanto al plazo de tiempo durante el cual ha permanecido vigente la regulación que por medio de la Ley 17/2005, de 19 de julio, en la LTSV no es fruto de la casualidad. Ciertamente es posible determinar de manera precisa el momento de entrada en vigor de esa modificación, que tenía lugar, en virtud de lo establecido en la disp. final segunda de la propia Ley 17/2005, de 19 de julio, a los veinte días de su publicación en el BOE, hecho que tuvo lugar el 20 de julio de 2005.

Ahora bien, no ocurre lo mismo a la hora de determinar el momento en el que la norma fenece. Ello es debido a que aunque la disp. final séptima de la Ley 18/2009, de 23 de septiembre, que fue publicada en el BOE de 24 de noviembre, establece que la presente Ley entrará en vigor a los seis meses de su publicación en el BOE también señala que "y los efectos de esta Ley que sean favorables para el infractor, que entrarán en vigor el día siguiente al de su publicación en el BOE", y parece evidente que la reducción del plazo de prescripción de las infracciones muy graves es un claro beneficio para el responsable de esa infracción.
} 
al que ya tenían las graves, equiparándolo al previsto para las faltas en el art. 131.2 $\mathrm{CP} / 1995$.

La regulación parece adecuada. Mucha más si el término de comparación empleado es la regulación anterior. Parece conveniente, y proporcionado, establecer plazos de tiempo diferentes para la prescripción de las infracciones y hacerlo tomando como referencia la calificación que, de las mismas, efectúa la propia LTSV. Distinguir en dos bloques uniendo a estos efectos las infracciones graves y las muy graves por contraposición a las que merecen la consideración de leves tampoco parece desacertado.

El plazo de tiempo que se determina para las infracciones graves y muy graves no supera, como hemos puesto de manifiesto, el referente empleado para las faltas por el $\mathrm{CP} / 1995$, límite que, entiendo, no debía de superarse en aras a lograr una construcción jurídica adecuada.

El sistema instaurado adquiere así una lógica jurídica de la que ciertamente no hacía gala la redacción anterior.

De esta manera el problema se circunscribe a determinar el momento en el que las nuevas determinaciones sobre los plazos de prescripción de las infracciones en materia de tráfico y seguridad vial se incorporan a nuestro ordenamiento jurídico y comienzan a producir sus efectos. Ello se debe a cuando menos la peculiar fórmula empleada por la propia Ley 18/2009, de 23 de noviembre, sobre la entrada en vigor de las normas que en ella se contienen.

La disp. final séptima de la Ley, que es la que contiene las prescripciones sobre la entrada en vigor, se compone de tres partes fácilmente diferenciables, puesto que establece que:

\footnotetext{
“La presente Ley entrará en vigor a los seis meses de su publicación en el «Boletín Oficial del Estado», salvo los artículos 9.bis 2, 59 bis, 77 y 78, que entrarán en vigor en el plazo de 1 año, y los efectos de esta Ley que sean favorables para el infractor, que entrarán en vigor el día siguiente al de su publicación en el "Boletín Oficial del Estado»".
}

De esta manera hay una primera determinación de carácter genérico que señala que entrará en vigor a los seis meses de su publicación, una segunda que determina que determinados preceptos, concretos y determinados (arts. 9. bis 2, 59 bis, 77 y 78 LTSV) lo harán cuando transcurra un año desde su publicación y una tercera, que es la que aquí interesa, conforme a la cual todos los efectos previstos en la Ley 18/2009, de 23 de noviembre que sean favorables para el infractor entraran en vigor al día siguiente de su publicación en el BOE. Y esto es, sin lugar a dudas, lo que sucede con la reducción del plazo de prescripción de las infracciones muy graves en materia de tráfico y seguridad vial que pasa de una año a seis meses, motivo por el cual es preciso 
entender, y a mi juicio sin ningún género de dudas, que esta previsión queda incorporada a nuestro ordenamiento desde el 25 de noviembre de 2009.

\section{c) Sobre el cómputo de los plazos de prescripción de las infracciones}

Ínsito al plazo de prescripción de las infracciones se ubica la determinación del momento a partir del cual comienza a contarse, a computarse, ese plazo de tiempo de la prescripción, o lo que es lo mismo, la determinación del dies a quo.

El párrafo segundo del art. 92.1 LTSV establece que "el plazo de prescripción comenzará a contar a partir del mismo día en que los hechos se hubieran cometido", términos que se corresponden con los dispuestos en el art. 132.2 LRJ - PAC ${ }^{94}$.

Ello supone que el primer día del plazo de prescripción, aquel a partir ha de iniciarse el cómputo del plazo, es el mismo día en el que tiene lugar la comisión de la infracción administrativa, día que, por lo tanto, no queda excluido del cómputo del plazo de prescripción. Pero esta opción, que ya estaba implantada en la LTSV antes de que fuera introducida la redacción hoy vigente, por medio de la Ley 18/2009, de 23 de noviembre, no es la que ha existido a lo largo de las diferentes versiones que se han ido sucediendo a lo largo de la vigencia de la LTSV que, en su redacción originaria, excluía del plazo del prescripción el día en el que se hubieren cometido los hechos que constituían la infracción administrativa ${ }^{95}$.

En el caso de las infracciones en materia de tráfico y seguridad vial, en la inmensa mayoría de los supuestos previstos, nos enfrentamos a infracciones que se consuman en el acto, conductas que son constatadas en un momento concreto que se corresponde con la denuncia como resultado de los hechos observados o detectados, tal y como establece el art. 74 LTSV $^{96}$.

\footnotetext{
${ }^{94}$ La redacción del art. 132.2 LRJ - PAC lo es en los siguientes términos:

"El plazo de prescripción de las infracciones comenzará a contarse desde el día en que la infracción se hubiera cometido".

${ }^{95}$ En la redacción originaria de la LTSV el cómputo del plazo de prescripción no se realizaba desde el día en que los hechos se hubieran cometido, y esta no era la opción elegida. De hecho el primer inciso del art. 81.1 LTSV establecía, en su redacción original, que "la acción para sancionar las infracciones prescribe a los dos meses, contados a partir del día siguiente a aquél en que se hubiesen cometido". En la reforma efectuada por medio de la Ley 5/1997, de 24 de marzo se optó por modificar el diez a quo y establecer que "la acción para sancionar las infracciones prescribe a los tres meses contados a partir del día en que los hechos se hubieran cometido" y la Ley 17/2005, de 19 de julio, mantuvo esta decisión al disponer en el primer inciso del párrafo segundo del art. 81.1 LTSV que "el plazo de prescripción de las infracciones se cuenta a partir del día en que los hechos se hubieran cometido".

${ }^{96}$ En este sentido, tal y como señala el art. 74.1 LTSV "Ios Agentes de la Autoridad encargados de la vigilancia del tráfico deberán denunciar las infracciones que observen cuando ejerzan funciones de vigilancia y control de la seguridad vial". Ahora bien, el procedimiento sancionador puede iniciarse, además de por la notificación de la denuncia en el acto al denunciado (art. 73.2 LTSV), porque la autoridad sancionadora haya tenido conocimiento de de los hechos a través de medios de captación y
} 
d) Sobre la interrupción de la prescripción de las infracciones de tráfico y seguridad vial

Fijados por el art. 92.1 LTSV tanto los diferentes plazos de prescripción de las infracciones en función de la propia calificación legal de esas conductas así como el momento en el que empieza a computarse ese plazo, resulta preciso determinar los supuestos y formas que pueden dar origen a la interrupción y reanudación de esos plazos de prescripción de las infracciones en materia de tráfico y seguridad vial.

La LTSV ha tenido siempre presente, desde su redacción original, que los plazos establecidos para la prescripción de las infracciones eran, por su propia naturaleza, susceptibles de ser interrumpidos.

La actual y vigente redacción del art. 92.2 LTSV dirige el primero de sus párrafos a determinar las causas o motivos que dan lugar a esa interrupción de la prescripción de las infracciones.

Las causas previstas, y así establecidas, requieren de una actividad o "actuación administrativa" que, en función de los diferentes casos señalados, tendrán que ser conocidas, o no, por el infractor - denunciado. Esos hechos que motivan la interrupción del plazo de prescripción de las infracciones se agrupan en torno a dos grupos que conforman los dos incisos en los que se encuentra estructurado el propio párrafo primero del art. 92.2 LTSV y que son:

- Cualquier actuación administrativa de la que tenga conocimiento el denunciado

- Cualquier actuación administrativa que esté encaminada a averiguar la identidad o el domicilio del denunciado $y$ se practique con otras Administraciones, Instituciones u organismos

- La práctica de la notificación de las denuncias conforme a lo establecido en los arts. 76, 77 y 78 de la propia LTSV

\section{e) Sobre las actuaciones administrativas de las que tiene conocimiento el denunciado}

Cometida una infracción, y detectada ésta, se inicia el plazo de tiempo en el que la Administración puede imponer la correspondiente sanción al responsable de esa actuación proscrita por la LTSV.

reproducción de imágenes que permitan la identificación del vehículo -art. 76.2 c) LTSV- o por denuncias realizadas por quienes no ostentan la condición de "agente de la autoridad encargado del tráfico" (denuncias voluntarias). En todo caso, una vez incoado el expediente sancionador se entiende que el dies a quo del plazo de prescripción de la infracción es el mismo día en el que se ha cometido esa infracción. 
Conforme al sistema establecido como ordinario por la propia LTSV si los Agentes de la Autoridad encargados de la vigilancia del tráfico observan, en el ejercicio de sus funciones, unos hechos que pueden ser constitutivos de una infracción de las previstas en la LTSV tienen que proceder a denunciarlos ("deberán denunciar las infracciones que observen" en términos del art. 74.1 LTSV. Y la LTSV establece, asimismo, como actuación normal, que en circunstancias normales, esa denuncia tienen que ser puesta en conocimiento del infractor - denunciado de forma inmediata a que se produzcan esos hechos objeto de denuncia ("las denuncias se notificarán en el acto al denunciado", tal y como determina el art. 76.1 LTSV).

Téngase en cuenta, además, que aunque el principio general impuesto en nuestro ordenamiento jurídico administrativo es que el procedimiento sancionador se incoará de oficio por la Autoridad competente que tenga noticia de los hechos que puedan constituir infracciones tipificadas en la Ley, planteamiento que, recogido por el art. 73.1 LTSV, es plasmación del genéricamente establecido en el art. 11 REPEPOS. Pero, al mismo tiempo, y en el apartado 2 del propio art. 73 LTSV, se establece que "no obstante, la denuncia formulada por los Agentes de la autoridad encargados del servicio de vigilancia del tráfico y notificada en el acto al denunciado, constituye el acto de iniciación del procedimiento sancionador, a todos los efectos".

Siendo así, y en la medida en la que, tal y como está legalmente previsto, de forma inmediata a la comisión de la infracción se produzca la notificación de la denuncia, en este supuesto, la superposición de ambos elementos supondrá que el plazo de prescripción de esa infracción comenzará a contar desde el momento en el que al infractor - denunciado le es notificada la denuncia ${ }^{97}$, que como se acaba de señalar supone, a todos los efectos, la iniciación del procedimiento sancionador, momento que, en estos casos, vendrá a coincidir, dada la propia inmediatez entre comisión de los hechos constitutivos de infracción y notificación de la denuncia, en el mismo día, lo que, de hecho, no afectará al diez a quo del plazo de prescripción de la infracción y, como consecuencia, al plazo de prescripción y fin del mismo ${ }^{98}$.

Pero la propia LTSV al lado mismo de la instauración, como principio general, de la notificación en el acto al denunciado (art. 76.1 LTSV), establece la posibilidad en el art.

\footnotetext{
${ }^{97}$ En puridad no es exactamente así. Y no lo es puesto que, como se ha puesto de manifiesto, la LTSV establece que "el plazo de prescripción comenzará a contar a partir del mismo día en que los hechos se hubieran cometido", luego producida esa infracción se inicia el plazo de prescripción que resulta interrumpido por la notificación de la denuncia al infractor - denunciado y, perfeccionada (realizada) esa notificación, se reanuda (reinicia) el plazo de prescripción de la infracción. Dado que el plazo de prescripción de las infracciones se computa, para la determinación del diez a quo, en días, el sistema establecido ignora (desprecia) los espacios temporales inferiores (horas, minutos...)

${ }^{98}$ Ciertamente, en hipótesis, podría darse el supuesto de notificación inmediata, en el acto, de unos hechos constitutivos de infracción conforme a lo establecido en la LTSV, cometidos en los últimos minutos del día y que la notificación de la denuncia al infractor - denunciado fuera practicada en los primeros minutos del día siguiente, situación en la que habría un cambio de fecha que afectaría al plazo de prescripción de la infracción.
} 
76.2 LTSV, que ha de entenderse como excepción a esa norma general de que "no obstante, la notificación podrá efectuarse en un momento posterior", posibilidad que, para su validez, queda condicionada por la propia LTSV a que concurra alguna de las circunstancias que a continuación se detallan ("siempre que se dé alguna de las siguientes circunstancias" en términos de la propia LTSV), lo que se configura como una lista cerrada de opciones o numerus clausus de posibilidades, por mucho que, como tendremos ocasión de analizar, alguna de las opciones legalmente previstas precise y tenga que de ser detallada en el supuesto específico (por el Agente denunciante) en función de las especiales motivos presentes en ese caso concreto.

Pero lo que aquí interesa es el impacto de la notificación realizada con posterioridad a la comisión de los hechos en cuanto al plazo de prescripción establecido para la prescripción de esa infracción, puesto que en tanto que la denuncia no sea notificada $y$, en consecuencia, puesta en conocimiento del denunciado, no se habrá cumplido con la específica previsión que, en primer término, se realiza en el propio art. 92.2 LTSV.

$Y$ en este caso, en el de las notificaciones que no son efectuadas en el acto, nos encontramos, como de hecho ocurre, con la falta de certeza respecto del responsable de la infracción, ya que la identidad del denunciado (más bien destinatario de la denuncia) no está comprobada y puede darse o no darse. De este modo a la persona a la que se le va a dirigir la notificación, por su relación con el vehículo, puede coincidir, o no, con el autor de la infracción, situación que nos ubica, caso de no coincidir destinatario de la identificación con infractor, en el siguiente de los supuestos previstos en el párrafo primero del art. 92.2 LTSV, cuando se hace referencia a que "la prescripción se interrumpe por cualquier actuación administrativa... encaminada a averiguar su identidad o domicilio (del denunciado, se entiende) y se practique con otras administraciones, Instituciones u Organismos".

f) Sobre las actuaciones administrativas para averiguar la identidad o el domicilio del denunciado

El segundo supuesto que se detalla en el párrafo primero del art. 92.2 LTSV con efectos interruptivos del plazo de prescripción de las infracciones en materia de tráfico es el de cualquier actuación administrativa que esté encaminada a averiguar la identidad del denunciado o su domicilio y que se practique con otras administraciones, Instituciones u Organismos".

De la lectura del inciso parece desprenderse que se requiere de la confluencia de dos elementos en esa actuación administrativa para que se pueda entender producida la interrupción del plazo de prescripción de la infracción, ya que no parece suficiente, por sí mismo, que esa actividad tenga como fin llegar a conocer o "inquirir la verdad hasta 
descubrirla ${ }^{99 \prime \prime}$, en este caso de una identidad o de un domicilio, puesto que la parte final del propio inciso de la LTSV añade (o eso parece) que esa actuación tenga un destinatario externo que, además, se concreta, al ser la referencia a "otras administraciones, Instituciones u Organismos".

Los términos en los que se encuentra redactado el art. 92.2 LTSV generan al respecto un gran número de dudas al respecto. Entre ellas ¿Qué ocurre caso de estar dirigida esa actuación administrativa de indagar sobre el denunciado o su domicilio a otros sujetos como, por ejemplo, meros particulares, ya sean personas físicas o jurídicas?, ¿Se interrumpe, o no, en ese caso el plazo de prescripción de la infracción?, ¿Es preciso que esa actuación administrativa que esté encaminada a averiguar la identidad del denunciado o su domicilio se proyecte externamente a la dependencia administrativa en la que se origina?

El análisis del tratamiento que está cuestión ha tenido desde la promulgación de la LTSV y las diferentes redacciones que se han ido sucediendo no facilitan su entendimiento. Más bien lo complican y oscurecen.

En la redacción originaria el segundo inciso del art. 81.1 LTSV establecía que "la prescripción (de las infracciones) se interrumpe por cualquier actuación de la Administración de la que tenga conocimiento el denunciado o esté encaminada a averiguar su identidad o domicilio, o por la notificación efectuada con lo establecido en el art. 78". De estos términos parece deducirse, en lo que aquí interesa, que cualquier actuación administrativa con o sin conocimiento del denunciado que tuviera como finalidad averiguar tanto su identidad como su domicilio era suficiente para provocar la interrupción del plazo de prescripción. Esta situación se mantuvo tras la promulgación de la Ley 5/1997, de 24 de marzo, que, si bien modificó el art. 81.1 LTSV, vino a mantener, casi literalmente, los términos en los que originariamente se encontraba redactado el inciso segundo del párrafo primero del art. $81.1 \mathrm{LT}^{100}$.

Más enjundia tenía, sin lugar a dudas, la modificación que, por medio de la Ley 17/2005, de 19 de julio, daba nueva redacción a la totalidad del art. 81 LTSV. En el particular de la interrupción de la prescripción de las infracciones se establecía en el inciso segundo del párrafo segundo del art. 81.1 LTSV que "la prescripción se interrumpe por cualquier actuación administrativa de la que tenga conocimiento el denunciado o esté encaminada a averiguar su identidad o domicilio y se practique con

\footnotetext{
${ }^{99}$ Términos de los que aquí hacemos uso por ser, precisamente, los empleados por el Diccionario de la Real Academia Española al definir, en primer lugar, el término averiguar.

${ }^{100}$ De hecho la Ley 5/1997, de 24 de marzo, daba nueva redacción al art. 81 LTSV y en cuanto al segundo inciso determinaba que "la prescripción se interrumpe por cualquier actuación administrativa de la que tenga conocimiento el denunciado o esté encaminada a averiguar su identidad o domicilio o por la notificación efectuada de acuerdo con lo establecido en el art. 78" términos, estos, que venían a coincidir con la versión original de la LTSV ya que los cambios se limitaban a sustituir la expresión "actuación de la Administración" por "actuación administrativa" y a eliminar que tras la palabra "domicilio" aparecía en el texto en la redacción originaria.
} 
proyección externa a la dependencia en que se origine" a lo que en el inciso final (ahora separado por un punto) se añadía que "también se interrumpe la prescripción por la notificación efectuada de acuerdo con lo establecido en el artículo 78". El núcleo de la modificación se centraba en la adición de un requisito que recaía, directamente, sobre la propia naturaleza de la actuación administrativa que ahora tenía que reunir la condición de tener "proyección externa a la dependencia en la que se origine".

Condición, la de que la actuación administrativa lo sea con proyección externa a la dependencia en la que se origine, que ha desaparecido de la LTSV con la reforma efectuada por medio de la Ley 18/2009, de 23 de noviembre, y que queda sustituida por "cualquier actuación administrativa... encaminada a averiguar su identidad o domicilio y se practique con otras administraciones, Instituciones u Organismos".

Desde esta perspectiva, la que nos ofrece la evolución normativa de la regulación de la interrupción de la prescripción de las infracciones en la LTSV, parece que el requisito de la "proyección externa" es ahora todavía más concreto puesto que esa "actuación administrativa" tiene que seguir siendo "hacia el exterior" pero únicamente con "otras Administraciones, Instituciones u Organismos", de manera que la "proyección externa" no sería suficiente para el caso de actuaciones administrativas encaminadas a sujetos que no reúnan esa condición de "otras Administraciones, Instituciones u Organismos", como es el caso de las personas, físicas o jurídicas, de naturaleza privada.

\section{g) Sobre la práctica de la notificación de la propia denuncia}

El párrafo primero del art. 92.2 LTSV se cierra con un inciso conforme al cual "también se interrumpe (la prescripción de las infracciones) por la notificación efectuada de acuerdo con los arts. 76, 77 y $78 "$.

Llama, en primer lugar, la atención la referencia en bloque a la regulación que la propia LTSV realiza de la notificación de las denuncias lo que supone, por ejemplo, que conforme a lo establecido en el art. 76.1 LTSV (precepto incluido en la referencia que aquí se realiza) se interrumpe el plazo de prescripción de las infracciones por las denuncias que se notifican en el acto a los denunciados... como no podía ser de otra manera, dado que esa acción constituye a todos los efectos, como indica el art. 73.2 in fine de la propia LTSV el acto de iniciación del procedimiento sancionador.

Lo cierto es que la referencia, tal y como se encuentra efectuada en la LTSV, va más allá de lo que pudiera parecer, algo que no es fruto del error y del azar, puesto que, sin duda, el efecto pretendido está perfectamente medido. Y ello porque pudiera parecer que la interrupción del plazo de prescripción de las infracciones requiere de la notificación "efectiva", y no es así. 
Los artículos a los que se remite el inciso final del párrafo primero del art. 92.2 LTSV no se limitan a regular la notificación. También establecen cuando se va a entender que esa notificación ha sido practicada aunque en realidad no haya sucedido. Es lo que ocurre con las previsiones efectuadas en los arts. 77.2 párrafo segundo y 78.1 LTSV $^{101}$.

La consecuencia es que interrumpe el plazo de prescripción de las infracciones tanto la notificación de la denuncia como los intento de notificación a los que legalmente se les atribuye el mismo efecto que el de haber realizado, efectivamente, ese notificación.

\section{h) Sobre la reanudación del plazo de prescripción de las infracciones de tráfico y seguridad vial}

La redacción originaria no contenía prescripción específica alguna sobre la reanudación del plazo de prescripción.

La redacción vigente, que se encuentra en el párrafo segundo del art. 92.2 LTSV, fue introducida (en el entonces último inciso del párrafo segundo del art. 81.2 LTSV) por medio de la Ley 19/2001, de 19 de diciembre. Los términos de los que entonces se hizo uso y que señalaban que "la prescripción se reanuda si el procedimiento se paraliza durante más de un mes por causa no imputable al denunciado" no fueron modificados ni por la Ley 17/2005, de 19 de julio, y se han conservado en la redacción realizada por la Ley 18/2009, de 23 de noviembre, para el art. 92 LTSV. Idénticos términos eran los empleados por el inciso final del párrafo segundo del art. 18.1 del RPSTSV ${ }^{102}$.

Desde una perspectiva general es preciso señalar que el art. 132.2 LRJ - PAC ${ }^{103}$ determina esta misma solución en cuanto a la reanudación del plazo de prescripción

101 El párrafo segundo del art. 77.2 LTSV establece que las notificaciones enviadas a la Dirección Electrónica Vial (DEV) se entenderán rechazadas cuando existiendo constancia de su recepción transcurrieran diez días naturales sin que se acceda a su contenido. En este caso la LTSV entiende que se ha rechazado la notificación y "el rechazo se hará constar en el expediente sancionador, especificándose las circunstancias del intento de notificación, y se tendrá por efectuado el trámite, continuándose el procedimiento".

El art. 78.1 LTSV señala que las notificaciones que no puedan efectuarse en la Dirección Electrónica Vial (DEV) o en el domicilio indicado se efectuarán en el Tablón Edictal de Sanciones de Tráfico (TESTRA) y que "transcurridos veinte días naturales desde que la notificación se hubiera publicado en el TESTRA se entenderá que ésta ha sido practicada, dándose por cumplido dicho trámite y continuándose con el procedimiento".

102 Los términos utilizados por el art. 18.1 RPSTSV han permanecido en los previstos en la redacción original a pesar de las alteraciones que, ese artículo, sufrió tanto por el RD 116/1998, de 30 de enero como por el RD 318/2003, de 14 de marzo.

${ }^{103}$ En el párrafo segundo del art. 132.2 LRJ - PAC se establece que "interrumpirá la prescripción la iniciación, con conocimiento del interesado, del procedimiento sancionador, reanudándose el plazo de prescripción si el expediente sancionador estuviera paralizado durante más de un mes por causa no imputable al presunto responsable", términos equivalentes, cuando no idénticos, a los empleados por la LTSV tanto en la versión anterior a la Ley 18/2009, de 23 de noviembre (art. 81.1 párrafo segundo in fine LTSV), como en los que recibe tras la modificación operada en virtud de esa referida Ley (art. 92.2 párrafo segundo LTSV). 
de las infracciones administrativas, sin que el REPEPOS contenga disposición alguna sobre esta cuestión ${ }^{104}$.

Lo expuesto pone de manifiesto un alto grado de similitud, y de congruencia, entre el sistema que de manera general se establece por medio de la LRJ - PAC y el que manera particular se instaura en el concreto ámbito del tráfico y la seguridad vial.

\section{i) La resolución como límite de la prescripción}

La prescripción de la infracción se encuentra limitada por la resolución sancionadora de manera que, dictada esta, concluye la posibilidad de que la prescripción actúe.

Y ello no es posible porque una vez dictada la resolución sancionadora, la prescripción no puede ser trasladada a una fase, la del recurso, que está orientada no a perseguir la infracción sino, simplemente, a determinar si el órgano jerárquicamente inferior actuó o no con arreglo al ordenamiento jurídico ${ }^{105}$.

Con la resolución sancionadora se pone fin al expediente y "en este momento se produce la interrupción de la prescripción, abriéndose la vía impugnatoria, en la que ya no opera este instituto sino el del silencio negativo" ${ }^{106}$ y "no cabe trasladar el plazo prescriptivo a la vía administrativa de recursos" ${ }^{107}$.

\section{DE LA CADUCIDAD DEL PROCEDIMIENTO SANCIONADOR}

a) De las previsiones específicamente establecidas en la LTSV

El art. 92.3 LTSV establece el plazo de un año, desde la iniciación del procedimiento, para que la Administración produzca la correspondiente resolución sancionadora, y a que, en caso contrario, se producirá la caducidad de ese procedimiento, lo que conllevará el archivo de las actuaciones practicadas.

\footnotetext{
${ }^{104}$ EI art. 6 REPEPOS, bajo la rúbrica, prescripción y archivo de las actuaciones limita su contenido a la forma en la que el órgano administrativo competente tiene que actuar en los casos en que se constate la prescripción de la infracción, ya sea en fase de actuaciones previas, acordando la no procedencia de iniciar el procedimiento sancionador, ya sea una vez que se ha iniciado el procedimiento sancionador, supuesto en el que se tendrá que acordar la conclusión del procedimiento con el correspondiente archivo de las actuaciones.

De esta manera el REPEPOS no contiene norma alguna sobre la reanudación del plazo de prescripción de las infracciones administrativas.

${ }^{105}$ Cfr. SSTS de STS de 27 de mayo de 1992 (RJ 1992, 3729) y de 4 de julio de 2012 (RJ 2012, 8983).

106 Por todas, SSTS de 21 de mayo de 1991 (RJ 1991, 4334), de 27 de mayo de 1992 (RJ 1992, 3729), de 28 de octubre de 1996 (RJ 1996, 7628) y 15 de diciembre de 2004 (RJ 2005, 4800).

107 SSTS de 23 de junio de 1997 (RJ 1997, 5317), 22 de junio de 1998 (RJ 1998, 5678) y 4 de julio de 2012 (RJ 2012, 8983).
} 
La escueta regulación contenida en el párrafo primero del art. 92.3 LTSV da lugar a diversas reflexiones sobre los términos en los que se regula la caducidad del procedimiento sancionador en materia de tráfico y seguridad vial.

La primera de ellas recae sobre el plazo de tiempo establecido al determinar que será el de un año desde el inicio del procedimiento. Espacio de tiempo generoso en exceso por comparación tanto con lo previsto de manera general en el art. 20.6 REPEPOS como de manera la previa en el propio ámbito del tráfico y la seguridad vial ${ }^{108}$. En ambos casos la previsión giraba en torno al plazo de seis meses para que recayera la resolución sancionadora.

$\mathrm{Ni}$ hay motivo alguno, y el elevado número de recursos en este ámbito no lo era, para un plazo tan amplio, ni se ofrece explicación alguna sobre ello para que la vigente regulación así lo mantenga.

En segundo lugar, porque se trata de un plazo de tiempo en el que, en los términos establecidos, puede determinarse su inicio, pero en el que su final queda inmerso en la oscuridad de un trámite que el interesado no puede controlar de forma efectiva. Sin lugar a dudas la previsión que, en su momento efectuaba el art. 16 RPSTSV (en la redacción recibida del RD 137/2000, de 4 de febrero), conforme a la que se exigía ya no la resolución, sino su notificación, ofrecía al interesado una seguridad jurídica ${ }^{109}$ mayor que la actual que se conforma con que la resolución haya sido dictada.

Por otra parte, los términos en los que se establece la caducidad permiten eliminar cualquier sombra de duda (si es que alguien podía tenerla) del deber del instructor de tomar en consideración la existencia de la caducidad en el procedimiento, porque se impone la obligación de análisis de la concurrencia o no de la caducidad del procedimiento algo que, siendo a todas luces evidente, no ha estado tan claro desde la promulgación de la LTSV que, en su redacción original, no contenía previsión expresa alguna sobre la caducidad del procedimiento ni, por tanto, sobre el necesario control de oficio por parte del órgano competente para dictar la resolución, lo que se deriva

\footnotetext{
${ }^{108}$ La redacción originaria de la LTSV no contenía referencia alguna a la caducidad del procedimiento sancionador. El art. 16 RPSTSV determinó un plazo de seis meses más treinta días desde el inicio del procedimiento ("Si no hubiese recaído resolución transcurridos treinta días desde la finalización del plazo de seis meses desde la iniciación del procedimiento, se producirá la caducidad de éste y se procederá al archivo de las actuaciones..."), previsión que fue reformada por el RD 137/2000, de 4 de mayo, que fijo los términos de la caducidad del procedimiento sancionador "Si no hubiese notificado la resolución transcurridos seis meses desde la iniciación del procedimiento...". La Ley 19/2001, de 19 de diciembre, introdujo en el art. 81.2 LTSV el plazo de un año al prescribir que "si no hubiere recaído resolución sancionadora transcurrido un año desde la iniciación del procedimiento, se producirá la caducidad de éste y se procederá al archivo de las actuaciones", previsión legal que fue trasladada al RPSTSV, de manera expresa, por medio del RD 318/2003, de 14 de marzo.

${ }^{109}$ Pues este es "el fundamento de la prescripción y caducidad se liga al principio de seguridad jurídica", tal y como se ha señalado, entre otras, en las SSTS de 7 de diciembre de 1987 (RJ 1987, 9371) y de 23 de enero de 1990 (RJ 1990, 338) y en la STSJ Cantabria de 10 de septiembre de 1997 (RJCA 1997, 1883) y en al STSJ Canarias - Las Palmas de 23 de marzo de 2001 (JUR 2001, 185990).
} 
de su carácter de orden público que hace que pueda (y deba) ser apreciada en cualquier momento, de oficio, de forma automática y sin necesidad de solicitud intimación $^{110}$.

\section{b) Sobre algunas cuestiones previstas en el régimen general}

Ya ha quedado señalado, en términos de comparación, el desmesurado plazo previsto para la caducidad del procedimiento sancionador en el art. 92.3 LTSV que duplica al que determina el art. 20.6 REPEPOS $^{111}$, precepto que se remite al art. 43.4 LRJ - PAC norma que, no conviene olvidar, ha sufrido importantes modificaciones de modo que la redacción vigente poco tiene que ver con la originaria a la que se remite el REPEPOS.

Pero en el REPEPOS se esconde otra previsión cuyo contenido, y posible aplicación al procedimiento sancionador en materia de tráfico y seguridad vial, se hace preciso, al menos, tomar en consideración.

Se trata de la previsión que, efectuada en el art. 6.2 REPEPOS bajo la rúbrica "prescripción y archivo de actuaciones" establece que "transcurridos dos meses desde la fecha en que se inició el procedimiento sin haberse practicado la notificación de éste al imputado, se procederá al archivo de las actuaciones, notificándoselo al imputado, sin perjuicio de las responsabilidades en que se hubiera podido incurrir".

Es una previsión cercana, pero diferente, puesto que no establece un plazo de caducidad del procedimiento por el transcurso de un plazo de tiempo sin que el órgano competente haya dictado la oportuna resolución sancionadora. De ser así (que es lo que ocurre con el art. 20.6 REPEPOS) no habría problema alguno puesto que el art. 92.3 LTSV contiene previsión específica para el procedimiento sancionador en materia de tráfico y seguridad vial. La complicación surge desde el momento que la LTSV

\footnotetext{
${ }^{110}$ Cfr. SSTS de 19 de julio de 1996 (RJ 1996, 6342) y STSJ La Rioja de 10 de febrero de 1997 (RJCA 1997, 348), STSJ Castilla y León - Valladolid de 24 de noviembre de 1998 (RJCA 1998, 4401), y SSTSJ Región de Murcia de 2 de septiembre de 2000 (RJCA 2000, 1786) y de 30 de marzo de 2001 (JUR 2001, 141528).

${ }^{111}$ De hecho el párrafo primero de los dos que componen el art. 20.6 REPEPOS se encuentra redactado, literalmente, en los siguientes términos:

"Si no hubiese recaído resolución transcurridos seis meses desde la iniciación, teniendo en cuenta las posibles interrupciones de su cómputo por causas imputables a los interesados o por la suspensión del procedimiento a que se refieren los artículos 5 y 7 , se iniciará el cómputo del plazo de caducidad establecido en el artículo 43.4 de la Ley 30/1992, de Régimen Jurídico de las Administraciones Públicas y del Procedimiento Administrativo Común". Y el párrafo segundo del art. 20.6 REPEPOS señala que:

"Transcurrido el plazo de caducidad, el órgano competente emitirá, a solicitud del interesado, certificación en la que conste que ha caducado el procedimiento y se ha procedido al archivo de las actuaciones".

Lo que difiere, claramente, de la previsión efectuada en el art. 16 RPSTSV que añade la previsión en cuanto al archivo de las actuaciones de oficio por el órgano competente para dictar la resolución.
} 
contiene previsiones en cuanto a la notificación de las denuncias en momento posterior (art. 76.2 LTSV) pero sin que ello suponga previsión expresa del plazo en el que ello ha de efectuarse, y es en ese momento cuando la previsión de supletoriedad del régimen general establecida en el art. 70.1 LTSV puede dar lugar a la aplicación de una norma ni prevista ni esperada, conforme a la que iniciado un procedimiento sancionador en materia de tráfico y seguridad es preciso notificar de su existencia al interesado puesto que, caso de no hacerlo, y caso de aplicar el art. 6.2 REPEPOS habría que proceder al archivo de actuaciones algo que no impediría, en tanto no se produjera la prescripción de la infracción el inicio de un nuevo procedimiento sancionador.

Esta previsión, calificada de "preclusión del plazo para notificar el inicio del expediente" ha sido objeto de alegación y aplicación en todo tipo de procedimientos sancionadores y, a falta de previsión específica en la LTSV (ni en el RPSTSV) para el plazo en el que la notificación ha de ser realizada al denunciado, nada impide su aplicación en este ámbito, algo que podría ser solventando mediante el establecimiento de la norma específica en al LTSV o en el Reglamento de procedimiento sancionador que debía haberse tras la modificación efectuada en el régimen sancionador por la Ley 18/2009, de 23 de noviembre ${ }^{112}$.

c) Del supuesto de paralización del procedimiento sancionador por actuaciones penales

En el párrafo segundo del art. 92.3 LTSV se establece un supuesto que da lugar a la suspensión del plazo establecido para la caducidad del procedimiento, cuando la paralización del procedimiento se hubiera producido a causa del conocimiento de los hechos por la jurisdicción penal.

El cómputo del plazo de caducidad establecido se suspende, y se reanuda "una vez haya adquirido firmeza la resolución judicial" por "el tiempo que restaba en el momento de acordar la suspensión", lo que, en definitiva, supone la interrupción sin que ambas partes, la previa y posterior al proceso penal, puedan superar el año previsto en el art. 92.3 párrafo primero LTSV.

Esta previsión necesita ser puesta en relación con la preferencia que a las actuaciones penales otorga el art. 72 LTSV y todo lo que ello supone para el procedimiento administrativo sancionador, disposición objeto de análisis en el marco de la concurrencia de actuaciones administrativas y penales. ${ }^{113}$

\footnotetext{
${ }^{112}$ Tal y como establecía la disp. final Sexta. 2 de la propia Ley 18/2009, de 23 de noviembre, y que otorgaba un plazo de seis meses para ello.

${ }^{113}$ Véase el apartado VI del capítulo sobre Las fases del procedimiento administrativo sancionador en materia de tráfico y seguridad vial en el que se analizan las actuaciones administrativas y penales.
} 


\section{d) La resolución como límite de la caducidad del procedimiento}

De los propios términos del art. 92.3 LTSV (en cuanto disponen que "si no se hubiera producido la resolución sancionadora...") se desprende que el ámbito de la caducidad del procedimiento queda limitado y finaliza con la emisión de la resolución sancionadora y que, al igual que sucede con la prescripción de la infracción, con la resolución desaparece la posibilidad de que se produzca la caducidad del procedimiento.

Por ello, el instituto de la caducidad no opera en fase de recurso, puesto que durante su tramitación ya no corre el plazo establecido para la caducidad, sino los plazos establecidos para entender, en su caso, desestimado el recurso por silencio administrativo ${ }^{114}$ y no cabe su aplicación "a la vía administrativa de recurso, es decir, en los casos en que la Administración ya ha culminado el procedimiento sancionador mediante la imposición de la medida coercitiva correspondiente, pues la vía de recurso no cabe configurarla como una prolongación del expediente administrativo, sino como un plano supraordenado al expediente encaminado a la revisión de los actos que pusieron fin al mismo» ${ }^{115}$.

\section{DE LA PRESCRIPCIÓN DE LAS SANCIONES}

a) Enfoque y tratamiento (legal) de la cuestión

La LTSV ubica, al lado mismo de la regulación de la prescripción de las infracciones en materia de tráfico y seguridad vial, la regulación correspondiente a la prescripción de las sanciones impuestas como consecuencia de la realización de esas conductas proscritas por la Ley.

La Ley 18/2009, de 23 de noviembre, introduce varios cambios en la regulación que, hasta ese momento, había figurado en la LTSV. Regulación anterior que, por otra parte, ya se regía por criterios en nada semejantes a los establecidos para la prescripción de las infracciones.

De esta manera llama poderosamente la atención el tratamiento conjunto que de la prescripción de infracciones, de la prescripción de sanciones y de la caducidad del procedimiento se realiza en un mismo artículo de la LTSV. Más aun si se tiene en cuenta que hasta la modificación llevada a efecto por la Ley 18/2009, de 23 de

\footnotetext{
${ }^{114}$ Como se ha señalado en STSJ Islas Baleares de 8 de marzo de 1996 (RJCA 1996, 296), SSTSJ Cantabria de 25 y 26 de noviembre de 1996 (RJCA 1996, 1771 y 1821), STSJ Castilla - La Mancha de 12 de enero de 2000 (RJCA 2000, 203) y STSJ Región de Murcia de 14 de marzo de 2001 (RJCA 2001, 501).

${ }^{115}$ Cfr. SSTS de STS de 27 de mayo de 1992 (RJ 1992, 3729) y de 15 de diciembre de 2004 (RJ 2005, 4800).
} 
noviembre, el art. 81 LTSV regulaba todas estas cuestiones (o al menos lo pretendía) bajo la rúbrica "prescripción", sin hacer mención siquiera a la caducidad. Con la nueva redacción, ubicada ahora en el art. 92 LTSV, al menos se hace referencia, en la nueva rúbrica, a ambas, al adoptar los términos de "prescripción y caducidad"116.

El párrafo primero del art. 92.4 LTSV realiza, en primer lugar, una distinción en función de la propia naturaleza de la sanción, entre las sanciones pecuniarias y las que no lo son. El plazo de prescripción que se establece es distinto, y también lo es el régimen legal a que se encuentran sometidos tanto el cómputo como la interrupción de ese plazo de prescripción, cuestiones que serán abordadas en los apartados correspondientes.

En segundo lugar se establecen unas normas en cuanto al cómputo del plazo de prescripción que difieren de las determinadas para el cómputo del plazo de prescripción de las infracciones y no sólo en cuanto a los plazos que se marcan sino, y esa es la gran diferencia, en cuanto a la propia determinación del dies a quo desde el que se va a computar ese plazo de prescripción de las sanciones, cuestión que no supone ninguna característica innovadora, es decir, propia y específica del procedimiento sancionador en materia de tráfico y seguridad vial ya que sus raíces, en cuanto a planteamiento, proceden de las propias determinadas establecidas, de manera general por la LRJ - PAC en su art. 132.3 párrafo primero ${ }^{117}$.

Aun así llama poderosamente la atención que mientras que en un caso, las infracciones, el plazo de prescripción comienza a contarse desde el mismo día en el que se comete la infracción, en el otro, las sanciones, el plazo de prescripción

\footnotetext{
${ }^{116}$ Aunque sea de manera incidental parece oportuno dejar constancia del desafortunado uso que de los términos realiza, y sigue realizando tras la modificación llevada a cabo por medio de la Ley 18/2009, de 23 de noviembre, la LTSV.

Antes de la Ley 18/2009, de 23 de noviembre, el Capítulo III del Título VI de la LTSV, espacio en el que se encontraba el art. 81 LTSV, recibía la denominación "de la prescripción y cancelación de antecedentes". Esa redacción inducía a pensar, por los términos empleados, que el contenido de ese Capítulo III tenía que estar en relación con los antecedentes, con como prescribían y con como se producía su cancelación. Un uso adecuado del lenguaje hubiera obligado a hacer uso de unos términos que explicaran de una forma más diáfana lo que el lector iba a encontrarse. Tal hubiera sido una fórmula del estilo "de la prescripción y de la cancelación de antecedentes" o, mejor aún, "de la prescripción de infracciones y sanciones y de la cancelación de antecedentes".

La nueva redacción otorgada al texto de la LTSV por la Ley 18/2009, de 23 de noviembre, no ha mejorado, a mi juicio, la situación. El Capítulo VI del Título V recibe la denominación "de la prescripción, caducidad y cancelación de antecedentes", con lo que se mantiene el mensaje al lector de que en esa parte del texto de la Ley se va a encontrar con la regulación de los antecedentes y de la forma en la que éstos prescriben, caducan y se cancelan. La única mejora se limita, de esta manera, a la introducción del término caducidad, eso sí, sin que se sepa muy bien, sin que se pueda tener una idea, del contenido de ese Capítulo.

${ }^{117}$ Lugar en el que podemos encontrar un tratamiento idéntico para el plazo de prescripción de las sanciones administrativas:
}

“El plazo de prescripción de las sanciones comenzará a contarse desde el día siguiente a aquel en que adquiera firmeza la resolución por la que se impone la sanción". 
comienza a contarse desde el día siguiente a aquél en que adquiera firmeza en vía administrativa la sanción.

\section{b) Los plazos de prescripción de las sanciones}

Poco interesa añadir aquí a las parcas previsiones efectuadas en el art. 92.4 LTSV que se limitan a establecer diferentes plazos de prescripción en función de la naturaleza de la sanción y, así, se dispones que el correspondiente a las multas pecuniarias será de cuatro años y de uno para el resto de las sanciones. Cabe preguntarse a que tipo de sanciones resulta aplicable ese plazo de prescripción de un año desde el momento que, tras la reforma efectuada por la Ley 18/2009, de 23 de noviembre, la misma que dio redacción a este art. 92 LTSV, en el art. 67 LTSV la única sanción prevista es la multa, a salvo, eso sí, la consideración que deba recibir la detracción de puntos.

Plazo de prescripción que comienza a correr con la firmeza de la sanción y que en cuanto a su cómputo e interrupción habrá de regirse por lo establecido en la Ley General Tributaria.

\section{I) Impugnación de la resolución sancionadora}

\section{DE LA NECESIDAD DE RESOLUCIÓN SANCIONADORA Y DE SUS EFECTOS}

La tramitación del procedimiento sancionador conlleva la necesidad de resolución a la que se refiere el art. 82.1 LTSV.

El órgano con competencia para sancionar tiene la obligación de dictar resolución que ponga fin al procedimiento sancionador y de poner en conocimiento de los interesados esa resolución, ya que, en caso de no hacerlo se produciría, una vez transcurrido el plazo establecido para ello, la caducidad del procedimiento ${ }^{118}$.

Así, el procedimiento sancionador ordinario requiere de la existencia de una resolución que, de forma expresa, de manera motivada, resolviendo todas las cuestiones planteadas y dictada dentro del plazo establecido para ello, ponga fin a ese procedimiento iniciado de oficio por la Administración sancionadora.

El art. 82.1 LTSV determina los efectos de la resolución sancionadora que pone fin al procedimiento ordinario al establecer que "podrán fin a la vía administrativa" y permitirá que "la sanción se pueda ejecutar desde el día siguiente de su notificación", con plenos efectos una vez transcurrido el plazo de treinta días naturales desde que se pueda entender que ha sido (o se puede tener por) notificada (con remisión en este punto a lo señalado en el art. 81.5 LTSV).

\footnotetext{
${ }^{118}$ Véase sobre ello los apartados que, en este mismo Capítulo, analizan la resolución del procedimiento sancionador ordinario (II.F) y la caducidad del procedimiento (II.H.3).
} 


\section{LA IMPUGNACIÓN EN VÍA ADMINISTRATIVA}

a) Recurso de reposición y sus efectos

El art. 82.2 LTSV dispone que "contra las resoluciones sancionadoras, podrá interponerse recurso de reposición, con carácter potestativo, en el plazo de un mes contado desde el día siguiente al de su notificación", lo que significa que la previsión establecida en la LTSV por medio de la Ley 18/2009, de 23 de noviembre, supone la inexistencia del recurso alzada en el ámbito del tráfico y la seguridad vial.

De esta forma, las resoluciones sancionadoras que, como se ha señalado, ponen fin a la vía administrativa (art. 82.1 LTSV), son impugnables, únicamente, mediante el recurso potestativo de reposición.

Sobre el diseño efectuado para combatir las resoluciones sancionadoras dictadas en el marco del procedimiento sancionador ordinario hay que tener presente que:

- No cabe recurso de alzada

- Solo son impugnable en reposición

- La vía administrativa está agotada

- El de reposición es un instrumento potestativo, por lo que no resulta necesaria su interposición para poder acudir a la vía contencioso - administrativa

La LTSV hace uso de la previsión establecida en el art. 107.2 LRJ - PAC ${ }^{119}$ y sustituye (elimina) el recurso de alzada como medio de revisión de las resoluciones que ponen término a los procedimiento sancionadores ordinarios de tráfico y seguridad vial.

El hecho de encontrarnos en el ámbito de un procedimiento sancionador podría ser razón para valorar tanto la oportunidad como la viabilidad de esta decisión normativa por la que se impide el uso del recurso de alzada frente a las resoluciones sancionadoras puesto que el art. 107.2 LRJ - PAC parece plantear la sustitución del recurso de alzada y, no tanto, la supresión que aquí se produce, ya que las previsiones del art. 107 LRJ - PAC quedan limitadas a la interposición de un recurso de carácter potestativo ante quien ha dictado (o se entiende que lo ha hecho) la resolución que se pretende impugnar.

\footnotetext{
${ }^{119}$ Precepto en el que se establece que:

"Las leyes podrán sustituir el recurso de alzada, en supuestos o ámbitos sectoriales determinados, y cuando la especificidad de la materia así lo justifique, por otros procedimientos de impugnación, reclamación, conciliación, mediación y arbitraje, ante órganos colegiados o Comisiones específicas no sometidas a instrucciones jerárquicas, con respeto a los principios, garantías y plazos que la presente Ley reconoce a los ciudadanos y a los interesados en todo procedimiento administrativo."
} 
El art. 82.2 LTSV dispone que el plazo para la interposición será el de un mes desde la notificación de la resolución, lo que viene a coincidir con lo establecido en el art. 117.1 LRJ - PAC para la impugnación de actos expresos, como aquí sucede.

Como previsiones específicas el art. 82 LTSV determina que la interposición del recurso de reposición no suspenderá la ejecución de la sanción impuesta, y que, caso de ser solicitada, se entenderá denegada transcurrido un mes desde su solicitud sin que se haya resuelto (apartado 3), que en el recurso no se podrán tomar en consideración hechos, documentos y alegaciones del recurrente que pudieran haber sido aportados en el procedimiento originario (apartado 4) y que se entenderá desestimado si no recae resolución expresa en el plazo de un mes, quedando expedita la vía contenciosoadministrativa (apartado 5).

Sobre la resolución del recurso el art. 82.2 párrafo segundo determina que "el recurso se interpondrá ante el órgano que dictó la resolución sancionadora, que será el competente para resolverlo", sobre lo que es preciso señalar que esa competencia recae, por la propia naturaleza del recurso potestativo de reposición, en el órgano al que se la LTSV atribuye (art. 71 LTSV) la competencia sancionadora, algo que es independiente de las previsiones de la propia Ley que permiten la conversión de la denuncia notificada en el acto por los Agentes de la autoridad (art. 73.2 y 81.5 LTSV) y de las realizadas en materia de delegación de la competencia. De manera que, en todo caso, hay que entender que el conocimiento y resolución del recurso potestativo de reposición corresponde al órgano titular de la competencia sancionadora ${ }^{120}$.

\section{b) Comunidades Autónomas y Administración Local}

Sobre la determinación de los recursos procedentes frente a las resoluciones sancionadores que, en el ámbito del tráfico y la seguridad vial, puedan ser dictadas por los órganos con autonómicos y locales con competencias en esta materia, el art. 82.6 LTSV establece una previsión con la que se intenta compatibilizar la normativa específica de estas Administraciones con la previsión establecida en el art. 82.2 LTSV conforme a la cual frente a las resoluciones sancionadores únicamente cabe el recurso potestativo de reposición.

\section{LA IMPUGNACIÓN ANTE LA JURISDICCIÓN CONTENCIOSO - ADMINISTRATIVA}

Las previsiones establecidas en el art. 81 y 82 LTSV determinan la necesidad de una resolución sancionadora expresa a la que, como se ha señalado, el art. 82.1 LTSV atribuyé el poner fin a la vía administrativa.

\footnotetext{
${ }^{120}$ Véase, sobre esta cuestión, lo señalado en el Capítulo en el que se trata de la "Competencia para sancionar las infracciones de tráfico y seguridad vial" y, en especial, el apartado relativo a "El ejercicio de la competencia por el órgano delegado".
} 
De esta forma la impugnación en vía administrativa es potestativa y no se convierte en requisito previo para acudir a la revisión jurisdiccional y, así, la resolución sancionadora con la que finaliza el procedimiento ordinario es susceptible de impugnación mediante la interposición del correspondiente recurso contencioso - administrativo.

El conocimiento de ese recurso viene atribuido, por el art. 8 LJCA, a los Juzgados de lo Contencioso - Administrativo de la Provincia en la que se hubiera dictado la resolución por el Jefe Provincial de Tráfico, órganos competentes de las Comunidades Autónomas o Administración Local correspondiente. Únicamente en la caso de la competencia atribuida al Director General de Tráfico (por el art. 71.8 LTSV en materia de publicidad) la competencia para conocer del recurso contencioso - administrativo estaría atribuida a los Juzgados Centrales de lo Contencioso - Administrativo (art. 9 LCA).

\section{EL PROCEDIMIENTO SANCIONADOR ABREVIADO}

\section{A) Ubicación de este procedimiento en el marco del procedimiento sancionador en materia de tráfico}

Tras la reforma efectuada por la Ley 18/2009, de 23 de noviembre, la LTSV regula este procedimiento sancionador abreviado en el art. 80 LTSV, si bien es cierto que en el artículo previo (art. 79 LTSV) se hacen referencias (dos) a este procedimiento abreviado que, como se ha tenido la oportunidad de analizar, de un lado, excluyen la posibilidad de tramitación por el procedimiento abreviado los expedientes administrativos cuyo origen se encuentre en las infracciones tipificadas en los apartados 5 h), j) y 6 del art. 65 LTSV y, de otro, establece que en las denuncias por incumplir la obligación de asegurar el vehículo establecida en la LRCSCV podrá hacerse uso tanto del procedimiento sancionador ordinario como del abreviado.

El Preámbulo que antecede a la Ley 18/2009, de 23 de noviembre, destaca que son tres las principales novedades que caracterizan ahora al procedimiento sancionador de tráfico señalando, en primer lugar, el establecimiento de un procedimiento abreviado ${ }^{121}$.

El legislador realiza, en el propio Preámbulo de la Ley 18/2009, de 23 de noviembre, una serie de consideraciones sobre el procedimiento sancionador abreviado que introduce en el sistema de la LTSV. Las tres reflexiones que se contienen en el párrafo cuarto del apartado $\mathrm{V}$ del Preámbulo resumen las razones que han llevado a introducir este procedimiento sancionador abreviado y que se sintetizan en dos premisas y una conclusión.

${ }^{121}$ Cfr. El párrafo 3o del apartado V del Preámbulo de la Ley 18/2009, de 23 de noviembre. 
1) Primera premisa: La búsqueda de un sistema, de un modelo, que permita una contestación rápida y efectiva

El ya citado párrafo cuarto del apartado V del Preámbulo de la Ley 18/2009, de 23 de noviembre se inicia con un primer inciso que contiene una aseveración, en forma de comparación, tan categórica que raya en lo axiomático al afirmar que "el procedimiento abreviado ahora diseñado es similar a los coloquialmente conocidos en el ámbito penal como «juicios rápidos»".

Se trata de una expresa manifestación de la envidia que, en los responsables del procedimiento administrativo sancionador en materia de tráfico, produce la velocidad con la que se produce (con la que se puede llegar a producir) en el ámbito penal la respuesta a los delitos contra la seguridad vial.

2) Segunda premisa: Crear un modelo transaccional entre la Administración y el infractor que suponga ventajas para ambas partes

Se trata ahora de ofrecer al infractor la posibilidad de suscribir un pacto con la Administración sancionadora que le permita cumplir rápidamente el castigo impuesto a cambio de una rebaja sustantiva en éste. Un sistema del que, como expresamente se señala, obtienen ventajas el denunciado y, también, la Administración.

3) Corolario de ambas premisas: Beneficios, Eficiencia administrativa y efecto social

De las ventajas evidentes que para Administración e infractor se derivan del acuerdo hay que añadir el refuerzo del principio antes apuntado de la sanción como elemento de seguridad activa, toda vez que se afianza en los conductores la configuración de una justicia administrativa vial que actúa con inmediatez y se aleja de sensaciones de impunidad.

A ello hay que añadir un mensaje subliminal: se trata de imponer este procedimiento como la forma ordinaria de resolver los expedientes con el riesgo de convertir el procedimiento en un mero formalismo y penalizar los "errores" sancionadores que quedaran avocados, para quien sobre ellos quiera discutir, al proceso contencioso administrativo. 


\section{B) El pago de la multa en el plazo de quince días naturales como presupuesto del procedimiento sancionador abreviado}

1. El pago de LA MULTA COMO PRESUPUesto

El art. 80 LTSV se inicia con los términos "una vez realizado el pago de la multa", expresión que supone que esa acción, la del pago (voluntario), es el presupuesto determinante que origina la tramitación por el procedimiento sancionador abreviado.

Que sea, en el caso de las denuncias notificadas en el acto, en ese mismo momento, o que se realice con posterioridad, dentro del plazo que para ello se establece, no tiene mayor trascendencia. Se trata de la efectiva realización del pago. Algo sencillo de entender si se asume que ni se requiere el pago completo de la cantidad previamente establecida, puesto que esa decisión, la de pagar, tiene como primera consecuencia una reducción del 50 por ciento en el importe que se ha fijado para la multa, y que el plazo de quince días naturales (desde el siguiente a su notificación) está sujeto, por la incongruencia en su determinación en otros lugares de la propia LTSV a una interpretación que supone la ampliación de ese referido plazo hasta los veinte días naturales, tal y como se ha expuesto al analizar ese mismo plazo de tiempo, del que dispone el denunciado, para formular alegaciones ${ }^{122}$.

\section{EL PAGO DE LA MULTA COMO ELECCIÓN Y FIN DEL PROCEDIMIENTO}

El pago por el interesado, en el plazo que para ello se le ofrece, supone la derivación del procedimiento sancionador desde el cauce ordinario al abreviado y la propia conclusión del procedimiento.

$Y$ todo ello, junto con el resto de consecuencias previstas, en el mismo instante en el que se hace efectivo el pago de la multa, que tampoco se realiza de manera íntegra, al establecerse una bonificación del cincuenta por ciento sobre la cuantía que se ha establecido.

\section{C) Las consecuencias}

En el Préambulo de la Ley 18/2009, de 23 de noviembre se señala, como uno de los pilares sobre los que sustenta el establecimiento de un procedimiento sancionador abreviado, que "se trata ahora de ofrecer al infractor la posibilidad de suscribir un pacto con la Administración sancionadora que le permita cumplir rápidamente el castigo impuesto a cambio de una rebaja sustantiva en éste". Ese acuerdo, o transacción, se concreta en las consecuencias que supone la propia tramitación de un

\footnotetext{
${ }^{122}$ Tal y como se señala al analizar el plazo del que dispone el denunciado para formular alegaciones, se reitera en la propuesta de prueba (apartado II.C de este mismo capítulo).
} 
expediente sancionador por este procedimiento en lugar de hacerlo por el procedimiento ordinario, consecuencias que se detallan en el art. 80 LTSV.

\section{LA REDUCCIÓN DEL 50 POR 100 DEL IMPORTE DE LA SANCIÓN DE MULTA}

a) ¿Consecuencia o presupuesto?

La primera consecuencia que se establece en el art. 80 a) LTSV es la de reducir a la mitad el importe de la cantidad de la multa correspondiente. La cantidad, y por lo tanto el beneficio económico que obtiene el denunciante, son perfectamente conocidos por el interesado desde el momento en que la cuantía de la sanción económica figura en la denuncia, puesto que conforme a lo establecido en el art. 74.3 a) LTSV se establece, entre los contenidos necesario de a denuncia, "la sanción que pudiera corresponder".

La primera cuestión que se plantea sobre esta "consecuencia", en los términos utilizados por el propio art. 80 LTSV es si realmente se trata de una consecuencia, de un presupuesto o de ambas.

Efectivamente, y como dispone el art. 80 LTSV, es una consecuencia, puesto que el resultado final para el denunciado que, pudiendo, opte por la tramitación del expediente sancionador por el procedimiento abreviado es la minoración de la sanción prevista a la mitad de la inicialmente establecida. Pero, al mismo tiempo, se trata de un presupuesto, ya que la decisión de que un expediente concreto sea tramitado por el procedimiento abreviado no está en poder de la Administración. Quién condiciona y determina, mediante la toma la decisión de pagar en el plazo establecido (ya sea de quince o de veinte días naturales), el procedimiento sancionador a seguir es el denunciado, lo que supone que la decisión de pagar en el plazo establecido se convierte en un auténtico presupuesto para la tramitación (y terminación) del expediente por el procedimiento sancionador abreviado, de manera que en los casos en los que no se realice el pago en plazo la tramitación será realizada por el procedimiento sancionador ordinario.

\section{b) Beneficio económico transaccional}

Sea como fuere, el presupuesto - consecuencia de la reducción del 50 por 100 del importe de la sanción de multa se constituye en el eje del acuerdo transaccional como beneficio central para el denunciado.

Este beneficio, consistente en pagar la mitad de la sanción legalmente prevista, es a lo que el Preámbulo de la propia Ley 18/2009, de 23 de noviembre, se refiere al indicar que "se trata de ahora de ofrecer al infractor la posibilidad de suscribir un pacto con la Administración sancionadora que le permita cumplir rápidamente el castigo impuesto a cambio de una rebaja sustantiva en éste". 
La conceptualización del acuerdo, en sus propios términos, es simple: el denunciado acepta la sanción sin presentar alegaciones, paga la mitad de la sanción que está prevista para esa infracción y la Administración se da por satisfecha. Pago que no supone reconocimiento de responsabilidad.

Cuestión distinta es la discusión sobre el porcentaje que legalmente se ha determinado ${ }^{123}$. Es cierto que puede objetarse que el 50 por ciento es un porcentaje elevado. Se trata de reducir a la mitad la consecuencia inicialmente prevista por la Ley. Se trata de una decisión de política sancionadora que, no lo olvidemos, tiene que resultar lo suficientemente atractiva para el denunciado como para eliminar sus ansias de discutir la infracción y su resultado.

En términos comparativos supone un incremento muy importante desde lo previsto en el régimen anterior que, no conviene olvidarlo, ya era del 30 por ciento. El aumento en la previsión busca el incremento de denunciados que acepten "suscribir un pacto con la Administración sancionadora". Esa, y no otra, es la intención del legislador, que, como en todo acuerdo, busca, a cambio de determinadas cesiones, otro tipo de beneficios, perfectamente determinados, absolutamente tangibles y que se centran en la eficiencia en la gestión.

Como término de comparación, en el propio ámbito de tráfico, tenemos la forma de actuación de los Ayuntamientos en el marco del estacionamiento regulado. Las prácticas que, habitualmente, se realizan se basan en el reconocimiento inmediato de la conducta a cambio de una importante reducción de la sanción, opción que disuade a la inmensa mayoría de denunciados de enredarse en un procedimiento estéril para sus intereses y que la práctica ha convertido en antieconómico, independientemente de tener la razón o carecer de ella.

\section{c) Alcance del beneficio de reducción del 50 por ciento}

La previsión efectuada en el art. 80 a) LTSV es, en sus propios términos, "la reducción del 50 por 100 del importe de la sanción de multa" y este es, en cuanto a las consecuencias previstas por la LTSV $^{124}$ para una infracción concreta, el alcance del acuerdo transaccional entre denunciado y Administración.

Las infracciones previstas en la LTSV pueden tener previstas otras consecuencias accesorias. La más clara es que determinadas conductas tienen asociadas, aparejadas en términos de la propia Ley, la pérdida de puntos en los términos previstos en el Anexo II LTSV.

\footnotetext{
${ }^{123}$ HUERGO advierte que "puede atentar al principio de proporcionalidad cuando haya una diferencia excesiva e injustificada entre la cuantía de la sanción para el caso de su no aceptación por el infractor (Los contratos sobre los actos y las potestades administrativas, Civitas, 1998, pág. 430), algo que, en la práctica, sucede, por estar así previsto, en todas las Ordenzanzas Municipales que regulan el régimen de estacionamiento.

${ }^{124}$ Contempladas en los arts. 67 y 68 y en los Anexos II y IV LTSV.
} 
La previsión efectuada en el art. 80 a) LTSV no alcanza a los puntos que una determina infracción tiene asociada, y se limita, exclusivamente, a minorar la cuantía de la sanción económica.

Aunque, sin duda, existirán voces que criticarán que el beneficio para el infractor debería alcanzar también a los puntos, es decir, a todas las consecuencias derivadas de la infracción, parece lógica la solución adoptada y limitar la transacción al estricto ámbito de la multa correspondiente. Ambas medidas, sanción económica y, en su caso, detracción de puntos, cumplen funciones de naturaleza diferente $y$, en ese sentido, la limitación del acuerdo transaccional al ámbito de la sanción económica se nos antoja acertada.

Téngase presente, a este respecto, que en tanto que la multa es una consecuencia que se agota en el marco de la propia infracción de la que es consecuencia, la detracción de puntos se enmarca en el ámbito de un sistema, el de la autorización para conducir por puntos, que produce sus efectos sobre el desarrollo de la actividad de conducir del titular de la correspondiente licencia o autorización. Desde este punto de vista negociar sobre la base de una sanción económica correspondiente a una conducta concreta y determinada no tiene nada que ver con establecer acuerdos que afecten al saldo de puntos que, como crédito social, tiene el titular de una autorización para poder realizar la actividad de conducir vehículos a motor, actividad que, legalmente, está sometida al régimen de autorización administrativa previa.

Entiendo que los términos, y el alcance, del presupuesto - consecuencia de la reducción de la sanción económica correspondiente a una determina conducta están establecidos de una manera coherente, sin que en esa transacción deban introducirse otros elementos como los relativos a la detracción de puntos que, en su caso, pudieran estar presentes, como secuela, en la infracción.

Nada señala el art. 80 LTSV sobre la recepción de esa cantidad. Nada se indica en este precepto sobre la recepción por el propio agente denunciante al momento de la notificación, el ingreso posterior dentro de plazo, el pago mediante medios electrónicos... resulta obvio que cualquiera de esos medios conlleva la emisión del correspondiente documento que acredite el pago. La mayor precisión en este sentido se limita a la previsión efectuada en el 74.3 c) LTSV que determina, como contenido de la propia denuncia para las que fueran notificadas en el acto, que "si el denunciado procede al abono de la sanción en el acto deberá señalarse, además, la cantidad abonada y las consecuencias derivadas del pago de la sanción previstas en el art. 80". La práctica demuestra que para cobrar todo son facilidades y este caso no iba a constituir una excepción a un principio tan consolidado. 
2. LA RENUNCIA A FORMULAR ALEGACIONES QUE, EN CASO DE QUE FUESEN FORMULADAS, SE TENDRÁN POR NO PRESENTADAS

Al lado del tangible beneficio para el denunciado de minorar el importe de la multa a la mitad, se establece, de manera correlativa, una carga en forma de limitación o sacrificio, puesto que se establece, y se hace en términos de condición, que el denunciado al pagar la sanción con el 50 por ciento de descuento "renuncia a formular alegaciones" y, por si la fórmula utilizada no fuera clara, en cuanto a sus consecuencias, se añade que "en el caso de que fuesen formuladas se tendrán por no presentadas".

El art. 80 b) LTSV realiza, en el marco del procedimiento sancionador abreviado, la consideración básica que la LTSV efectúa en el marco de la tramitación de expedientes sancionadores en el art. 79.1, en cuanto una vez que se ha notificado la denuncia, o se entiende que esta se ha practicado, el denunciado tiene que optar entre pagar la mitad de la multa prevista o formular alegaciones. Lo uno o lo otro ${ }^{125}$.

De esta manera el sistema se conforma en torno a un binomio de cesiones mutuas entre denunciado y administración sancionadora. Esta es la base del pacto que la LTSV ofrece. Quid pro quo, te ofrezco la posibilidad de reducir la sanción que corresponde (pagar menos) a cambio de que no presentes alegaciones.

La extrema claridad de lo que la administración pide a cambio de minorar la sanción no es fruto de la casualidad o de un intento reiterativo. Se basa en la experiencia previa. En los intentos anteriores que, en los términos en los que fueron formulados terminaron presentando consecuencias para la Administración que vio como no lograba el objetivo perseguido.

Es preciso medir bien el alcance de esta consecuencia. El análisis de las diferentes resultados recogidos en las diferentes letras en las que se desarrolla el contenido del art. 80 LTSV se entremezclan, pero es preciso no confundir el alcance de cada una de ellas como única manera de determinar los términos en los que establecido el pacto que la Administración, en virtud de lo establecido en el art. 80 LTSV, le ofrece al infractor por medio de la tramitación del expediente sancionador por el procedimiento abreviado.

Sus efectos inmediatos, los de renunciar a presentar alegaciones, son claros. También es diáfana su relación con el beneficio económico que se obtiene. Así, las consecuencias de esta transacción "dinero a cambio de que no presentar alegaciones" no presentan mayores dudas.

\footnotetext{
${ }^{125}$ Con el objetivo de eliminar el problema surgido con la interpretación que de la normativa anterior efectuada en el RPSTSV hizo de 27 de octubre de 2004 de la modificación efectuada por el RD 318/2003, de 14 de marzo, del art. 12.2 párrafo segundo RPSTSV y había supuesto la anulación en cuanto a los efectos previstos a la reducción de la sanción. Véase el capítulo destinado al examen de la evolución de la regulación del procedimiento sancionador el apartado destinado al citado Real decreto y, en particular, la nota 235.
} 
No ocurre lo mismo con sus efectos mediatos. Los que van más allá de ese binomio, pues, como tenemos ocasión de analizar otra consecuencia es el agotamiento de la vía administrativa, por tener un acto administrativo firme, que ya sólo puede ser combatido, por declararse únicamente recurrible, en el orden jurisdiccional contencioso - administrativo.

La no presentación de alegaciones frente a la denuncia formulada supone asumir una tremenda limitación caso de querer, posteriormente, combatir esa denuncia convertida ya en acto sancionador firme. $Y$ ello porque, en ese caso, el objeto del recurso contencioso - administrativo estaría limitado al contenido de la denuncia realizada, cuestión objeto de análisis en el apartado correspondiente.

3. LA TERMINACIÓN DEL PROCEDIMIENTO, SIN NECESIDAD DE DICTAR RESOLUCIÓN EXPRESA, EL DÍA EN QUE SE REALICE EL PAGO

La tercera de las consecuencias que el art. 80 LTSV determina para la tramitación del expediente sancionador por el procedimiento abreviado es la finalización del propio procedimiento sin que sea necesario dictar resolución expresa $y$, además, ello se produce, a efectos de determinar la fecha, el día en el que se realiza el pago voluntario de la multa.

La letra c) del art. 80 LTSV contiene dos elementos. El primero de ellos es, además, una reiteración sobre el contenido legal establecido en el párrafo inicial del propio art. 80 LTSV. El segundo automatiza un resultado al eximir a la Administración sancionadora de dictar una resolución expresa para dar por concluido el procedimiento.

\section{a) Forma: "La terminación del procedimiento, sin necesidad de dictar resolución expresa,..."}

El art. 80 c) LTSV contiene una norma muy especial en cuanto a la forma en la que finaliza el procedimiento sancionador abreviado al establecer "la terminación del procedimiento, sin necesidad de dictar resolución expresa, el día en que se realice el pago".

La regulación legal aquí efectuada, en los términos en los que se encuentra redactada, supone que para que el procedimiento se dé por terminado no es preciso que se produzca una actividad de la Administración sancionadora, al menos de una forma explícita o manifiesta. La terminación del procedimiento sancionador abreviado no requiere de un acto administrativo "expreso" que trascienda a la propia Administración y llegue a la esfera del interesado comunicándole el fin de las actuaciones correspondientes al expediente sancionador.

Lo que dispone la LTSV es lo que debe de suponer el ciudadano que, habiendo sido objeto de una denuncia, actúa el marco de las normas establecidas y pone en marcha 
el procedimiento sancionador abreviado. En este sentido, el mensaje de la LTSV es que si paga la mitad de la sanción prevista en el plazo marcado (15 - 20 días desde que recibe la notificación) esta historia (en la medida que el denunciado así lo desee) ha concluido, sin que quepa esperar confirmación alguna sobre ello. El recibo que acredita el pago es la prueba de ello.

La fórmula establecida dista mucho, ciertamente, de las formas tradicionales que ponen fin al procedimiento administrativo. No hay una resolución (expresa) de la Administración. Ni se trata de desistimiento, ni de renuncia a un derecho, ni de un supuesto de declaración de caducidad. Y mucho menos aún de una imposibilidad material de continuar con el procedimiento... ${ }^{126}$

Es cierto que el art. 42 LRJ - PAC dispone la "obligación de resolver", estableciendo, en el párrafo inicial del apartado primero, que "la Administración está obligada a dictar resolución expresa en todos los procedimientos y a notificarla cualquiera que sea su forma de iniciación" pero también lo es que en el párrafo tercero de ese mismo art. 42.1 LRJ - PAC se establece que "se exceptúan de la obligación, a la que se refiere el párrafo primero, los supuestos de terminación del procedimiento por pacto o convenio..."

De nuevo es preciso mirar hacia el Preámbulo de la Ley 18/209, de 23 de noviembre, y recordar la declaración de intenciones que realiza al señalar que "se trata de ahora de ofrecer al infractor la posibilidad de suscribir un pacto con la Administración sancionadora que le permita cumplir rápidamente el castigo impuesto a cambio de una rebaja sustantiva en éste".

Entiendo que nos encontramos ante la terminación del procedimiento por pacto o convenio pues no es preciso que para cada caso concreto la Administración sancionadora alcance el acuerdo y que convenie la solución. El pacto o convenio lo es por referencia a una marco legalmente establecido al que, para una situación concreta, se adhiere el denunciado, que lo que hace es aceptar, libremente, la posibilidad que se le concede de suscribir, en ese caso concreto y determinado, ese pacto que se le ofrece en unas condiciones legalmente prefijadas, acuerdo que se limita a ese caso (denuncia concreta) y que no supone que en otros casos tenga la obligación de optar, necesariamente, por suscribir ese pacto.

Esa "posibilidad de suscribir un pacto con la Administración sancionadora" es una auténtica terminación convencional del procedimiento en un marco preestablecido por la LTSV que fija las condiciones de ese acuerdo. $Y$ en esa transacción el denunciado sabe, porque está predeterminado por la Ley, que si realiza el pago en tiempo y forma en la medida que ha cumplido con su parte del acuerdo la Administración actuará en

\footnotetext{
${ }^{126}$ Por recoger los supuestos previstos en el art. 87 LRJ - PAC sobre las formas más o menos normales que "pondrán fin al procedimiento".
} 
consecuencia, lo que supone la existencia de un marco preestablecido que dota de seguridad jurídica a la actuación del interesado.

Cuestión distinta es que la Administración tendrá que establecer los mecanismos para comprobar que ese procedimiento, iniciado de oficio, pueda darse por terminado. En este sentido es preciso señalar que son cuestiones totalmente diferentes dar por terminado un expediente, que esa terminación se haga mediante una resolución expresa y que la finalización del expediente (medie o no medie resolución) sea puesta en conocimiento del interesado.

En el caso de los expedientes tramitados por el procedimiento sancionador abreviado la previsión establecida en el art. 80 c) LTSV supone que dándose determinadas condiciones la consecuencia es que el procedimiento termina. Que, además, finaliza "sin necesidad de dictar resolución expresa". Y que, por lo tanto, no se va a realizar comunicación alguna de la terminación del procedimiento puesto que se parte de la premisa que el interesado, el denunciado, conoce perfectamente que el procedimiento ha concluido.

Por otra parte hemos de tener presente los efectos que, en especial para el denunciado, tendría la inexistencia de esta previsión, es decir, que la terminación del procedimiento requiriera de que la Administración sancionadora dictara una resolución expresa que pusiera fin al procedimiento.

En ese caso una vez que la Administración hubiera comprobado el cumplimiento de los requisitos establecidos (pago en tiempo y forma) procedería a dictar la resolución que, por lógica temporal, tendría una fecha posterior al pago, para, posteriormente notificarla al interesado. Una vez que la resolución hubiera sido notificada, o se hubieran cumplido los requisitos para entender que ese notificación había sido practicada, tendríamos la fecha, a partir de la cual, se empezarían a producir determinados efectos, entre ellos, por destacar uno, el plazo para recuperar puntos, caso de haberlos perdido... Ese ejemplo, a título de muestra, pretende poner en evidencia que una vez previsto un procedimiento como el sancionador abreviado, el denunciado que opte por este camino lo que realmente quiere es que todo se desarrolle de la forma más rápida posible, pues eso es lo que conviene a sus intereses.

Es cierto que se podía haber construido una previsión normativa conforme a la cual la resolución expresa fuera precisa y en esa resolución se retrotrajeran los efectos a la fecha en la que el pago hubiera sido realizado, consiguiendo, eso sí, el mismo resultado para el interesado. Pero en ese caso la Administración hubiera tenido que seguir dictado resolución expresa y hubiera tenido que seguir notificando esa resolución expresa, con el consiguiente esfuerzo adicional para, no nos engañemos, obtener el mismo resultado que el ahora establecido en la LTSV.

Ello supone que, desde la óptica de los principios generales contenidos en el art. 3 LRJ - PAC la terminación del procedimiento sancionador abreviado sin necesidad de dictar 
resolución es una solución no solo correcta sino adecuada a los fines perseguidos, combinado las garantías que nuestro ordenamiento exige con la eficiencia en la prestación del servicio y la certeza del resultado.

Téngase en cuenta, además, que de no mediar una prescripción como esta, conforme a la cual el procedimiento termina sin necesidad de dictar resolución expresa, nos encontraríamos en el ámbito de la regulación general efectuado por la LRJ - PAC y, en este sentido, el art. 44.2 LRJ - PAC establece que "en los procedimientos en los que la Administración ejercite potestades sancionadoras $o$, en general, de intervención, susceptibles de producir efectos desfavorables o de gravamen, se producirá la caducidad".

b) Dies a quo: "La terminación del procedimiento ... el día en que se realice el pago"

La letra c) del art. 80 LTSV insiste en establecer una prescripción que ya se encuentra contenida en el párrafo inicial del propio art. 80 LTSV. El legislador viene a reiterar que el pago voluntario de la multa tiene como consecuencia que se tendrá por concluido el procedimiento sancionador.

Ahora bien, una lectura detallada permite identificar un matiz adicional en la redacción de la letra c) del art. 80 LTSV sobre lo establecido en el párrafo inicial del propio art. 80 LTSV. Mientras que en ese párrafo inicial del art. 80 LTSV lo que se establece es que "una vez realizado el pago voluntario de la multa... se tendrá por concluido el procedimiento sancionador", en la letra c) del art. 80 LTSV se especifica el momento exacto en el que el procedimiento sancionador se da por terminado al señalar, como consecuencia, "la terminación del procedimiento... el día en que se realice el pago".

La previsión legal que se efectúa supone que, a todos los efectos, el procedimiento sancionador se tiene por concluido en la fecha en la que es realizado el pago de la sanción.

La solución adoptada parece, al menos, igual de eficaz que la alternativa tradicional. Pero, al mismo tiempo, se muestra como más eficiente y está más orientada al servicio a los ciudadanos (por infractores que estos sean), puesto que una vez realizado el pago conocen las consecuencias y tienen plena seguridad jurídica (certeza) en cuanto al momento en que se producen determinados efectos.

4. El agOtAMIENTO de LA VÍA ADMINISTRATIVA SIENDO RECURRIBLE ÚNICAMENTE ANTE EL ORDEN JURISDICCIONAL CONTENCIOSO-ADMINISTRATIVO

Las tres primeras consecuencias determinadas en el art. 80 LTSV (reducción de la multa, renuncia a presentar alegaciones y terminación del procedimiento) tienen, como consecuencia inmediata, la que se enuncia en cuarto lugar en el art. 80 d) LTSV, 
que es que se ha agotado la vía administrativa y queda expedita la vía contenciosoadministrativa.

En realidad no sería preciso que la LTSV hubiera manifestado, expresamente, esta consecuencia, puesto que se deriva directamente de las anteriores y, concretamente, de la terminación del procedimiento.

Lo que es realmente significativo es la desaparición, como tal, de recursos ordinarios en vía administrativa. Pero en este caso, en un procedimiento sancionador de base puramente transaccional, la Ley cumple con determinar la existencia de un acto impugnable ante el orden jurisdiccional contencioso - administrativo. No hace falta más.

En el marco del procedimiento sancionador abreviado establecido el presupuesto consecuencia del pago de la sanción, con la correspondiente bonificación en la cuantía fijada del 50 por 100, la renuncia por parte del denunciado a presentar alegaciones, y la terminación del procedimiento sin necesidad de que sea dictada resolución expresa, no podría establecerse consecuencia distinta a la aquí prevista, en cuanto al término de la vía administrativa, previsión que, como se ha puesto de manifiesto podría haberse omitido teniendo en cuenta que el art. 80 e) LTSV establece que "el plazo para interponer el recurso contencioso-administrativo se iniciará el día siguiente a aquel en que tenga lugar el pago".

Cuestión distinta es la posibilidad de recurrir en vía contencioso - administrativa.

5. RECURRIBILIDAD EN EL ORDEN JURISDICCIONAL CONTENCIOSO - ADMINISTRATIVO Y PLAZO PARA INTERPONER EL RECURSO CONTENCIOSO-ADMINISTRATIVO SE INICIARÁ EL DÍA SIGUIENTE A AQUEL EN QUE TENGA LUGAR EL PAGO

Las consecuencias que, legalmente, se han ido estableciendo para los expedientes tramitados por el procedimiento sancionador abreviado nos han ubicado en el orden jurisdiccional contencioso-administrativo, único lugar en el que el denunciado podría combatir la denuncia una vez tomada la decisión de optar por el procedimiento transaccional que le ofrece la LTSV.

Realizado el pago, y condicionados a ese pago todos los efectos relativos al procedimiento, la siguiente consecuencia es el hecho de que el plazo para recurrir queda fijado por el momento en el que se realiza el pago voluntario de la multa acogiéndose a la reducción del 50 por 100 y, por lo tanto, el dies a quo para iniciar el plazo de tiempo en el que el interesado puede proceder a recurrir en vía contenciosoadministrativa no puede ser otro que "el día siguiente a aquél en que tenga lugar el pago".

Téngase presente que no nos encontramos en un supuesto en el que la terminación del procedimiento se produce sin necesidad de dictar resolución expresa. En este 
sentido, de no mediar una prescripción como la que realiza el art. 80 e) LTSV, nos encontraríamos ante una situación equivalente a la resolución por silencio administrativo por falta de resolución expresa de un procedimiento iniciado de oficio que en el ámbito sancionador provocaría (en el ámbito general de actuación de la LRJ PAC) la caducidad del expediente sancionador.

De lo que se trata es de dotar de seguridad jurídica al interesado que está en condiciones de conocer con certeza el plazo, y desde cuando se inicia, lo que le permite determinar hasta cuando dispone para impugnar en el orden contencioso administrativo la resolución sancionadora en la que se ha convertido, a efectos de objeto de impugnación, la denuncia por la infracción de determinados hechos.

El denunciado tiene, así, certeza sobre el plazo para recurrir. Cuestión distinta es de los medios de los que dispone, y en particular de la efectividad o idoneidad de los mismos, para combatir el acto administrativo caso de querer impugnarlo.

Lo que se habrá consolidado como objeto del recurso contencioso - administrativo es una denuncia con el contenido legalmente previsto (así debiera ser) y nada más, puesto que es lo único que encontraremos en el expediente administrativo junto a la notificación de la misma y la certificación de que el denunciado ha procedido a realizar el pago bonificado de la sanción prevista en esa denuncia y que lo ha hecho en el plazo de tiempo establecido. Nada más encontraremos en ese expediente sancionador. No hay alegaciones, no puede haberlas pues están proscritas en el marco del pacto que se ofrece al denunciado (renuncia a formular alegaciones y en el caso de que fuesen formuladas se tendrán por no presentadas), ni propuesta de resolución, ni resolución expresa por la autoridad competente para sancionar.

El denunciado, convertido en demandante en el correspondiente proceso contencioso - administrativo, discutirá en el estricto espacio del contenido de la denuncia.

La LTSV no exige al denunciado reconocimiento de la conducta ni de los hechos para acogerse al pago voluntario y a la reducción de la cuantía de la multa. Si lo hubiera hecho se hubiera establecido un acto propio que hubiera impedido recurrir en vía administrativa y contencioso - administrativo o, al menos, lo hubiera limitado a supuestos tasados.

6. La fiRMEZA de la sanción en la Vía administrativa deSDe el MOMENTO del pago, PRODUCIENDO PLENOS EFECTOS DESDE EL DÍA SIGUIENTE

De la misma manera se asocian al día en que se efectúa el pago de la multa los efectos correspondientes a la firmeza de la sanción en vía administrativa.

La argumentación ya nos resulta conocida desde el momento en el que lo que se busca es la certeza en cuanto a la apertura de determinados plazos de tiempo, como puede ser el de la recuperación de puntos perdidos, y el beneficio para el denunciado que es 
el primer interesado en que esos plazos se pongan en marcha lo más rápidamente posible.

La previsión efectuada en el art. 80 f) LTSV es, así, resultado inmediato del resto de consecuencias que se han ido estableciendo en las letras que la preceden. En concreto de la terminación del procedimiento sin necesidad de resolución expresa que lleva a asociar a la acción del denunciado que actúa como presupuesto básico de que el expediente se tramite por el procedimiento sancionador abreviado, es decir, al pago realizado de forma voluntaria el resto de consecuencias, llevando a ese momento, el día que se realiza el pago, de una forma tan automática como segura y cierta, el inicio de todos los plazos que se derivarían de la propia terminación del procedimiento.

7. La sanción no computará como antecedente en el Registro de Conductores e INFRACTORES, SIEMPRE QUE SE TRATE DE INFRACCIONES GRAVES QUE NO LLEVEN APAREJADA PÉRDIDA DE PUNTOS

La última de las consecuencias que se establece en el art. 80 f) LTSV para los expedientes sancionadores tramitados por el procedimiento sancionador abreviado es que la sanción impuesta "no computará como antecedente en el Registro de Conductores e Infractores, siempre que se trate de infracciones graves que no lleven aparejada pérdida de puntos".

Dentro del sistema transaccional establecido se trata de otro beneficio para el infractor - denunciado que, en este caso, y a diferencia de lo que ocurre con el beneficio de reducción de multa, que alcanza a todos los casos susceptibles de ser tramitados por el procedimiento sancionador abreviado, limita sus efectos a las infracciones graves que no supongan la pérdida de puntos, lo que a contrario sensu significa que esta consecuencia no se produce ni para las infracciones graves que tienen aparejada la pérdida de puntos ni para las infracciones muy graves.

La interpretación del alcance de la consecuencia prevista en el art. 80 g) LTSV requiere integrar las previsiones efectuadas en ese precepto con las establecidas sobre permisos y licencias de conducción en el art. 60 LTSV (en especial las contenidas en el apartado 5) y con las determinaciones realizadas en el art. 93 LTSV sobre anotación y cancelación de antecedentes.

El beneficio que para el denunciado se ofrece, dentro del pacto con la Administración sancionadora, es que la infracción grave, siempre que esa infracción no sea de las que conforme a lo establecido en el Anexo II lleve aparejada pérdida de puntos, no será inscrita en el Registro de Conductores e Infractores. En realidad los términos en los que está redactado el art. 80 g) LTSV señalan que "la sanción no computará como antecedente", pero para que no se produzca ese efecto, para que esa infracción no produzca los resultados que se derivarían de su anotación (inscripción) en el Registro de Conductores e infractores, existen dos posibilidades. La primera consistiría en no 
llevar a efecto la anotación, con lo cual no quedaría constancia de la misma, motivo por el cual no se producirían efectos sobre los antecedentes del infractor. Sencillamente no existiría a efectos del Registro de Conductores e Infractores puesto que nunca se habría llegado a anotar en él. La segunda opción, más complicada, consistiría en la inscripción de la infracción acompañada de una nota explicativa mediante la que quedara constancia que el expediente sancionador correspondiente a esa infracción se había tramitado por el procedimiento sancionador abreviado motivo por el cual esa infracción no computaba como antecedente para el infractor. Obviamente parece mucho más eficiente no realizar en el Registro de Conductores e Infractores anotaciones inocuas al fin que, con ello, se persigue.

Pero lo cierto es que ni el art. 93 LTSV ni el art. 77 RGCon contienen prescripción alguna sobre el procedimiento a seguir en estos casos.

La actual redacción del art. 93.1 LTSV, que procede, al igual que la regulación del procedimiento sancionador abreviado de la Ley 18/2009, de 23 de noviembre, señala que "las sanciones graves y muy graves deberán ser comunicadas al Registro de Conductores e Infractores por la Autoridad que la hubiera impuesto en el plazo de los quince días naturales siguientes a su firmeza en vía administrativa" por lo que no encontramos en este precepto prescripción alguna sobre la forma de tratar la consecuencia prevista en el art. $80 \mathrm{~g}$ ) LTSV.

Y lo mismo sucede con las previsiones efectuadas en el marco del RGCon, puesto que en el art. 76 LTSV se establece que "en el Registro de conductores e infractores se recogerán y gestionarán de forma automatizada los datos de carácter personal de los solicitantes y titulares de autorizaciones administrativas para conducir, así como su comportamiento y sanciones por hechos relacionados con el tráfico y la seguridad vial, con la finalidad de controlar el cumplimiento por los titulares de las autorizaciones administrativas para conducir de las exigencias previstas por la normativa vigente" y en el art. 77, que regula los datos que han de figurar en el Registro de Conductores e Infractores, se determina que, entre los datos que en ese Registro han de figurar, estarán las "condenas judiciales que afecten a la autorización administrativa para conducir y las sanciones administrativas que sean firmes impuestas por infracciones graves y muy graves".

Así pues, nada permite indicar que las infracciones graves que no supongan pérdida de puntos, aunque hayan sido tramitadas por medio del procedimiento sancionador abreviado, no tengan que anotarse en el Registro de Conductores e Infractores.

Si esto es así tendría que establecerse un sistema que, como indicábamos, acompañe a la anotación de esas infracciones indicando que, tal y como prescribe el art. 80 g) LTSV, no computan como antecedente del titular de la autorización administrativa.

Por todo lo expuesto parece mucho más sencillo que, en estos casos, no se proceda a realizar la anotación de la infracción grave en el Registro de Conductores e Infractores. 
Más aún si tenemos en cuenta que conforme a lo establecido en el art. 80 c) LTSV la terminación del procedimiento no requiere de resolución expresa, por lo que la autoridad con competencia para sancionar no tiene porque enviar (comunicar) al Registro de Conductores e Infractores una resolución. Por lo tanto lo razonable sería enviar una comunicación al Registro en el caso de las infracciones muy graves y de las infracciones graves que supongan pérdida de puntos y no hacerlo en el caso de las infracciones graves que no tengan como consecuencia la pérdida de puntos para el titular de la autorización administrativa. Lo que aquí se propugna es dar, a las infracciones graves que no supongan pérdida de puntos y que hayan sido tramitadas por el procedimiento sancionador abreviado, el mismo tratamiento que ya de por sí reciben las infracciones leves que, en ningún caso, son anotadas en el Registro de Conductores e Infractores.

Toda esta exposición quedaría en el plano teórico si la previsión efectuada en el art. 80 g) LTSV se limitara al mero formalismo de la anotación o no en el Registro de Conductores e Infractores. Pero la realidad es que este precepto contiene un beneficio tangible para el infractor - denunciado. La previsión, consecuencia de la terminación del procedimiento sancionador abreviado, consistente en que "la sanción no computará como antecedente en el Registro de Conductores e Infractores, siempre que se trate de de infracciones graves que no lleven aparejada pérdida de puntos".

El sentido práctico configuran esta previsión como un efecto derivado de la terminación del procedimiento sin resolución expresa... a partir de ahí resulta más sencillo prescindir de trámite alguno cuando no hay pérdida de puntos y la consecuencia adicional (que, posiblemente, se trate más que de algo buscado de propósito de algo producto de la casualidad) de conceder, como beneficio adicional, que las infracciones graves que no supongan pérdida de puntos no consten en el Registro a efectos de antecedentes.

\section{D) A modo de conclusiones: Una valoración en conjunto de las consecuencias establecidas para las denuncias (expedientes sancionadores) tramitadas por el procedimiento sancionador abreviado}

Vaya por delante que, en ocasiones, teoría (jurídica) y práctica (social) no discurren de forma paralela. El análisis de las escuetas previsiones efectuadas por la LTSV para regular el procedimiento sancionador abreviado no hace sino encadenar un sinfín de interrogantes jurídicos, algunas de las cuales plantean verdaderos problemas en cuanto a la respuesta que deban recibir. Otras, sencillamente, no la tienen. Eso, o hay que echarle mucha imaginación. 
Pero frente a ello la práctica se empeña en demostrar, con datos y cifras, que el sistema establecido "funciona"127.

La primera de esas cuestiones es (intentar) determinar si, realmente las previsiones realizadas en los arts. 79 y 80 LTSV permiten establecer que lo regulado es un procedimiento sancionador o si, en realidad, nos encontramos ante otra cosa.

El procedimiento se reduce a un trámite de parte, el pago de la mitad del importe legalmente previsto como consecuencia de la infracción cometida y a que la Administración se limita a recibir el pago correspondiente a la mitad de la sanción prevista.

Un procedimiento iniciado, de eso no cabe duda, termina con el pago de una parte (la mitad) de la sanción que, conforme a la propia LTSV, correspondería a esa conducta. Y el procedimiento finaliza sin resolución expresa del órgano competente.

Si el pago (de la mitad de la multa establecida) tiene como consecuencia "la terminación del procedimiento, sin necesidad de dictar resolución expresa", tal y como indica el art. 80 c) LTSV, tiene que haber una resolución, para poder dar por finalizado ese procedimiento y, si no es expresa tendrá que ser mediante una resolución "tácita" (no hay otra opción).

Y tiene que haber una resolución (tácita, pero resolución) porque la falta de resolución expresa en los procedimientos iniciados de oficio en aquellos casos en los que la Administración ejercite potestades sancionadoras o, en general, de intervención, susceptibles de producir efectos desfavorables o de gravamen, se producirá la caducidad (art. 44 LRJ - PAC) a lo que el art. 138 LRJ - PAC añade que "la resolución que ponga fin al procedimiento habrá de ser motivada y resolverá todas las cuestiones planteadas en el expediente". Ni siquiera en las previsiones que se realizan sobre el procedimiento simplificado en el REPEPOS (arts. 23 y 24) se prevé que este tipo de procedimientos concluyan sin mediar resolución, al establecer que "se dictará resolución en la forma y con los efectos previstos en el Capítulo IV (del propio REPEPOS, donde ser regula la resolución sancionadora).

Si bien es cierto que el art. 42.1 LRJ - PAC dispone que aunque "la Administración está obligada a dictar resolución expresa en todos los procedimientos y a notificarla cualquiera que sea su forma de iniciación", en ese mismo lugar se establece que se exceptúan de esa obligación "los supuestos de terminación del procedimiento por pacto o convenio".

127 En el plano del propio procedimiento sancionador y partiendo de los propios objetivos que establecidos en el Preámbulo de la ley 18/2009, de 23 de noviembre, se han reducido plazos, incertidumbres, alegaciones formuladas... en el, a mi juicio, mucho más relevante del resultado, el procedimiento ha cumplido con el objetivo de profundizar en la idea de la sanción de tráfico con un elemento de seguridad, la percepción de la efectividad y de "que una adecuada gestión del procedimiento sancionador influye de un modo directo en la reducción de la siniestralidad" (párrafo último del apartado I del Preámbulo). Las cifras, y en especial las de siniestralidad, avalan el sistema. 
$\mathrm{Y}$, frente a ello, el procedimiento sancionador abreviado previsto en la LTSV concluye por una resolución que no es expresa ni está motivada. Una previsión que no se corresponde con los supuestos previstos en el art. 8 REPEPOS sobre los efectos que pudiera tener sobre el procedimiento sancionador el reconocimiento de responsabilidad o el pago voluntario en cualquier momento anterior a la resolución.

Sobre el hecho de que no se produzca una resolución expresa hay que señalar que el art. 92.3 LTSV contiene un matiz diferencial respecto de lo previsto en el art. 20.6 REPEPOS. Así, mientras la norma general utiliza los términos "si no hubiese recaído resolución..." la LTSV utiliza la expresión "si no se hubiera producido la resolución...". Y una resolución tácita no puede recaer (en el sentido de que este verbo parece exigir que la resolución sea expresa) pero si se puede tener por producida.

La motivación, por su parte, de esa resolución tácita con la que finaliza el procedimiento sancionador abreviado habría que buscarla en el propio acto de iniciación del procedimiento, al que la propia LTSV atribuye (eso sí, siempre que se cumplan determinadas condiciones) el que pueda llegar a constituirse en "acto resolutorio del procedimiento sancionador" (art. 81.5 LTSV), y el consentimiento, y conocimiento que ellos supone, realizado por el denunciado mediante la realización del pago voluntario.

La Administración ofrece al denunciado un descuento del 50 por 100 en la cuantía de la sanción, que, en el caso de que esa infracción (grave) no tuviera aparejada la pérdida de puntos, no será inscrita en el Registro de Conductores e Infractores y no computará como antecedente y la terminación del procedimiento.

A cambio pide el pago de la mitad de la sanción y que el denunciado renuncie a su derecho de formular alegaciones.

Pero no se exige ni el reconocimiento de responsabilidad ni la renuncia a acudir al orden contencioso - administrativo.

De este planteamiento ambas partes se derivan otras consecuencias adicionales (tangibles e intangibles) para ambas partes.

La Administración obtiene la mitad de la cuantía prevista pero, a cambio, el coste de gestión tiende a cero. El resultado, desde un punto de vista estrictamente económico, y desde la eficiencia en la gestión es, sin lugar a dudas, más efectivo.

Al lado de ese tangible (del que nada se dice en lugar alguno) se sitúa un intangible al que si se hace referencia, pues el triunfo de este sistema conlleva la percepción de la eficacia del sistema, lo que el propio legislador denomina "el refuerzo del principio antes apuntado de la sanción como elemento de seguridad activa, toda vez que se afianza en los conductores la configuración de una justicia administrativa vial que actúa con inmediatez y se aleja de sensaciones de impunidad" (Preámbulo Ley 18/2009, de 23 de noviembre, apartado V, párrafo cuarto). 
Al denunciado se le exige pagar. Pagar la mitad de la multa que le correspondería. Y que tenga por terminada la vía administrativa. Planteamiento, que al no extenderse a la vía judicial, está alineado con la eficiencia económica en la gestión de la competencia sancionadora. Pero como hemos tenido oportunidad de señalar ni se le exige que reconozca su responsabilidad ni el renunciar a la impugnación en vía contencioso - administrativo forma parte del acuerdo.

En este caso la previsión normativa va más allá. Una vez más el pensamiento de NieTo, ese de "parece que el Estado no busca culpables, ni siquiera autores, sino responsables, hasta el punto que a la mera inobservancia se corresponde la mera responsabilidad" que en este caso se encuentra superado. El Estado no busca culpables, ni siquiera autores, ni responsables... busca quien pague la sanción. El tangible final, sanción menos coste de para lograr su abono, y el intangible del mensaje a los ciudadanos de la efectividad del sistema sancionatoria en forma de él que infringe, paga. Hasta el punto de que la LTSV no exige el reconocimiento de la responsabilidad. Exige el pago, pero no es preciso, para ello, para que ese pago sea admitido una declaración del denunciado asumiendo su responsabilidad. La realización del pago voluntario no se encuentra sometida a condición alguna que permita determinar que el pago de la sanción efectuado de forma voluntaria por el denunciado supone que este asume la responsabilidad por los hechos y reconoce que ha infringido la Ley, y menos aún que ese reconocimiento tengo carácter definitivo y condicione su actuación en adelante. No hay disposición expresa sobre ello, ni esta conclusión se puede extraer, de manera tácita, de las previsiones de la LTSV ${ }^{128}$.

Estar de acuerdo con que ello sería lo razonable y que la inatacabilidad de esa sanción debiera conformar parte del pacto entre Administración y denunciado no supone que existan elementos que permitan defender esa posición. El sistema no sería ni más fuerte ni más débil con esa previsión expresa, ni los derechos del denunciado estarían en peor posición que la prevista en la normativa vigente. Los problemas serían exactamente los mismos.

En todo caso hay unos límites que entiendo indisponibles y que no siempre ha sido objeto de consideración por las previsiones establecidas en la LTSV. El espacio hábil

\footnotetext{
128 Algo que CANO CAMPOS se plantea (El régimen jurídico - administrativo del tráfico, 2a ed., Madrid, Civitas, 2010, 2a ed., págs. 546 - 5487) y HUERGO afirma (Los contratos sobre los actos y las potestades administrativas, Civitas, 1998, págs. 423 - 430). Este último considera que "la renuncia al ejercicio de este poder en relación con un acto administrativo concreto esté implícita en la conformidad de la sanción". Y estando de acuerdo con que ello debiera de ser así entiendo que la regulación efectuada en el art. 80 LTSV no supone aquiescencia ni reconocimiento ni, por tanto, acto propio que impida combatir la actuación administrativa en el espacio que la propia LTSV permite. La regulación es, sin lugar adudas, inadecuada en este punto, temerosa, también sin duda, de interpretaciones que entendieran que se vulneraba el derecho a la tutela judicial efectiva por impedir defenderse de la actuación administrativa ante los Tribunales. Es absurdo (carecería de sentido, en términos de HUERGO, pag. 424), pero es así, y forma parte del pacto que se ofrece. $Y$, en este caso, no se establece una conformidad expresa, como sucede en (por ejemplo) el ámbito tributario.
} 
tiene que situarse y, por tanto, respetar que la comisión de la infracción no resulte más beneficiosa para el infractor que el cumplimiento de la norma infringida $y$, al mismo tiempo, que la defensa del derecho no suponga (caso de tener razón) un sacrificio mayor que la propia infracción. 


\title{
Capítulo VI
}

\section{EL PERMISO DE CONDUCIR POR PUNTOS}

\begin{abstract}
SUMARIO: I. LA INTRODUCCIÓN DEL PERMISO Y LICENCIA DE CONDUCCIÓN POR PUNTOS EN LA LEY DE TRÁFICO Y SEGURIDAD VIAL: A) La idea del permiso por puntos; B) El concepto del permiso por puntos. II. EL SISTEMA Y LA NATURALEZA DE LA DETRACCIÓN DE PUNTOS: A) Aproximación al sistema; B) Sobre la naturaleza de los puntos y su detracción: 1. UNA EVALUACIÓN SUBJETIVA Y AJURÍDICA; 2. LA SUSPENSIÓN DEL PERMISO COMO SANCIÓN; 3. LAS PREVISIONES ANTERIORES: a) La regulación previa introducida en la LTSV por la Ley 19/2001, de 19 de diciembre; b) Los antecedentes mediatos (el RGCon/1997); 4. EL PLANTEAMIENTO FORMAL DE LA LEY 17/2005, DE 19 DE JULIO; 5. LA DETRACCIÓN DE PUNTOS COMO SANCIÓN; 6. UN ANÁLISIS DIFERENCIAL ALTERNATIVO: a) Una premisa como punto de partida; b) El sistema y sus elementos (el sistema por puntos y los puntos); c) La consecuencia; d) Algunas reflexiones y una conclusión provisional. III. EL PROCEDIMIENTO PARA LA DECLARACIÓN DE PÉRDIDA DE VIGENCIA: A) Ubicación; B) El Procedimiento de declaración de pérdida de vigencia: 1. El PRESUPUeSTO; 2. COMPETENCIA; 3. LA TRAMITACIÓN; IV. ALGUNAS CONSIDERACIONES ADICIONALES Y UNA CONCLUSIÓN.
\end{abstract}

\section{LA INTRODUCCIÓN DEL PERMISO Y LICENCIA DE CONDUCCIÓN POR PUNTOS EN LA LEY DE TRÁFICO Y SEGURIDAD VIAL}

\section{A) La idea del permiso por puntos}

La introducción del permiso por puntos en la Ley de Tráfico y Seguridad Vial por medio de la Ley 17/2005, de 19 de julio, viene precedida de diversos estudios ${ }^{1}$ y, sobre todo, de la experiencia de su previa implantación en diversos países de nuestro entorno.

No se trata tanto de realizar aquí un estudio histórico exhaustivo del permiso por puntos $^{2}$, ni de analizar, de forma separada y comparada, los diferentes sistemas que están funcionado en Europa, como de determinar, tanto de manera general como específicamente, el sistema desarrollado en nuestro ordenamiento, cual sea su

\footnotetext{
${ }^{1}$ Véase, en este sentido, en el marco del capítulo de esta obra destinado al análisis de la evolución del procedimiento sancionador el apartado sobre la ley 17/2005, de 19 de julio, lugar en el que se da cuenta de la aprobación por la Comisión de Justicia e Interior del Congreso de los Diputados del Informe de la Subcomisión de Seguridad Vial y Prevención de Accidentes de Tráfico de 16 de diciembre de 2003 y, en particular, las notas 251 a 253.

${ }^{2}$ A ello dediqué una monografía en el momento de promulgación de la Ley 17/2005, de 19 de julio, y entrada en vigor del permiso y licencia de conducción por puntos (Permiso y Licencia de conducción por puntos, Aranzadi, 2006, 210 págs.)
} 
naturaleza y su relación con el régimen sancionador establecido en materia de tráfico y seguridad vial.

\section{B) El concepto del permiso por puntos}

Cuando se introduce en nuestro sistema no es, siquiera, una idea novedosa. El concepto de autorizaciones administrativas para conducir por puntos está funcionado en varios países de nuestro entorno y, en algunos de ellos, esa implantación se había realizado hacía décadas ${ }^{3}$.

El elemento común que permiten establecer la existencia de un sistema por puntos es que la vigencia de las autorizaciones queda sometida a que su titular no sea considerado como un infractor reincidente.

Desde el punto de vista del procedimiento administrativo sancionador en materia de tráfico y seguridad vial lo que aquí interesa es determinar la naturaleza (sancionadora o no) de ese sistema y, en particular, de la detracción de puntos y de la consecuencia atribuida en ese sistema a la pérdida de todos los puntos por el titular de la autorización administrativa que habilita la conducción de vehículos en cuanto que ello conlleva la privación del derecho a realizar esa actividad.

\section{EL SISTEMA Y LA NATURALEZA DE LA DETRACCIÓN DE PUNTOS}

\section{A) Aproximación al sistema}

La propia introducción en la LTSV, por medio de la Ley $17 / 2005$, de 19 de julio, del permiso y licencia de conducción por puntos, supone la discusión de cuál sea la naturaleza de esos puntos.

El análisis que aquí acometemos es fruto, precisamente, de ello, y de sus consecuencias en cuanto a objeto, en su caso, del procedimiento administrativo sancionador.

Por ello, y sin pretender un análisis total de esta cuestión ${ }^{4}$, si resulta preciso tener presentes determinadas cuestiones de entre las que rodean, configuran y dan forma a ese sistema, a esos puntos sobre los que se sustenta, a la detracción de los mismos y a la pérdida de vigencia de la autorización cuando su titular pierde la totalidad de los puntos.

\footnotetext{
${ }^{3}$ Aunque no todos los sistemas son iguales está filosofía ha sido implantada en países como Alemania (1974), Francia (1992), Reino Unido (1995), Irlanda (2001), Luxemburgo (2002), Italia (2003).

${ }^{4}$ Sobre la que CANO CAMPOS ha realizado un profundo estudio en "¿Es una sanción la retirada de puntos del permiso de conducir?", RAP, no 184, enero - abril, 2011, págs. 79 - 119.
} 
Porque el problema no se centra tanto en el sistema y en los puntos como en la situación a la que se llega cuando el titular de una autorización para conducir se queda sin ellos y, por lo tanto, se produce la situación prevista en el art. 63.6 LTSV conforme a la que "la Administración declarará la pérdida de vigencia de la autorización para conducir cuando su titular haya perdido la totalidad de los puntos asignados..."

En términos de resultado, y al margen de cuál sea la construcción jurídica que da lugar a ello, el titular de esa autorización administrativa, que le habilita para conducir vehículos, se ve privado de la posibilidad de realizar esa actividad, la de conducir, por haber dejado de cumplir con el requisito que en la propia LTSV se establece para ello, como es el de haber obtenido y poseer la preceptiva autorización administrativa.

Esta privación del permiso que, como se ha señalado, lo es por la declaración de la Administración competente de la pérdida de vigencia de la autorización, requiere de una serie de reflexiones que permitan determinar (o, al menos, estar en disposición de intentarlo) cuál sea la naturaleza de esa medida.

\section{B) Sobre la naturaleza de los puntos y su detracción}

\section{UNA EVALUACIÓN SUBJetIVA Y AJURÍDICA}

La consecuencia, como resultado, de la declaración de pérdida de vigencia de una determinada autorización administrativa de las que habilitan para conducir por haberse quedado su titular sin ninguno de esos puntos (por haberlos perdido todos) es, sin lugar a dudas, y desde la perspectiva de ese conductor, dañina, y le supone un perjuicio, puesto que se le prohíbe hacer algo para lo que, hasta el momento en el que se declara la perdida de vigencia de su autorización, estaba facultado. Y lo estaba por haber obtenido, previamente, la preceptiva autorización (permiso o licencia de conducción) a la que se somete la actividad de conducir vehículos, cumpliendo los requisitos que para ello establece la propia Administración que ahora procede a dejarla sin valor.

Esa declaración de la Administración tiene como resultado, de forma directa y concreta, que quien hasta ese momento podía conducir ya no puede hacerlo. Y que no va a poder hacerlo hasta que el titular obtenga un nuevo permiso, algo que queda sometido, de un lado, al transcurso de determinado espacio de tiempo y, de otro, al cumplimiento de determinadas condiciones.

La pérdida de todos los puntos atribuidos al titular de un permiso o licencia de conducción, el hecho de que esa persona se quede sin puntos, conlleva una consecuencia negativa, como es la imposición de una obligación de no hacer algo (no conducir vehículos), lo que se constituye como una prohibición. 
Se puede establecer la existencia de una percepción social de que esa declaración de la pérdida de vigencia del permiso de conducir por la pérdida de puntos es una privación del derecho a conducir vehículos y que, como tal, se trata de una sanción, algo que encuentra su fundamento en la propia regulación que, del régimen sancionador, se ha realizado en el ámbito del tráfico a través del tiempo.

\section{LA SUSPENSIÓN DEL PERMISO COMO SANCIÓN}

Aunque la actual redacción de la LTSV no prevé, en el marco de regulación de las sanciones (art. 67 LTSV), la existencia de ninguna otra que no sea la de multa, se trata de una configuración relativamente reciente, puesto que ello únicamente es así desde la reforma efectuada en la LTSV por la Ley 18/2009, de 23 de noviembre.

La redacción originaria de la LTSV contemplaba, además, la posibilidad de la suspensión del permiso o licencia de conducción como sanción, previsión que continuó en la Ley hasta la total revisión del régimen sancionador que se efectúa por medio de la Ley 18/2009, de 23 de noviembre ${ }^{5}$.

Por ello, y aunque la medida de suspensión de la autorización administrativa ha podido, y puede, tener diversa naturaleza ${ }^{6}$, se identifica, en primer término, como una medida sancionadora (ya sea administrativa o penal).

Sin duda, este hecho, el de que la suspensión del permiso y licencia de conducción haya sido durante bastante tiempo una sanción administrativa que, junto con la multa, era la respuesta prevista para las infracciones muy graves (en todo caso) y para las infracciones graves (como una posibilidad real), ha supuesto que la pérdida o privación de la autorización administrativa, sea por el motivo que sea y sea de la forma que sea,

\footnotetext{
${ }^{5}$ Aunque la inicial redacción contenida en el inciso final del art. 67.1 LTSV fue objeto de diversos cambios (por la Ley 5/1997, de 24 de marzo, la Ley 19/2001, de 19 de diciembre y la Ley 17/2005, de 19 de julio) se mantenía la posibilidad de imponer la suspensión de la autorización administrativa y de que ello fuera una sanción de las previstas en la Ley. Algo que inicialmente era una posibilidad ("podrá imponerse además" en términos de la propia redacción originaria) para, a partir de la Ley 5/1997, de 24 de marzo, y hasta la Ley 18/2009, de 23 de noviembre, ser una posibilidad en el caso de las infracciones graves y una sanción que "se impondrá en todo caso" paras las infracciones muy graves.

A mi juicio una de las mayores perversiones del sistema en cuanto que considero que la regulación establecida es la razón por la que se produce un crecimiento exponencial de alegaciones y recursos por parte de los que resultaban denunciados ya que la comisión de una infracción grave podía suponer la suspensión del permiso de conducir, algo contra lo que se rebelaban, con todos los medios a su alcance, los afectados por tal medida.

${ }^{6}$ La suspensión de la autorización administrativa para conducir podía tratarse de una sanción administrativa (prevista en la LTSV y fuera de ella, como es el caso de la LOSC), una pena de las establecidas en el Código Penal o una medida cautelar de las previstas en el art. 64 LTSV e, incluso, la intervención del permiso de conducir por el agente de la autoridad contemplada en el art. 71 bis LTSV, precepto que fue incorporado al texto de la Ley por la Ley 62/2003, de 30 de diciembre, como medida cautelar y que permaneció en ella hasta la reforma efectuada por la Ley 18/2009, de 23 de noviembre.
} 
se perciba como una sanción y se tienda a descartar la posibilidad de su uso con una naturaleza diferente a la puramente sancionadora.

La percepción como sanción no lo es tanto por la medida que supone la privación y su naturaleza como por su resultado. Y la pérdida de la autorización administrativa, ya se trate de una sanción como tal, de una consecuencia derivada o accesoria, de una medida provisional o cautelar e incluso de su pérdida de vigencia, es percibida (en todos los casos) como una medida sancionatoria en tanto en cuanto supone la intromisión en la esfera jurídica del afectado por esa medida, quedando el hecho de su naturaleza (ya sea punitiva o tenga una esencia y propiedades distintas) en un plano absolutamente secundario para el interesado.

El hecho de que diferentes figuras jurídicas tengan como consecuencia un resultado que, para el afectado, pueda ser reducido a la pérdida de una autorización (ya sea suspensión, privación, retirada, revocación, pérdida de vigencia...) y, por tanto, a la desaparición de los efectos favorables que su tenencia o posesión significaban, ocasionan esa percepción por el administrado, que percibe esa medida como una sustracción patrimonial que ni siquiera puede ser pagada (y evitada) con dinero. Pero ello no significa que por esa similitud en sus consecuencias nos hallemos ante una sanción administrativa ${ }^{7}$.

\section{LAS PREVISIONES ANTERIORES}

a) La regulación previa introducida en la LTSV por la Ley 19/2001, de 19 de diciembre

Tal vez sea preciso mirar hacia atrás e indagar en las redacciones anteriores que, a través del tiempo y antes de que fueran introducidas las previsiones establecidas por medio de la Ley 17/2005, de 19 de julio, conformaban la regulación de la LTSV.

El hecho de que en las redacciones anteriores del art. 63 LTSV no figurara una previsión similar a la que se introduce por medio de la Ley 17/2005, de 19 de julio, sobre la pérdida de vigencia de la autorización administrativa para conducir por la petición de puntos asignados no significa que se trate de una norma absolutamente novedosa. Es cierto que el permiso con puntos, como sistema, se introduce en ese momento, pero la privación del permiso (o licencia) de conducción, la revocación, en los términos empleados por la redacción originaria del art. 63 LTSV hasta su modificación por la Ley 19/2001, de 19 de diciembre, y sustitución por la expresión

\footnotetext{
${ }^{7}$ Como ha señalado NiETo, quien advierte que ni se trata de una cuestión sencilla ni a todo acto de gravamen se le puede atribuir la naturaleza de sanción administrativa ni, por tanto, le resulta aplicable el procedimiento sancionador (Cfr. Derecho Administrativo Sancionador, Madrid, Tecnos, 2012, 5a ed., pág. 156)
} 
"pérdida de vigencia" ${ }^{8}$, ya se había recogido en la LTSV. No desde un primer momento, pero sí a partir de la primera gran reforma que de la Ley se realiza por medio de la Ley 19/2001, de 19 de diciembre.

En ese momento se introduce en la LTSV un supuesto de revocación del permiso o licencia de conducción para el caso de reincidencia en la comisión de infracciones muy graves, previsión que se efectúa mediante la introducción de una nueva redacción para el art. 67 LTSV $^{9}$ en el que, conforme a lo establecido en su rúbrica, se regulan las cuestiones relativas a las sanciones.

De esta forma se establecía la revocación de la autorización administrativa como sanción para un supuesto concreto, el de la reincidencia en la comisión de infracciones muy graves, entendiendo por que se reputarían como reincidentes "a quienes hubieren sido sancionados en firme en vía administrativa durante los dos años inmediatamente anteriores por dos infracciones muy graves de las previstas en el art. 65.5 de esta Ley" (art. 67.3 párrafo segundo LTSV).

El conjunto de elementos de presentes en esta previsión eran, como presupuesto, la sanción firme por la comisión de un número de infracciones de las calificadas como muy graves (tres) y que ello sucediera en un determinado espacio de tiempo ( 2 años), y como consecuencia la revocación de la autorización y la prohibición de obtención de una nueva autorización administrativa para conducir mientras no se hubiera cancelado la sanción que dio origen a la revocación, para lo que era preciso el transcurso de dos años desde su total cumplimiento, conforme a lo establecido en el art. 82 LTSV en la redacción recibida de la propia Ley 19/2001, de 19 de diciembre.

Si bien es cierto que esta previsión, la de la revocación del permiso o licencia como sanción por reincidencia en la comisión de infracciones muy graves, podía ser sustituida por la sanción de suspensión de un año con carácter continuado ${ }^{10}$ siempre y

\footnotetext{
${ }^{8}$ Algo que se advierte de manera expresa en la Exposición de Motivos de la Ley 19/2001, de 19 de diciembre, lugar en el que se señala que "en el Título IV, relativo a las autorizaciones administrativas, las modificaciones de los capítulos III y IV sustituyen el término revocación de la autorización, por el de pérdida de vigencia, y el de anulación por el de lesividad, en consonancia con los conceptos legales del procedimiento administrativo común" (cfr. el párrafo quinto de la referida Exposición de Motivos).

${ }^{9}$ En este sentido el párrafo segundo de la disp. final cuarta establecía que "las previsiones contenidas en los apartados 1 y 3 del art. 67 y en el apartado 1 del art. 72, en cuanto se refiere a la sustitución o renovación de las autorizaciones administrativas para conducir por determinados cursos u otras medidas también reeducadoras, entrarán en vigor en el momento de completarse por el Gobierno el desarrollo reglamentario de los cursos de reciclaje y sensibilización en materia de seguridad vial previstos en dichos preceptos".

10 Esta previsión, la de que la ejecución de ese año de sanción de suspensión de la autorización administrativa lo fuera de forma continuada, fue introducido en el art. 67.3 LTSV por la Ley 62/2003, de 30 de diciembre, de medidas Fiscales, Administrativas y del Orden Social, ya que la redacción que en la LTSV se introducía por medio de la ley 19/2001, de 19 de diciembre, se remitía al art. 67.1 LTSV y a lo en él establecido, de manera general, para la sanción de suspensión, lugar en el que se establecía que "el cumplimiento de la sanción de suspensión de la autorización para conducir podrá fraccionarse en la forma que reglamentariamente se determine".
} 
cuando el titular solicitase la realización de un curso de reciclaje y sensibilización y acreditase haberlo superado con aprovechamiento dentro del plazo y en las condiciones que reglamentariamente se determinaran. En tal caso, la revocación del permiso o licencia de conducción se sustituirá por la sanción de suspensión de los mismos durante un año.

En estos términos la revocación de la autorización administrativa por reincidencia en la comisión de infracciones muy graves se configura como una sanción, formalmente introducida en ese marco, con un castigo durísimo, que en términos de temporalidad nada tiene que envidiar a las previsiones penales, y que invita a su reconducción, mediante la transacción que, por la propia LTSV, se ofrece al interesado, hacia una sanción menor. Previsión que desaparece con la Ley 17/2005, de 19 de julio, y la implantación del sistema del permiso y licencia de conducción por puntos.

\section{b) Los antecedentes mediatos (el RGCon/1997)}

Pero es que esa previsión introducida en el art. 67.3 LTSV por la Ley 19/2001, de 19 de diciembre, no es, tampoco, una innovación en sí misma, y encuentra apoyo, a su vez, en una regulación anterior en materia de tráfico y seguridad vial ubicada, eso sí, fuera de la LTSV.

El art. 41 del Reglamento General de Conductores (aprobado por el RD 772/1997, de 30 de mayo - RGCon/1997) establecía el procedimiento para la declaración de pérdida de vigencia de las autorizaciones administrativas cuando se tuviera conocimiento "de la presunta desaparición de alguno de los requisitos que, sobre conocimientos, aptitudes o comportamientos esenciales para la seguridad de la circulación o aptitudes psicofísicas, se exigían para el otorgamiento de la autorización" (art. 41.1 RGCon/1997), sin que la redacción originaria contuviera previsión adicional alguna en cuanto a que ello pudiera derivarse de la comisión de infracciones (determinado número, de determinado tipo o calificación, en determinado espacio de tiempo) por el titular del permiso o de la licencia de conducción.

Este art. 41 RGCon/1997 fue modificado por el RD 1110/1999, de 15 de junio. En la propia introducción que antecede a esa reforma se señala, en el marco de la previsión efectuada (en ese momento) en el art. 63 LTSV conforme a la que la vigencia de las autorizaciones administrativas está subordinada a que se mantengan los requisitos exigidos para su otorgamiento (apartado 3) y que la Administración podrá revocar las mencionadas autorizaciones cuando, después de otorgadas, se acredite que han desaparecido los requisitos que se exigían para ello (apartado 4), que "cuando el comportamiento del conductor, reflejado en la comisión frecuente de infracciones graves o muy graves, es contrario a las normas reguladoras de la circulación, dicho comportamiento, además de no ofrecer garantías suficientes para el mantenimiento 
de la seguridad vial, permite presumir que el conductor ha perdido o carece de los conocimientos, habilidades, aptitudes o comportamientos exigibles, lo que determina la necesidad de que realice un período de formación específica o sea sometido a una nueva comprobación por la Administración, a través de las correspondientes pruebas de control".

Previsión que, trasladada al texto del RGCon/1997, se concreta en que "en materia de conocimientos, aptitudes, habilidades o comportamientos podrá considerarse que existe una presunta desaparición de los mismos cuando el titular de la autorización, durante el período de dos años, haya sido sancionado en firme en vía administrativa por la comisión de tres infracciones graves, o dos muy graves, o dos infracciones graves y una muy grave, sea cualquiera el vehículo con el que se hubieran cometido" (art. 42.2 RGCon/1997) ${ }^{11}$.

Previsión que es objeto de modificación, en cuanto a sus presupuestos, por medio del RD 1598/2004, de 2 de julio, que fija los términos del art. 41.2 RGCon/1997 en que "en materia de conocimientos o comportamientos, podrá considerarse que existe una presunta desaparición de éstos cuando el titular de la autorización, durante el período de dos años, haya sido sancionado en firme en vía administrativa por la comisión de tres infracciones muy graves, sea cual sea el vehículo con el que se hubieran cometido", cualificando el requisito al exigir que se trate de tres infracciones de las calificadas como muy graves y eliminado la posibilidad de acreditar el requisito que se entendía perdido mediante la realización de un curso de reciclaje y sensibilización ${ }^{12}$.

\footnotetext{
${ }^{11}$ A lo que se añadía, en el apartado 3 B) a) del propio art. 41 RGCon/1997 sobre la forma de acreditar la existencia de ese requisito que, se entendía, había desaparecido, que:

"Si la desaparición afecta a los conocimientos, habilidades, aptitudes o comportamientos para conducir, sometiéndose a las pruebas de control de conocimientos y de aptitudes y comportamientos correspondientes ante cualquier Jefatura Provincial de Tráfico, previa solicitud con al menos veinticuatro horas de antelación. Dichas pruebas, salvo en el supuesto previsto en el párrafo siguiente, podrán ser sustituidas, a elección del interesado, por la realización con aprovechamiento de un curso de reciclaje y sensibilización en un centro de formación de conductores autorizado para ello. Dicho curso estará basado, fundamentalmente, en los principios que se recogen en el artículo 43 de este Reglamento, especialmente en los párrafos a), b), c), d), f) y g). El director del centro que imparta el curso certificará si los conocimientos, habilidades, aptitudes y comportamientos adquiridos por el conductor durante el curso han alcanzado el nivel compatible con la seguridad vial. La duración, contenido y características de los cursos de reciclaje y sensibilización y los requisitos que han de reunir los centros que los impartan serán determinados por el Ministro del Interior.

Cuando las infracciones a que se refiere el apartado 2 del presente artículo, se cometan dentro de los dos primeros años de vigencia del permiso, además de realizar un curso de reciclaje y sensibilización de los previstos en el párrafo anterior, será, en todo caso, obligatorio el sometimiento a las pruebas de control de conocimientos y aptitudes y comportamientos correspondientes".

${ }^{12}$ Cuestión sobre la que el texto que antecede a la modificación reglamentaria prescribe que:

"A fin de evitar una duplicidad de cursos de reciclaje y sensibilización de los conductores, se suprimen los cursos previstos en el artículo 41 cuya realización se contemplaba como una manera de acreditar la existencia del requisito o requisitos cuya pérdida se presume y que
} 
Redacción que, muy próxima en el tiempo a la regulación de las autorizaciones por puntos que realiza la Ley 17/2005, de 19 de julio, permanece hasta su derogación por el RD 818/2009, de 8 de mayo, por el que se aprueba el Reglamento General de Conductores (RGCon/2009), que es el vigente, y en el que se regula la pérdida de vigencia de la autorización administrativa para conducir al perder, su titular, la totalidad de los puntos asignados.

El sistema entonces establecido, en cuanto a la composición y distribución de los elementos que lo integraban, establecía una estructura que presentaba instrumentos comunes y similitudes con el posteriormente introducido. En ambos casos la comisión de infracciones, y una vez declarada su firmeza, derivaba en pérdida de vigencia de la autorización que habilitaba la conducción de vehículos.

Sin duda, el sistema pergeñado en las modificaciones del RGCon/1997 era más rudimentario, pero la esencia se sustentaba en determinar que la comisión de las conductas más reprobables (por su calificación) en un espacio contenido de tiempo (dos años) podía ser tomado como un indicio (que permite presumir) que ese conductor ya no reúne los requisitos (conocimientos o comportamientos) que se exigen para la obtención de esa autorización.

Esta previsión se encontraba, eso sí, fuera del territorio correspondiente al régimen sancionador, al cobijo de la regulación reglamentaria propia de las autorizaciones y su pérdida de vigencia, sin siquiera encontrar reflejo en el texto de la LTSV (art. 63). Algo que sería totalmente impropio en la medida que esas previsiones supusieran la existencia de una sanción y para lo que poco importaría el lugar en el que esas disposiciones se hubieran ubicado, porque Las cosas son lo que son y la naturaleza de las instituciones está en su estructura y en su función, no en el nombre que les demos, aunque el bautizo lo haga el legislador ${ }^{13}$.

$Y$ ese fue el motivo por el que el Tribunal Supremo tuvo que determinar si la modificación llevada a cabo en el RGCon/1997 por el RD 1110/1990, de 25 de junio, consistía en el establecimiento de una medida sancionadora que exigía, para su implantación, una norma con rango de Ley. $\mathrm{Y}$, frente al recurso contencioso administrativo interpuesto, el Tribunal Supremo resolvió que la revocación de autorizaciones prevista en el art. 41 RGCon/1997, en la redacción recibida del RD 1110/1999, de 25 de junio, se encontraba regulado en un lugar distinto al que la LTSV

motiva el inicio del procedimiento para la declaración de la pérdida de vigencia de la autorización para conducir, de tal forma que, al suprimirse, solamente podrán acreditarse dichos requisitos mediante la realización nuevamente de la prueba o pruebas que se consideren procedentes. Con esta modificación, los cursos de reciclaje y sensibilización serán exclusivamente los regulados en el artículo 67.3 del Texto Articulado de la Ley sobre tráfico, circulación de vehículos a motor y seguridad vial, como medida que evita la revocación de los permisos de conducción para los infractores reincidentes en infracciones muy graves".

13 En los términos empleados por MendizABAL ALLENDE en su Voto Particular (F. 2) a la STC 164/1995, de 13 de noviembre. 
destinaba a infracciones y sanciones, por lo que no era una sanción, y que la norma impugnada "únicamente establece unos supuestos que permiten establecer una presunción apta para iniciar el expediente de revocación" de conformidad con lo previsto en el art. 63 LTSV $^{14}$.

Así pues, en ese momento y para el Tribunal Supremo, la previsión de revocación del permiso o de la licencia de conducción a su titular por la reiterada comisión de infracciones, y una vez declarada la firmeza de las sanciones que a ellas correspondía, era un "hecho objetivo real y constatado" que no tenía la naturaleza de sanción administrativa (ya que el Reglamento se limitaba a establecer "unos supuestos que permiten establecer una presunción apta para iniciar el expediente de revocación”).

${ }^{14}$ La STS de 24 de mayo de 2001 (RJ 2001, 4187) establecía que:

"La revocación de autorizaciones, supuesto al que se refiere el artículo 41 del Reglamento General de Conductores en la redacción que le da el Real Decreto 1110/1999 que ahora se recurre, aparece regulada en un Título distinto, el IV, de la Ley de Seguridad Vial, que la materia relativa a infracciones y sanciones que lo está en el Título V. Por tanto, la cancelación de tales sanciones sólo produce efectos en cuanto a que éstas puedan ser tomadas en consideración a fin de graduar las sanciones previstas en la Ley, pero en nada afecta a que una conducta reiterada pueda ser considerada como indiciaria de la pérdida de unos determinados conocimientos, aptitudes, habilidades o comportamientos exigibles para la obtención y permanencia en la posesión de una licencia para conducir vehículos a motor. Ello es así porque la cancelación de la anotación de la sanción, al tener limitados sus efectos por imperativo legal al extremo de que puedan considerarse como antecedentes las sanciones anteriores cuya anotación se cancela, tiene como finalidad exclusiva anular los efectos penales ligados a la vigencia de la inscripción pero, como es lógico, no determina «per se» que si se ha dejado de estar en posesión de determinados conocimientos, aptitudes, habilidades, o pautas de comportamientos exigibles para obtener y continuar en la posesión de una licencia para conducir, esos conocimientos, aptitudes, habilidades o hábitos de comportamiento se recuperen por una simple actuación administrativa encaminada exclusivamente a dejar sin efecto, al único fin de agravación de las posibles sanciones futuras, infracciones anteriores" (F. 1)

Y que:

"El argumento del recurrente es incorrecto por cuanto el Real Decreto recurrido lo único que establece, partiendo de un hecho objetivo real y constatado, cual es la existencia de determinado número de sanciones por faltas graves o muy graves, es la procedencia de la apertura de un expediente administrativo, legalmente previsto en el artículo 63 de la Ley de Seguridad Vial, para, si se acredita la pérdida de alguno de los requisitos exigibles para la posesión de un permiso de conducir en materia de conocimientos, aptitudes, habilidades y comportamientos, proceder a la revocación de dicho permiso.

No se trata en modo alguno, como parece pretender la recurrente, de revocar por meras sospechas un permiso concedido, ni tampoco, es evidente, de iniciar el expediente en virtud de hechos no constatados. El Real Decreto impugnado únicamente establece unos supuestos que permiten establecer una presunción apta para iniciar el expediente de revocación, expediente que la propia Ley de Seguridad Vial establece se inicie en virtud de una presunción de carencia, por parte del titular del permiso, de los requisitos a cuyo mantenimiento se supedita legalmente por el propio precepto la vigencia de aquél, todo ello de conformidad con el artículo 63 de la citada Ley de Seguridad Vial" (F. 2) 


\section{El PLANTEAMIENTO FORMAL DE LA LeY 17/2005, DE 19 DE JULIO}

La introducción del sistema del permiso y licencia por puntos se realiza mediante la incorporación de una serie de determinaciones en el articulado de la LTSV.

Así, en el art. 60.4 LTSV se dispone que "el permiso y la licencia para conducir podrán tener vigencia limitada en el tiempo, y podrán ser revisados en los plazos y condiciones que reglamentariamente se determine" y que "de igual manera, la vigencia del permiso o la licencia de conducción estará condicionada a que su titular no haya perdido su asignación total de puntos...", en el art. 63 LTSV "la pérdida de vigencia de la autorización para conducir cuando su titular haya perdido la totalidad de los puntos asignados" y la determinación en el Anexo II de las infracciones que llevan aparejadas la pérdida de puntos.

Nótese como el legislador es, en este caso, bastante cuidadoso en cuanto a no dejar rastro formal alguno, en la parte de la norma en la que se regula el régimen sancionador (Título que, en ese momento, recibía la denominación de "infracciones y sanciones"), hasta el punto que la relación que se deriva de la pérdida de puntos por la comisión de infracciones se lleva a la disp. adic. primera LTSV ${ }^{15}$.

Pero todas estas cautelas desaparecen al explicar la reforma que se realiza y, así, desde el mismo inicio de la Exposición de Motivos de la Ley 17/2005, de 19 de julio (en la que el término "puntos" se repite de forma incesante a modo de letanía) se generan dudas sobre cuál ha de ser la naturaleza que corresponda a esa detracción de puntos, al manifestar que los dos elementos esenciales sobre los que se asienta el sistema son "su carácter eminentemente reeducador" y "su efecto punitivo" ${ }^{16}$, términos que

${ }^{15}$ En la que, bajo la rúbrica "pérdida de puntos en los permisos y licencias de conducción” se establecía que:

"Cuando un conductor sea sancionado en firme en vía administrativa por la comisión de alguna de las infracciones graves o muy graves que se relacionan en el anexo II, los puntos que corresponda descontar del crédito que posea en su permiso o licencia de conducción quedarán descontados de forma automática y simultánea en el momento en que se proceda a la anotación de la citada sanción en el Registro de conductores e infractores, quedando constancia en dicho Registro del crédito total de puntos de que disponga el titular de la autorización"

${ }^{16}$ En los cuatro primeros párrafos de la Exposición de Motivos de la Ley 17/2005, de 19 de julio se señala que:

"Se pretende con esta Ley establecer un sistema que ha dado en denominarse "permiso y licencia de conducción por puntos " y que, incidiendo sobre las autorizaciones administrativas para conducir, sea la combinación de dos elementos esenciales.

En primer lugar, su carácter eminentemente reeducador al configurar el cauce adecuado para modificar aquellos comportamientos, mediante la realización de cursos de sensibilización y reeducación vial de los conductores multirreincidentes, con el objetivo esencial de modificar los comportamientos infractores, cursos cuya superación, junto al cumplimiento de otros requisitos y pruebas que se establecen, permitirá la recuperación parcial o total del capital de puntos que, según los casos, corresponda a un conductor.

Esta voluntad reeducadora se va a llevar a cabo, esencialmente, con un claro objetivo de sensibilización y permanente llamada de atención sobre las gravísimas consecuencias que, para 
siembran la confusión en cuanto que podrían resultar base suficiente para afirmar el carácter sancionador que la propia reforma pretende negar cuando en esa misma Exposición de Motivos se indica que "no se trata, por otro lado, de idear una doble penalización para unos mismos hechos"17.

\section{LA DETRACCIÓN DE PUNTOS COMO SANCIÓN}

No fue necesario el transcurso de demasiado tiempo para que se planteara que la detracción de puntos era, en realidad, una medida de naturaleza sancionadora. De hecho podemos encontrar planteamientos que así lo entienden anteriores a la instauración en nuestro sistema del permiso de conducir por puntos. Es el caso de la Sentencia de las Sentencias del TEDH de 23 de septiembre de 1998 (caso Malige contra Francia) y de 6 de octubre de 2011 (caso Wagner contra Luxemburgo) ${ }^{18}$ en las que se determina que "aunque la medida de retirada presenta un carácter preventivo, reviste además un carácter punitivo y disuasivo y se parece por tanto a una pena accesoria" y que "la voluntad del legislador de disociar la sanción de retirada de puntos de las demás penas pronunciadas por el Juez penal no puede cambiar su naturaleza" ${ }^{19}$.

Entre nosotros no han faltado voces que han apuntado la naturaleza sancionadora de la detracción de puntos, corriente mayoritaria a la que se han unido resoluciones de diversos órganos de la Administración de Justicia. Incluso en este sentido se ha manifestado la naturaleza jurídica de la pérdida de puntos debe tener, forzosamente, la consideración de sanción siquiera sea como accesoria de la principal ${ }^{20}$, que es una

la seguridad vial y para la vida de las personas, tienen los comportamientos reincidentes en la inobservancia de las normas que regulan el fenómeno creciente y cada vez más complejo de la circulación o tránsito de vehículos a motor, poniendo así en permanente riesgo el primero de nuestros derechos fundamentales que es el derecho a la vida y a la integridad física y moral de los usuarios de las vías públicas.

$\mathrm{Y}$, en segundo lugar, su efecto punitivo para aquellos comportamientos, consistente en la disminución o pérdida del crédito en puntos con que cuenta un conductor, titular de permiso o licencia de conducción. Puntos que son, por otra parte, reflejo del nivel de confianza que como tal conductor le otorga la sociedad en un momento dado y cuya pérdida, a su vez, señala el reproche que tales conductas merecen, derivado y con un claro sustento en la reiterada comisión de infracciones".

17 Desafortunada expresión en cuanto que, literalmente, va más allá de la posibilidad de que una sanción concreta pueda estar compuesta por diversos elementos (como ocurría tradicionalmente, por ejemplo, en el caso de las infracciones muy graves en la LTSV hasta la reforma efectuada por medio de la Ley 1872009, de 23 de noviembre, a las que correspondía una sanción compuesta por una multa y una privación temporal de la autorización para conducir), al hacer uso de los términos "doble penalización" que, en puridad, serían más propios de una referencia al "non bis in idem".

${ }^{18}$ Algo sobre lo que ya se hizo eco MORENO TRAPIELLA en "Análisis de la regulación española del permiso de conducir por puntos y su confrontación con la jurisprudencia del Tribunal Europeo de Derechos Humanos", en el no 6.668 del Diario La Ley de 9 de marzo de 2007.

${ }^{19}$ STEDH de 23 de septiembre de 1998 (caso Malige), ap. 39.

${ }^{20}$ Las SSTSJ Canarias - Las Palmas de 8 y de 15 de mayo de 2009 (JUR 2009, 320676 y 292472) y de señalan que "a propósito de la naturaleza jurídica de la «pérdida de puntos», aunque la respuesta a esta 
sanción accesoria de la sanción económica ${ }^{21}$, aunque en otros casos se considere que se trata de una medida accesoria, de carácter preventivo, sin que esa medida, por sí misma suponga la pérdida de la autorización ${ }^{22}$, llegando el Tribunal Supremo a afirmar que "es indudable que la pérdida de puntos es una medida que tiene carácter materialmente sancionador" ${ }^{23}$.

Ante este caudal de valoraciones autorizadas la misión de contención se antoja demasiado ardua y lo sencillo es, sin duda, y aunque no se tenga demasiado claro (o se piense lo contrario ${ }^{24}$ ), sumarse a ese torrente de opinión uniforme y mantener lo que

cuestión no esté explícita -consciente y deliberadamente- en pasaje alguno del articulado de la Ley $17 / 2005$, de 19 de julio, por la que se regula el permiso y la licencia de conducción por puntos y se modifica el texto articulado de la ley sobre tráfico, circulación de vehículos a motor y seguridad vial, sin embargo, el carácter punitivo de la sedicente medida viene proclamado expresamente y sin rodeos en la Exposición de Motivos de la referida Ley. La conclusión obtenida no es baladí habida cuenta de la incidencia que en la tarea de cuantificar el valor del asunto litigioso debe tener, forzosamente, la consideración de la retirada de puntos como una tercera sanción, siquiera con la condición de accesoria de las principales".

${ }^{21}$ STSJ de Madrid de 3 de diciembre de 2009 (JUR 2010, 108723).

${ }^{22}$ La STSJ de Madrid de 16 de abril de 2010 (JUR 2010, 233406) en la que se afirma que:

"En el presente caso, aunque la cuantía del procedimiento se fijara en indeterminada, lo cierto es que la misma era perfectamente cuantificable. Se ha de señalar que en este supuesto enjuiciado la multa que se impugna en vía jurisdiccional es de $140 €$. La pérdida de dos puntos por parte del conductor sancionado en su carné de conducir es una medida accesoria a esa principal de la sanción económica, y, además, de carácter preventiva, que en ningún caso produce una disminución patrimonial que pueda ser evaluable a efectos de determinar la cuantía del recurso. El carácter preventivo viene determinado en que la indicada medida no supone la pérdida actual de la autorización administrativa para conducir, sino la posibilidad de que en el futuro, si se pierden otros puntos, se pueda producir ese hecho, de ahí el carácter igualmente intimidatorio que puede tener para el conductor esa consecuencia añadida a la multa pecuniaria. Pero, se reitera, esa medida no supone ya la pérdida de dicha autorización, porque ello acaecerá en el futuro si se cumplen otros requisitos (pérdida de todos los puntos) y por medio de una resolución que así lo acuerde" (F. 3).

Posición que también podemos encontrar, entre otras, en las SSTSJ de Madrid de 1 de abril de 2011 (JUR 2011, 187658), de 7 de julio de 2011 (JUR 2011, 309581), 18 de noviembre de 2011 (JUR 2012, 201246), 28 de noviembre de 2011 (JUR 2012, 200694), de 16 de diciembre de 2011 (JUR 2012, 200863) y de 14 de diciembre de 2012 JUR 2013, 44509).

${ }^{23}$ La STS de 4 de junio de 2009 (RJ 2009, 6502) señala que:

"Aunque la Abogacía del Estado se expresa en este punto con alguna indefinición, y pese a que la pérdida de puntos no aparece incluida en el catálogo de sanciones del art. 67 del Texto Articulado aprobado por Real Decreto Legislativo 339/1990, de 2 de marzo (redacción dada por la Ley $17 / 2005$, de 19 de julio), es indudable que la pérdida de puntos es una medida que tiene carácter materialmente sancionador. El que el descuento de los puntos no se haga efectivo sino cuando la sanción es firme no viene sino a confirmar la naturaleza sancionadora de la pérdida de puntos, pues es también después de la firmeza cuando se produce la anotación de sanción en el Registro de conductores e infractores (art. 82 y disp. adicional segunda del Texto Articulado, según modificación introducida por la Ley 17/2005, de 19 de julio)".

${ }^{24}$ Caso de CASINO RUBIO que mantiene la naturaleza de revocación ("La disputada naturaleza jurídica de la declaración de pérdida de vigencia del permiso de conducción por extinción del saldo de puntos", 
parece evidente, esto es, que nos encontramos ante una medida de carácter sancionador y que "la actual configuración de la pérdida de puntos, y de la eventual revocación del permiso de conducir por ese motivo, encaja mucho mejor en el concepto de sanción administrativa que ofrece nuestro Derecho que en otras medidas como pueden ser la revocación de la autorización por incumplimiento de las condiciones a que se somete o por la pérdida sobrevenida de la capacidad para conducir". ${ }^{25}$ Todo parece apuntar hacia ello y no son pocos (ni poco cualificados, precisamente) los que así lo señalan. Pero, tal vez, antes de hacerlo no esté de más hacer algunas reflexiones, aunque ello nos lleve a esa misma conclusión o alguna que pudiera ser parecida.

\section{UN ANÁLISIS DIFERENCIAL ALTERNATIVO \\ a) Una premisa como punto de partida}

Con independencia de cuál sea la interpretación que de la detracción de puntos y de la pérdida de vigencia de la autorización para conducir se efectúe si parece que pueda encontrarse un punto de partida común, admisible de manera general, como es el hecho de considerar que la intención de quién puso letra al permiso por puntos quería construir un sistema que no tuviera naturaleza sancionadora algo que, por sí mismo, no resulta suficiente para modificar, caso de tenerlo, ese carácter punitivo ${ }^{26}$.

Así planteado, y admitida esta premisa, el problema se centra en resolver dos cuestiones. La primera si el legislador logró ese objetivo, algo que, como hemos señalado en el apartado anterior, mayoritariamente se niega. La segunda si resulta posible la construcción de un sistema de este tipo sin que sea preciso acudir a técnicas sancionadoras.

\section{b) El sistema y sus elementos (el sistema por puntos y los puntos)}

El permiso por puntos se configura como un sistema ${ }^{27}$ que se articula en torno a una serie de elementos. Uno de ellos es la consecuencia, como cumplimiento de una serie

Documentación Administrativa, no 284 - 285, mayo - diciembre 2009, págs. 264 - 270) y el mío propio al tiempo de promulgarse la Ley 17/2005, de 19 de julio (Permiso y Licencia de conducción por puntos, Aranzadi, 2006).

${ }^{25}$ CANO CAMPOS, T. “¿Es una sanción la retirada de puntos del permiso de conducir?”, RAP, no 184, enero - abril, 2011, pág. 115.

${ }^{26}$ Como advertía de forma expresa la STEDH de 23 de septiembre de 1998 (caso Malige), a la que ya se ha hecho referencia, al señalar que "la voluntad del legislador de disociar la sanción de retirada de puntos de las demás penas pronunciadas por el Juez penal no puede cambiar su naturaleza".

${ }^{27}$ Así lo señala la Exposición de Motivos de la Ley 17/2005, de 19 de julio, es su mismo inicio al indicar que "se pretende con esta Ley establecer un sistema que ha dado en denominarse "permiso y licencia 
de requisitos ${ }^{28}$, de que el titular del permiso o licencia de conducción deja de disponer de los efectos que la previa obtención de esa autorización le atribuye, ese titular, cuando se queda sin puntos, deja de estar habilitado para la conducción de vehículos. Formalmente, y así lo indica la Ley (art. 63.6 LTSV), porque la inexistencia de saldo, la pérdida de todos los puntos, conlleva que la Administración declare la pérdida de vigencia de esa autorización. Materialmente, y conforme señalan los tribunales y la doctrina más autorizada, por la imposición de una sanción cuyo contenido es, precisamente, la prohibición de conducir.

En ambos supuestos el titular pierde la cobertura de esa licencia. En un caso por haber desaparecido los requisitos que se exigen para su mantenimiento. En otro porque se le impone una sanción.

Y ello se sustenta en el elemento instrumental que da nombre al sistema: los puntos. Es preciso que el titular conserve algún punto (al menos uno de ellos) para que la autorización produzca sus efectos o no se imponga la sanción por la que se le priva del derecho a conducir vehículos (a motor y ciclomotores).

Pero el sistema está planteado (art. 60 LTSV) de manera que los puntos se asignan, se conservan, se pierden, se obtienen, se recuperan... y mientras el titular mantenga uno de esos puntos conserva la autorización. Y ello, independientemente del número de infracciones cometidas y de los puntos que a lo largo del tiempo haya llegado a perder.

Desde ese punto de vista la cuestión es si la pérdida de puntos es una sanción en todo caso o, únicamente, cuando conlleve de manera efectiva la privación del derecho a conducir. Y así nos encontramos con Sentencias, como la del TS de STS de 4 de junio de 2009 (RJ 2009, 6502), la del TSJ de Madrid de 3 de diciembre de 2009 (JUR 2010, 108723) o las del TSJ de Canarias - Las Palmas Las SSTSJ Canarias - Las Palmas de 8 y de 15 de mayo de 2009 (JUR 2009, 320676 y 292472) que consideran que la pérdida de puntos es una sanción y lo es en todo caso, y con resoluciones judiciales (las ya referidas del propio TSJ de Madrid) que, en el caso de las detracciones de puntos que no suponen el agotamiento del saldo de puntos, se muestran más cautas y se refieren a esa pérdida de puntos como "una medida accesoria a esa principal de la sanción económica", medida que se califica de "preventiva" e, incluso, de "intimidatoria". Sanción en todo caso, sanción en algunos casos, sanción cuando, en el marco de otro procedimiento se produce la declaración de pérdida de vigencia de la autorización,

de conducción por puntos» y que, incidiendo sobre las autorizaciones administrativas para conducir, sea la combinación de dos elementos esenciales".

Sobre el análisis de los sistemas jurídicos véase GonZÁlez NAVARRo, Francisco Derecho Administrativo Español, Tomo I, EUNSA, Pamplona, 3a Ed. 1995, pp. 459 y ss.

${ }^{28}$ En los términos empleados por las Sentencias del TSJ de Madrid a las que se ha hecho referencia en la nota 22 de este mismo capítulo cuando se señala que "esa medida (en referencia a la pérdida de puntos) no supone ya la pérdida de dicha autorización, porque ello acaecerá en el futuro si se cumplen otros requisitos (pérdida de todos los puntos) y por medio de una resolución que así lo acuerde" (F. 3)." 
sanción con una eficacia demorada en el tiempo y sometida a la acumulación con otras sanciones que, en conjunto, supongan la pérdida de todos los puntos del titular de la autorización para conducir...

\section{c) La consecuencia}

De igual manera podemos aislar la consecuencia prevista para el caso en el que el titular del permiso se quede sin puntos. En el plano específico calificaremos ese resultado como pérdida de vigencia por desaparición de los requisitos o como sanción. Supuestos, ambos, que difieren de la medida de suspensión (o privación) de la autorización para conducir prevista, como sanción, en el régimen anterior. Pero desde una perspectiva general y práctica en todos estos casos lo que sucede es que se impide conducir a quien disponía de la autorización administrativa exigida para ello, se le priva de ese derecho.

Pero el sistema previsto en el art. 63.6 LTSV es un poco más complejo. Los tres párrafos en los que se descompone el referido apartado de la Ley no se limitan a determinar la declaración de pérdida de vigencia del permiso o licencia (apartado 1), al establecer que ese titular no podrá volver a obtener la autorización hasta transcurridos seis meses -tres meses en el caso de los conductores profesionales- (apartado 2), períodos de tiempo que se multiplican por dos en el caso de una nueva pérdida de totalidad de los puntos (apartado 3).

Aunque estas previsiones tienden a confundirse, pueden diferenciarse dos elementos distintos. De un lado, la pérdida de vigencia $y$, de otro, una medida temporal de prohibición de obtener (recuperar) la autorización administrativa que toma en consideración, en cuanto a su duración, al tipo de conductor e incorpora mecanismos de reincidencia.

Esta segunda medida, la que establece un plazo de tiempo durante el cual el titular de la autorización cuya pérdida de vigencia se declara, si muestra los elementos propios de una sanción.

Si esto es así, y se considera que la privación del permiso de conducir (su declaración de pérdida de vigencia) es una sanción porque se impide al titular su obtención durante un espacio de tiempo, habría que plantearse lo que sucedería en el caso de que la norma se limitase a la declaración de pérdida de vigencia, algo que resulta mucho más coherente con la causa de la que se deriva y que es, no lo olvidemos, la desaparición de los conocimientos o comportamientos que se requieren para conducir. La previsión sería, al igual que en el resto de requisitos, someterse y superar las pruebas que permiten el control de esos conocimientos y habilidades, es decir, volver a pasar las pruebas establecidas para la obtención de la autorización, en los términos 
establecidos, de manera general, para el resto de supuestos en el art. 36.3 B) a) RGCon.

\section{d) Algunas reflexiones y una conclusión provisional}

La privación del derecho a conducir por la declaración de pérdida de vigencia de la autorización administrativa para conducir como consecuencia de la pérdida de los puntos asignados a su titular ha convivido (en el período que abarca desde la Ley 17/2005, de 19 de julio, hasta la Ley 18/2009, de 23 de noviembre) con la sanción de suspensión de la autorización, previsión que aunque no está vigente por no figurar entre las previstas en la actualidad en el art. 67 LTSV sigue influyendo en cuanto a la forma de de percibir y entender cualquier medida que suponga, de una forma o de otra, la privación de derecho a conducir.

La regulación que, de manera previa, puede ser tomada como antecedente de la pérdida de vigencia por pérdida de la totalidad de los puntos era la revocación que, como hemos tenido oportunidad de analizar, introducida en el art. 67.3 LTSV por la Ley 19/2001, de 19 de diciembre, era una sanción durísima, al impedir la obtención de la autorización en tanto en cuanto no se hubieran cancelado la sanción que la hubiera originado. Si bien es cierto que como alternativa se ofrecía una posibilidad transaccional para suavizar esas consecuencias y que, frente a esa amenaza, se constituía en invitación al acuerdo.

La pérdida de vigencia no es una sanción en todo caso. Ni siquiera en el marco del Tráfico y seguridad Vial. No es, por ejemplo, en el caso previsto en el art. 35 del Reglamento de Escuelas particulares de conductores aprobado por el RD 1295/2003, de 17 de octubre, que exige, como condición, el mantenimiento de los requisitos para su otorgamiento.

Vincular la naturaleza de la pérdida de la autorización administrativa al de una sanción, y hacerlo en todo caso, puede ser objeto de discusión. El hecho de que la normativa vigente fije un espacio de tiempo determinado puede no ser razón suficiente. Un cambio en los términos eliminado al plazo e imponiendo otros requisitos que requieran del transcurso de tiempo para ser cumplidos produciría las mismas consecuencias. $^{29}$

En definitiva, nos encontramos con tres planos diferentes. De un lado lo que se quiso hacer, eludiendo el que fuera una sanción y buscando la protección de la ubicación de la pérdida de vigencia. De otro lo que, de manera efectiva, parece ser que se logró, y

\footnotetext{
${ }^{29}$ Imaginemos que en lugar del plazo de seis meses (tres para profesionales) se impone, como forma de determinar, controlar y comprobar que concurren los requisitos de conocimientos y habilidades, un curso de 300 horas que, incluso, podría ser gratuito...
} 
que mayoritariamente se entiende que es una sanción. $Y$, finalmente, las discusiones sobre esa interpretación el hecho de que, en sucesivas reformas, se llegara a modificar la naturaleza del sistema establecido.

Pero es que, además, se ignora que la tramitación de esa medida, la de declaración de pérdida de vigencia de las autorizaciones para conducir (sancionadora o no), tiene previsto, al margen de lo regulado en el régimen sancionador de la Ley y de los arts. 70 a 82 LTSV en los que se regula el procedimiento sancionador en materia de tráfico y seguridad vial, un cauce de tramitación específico en el marco de los arts. 34 a 40 Reglamento General de Conductores (RGCon).

\section{EL PROCEDIMIENTO PARA LA DECLARACIÓN DE PÉRDIDA DE VIGENCIA}

\section{A) Ubicación}

Las previsiones efectuadas en el art. 63.6 LTSV sobre la declaración por la Administración de la pérdida de vigencia de la autorización por la pérdida de los puntos asignados se articulan conforme a lo establecido en el Reglamento General de Conductores (RGCon) para ese tipo de procedimientos.

De esta forma, el RGCon desarrolla, de manera coherente, las previsiones conforme a lo establecido en la propia LTSV.

De manera que, mientras que la detracción de puntos en los supuestos en los que, conforme a lo dispuesto en el Anexo II LTSV así este previsto, se realiza en el marco del propio procedimiento sancionador en el que se depuran las responsabilidades por la comisión de infracciones y, caso de que la sanción impuesta adquiera firmeza, serán anotados, junto con la propia sanción por la infracción grave o muy grave a la que acompañan, en el Registro de Conductores e Infractores.

Ello resuelve la primera cuestión que, en el plano teórico, se podría formular, ya que los puntos y su detracción, en cuanto que están asociados a determinadas infracciones siguen su misma tramitación y obtienen, por tanto, las mismas garantías previstas y establecidas para la imposición de las sanciones conforme al procedimiento establecido en los arts. 70 a 82 LTSV.

Tras la aprobación de la Ley 17/2005, de 19 de julio, el RD 62/2006, de 27 de enero, modificó en entonces vigente RGCon/1997 (RD 772/1997, de 30 de mayo) que, posteriormente, sería derogado por el vigente RGCon aprobado por el RD 818/2009, de 8 de mayo, de manera que el procedimiento para la declaración de la pérdida de vigencia del permiso o licencia de conducción por haber perdido su titular la totalidad de los puntos asignados se encuentra regulado en el seno de la regulación reglamentaria de las autorizaciones administrativas para conducir efectuada en el 
RGCon, en coherente desarrollo, como se ha puesto de manifiesto, con las previsiones efectuadas, en este ámbito por los arts. 60 y 63 LTSV.

Así, en los arts. 34 a 40 RGCon, se realizan las prescripciones correspondientes sobre "la nulidad o lesividad y pérdida de vigencia de las autorizaciones administrativas para conducir", marco en el que podemos encontrar las prescripciones genéricas y un precepto en el que, de manera específica, el art. 37 RGCon, con el que se pretende la ordenación del "procedimiento para la declaración de pérdida de vigencia por la pérdida total de los puntos asignados".

\section{B) El Procedimiento de declaración de pérdida de vigencia}

\section{EL PRESUPUESTO}

La causa que origina la declaración de la pérdida de vigencia de la autorización administrativa para conducir es la pérdida total de los puntos asignados. Puntos que se inscriben en el Registro de Conductores e Infractores ${ }^{30}$ una vez que las sanciones graves o muy graves, impuestas por infracciones a las que el Anexo II LTSV atribuye la pérdida de puntos, han ganado firmeza ${ }^{31}$.

La vigente redacción del art. 35.1 RGCon dispone que "se declarará la pérdida de vigencia de las autorizaciones administrativas cuyo titular no posea los requisitos para su otorgamiento o haya perdido totalmente su asignación de puntos" términos de los que se desprende que se trata de dos supuestos distintos (de una lado los requisitos exigidos para su otorgamiento $y$, de otro, la carencia de puntos) y que se materializa en dos artículos distintos (arts. 36 y 37 RGCon) en los que se regulan de manera separada $^{32}$.

\footnotetext{
${ }^{30} \mathrm{Al}$ ser el "crédito de puntos del que se dispone", conforme establece el 77 k) del propio RGCon, uno de los datos que han de figurar en el Registro de Conductores e Infractores.

${ }^{31}$ Recuérdese que, conforme determina el art. 93.1 LTSV “las sanciones graves y muy graves deberán ser comunicadas al Registro de Conductores e Infractores por la autoridad que la hubiera impuesto en el plazo de quince días naturales siguientes a su firmeza en vía administrativa".

${ }^{32}$ Los términos empleados en el RGCon/2009 no se corresponden, exactamente, con los empleados por el RGCon/1997 (en la redacción recibida del RD 62/2006, de 27 de enero), que en el art. 39.1 establecía que "con independencia de lo dispuesto en el artículo anterior, la vigencia de las autorizaciones para conducir estará condicionada a que su titular mantenga los requisitos exigidos para su otorgamiento y a que no haya perdido su asignación total de puntos", términos que venía a equiparar ambos supuestos (mantenimiento de requisitos y conservación de puntos) mucho más que la vigente redacción en la que la partícula "o", como conjunción disyuntiva, y diferenciadora, viene a determinar dos supuestos distintos, algo de lo que se puede inferir (y apoyar la tesis) del diferente carácter de este supuesto, frente a los requisitos exigidos para la obtención de la autorización, y su naturaleza sancionadora.
} 


\section{COMPETENCIA}

El art. 35.2 RGCon concreta la previsión efectuada por el art. 63.6 LTSV en cuanto a la declaración de pérdida de vigencia y atribuye esa competencia al Jefe Provincial de Tráfico, y que el art. 37.3 del propio RGCon precisa en el Jefe de Tráfico de la provincia correspondiente al domicilio del titular de la autorización, cuestión que puede, en la práctica, plantear alguna duda en función de que limitemos la determinación a la establecida en la propia autorización y que ha de figurar en el Registro de Conductores e Infractores o se pretenda hacer uso de otras posibilidades, como las previstas en la LTSV en el marco del procedimiento administrativo sancionador ${ }^{33}$.

Aunque a buen seguro habrá todo tipo de interpretaciones garantistas, entiendo que el deber del titular establecido en el art. 10 RGCon de mantener actualizados los datos que figuran en el permiso y la expresa referencia que en ese precepto se realiza al "domicilio del titular" son motivo suficiente para tomar ese lugar como el determinante a la hora de establecer la competencia para la tramitación del procedimiento de pérdida de vigencia.

Esta atribución de competencia se corresponde con la genéricamente establecida, tras la reforma efectuada en la LTSV por la Ley 18/2009, de 23 de noviembre, que residencia en los a los Jefes Provinciales el común de las competencias, como es el caso de la sancionadora fijada en el art. 71.2 LTSV.

\section{LA TRAMitACIÓN}

El art. 37 RGCon determina la forma en la que se ha de tramitar este procedimiento mediante la determinación de unas sencillas prescripciones.

El presupuesto para su inicio, como se ha señalado, es la constatación del hecho de que el titular de la autorización carece de puntos por haberlos perdido todos, lo que implica la firmeza de las diferentes sanciones que suponen detracción de puntos, la inscripción de las mismas en el Registro de Conductores e Infractores y que los efectos de esas substracciones determinen la inexistencia de puntos.

El acuerdo del Jefe Provincial de Tráfico constatará ese hecho y tendrá que contener "una relación detallada de las resoluciones sancionadoras firmes en vía administrativa que hubieran dado lugar a la pérdida de los puntos, con indicación del número de puntos que a cada una de ellas hubiera correspondido", es decir, la aportación de los datos que permitan determinar la pérdida de todos los puntos asignados.

\footnotetext{
${ }^{33}$ Véase, sobre ello, el apartado destinado en esta obra al análisis de la notificación en el procedimiento administrativo sancionador.
} 
El propio art. 37.1 RGCon prevé la participación del titular de la autorización, objeto del procedimiento, al que se le dará vista del expediente en los términos previstos en la LRJ - PAC, referencia que nos sitúa en las previsiones que, sobre la participación de los interesados se efectúan en el art. 84 LRJ - PAC, concediendo al titular de la autorización (el interesado en ese procedimiento) un plazo máximo de diez días para formular las alegaciones que estime conveniente ${ }^{34}$.

El art. 37.2 RGCon adopta una posición de predestinación ya que automatiza el resultado del procedimiento al establecer que, transcurrido ese plazo, "el Jefe Provincial de Tráfico dictará resolución declarando la pérdida de vigencia del permiso o de la licencia de conducción", sin que se prevea ninguna otra posibilidad, ni que pueda suceder algo diferente, y ello independientemente de lo que pudiera haber alegado y probado el interesado. Es cierto que el procedimiento, como el propio sistema del permiso por puntos en el que se inserta esta declaración de pérdida de vigencia por la pérdida de todos los puntos, se fundamenta en unos hechos (sanciones firmes por la comisión de infracciones que suponen la pérdida de puntos e inscripción en el Registro de Conductores e Infractores) que tienden a producir un efecto matemático, en cuanto a la pérdida de los puntos, de la que se sigue la declaración de pérdida de vigencia. Pero la práctica demuestra la existencia de situaciones imprevistas, cuando no de errores, que no aconsejan una redacción en términos que denotan una infalibilidad que no puede predicarse (como norma absoluta) de ninguna obra humana, ni siquiera del sistema del permiso por puntos. Por ello, por la existencia de posibilidades que se salen de ese cauce preestablecido, el RGCon no puede pretender que iniciado el procedimiento para declarar la pérdida de vigencia por la pérdida de todos los puntos ello haya de suponer, de manera necesaria y en todo caso, la adopción de una resolución en ese sentido. Parece que ello será la normal, siempre y cuando el procedimiento ponga de manifiesto la realidad de esa previa constatación.

En ese caso, se dictará la resolución correspondiente declarando la pérdida de vigencia del permiso o de la licencia de conducción, resolución que ha de ser notificada al interesado, para lo que el art. 37.2 RGCon ofrece un plazo de quince días, en los términos previstos en la LRJ - PAC, de lo que se desprende que resultan aplicables, por tanto, las previsiones establecidas en los arts. 58 y 59 LRJ - PAC, y no las previsiones de del especial y específico sistema establecido en la LTSV tanto para las denuncias que no se entreguen en el acto y las demás notificaciones a que dé lugar el procedimiento sancionador previstas en el marco del procedimiento sancionador en materia de tráfico y seguridad vial.

\footnotetext{
${ }^{34}$ Forma de establecer el plazo, como derecho del interesado, en un "máximo de diez días" que, aunque lo respeta, no se corresponde con lo previsto en el art. 84.2 LRJ - PAC en cuanto que en este precepto se dispone que "los interesados, en un plazo no inferior a diez días ni superior a quince, podrán alegar y presentar los documentos y justificaciones que estimen pertinentes", de manera que el espacio mínimo establecido en la LRJ - PAC se viene a corresponder con el máximo permitido en el RGCon.
} 
Esa resolución por la que se declara la pérdida de vigencia de la autorización para conducir deberá ser entregada por el titular en la Jefatura Provincial de Tráfico. A ello se añaden las previsiones que sobre suspensión cautelar y efectos se efectúan en los arts. 39 y 40 del propio RGCon.

\section{ALGUNAS CONSIDERACIONES ADICIONALES Y UNA CONCLUSIÓN}

La regulación, de manera específica, de un procedimiento para la declaración de pérdida de vigencia por la pérdida total de los puntos asignados plantea una serie de cuestiones que, en la mayoría de los casos, se encuentran relacionadas con la propia naturaleza de esta medida.

La defensa del carácter sancionador de la detracción de puntos y de la privación de la autorización para conducir por ese motivo tendría como consecuencia la necesidad de tramitar ese acuerdo y resolución de pérdida de vigencia conforme a las normas establecidas en los arts. 70 a 82 LTSV, ya que como señala el primero de esos preceptos no se podrá imponer sanción alguna por las infracciones tipificadas en la LTSV "sino en virtud del procedimiento instruido conforme a lo dispuesto en el presente capítulo y en las disposiciones reglamentarias que lo desarrollen" $y$, supletoriamente, por la LRJ - PAC y el REPEPOS.

Ello afectaría a las previsiones establecidas en el RGCon y a las que, de manera general, le resultan aplicables. Es el caso del régimen de recursos, que para las resoluciones adoptadas en el marco de lo previsto en el art. 37 RGCon y las previsiones de la LRJ PAC suponen la impugnación mediante el correspondiente recurso de alzada, algo que no sucede en el caso de las sanciones en materia de tráfico y seguridad vial, puesto que la resolución pone fin a la vía administrativa (art. 82.1 LTSV) y frente a ella únicamente cabe el recurso potestativo de reposición (art. 82.2 LTSV), lo que, a su vez, supone que el conocimiento de ese recurso está atribuido, en el caso de la alzada, al superior jerárquico, es decir, al Director General de Tráfico, mientras que el de reposición compete al propio Jefe Provincial de Tráfico.

Si la detracción de puntos, y la pérdida de vigencia de la autorización por ese motivo, "es una medida que tiene carácter materialmente sancionador" (STS de 4 de junio de 2009, RJ 2009, 6502 ${ }^{35}$ ) habrán de tramitarse como tales y mediante el procedimiento legalmente establecido para ello. Pero en esa misma resolución del Tribunal Supremo, y frente a la impugnación de las previsiones efectuadas en el RGCon por las que se

\footnotetext{
${ }^{35}$ A la que nos hemos referido anteriormente y a la que se hace referencia en la nota 23 de este mismo capítulo, y que si bien está referida al derogado RGCon/1997 lo es en la redacción recibida del RD 62/2006, de 27 de enero, que lo adaptaba a lo dispuesto en la Ley 17/2005, de 19 de julio, por la que se introducía en la LTSV el sistema de las autorizaciones por puntos y que se ha mantenido en el vigente RGCon.
} 
regulaba un procedimiento al margen del establecido para la imposición de sanciones en materia de tráfico y seguridad vial, se considera que la pérdida de vigencia del permiso "no es el efecto directamente derivado de una concreta actuación sancionadora sino una consecuencia de segundo grado a la que se llega por agregación de los efectos de varias infracciones" y "de ahí que se articule un procedimiento autónomo, en el que se da audiencia del interesado, con la específica finalidad de asegurar que esa declaración de pérdida de vigencia del permiso se ajusta a las previsiones legales". Lo que muestra como el propio Tribunal Supremo ha atribuido y ha negado el carácter materialmente sancionador de esta medida ${ }^{36}$.

Sigo creyendo que es posible defender la naturaleza que el legislador quiso atribuir al permiso por puntos hay bastante de cierto en pensar que "la LTSV ha incluido la «peligrosidad» del conductor como requisito de aptitud para poder obtener el permiso de conducir" ${ }^{37}$. Aunque, a fin de cuentas, tal vez hubiera resultado mucho más simple establecer, de manera expresa, que los puntos y sus consecuencias eran una sanción. De esa forma nada habría que discutir sobre su naturaleza, no sería preciso regular un procedimiento diferente al establecido por la LTSV para la imposición de sanciones, no se tendrían que tramitar procedimientos diferentes sometidos a normas distintas, la pérdida de vigencia no sería impugnable en alzada y se les podría aplicar el régimen de notificaciones establecido para el procedimiento sancionador y todas las comunicaciones a que dé lugar, con Dirección Electrónica Vial (DEV) y Tablón Edictal de Sanciones de Tráfico (TESTRA) incluidos.

Concepto, el de "peligrosidad", que algunos años después pudiera enlazarse con aquella idea de que "la responsabilidad de quienes, sirviéndose de aquellos medios en forma antirreglamentaria o menospreciando su riesgo constituyen un peligro para la seguridad de las personas o las cosas" con la que se cerraba la explicación que precedía a la Ley 47/1959, de 30 de julio, sobre regulación de la competencia en materia de tráfico en el territorio nacional, a la que ya hemos hecho referencia y que se me antoja constituye el paso entre la represión y la prevención.

\footnotetext{
${ }^{36}$ Lo que unido a todas las posiciones que sobre esta cuestión se han mantenido por los diferentes órganos jurisdiccionales recuerda la parábola del portal de Belén expuesta por Nieto (El arbitrio judicial, Ariel, Barcelona, 2000, pág. 400 y ss.)

37 Como manifiesta CASINO RUBIO ("La disputada naturaleza jurídica de la declaración de pérdida de vigencia del permiso de conducción por extinción del saldo de puntos", Documentación Administrativa, no 284 - 285, mayo - diciembre 2009, págs. 266) que añade "lo único que sucede, bien se comprende, es que esa peligrosidad y, por tanto, la capacidad o no para conducir sin riesgo no puede verificarse ex ante al tiempo del otorgamiento del permiso, salvo a través de un inaceptable juicio de intenciones. Sencillamente, como es trivial, porque en ese momento la Administración desconoce el comportamiento del futuro conductor e ignora, por lo tanto, si el titular del permiso de conducir va a utilizarlo luego con riesgo o no para la seguridad del tráfico", afirmación que completa con una nota en la que señala que "Tengo por seguro que si la Administración conociera al tiempo de la correspondiente solicitud del permiso que el interesado es, por las razones que sean, una persona peligrosa para la seguridad vial no dudaría en denegar su concesión por incumplimiento de los requisitos de aptitud personal necesarios".
} 
Porque, tal vez, el determinar que la pérdida de puntos y la privación de la autorización (ya se trate de una pérdida de vigencia, sanción material o consecuencia sancionatoria de segundo grado) es un sanción, sea (y lo sea al mismo tiempo) la regulación que mejor garantice la defensa de los interesados y la que resulte más eficaz para la defensa de los intereses que el régimen sancionador en materia de tráfico y seguridad vial encarna y tiene la obligación de cumplir, como medio ya no solo de reprimir a un individuo sino, y al mismo tiempo, de prevenir la seguridad colectiva con fin último y prioritario del sistema. 
Del análisis efectuado a lo largo de los capítulos precedentes se derivan las siguientes CONCLUSIONES:

1) La evolución del procedimiento sancionador en materia de tráfico y seguridad vial ha sido muy importante en los últimos años, pero hasta momentos muy recientes ha sido lenta, ha mantenido una gran distancia con la necesidad social que pretendía regular y no ha estado enfocada hacia su auténtica finalidad.

Así, el procedimiento sancionador se ha limitado a ser un cauce a través del que canalizar la represión particular de conductas contrarias a la ordenación establecida, sin atender a su primordial misión de garantizar la seguridad vial.

2) El procedimiento sancionador en materia de tráfico y seguridad vial es un medio activo de prevención de la seguridad vial, y así tiene que ser considerado $y$, por tanto, su regulación tiene que girar sobre esa idea.

El procedimiento administrativo sancionador es un instrumento de protección de la seguridad vial. Ciertamente es el cauce para la imposición de sanciones, pero el procedimiento sancionador no se agota en esa finalidad. Es una herramienta activa y se constituye en la palanca más poderosa de entre las que dispone la Administración para luchar contra la siniestralidad vial.

3) Para que el procedimiento sancionador en materia de tráfico y seguridad vial cumpla con esa función tiene que ser eficiente, y esa eficiencia no se mide ni por el número de sanciones impuestas ni por el dinero recaudado.

La eficiencia del sistema se mide por la capacidad de imponer la sanción prevista en el menor plazo de tiempo y conforme al sistema establecido, respetando todas las garantías que el ordenamiento otorga al responsable. La percepción por el ciudadano de que le sistema es eficaz, y de que si comete una infracción va a ser sancionado, incrementa (exponencialmente) la eficiencia del sistema y redunda, por tanto, en la seguridad vial.

4) A pesar de todas las carencias que el sistema presenta, y que no son pocos, se puede afirmar que el procedimiento administrativo sancionador en materia de tráfico y seguridad vial ha mejorado.

En los últimos años (desde 2005) se ha hecho más eficiente y ello ha supuesto un descenso de la siniestralidad, muestra evidente de que la línea seguida es correcta. Pero ello no significa que no existan carencias y disfunciones, que es necesario corregir para dotar al sistema de una mayor consistencia $y$, en consecuencia, de un mayor grado de efectividad. 
5) En el plano interno del procedimiento administrativo sancionador resulta preciso introducir diversas modificaciones:

a) Acometer la regulación de las personas responsables, delimitando de una forma precisa e inequívoca, su posición. Ello requiere de la depuración de las infracciones y de la conducta que se tipifica, determinado, de forma clara e inteligible, la posición del autor y la del resto de responsables designados como garantes de esas conductas.

b) Determinar, de manera precisa y coherente, la forma y el lugar en que se han de realizar las notificaciones $y$, en particular, en la designación de lo que se haya de entender por domicilio a efectos de esas notificaciones, la prelación de los lugares de comunicación y la actuación que ha de realizar la Administración para que se entienda cumplido con ese deber.

c) Precisar los derechos y obligaciones que corresponden al titular del vehículo, por el hecho de serlo, y establecer un estatuto que defina esa posición, dada la posición de garante en la que se le ubica.

d) Definir con claridad los elementos formales y materiales que, en la práctica, se ha mostrado como ambiguos en el procedimiento sancionador abreviado, sin olvidar, eso sí, en ningún momento todo lo que se ha conseguido con su implantación.

6) En el marco general del procedimiento administrativo resulta necesario desarrollar las medidas para la necesaria adaptación a la Administración electrónica y la regulación que en nuestro sistema se efectúa para ella.

La LTSV ha evolucionado creando un marco específico, que resulta preciso seguir desarrollando y puliendo para conjugar las garantías que se establece para el ciudadano con las medidas que doten de eficacia y eficiencia al sistema.

7) En el escenario punitivo global se hace preciso dar coherencia al conjunto de medidas, administrativas y penales, y a la necesaria coordinación en el caso de concurrencia de actuaciones.

En el escenario actual no existe la necesaria coordinación entre los tipos penales y las infracciones administrativas calificadas como muy. Es necesario determinar los espacios de actuación correspondientes a cada ámbito y dar coherencia al ius punitivo en su conjunto.

8) En el marco trasnacional y, en particular, en el ámbito de la Unión Europea, se hace preciso desarrollar medidas que permitan el tratamiento de las infracciones contra la seguridad vial de una forma global, independientemente del lugar en el que se hayan cometido y la nacionalidad del sujeto responsable. 
No es posible que en el marco de la Unión Europea las responsabilidades se diluyan por el hecho de que el responsable sea nacional de otro Estado miembro.

9) Uno de los elementos que se ha mostrado como claves en la reducción de la siniestralidad vial ha sido, sin lugar a dudas, el permiso de conducir por puntos. Es preciso precisar su ubicación en el sistema y determinar, de forma clara e inequívoca, su naturaleza, algo que habrá de hacerse no desde el voluntarismo, sino desde el análisis de cuál sea el lugar en el que su delimitación se muestre más eficaz y eficiente.

10) Todo ello muestra la importancia de la norma jurídica, y la necesidad de su eficiencia, que ha de encontrar su fundamento en su propia razonabilidad y consistencia.

\section{COROLARIO}

Frente a la tentación de despreciar la norma jurídica como instrumento al servicio de las necesidades sociales, la regulación del procedimiento sancionador se presenta como una de las mayores palancas (sino la mayor) para garantizar la seguridad vial. Frente a los avances conseguidos, y que se han materializado en la reducción de víctimas en la actividad del tráfico, lo que supone que se han salvado vidas (miles de vidas), no cabe más que el continua análisis de las mejoras que, en la regulación del procedimiento administrativo sancionador, puedan permitir acercarse al ideal que representa la seguridad vial. 


\section{Bibliografía}

ACín FERRER, ÁNGelA: "Multas: nuevas perspectivas para la imposición y recaudación de multas de tráfico", Tributos Locales, no 83, 2008, Págs. 67-68.

"La revolucionaria simplificación del procedimiento de recaudación de multas de tráfico", La administración práctica: enciclopedia de administración municipal, no 2/2009, Bayer Hermanos, págs. 149 - 155.

"Procedimiento administrativo: Notificaciones telemáticas. Aplicación en las entidades locales" en La Administración Práctica, no 9/2011, Aranzadi, págs. 749 - 755.

"Tráfico: Impuesto sobre vehículos de tracción mecánica, Sanciones por infracciones de tráfico, Notificaciones" en La Administración Práctica, no 1/2012, Aranzadi, 2012

"Sanciones. Notificaciones de sanciones de tráfico. Procedimiento", La administración práctica: enciclopedia de administración municipal, no 7/2012, Aranzadi, págs. 571 576.

AGUADO I CUDOLÀ, VICENÇ: "El procedimiento administrativo sancionador en materia de tráfico, circulación de vehículos a motor y seguridad vial: El debido equilibrio entre especialidades y garantías comunes", Documentación Administrativa, № $284-285$, mayo - diciembre 2009, págs. 11 - 31.

Alamo GonzÁlez, NAYRA: La utilización de las nuevas tecnologías en las relaciones entre las Administraciones Públicas y los ciudadanos (en particular, registros telemáticos y notificaciones telemáticas): hacia un cambio de modelo, Revista Española de Derecho Administrativo, no 133, Civitas, 2007, págs. 89 - 130.

Alarcón SOtOMAYOR, LucíA: "La eficacia y la ejecución de las sanciones de tráfico", Documentación Administrativa, no 284 - 285, mayo - diciembre 2009, págs. 121 - 152.

ALMOACID LAMELAS, VÍctOR: "La notificación en el procedimiento administrativo y electrónico local: evolución y medios", El Consultor, no 15 - 16, 2011, págs. 1852 - 1871

Alonso IbáÑez, MARía del Rosario: "El incumplimiento de la obligación de resolver", Silencio administrativo. Estudio general y procedimientos sectoriales, Tirant lo Blanch, 2012, págs. $185-273$.

Aparicio izquierdo, F., Arenas Ramírez, B., Mira McWilliams, J. M., Paez Ayuso, J.: "The endurance of the effects of the penalty point system in Spain three years after. Main influencing factors", Accident analysis and prevention, Vol. 43, lusse 3, Elsevier, 2011, págs. $911-922$.

Arce fernández, Miguel Ángel: "Gestiones previas a la notificación edictal de persona con domicilio ignorado o en paradero desconocido. Especial incidencia en el Procedimiento Sancionador, notificación de sanción de tráfico que se impugna en reclamación económico - administrativa”, Tributos Locales, no 69, 2007, págs. 101 - 108. 
ARnaldo Fernández del CAStillo, Mario: "El proyecto de reforma de la ley sobre Tráfico en materia sancionadora y su integración en el ámbito local y europeo", en /l Foro Nacional de Derecho de la Circulación, Madrid, DGT, 2009.

Artetxe Palomar, Eugenio: "El deber de identificación del conductor: análisis del art. 72.3 del Texto Articulado de la Ley de Seguridad Vial", Revista Vasca de Administración Pública, núm. 42, 1995, págs. $9-34$.

AtIENZA LóPEZ, José IGNACIO: "Multa de tráfico: identificación de conductor", CEF Legal: Revista práctica de derecho. Comentarios y casos prácticos, №. 148, 2013, págs. 35 - 38.

Blanquer Criado, David Vicente: "Discrecionalidad y responsabilidad en el ejercicio de la potestad reglamentaria", Administración y justicia: un análisis jurisprudencial: liber amicorum Tomás-Ramón Fernández, (coord. por Eduardo García de Enterría Martínez - Carande, Ricardo Alonso García), Vol. I, Civitas, 2012, págs. 703-726

Blasco Delgado, Carolina: La prescripción de las infracciones y sanciones tributarias, Aranzadi, 2003, 246 págs.

CANO CAMPOS, TOMAS: "El control jurisdiccional de los Decretos Legislativos: la adecuación a las bases de la Ley sobre Tráfico y Seguridad Vial : comentario a la STS (Sala 3a Secc. 6aㅡ) de 21 de octubre de 1993", Revista jurídica española de doctrina, jurisprudencia y bibliografía, La Ley, 1995, Tomo I, pág. $1086-1092$.

"Non bis in idem, prevalencia de la vía penal y teoría de los concursos en el Derecho administrativo sancionador", RAP, no 156, enero - abril, 2001, págs. 191 - 250.

El permiso de conducción en España: significado y régimen jurídico, Civitas, 2002, 232 págs.

Los ayuntamientos y el tráfico, lustel, 2006, 256 págs.

Presunciones y valoración legal de la prueba en el derecho administrativo sancionador, Civitas, 2008, 242 págs.

"La culpabilidad y los sujetos responsables en las infracciones de tráfico", Documentación Administrativa, no 284 - 285, mayo - diciembre 2009, págs. 83 - 119.

"El nuevo procedimiento de imposición de las sanciones de tráfico", REDA, Civitas, no 147, 2010, págs. $537-578$.

“¿Es una sanción la retirada de puntos del permiso de conducir?”, RAP, no 184, enero - abril 2011, págs. 79 - 119.

"El silencio administrativo en materia de tráfico y seguridad vial", El silencio en la actividad de la Administración Pública (coordinado por Luciano José Parejo Alfonso), Tirant lo Blanch, 2011, págs. $273-292$.

"Las competencias de los municipios en materia de tráfico", Tratado de derecho municipal (Coordinado por Santiago Muñoz Machado), Vol. 3, lustel, 2011, págs. 2565 $-2632$

Legislación sobre tráfico, circulación de vehículos y seguridad vial, Tecnos, 2011, 1088 págs. 
Carballeira Rivera, Teresa: "Los titulares de la potestad sancionadora. Los entes locales", Documentación Administrativa, no 280 - 281, 2008, págs. 235 - 260.

Carretero pérez, Adolfo y Carretero SÁnChez, Adolfo: "Derecho administrativo sancionador", Tratado de derecho municipal (Coordinado por Santiago Muñoz Machado), Vol. 1, lustel, 2003, págs. $1281-1306$.

CARRO FERNÁNDEZ - VALMAYOR, José LUIS: "La potestad sancionadora municipal", Tratado de derecho municipal (Coordinado por Santiago Muñoz Machado), Vol. 1, lustel, 2003, págs. $1281-1306$.

CASINO RUBIO, MIGUEL: "La indebida confusión entre sanciones y otras medidas administrativas de policía (comentario a la STS de 2 de febrero de 1998)", REALA, № 283, págs. 569 y ss.

La increíble historia del deber de identificar al conductor infractor, Civitas, 2010, 245 págs.

"Presunción legal de culpabilidad versus prueba indiciaria de la autoría en las infracciones de tráfico", RAP, no 182, mayo - agosto 2010.

"La disputada naturaleza jurídica de la declaración de pérdida de vigencia del permiso de conducción por extinción del saldo de puntos", Documentación Administrativa, no 284 - 285, mayo - diciembre 2009, págs.. 253- 271.

Castillo manzano, José ignacio, Castro nuño, Mercedes, Pedregal, Diego J.: “An econometric analysis of the effects of the penalty points system driver's license in Spain", Accident analysis and prevention, Vol. 42, Issue 4, Elsevier, 2010, págs. 1310 - 1319.

CAZORLA PRIETO, LUIS MARÍA: El lenguaje jurídico actual, Aranzadi, 2007, 176 págs.

CORRALES ElizONDO, Agustín: "Acreditación de la notificación administrativa (arts. 58 y 59, L 30/1992)", Actualidad Administrativa, no 8, 2004, págs. 968 - 977.

Cueto Pérez, Miriam: "Los principios de potestad sancionadora de las Administraciones Públicas. Tipicidad y responsabilidad", Documentación Administrativa, 2010, № 280 281, enero - agosto 2008, págs. 95 - 117.

De Asís Roig, Rafael F. DE: El Juez y la motivación en el Derecho, Dykinson, Madrid, 2005, 168 págs. (pp. 80-82)

De Castro y Bravo, Federico: Temas de Derecho Civil, Civitas, 2008, 185 págs.

De Miguel CanUto, EnRIQue: La prescripción de las infracciones y sanciones tributarias, Tirant lo Blanch, 2000, 174 págs.

De Palma del Teso, Angeles: el principio de culpabilidad en el derecho administrativo sancionador, Tecnos, 1996, 225 págs.

DíEZ - PIZAZO, LUIS: Derecho y masificación social. Tecnología y Derecho privado (Dos esbozos), Civitas, 1979, 136 págs.

Dirección del Servicio JuRídico del Estado: Manual de Derecho Administrativo Sancionador, Civitas, 2009, 2ạ edición, 2 Tomos, 2896 págs. 
DiRECCIÓN GeNERAL DE TRÁFICO: 5 años del permiso por puntos, DGT, 2011, 69. Págs.

DURÉNDEZ SÁEZ, IGNACIO: El Procedimiento Administrativo Sancionador del Orden Social, Aranzadi, 2009, 392 págs.

ESCRIBANO LÓPEZ, FRANCISCO: "El procedimiento sancionador en la Ley de Derechos y Garantías de los contribuyentes y su desarrollo reglamentario", Revista de Contabilidad y Tributación, CEF, no 196, 1999, págs. 3 - 20.

FERNÁNDEZ, TOMAS - RAMÓN: De la arbitrariedad de la Administración, Civitas, 2008, 5a edición ampliada, 262 págs.

Fernández fernández, Juan José y del castillo Vázquez, IsAbel cecilia: Manual de las notificaciones administrativas, 2ª edición, Civitas, 2004, 653 págs.

FERNÁNDEZ TORRES, JuAN RAMÓN: "Arbitrariedad y discrecionalidad, dos décadas después", Administración y justicia: un análisis jurisprudencial: liber amicorum Tomás-Ramón Fernández (coord. por Eduardo García de Enterría Martínez - Carande, Ricardo Alonso García), Vol. 1, 2012, , págs. 1111-1146.

Fuertes LóPez, F. JAVIeR: Permiso y Licencia de conducción por puntos, Aranzadi, 2006, 110 págs. "Las notificaciones en el procedimiento sancionador en materia de tráfico (Teoría y práctica de un despropósito en la teoría y en la práctica)", Actualidad Jurídica Aranzadi, no $767 / 2008$.

"De la práctica de Notificaciones en el domicilio del interesado (interpretación del inciso "en una hora distinta» del art. 59.2 LRJ - PAC)", Actualidad Jurídica Aranzadi, no 656, 2005

FUERTES, MeRCEDES: “Once tesis y una premática para restablecer la dignidad de la Ley", RAP, no 177, septiembre - diciembre 2008, págs. 119 a 155.

Gamero CASADO, EduARDO: "La notificación por correo electrónico tras la ley 24/2001, de 27 de diciembre", Revista Española de Derecho Administrativo, no 116, Civitas, 2002, págs. $501-528$.

Notificaciones telemáticas y otros medios de notificación administrativa en el procedimiento común, Bosch, 2005, 274 págs.

"El régimen de notificaciones: la dirección electrónica vial (DEV) y el tablón edictal de sanciones de tráfico (TESTA)", Documentación Administrativa, no 284 - 285, mayo diciembre 2009, págs. $33-60$.

GARCía AMADO, JUAN ANTONIO: "Sobre el ius puniendi: su fundamento, sus manifestaciones y sus límites", Documentación Administrativa, no 280 - 281, 2008, págs. 11 - 41.

García de EnterRíA, EduARDo: "El problema jurídico de las sanciones administrativas", REDA, núm. 10, págs. $339-430$.

García de Enterría, Eduardo y Fernández, Tomas - Ramón: Curso de Derecho Administrativo I, Civitas, 2008, 11a edición, 754 págs.

Gómez Tomillo, Manuel: Derecho Administrativo Sancionador. Parte general. Teoría general y práctica del Derecho Penal Administrativo, Aranzadi, 2008, 714 págs. 
GonzÁlez Navarro, Francisco: Derecho Administrativo Español, Tomo I, EUNSA, Pamplona, 3ạ Ed. 1993, 1248 págs.

Gónzález Pérez, Jesús: Sistema Jurídico de las Administraciones Públicas, Civitas, 2009, 295 págs.

González Pérez, francisco y González navarro, Francisco: Comentarios a la ley de Régimen Jurídico de las Administraciones Públicas y Procedimiento Administrativo Común (Ley 30/1992, de 26 de noviembre), 5o edición, Civitas, 2012, 2416, págs.

Hernando Orejana, luis Carlos, "La presunción de veracidad de las denuncias de tráfico no instantáneas", Actualidad Administrativa, Núm. 22, La Ley, 2008 págs. $2619-2631$.

HUERGO LORA, AlEJANDRO: Los contratos sobre los actos y las potestades administrativas, Civitas, 1998, 471 págs.

Las sanciones administrativas, lustel, 2007, 470 págs.

JIMENEZ CAMPO, JAVIER: "El control jurisdiccional y parlamentario de los decretos legislativos", Revista de Derecho Político, no 10, 1981, págs. 77 - 106.

"El legislador de los derechos fundamentales", Estudios de derecho público en homenaje a Ignacio de Otto (coord. por Ubaldo Gómez Alvarez), Universidad de Oviedo, 1993, págs. $473-510$.

JIMENO BULNES, MAR: "La «prueba» de alcoholemia y el nuevo delito del art. 380 CP: aspectos procesales", Actualidad Administrativa, № 354, Aranzadi, 1998

JUNCEDA Moreno, JAVIER: "¿Una vuelta hacia la responsabilidad objetiva en Derecho administrativo sancionador? (A propósito de la STC 154/1994, de 23 de mayo)", Revista Española de Derecho Administrativo, núm. 86, abril - junio 1995, págs. 261 269.

"A vueltas con el deber de identificación del infractor de tráfico y la aplicación con matices de los principios penales en derecho administrativo sancionador", Revista Jurídica de Asturias, no 20, 1996, págs. 123 - 134.

"Derecho sancionador en materia de tráfico. En especial, la retirada del permiso de conducir", RAP, núm. 145, 1998, enero - abril 1998, págs. 399 - 430.

"Los principios de proporcionalidad y prescriptibilidad sancionadores", Documentación Administrativa, № 280 - 281, enero - agosto 2008, págs. 119 - 131 .

LEDESMA MUÑIZ, RAMÓN: "El nuevo procedimiento sancionador de tráfico", Documentación Administrativa, no 284-285, mayo - diciembre 2009, págs. 11-31.

Decálogo para la correcta gestión de las sanciones de los radares de velocidad, Pons, 2013, 86 págs.

LóPez Menudo, Francisco: "Principios del procedimiento sancionador", Documentación Administrativa, no $280-281$, 2008, págs. 159- 194. 
LÓPEZ SANTOS, EMILIO: "La práctica de las notificaciones administrativas", luris: Actualidad y práctica del derecho, № 84, la Ley, 2004 , págs. $50-71$.

LOZANO CUTANDA, BLANCA: "El principio de oficialidad de la acción sancionadora administrativa y las condiciones necesarias para garantizar su efectividad", RAP, no 161, mayo - agosto 2003, págs. $83-121$.

MAGRO SERVET, VICENTE: "La necesaria identificación exacta del conductor infractor por el titular del vehículo como garantía de exculpación", Tráfico y Seguridad Vial, №. 146, 2011, La Ley, págs. 7-16.

Manteca Valdelande, Víctor: "Alegaciones e identificación del conductor en los expedientes", Actualidad Administrativa, no 11/2004, La Ley, págs. 1378 - 1386.

Martín Delgado, ISAAC: "Naturaleza, Concepto y régimen jurídico de la actuación administrativa", RAP, no 180, septiembre - diciembre 2009, págs. $353-386$.

Martín MAteo, Ramón: Manual de derecho Administrativo, 28a edición, Aranzadi, 2009, 480 págs.

MARTín ReBollo, LUIS, Leyes Administrativas, 18ª edición, Aranzadi, 2012, 2680 págs.

"Reflexiones discretas sobre el método y el procedimiento", La técnica legislativa a debate, (coord. por Jesús María Corona Ferrero, José Tudela Aranda, Francesc Pau i Vall), Tecos (AELPA), 1994, págs. 73 a 82.

"El procedimiento como garantía" (Una reflexión sobre el fortalecimiento de las formas y la reducción de los principios), Derechos y garantías del ciudadano: estudios en homenaje al profesor Alfonso Pérez Moreno (coord. por Francisco López Menudo), lustel, 2011, págs., 787 a 796.

MARTín - RETORTILLO BAQUER, LORENZO: "Las sanciones administrativas en relación con la defensa de los consumidores, con especial referencia a la publicidad de las mismas", RAP, no 126, 1991, págs. $133-187$.

MARTínez RUIZ, Jesús: "El delito de desobediencia a los agentes de la autoridad en el ámbito de la seguridad vial", Delincuencia en materia de tráfico y seguridad vial, Dykinson, 2008, págs. $217-253$.

MenÉndez Sebastián, eva maría: "Los principios de la potestad sancionadora de las Administraciones públicas. Legalidad e irretroactividad", Documentación Administrativa, no $280-281$, 2008, págs. $65-94$.

MONTANER FERNÁNDEZ, RAQUel: "Los nuevos delitos contra la seguridad vial: una muestra de la Administración del Derecho Penal", Documentación Administrativa, no 284 - 285, mayo - diciembre 2009, págs. 305 - 322.

Montoro González, luis Vicente, Roca Ruiz, Javier y Tortosa GiL, Francisco Manuel: “Influencia del permiso de conducción por puntos en el comportamiento al volante percepción de los conductores", Psicothema, Vol. 20, № 4, 2008, págs.. 652-658. 
MOREno CATENA, VíctoR: "Libertad de circulación y normas sobre circulación de vehículos a motor", VIII Jornadas Nacionales Derecho y Tráfico, DGT, 1993.

Moreno TRAPIella, Prudencio: "Análisis de la regulación española del permiso de conducir por puntos y su confrontación con la jurisprudencia del Tribunal Europeo de Derechos Humanos", Diario La Ley, no 6668, de 9 de marzo de 2007.

"El control judicial de las sanciones administrativas en el convenio europeo de derechos humano", Documentación Administrativa, № 280 - 281, 2008, págs. 323 358.

Muñoz Machado, Santiago: Tratado de Derecho Administrativo y Derecho Público General, Tomo I, La formación de las Instituciones Públicas y su sometimiento al Derecho, 3응 edición, lustel, 2011, 1064 págs.

Tratado de Derecho Administrativo y Derecho Público General, Tomo IV, La actividad Administrativa, lustel, 2011, 1128 págs.

Muñoz Cuesta, Francisco Javier: “Conducción de vehículo motor o ciclomotor con privación total de puntos: aspectos prácticos", Revista Aranzadi Doctrinal no 3/2011, págs. 33 42.

"Conducción temeraria con consciente desprecio de la vida de los demás causando la muerte a tercero: comentario STS, Sala 2a a de 17 de noviembre 2005", Repertorio de Jurisprudencia Aranzadi, no 7/2006, págs. 20913 - 20916.

Los delitos de conducción a velocidad excesiva y con tasas de alcohol superior a 0,60 mg por litro de aire espirado del art. 379 del Código Penal redactado conforme a la LO 15/2007, Repertorio de Jurisprudencia Aranzadi, no 7/2007, págs. 473-476.

MuÑOz MEDINA, Miguel MARÍA: La potestad sancionadora de la Administración en materia de tráfico, 2a edición, Colex, 2012, 360 págs.

Navarro Olivella, Pere: Reflexiones sobre la política de seguridad vial, Pons, 2013, 106 págs.

Nicolás Fraile, CARlos: "Radares: Una historia a toda velocidad", Tráfico y Seguridad Vial, no 204, DGT, 2010, págs. 38 - 41.

Nieto, AlejAndro: Derecho Administrativo Sancionador, 4a edición, Tecnos, 2005, 591 págs.

Derecho Administrativo Sancionador, 5ạ edición, Tecnos, 2012, 611 págs.

El arbitrio judicial, Ariel, Barcelona, 2000, pág. 444.

Olmedo GayA, ANA ISABel: "Notificación y publicación de los actos administrativos tras la ley 4/1999, de 13 de enero, de modificación de la Ley 30/1992, de 26 de noviembre, de Régimen Jurídico de las Administraciones Públicas y del Procedimiento Administrativo Común", Actualidad Administrativa, no 26, 1999, págs. 7655 - 768.

Padrós Reig, Carlos: "El deber de identificar el conductor desconocido en el procedimiento sancionador por infracciones de tráfico. Comentario a la STC 63/2007, de 27 de marzo", Revista Vasca de Administración Pública, núm. 79, 2007, págs. 127 - 162. 
Palomar Olmeda, Alberto: La actividad administrativa efectuada por medios electrónicos, Aranzadi, 2007, 392 págs.

El procedimiento sancionador de tráfico y seguridad vial (A propósito de las cámaras en los semáforos), inédito (libro homenaje Santamaría Pastor)

Parejo Alfonso, LuCiAno José: Seguridad pública y policía administrativa de seguridad, Tirant lo Blanch, 2008, 149 págs.

"La deriva de las relaciones entre los derechos administrativo y penal. Algunas reflexiones sobre la necesaria recuperación de su lógica sistemática", Documentación Administrativa, no 284-285, mayo - diciembre 2009, págs. 273-304

Pinaglia-Villalón y GaVIRA, JUAN IGNACIO: "Análisis jurisprudencial del incumplimiento por el titular de un vehículo de la obligación de facilitar a la Administración la identificación del conductor del vehículo en el momento de ser cometida una infracción", Revista de responsabilidad civil, circulación y seguro, no. 7/2012, págs. 29 -41.

Puerta seguido, Francisco Eugenio: “"La prohibición de bis in idem» en la legislación de tráfico", Documentación Administrativa, oo 284 - 285, mayo - diciembre 2009, págs. $219-251$.

Pulido Quecedo, Manuel Francisco: "Las competencias de Navarra en materia de ordenación de transportes por carretera", Revista Jurídica de Navarra, no 2, julio - diciembre 1986, págs. $31-49$

"Sobre la eficacia de las notificaciones administrativas rechazadas (La interpretación judicial de la expresión «intento de notificación debidamente acreditado» del apartado 4 del art. 58 de la LRJ - PAC", Actualidad Jurídica Aranzadi, № 610.

PRIETo de Pedro, Jesús: Lenguas, lenguaje y Derecho, Civitas, 1991, 192 págs.

"Los vicios del lenguaje legal. Propuestas de estilo", La calidad de las leyes (coordinado por Fernando Sáinz Moreno, Juan Carlos da Silva Ochoa), Parlamento Vasco, 1989, págs. $121-156$.

QUINTANA LóPEZ, TOMÁs: "La desconcentración en la organización de los Municipios", Documentación Administrativa, № 228, 1991, págs. 145 - 166.

"La inactividad de la Administración como acto administrativo: STC 294/1994", Poder Judicial, no 36, 1994, págs. 415 - 418.

Rázquin lizarraga, Martín María: "La nueva fijación legal de plazos de resolución y de notificación de los procedimientos administrativos y de los efectos del silencio administrativo", Revista Española de Derecho Administrativo, № 113, Civitas, 2002, págs. $31-50$.

Rebollo Puig, Manuel e Izquierdo Carrasco, Manuel: Derecho Administrativo Sancionador, Lex Nova, 2009, 1024 págs.

RIVERO ORTEGA, RICARDO: "La obligación de resolver", Silencio administrativo. Estudio general y procedimientos sectoriales, Tirant lo Blanch, 2012, págs. $135-184$. 
RODRÍGUEZ DE SANTIADO, JOSÉ MARÍA: "El pago voluntario de las multas en cuantía reducida; legalidad, eficacia, seguridad jurídica y tutela judicial efectiva", Documentación Administrativa, no 284-285, mayo - diciembre 2009, págs. 153-180.

Rodríguez Natal, Miriam, veleiro Couto, Elena, Balbuena Jiménez, José y Romero Sánchez, Juan: “Incidencia judicial práctica de la modificación operada por la Ley 18/2009, de 23 de noviembre por la que se modifica el texto articulado de la Ley sobre tráfico, circulación de vehículos a motor y seguridad vial, en materia sancionadora", Documentación Administrativa, no 284-285, mayo - diciembre 2009, págs. 323 - 339.

RUiz zAPATERO, Guillermo Gonzalo: La notificación tributaria obligatoria en una dirección electrónica habilitada", Quincena Fiscal, no 5, Aranzadi, 2012, págs.. 57 - 75.

SÁnChez Melgar, Julián: "El principio «non bis in idem» ante el Tribunal Constitucional" (comentario de la STC 2/1981, de 30 de enero), Veinticinco años de jurisprudencia constitucional. 25 sentencias fundamentales comentadas, (Coord. Alberto Dorrego de Carlos)Difusión Jurídica y temas de Actualidad, 2007, págs. 225 - 234.

SÁNCHEZ AdSUAR, MARCOS: "La propuesta de resolución en los procedimientos sancionadores en materia de tráfico, antes y después del RD 137/2000", Sentencias de TSJ y AP y otros Tribunales, num. 17/2000, parte Comentario, Aranzadi, 2000.

SANTAMARÍA PASTOR, JUAN ALFONSO: "De nuevo sobre el arbitrismo del legislador: las reformas del proceso contencioso - administrativo hechas por la Ley 37/2011, de 10 de octubre", Administración y justicia: un análisis jurisprudencial: liber amicorum Tomás-Ramón Fernández (coord. por Eduardo García de Enterría Martínez - Carande, Ricardo Alonso García), Vol. 1, 2012, , págs. 2147-2181.

SANTA - MARÍA PÉREZ, LUIS FlORENCIO: "Análisis jurídico de la pérdida de puntos y de la ineficacia sobrevenida del permiso o licencia de conducir por pérdida del saldo total de puntos asignado. Consecuencias ante la jurisdicción contencioso-administrativa", en II Foro Nacional de Derecho de la Circulación, Madrid, DGT, 2010, págs. 109 y ss.

SANZ ClaviJo, Alfonso: "La notificación edictal en los procedimientos tributarios: su aplicación en las reclamaciones económico - administrativas", Quincena Fiscal, no 17/2009, Aranzadi, págs. $47-74$

SANZ Rubiales, Í̃̃IGO: "Principio de legalidad y potestad sancionadora en la Administración Local”, REALA, no 264, 1994, págs. $671-690$.

"Potestad sancionadora administrativa, non bis in idem y primacía del orden penal (comentarios a la STC 177/1999, de 11 de octubre)", Poder Judicial, no 59, 2000, págs. $545-572$.

"Contenido y alcance de la prohibición de reformatio in peius en el procedimiento administrativo", RAP, no 190, enero - abril 2013, págs. 241 - 276.

SCHMIDT - ASSMANN, EBERHARD: La Teoría general del derecho administrativo como sistema, Marcial Pons, 2003, 475 págs.

SChÜNeMANN, BERnD: Temas actuales y permanentes del derecho penal después del milenio, Tecnos, 2002, 312 págs. 
Silva SÁnChez, Jesús MARía: La expansión del Derecho Penal, 2a edición, Civitas, 2001, 168 págs.

SOSA WAGNeR, Francisco: Manual de Derecho Local, 9o edición, Aranzadi, 2005, 288 págs.

"Los principios del Régimen local", Tratado de derecho municipal (Coordinado por Santiago Muñoz Machado), Vol. 1, lustel, 2003, págs. 157 - 192.

SOSPEDRA NAVAS, Francisco José: Proceso Penal, Vol. I, Civitas, 2003, 1146 págs.

SUÁREZ LÓPEZ, JOSÉ MARÍA: “La incidencia del principio non bis in idem ante ilícitos en materia de tráfico y seguridad vial", Delincuencia en materia de tráfico y seguridad vial, Dykinson, 2008, págs. $37-63$.

SUAY RINCÓN, JOSÉ: "La potestad sancionadora de la Administración y sus exigencias actuales: un estudio preliminar", Documentación Administrativa, no 280 - 281, 2008, págs. 43 - 64.

TolíVAR ALAS, LeOPOLDO: "Renovación legislativa y Consejo de Estado", Revista Española de Derecho Administrativo, № 31, Civitas, 1981, págs. 683 - 696.

"Las sanciones administrativas y la despenalización de faltas contra el régimen de las poblaciones", Revista de estudios de la administración local y autonómica, no 242, 1989, págs. $257-282$.

"Título III. Objeto del Recurso Contencioso Administrativo. Capítulo IV. Cuantía del recurso: Artículos 40, 41 y 42", Revista Española de Derecho Administrativo, no 100, Civitas, 1998, págs. $369-374$.

"Concurrencia de sanciones: una construcción inacabada", Documentación Administrativa, no $280-281$, 2008, págs. $133-158$.

"El ejercicio de la potestad sancionadora por los municipios", Revista de Estudios Locales, CUNAL, no 1 (extra), 2002, págs. 233-237.

TOMÁs MARTínez, Gema, "Fuentes jurídicas del principio "qui tacet, consentire videtur". Realidad jurídica versus difusión social", Revue internationale des droits de l'antiquité, no 50, 2003, págs. $383-400$.

TORRES FERNÁNDEZ, MARÍA ElenA: "Reflexiones sobre algunos efectos administrativos del llamado "carnet por puntos» en las consecuencias penales de los delitos contra la seguridad en el tráfico", Delincuencia en materia de tráfico y seguridad vial, Dykinson, 2008, págs. $95-122$.

Trabado Álvarez, Concepción, "Non bis in idem por la condena conjunta contra la seguridad del tráfico, alcoholemia y de negativa a someterse a las pruebas de alcoholemia", Diario La Ley, no 7681, 2011.

Vidal Maestre, Javier tiberio y Alcázar Avellaneda, Juan Miguel: "El recurso contenciosoadministrativo interpuesto contra el boletín de denuncia y la presentación de alegaciones en vía administrativa. El artículo 81.5 de la Ley de Seguridad Vial", Diario La Ley, no 7865, 2012.

ZAPATA HíJAR, JUAN CARLOS: Tráfico. Nuevo régimen sancionador, La Ley, 2011, 424 págs.

ZAPATERO, VIRGILIO: El arte de legislar, Aranzadi, 2011, 386 págs. 


\section{Otras fuentes de información}

DGT (Estadísticas e indicadores)

http://www.dgt.es/portal/es/seguridad vial/estadistica/

EUROSTAT (Comisión Europea)

http://epp.eurostat.ec.europa.eu/portal/page/portal/statistics/themes

IRTAD (International Traffic SafetyData anda Analysis Group)

http://internationaltransportforum.org/irtadpublic/index.html

Ministerio de Fomento (Mapa de Tráfico 2012)

http://www.fomento.es/MFOM/LANG_CASTELLANO/DIRECCIONES_GENERALES/CARRETERAS/TRAFICO_VELOCIDADES/

Pulitzer Centre, Roads Kill

http://roadskillmap.com/\#67.067433335108298,36.5625,1

The world factbook

https://www.cia.gov/library/publications/the-world-factbook/ 